UNIVERSIDADE DE SÃO PAULO

ESCOLA DE COMUNICAÇÕES E ARTES

JULIANA MARIA DE SIQUEIRA

\title{
Quem educará os educadores?
} A Educomunicação e a formação de docentes em serviço 

JULIANA MARIA DE SIQUEIRA

\section{Quem educará os educadores? A Educomunicação e a formação de docentes em serviço}

Dissertação apresentada ao Programa de Pós-Graduação em Ciências da Comunicação, Área de Concentração Interfaces Sociais da Comunicação, Linha de Pesquisa Educomunicação, da Escola de Comunicações e Artes da Universidade de São Paulo, como requisito parcial para a obtenção do título de Mestre em Ciências da Comunicação, sob a orientação do Prof. Dr. Adilson Odair Citelli. 
Autorizo a reprodução e divulgação total ou parcial deste trabalho, por qualquer meio convencional ou eletrônico, para fins de estudo e pesquisa, desde que citada a fonte.

Catalogação na Publicação

Serviço de Biblioteca e Documentação

Escola de Comunicações e Artes da Universidade de São Paulo

Siqueira, Juliana

Quem educará os educadores? A Educomunicação e a formação de docentes em serviço/ Juliana Siqueira. - - São Paulo : J. Siqueira, 2009.

357 p. : il.

Dissertação (Mestrado) - Departamento de Comunicações e Artes/Escola de Comunicações e Artes/USP.

Orientador: Prof. Dr. Adilson Odair Citelli.

Bibliografia

1. Comunicação 2. Educomunicação 3. Formação de professores 4. Educação para os meios 5. Programa Pedagogia da Imagem 6. Siqueira, Juliana I. Citelli, Adilson Odair II. Título

CDD 21 ed. -302 
Juliana Maria de Siqueira

Quem educará os educadores? A Educomunicação e a formação de docentes em serviço

Dissertação apresentada à Escola de Comunicações e Artes (ECA) da Universidade de São Paulo (USP) para obtenção do título de Mestre. Área de Concentração: Interfaces Sociais da Comunicação

Aprovada em:

Banca Examinadora: 

À minha familia, em especial, à minha mãe, a primeira educadora.

À memória da professora Luciane Ribeiro Vilela, uma batalhadora.

E aos que agem com ética pela nossa humanização. 



\section{RECONHECIMENTO}

"Devo tudo a todos", disse certa vez o artista plástico Carlos Scliar. É exatamente assim que me sinto neste momento, em que alguns anos de trabalho duro, estudos e aprendizado culminam na produção de uma dissertação de mestrado. Chegar aqui seria impossível sem o incentivo, a colaboração, a orientação, o amor e o diálogo das inúmeras pessoas que, comigo, compartilham desta história.

A entrada no curso de Mestrado em Ciências da Comunicação, na linha de pesquisa Educomunicação, constituiu um marco importante da minha trajetória de vida. Muito além da perspectiva profissional que a pós-graduação abre, habilitando-me para o exercício acadêmico e a atividade de pesquisa, essa experiência adquiriu um valor existencial, pelo que me proporcionou de amadurecimento, ampliação das visões de mundo e compreensão de meu lugar e papel na transformação da realidade que me cerca. Meu reconhecimento ao Programa de Pós-Graduação em Ciências da Comunicação da ECA/USP e ao Museu da Imagem e do Som de Campinas (MIS), pela oportunidade de realizar estes estudos.

Minha motivação inicial para cursar o mestrado veio de uma inquietação profissional - a necessidade de analisar mais profundamente o programa educativo desenvolvido ao longo de minha atuação como agente cultural no MIS. Durante a jornada, entretanto, as experiências e interações com os outros me revelavam novos modos de olhar o meu fazer: a que $(\mathrm{m})$ serve, como se constrói, que sentidos emergem dali. Fui vivenciando, então, o verdadeiro significado da dialogia, da comunicação, da formação: ensaiar a criação, transformar a realidade, humanizar-nos. Ao realizar esse percurso, minha prática foi adquirindo novos sentidos, e a compreensão dos processos e contextos envolvidos nesse fazer dissipava as angústias e me dava mais esperança. Os colegas que constroem comigo projetos e aspirações de mudança são peças-chave dessa transformação. Juntos, vamos mudando e desmudando, nos refazendo e nos educando. Sempre provisoriamente. Sempre em comunhão. Entre tantos outros estão: Batata (Ronaldo Simões Gomes), Orestes Toledo, Rita Francisco, Adriana Verri, Joaquim Andrade, Lúcia Bachiega, Analice Dias, Tânia Costa, Maria das Graças da Cruz, Luciane Vilela (in memorian), Carla Feriani, Walquíria de 
Carvalho, Akiko Watanabe, Marli Queiroz, Sara Bueno, Dalva Amaral, professoras e professores participantes do curso Pedagogia da Imagem.

Embora sendo de minha responsabilidade a elaboração da pesquisa e a produção dos relatos e análises aqui apresentados, o programa que lhes deu origem (o Pedagogia da Imagem) é uma construção coletiva, assim como o é o campo em que este trabalho se inscreve, a Educomunicação. Dessa forma, se expresso aqui um conhecimento, este não é um produto individual, mas fruto de um esforço cotidiano, que muito me antecede e ultrapassa, e do qual fazem parte meu orientador, Prof. Dr. Adilson Odair Citelli, e seus colegas do Departamento de Comunicações e Artes, pesquisadores da Educomunicação; os examinadores que generosamente contribuíram com sua avaliação e recomendações e participam desta banca, Prof. Dr. Ismar de Oliveira Soares e Profa. Dra. Corinta Maria Grisolia Geraldi da Faculdade de Educação da Unicamp; as professoras que colaboraram na minha formação e influenciaram profundamente a configuração deste trabalho, Dra. Maria Immacolata Vassallo de Lopes e Dra. Cremilda de Araújo Medina, e os colegas de pós-graduação, dentre os quais destaco Ana Luíza Zaniboni Gomes, Queila Borges e Gracinda Carvalho, além dos que convivem comigo na Prefeitura Municipal de Campinas.

Finalmente, agradeço à família e aos amigos, cuja constância e amor sempre dissolveram minhas inseguranças e renovaram-me as forças para prosseguir na caminhada. 
Creio que percebemos alguma coisa, principalmente, quando desconfiamos que temos muito a aprender. Assumimos a responsabilidade de estimular nos outros essa capacidade de pensar, optar, teimar, lutar, criar, sentir-se gente - viver conscientemente o mundo de hoje.

Carlos Scliar

A resignação é um suicídio cotidiano.

Recolhido de uma faixa de protesto, escrita por trabalhadores em greve, em Paris, no outono de 2003 



\section{RESUMO}

SIQUEIRA, J. M. de. Quem educará os educadores? A Educomunicação e a formação de docentes em serviço. 2009. 357 p. Dissertação (Mestrado) - Escola de Comunicações e Artes, Universidade de São Paulo, São Paulo, 2009.

As possibilidades e os limites da formação continuada de docentes para a incorporação crítica e dialógica dos meios de comunicação e suas linguagens, em sala de aula, são investigados a partir do estudo de caso do curso Pedagogia da Imagem, promovido pelo Museu da Imagem e do Som de Campinas, nos anos de 2006 e 2007. Observando a situação de formação como um fenômeno comunicativo, foi desenvolvido um estudo de recepção, com foco nas mediações culturais que nele atuam, no contexto em que ele se dá e nos sentidos construídos e legitimados pelas suas participantes. Situada no campo que atravessa as áreas da Comunicação e da Educação, denominado Educomunicação, a pesquisa assume o compromisso ético e político com a construção da autonomia dos sujeitos do processo educativo e se apóia nos conceitos de reflexividade e profissionalização e na abordagem social da formação de professoras. O edifício metódico foi construído a partir da Teoria da Estruturação de A. Giddens, gerando categorias de análise que articulam as dimensões subjetivas (significação da/na prática pedagógica), estruturais (contexto escolar e suas determinações sociopolíticas e econômicas) e coletivas (identidade e consciência profissional). A coleta de dados associou procedimentos quantitativos (aplicados ao universo das participantes do grupo) e qualitativos (estudos em profundidade realizados junto a uma amostra de quatro escolas municipais). Os resultados apontam para a complexidade dos fatores envolvidos na construção e avaliação de programas bem-sucedidos de formação docente, bem como para a relevância do desenvolvimento de propostas educomunicativas no ambiente escolar.

\section{PALAVRAS-CHAVE}

Comunicação; Educomunicação; Formação de professores; Educação para os meios; Programa Pedagogia da Imagem. 


\section{ABSTRACT}

SIQUEIRA, J. M. de. Who educates the educators? Educommunication and teachers' formation. 2009. 357 p. Dissertation (Master’s) - Escola de Comunicações e Artes, Universidade de São Paulo, 2009.

The possibilities and the limits of teachers' formation, for a critical and dialogic assimilation of media and its languages, in classrooms, are investigated through the case study of "Pedagogia da Imagem" course, offered by Museu da Imagem e do Som de Campinas, during 2006-2007. Watching the formation situation as a communicational phenomenon, a reception study was developed, with focus on the cultural mediations that act on it, the context in which it happens and the meanings produced and legitimated by its participants. Settled on the field that goes through the areas of Communication and Education, named Educommunication, the research has an ethical and political commitment to build the autonomy of the individuals of the educational process, and it is supported by the concepts of reflexivity and professionalization, and the social approach to teachers' formation as well. The methodic building was raised from the Structuration Theory, of A. Giddens, originating analysis categories that articulate three dimensions: subjective ones (meanings of/on pedagogical practice), structural ones (school context and its sociopolitical and economic determinations) and collective ones (professional identities and consciousness). The data collection associated quantitative procedures (applied to the whole group of participants) and qualitative ones (in-depth studies developed with four public schools). The results point to the complexity of the aspects involved on creation and evaluation of successful programs for teachers' formation, and to the importance of developing educommunicational projects on school environment.

\section{KEYWORDS}

Communication; Educommunication; teachers' formation; media literacy; "Pedagogia da Imagem" Program. 


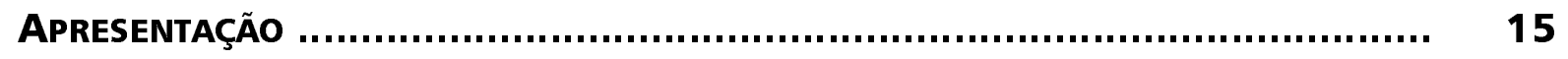

1 Condições sociais de realização da pesquisa e o compromisso ético ................. 20

2 Desafios epistemológicos ............................................................... 24

3 Enunciando o problema da pesquisa .................................................. 31

4 Sobre o Ceforma e o curso Pedagogia da Imagem ................................... 31

I CONSOLIDAÇÃo dO OBJETO DE PESQUISA ............................................. 37

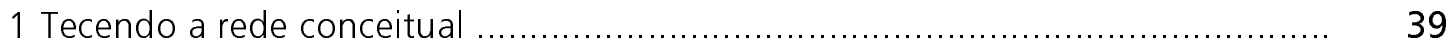

1.1 Sujeito: agente da comunicação e da educação ............................................... 39

1.2 O contexto da ação: visão crítica para um projeto de sociedade democrática ....... 48

1.3 Formação docente: entre o diálogo e o conflito ............................................. 59

1.4 A contribuição da Educomunicação: em busca de uma síntese ............................ 76

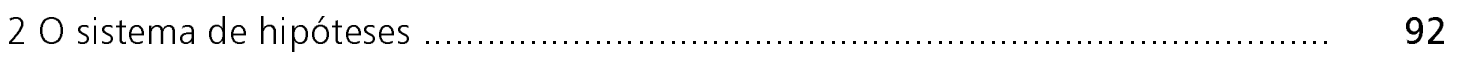

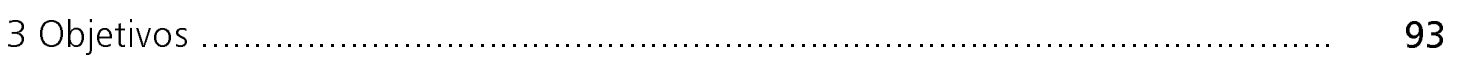

4 Procedimentos metodológicos ........................................................ 95

4.1 Delimitação do objeto empírico (amostragem) …………................................ 95

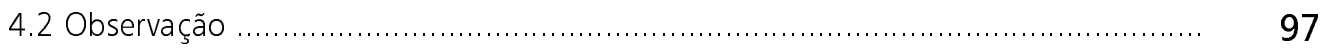

4.3 Preparação do material (pré-análise) …………............................................ 100

4.4 Análise descritiva .................................................................................. 100

II PEdAgogia da IMAgem: A CONSTRUÇÃo de UM PROJeto EDUCOMUNiCATIVO ...... 103

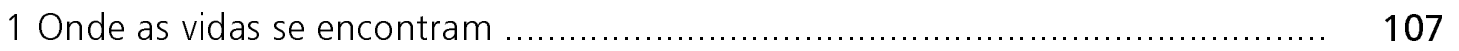

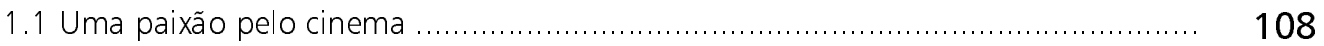

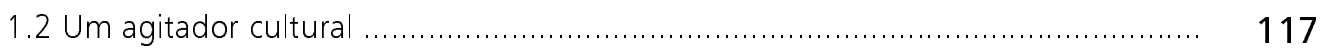

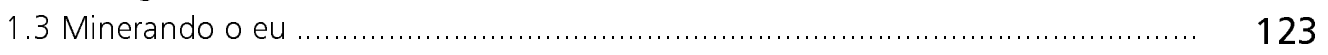

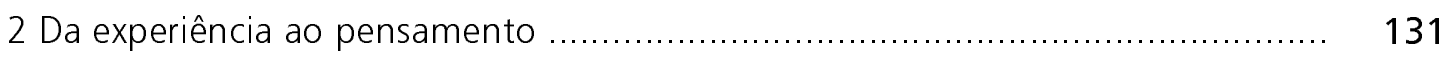

2.1 Desafios cotidianos: a construção metodológica da Pedagogia da Imagem .......... 145

2.2 Criações autorais, plurais: breve relato dos projetos desenvolvidos ...................... 158

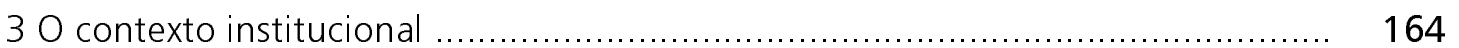

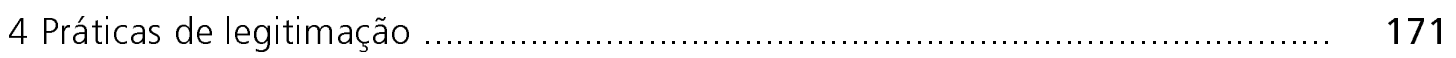


1 Formar-se professora, tornar-se professora ......................................... 181

1.1 As expectativas e os sentidos da formação para as professoras ........................... 184

1.2 A experiência das professoras no uso do vídeo e outras linguagens .................... 199

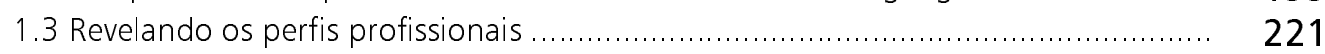

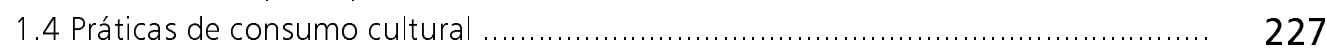

1.5 Histórias de vida: trajetórias singulares desenhando projetos autorais ................ 255

1.60 elemento subjetivo na formação continuada: poderes e limites do agente e parâmetros para ação ……………........................................................ 287

$2 \mathrm{O}$ ecossistema educativo-comunicativo ……........................................ 292

2.1 O entorno das escolas, na lente das professoras .............................................. 305

2.2 Escola, do entorno ao interno: duas visões contrastantes .................................. 311

2.30 elemento estrutural na formação: criando ecossistemas participativos .............. 315

3 A dimensão coletiva da formação: o professor reflexivo e a busca de uma nova identidade profissional

IV À GUISA dE CONCLUSÃO: REVENDO O PERCURSO .................................. 329

V REFERÊNCIAS BIBLIOGRÁFICAS ...................................................... 333

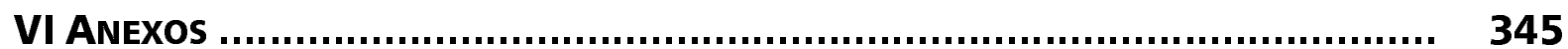


APRESENTAÇÃO 

Quem educará os educadores? A pergunta essencial, inspirada na observação de Karl Marx, de que o próprio educador precisa ser educado, traz implícita a visão de mundo de quem não se satisfaz com o cenário desenhado pelas circunstâncias históricas atuais, acredita na possibilidade de mudança e assume o compromisso de promover uma educação voltada para a transformação social. É certo que a renovação da educação não antecede à da sociedade, nem os educadores colocam-se acima dos demais agentes de mudança. Entretanto, uma formação voltada para a emancipação é fator decisivo para a participação ativa dos cidadãos na construção de uma via alternativa para uma organização social mais justa, democrática e capaz de satisfazer às necessidades humanas de maneira sustentável. Desse modo, somos imediatamente remetidos ao problema proposto na terceira tese sobre Feuerbach: ${ }^{1}$ o da produção de uma prática transformadora - também no espaço da escola.

Conquanto vários autores já tenham ensaiado diferentes respostas para a questão, o problema concreto permanece sem solução. Seja porque ainda mantém a sua relevância, seja porque ainda merece atenção. A fim de guiar-me nessa busca, recorro a Paulo Freire, para quem "ninguém educa ninguém; ninguém educa a si mesmo. Os homens se educam entre si, mediatizados pelo mundo". ${ }^{2}$ Assim, a pergunta inicial passa a abarcar também o problema de como se dá essa (trans)formação: necessariamente na interação social, no diálogo, na abertura para o outro, no confronto com a realidade concreta que nos cerca e nos embates entre o que fomos, o que somos, o que acreditamos ser e o que queremos produzir. Finalmente, coloca-se o problema de fundo: não havendo educação neutra, que projetos e propostas têm os formadores de professoras e professores?

Essas dimensões, que reconheço na pergunta “Quem educará os educadores?”, foram as linhas-mestras que segui para investigar o problema dos limites e possibilidades da formação de docentes em serviço para a incorporação crítica e dialógica dos meios de comunicação e suas linguagens em sala de aula.

\footnotetext{
1 "A doutrina materialista, que pretende serem os homens produto das circunstâncias e da educação e em conseqüência, que os homens transformados sejam produto de outras circunstâncias e de uma educação diferente, esquece que são precisamente os homens que transformam as circunstâncias e que o educador tem, ele mesmo, necessidade de ser educado. É por isso que ela tende inevitavelmente a dividir a sociedade em duas partes, estando uma acima da sociedade [...]. A coincidência da modificação das circunstâncias e da atividade humana não pode ser considerada e compreendida racionalmente senão como uma prática revolucionária." (MARX, Karl e ENGELS, Friedrich. Teses sobre Feuerbach. In: A ideologia alemã e outros escritos. Primeira parte. Rio de Janeiro: Zahar Editores, 1965, p. 88.)

${ }^{2}$ FREIRE, Paulo. Pedagogia do Oprimido. 17. ed. Rio de Janeiro: Paz e Terra, 1987, p. 39.
} 
Tal proposta de investigação nasceu de uma necessidade concreta, um problema real enfrentado cotidianamente em meu trabalho como agente cultural do Museu da Imagem e do Som de Campinas (MIS). Envolvida desde o ano de 2003 com um programa de formação de professoras ${ }^{3}$ da rede pública municipal, voltado para a incorporação dos meios de comunicação e suas linguagens em sala de aula, via-me constantemente debatendo com a equipe de mediadores a efetividade das ações empreendidas. Queríamos nos assegurar de que as proposições do curso - chamado Pedagogia da Imagem - chegassem aos alunos e promovessem mudanças efetivas no processo ensino-aprendizagem. Diversas vezes revisamos nossas formulações teóricas e metodológicas, estratégias e recursos didáticos. Ainda assim, sobressaía o sentimento de que as transformações tão esperadas vinham em ritmo lento, diferentemente de como desejávamos. Sabíamos que não era o caso de culpar as professoras, elas também ávidas por mudanças. Compreendemos que o processo de formação era complexo, envolvendo diversos fatores, e que a questão merecia ser estudada sistematicamente.

Na busca de explicações, descobri a Educomunicação - proposta do Núcleo de Comunicação e Educação da Escola de Comunicações e Artes da USP. A afinidade de suas proposições com as da equipe do MIS fez crescer o entusiasmo em relação ao projeto - a despeito das dificuldades enfrentadas - e o sentimento de que o trabalho era não apenas viável, como socialmente relevante.

À medida que fui me aprofundando nos estudos, percebi que, também no campo científico, as respostas não estavam dadas: era preciso construí-las. Autores como Ismar de Oliveira Soares e Adilson Citelli apontavam em diversos textos a importância da formação de educadores em serviço para a concretização da proposta educomunicativa e a superação de um cenário de crise na escola brasileira, diante da concorrência oferecida pelos meios de comunicação de massa:

As dificuldades naturais de apreensão desse novo processo - todo ele implicado em uma reconfiguração nos modos de se disponibilizar a informação e se operar o conhecimento - assim

\footnotetext{
${ }^{3}$ Ao referir-me ao programa Pedagogia da Imagem, passarei a empregar o termo "formação de professoras" ou "educadoras" visto que, embora não atendamos exclusivamente as mulheres, estas representam mais de 90\% do número de participantes dos cursos. Da mesma maneira, quando tratar das ações produzidas pelo conjunto dos realizadores do programa, empregarei o plural, visto que são uma construção coletiva. De modo geral, neste trabalho, empregarei a primeira pessoa do plural para denotar ações ou conhecimentos produzidos coletivamente, por um conjunto de atores ou pesquisadores. Apenas quando utilizar a primeira pessoa do singular estarei me referindo a decisões e posicionamentos individuais.
} 
como os obstáculos decorrentes da própria formação dos profissionais da área, quase sempre orientados para desenvolver estratégias de ensino/aprendizagem segundo a tradição do discurso pedagógico, fez com que o número de educadores prontos para responder às demandas postas em cena pelas novas linguagens fosse pequeno. ${ }^{4}$

Segundo o próprio Citelli, a reflexão sobre os programas de formação dos educadores em serviço, com foco na interface Comunicação-Educação constitui uma das "grandes linhas cujas implicações teóricas e metodológicas precisam ser tratadas em suas circunstâncias específicas". ${ }^{5}$ Ele também vê urgência em observar o perfil de formação dos professores e em oferecer uma "resposta qualificada a uma pergunta: como os docentes e as escolas estão recebendo e conciliando o que lhes é requisitado pelas diferentes vozes sociais e pelas demandas postas pela sociedade videotecnológica?"6

No campo da Educação, a formação continuada é um tema mais recente que o da formação inicial e tem recebido crescente atenção dos pesquisadores - nem sempre pelos motivos mais desejáveis. ${ }^{7}$ Também aqui as respostas são provisórias e parciais, incapazes de lidar com a complexidade do real. Isabel Alarcão, Catedrática da Universidade de Aveiro, Portugal, ressalta que a noção de projeto tem estado ausente na maioria dos casos - não apenas como metodologia de formação, mas sobretudo nas suas dimensões sociais, políticas e institucionais, capazes de acolher projetos pessoais e de grupos detentores de identidade profissional. Para Alarcão, por adiar-se o enfrentamento desse problema teórico, a “[...] formação de professores [...] tem saltado de modelo em modelo, sem avaliações consistentes e sistemáticas que permitam analisá-los em seus princípios, realizações, resultados e contextos." ${ }^{8}$

\footnotetext{
${ }^{4}$ CITELLI, Adilson. Comunicação e educação: a linguagem em movimento. 2. ed. São Paulo: Editora Senac São Paulo, 2002, p. 151-152.

${ }^{5}$ Idem, ibidem, p. 156.

${ }^{6}$ Idem, ibidem, p. 228.

${ }^{7}$ Emília Freitas de Lima lembra que a valorização da formação continuada tem trazido a contrapeso a desqualificação e, em alguns casos, a substituição das políticas de formação inicial, "[...] contribuindo para reforçar as tendências mais negativas rumo à desprofissionalização e à exclusão do magistério. Tais tendências dizem respeito tanto às condições materiais quanto ao processo de despossessão simbólica, onde os professores cada vez mais se limitam a operadores do ensino, sendo relegados a um papel mais e mais alienado". Cf. LIMA, Emília Freitas de. Formação de professores - passado, presente e futuro: o curso de Pedagogia. In: MACIEL, Lizete S. B. \& SHIGUNOV NETO, Alexandre. (orgs) Formação de professores: passado, presente e futuro. São Paulo: Cortez, 2004, p. 12-13.

${ }^{8}$ ALARCÃO, Isabel. Prefácio. In: MACIEL, Lizete S. B. \& SHIGUNOV NETO, Alexandre. (orgs). Formação de professores, p. 11.
} 
A partir desse momento, o problema das possibilidades e limites da formação de professoras voltada para a Educomunicação passou a configurar-se como um tema de pesquisa científica. Se nem o campo da Comunicação nem o da Educação forneciam respostas satisfatórias, seria possível aproximá-los e, aproveitando as contribuições de ambos, produzir conhecimento que avançasse em direção a uma solução, ainda que provisória. Antes de enunciar a problemática, contudo, faz-se necessário dar um segundo passo e compreender os desafios éticos e epistemológicos que essa tarefa impõe.

\section{Condições sociais de realização da pesquisa e o compromisso ético}

Para o pesquisador, a investigação científica não é um exercício isento de engajamento. Sobretudo como é o meu caso - quando se trata de eleger um objeto de estudos com o qual se tem um vínculo direto. Sendo assim, é preciso explicitar que procedimentos asseguram a objetividade do conhecimento produzido e a que compromissos éticos e políticos minha proposta se vincula - compromissos esses que nascem de uma determinada compreensão do contexto social brasileiro e de uma visão da sociedade que se deseja construir.

Em Ciências Sociais, a preocupação com o desenvolvimento de um saber sistemático e secular acerca da realidade, empiricamente validável e não-apriorístico, levou os pesquisadores à busca da objetividade. ${ }^{9}$ No extremo oposto, a subjetividade passou a ser vista como a indesejável contaminação dos preconceitos do investigador na coleta e interpretação de dados, provocando a sua distorção e, conseqüentemente, invalidação. O grau de implicação do pesquisador com o objeto da pesquisa tornou-se alvo de polêmica: para uns, o terreno mais familiar propiciava maior controle sobre a qualidade dos dados obtidos; para outros, o envolvimento pessoal deveria ceder lugar a situações de distanciamento temporal ou espacial com relação ao objeto. Conquanto nenhuma dessas posições tenha se sobressaído como solução para o impasse criado, cresceu a atitude cética em relação à possibilidade de se atingir um conhecimento puramente objetivo e neutro. Conclui-se, uma vez que os estudiosos se acham enraizados num meio so-

\footnotetext{
${ }^{9}$ WALLERSTEIN, Immanuel et al. Para abrir as Ciências Sociais. Lisboa: Europa-América, 1996. p. 125-130.
} 
cial concreto, impossibilitados de se desvencilhar totalmente de seus pressupostos e preconceitos, que "os dados da investigação são sempre selecções da realidade, baseadas nas mundividências ou nos modelos teóricos do seu tempo e filtradas pelas perspectivas de certos grupos específicos de cada época”. ${ }^{10}$ Portanto, o distanciamento do pesquisador em relação ao objeto de investigação não é o que assegura a objetividade científica desejada. Mesmo porque, como lembra Thiollent, tal distanciamento não existe: "no estudo sociológico de qualquer problema social, cultural ou político, sempre devemos considerar que o próprio sociólogo é um de seus componentes". ${ }^{11}$ A objetividade é, pois, um horizonte do qual tentamos nos aproximar por meio da atitude de vigilância epistemológica, que se manifesta em diferentes níveis.

Um primeiro nível de vigilância epistemológica refere-se à atitude empirista do cientista, abrindo-se ao inesperado, permitindo-se observar a complexidade dos fenômenos e mantendo-se sensível em relação às linguagens e concepções dos sujeitos estudados, ${ }^{12}$ buscando incorporá-las à sua teorização e não impor à realidade sua problemática e suas categorias teóricas. Estas não devem ser dadas de antemão, mas mantêm a flexibilidade necessária para ter seu sentido captado no contexto específico do estudo. Do pesquisador, exige-se a reflexividade e o relativismo cultural, numa perspectiva de questionamento, mais do que de observação unilateral. ${ }^{13}$ Desta maneira, no movimento contínuo da teoria à prática e da prática à teoria, observação e análise se desenvolvem num estreito vínculo que enriquece o processo de produção do conhecimento. Nesta investigação, a conjugação entre a aplicação da etnometodologia à pesquisa de campo e a adoção do método narrativo na análise dos dados colaboraram para atender a esse requisito.

Um segundo nível de vigilância epistemológica diz respeito à manutenção da dupla coerência (interna/externa) da pesquisa. Uma vez que toda técnica contém, em si, certa representação da sociedade ou

\footnotetext{
${ }^{10}$ WALLERSTEIN, I. et al. Para abrir as ciências sociais, p. 127.

${ }^{11}$ THIOLLENT, Michel J. M. Crítica metodológica, investigação social e enquete operária. São Paulo: Editora Polis, 1980, p. 47.

${ }^{12}$ EZPELETA, Justa; ROCKWELL, Elsie. Pesquisa participante. São Paulo: Cortez: Autores Associados, 1986, p. 38. Mais adiante, à página 50, afirmam as autoras sobre o método etnográfico: "O etnógrafo observa e paralelamente interpreta. Seleciona do contexto o que há de significativo com relação à elaboração teórica que está realizando. Cria hipóteses, realiza uma multiplicidade de análises, reinterpreta, formula novas hipóteses. Constrói o conteúdo dos conceitos iniciais, não o pressupondo."

${ }^{13}$ THIOLLENT, M. J. M. op. cit, p. 52.
} 
dos grupos sociais, ${ }^{14}$ trata-se de manter a conexão entre o recorte teórico e a metodologia aplicada a cada fase da pesquisa, explicitando as escolhas entre as diferentes opções metodológicas disponíveis. Esse procedimento é, portanto, o que torna possível que os resultados de uma investigação possam ser criticados, avaliados, reproduzidos ou contestados pela comunidade científica. Mais além, é o que permite responder à questão: no bojo de uma determinada visão da sociedade e de uma dada compreensão histórica, o que torna esta investigação pertinente ou relevante?

Busquei ser coerente com a seguinte visão: a presença massiva dos meios de comunicação em nosso cotidiano, assim como a importância que os processos de produção e circulação de informações assumem, atualmente, nas mais diferentes esferas sociais, são fatos amplamente reconhecidos. Sendo inegáveis e irreversíveis os processos que fizeram a comunicação mediática desempenhar papel de centralidade na organização da sociedade contemporânea, tornou-se necessário compreender as novas formas de interação geradas nesse contexto - e como elas afetam as condições de participação e disputa dos diferentes grupos. Em outras palavras, é preciso levar em conta que, a partir da introdução dos meios de comunicação de massa $(\mathrm{MCM})$ e das novas tecnologias da informação em nossa vida diária, transformam-se os modos de existência, sensibilidade, percepção e aprendizado dos indivíduos. Em torno dos media, os atores sociais produzem estratégias de apropriação, organização e utilização mais ou menos efetivas, mais ou menos emancipadoras, mais ou menos democráticas. Visto que a comunicação constitui terreno essencial da sociabilidade, a atuação nas experiências coletivas e a própria conquista da cidadania passam a depender das possibilidades de acesso e dos usos desenvolvidos por aqueles agentes.

Tendo em vista a construção de uma sociedade plural e igualitária, faz-se necessário que as disputas pela hegemonia entre os diferentes atores ocorram em bases menos assimétricas, também e principalmente, no campo da comunicação. Para isso, independentemente das suas inserções sociais e culturais, os indivíduos têm o direito de posicionar-se autonomamente nesse cenário, dispondo da proficiência comunicativa requisitada para compreender as proposições que lhes são feitas via MCM e elaborar as suas próprias, e de espaço onde possam expressar-se livremente. Seria ingênuo supor que tais habilidades se desenvolvessem espontaneamente (sobretudo em função do alto grau de complexidade envolvido nos

\footnotetext{
${ }^{14}$ THIOLLENT, M. J. M. Crítica metodológica, investigação social e enquete operária, p. 31-39.
} 
processos de produção e circulação das mensagens mediáticas), ou que os referidos espaços estivessem automaticamente abertos à participação de todos (haja vista a concentração da propriedade dos meios de difusão de informações): é preciso construí-los. Essa tarefa, que constitui a Educação para a Comunicação e que também envolve a criação de espaços ou ecossistemas comunicativos, ${ }^{15}$ precisa ser empreendida de maneira organizada e consciente por entidades ou grupos comprometidos com a transformação social. Dentre todos, a escola é um espaço privilegiado para levar adiante esse projeto, graças à legitimidade cultural conquistada como uma instituição depositária do espírito crítico, responsável pela elaboração das aprendizagens e pela coerência da informação. ${ }^{16}$ Mais que isso, a escola é o espaço de iniciação do indivíduo na vida pública, realizando a mediação entre o mundo privado da família e a sociedade e promovendo a convivência que representa o substrato da cidadania democrática. ${ }^{17}$ É certo que a formação de docentes em serviço é um dos requisitos para a escola assumir essa tarefa, e que, num curto e médio prazo, é a condição necessária para promover a transformação das práticas pedagógicas no sentido da incorporação crítica e dialógica dos media na escola. Nesse terreno, pois, firmo o compromisso social desta pesquisa.

Finalmente, um terceiro nível de vigilância epistemológica tem a ver com a capacidade de o investigador posicionar-se consciente e criticamente em relação aos princípios que atravessam a construção de sua pesquisa. Em outras palavras, diante da impossível neutralidade, é preciso incorporar racionalmente a subjetividade do autor, desmistificando o processo científico. Para atender a essa exigência, busquei uma estrutura capaz de abarcar a complexidade de minha relação com o objeto e os diferentes sujeitos presentes e co-atuantes da pesquisa. Submeti-me, eu própria, a diferentes procedimentos aplicados às pro-

\footnotetext{
${ }^{15} \mathrm{O}$ termo ecossistema comunicativo foi definido por Ismar de Oliveira Soares como "a organização do ambiente, a disponibilização dos recursos, o modus faciendi dos sujeitos envolvidos e o conjunto das ações que caracterizam determinado tipo de ação comunicacional". Outros autores também trabalham com a noção de ecossistemas comunicativos. Martín-Barbero enfatiza, em sua abordagem sobre as mediações, a necessidade de superar a visão instrumental das tecnologias. Pierre Lévy destaca que a aprendizagem ocorre no contexto de uma ecologia cognitiva. Daniel Prieto Castillo reconhece vários modelos de ecossistemas comunicativos, que se distinguem segundo o grau de interatividade nos processos de trocas simbólicas. Para Soares, é importante destacar que o ecossistema comunicacional ainda não está dado, mas é construído pela vontade política dos agentes sociais. SOARES, Ismar de Oliveira. Metodologias da Educação para a Comunicação e gestão Comunicativa no Brasil e na América Latina. In: BACCEGA, Maria Aparecida (org) Gestão de processos comunicacionais. São Paulo: Atlas, 2002, p. 125.

${ }^{16}$ BELLONI, Maria Luiza. Educação para a mídia: missão urgente da escola. In: Comunicação e Sociedade. Revista de Estudos de Comunicação. v. 10, no 17, ago 1991, p. 41.

${ }^{17}$ Esta é a proposição de Júlio Groppa Aquino e Rosely Sayão, fundamentada nos estudos de Hannah Arendt. SAYÃO, Rosely; AQUINO, Júlio Groppa. Em defesa da escola. Campinas: Papirus, 2004. (Papirus Debates)
} 
fessoras. Permiti-me ser entrevistada e filmada, durante a participação em grupos de discussão. O resultado é um palimpsesto: se narro suas histórias de vida, sua aprendizagem, a elaboração de seus projetos pedagógicos e os contextos de realização de seu trabalho, nas entrelinhas conto como a nossa proposta de formação vai sendo constituída e modificada, sob as mesmas condições. Se isso não me desloca definitivamente da posição de pesquisadora, nem anula as assimetrias e os conflitos nas relações com os outros sujeitos na investigação, torna claro o ponto onde se origina o meu olhar e como, a partir dele, interajo com os demais.

\section{Desafios epistemológicos}

A investigação no campo transdisciplinar da Educomunicação - assim como em qualquer outro campo das Ciências Sociais - encontra-se diante de um desafio epistemológico que consiste na necessidade de erigir novas abordagens teóricas e metodológicas capazes de lidar com a realidade mundializada, acelerada e múltipla em que vivemos: "[...] a reflexão sobre a sociedade global transborda os limites convencionais desta ou daquela ciência social e logo fica evidente que qualquer análise envolve necessariamente várias ciências" ${ }^{18}$ Por todas as áreas cresce a percepção de que a estrutura disciplinar tradicional e o saber fragmentário que ela condiciona são insuficientes e inadequados para a produção de um conhecimento que possa solucionar os problemas complexos que hoje se colocam à humanidade - nas palavras de Edgar Morin, questões transversais, multidimensionais e planetárias. Mais ainda: a lógica da simplificação "projeta sobre a sociedade e as relações humanas as restrições e os mecanismos inumanos da máquina artificial com sua visão determinista, mecanicista, quantitativa, formalista, que ignora, oculta e dissolve tudo o que é subjetivo, afetivo, livre e criador", ${ }^{19}$ eliminando as possibilidades de um juízo crítico e corretivo, bem como a visão de longo prazo.

\footnotetext{
${ }^{18}$ LOPES, Maria Immacolata V. de. Por um paradigma transdisciplinar para o campo da Comunicação. In: DOWBOR, Ladislau et al. (orgs). Desafios da comunicação. Petrópolis: Vozes, 2001, p. 113.

19 MORIN, Edgar. Educação e complexidade: os sete saberes e outros ensaios. 3. ed. São Paulo: Cortez, 2005. p. 18. Menos radical é a posição da Comissão Calouste Gulbekian para a reestruturação das Ciências Sociais, da qual participam Immanuel Wallerstein (seu presidente), Ilya Prigogine, Dominique Lecourt, Calestous Juma, Evelyn Fox Keller, Jürgen Kocka, Valentin Mudimbe, Kinhide Mushakoji, Peter Taylor e Michel-Rolph Trouillot: "O momento que actualmente vivemos não é, propriamente, de falência da estrutura disciplinar exis-
} 
A ciência necessita reformar seu pensamento, religando os saberes e seus contextos. O ponto de partida para superar a fragmentação do conhecimento talvez seja a eleição de um novo ponto de vista, externo às disciplinas, que retorne à concretude dos fenômenos para reconhecer, neles, seus modos de interrelação. Não se trata de eliminar tudo o que já foi produzido até agora pelas ciências tradicionais, abolir os recortes disciplinares e muito menos tentar somar ou sobrepor as visões parciais de cada campo preexistente, mas de integrar esses saberes num novo quadro, multidimensional.

Assim pode ser com a Educomunicação. Se nós, seus pesquisadores, iniciarmos essa tarefa pela compreensão dos campos instituídos da Comunicação e da Educação, com suas tradições, métodos e especificidades, chegaremos à conclusão de que, apesar de guardar elementos comuns, entre ambos, não pode existir outra coisa senão a interdisciplinaridade. ${ }^{20} \mathrm{Se}$, ao contrário, nos voltarmos às práticas sociais e observarmos seu imbricamento, seremos forçados a reconhecer que a aceleração dos fenômenos comunicacionais e a difusão dos modos de aprendizado na vida contemporânea provocaram uma mudança qualitativa, na própria natureza desses processos, de tal modo que eles passaram a ser constitutivos das relações humanas na sociedade do conhecimento.

Superando a visão fragmentária de suas disciplinas, percebemos que comunicação e educação, como práticas sociais, estão profundamente interligadas. Pelos dispositivos de comunicação, os indivíduos aprendem mais e mais rapidamente que pelos sistemas educativos tradicionais. ${ }^{21}$ Por seu turno, a comunicação - entendida como interação simbólica - é a própria essência da educação dialógica. ${ }^{22}$ Já não

tente. O que se passa é que estamos num momento em que essa estrutura foi posta em causa e em que diversas estruturas concorrentes entre si procuram vingar. É nossa convicção que a tarefa mais urgente é a de fazer com que se proceda a uma discussão abrangente das questões subjacentes a todo este fenómeno." (Cf. WALLERSTEIN, I. et al. Para abrir as Ciências Sociais, p. 141.)

${ }^{20}$ Essa é a conclusão de Edson Gabriel Garcia, que vê a Educomunicação apenas como uma relação interdisciplinar e não um novo campo. GARCIA, E. G. Comunicação e educação: campos e relações interdisciplinares. Disponível em <http://www.eca.usp.br/nucleos/nce/perfil_edson.html>. Acessado em 20 jul 2006.

${ }^{21}$ A afirmação, de Guillermo Orozco Gómez, refere-se aos jovens. OROZCO GÓMEZ, G. Professores e meios de comunicação: desafios, estereótipos. In: Revista Comunicação e Educação. São Paulo: CCAVECA/USP; Editora Moderna, no 10, set.-dez. 1997. Martín-Barbero também destaca os novos modos de aprendizagem na sociedade contemporânea: para ele, os novos modos de ser e sentir estão calcados num desordenamento cultural que encontra suas raízes no descentramento do livro e da palavra impressa, operado pela introdução dos meios eletrônicos audiovisuais. MARTín-BARBERO, Jesús. Heredando el futuro. Pensar la educación desde la comunicación. In: Revista Nómadas. Bogotá: Fundación Universidad Central. n 5, set. 1996.

${ }^{22}$ Segundo Heloísa Dupas Penteado, a educação escolar é, em si mesma, um processo de comunicação e a pedagogia não é outra que uma pedagogia da comunicação, construída de interatividade e de significação. PENTEADO, H. D. Comunicação escolar: uma metodologia de ensino. São Paulo: Salesiana, 2002. 
basta falar desses fenômenos apenas em suas dimensões particulares, reduzindo sua compreensão à abordagem instrumental, como sói acontecer em seus campos distintos. Ambos são produzidos pela ação concreta individual e coletiva e estão, ao mesmo tempo, profundamente vinculados às condições sociais, políticas, econômicas e culturais mais amplas. Eis aí o miradouro da Educomunicação, onde um novo olhar, não-condicionado pelo conservadorismo, pode fertilizar a abordagem transdisciplinar. ${ }^{23}$

Se, como afirmou Marcel Proust, uma verdadeira viagem de descoberta não se resume à busca de novas terras, mas envolve a construção de um novo olhar, ${ }^{24}$ a tarefa a se empreender para o desenvolvimento de uma perspectiva educomunicativa é a de traduzir essa compreensão dos fenômenos numa construção teórica e metodológica ao mesmo tempo criativa e rigorosa, que cumpra os seguintes requisitos:

a) reconhecer o papel ativo dos sujeitos nos processos comunicativo e educativo, compreendendo que sua ação contribui para a produção de significação, visibilidade, legitimidade, modos de participação e configuração dos ecossistemas educomunicativos - e, portanto, centrando a análise na produção comunicativa dos atores sociais;

b) integrar a ação educomunicativa nos contextos sociais, políticos e culturais, tomando a ação individual ou coletiva como parte do processo histórico de disputa pela hegemonia e problematizando criticamente as assimetrias existentes entre os diferentes atores sociais;

c) superar a visão fragmentada, unilinear e parcial da comunicação e da educação, desenvolvendo uma análise integral e dialógica ${ }^{25}$ desses fenômenos;

d) reafirmar o compromisso ético com a redução das desigualdades, em nome da construção de espaços de participação e aprendizado horizontais, abertos às diversidades e democráticos.

\footnotetext{
${ }^{23}$ Edgar Morin diferencia a interdisciplinaridade (reunião de diferentes disciplinas "sem poder fazer outra coisa senão afirmar cada uma seus próprios direitos e suas próprias soberanias em relação às exigências do vizinho"), a polidisciplinaridade (associação de disciplinas em torno de um projeto ou objeto comum, para o qual colaboram) e a transdisciplinaridade (na qual os esquemas cognitivos atravessam as disciplinas, colocando-as em transe). Cf. MORIN, E. Educação e complexidade, p. 50.

24 "Pois se fôssemos a Marte ou a Vênus conservando os mesmos sentidos, eles revestiriam do mesmo aspecto que têm as coisas da Terra tudo o que pudéssemos ver. A única viagem verdadeira, o único banho de Juventa seria não partir em demanda de novas paisagens, mas ter outros olhos, ver o universo com os olhos de outra pessoa, de cem pessoas, ver os cem universos que cada uma delas vê, que cada uma delas é." (PROUST, Marcel. A prisioneira. 13. ed. Trad. Manuel Bandeira e Lourdes de Sousa de Alencar. São Paulo: Globo, 2002, p. 238.) ${ }_{25}$ A análise é dialógica no sentido de diálogo, desenvolvido por Paulo Freire, mas também no sentido concebido por Edgar Morin: de duas ou mais lógicas ligadas em uma unidade, de forma complexa (complementar, concorrente, antagônica), opondo-se à dialética. Para esse autor, a dialogia é um dos três princípios de reaprendizagem pela religação. Os outros dois são o rompimento com a causalidade linear em favor de uma causalidade em espiral e o princípio hologramático, pelo qual não apenas a parte está no todo, como também o todo está na parte. MORIN, E. op. cit.
} 
O repto de construir o olhar específico da Educomunicação - colocado ao conjunto dos que se propõem a estudá-la - pode ser recompensador. Não apenas por conjugar os serviços de diferentes disciplinas no enfrentamento dos novos problemas que verificamos no terreno, mas também por favorecer a formação de cientistas policompetentes, capazes de desenvolver um esquema cognitivo inédito, que permita realizar "articulações, organizadoras ou estruturais, entre disciplinas isoladas e [...] conceber a unidade do que era desunido". ${ }^{26}$ A sua institucionalização, com vistas à formação de educomunicadores (profissionais e pesquisadores aptos a atuar nas diversas áreas), não constitui, nesse sentido, um paradoxo. Ela não se refere à sua dimensão epistemológica, mas pragmática e organizativa.

A dificuldade de concretizar esse projeto reside, primordialmente, na conjugação entre linguagens e conceitos fundamentais de diferentes campos, que não podem ser simplesmente transferidos de um a outro. É preciso, ainda, ter em conta certas contradições, como adverte Maria Immacolata Vassallo de Lopes. Segundo ela, a proposta transdisciplinar tem causado tensões e polêmicas, sobretudo na América Latina, onde existe a tendência de se instalar a pesquisa de comunicação no espaço das ciências sociais e humanas, com enfoque sociocultural. O resultado seria o enfraquecimento do campo da Comunicação, com obstáculos à delimitação de um objeto próprio e à sua legitimação acadêmica. Entretanto, essa mesma debilidade poderia contribuir para o seu arejamento e integração: "[...] talvez daí ela tenha arrancado o sentido crítico e transformador que tem sido uma das marcas distintivas do pensamento latinoamericano em comunicação". ${ }^{27}$

Tais considerações, porém, não devem dissuadir aos que pretendem lançar-se ao desafio. Diversos campos têm condições de fornecer aportes para tal empreendimento e sua integração pode ser ensaiada com base no modelo de rede conceitual desenvolvido por G. Wersig. Nesse modelo, a estrutura teórica de um novo campo é tecida coletivamente, não pela formulação de leis gerais, mas por uma estratégia de ação em que conceitos científicos fundamentais funcionam como atratores de materiais teóricos e empíricos que são reestruturados dentro de um novo entrelaçamento. A partir de uma proto-rede de conceitos básicos, outros cientistas podem acrescentar novas formulações, tornando a trama mais complexa

\footnotetext{
${ }^{26}$ MORIN, Edgar. A cabeça bem-feita. Repensar a reforma. Reformar o pensamento. Rio de Janeiro: Bertrand Brasil, 2000, p. 111.

${ }^{27}$ LOPES, M. I. V. de. Por um paradigma transdisciplinar para o campo da Comunicação, p. 115.
} 
e coesa e ampliando seu caráter científico. ${ }^{28}$ Optei por contribuir com a proto-rede existente a partir da teoria da estruturação de Anthony Giddens, por acreditar que sua proposta é coerente com os requisitos anteriormente expostos.

Considerando que o meu ponto de partida é investigar possibilidades e limites da formação continuada para uma ação transformadora no ambiente escolar, o quadro de referências da pesquisa solicita uma formulação teórica apta a integrar, na interpretação dessa ação, a intencionalidade humana, o caráter ativo do sujeito e sua capacidade de compreender o que faz, tanto quanto as condições objetivas nas quais essa ação se torna possível. É precisamente esta a grande contribuição da teoria da estruturação de Giddens - converter o dualismo entre subjetivismo (o agente pode tudo) e objetivismo (as circunstâncias se impõem aos indivíduos) em dualidade: os atores sociais "fazem sua própria história, mas não a fazem como querem; não a fazem sob circunstâncias de sua escolha”. ${ }^{29}$ Sendo assim, o fazer humano é encarado de maneira complexa: corrobora tanto a transformação quanto a reprodução da sociedade. As noções de mudança social e de processo histórico que derivam desse entendimento são, pois, bem diferentes do evolucionismo; estão mais próximas do conceito de historicidade: "um sentido definido de vida num mundo social constantemente exposto à mudança”. ${ }^{30}$

Levando em conta, ainda, que esta pesquisa abarca no seu quadro de preocupações a discussão e a construção da autonomia das educadoras, ressaltando seu papel ativo no processo de formação, a teoria que nos serve de base precisa enfrentar o problema de como se constitui esse sujeito, sem ignorar o desgaste sofrido por este conceito ao longo das últimas décadas. Mais uma vez, para Giddens, a resposta está na superação das dicotomias:

[...] admito a exigência de que o sujeito seja descentrado e considero isso básico para a teoria da estruturação. Mas não aceito que isso implique a evaporação da subjetividade num universo

\footnotetext{
${ }^{28}$ A proposta de Wersig refere-se originalmente ao campo da Ciência da Informação. WERSIG, G. Information science: the study of postmodern knowledge usage. Information Processing \& Management, v. 29, n. 2 , 1993.

${ }^{29}$ A alusão à afirmativa de Marx é feita pelo próprio autor, cf. GIDDENS, Anthony. A constituição da sociedade. São Paulo: Martins Fontes, 2003, p. XXIII.

${ }^{30}$ Idem, ibidem. p. XXXI.
} 
vazio de sinais. Pelo contrário, consideramos que as práticas sociais, ao penetrarem no espaço e no tempo, estão na raiz da constituição do sujeito e do objeto social. ${ }^{31}$

Esse sujeito social se posiciona de maneira múltipla, dentro de relações sociais conferidas por identidades sociais específicas. Arrisco-me a dizer que, além de corporificado, ele é “ecologizado", na medida em que não apenas ele está posicionado em relação aos demais, como também os contextos de interação social o estão. Dessa maneira, o domínio básico de estudo, nessa perspectiva, são as práticas sociais ordenadas no espaço e no tempo.

Segundo a teoria da estruturação, na prática social, a ação transformadora humana (individual ou coletiva) é possível e condicionada por três grandes estruturas institucionais: as de significação (ligadas aos esquemas interpretativos subjetivos, à capacidade de agenciamento/criação/produção de sentido pelo indivíduo), as de dominação (relacionadas ao poder advindo da distribuição do acesso aos meios) e as de legitimação (vinculadas às normas sociais). Além da ação institucionalmente delimitada, os sujeitos sociais também são capazes de produzir sua consciência prática - sob forma não necessariamente discursiva.

Significação, dominação e legitimação funcionam como os conceitos atratores de minha rede teórica. No centro da teia estão o sujeito, sua ação e o contexto em que ela ocorre. Produzindo sua ação, a professora exerce sua autonomia e se torna autora de um projeto educativo. Ela o cria tendo em vista determinadas circunstâncias, as quais é capaz de reconhecer pela reflexividade que possui em relação às condições objetivas da estrutura escolar. Ao mesmo tempo, ela o faz acionando seu capital cultural, formado a partir de elementos que compõem a sua subjetividade, como sua história de vida, sua formação anterior, seus hábitos culturais e sua experiência profissional. Ao desenvolver seu projeto, durante a formação, a professora está incorporando novas habilidades comunicativas e saberes ao seu repertório, e esse movimento desencadeia a necessidade de rever e reintegrar elementos de sua identidade profissional e de sua consciência prática, vinculados às ideologias que compartilha com as colegas de trabalho. Tais elementos fazem parte de uma dimensão coletiva, na qual a concretização do projeto educativo depende da visibilidade e legitimidade que ele consegue alcançar junto aos membros da comunidade esco-

${ }^{31}$ GIDDENS, Anthony. A constituição da sociedade, p. XXIV. 
lar. Uma vez legitimado o projeto, este passa a ser institucionalizado, gerando (ou não) transformações nas políticas de ensino, de formação e no projeto político-pedagógico da escola. Esses últimos são elementos estruturais, que definem as rotinas das educadoras e regulam a distribuição e o acesso a recursos, tempos e espaços - componentes, portanto, do ecossistema escolar. A professora desenvolve o seu trabalho inicialmente constrangida por tais condições, mas seu projeto acaba por deslocar aquelas posições iniciais. É por essa razão que, na sua ação, o sujeito-professora colabora tanto para a reprodução quanto para a transformação social.

Nessa teia se entrelaçam conceitos próprios da Comunicação, da Educação e das Ciências Sociais, como podemos verificar no esquema a seguir:

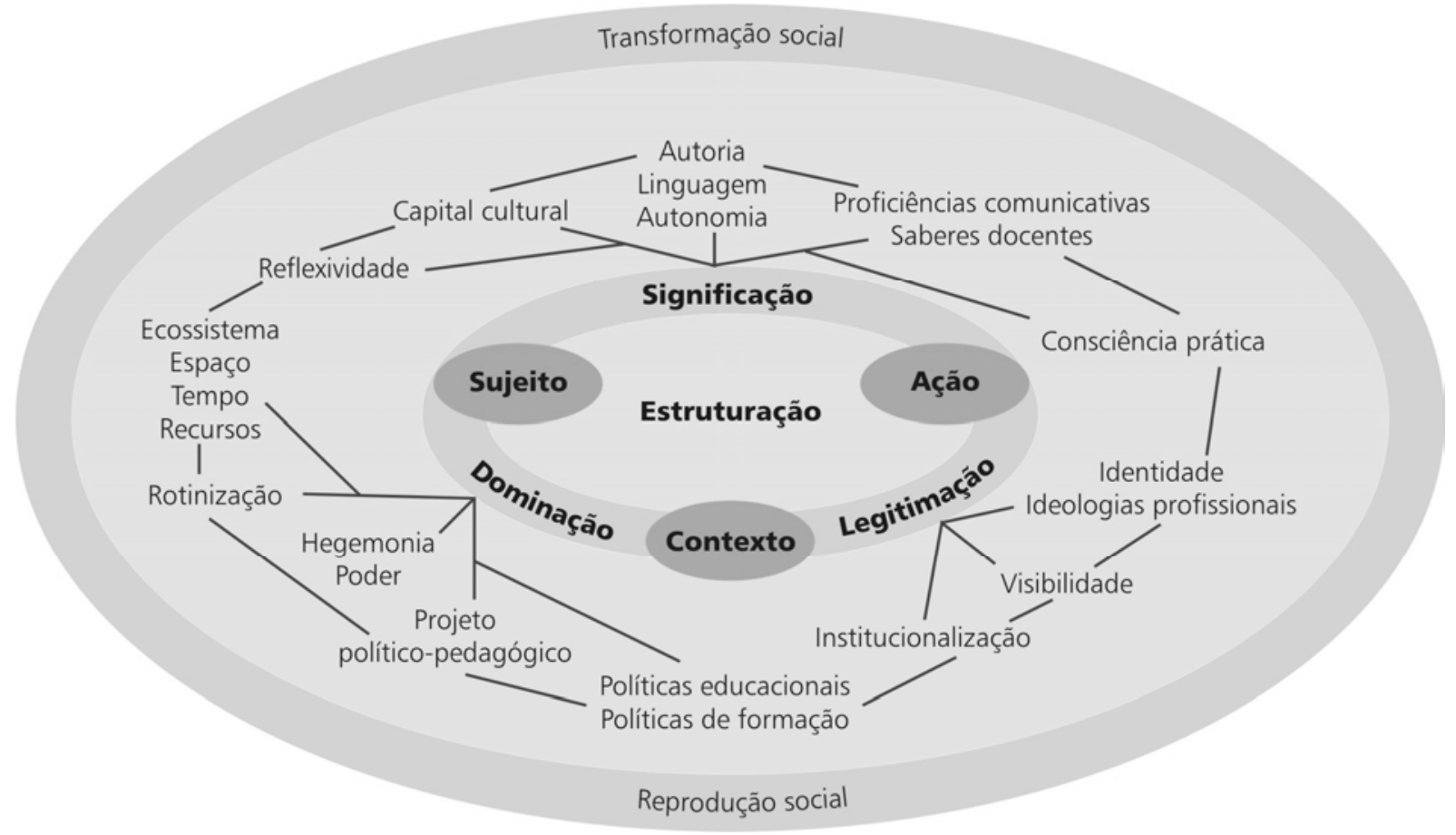

Figura 1: A rede conceitual da pesquisa

Esboçada a rede conceitual da investigação, cujos termos serão aprofundados no quadro de referências teóricas, posso agora explicitar a problemática. 


\section{Enunciando o problema da pesquisa}

A questão geral - quais as possibilidades e limites da formação continuada de professoras para o trabalho crítico e dialógico com os meios de comunicação e suas linguagens, em sala de aula - pode ser desdobrada nos seguintes eixos:

a) Como se dá a produção (subjetiva, autoral) de um projeto pedagógico pela educadora em formação continuada e que sentidos emergem em seu trabalho?

b) Em que medida o contexto sociopolítico e econômico (da escola, do bairro, do município) restringe a ação transformadora da educadora em formação?

c) Como o grupo em formação produz a legitimação das propostas educomunicativas frente à comunidade escolar, aos pares è̀ sociedade em geral?

A investigação foi desenvolvida por meio do estudo de caso das professoras da Rede Municipal de Campinas, inscritas no curso Pedagogia da Imagem pelo Centro de Formação do Magistério (Ceforma) ou por meio de iniciativas institucionais das escolas, entre 2006 e 2007.

\section{Sobre o Ceforma e o Curso Pedagogia da Imagem}

O Ceforma é um equipamento público destinado à formação dos profissionais da educação, em cursos ou grupos de trabalho, vinculado à Coordenadoria Setorial de Formação da Secretaria Municipal de Educação de Campinas (SME). As atribuições dessa coordenadoria foram definidas pelo decreto ${ }^{\circ}$ 14.460, de 30/09/2003:

I - realizar ações de formação em serviço de todos os profissionais da Secretaria Municipal de Educação (SME), no que se refere às atividades específicas de sua função e àquelas que os constituem como educadores;

II - organizar as ações para suprir as necessidades básicas de formação dos profissionais, exigidas para o exercício da função; 
III - viabilizar as diversas possibilidades formativas, tais como grupos de estudos/pesquisa, palestras, oficinas, dentre outros;

IV - viabilizar e organizar o material que subsidie a reflexão curricular de modo mais amplo que as especificidades das áreas de conhecimento;

$\mathrm{V}$ - articular a integração da formação entre a SME e a FUMEC;

VI - sistematizar o processo de vivência curricular, de forma a construir o currículo em movimento constante de pesquisa-ação, fundado na promoção constante da investigação e da produção acerca do trabalho pedagógico desenvolvido com a Rede e pela Rede. ${ }^{32}$

Os cursos de formação que o Ceforma oferece são realizados em parceria com universidades, por profissionais contratados pela SME ou, ainda, por profissionais da rede municipal. Têm carga horária mínima de 30 horas/aula, podendo ser centralizados ou organizados por regiões. A participação (certificada, mas não remunerada) é aberta a professoras e monitoras infantis da rede municipal e profissionais de entidades conveniadas com a Prefeitura. Os grupos de trabalho têm como finalidade encontrar soluções e produzir conhecimento sobre questões do cotidiano ou temas relevantes para uma determinada realidade. Podem ser organizados por escola, por região ou, ainda, pela Coordenadoria Setorial de Formação. Sua carga horária é variável, de acordo com as propostas. Docentes participantes recebem até 3 horas/aula semanais e os coordenadores, até 12 horas/aula semanais para realizar a função. ${ }^{33}$

De 2004 a 2006, foram abertas entre 1000 e 1500 vagas em 25 cursos de formação ou grupos de trabalho, para um universo de aproximadamente 4,5 mil professoras, monitoras e especialistas da SME de Campinas e da Fundação Municipal para Educação Comunitária (Fumec). Em 2007, o número de vagas foi de aproximadamente 3400, com 76 cursos sendo oferecidos. Entretanto, muitos deles tiveram de ser suspensos por um volume de inscrições insuficiente. Voltados ao estudo da comunicação, destaca-

\footnotetext{
32 CAMPINAS. Lei no 14.460. 30 set. 2003. Reorganiza a estrutura administrativa, as atribuições dos departamentos, coordenadorias e setores da Secretaria Municipal de Educação e dá outras providências. Diário Oficial do Município, Campinas, 1 out. 2003. p. 8.

${ }^{33}$ A partir de 2008, com a entrada em vigor do novo Plano de Cargos, Carreiras e Vencimentos dos Servidores do Município de Campinas (Lei no 12.985 de 28 de junho de 2007 e Resolução SME no 15/2007), a participação e remuneração em atividades de formação sofreu grandes alterações. Se, anteriormente, a freqüência aos grupos de trabalho era remunerada por meio do seu enquadramento como Trabalho Docente em Projetos (TDPR), com a nova legislação, ocorreu a extinção do TDPR, que foi parcialmente substituído pelas CHP e HP (respectivamente, Carga Horária Pedagógica, destinada ao trabalho pedagógico direto com alunos, exclusivamente dedicado ao reforço nas áreas de Português e Matemática, com vistas à melhoria de índices de desempenho escolar, e Horas-Projeto, nas quais é possível realizar a formação docente, mas apenas em cursos previamente determinados pelo Departamento Pedagógico, DEPE, e aprovados pelos Núcleos de Ação Educativa Descentralizada, NAEDs, focados em itens curriculares disciplinares). As HP são remuneradas pela SME a partir da distribuição de um saldo limitado de horas, conferido pelo DEPE aos NAEDs. Isso significa que a participação de docentes em cursos passou a depender da disponibilidade de horas e da aprovação sucessiva pelo NAED e DEPE, O que criou uma série de restrições.
} 
vam-se cursos que tematizavam a leitura crítica de jornal, o uso pedagógico do rádio e o trabalho com o corpo e com a arte, ligados ao programa Linguagem e Educação. ${ }^{34}$

Em 2008, acompanhando alterações nas regras de distribuição de horas e de remuneração da participação em cursos, a oferta de formação continuada foi sensivelmente reduzida, não apenas quanto ao número de vagas, como também em relação às temáticas abrangidas. Priorizando itens obrigatórios do currículo, a formação oficial deixou de proporcionar cursos e grupos em áreas como meio ambiente, transversalidades e as mídias e suas linguagens (entre eles, Imprensa na Escola, Rádio e TV, Histórias em Quadrinhos e o próprio Pedagogia da Imagem). Na área de Artes, restou apenas um grupo de formação com 25 vagas. Em informática, dois cursos totalizando 60 vagas. O Pró-Dança, já tradicional na rede, foi extinto. No anexo A encontra-se a relação dos cursos disponibilizados pelo Ceforma de 2006 a 2008.

Quadro 1: Formação continuada realizada pela SME de Campinas

\begin{tabular}{ccc}
\hline & \multicolumn{2}{c}{ Cursos e GTs oferecidos pelo Ceforma } \\
\hline Ano & Cursos e GTs & Vagas totais \\
\hline 2006 & 25 & 1500 \\
\hline 2007 & 76 & 3400 \\
\hline 2008 & 30 & 1400 \\
\hline
\end{tabular}

Fonte: Ceforma e Diário Oficial do Município

Vinculado, até 2007, ao programa Linguagem e Educação, o curso Pedagogia da Imagem foi organizado e proposto em 2003 por uma equipe de agentes culturais e historiadores do Museu da Imagem e do Som de Campinas, local onde era realizado. ${ }^{35}$ Inicialmente estruturado com duração semestral, foi sendo ampliado e, em 2005, foi oferecido com duração anual e carga horária de 60h. Em 2006, essa carga horária passou a 105h e, em 2007, a 160h, contando horas presenciais, de estudo e de prática na escola. Desde o início, a procura pelo curso tem sido grande, atingindo 106 candidatas em 2006, para 40 vagas disponíveis (28 delas concluíram o curso). Em 2007, terminaram o curso no MIS 19 educadoras, de 39 que iniciaram a formação.

\footnotetext{
${ }^{34}$ SECRETARIA Municipal de Educação de Campinas. Educação abre inscrições para cursos de formação continuada. Disponível em <www.campinas.sp.gov.br/smenet/noticias/noticia_2004_02_26b.htm>. Acessado em 13 set 2005.

${ }^{35} \mathrm{O}$ MIS é ligado à Secretaria Municipal de Cultura.
} 
Paralelamente ao curso oferecido por meio do Ceforma, a equipe da Pedagogia da Imagem organizou, em 2007, uma atividade formativa específica para atender a Escola Municipal de Ensino Fundamental (EMEF) Edson Luís Lima Souto. Nesse projeto institucional da escola foram atendidas 14 professoras.

Quadro 2: Oferta e demanda pelo curso Pedagogia da Imagem

\begin{tabular}{ccccc}
\hline \multicolumn{4}{c}{ Curso Pedagogia da Imagem oferecido via Ceforma } \\
\hline Ano & Carga horária & Vagas & Interessados & Formados \\
\hline 2006 & $105 \mathrm{~h}$ & 40 & 106 & 28 \\
\hline 2007 & $160 \mathrm{~h}$ & 40 & 46 & 19 \\
\hline Programa de formação na EMEF Edson Luís Lima Souto \\
\hline 2007 & $60 \mathrm{~h}$ & - & 14 & 13 \\
\hline
\end{tabular}

Fonte: Equipe Pedagogia da Imagem - MIS

Mesmo deixando de fazer parte do menu disponibilizado pelo Ceforma, em 2008, o programa Pedagogia da Imagem não se extinguiu: transformou-se. Graças a um trabalho de articulação com orientadoras pedagógicas, professoras e diretoras de EMEFs, muitas delas participantes do curso, ainda no final de 2007, pudemos abrir neste ano turmas mistas para professoras e alunos nas seguintes EMEFs: Pe. José Narciso Vieira Ehrenberg, Dulce Bento Nascimento, Edson Luís Chaves e Pe. Leão Vallerie (esta com dois grupos), além de acompanhar projetos desenvolvidos já autonomamente por professoras nas EMEFs Correa de Mello, Violeta Dória Lins e EMEI Recanto da Alegria e de desenvolver atividades pontuais (dinâmicas e debates) em inúmeras outras escolas. Cada uma das unidades encontrou uma forma própria para incluir a atividade no seu projeto pedagógico, de forma a assegurar a remuneração das docentes participantes. Também fizemos parcerias com setores da Assistência Social e da Saúde para formação popular em audiovisual.

Os objetivos da formação docente na Pedagogia da Imagem são:

a) promover a reflexão sobre a prática docente e sobre o sentido da introdução de meios e linguagens da comunicação na escola; 
b) familiarizar as educadoras com as tecnologias e linguagens da comunicação, ensaiando com elas metodologias que incorporem esses elementos no seu trabalho pedagógico, com foco no protagonismo do aluno;

c) incentivar a aproximação da professora ao universo sociocultural do aluno e da comunidade onde se insere a escola, problematizando os conflitos existentes nessa relação e discutindo a necessidade de estabelecer um diálogo horizontal como ponto de partida para a ação pedagógica;

d) fomentar a criatividade no desenvolvimento, sistematização e intercâmbio de metodologias e materiais de trabalho que incorporem os meios de comunicação e suas linguagens;

e) orientar a aquisição e incentivar a organização e o uso de recursos tecnológicos já existentes na escola, para fins pedagógicos e culturais;

f) discutir criticamente temas transversais e os modos como são abordados nos diferentes meios de comunicação.

A metodologia de trabalho, inspirada na pedagogia de Paulo Freire, inclui a pesquisa do perfil cultural das professoras, discussões em grupo, leituras, seminários, oficinas práticas, exibição e debate de filmes, sessões de sistematização de conhecimentos, visitas técnicas, palestras com convidados, produção e análise de materiais audiovisuais e o desenvolvimento de projetos nas escolas sob orientação e acompanhamento dos coordenadores do curso. No anexo B, encontram-se os programas construídos nos anos de 2006 e 2007. 

I CONSOLIDAÇÃO DO OBJETO DE PESQUISA 



\section{Tecendo a rede conceitual}

Promover a aproximação entre os Campos da Comunicação e da Educação, com vistas à tessitura de uma rede conceitual que fundamente e favoreça a compreensão das ações voltadas para a incorporação das linguagens e dos discursos mediáticos às práticas pedagógicas, solicita o recurso a um quadro teórico que ponha em relevo o papel dos sujeitos nos processos comunicativos e educacionais e, ao mesmo tempo, conserve uma perspectiva crítica. Seja pelo viés da linguagem, seja pelo da cultura, esse diálogo se torna possível a partir de diferentes abordagens, desenvolvidas nos referidos campos e nas Ciências Sociais.

\subsection{Sujeito: agente da comunicação e da educação}

Ao longo do século XX, o percurso das teorias da Comunicação foi-se orientado para a compreensão das relações - permanentemente tensionadas - entre os pólos vivos do processo comunicativo. Armand e Michèle Mattelart demonstram que, com a afirmação de novas metodologias de pesquisa, que assumiam como unidades de análise a pessoa, o grupo e as relações intersubjetivas na experiência cotidiana, diversas pesquisas fizeram reacender o debate sobre o papel do ator em relação ao sistema e sobre a autonomia das audiências diante do aparato da comunicação social. ${ }^{36}$ Com isso, as teorias estruturaisfuncionalistas, que por muito tempo dominaram a cena sociológica, foram perdendo terreno, suspeitas de produzir interpretações que reificavam os fatos sociais.

Esses estudos frutificaram nos campos da linguagem e da cultura e incluem: a lingüística pragmáticoenunciativa (noção de jogos de linguagem de Wittgenstein e teoria dos atos de fala de Austin - anos 50 e 60); a pesquisa literária de inspiração bakhtiniana (anos 60); as sociologias interpretativas (interacionismo simbólico, fenomenologia social e etnometodologia - anos 60); a sociologia habermasiana do

\footnotetext{
${ }^{36}$ MATTELART, Armand; MATTELART, Michèle. História das teorias da comunicação. 7. ed. São Paulo: Edi-
} ções Loyola, 2004. 
agir comunicativo (anos 80); os Cultural Studies com foco nas audiências (anos 80) e mesmo as sociologias funcionalistas (corrente dos Uses and Gratifications com a noção de leituras negociadas, anos 80).

\section{a) A compreensão dos fenômenos da linguagem e da produção de sentidos}

No campo da lingüística, a compreensão da linguagem numa dimensão instrumental-veicular foi cedendo espaço para concepções que enfatizam a dialogicidade e o papel ativo dos sujeitos envolvidos no processo de produção de sentido. De acordo com Adilson Citelli, as conceituações que tomavam a palavra como veículo para expressão do pensamento ou como instrumento formal para as idéias não permitiam compreender a dinâmica dos signos, senão como mero recurso descritivo das experiências humanas e das coisas do mundo. Um reducionismo, pois “[...] homens e mulheres não se apropriam dos estoques de sons, imagens e palavras como se estivessem procurando formas para exprimir conteúdos preexistentes". ${ }^{37}$

Implícita nessas formulações, que advogam a neutralidade das palavras, está a idéia de que os fenômenos da linguagem são completamente independentes da ideologia e que os discursos não possuem natureza própria, senão nas suas vinculações imediatas com fatos e acontecimentos a que se referem. Assim sendo, os contextos lingüísticos ou socioculturais nos quais os enunciados são formulados não desempenhariam qualquer função na produção dos sentidos. O próprio Citelli nos lembra o quão empobrecedor é esse conceito de linguagem, comparado a outras abordagens:

[...] ela [a linguagem] sugere e permite (veja-se a gama de possibilidades abertas pela idéia da produtividade discursiva); recobre e despista (o estereótipo é um bom exemplo disso); autorefere (ao deixar de ser apenas discurso sobre o real, torna-se discurso sobre os próprios mecanismos de se elaborar o real no discurso). ${ }^{38}$

\footnotetext{
${ }^{37}$ CITELLI, Adilson. Palavras, meios de comunicação e educação. São Paulo: Cortez, 2006. p. 29.
}

${ }^{38}$ Ibidem, p. 37. 
Já desde a primeira metade do século XX, desenvolvem-se teorias que consideram a linguagem em sua dimensão constitutiva da realidade, inseparável dos contextos em que se exercita como ação e irredutível ao caráter representativo do mundo. As principais contribuições, nessa direção, vêm das abordagens pragmáticas de Ludwig Wittgenstein e John Austin e da filosofia da linguagem de Mikhail Bakhtin.

Para Wittgenstein, os sentidos não estão fixados no cá da linguagem ou no lá do mundo, mas são produzidos no jogo que articula essas duas dimensões no interior de um enunciado. As regras desse jogo não existem a priori: dependem das circunstâncias mesmas em que entram em ação - os interlocutores, suas intenções, seu universo cultural, suas posições relativas, além, é claro, das palavras e seus usos.

A Teoria dos Atos de Fala, de John Austin, reafirma a dimensão pragmática e comunicativa da linguagem, na medida em que é por meio dela que os sujeitos agem e participam da vida social. Sendo assim, todo enunciado tem como objetivo promover uma performance ou realizar algo. Em cada ato de fala se integram três níveis: o locucionário (que permite dizer algo pela articulação dos elementos lingüísticos), o ilocucionário (que provoca efeitos de sentido, expressando vereditos, exercícios de poder ou direitos, compromissos, comportamentos ou exposições) e o perlocucionário (a ação ou performance propriamente dita que resulta do enunciado).

Por sua vez, a teoria elaborada por Mikhail Bakhtin evidencia a natureza interativa da linguagem, ao afirmar que sua função central é a comunicação e que a condição necessária para sua realização é a existência do par locutor-ouvinte:

A verdadeira substância da língua não é constituída por um sistema abstrato de formas lingüísticas nem pela enunciação monológica isolada, nem pelo ato psicofísico de sua produção, mas pelo fenômeno social da interação verbal, realizada através da enunciação ou das enunciações. A interação verbal constitui assim a realidade fundamental da língua. ${ }^{39}$

Segundo o autor, sendo um fenômeno social, essencialmente ação, a linguagem constitui a substância mesma da consciência (é a expressão que organiza a atividade mental, que a modela e determina sua orientação). A consciência ou mundo interior do indivíduo, portanto, floresce nas interações, no exercício

${ }^{39}$ BAKHTIN, Mikhail. Marxismo e filosofia da linguagem. 11. ed. São Paulo: Hucitec, 2004. p. 123. 
da enunciação, e é dada pela sua inserção social imediata ou mais ampla. Assim, quanto mais forte, organizada e diferenciada a coletividade na qual o sujeito se inscreve, mais distinto e complexo será seu mundo interior, maior será seu grau de consciência, a possibilidade de ser para si.

Apoiando-nos nas teses de Mikhail Bakhtin sobre a interação verbal, podemos compreender a importância da expressão do sujeito (educando/educador/comunicador) e da incorporação de seu contexto sociocultural nos processos de ensino-aprendizagem e comunicação social. De sua análise, depreendemos que promover o verdadeiro diálogo ou interação verbal no espaço escolar/cultural da comunidade, longe de ser a realização de um simples jogo de perguntas e respostas com sentidos pré-definidos, é estimular a expressão das pessoas, identificar com elas as orientações que revelam seus lugares de origem, suas inserções socioculturais e as ideologias do cotidiano que marcam seu discurso, caminhando com elas dos níveis mais fortuitos aos mais substanciais, onde possam adquirir a consciência crítica dos padrões ideológicos a que estão expostas e mobilizar a energia criadora necessária para a sua transformação. Tal exercício da linguagem as constitui como sujeitos históricos e transforma a sala de aula, a escola e a comunidade em um lugar de manifestação essencialmente polifônica. ${ }^{40}$ A partir de então, entende-se que, realizada no jogo dialógico entre emissores e receptores, a produção de sentidos não está centralizada em uma ou outra instância, mas nos deslocamentos entre ambas. ${ }^{41}$

Fundamentando-se nesses aportes teóricos, o campo da Comunicação deixa de abordar o público dos meios de massa como um alvo inerte das mensagens. Entretanto, são os avanços nos estudos culturais que permitirão superar a crença no receptor rendido incondicionalmente aos mecanismos manipulató-

\footnotetext{
${ }^{40}$ Aqui, o termo é uma apropriação do conceito formulado por Mikhail Bakhtin, no âmbito da teoria literária, para caracterizar a obra de Dostoievski e gerar a categoria do "romance polifônico". (BAKHTIN, M. Problemas da poética de Dostoievski. São Paulo: Forense-Universitária, 1963.) Originalmente, o termo refere-se ao fato de que, nesse tipo de romance, as vozes narrativas (personagens ou narrador) têm a mesma potência, dialogam com igualdade de poderes, sem o fechamento estético que confere ao narrador a palavra definitiva, transformando as demais vozes em objetos da narração. A incorporação dessas dimensões do conceito bakhtiniano nos parece adequada para repensar o exercício da linguagem em sala de aula. As implicações éticas da polifonia são discutidas em TEZZA, Cristóvão. "A polifonia como uma categoria ética". In: X Congresso Internacional sobre Mikhail Bakhtin, Gdansk, Polônia, jul. 2001.

${ }^{41}$ Para explicar o processo de produção de sentidos, Adilson Citelli recorre à metáfora de uma travessia sem atracadouros possíveis, apenas com instâncias de passagem, e justifica: "não é oportuno isolar pólos de produção dos sentidos imaginando que autonomamente possam orientar a construção das mensagens." (CITELLI, A. Comunicação e educação, p. 53.)
} 
rios dos poderosos agentes da indústria cultural. Com eles, entrarão em cena novas instâncias que disputam com os meios a orientação dos sentidos comunicacionais.

\section{b) A contribuição dos estudos culturais}

Surgidos em meados da década de 1950, os estudos culturais conduzidos pelo Centre for Contemporary Cultural Studies da Universidade de Birmingham consolidaram, nos anos que vão de 1968 a 1979, suas firmes bases teóricas. ${ }^{42}$ Nas décadas seguintes, tais estudos alcançaram legitimidade no meio acadêmico britânico. Recentemente, a incorporação das contribuições de Bakhtin levou os Estudos Culturais a uma "virada lingüística", com foco na discussão das identidades e dos discursos. Entre seus maiores expoentes estão Richard Hoggart, Raymond Williams, E. P. Thompson e Stuart Hall - cada um deles apresentando rupturas com as tradições de pensamento em que estava situado.

A escola de Birmingham foi responsável por estabelecer um contraponto ao pensamento marxista, passando a considerar a cultura como uma dimensão essencial para compreender as transformações históricas. Em vez de um conceito fechado de cultura, R. Williams desenvolveu uma noção complexa, que articula: a) cultura como o conjunto das descrições pelas quais as sociedades dão sentido e refletem suas experiências comuns; b) cultura como um modo de vida global, que relaciona os elementos das práticas sociais:

A cultura não é uma prática; nem apenas a soma descritiva dos costumes e "culturas populares" [folkways] das sociedades [...]. Está perpassada por todas as práticas sociais e constitui a soma do inter-relacionamento das mesmas. [...] A cultura é esse padrão de organização, essas formas características de energia humana que podem ser descobertas como reveladoras de si mesmas [...] dentro ou subjacente a todas as demais práticas sociais. ${ }^{43}$

\footnotetext{
${ }^{42}$ SOVIK, Liv. Apresentação: para ler Stuart Hall. In: HALL, Stuart. Da diáspora: identidades e mediações culturais. Org: Liv Sovik. Belo Horizonte: Editora UFMG; Brasília: Representação da UNESCO no Brasil, 2003. p. 9-22.

${ }^{43} \mathrm{HALL}$, Stuart. Estudos culturais: dois paradigmas. Ibidem, p. 136.
} 
Essa noção veio superar, por um lado, as definições idealistas e civilizadoras de cultura e, por outro, o materialismo vulgar que a considerava mero reflexo determinado pela base econômica, sem efetividade social.

Thompson, por sua vez, resgatou o conceito gramsciano da hegemonia para explicitar que a cultura só existe como luta e confronto entre modos de vida opostos, e não como um modo de vida global. Assim, numa sociedade, existem práticas culturais dominantes, residuais e emergentes exercendo mútuas pressões. Para ele, cultura são as disciplinas ou sistemas humanos complexos (articulados ou não, formalizados em instituições ou não) que lidam com, transmitem ou distorcem a experiência de vida. ${ }^{44}$ Existe, pois, uma dialética, mas não determinação mecânica, entre a base econômica e a cultura, o ser e a consciência social.

O paradigma culturalista influenciou profundamente os estudos da Comunicação, provocando redirecionamento de abordagens e reconectando pensamento e realidade histórica. Do ponto de vista teórico, ele permite compreender a relação público-meios de massa como um terreno não-homogêneo de disputas por significados e, portanto, coloca mais ênfase na produção criativa ou no papel dos atores sociais, aí incluído o receptor. ${ }^{45}$ Do ponto de vista metodológico, faz com que a crítica da Comunicação deixe de lado as excessivas abstrações estruturalistas (com sua visão determinista e evolucionista) e retorne aos problemas concretos do campo. Na medida em que qualquer análise passa a ter como base de autenticação a experiência, a teoria passa a dialogar com as demandas concretas de segmentos sociais que contestam a hegemonia cultural na sociedade mediática e de consumo.

Seguindo a trilha deixada por esses pensadores, na América Latina, Jesús Martín-Barbero desenvolve o conceito de mediações, que ressalta os processos socioculturais pelos quais os receptores balizam seus modos de apropriação dos discursos mediáticos e produção de sentidos. Sua análise parte dos "lugares dos quais provêm as construções que delimitam e configuram a materialidade social e a expressividade

\footnotetext{
${ }^{44} \mathrm{HALL}$, Stuart. Estudos culturais: dois paradigmas, p. 140.

45 "É a noção de que o significado não é fixo [...]. A noção de que o sentido sempre possui várias camadas, de que ele é sempre multirreferencial." HALL, S. Da diáspora, p. 354.
} 
cultural" dos meios - a cotidianidade familiar, a temporalidade social e a competência cultural ${ }^{46}$ - e segue em direção às lógicas de produção e dos usos. Oriundas do público, as demandas são recicladas e semantizadas pelo sistema produtivo da comunicação via dispositivos concretos: a competitividade industrial, os níveis e fases de decisão na produção de cada gênero, as ideologias profissionais, as rotinas de produção (serialidade) e, finalmente, as estratégias de comercialização. Os usos, articulados pela diferença social de classes, desdobram-se em competências culturais e interferem nos modos de ver, na organização do tempo e do espaço cotidianos.

Essa proposta lança o estudo da recepção diretamente no campo cultural: "dos conflitos articulados pela cultura, das mestiçagens que a tecem e dos anacronismos que a sustentam, e por fim do modo com que a hegemonia trabalha e as resistências que ela mobiliza, do resgate, portanto, dos modos de apropriação e réplica das classes subalternas". ${ }^{47}$ E vai além, no terreno dos desafios colocados pela transformação tecnológica à democratização da sociedade. ${ }^{48}$

Emerge daí a necessidade de assumir um entendimento mais abrangente dos processos culturais, escapando ao viés que opõe a "alta cultura" ao popular e este, folclorizado, ao massivo. É no reconhecimento das mestiçagens ou hibridações (como propõe García Canclini) ${ }^{49}$ que tais processos e as identidades deles derivadas podem ser compreendidos em sua historicidade e complexidade. ${ }^{50}$ Sem dúvida, uma

\footnotetext{
${ }^{46}$ A família, unidade básica de audiência da TV na América Latina, é "lugar social de uma interpelação fundamental para os setores populares [e...] um dos espaços fundamentais de leitura e decodificação da televisão". A temporalidade social refere-se à tensão permanente entre o tempo produtivo, valorizado pelo capital, que transcorre e é medido, e o tempo ritual que constitui a cotidianidade, repetitivo, feito não de unidades contáveis, mas de fragmentos, pelo qual a TV inscreve a cotidianidade no mercado. A competência cultural diz respeito ao reconhecimento dos gêneros que expressam o conteúdo da comunicação de massa e por meio dos quais se materializam as demandas de mercado por parte do público. (MARTíN-BARBERO, Jesús. Dos meios às mediações: comunicação, cultura e hegemonia. 2. ed. Rio de Janeiro: Editora UFR, 2003, p. 305-310.)

${ }^{47}$ Idem, ibidem, p. 312.

${ }^{48} \mathrm{Se}$, de acordo com Miguel de Moragas Spa, o âmbito da recepção envolve competências comunicativas que servem de ativação ou freio da participação social, então a democratização dos meios não diz respeito apenas ao seu controle, mas também às lógicas de seus usos.

${ }^{49}$ GARCÍA CANCLINI, Néstor. Culturas híbridas; estratégias para entrar e sair da modernidade. 4. ed. São Paulo: Edusp, 2003.

${ }^{50}$ Ainda, lembremos, com Stuart Hall, as conseqüências dos processos de transnacionalização sobre as identidades culturais: "a globalização tem, sim, o efeito de contestar e deslocar as identidades centradas e 'fechadas' de uma cultura nacional. Ela tem um efeito pluralizante sobre as identidades, produzindo uma variedade de possibilidades e novas posições de identificação, e tornando as identidades mais posicionais, mais políticas, mais plurais e mais diversas; menos fixas, unificadas ou trans-históricas." (HALL, S. A identidade cultural na pós-modernidade. 3. ed. Rio de Janeiro: DP\&A Editora, 1999. p. 87.)
} 
perspectiva instigante para refletirmos também sobre o anacronismo que representa a impermeabilidade do discurso escolar aos media.

\section{c) Dialogia: linguagem e cultura no pensamento pedagógico}

Tal como as teorias da comunicação, o pensamento pedagógico viu surgir, ao longo do século XX, abordagens dialógicas, em oposição às concepções de filiação funcionalista e estruturalista. Estas restringiam a educação a um processo de transmissão e acumulação de informações abstratas e anistóricas, por meio de relações altamente hierarquizadas e individualizantes, nas quais o aprendiz desempenhava papel de mero objeto (o paradigma comunicacional aqui implícito é o informacional: supõe o modelo estímulo-resposta e visa à obtenção de efeitos controlados).

A compreensão do caráter contextual, interativo e social da linguagem influenciou toda uma linha do pensamento educacional centrada na experiência do aluno e na interação com o professor. Entende-se que a linguagem não só transmite, mas cria e constitui o conhecimento, e que é no discurso e no intercâmbio entre indivíduos e grupos que se originam as categorias nas quais se estrutura a consciência. A reflexão, fase vital em toda aprendizagem autêntica, é um processo que se inicia como um diálogo para somente depois se fazer interior. ${ }^{51} \mathrm{O}$ espaço escolar, então, passa a ser visto como o lugar da socialização e das interações grupais - elementos essenciais dos processos educativos.

Seguindo essa perspectiva, ao redor do mundo, sucedem-se experiências e teorias que buscam renovar a educação. Dentre elas, destacam-se a Escola Nova, o Construtivismo e o Sócio-interacionismo. As proposições mais instigantes que emergem desse pensamento pedagógico consideram o aprendiz como o mediador do discurso escolar, sujeito que faz história, na experimentação, questionamento e problematização do cotidiano. Ainda, levam em conta a corporeidade, isto é, as dimensões afetivas e sensitivas envolvidas na formação da consciência, inseparável da experiência do corpo. A afirmação do sujeito-

\footnotetext{
${ }^{51}$ KAPLÚN, M. Processos educativos e canais de comunicação. In: Comunicação e Educação. São Paul o: CCA ECA USP, no 14, jan.-abr. 1999.
} 
educando, por sua vez, requisita a quebra das rígidas hierarquias escolares, deslocando o eixo do discurso e estabelecendo um fluxo comunicativo professor-aluno, tendo como objeto a realidade a ser conhecida. A comunicação torna-se, assim, requisito essencial para a realização da educação, na qual o saber dialogicamente produzido conduz à emancipação.

Tal perspectiva é a base compartilhada por diversas concepções pedagógicas progressistas que, conservando suas especificidades, têm sido formuladas no Brasil, a partir dos anos 50. Segundo Moacir Gadotti, naquele momento, os educadores brasileiros procuraram trilhar caminhos próprios, superando a dependência em relação a modelos, paradigmas e teorias elaborados em outros contextos. ${ }^{52}$ Dentre as propostas elaboradas, destaco as que buscam explorar a dimensão comunicativa (dialógica e culturalmente contextualizada) da educação.

Paulo Freire é quem inaugura essa tradição crítica, propondo que a educação (processo essencialmente humanizador) desempenha um papel político na construção de uma sociedade aberta, organizando as massas e ampliando sua participação. Para isso, a relação educativa deve ser horizontal, com o objetivo de gerar uma cultura vinculada aos interesses dos oprimidos, e não das elites. Criticando a educação bancária, propõe a produção de um saber emancipador, que parte da consciência da própria situação existencial em direção à práxis social engajada. O diálogo é, para ele, o requisito para se ultrapassar a visão imediata da vivência e alcançar o entendimento totalizante do contexto:

[...] esta educação em que educadores e educandos se fazem sujeitos de seu processo, superando o intelectualismo alienante, superando o autoritarismo do educador 'bancário', supera também a falsa consciência do mundo. [...] O mundo, agora, já não é algo sobre que se fala com falsas palavras, mas o mediatizador dos sujeitos da educação, a incidência da ação transformadora dos homens, de que resulte a sua humanização. ${ }^{53}$

Herdeiro desse pensamento, Carlos Rodrigues Brandão dedica-se ao problema da educação popular ou participante. De acordo com sua abordagem, a educação é um processo humanizador que ocorre ao longo de toda a vida, em espaços não necessariamente formais e de muitos modos distintos. A institucionalização do ensino, feita para orientar e controlar essa atividade, termina por reproduzir as desigual-

${ }^{52}$ Cf. GADOTTI, Moacir. Pensamento pedagógico brasileiro. 8. ed. rev. ampl. São Paulo: Ática, 2006.

${ }^{53}$ FREIRE, Paulo. Pedagogia do oprimido, p. 35. 
dades sociais, servindo aos interesses de grupos e classes dominantes. Sob o prisma de Brandão, a educação deixa de ser vista como um projeto salvacionista para ser encarada como uma luta possível, dentre outras práticas sociais, para a transformação da realidade. Comprometida politicamente com o oprimido, sua tarefa é fazer com que este aprenda a dizer a própria palavra, produzir o poder popular através de um novo saber popular. Também aqui, o conhecimento é construído a partir da inserção cultural.

\subsection{O contexto da ação: visão crítica para um projeto de sociedade democrática}

De acordo com o exposto até agora, ao aproximarmos os campos da comunicação e da educação a partir dos vetores da cultura e da linguagem, ressaltamos a capacidade de agenciamento histórico dos sujeitos dos processos sociais. Essa capacidade, contudo, se exerce num dado contexto e em relação a ele. Portanto, para ser efetiva, a ação social inclui uma dimensão reflexiva que abarca, ao mesmo tempo, uma visão crítica da realidade e um projeto para sua transformação. Dois pontos cruciais para os quais essa reflexividade se dirige, hoje, são as assimetrias nas relações de poder e o acesso às tecnologias de informação e comunicação.

\section{a) Acesso às tecnologias: por que, como e para quê?}

Se, nos dias atuais, estabeleceu-se um certo consenso sobre a urgência de incorporar os meios de comunicação e as tecnologias da informação aos processos educativos, isso não nos isenta da necessidade de discutir por que, como e para quê essa incorporação deve ser realizada. Para os neoliberais, trata-se de formar "capital humano" suficientemente qualificado para atuação num mercado de trabalho cada vez mais exigente e sofisticado, integrando-o ao circuito do consumo segundo uma lógica de estratificação e da máxima rentabilidade. Assim, o processo educativo deve oferecer a cada "público-alvo" as competências técnicas estritamente necessárias para obter os desempenhos esperados dos indivíduos, seja no ambien- 
te de trabalho, como consumidor ou mesmo como cidadão e eleitor. Qualquer esforço extra é considerado ineficaz. Para a maioria, portanto, bastará o saber operatório de certos equipamentos, enquanto bem poucos terão o privilégio de conhecer e elaborar os projetos de pensamento inerentes a cada tecnologia. Essa visão reforça e amplia as desigualdades sociais a partir das diferenças culturais:

[...] aparece um segundo elemento de divisão social mais importante que a conectividade técnica: a capacidade educativa e cultural de utilizar a Internet [podemos dizer, de modo mais abrangente, qualquer tecnologia.... Trata-se antes de saber onde está a informação, como buscála, como transformá-la em conhecimento específico para fazer aquilo que se quer fazer. Essa capacidade de aprender a aprender; essa capacidade de saber o que fazer com o que se aprende; essa capacidade é socialmente desigual e está ligada à origem social, à origem familiar, ao nível cultural, ao nível de educação. É aí que está, empiricamente falando, a divisória digital neste momento. ${ }^{54}$

Há, porém, uma visão alternativa, que concebe o ser humano não como um recurso produtivo, mas a partir de um projeto de humanização: ser pleno, ser mais, como diria Paulo Freire. Nesse projeto, a cultura desempenha papel fundamental, e a tecnologia não pode ser compreendida como simples instrumento de produção. Os meios de comunicação e as tecnologias da informação, dessa perspectiva, são bens culturais que, introduzidos no cotidiano e apropriados de diferentes maneiras pelos grupos sociais, dialeticamente reproduzem e transformam seus modos de vida e são reinvestidos nos processos de produção de identidades socioculturais, de participação política e de construção histórica. Ora, esses bens e os saberes que eles contêm e acionam não estão igualmente disponíveis aos diversos grupos sociais, tampouco seus usos possuem o mesmo significado para todos eles: "à medida que descemos na escala econômica e educacional, diminui a capacidade de apropriar-se do capital cultural [...]",55 bem como de converter os seus produtos simbólicos em patrimônio cultural e de legitimar suas narrativas como testemunhos históricos. Como lembra Gianni Vattimo, o relato histórico se produz não apenas a partir do que se julgou relevante, mas sobretudo daquilo que certos grupos que tinham condições de registrar (leia-se: meios de registro e preservação, conhecimentos históricos e capital cultural) julgavam relevante. $^{56}$

\footnotetext{
${ }^{54}$ CASTELLS, Manuel. Internet e sociedade em rede. In: MORAES, Dênis de. Por uma outra comunicação. Rio de Janeiro: Record, 2003. p. 265-266.

${ }^{55}$ GARCÍA CANCLINI, Néstor. Culturas híbridas, p. 194.

${ }^{56}$ VATTIMO, Gianni. A sociedade transparente. Lisboa: Relógio d'água, 1992, p. 9.
} 
Para García Canclini, é possível democratizar não só o acesso aos bens culturais, mas também a capacidade de hibridá-los, de combinar os repertórios multiculturais, desde que se incentive o reconhecimento das diversidades e a afirmação das solidariedades entre elas. As políticas democratizadoras devem evitar serem capturadas na armadilha do elitismo e da hierarquização entre culturas, determinando quais bens são legitimamente socializáveis e quais não o são. A educação imbuída do ideal democrático necessita construir espaços para o reconhecimento e o desenvolvimento coletivos, bem como proporcionar as condições reflexivas, críticas e sensíveis para questionar os obstáculos a esse projeto. ${ }^{57}$ Além do domínio dos meios e recursos necessários para a criação das próprias narrativas, a escola precisa incentivar entre os educandos uma postura desdogmatizadora dos discursos, permitindo que se libertem da rigidez das narrações monológicas.

Podemos, então, retomar a questão de por que, como e para quê a escola deve incorporar meios de comunicação e tecnologias da informação. Em primeiro lugar, como ressalta Martín-Barbero, para os filhos das classes populares, "a escola é o espaço decisivo de acesso às novas formas de conhecimento". 58 Abrir-se às tecnologias informáticas e aos meios audiovisuais, de maneira crítica e criativa, é um requisito para enfrentar as desigualdades e exclusões geradas no novo contexto sociocultural.

Em segundo lugar, considerar a dimensão cultural como inerente a toda tecnologia constitui uma resistência aos processos de desterritorialização que legitimam e aceleram a homogeneização das culturas, o desenraizamento das comunidades e o esfacelamento de suas identidades. Ao revalorizar o aspecto cultural e, portanto, local, o processo educativo pode enfatizar o direito à autogestão e à memória própria de cada grupo, estimulando sua capacidade de construir relatos e imagens de si mesmos. Para isso, não é necessário rechaçar a tecnologia, visto que as redes já se tornaram ponto de encontro e intercâmbio de minorias ou coletividades marginalizadas, bem como de grupos de trabalho educativo ou artístico. Por seu turno, a comunicação é cada vez mais percebida como instância da produção do reconhecimento social, da constituição e expressão dos imaginários e identidades. Dessa maneira, assumindo a tecnicidade mediática como uma dimensão estratégica da cultura, a escola poderá inserir-se nos processos de

\footnotetext{
${ }^{57}$ VATTIMO, Gianni. A sociedade transparente, p. 157.

${ }^{58}$ MARTíN-BARBERO, Jesús. Globalização comunicacional e transformação cultural. In: MORAES, Dênis de. Por uma outra comunicação, p. 62.
} 
mudança que a sociedade atravessa: "Comunicação e educação reduzidas ao uso instrumental dos meios na escola, fica de fora aquilo que seria estratégico pensar: a inserção da educação nos complexos processos de comunicação da sociedade atual - o ecossistema comunicativo que constitui o ambiente circundante". 59

Um terceiro aspecto, finalmente, merece ser mencionado: o fato de que os processos de produção e reprodução da cultura dependem da sua comunicabilidade. Ora, se as comunidades possuem proficiências comunicativas ${ }^{60}$ diversas, os modos pelos quais se dá sua apropriação e ativação resultam em maior ou menor potencial criativo da cultura, sobretudo no que diz respeito ao reconhecimento das diversidades e à abertura para as diferenças. De acordo com Martín-Barbero, a mediação comunicativa nos processos culturais trabalha para fazer possível diminuir os espaços de exclusão e aumentar o número de emissores e criadores, na medida em que ativa nos sujeitos a sua capacidade de narrar e, ao fazê-lo, construir sua identidade. Trabalhar essas proficiências no espaço escolar significa adotar uma ética polifônica, onde as diferentes falas e habilidades sejam incorporadas sem populismos, mas mobilizando múltiplas possibilidades de apropriar-se do mundo e dar-lhe sentido. Assim, em vez de estimular a competição entre indivíduos, a educação criaria solidariedades e um sentido plural de coletividade, fortalecendo um espaço público democrático:

[...] comunicar é tornar possível que homens reconheçam outros homens em um duplo sentido: reconheçam seu direito a viver e a pensar diferente, e reconheçam a si mesmos nessa diferença, ou seja, que estejam dispostos a lutar a todo momento pela defesa dos direitos dos outros, já que nesses mesmos direitos estão contidos os próprios. ${ }^{61}$

\footnotetext{
${ }^{59}$ MARTíN-BARBERO, Jesús. Globalização comunicacional e transformação cultural. In: MORAES, Dênis de. Por uma outra comunicação.

${ }^{60}$ Em lugar da expressão "competências comunicativas", utilizada por Martín-Barbero e outros autores, termo que poderia ser equivocadamente compreendido como conjunto de saberes instrumentais e padronizados, vinculado a um contexto neoliberal de competição, prefiro utilizar "proficiências comunicativas". Aqui, confiro-lhe o sentido de um horizonte de domínio mais ou menos amplo (nunca total) do sujeito - ou, preferencialmente, um grupo sociocultural - sobre o campo da comunicação, que lhe permite lidar autonomamente com as questões práticas (técnicas, operacionais e simbólicas) a ele subjacentes e que adquire contornos específicos segundo as inserções sociais, históricas e culturais concretas desses sujeitos e grupos. Assim, a proficiência comunicativa não é estabelecida a priori, como um conteúdo de saberes e habilidades a serem adquiridos, mas é definida contextualmente para cada grupo social específico. A possibilidade de estabelecer o diálogo entre proficiências de diversos grupos, que assim se apropriam criativamente de novos conhecimentos e habilidades, explicita o seu caráter colaborativo e ilimitado.

${ }^{61}$ MARTÍN-BARBERO, Jesús. Globalização comunicacional e transformação cultural. In: MORAES, Dênis de. Por uma outra comunicação, p. 70-71.
} 
Essa questão, contudo, ainda não pode ser adequadamente explorada sem se considerar os problemas das assimetrias de poder no espaço educativo e o modelo ou projeto que lhe serve de base.

\section{b) Assimetrias de poder nas relações de comunicação e educação}

Redirecionando o foco de análise das técnicas e seus efeitos para os modos de composição e representação da linguagem, a categoria dialogal reforça o papel ativo dos sujeitos e grupos sociais nos processos comunicativo e educativo. Isso não significa que desapareçam as assimetrias e disputas entre os atores e se instale, automaticamente, o entendimento harmônico. Permanece a necessidade de conservar um aporte crítico que compreenda as estruturas em torno das quais se organizam os modos de produção, circulação e consumo das mensagens. Ressalte-se, porém, que essa compreensão não se pauta diretamente pela linha frankfurtiana, que vê na razão instrumental o triunfo definitivo dos comportamentos conformistas regressivos e que elimina, por conseguinte, qualquer possibilidade de emancipação. ${ }^{62}$ Contribuição mais efetiva oferece o conceito gramsciano da hegemonia, entendido como uma trama complexa de sistemas de aliança e negociações no estabelecimento da vontade geral, objeto de luta de sujeitos sociais historicamente inscritos.

Ao recuperar o papel do agente na produção e reprodução da vida social, o pensamento gramsciano reconecta a crítica aos movimentos populares. $\mathrm{Na}$ esfera política, o componente ideológico-cultural passa a ser considerado um fator não meramente determinado, mas estruturante das relações de domínio, um campo estratégico de disputas, espaço articulador de conflitos e de produção de sentidos. Gramsci rompe com a concepção da ideologia como falsa consciência de classe, em favor de uma visão que a incorpora às práticas e aos aparatos de poder. Para ele, a ideologia, "uma concepção de mundo que se mani-

\footnotetext{
62 Para Theodor Adorno, a indústria cultural não deixa espaço para disputas, na medida em que impele a comportamentos de dependência, conformismo e servidão: "Através da ideologia da indústria cultural, o conformismo substitui a consciência. [...] O sistema da indústria cultural reorienta as massas, não permite quase a evasão e impõe sem cessar os esquemas de seu comportamento. [...] Ela impede a formação de indivíduos autônomos, independentes, capazes de julgar e de decidir conscientemente." (ADORNO, T. A indústria cultural. In: COHN, Gabriel. Comunicação e indústria cultural. São Paulo: Companhia Editora Nacional e Editora da USP, 1971. p. 293-295).
} 
festa implicitamente na arte, na lei, na atividade econômica e em todas as manifestações da vida individual e coletiva", ${ }^{63}$ possui uma base filosófica e uma base orgânica, estando ambas essencialmente vinculadas. As visões de mundo são necessariamente elaboradas em formas práticas e populares de consciência, que tocam o senso comum e cotidiano. A consciência resulta do sistema de relações ideológicas nas quais os sujeitos estão inseridos e se forma no terreno concreto onde eles se movem e lutam.

A releitura da obra de Gramsci, operada a partir dos anos 70, permitiu inaugurar concepções mais frutíferas em torno da relação cultura-meios de comunicação. ${ }^{64}$ Além da teoria da hegemonia, a contribuição de Gramsci para o campo da comunicação abrange seu pensamento sobre a cultura popular, a discussão metodológica sobre as ciências sociais e a sua problematização do conhecimento e da política. Suas reflexões, que promovem uma superação de interpretações mais esquemáticas e dualistas das relações entre os meios e suas audiências, são fundamentais para quem, assumindo uma perspectiva dialógica da educação, busca incorporar criticamente a cultura do aluno, permeada pela presença dos media, e promover dinâmicas de ensino-aprendizagem centradas no pensamento autônomo do educando. ${ }^{65}$ Seguindo esse raciocínio, a educação para os meios passa a valorizar, ao invés dos efeitos, as mediações (complexas e contraditórias) entre a cultura e as vivências sociais do estudante e a cultura de massas.

Se, como vimos anteriormente, as concepções dialógicas enxergam o espaço escolar como o locus da socialização e das interações grupais, essenciais aos processos educativos, também essas relações são marcadas por disputas e assimetrias de poder. Maurício Tragtenberg nos adverte: no sistema educativo, o professor é impelido a disciplinar, reprimir e discriminar os alunos por meio de notas, provas e avaliações. Pautada por procedimentos coercitivos, a prática do ensino reduz-se ao campo da vigilância sobre o tempo, o espaço e o movimento, para produzir corpos dóceis. Evitando, contudo, resvalar para um pessimismo apocalíptico, Tragtenberg enxerga a escola como um local de contradição e o professor, como um agente ambíguo de reprodução, mas também de crítica e contestação dessa ordem.

\footnotetext{
${ }^{63}$ Apud HALL, Stuart. A relevância de Gramsci para o estudo de raça e etnicidade. In: Da diáspora, p. 321. ${ }^{64}$ Cf. SIERRA, Francisco. El legado de Gramsci. In: Introducción a la teoría de la Comunicación Educativa. Madrid: Sevilla Editorial, 2000. p. 145-173. Essa retomada de Gramsci é feita, de modo mais significativo, pelos culturalistas da Escola de Birmingham. Por meio do trabalho de Raymond Williams, E. P. Thompson e Richard Hoggart, o conceito crítico central da análise social deixa de ser a classe e se desloca para as questões de subjetividade e identidade.

${ }^{65}$ Idem, ibidem.
} 
A formação desse educador será a preocupação de Moacir Gadotti. Aprofundando a perspectiva dialógica, ele irá questionar a organização do processo ensino-aprendizagem exclusivamente em torno da figura do aluno: "Parece-me um equívoco buscar centrar a pedagogia seja no professor (pedagogia tradicional), seja no aluno (pedagogia nova), seja nos conteúdos. Centrando num pólo, destrói-se a dialeticidade (unidade e oposição) da própria educação, entre professor e aluno e entre forma e conteúdo”. ${ }^{6}{ }^{6}$

Sua proposta é a de uma pedagogia da comunicação, que resgate a relação necessária entre docente e aluno. O primeiro não deve tentar moldar o segundo, mas conduzi-lo a descobrir e trilhar um caminho próprio. Da mesma maneira, Gadotti rejeita a culpabilização dos educadores pela crise que se verifica no ensino: "a deterioração da educação, e, em particular, da escola pública, deve-se ao descaso que a burguesia nutre pela democratização da cultura. [...] Trata-se de uma crise profunda: a crise capitalista”. ${ }^{67}$ Ele recusa, ainda, o mito de que a educação (concebida segundo o modelo liberal) é a alavanca para o progresso social, na medida em que democratiza as oportunidades de acesso ao saber e torna-se um trampolim para a promoção individual. Essas promessas, segundo ele, não podem ser sustentadas, pois o horizonte que as norteia é o da produtividade e do crescimento capitalista. Romper esse aparente paradoxo impõe que se questione o contexto de desigualdades que a própria educação reproduz. A prática pedagógica, então, assumindo um papel contra-hegemônico, deve desocultar o conflito e afrontá-lo, explicitando os mecanismos da exploração e da dominação. Apenas por meio da pedagogia do conflito é possível criar condições objetivas para fazer brotar a solidariedade e a organização entre os sujeitos, superando o seu individualismo e isolamento.

Adilson Citelli chama a atenção para um aspecto fundamental: as assimetrias de poder não se manifestam apenas por meio dos indivíduos, mas são componentes do próprio sistema educacional, através dos eixos da hierarquia, da coerção e da exclusão. ${ }^{68}$ Perpassando toda a estrutura escolar, eles se materializam nos programas educativos rígidos, na burocracia que emperra a transformação, nos mecanismos excludentes que, apoiados na lógica da eficiência e do desempenho, impõem um ritmo de aprendizado impessoal que dita a ordem dos conteúdos e das avaliações. A hierarquia, em primeiro lugar, é expressa na

\footnotetext{
${ }^{66}$ GADOTII, M. Pensamento pedagógico brasileiro, p. 112.

${ }^{67}$ Idem, ibidem.

${ }^{68}$ CITELI, A. Comunicação e educação: a linguagem em movimento.
} 
maneira como os programas e currículos são organizados: a partir do alto, determinando os conteúdos, objetivos, estratégias de aplicação e avaliação com base em padrões que ignoram a diversidade das condições socioculturais locais. Oferecendo caminhos prontos a percorrer, eles restringem a criatividade de educadores e educandos e transformam o processo escolar numa rotina de procedimentos cujo sentido se esgota em seu cumprimento. Pelos mecanismos coercitivos, atuantes quer sobre alunos, quer sobre professores, a escola busca criar e manter consensos. Notas baixas, advertências, expulsões, demissões e mesmo a desvalorização dos profissionais pela precarização de suas condições de trabalho são alguns dos artifícios empregados para assegurar o cumprimento e a perpetuação de seus modelos. Já a exclusão, que se origina fora da escola, nas condições sociais que limitam o acesso ao ensino, reproduz-se no ambiente educacional que restringe a progressão do aluno e força a sua desistência. Ainda quando se adotam mecanismos falsamente compensatórios, como a progressão automática, o resultado é, mais uma vez, o fracasso da aprendizagem e o agravamento das desigualdades.

\section{c) Sentidos dos projetos educacionais}

Para além do espaço escolar, as relações de poder estão presentes, sobretudo, nas disputas pela orientação dos sentidos dos projetos educacionais.

Uma das tendências é a massificação do ensino, fundamentada em concepções reducionistas da linguagem, da cultura e da comunicação, voltadas para a transmissão de conteúdos e a instrumentalização dos alunos. Mário Kaplún alerta sobre suas conseqüências: resta cada vez menos espaço para a comunicação e os intercâmbios entre os educandos, menos interesse e menos vontade para criá-lo, menos consciência do alcance do diálogo como componente necessário da ação educativa. "Os saldos sociais e políticos dessa educação individualizada aparecem suficientemente evidentes: de estudantes educados em e para 
o silêncio cabe esperar cidadãos passivos e não participantes". ${ }^{69}$ Configura-se, assim, um risco que Theodor Adorno já havia denunciado nos anos 60:

[...] uma democracia com o dever de não apenas funcionar, mas operar conforme seu conceito, demanda pessoas emancipadas. Uma democracia efetiva só pode ser imaginada enquanto uma sociedade de quem é emancipado.

Numa democracia, quem defende ideais contrários à emancipação, e, portanto, contrários à decisão consciente independente de cada pessoa em particular, é um antidemocrata, até mesmo se as idéias que correspondem a seus desígnios são difundidas no plano formal da democracia. $^{70}$

Outra possibilidade é a politização da educação. Para Adorno, uma sociedade livre não deve educar apenas para a adaptação dos indivíduos, mas também para a contradição e a resistência. Uma democracia torna-se meramente formal se os cidadãos permanecem, de fato, em situação de menoridade - tutelados, governados a partir de fora, impedidos do acesso à experiência concreta pela imposição de modelos ideais estereotipados e dogmáticos, alienados, enfim. A conquista da emancipação se dá, simultaneamente, pela socialização e pelo fortalecimento da individualidade (contraposta ao individualismo). A educação que pretenda promover o desenvolvimento da consciência verdadeira, superando a heteronomia, deve ser, simultaneamente, uma educação para a experiência e para a imaginação. Sobretudo, precisa voltar-se para a criação de novos sentidos para se existir e agir no mundo.

Podemos daí inferir que promover uma educação emancipadora e politizada requisita um movimento cujo alcance extrapola os limites da sala de aula e da própria escola. Ela envolve, necessariamente, as relações com o seu entorno e com a comunidade que ali vive. É, portanto, um desafio a ser enfrentado nos projetos político-pedagógicos das unidades de ensino. Também nesta altura é preciso esclarecermos as orientações que assume o termo "projeto político-pedagógico". Dependendo dos campos ideológicos a que se vincula, este tanto pode converter-se em um instrumento de controle, burocratização e despolitização quanto no seu contrário.

\footnotetext{
${ }^{69}$ Cf. KAPLÚN, Mário. Processos educativos e canais de comunicação. In: Comunicação e Educação. São Paulo: CCA ECA USP, no 14, jan.-abr. 1999. p. 72.

${ }^{70}$ ADORNO, Theodor W. Educação e emancipação. 4. ed. Rio de Janeiro: Paz e Terra, 2006, p. 141-142.
} 
O ponto de vista estratégico-empresarial enxerga o projeto político-pedagógico como um instrumento de controle e avaliação (externa) de políticas públicas. ${ }^{71}$ Ancorado no discurso pretensamente neutro da qualidade total, ele se volta a questões exclusivamente técnicas e quantitativas, em detrimento da reflexão política. Tomando a qualidade do ensino como um problema de eficiência no serviço ao cliente, essa perspectiva se funda na extrema divisão/ reificação do trabalho: "[...] o pensamento separado da ação; o estratégico separado do operacional; os pensadores separados dos concretizadores; os estrategistas separados das estratégias" ${ }^{72}$ A comunidade torna-se "consumidora" do serviço escolar e sua participação fica restrita ao sentido de colaboração e responsabilização pelos erros. ${ }^{73}$ Vista desse ângulo, a autonomia da escola diz respeito somente à sua dimensão material, jurídico-administrativa, e não ao processo de tomada de decisões - vertical, autoritário e essencialmente externo. Limitando seu enfoque aos temas da eficiência e do custo, essa abordagem confere mais importância aos meios que aos fins da atividade educativa. O currículo assim concebido é a síntese dessas características: "simples organização formal das disciplinas, dos conteúdos e dos tempos pedagógicos, [...com] orientações metodológicas estabelecidas a priori" ${ }^{74}$

Opondo-se a essa concepção, existe uma corrente teórica que advoga a construção do projeto políticopedagógico a partir de um ponto de vista emancipador. Tal empreendimento deve ser uma tarefa coletiva e democrática, que abarca dimensões pedagógicas, culturais, profissionais e políticas. Ele se caracteriza, ainda, como práxis, isto é, um processo contínuo de ação-reflexão-ação, alimentado pela dinâmica de interação com a comunidade:

\footnotetext{
${ }^{71}$ Essa reflexão é aprofundada em VEIGA, IIma Passos Alencastro. Projeto político-pedagógico: novas trilhas para a escola. In: VEIGA, I. P. A; FONSECA, M. (orgs) As dimensóes do projeto político-pedagógico: novos desafios para a escola. 3. ed. Campinas: Papirus, 2004. p. 45-66.

${ }^{72}$ Ibidem, p. 47.

${ }^{73}$ Ao explorar os sentidos da (não) participação dos pais na escola, Virgínio Sá desvenda algumas armadilhas ocultas em propostas que, a pretexto de democratizar o espaço educativo, acabam criando novas formas de exclusão: "No quadro das atuais políticas educativas, a emergência de novas modalidades de investimento escolar (im)postas aos pais - freqüentemente apresentadas como propiciadoras de elevadas taxas de retorno, ao pressuporem recursos cada vez mais elevados por parte dos investidores - pode estar se configurando como uma nova forma de discriminação social, transferindo para as vítimas o ônus da sua desventura, processando assim a 'democratização da exclusão' [...], podendo igualmente assumir [...] a forma de uma 'engenharia a favor da desigualdade legítima', desresponsabilizando, 'de forma honrada' [...] o Estado pela promoção de uma efetiva igualdade de oportunidades". (SÁ, Virgínio. A (não)participação dos pais na escola: a eloqüência das ausências. In: VEIGA, I. P. A.; FONSECA, M. (orgs.) op. cit, p. 96-97).

${ }^{74}$ SANTIAGO, Anna Rosa Fontella. Projeto político-pedagógico e organização curricular: desafios de um novo paradigma. In: VEIGA, I. P. A.; FONSECA, M. (orgs) op. cit., p. 155.
} 
[...] o projeto pedagógico da escola, ao se identificar com a comunidade local, busca alternativas que imprimam dimensão política e social à ação pedagógica. Articular não só a comunidade escolar em torno do projeto político-pedagógico, mas manter o elo com a comunidade, articulando-se às propostas comunitárias, fortalecendo a práxis. ${ }^{75}$

Requisitar a participação da comunidade, nesse sentido, implica o questionamento dos campos abertos à sua intervenção e dos limites que as educadoras tendem a considerar suas "reservas profissionais". ${ }^{76}$ Não se trata apenas de exigir a presença dos familiares na escola, nem simplesmente sua colaboração e apoio às decisões das especialistas. É preciso problematizar as relações de poder no ambiente escolar e suas assimetrias. A democraticidade desse processo se expressa na organização curricular, fundada no conhecimento e articulação (isenta de hierarquizações e preconceitos) da realidade sociocultural que circunda e perpassa a escola:

os elementos da tradição e da cultura que condicionam as relações de saber e poder, as influências externas que modificam ou desenvolvem esses elementos, os processos de interação que conduzem as expectativas e aspirações individuais ou coletivas, tecendo ideais e utopias possíveis, as formas como a comunidade busca solução para os seus problemas, as condições concretas de existência e os interesses orientadores do trabalho e do lazer - enfim, todas as questões que identificam as condições de inserção da escola no campo social como proposta institucional de desenvolvimento de uma comunidade específica que participa, propõe e articula-se a contextos mais amplos. ${ }^{77}$

O projeto político-pedagógico emancipador já não é um mero instrumento gerencial, senão a própria identidade da escola. Ele só se realiza (no inacabamento e na provisoriedade) pela formação de indivíduos autônomos e reflexivos, que possam se afirmar como sujeitos - capazes de investigar, inclusive, os saberes dos quais são portadores. ${ }^{78}$ Esses novos homens e mulheres compreendem que o ponto de partida para a produção do conhecimento são as teias das relações sociais e que a subjetividade (ou a maneira como cada um elabora o próprio saber) se fortalece no respeito às práticas culturais dos outros. Essa ética polifônica coincide com a proposta de Boaventura de Sousa Santos, de construção de um conhecimento solidário - a transformação do saber científico em um novo senso comum, um conhecimento-emancipação, liberto do conservadorismo e do hermetismo, traduzido em autoconhecimento e

\footnotetext{
${ }^{75}$ VEIGA, I. P. A. Projeto político-pedagógico: novas trilhas para a escola, p. 63.

${ }^{76} \mathrm{O}$ termo é de SÁ, Virgínio. A (não)participação dos pais na escola, p. 79.

${ }^{77}$ SANTIAGO, A. R. F. Projeto político-pedagógico e organização curricular, p. 152.

78 SOUSA, José Vieira de. A identidade do sujeito social, ético e político e o projeto pedagógico da escola. In: VEIGA, I. P. A.; FONSECA, M. (orgs). As dimensões do projeto político-pedagógico, p. 215-237.
} 
sabedoria de vida, apto a ser apropriado privilegiadamente pelos oprimidos, marginalizados ou excluídos, nas suas múltiplas redes que articulam e traduzem as diversas identidades sociais. ${ }^{79}$

\subsection{Formação docente: entre o diálogo e o conflito}

Lamentavelmente, tem sobressaído nas políticas públicas brasileiras a perspectiva gerencial, segundo um modelo cuja implementação deve ocorrer em três etapas. ${ }^{80}$ A primeira é a implantação do Conselho Escolar, responsável por gerir o fundo repassado por meio da "conta escola”, encarregando-se da compra e recebimento de mercadorias e da contabilidade. A segunda etapa prevista é a construção do Plano de Desenvolvimento Escolar (PDE), nos moldes do planejamento estratégico e rezando a cartilha da qualidade total. Em último lugar, devem vir as ações voltadas para a formação da professora. Marília Fonseca denuncia:

Não é difícil concluir que a gestão escolar é reduzida a um modelo de gerência, centrado no controle dos insumos escolares entre os quais se incluem os mestres. Aliás, o fato de a formação docente estar situada na última escala do projeto escolar leva a crer que, se o desempenho dos alunos alcançar o mínimo exigido pelos critérios burocráticos, a formação do professor poderia sequer ser considerada no projeto. ${ }^{81}$

Contraditoriamente a essa constatação, o Plano Nacional de Educação (PNE) aprovado no ano de 2001 aponta que a valorização do magistério, por meio de uma política global que inclui a formação inicial, as condições de trabalho, salário e carreira e a formação continuada, é uma premissa para a melhoria da qualidade do ensino e uma exigência para se alcançarem as metas educacionais estabelecidas nos diversos níveis. No texto, a qualificação docente é considerada um dos maiores desafios para o avanço científico e tecnológico da sociedade e, portanto, para o desenvolvimento do País:

\footnotetext{
${ }^{79}$ SANTOS, Boaventura de Sousa. Para um novo senso comum - A ciência, o direito e a política na transição paradigmática. 6. ed. São Paulo: Cortez, 2007. (v. 1. Crítica da razão indolente: contra o desperdício da experiência).

${ }^{80}$ FONSECA, Marília. A gestão da educação básica na ótica da cooperação internacional: um salto para o futuro ou para o passado? In: VEIGA, I. P. A.; FONSECA, M. (orgs) As dimensões do projeto político-pedagógico, p. 13-44.

${ }_{81}$ Idem, ibidem, p. 38.
} 
A melhoria da qualidade do ensino, indispensável para assegurar à população brasileira o acesso pleno à cidadania e a inserção nas atividades produtivas que permita a elevação constante do nível de vida, constitui um compromisso da nação [...que] não poderá ser cumprido sem a valorização do magistério, uma vez que os docentes exercem um papel decisivo no processo educacional. ${ }^{82}$

A formação em serviço recebe destaque no PNE, em razão da "exigência de um nível de conhecimentos sempre mais amplos e profundos na sociedade moderna”, devendo contribuir para a abertura de novos horizontes na atuação profissional. Seu objetivo, conforme o plano, é promover a reflexão sobre a prática educacional e a busca do aperfeiçoamento técnico, ético e político. Dentre os princípios enunciados para a qualificação docente, inclui-se o "domínio das novas tecnologias de comunicação e da informação e capacidade para integrá-las à prática do magistério”.

O PNE estabelece como obrigação das secretarias estaduais e municipais de educação a coordenação, o financiamento e a manutenção de programas de formação continuada para docentes da rede pública, sugerindo o estabelecimento de parcerias com universidades e instituições de ensino superior. Na determinação das metas, contudo, a preocupação maior dos formuladores do plano parece ter sido a de garantir às educadoras o nível de formação mínimo exigido pela Lei de Diretrizes e Bases da Educação Nacional (LDB).

Desde a aprovação do plano, o tema da formação tem sido amplamente discutido e diversas iniciativas vêm sendo empreendidas, visando alcançar transformações em sala de aula, em favor do desenvolvimento de mestras capazes de promover um ensino mais complexo. Surpreendentemente, a docente parece recolocada no centro das atenções.

A percepção dos especialistas, contudo, é a de que essa nova centralidade de que se reveste o papel da educadora ainda não saiu do plano retórico. Por trás de grande parte das iniciativas de formação está, na realidade, o objetivo de adequar a escola aos projetos neoliberais, ${ }^{83}$ tornando seus resultados limitados. Reclama-se que os efeitos da formação em serviço são questionáveis - e por vezes recai sobre a professo-

\footnotetext{
${ }^{82}$ BRASIL. Ministério da Educação. Lei no 10.172/2001. 9 jan. 2001. Aprova o Plano Nacional de Educação e dá outras providências. Diário Oficial da União. Brasília, 10 jan. 2001.

${ }^{83}$ LIMA, Maria Emília C. de Castro. Sentidos do trabalho: a educação continuada de professores. Belo Horizonte: Autêntica, 2005.
} 
ra o ônus desse "fracasso": "Aparentemente, quase todas as críticas do sistema escolar são concentradas no mesmo bode expiatório: a formação de professores, que é considerada demasiado curta, inadequada, inadaptada, insuficiente, antiquada. Mas ela não merece nem este excesso de honra nem esta indignidade!" 84

Maria Emília de Castro Lima lembra que, historicamente, no Brasil, os programas de formação continuada são marcados

[...] pela: 1) descontinuidade no tempo, no espaço e nas políticas implementadas; 2) natureza modular de seus cursos de curta duração, presenciais e a distância, numa perspectiva de treinamento; e 3) clara desconsideração das contribuições dos profissionais diretamente interessados no seu desenvolvimento pessoal quando da definição, implementação e suspensão dos programas de formação. ${ }^{85}$

Sem orientações claras, recursos específicos e produção teórica sobre si mesmos, a maioria dos programas gera desconfiança entre as professoras. No seu movimento de eterno recomeçar, distanciados da realidade e dos problemas cotidianos de sala de aula, focados em temas ou habilidades específicas, pouco contribuem para o enfrentamento dos desafios contemporâneos colocados ao magistério.

O problema da formação continuada, sob esse prisma, desemboca num impasse: de um lado, há um aparente consenso sobre a importância e urgência dessa tarefa; de outro lado, as mudanças que ela promove parecem lentas e insuficientes. Superar essa contradição implica adotarmos um novo ponto de vista e nos perguntarmos de que tipo de formação estamos tratando e em que contexto ela se dá, para - só então - tentarmos compreender suas possibilidades e limites e buscarmos alternativas.

Ainda segundo Lima, a formação de educadores em serviço pode ser concebida sob três principais vertentes. A primeira, com origem na década de 60, coloca ênfase na relação processo-produto. Fundamentada no behaviorismo, parte do princípio de que a ação do professor (processo) tem um certo impacto

${ }^{84}$ PERRENOUD, Philippe. Práticas pedagógicas, profissão docente e formação: perspectivas sociológicas. Lisboa: Publicações Dom Quixote, 1993, p. 94. A docência é, para este autor, uma profissão impossível - aquela onde, por melhor que tenha sido, a formação é incapaz de garantir um desempenho elevado e regular da atividade profissional, uma vez que seu insucesso é constitutivo. As competências auxiliam, tanto quanto possível, no domínio das situações imprevisíveis. Cf. p. 176.

${ }^{85}$ LIMA, M. E. C. C. Sentidos do trabalho, p. 19. 
na aprendizagem dos estudantes (produto). Desconsiderando a complexidade dos processos ensinoaprendizado, esse modelo funcionalista propõe a avaliação da eficiência do ensino e do comportamento docente e presta-se bem a reforçar os procedimentos coercitivos sobre o professor, bem como à sua culpabilização pelos problemas enfrentados.

A segunda vertente, dotada de uma orientação cognitivista, surgiu por volta dos anos 80, deslocando o foco para o modo como os educadores em atividade processam informações e promovem mudanças em suas práticas. Sua principal preocupação é compreender os saberes e referenciais de competência dos docentes, com base nos quais se supõe que eles ordenam e executam suas ações. $\mathrm{O}$ enfoque fenomenológico veio ampliar essa visão, ao considerar a história de vida dos educadores, os saberes originários da experiência e as dimensões afetivas e emocionais envolvidas no processo ensino-aprendizagem. O problema dessa visão está, segundo Tardif, 86 no seu foco mentalista, que reduz o saber, exclusiva ou principalmente, a processos mentais cujo suporte é a atividade cognitiva dos indivíduos (é uma vertente subjetivista).

Finalmente, a terceira vertente, dita social, concebe o papel fundamental da linguagem, das interações e da cultura na estruturação da experiência humana. Ela toma o pensamento, as competências e os saberes docentes como construções socioculturais constitutivas do sujeito. O professor, aqui, inserido historicamente, torna-se autor de seu processo de formação e do projeto de ensino-aprendizagem que põe em prática em sala de aula.

Essa abordagem sociológica é desenvolvida por Philippe Perrenoud sob o prisma da profissionalização. ${ }^{87}$ Ele defende que os projetos de formação devem assumir uma perspectiva ao mesmo tempo realista e inovadora. Sem abrir mão dos objetivos transformadores, é preciso manter os pés no chão e considerar as características mais fundamentais da prática pedagógica e da profissão docente. Isso significa, em primeiro lugar, assumir que a prática educativa não é totalmente consciente e racional, mas também, em parte, molda-se pela rotina do trabalho. Esta facilita a criação de situações estereotipadas, cristalizadas à medida que (e enquanto) se mostram eficazes para lidar com os problemas cotidianos. Face ao inespe-

\footnotetext{
${ }^{86}$ TARDIF, M. Saberes docentes e formação profissional. 6. ed. Petrópolis, Vozes, 2004, p. 11-12.

${ }^{87}$ PERRENOUD, Philippe. Práticas pedagógicas, profissão docente e formação.
} 
rado, o professor toma decisões de improviso, recorrendo antes ao seu habitus ${ }^{88}$ e aos valores pessoais que aos modelos teóricos. Em suma, a prática docente articula elementos conscientes e inconscientes, improvisações e métodos regulares.

Um segundo aspecto ao qual as propostas de formação devem atentar é o modo como o educador realiza a transposição didática dos conteúdos e saberes para as situações concretas onde deverão ser ensinados. A ação do professor torna-se decisiva justamente na passagem do currículo formal para o currículo real. Ele é, em última instância, o responsável pela gestão da aula, interpretando as lógicas de construção do conhecimento pelos diferentes alunos e reorganizando e transformando o saber em problemas, tarefas, interrogações, projetos e atividades. É necessário, portanto, que a formação incorpore, compreenda e analise os modelos pelos quais essa transposição se efetiva.

Finalmente, a educação de docentes deve considerar a sala de aula como um espaço onde se manifestam heterogeneidades sociais, econômicas, culturais e de aprendizado, que terminam por se traduzir em hierarquias, segundo as opções dos professores, expressas na didática e nos modos de gestão de seu ecossistema educativo.

Dessas considerações, Perrenoud infere que uma mudança da prática pedagógica depende tanto de uma transformação no habitus como da disponibilização de modelos de ação para o professor. É uma questão de oferecer possibilidades ou constrangimentos concretos, mais do que difundir novas idéias. Estas podem ser tomadas como chaves de compreensão das situações em classe, favorecendo a tomada de consciência e a reflexividade do educador. Incentivando o trabalho em comum de seu corpo docente, a escola poderia fomentar o surgimento de novas leituras da experiência e, com isso, a reinvenção de atividades e materiais que enriquecem a apropriação pessoal do papel profissional. Aqui, surge a autoria do professor, ilustrada pela figura do bricoleur. Seu formador, presente no momento da ação criativa, disponível para proceder colaborativamente a reflexão e a compreensão dos fenômenos, coloca em prática um modelo clínico de educação em serviço, em que teoria e prática estão fortemente vinculadas. O resul-

\footnotetext{
${ }^{88}$ A noção de habitus, tomada de empréstimo a Bourdieu (conjunto de esquemas que permite engendrar uma infinidade de práticas adaptadas a situações sempre renovadas, sem nunca se constituir em princípios explícitos), permite que Perrenoud veja a prática docente para além da concretização de receitas.
} 
tado é a profissionalização do educador, momento em que a ação determinada por regras preestabelecidas (heterônoma) cede lugar a estratégias orientadas por objetivos e por uma ética e construídas autonomamente.

A formação que pretenda transformar a prática educativa deve lidar, de maneira realista, com os trânsitos do poder nas relações escolares - educador-sistema-educandos. A solidão e a invisibilidade do trabalho docente são, muitas vezes, táticas contra o aborrecimento e a angústia da profissão. Protegidos no isolamento, os professores permitem-se assumir variados graus de liberdade na organização de seu cotidiano, bem como um certo nível de dispersão e desordem - elementos que Perrenoud vincula ao prazer e à criatividade inerentes à sua atuação. Na relação com o trabalho escolar, o professor aprende a agir sobre as regras e com as regras do sistema, da mesma forma que os alunos o fazem, mesmo sem ter plena consciência do jogo que se estabelece. As propostas didáticas que visam a renovar o fazer pedagógico vêm interferir nesse equilíbrio de poder, enfraquecendo o controle dos mestres e ampliando o espaço de manobra dos aprendizes. Elas mobilizam, conseqüentemente, a criação de novas estratégias e mecanismos de resistência. Construir uma nova identidade profissional requer, porém, estimular o trabalho em equipe e a comunicação entre os sujeitos, visando a negociação dos conflitos e a gestão das diferenças:

[...] o verdadeiro objectivo da formação não é o de dispensar competências e sim o de dar uma identidade, um projecto, meios para se encontrar prazer profissional numa prática exigente. [...] Pensar a prática não é somente pensar a acção pedagógica na sala de aula nem mesmo a colaboração didáctica com os colegas. É pensar a profissão, a carreira, as relações de trabalho e de poder nas organizações escolares, a parte de autonomia e de responsabilidade conferida aos professores, individual ou colectivamente. ${ }^{89}$

Perrenoud evidencia, ainda, a contradição existente na vinculação das instituições formadoras aos sistemas de ensino que pretendem transformar: "Em termos gerais, [...] a formação está à imagem do sistema que a gere. Como é que ela o poderia mudar?" ${ }^{90}$ Tais instituições deveriam dispor de maior autonomia, meios de investigação, reflexão e experimentação, a fim de cumprir melhor a sua missão. A formação precisa, além disso, ser valorizada e tornada atrativa para o docente (inclusive em termos salariais e de perspectivas de crescimento na carreira). Uma vez cumpridos esses requisitos, no entanto, isso não sig-

\footnotetext{
${ }^{89}$ PERRENOUD, P. Práticas pedagógicas, profissão docente e formação, p. 200.

${ }^{90}$ Idem, ibidem, p. 96.
} 
nifica que serão alcançados, imediatamente e por si sós, resultados milagrosos nas práticas pedagógicas: não se pode mudá-las contra a vontade geral do sistema. Qualquer expectativa no sentido da transformação deve considerar efeitos a longo prazo. É na sua rotina estruturada que o professor irá consolidar ou, ao contrário, descartar as mensagens de formação:

Seria ingénuo acreditar que a formação [...] pode ser o único ou principal motor da profissionalização. Ela só pode acompanhar ou preparar uma evolução desejada por vários actores colectivos. É nesta condição que os novos professores podem contribuir para a mudança das práticas nas salas de aula e nos estabelecimentos de ensino. Só lhes podemos pedir que corram riscos no quadro de uma vontade global de mudança, confirmada por uma preocupação de inserção profissional favorável à renovação dos saberes e das atitudes. ${ }^{91}$

A profissionalização docente também é a preocupação de António Nóvoa. Ele compreende a formação como um momento-chave de socialização e configuração profissional, oposto à proletarização da classe (divisão entre concepção e execução do trabalho, estandardização das tarefas, desvalorização da força de trabalho e intensificação das exigências em relação à atividade laboral - operações que culminam na redução da autonomia do professor). Sendo assim, Nóvoa advoga a formação como desenvolvimento que conjuga as dimensões pessoais e profissionais e que adquire sentido ao ser integrado ao quadro das histórias de vida - um processo de constituição de identidades, que requer um investimento pessoal, um trabalho livre e criativo (autoral) de definição de projetos e trajetórias próprias, e que forneça, simultaneamente, meios críticos e reflexivos para o educador conduzir e participar da sua profissão.

Tal como Perrenoud, Nóvoa considera que a mudança das práticas pedagógicas não depende somente de idéias renovadas, mas, igualmente, das condições e contextos em que o profissional atua. A formação não é, portanto, a condição prévia da mudança no sistema escolar, mas um item do seu ecossistema: "É esta perspectiva ecológica de mudança integrada dos profissionais e dos contextos que dá um novo sentido às práticas de formação de professores." 92

\footnotetext{
${ }^{91}$ PERRENOUD, P. Práticas pedagógicas, profissão docente e formação, p. 153.

${ }^{22}$ NÓVOA, A. (coord.) Os professores e a sua formação. 2. ed. Lisboa: Publicações Dom Quixote, 1995. (Nova Enciclopédia, 39), p. 28.
} 
A reflexividade também está presente no pensamento desse autor português, para quem o saber proveniente da experiência deve ser integrado à consciência profissional a partir das grades de leitura fornecidas pela teoria. Ela pode ser compreendida como a produção de sentidos sobre as experiências da vida e, como tal, torna-se um processo coletivo e dialógico. O professor reflexivo é um investigador que concebe (e não somente aplica) os currículos e os métodos, em sala de aula.

A idéia do professor-reflexivo é - de acordo com a constatação de Carlos Marcelo García - o conceito mais utilizado, na atualidade, por investigadores, formadores de professores e educadores, para se referirem às tendências da formação. Originado no pensamento de J. Dewey, nos anos 30, o termo foi renovado e difundido por Donald Schön a partir dos anos 80, com o sentido de promover a reflexão na ação (práxis $)^{93}$ : "[...o ensino] é uma profissão em que a própria prática conduz necessariamente à criação de um conhecimento específico e ligado à ação, que só pode ser adquirido através do contacto com a prática, pois trata-se de um conhecimento tácito, pessoal e não sistemático." ${ }^{94}$

Essa noção tem fundamento na verificação empírica de que os professores possuem "teorias práticas", implícitas, sobre o que é o ensino - e isso, mesmo permanecendo inconsciente ou pouco articulado internamente, influencia a sua atuação em serviço. De acordo com seus defensores, a reflexividade profissional deve iniciar no nível técnico (das ações explícitas), passando pelo nível prático (do planejamento didático), até alcançar a crítica (das considerações éticas e políticas sobre a própria atividade). Sua aplicação à educação de professores impõe a criação de condições para a colaboração e o trabalho em equipe, que rompam o isolamento dos indivíduos, bem como o acompanhamento, apoio pessoal e assistência técnica, oferecidos pelos formadores, em relação às ações que aqueles implementam em sala de aula (esse coaching defendido por García assemelha-se à proposta da formação clínica de Perrenoud e à idéia de practicum reflexivo de Schön e Zeichner). A formação continuada é, portanto, uma tarefa de investigação e de constituição do professor como pesquisador:

\footnotetext{
${ }^{93}$ A historicidade da noção de professor-reflexivo ou professor-pesquisador é explorada em profundidade por CAMPOS, S.; PESSOA, V. I. F. Discutindo a formação de professoras e de professores com Donald Schön. In: GERALDI, C. M. G.; FIORENTINI, D.; PEREIRA, E. M. A. (orgs.) Cartografias do trabalho docente: professor(a)-pesquisador(a). Campinas: Mercado de Letras: Associação de Leitura do Brasil, 1998. (Coleção Leituras no Brasil), p. 183-206.

94 GARCÍA, Carlos Marcelo. A formação de professores: novas perspectivas baseadas na investigação sobre o pensamento do professor. In: NÓVOA, A. (coord.) Os professores e a sua formação, p. 51-76.
} 
Não é suficiente perguntar aos professores o que fazem, porque entre as ações e as palavras há por vezes grandes divergências. Temos que chegar ao que os professores fazem através da observação directa e registrada que permita uma descrição detalhada do comportamento e uma reconstrução das intenções, estratégias e pressupostos. ${ }^{95}$

Nesse modelo de educação continuada, a colaboração entre os formandos e o apoio técnico dos formadores, visando à resolução de problemas em contextos reais, gera uma situação de "fabricação coletiva de saberes". Ressalte-se, antes de mais nada, que essa parceria entre formadores e formandos não deve gerar uma nova hierarquia - a dos especialistas sobre os professores, nas quais os últimos apenas aplicam as conclusões dos primeiros. ${ }^{96} \mathrm{O}$ conhecimento, na prática reflexiva autêntica, não é dado de antemão, mas é produzido na cooperação, numa contínua negociação dos conteúdos. Esse suporte do grupo, ao lado de uma perspectiva de desenvolvimento pessoal que propicia tanto prazer quanto novas aprendizagens, é um elemento que impulsiona, no professor, a disposição para mudar seus métodos de trabalho. ${ }^{97}$

No pensamento de Schön, as formulações a respeito da reflexividade docente também incluem a crítica a um modelo de política educativa baseado na regulação de orientações que emanam de um governo central para uma periferia de instituições locais, reforçada pela distribuição de prêmios e punições. Nesse jogo, as respostas das escolas tendem a defender a manutenção de sua relativa autonomia. Como num "efeito cascata", qualquer tentativa dos professores de caminharem em direção a uma prática reflexiva culmina, muito provavelmente, num confronto com a burocracia escolar e com o saber da qual essa instituição é portadora. Conseqüentemente, “[...] o desenvolvimento de uma prática reflexiva eficaz tem que integrar o contexto institucional [e o...] professor tem de se tornar um navegador atento à burocracia”. ${ }^{98}$ Nesse campo de forças, Ken Zeichner ressalta, ainda, a interação escola-comunidade. Para ele, inserir essa problemática nos programas de formação de professores é uma iniciativa pertinente: diante

\footnotetext{
${ }^{95} \mathrm{SCHÖN}$, D. Formar professores como profissionais reflexivos. In: NÓVOA, A. (coord.) Os professores e a sua formação, p. 90.

${ }^{96}$ Essa é uma das quatro críticas que Zeichner aponta ao falso entendimento da reflexividade. As demais são: a limitação da reflexão à questão técnica do ensino; a individualização da reflexão; e, conseqüência da anterior, a individualização das responsabilidades pelos sucessos ou fracassos do trabalho pedagógico. Cf. GERALDI, C. M. G.; MESSIAS, M. G. M.; GUERRA, M. D. S. Refletindo com Zeichner: um encontro orientado por preocupações políticas, teóricas e epistemológicas. In: GERALDI, C. M. G.; FIORENTINI, D.; PEREIRA, E. M. A. (orgs.) Cartografias do trabalho docente, p. 237-274.

${ }^{97}$ CHANTRAINE-DEMAILLY, Lise. Modelos de formação contínua e estratégias de mudança. In: NÓVOA, A. (coord.) Os professores e a sua formação, p. 139-158.

${ }^{98}$ Ibidem, p. 87.
} 
dos desafios crescentes, urge alterar os padrões normais dessas relações, incentivando a configuração de um ambiente mais democrático.99

No interior dessa linha sociológica da formação, Maurice Tardif prefere realçar os processos de construção de conhecimento envolvidos no trabalho docente. Para ele, é importante articular os aspectos sociais e individuais do saber dos professores:

[...] não creio que se possa falar do saber sem relacioná-lo com os condicionantes e com o contexto do trabalho: o saber é sempre o saber de alguém que trabalha alguma coisa no intuito de realizar um objetivo qualquer. Além disso, o saber não é uma coisa que flutua no espaço: o saber dos professores é o saber deles e está relacionado com a pessoa e a identidade deles, com a sua experiência de vida e com a sua história profissional, com as suas relações com os alunos em sala de aula e com os outros atores escolares na escola, etc. ${ }^{100}$

A natureza social do saber reside em que: a) ele é partilhado por um grupo de agentes que possuem uma formação comum, trabalham numa mesma organização e estão sujeitos a condicionamentos e recursos comparáveis; b) sua posse e utilização são fundamentadas em todo um sistema que garante a sua legitimidade e orienta sua definição e seus usos; c) o objeto desse saber são as práticas sociais; d) tanto o que os professores ensinam quanto sua maneira de ensinar transformam-se com o tempo e as mudanças sociais; e) ele é adquirido no contexto de uma socialização profissional.

Entretanto, existe também uma natureza subjetiva desse saber, dada pela contribuição dos atores na sua construção concreta, em face dos seus contextos de trabalho, promovendo adaptações e transformações. Importa, ainda, considerar os sentidos dados pelos professores ao seu saber e ao seu fazer.

Para integrar essas duas dimensões, Tardif segue alguns fios condutores. O primeiro deles é a relação entre o saber e o trabalho: o uso dos saberes pelos professores não depende exclusivamente de fatores cognitivos, mas é mediado, sobretudo, em função de seu trabalho e das situações, recursos e condicionamentos ligados a ele. Os saberes são unificados e recompostos no e pelo trabalho. Em função de sua utilidade no

\footnotetext{
99 ZEICHNER, Ken. Novos caminhos para o practicum: uma perspectiva para os anos 90. In: NÓvOA, A. (coord.) Os professores e a sua formação, p. 115-138. 100 TARDIF, M. Saberes docentes e formação profissional, p. 11.
} 
ensino é que os saberes são hierarquizados, valorizados e postos em funcionamento. A experiência de trabalho converte-se, então, em saber sobre os saberes, em síntese, reflexividade.

Detendo-se na natureza interativa do trabalho do professor, Tardif desloca a ênfase do paradigma material-industrial (que pensa a escola a partir das divisões do trabalho, das especializações, da massificação e da seriação) e da racionalidade técnica (efeitos da educação, eficiência, qualidade total e modernização tecnológica) para o problema da interação humana: "A questão do saber está ligada, assim, à dos poderes e regras mobilizados pelos atores sociais na interação concreta. Ela também está ligada às interrogações relativas aos valores, à ética e às tecnologias da interação". ${ }^{101}$

Um outro fio condutor diz respeito à diversidade e à pluralidade dos saberes docentes: os profissionais (oriundos das ciências da educação e da ideologia pedagógica), os disciplinares (das ciências organizadas), os curriculares (dos discursos, objetivos, conteúdos e métodos constantes nos programas escolares) e os experienciais (o habitus, as habilidades, o saber-fazer e o saber-ser, eminentemente práticos). Aqui, a proposta de Tardif é de que os professores empenhem-se em uma estratégia de profissionalização, liberando os saberes da prática cotidiana e da experiência vivida, de modo a torná-los reconhecidos por outros grupos produtores de saberes, e a impor-se como "um grupo produtor de um saber oriundo de sua prática e sobre o qual poderia reivindicar um controle socialmente legítimo". ${ }^{102}$

A temporalidade do saber é mais um fio condutor do pensamento de Tardif. Esse elemento envolve tanto a história familiar e escolar dos professores (suas vivências como alunos) quanto a sua perspectiva de carreira. Ao longo do tempo, a trajetória profissional é marcada por momentos de socialização, consolidação de experiências de trabalho, transformações, mudanças, que passam a integrar a identidade e a subjetividade dos educadores.

Por fim, Tardif se debruça sobre o problema da formação. Para ele, é preciso superar a abordagem disciplinar e aplicacionista que a educação para o magistério até o momento tem adotado. Os projetos de reforma e profissionalização docente, porém, ainda estão em aberto, e os modelos de identidade dos pro-

101 TARDIF, M. Saberes docentes e formação profissional, p. 22.

102 Ibidem, p. 54. 
fessores (como tecnólogo do ensino, como prático reflexivo ou como ator social engajado) disputam espaço num campo de forças orientadas política e ideologicamente.

Emília Freitas de Lima demonstra como diferentes concepções do saber docente estão implícitas, historicamente, nas orientações dos projetos de formação, tanto das políticas públicas quanto do pensamento pedagógico brasileiro. Analisando os cursos de Pedagogia no Brasil, ela identifica três fases ou tendências. A primeira vai de 1939 até 1968, ano em que se realiza uma reforma universitária. Esse período é marcado por uma sólida formação teórica, conteudista e fragmentária, orientada pelos princípios da racionalidade técnica. A segunda fase, de 1968 até 1996, ano da aprovação da LDB, caracteriza-se pelo aprofundamento do paradigma da racionalidade técnica, com o crescente retalhamento dos saberes em especialidades e disciplinas. Observa Lima:

Em ambas as fases, é notória a inspiração epistemológica no paradigma da racionalidade técnica. Neste paradigma o conhecimento científico é visto como nocional e imutável, o saber escolar estritamente como conjunto de conhecimentos eruditos, valorizados pela humanidade (ou seja, um saber de classe) e os requisitos para a atuação docente resumem-se ao domínio dos conteúdos das disciplinas e à técnica para transmiti-los. Nesse contexto, a formação inicial era tida como capaz de dar conta da formação dos profissionais da educação, bastando, para tanto, incluir aqueles requisitos. ${ }^{103}$

A fase atual, porém, é marcada por uma crise ou deslocamento na concepção tradicional do conhecimento (agora entendido como uma construção provisória), bem como no entendimento do papel da escola, do saber escolar, da profissão docente e da formação de professores. Essa mudança - ou antes, esse questionamento - se impõe menos por força da lei ${ }^{104}$ que pela realidade social avassaladora, batendo às portas da escola. O reconhecimento da universalização do ensino como um dever do estado e um direito do cidadão, formalizado pela Constituição e assumido pela LDB, gerou uma demanda inédita das classes populares pela educação formal, mudando o sentido que outrora se atribuía à "educação para

\footnotetext{
${ }^{103}$ LIMA, E. F. Formação de professores, p. 16-17.

104 Segundo Pedro Demo, a LDB não é propriamente inovadora: não promove a superação do paradigma educacional vigente nem renova seus principais eixos norteadores. Para Alexandre Shigunov Neto e Lizete Maciel, ela é marcada por contradições: "enquanto o discurso presente expressa uma coisa, a prática apresenta caracte rísticas diferentes, ou seja, há uma contradição entre a teoria pregada e a prática realizada". Cf. SHIGUNOV NETO, A. e MACIEL, L. S. B. As políticas neoliberais e a formação de professores: propostas de formação simplistas e aligeiradas em épocas de transformações. In: SHIGUNOV NETO, A. e MACIEL, L. B. (orgs.) Formação de professores, p. 69.
} 
a vida” e evidenciando a urgência de um novo projeto educativo, mais inclusivo e orientado para a superação das desigualdades sociais. O desafio ainda não foi resolvido e, mais uma vez, as disputas tomam conta do campo da formação.

Neste momento decisivo, as pesquisas acadêmicas sobre a formação de professoras têm uma grande contribuição a oferecer, estabelecendo um diálogo com a prática escolar, que contribua para a valorização e profissionalização docente e faça corpo no enfrentamento das concepções e políticas tecnicistas e conservadoras. O panorama recente, nesse sentido, não é muito animador. Um balanço das teses e dissertações sobre a formação defendidas no Brasil, nos anos 90, feito por Marli André, ${ }^{105}$ revelou que há muita redundância de conteúdos, aspectos e formas de abordagem das pesquisas, e pouca atenção a questões atuais, relacionadas aos desafios mais urgentes que se colocam à escola: diversidade étnica e de gênero, violência, drogas, disciplina, meios de comunicação, informática e questões culturais. $\mathrm{O}$ estudo demonstrou que o problema da formação continuada é relativamente pouco estudado, a relação da professora com as práticas culturais é um tema quase esquecido e a formação para o uso das novas tecnologias só agora começa a receber maior atenção.

\section{a) O tema das tecnologias de informação e comunicação na formação docente}

No Estado de São Paulo, uma das iniciativas pioneiras para fomentar estudos e pesquisas visando à introdução da informática nos contextos educacionais foi a constituição do Núcleo de Informática Aplicada à Educação (Nied), da Unicamp, em 1983. O fundamento do trabalho do Nied é a Metodologia Logo de Ensino-Aprendizagem desenvolvida no Massachusetts Instituto of Technology por Seymour Papert, na qual são propostas situações de aprendizagem em que o aluno "constrói o seu conhecimento através do computador" ${ }^{106}$ Uma das linha de pesquisa ali implementadas foi justamente a "Formação de

\footnotetext{
${ }^{105}$ ANDRÉ, Marli. A formação de professores nas pesquisas dos anos 1990. In; SHIGUNOV NETO, A. e MACIEL, L. S. B. Formação de professores, p. 77-96.

106 "No processo de resolver um problema através do computador, o aluno descreve a resolução deste problema segundo uma linguagem de programação (no caso, o Logo). O computador, por sua vez, executa este programa e apresenta um resultado, permitindo ao aluno o confronto de suas idéias com esse resultado. Se algo a-
} 
profissionais da educação". No seu bojo, funcionou, de 1987 a 2001, o projeto "Formação de profissionais da área de educação para o uso integrado do computador às atividades educacionais", congregando pesquisadores sob a coordenação do Prof. Dr. José Armando Valente. A formação desenvolvida tinha como características ocorrer no local de atuação do profissional e voltar-se para os objetivos de seu trabalho. A meta era orientar o professor em relação ao uso do computador e subsidiar teórica e metodologicamente a elaboração e realização de atividades pedagógicas ou terapêuticas. Outros projetos vinculados à linha foram: "Desenvolvimento de metodologia pedagógica para uso da informática na educação não-formal" (2000); "Rede telemática para formação de professores: implantação da informática na educação e de mudanças nas escolas de países da América Latina” (2000, com foco nas mudanças pedagógicas e de gestão na escola, formação de valores e integração dos indivíduos nos atuais processos produtivos); e o "Centro Virtual Interamericano de Cooperação Solidária para a Formação de Educadores" (2001 a 2002, projeto decorrente do anterior e que gerou a criação de um portal educacional para formação de pessoal capaz de integrar as tecnologias às práticas pedagógicas e promover mudanças na escola pública). Ainda no âmbito da Unicamp, na Faculdade de Educação, formou-se, em 1994, o Laboratório de Estudos Audiovisuais - OLHO, liderado pelo Prof. Dr. Milton José de Almeida. ${ }^{107}$ Reunindo uma série de pesquisadores, o OLHO estuda a produção artística, cultural e social das imagens na sociedade contemporânea, com foco nas diferentes linguagens, nos meios de comunicação e nas artes plásticas e visuais, além de realizar vídeos a partir das pesquisas desenvolvidas. Mais recentemente, formaramse o LITE, Laboratório Interdisciplinar de Tecnologias Educacionais e, em 2004, o LANTEC, Laboratório de Novas Tecnologias Aplicadas na Educação (centrado no uso de ferramentas tecnológicas em ambientes educativos presenciais ou a distância, na sistematização do uso da linguagem do vídeo digital interativo em projetos pedagógicos e na construção de bibliotecas digitais interativas). A formação de docentes é um tema comum a esses grupos de pesquisa.

Destaca-se também como pioneiro o trabalho de Heloisa Dupas Penteado que, a partir da Faculdade de Educação da USP, desde o final dos anos 80, vem se dedicando ao estudo das relações ComunicaçãoEducação e da incorporação das tecnologias à prática pedagógica, com o objetivo de formar cidadãos

conteceu errado, o aluno pode depurar o programa e identificar a origem do erro. O processo de depuração permite a aquisição de conceitos ou estratégias, que levarão o aluno a melhorar seu programa e conseqüentemente, suas idéias." NIED. Disponível em <www.nied.unicamp.br>.

107 Diretório dos grupos de pesquisa no Brasil, CNPq. Disponível em <http://dgp.cnpq.br>. 
críticos. Esse esforço resultou no desenvolvimento da proposta da Pedagogia da Comunicação, que, inspirada no pensamento de Paulo Freire e Dermeval Saviani, considera a realidade dos alunos, marcada pela presença da TV, como ponto de partida do trabalho escolar, fundado no diálogo e no uso da imagem. Para ela, o ensino só se faz na comunicação e, por isso, a escola precisa ampliar o processo de socialização formal assimilando os instrumentos contemporâneos. Com isso, a Pedagogia da Comunicação revitalizaria o ensino e recuperaria seu significado. Mas sua proposta é mais ampla que a mediatização do ensino pelas tecnologias comunicacionais: trata-se de "[...] uma postura em educação que considera a existência dos meios de comunicação, mas que vai além disso, traduzindo-se em atitudes e procedimentos docentes providenciadores da educação escolar na direção de um processo comunicacional”. ${ }^{108}$

Outra pioneira que merece menção é Mariazinha Fusari, que, ainda em 1990, defendeu sua tese sobre os meios de comunicação na formação de professores, com foco na TV e no vídeo, ${ }^{109}$ tendo, a partir de então, desenvolvido importante produção na área. Seu ponto de partida foi a análise da educação para o uso dos meios de comunicação em cursos de formação docente. Três eixos de análise foram investigados junto a um universo de 69 estudantes de pedagogia e 166 alunos de magistério (segundo grau): o uso dos meios em suas aulas, como alunos e como professores; o uso de televisão e vídeo com/por crianças em escolas públicas e a natureza dos programas vistos; e as mudanças ocorridas após aulas sobre TV e vídeo. Já naquela época, os resultados apontaram para a "viabilidade e a necessidade de treinamento do professor quanto ao uso dos meios de comunicação e [constataram...] que o tema continua sendo pouco explorado nos cursos existentes", ${ }^{110}$ a despeito do interesse dos alunos de pedagogia pelo assunto e das mudanças em suas atitudes quando "submetidos a treinamento".

\footnotetext{
${ }^{108}$ PENTEADO, H. D. (org) Pedagogia da comunicação: teorias e práticas. 2. ed. São Paulo: Cortez, 2001, p. 9. A partir do trabalho recente da pesquisadora, constituiu-se, em 2007, um grupo de pesquisa denominado "Pedagogia da Comunicação/Formação de Professores", no qual já aparece a noção de que a formação de professores é um processo específico de comunicação". Cf. Diretório dos grupos de pesquisa no Brasil, CNPq. Disponível em <http://dgp.cnpq.br>.

${ }^{109}$ REZENDE E FUSARI, Maria Felisminda de. Meios de comunicação na formação de professores: televisão e vídeo em questão. 1990. 218p. Tese (Doutorado). Instituto de Psicologia da Universidade de São Paulo, São Paulo, 2008.

${ }^{110}$ REZENDE E FUSARI, M. F. de. Meios de comunicação na formação de professores.
} 
Sob sua orientação, Simone Rodrigues Batista defendeu um interessante trabalho de mestrado acerca da formação inicial de professores para exercitar a mediação da televisão. ${ }^{111}$ Sua pesquisa tinha como foco a capacidade dos docentes em mediar a relação entre programação televisual e as crianças telespectadoras, com o objetivo de formar leitores críticos e também produtores de comunicação social. A autora tentou superar o senso comum que vê as tecnologias da informação e da comunicação ora como uma panacéia para a educação, ora como responsáveis pelo esvaziamento crítico na formação dos alunos. Sua proposta era a de desenvolver uma metodologia para promover a incorporação das linguagens das mídias ao cotidiano escolar e nos cursos de formação de professores, para a concretização de uma pedagogia crítica.

O problema da formação continuada reaparece na dissertação de Neide Barea Tavares, defendida na Faculdade de Educação da USP, sob orientação de Marcelo Giordan. ${ }^{112}$ Marcada por um contexto de introdução dos computadores nas escolas públicas, no início dos anos 2000, a pesquisa encontrou professores "despreparados", mas cientes da necessidade de empregar a informática como um elemento motivador e transformador de sua prática docente. Tavares reconheceu que, naquele momento histórico, a informática educacional era vista como a solução "mágica" para resolver uma situação profissional problemática e para a qual os educadores se achavam desamparados: o desinteresse do aluno pela aprendizagem, a escassez de recursos materiais e financeiros e a superlotação das classes. Diante de uma formação inicial vista como precária, calcada num sistema fragmentado de ensino que privilegiava o esquema tradicionalista de transmissão de conhecimentos, a autora sugeriu a formação continuada em informática educacional como uma saída plausível para a aquisição das novas competências exigidas para a prática educacional - fundamentada, desta vez, no parâmetro da reflexividade, proposta por Schön e incorporada por Nóvoa.

Os conceitos de professor reflexivo e professor pesquisador continuam presentes em projetos mais recentes, como o de José Joelson de Almeida, sobre os contextos e situações de formação de professores

\footnotetext{
111 BATISTA, Simone Rodrigues. Televisão e formação inicial de professores: a importância da mediação docente. 1998. 160 p. Dissertação (Mestrado). Faculdade de Educação da Universidade de São Paulo, São Paulo, 1998.

112 TAVARES, Neide Rodriguez Barea. Formação continuada de professores em informática educacional. 2001. 174p. Dissertação (Mestrado). Faculdade de Educação da Universidade de São Paulo, São Paulo, 2001.
} 
em serviço com o uso de tecnologias da comunicação e informação. ${ }^{113}$ Utilizando-se de metodologia etnográfica, o autor buscou descobrir como e se ocorre a incorporação de tecnologias pelos professores. Concluiu pela influência da formação continuada e do interesse dos professores nessa incorporação, bem como levantou a possibilidade da formação mediante o uso de tecnologias, e da proposição de metodologias de formação docente em contextos semelhantes ao estudado.

Uma outra perspectiva sobre os cursos de formação relacionados à tecnologia da informação surge no trabalho de Helenice Bergmann, ${ }^{114}$ sob orientação de Heloísa Dupas Penteado. Aqui, a investigação tem foco na subjetividade que envolve o entrelaçamento das tecnologias da informação e da comunicação com a educação, captada por meio dos discursos dos docentes sobre suas experiências de vida e seus saberes teóricos e práticos. Realizando um estudo de caso junto a professores mediadores dos laboratórios de informática de escolas públicas estaduais do Espírito Santo, Bergmann identificou o perfil, a atuação e os sentidos que os educadores atribuíam ao uso das tecnologias na escola, analisando as interações no ambiente virtual de capacitação e mapeando as concepções de sociedade da informação e inclusão digital presentes na comunidade escolar. Esta delineou-se como um conceito largo, contextualizado nos aspectos sociais, econômicos, políticos, culturais e tecnológicos; envolvendo instituições públicas, privadas, terceiro setor e academia; e destinado a expandir a cultura digital e seu potencial de desenvolvimento humano, ampliando, transformando e socializando conhecimentos, no horizonte de uma sociedade mais solidária e democrática.

Este breve levantamento de trabalhos sobre a formação de professoras com foco nas tecnologias da comunicação e da informação não pretende ser exaustivo, o que fugiria ao meu objetivo. O relato, contudo, dá uma noção de como o tema foi surgindo nas pesquisas acadêmicas e sob quais abordagens foi-se desenvolvendo e institucionalizando. Vejamos agora como a Educomunicação pode contribuir nesse debate.

\footnotetext{
${ }^{113}$ ALMEIDA, José Joelson Pimentel de. Formação contínua de professores: um contexto e situações de uso de tecnologias de comunicação e informação. 2006. 192p. Dissertação (Mestrado). Faculdade de Educação da Universidade de São Paulo, São Paulo, 2006.

${ }^{114}$ BERGMANN, Helenice Maria Barcellos. Escola e inclusão digital: desafios na formação de redes de saberes e fazeres. 2006. 362p. Tese (Doutorado). Faculdade de Educação da Universidade de São Paulo, São Paulo, 2006.
} 


\subsection{A contribuição da Educomunicação: em busca de uma síntese}

Dentre os diversos questionamentos que põem em xeque a legitimidade da escola e a relevância social dos saberes que ela representa, um deles diz respeito à resistência dessa instituição aos meios de comunicação na tentativa de manutenção de seu horizonte cultural. ${ }^{115}$ Ora, tornou-se mister alargar, contaminar e hibridar esse horizonte, de modo que também a escola possa promover as alfabetizações pósmodernas - formas de produção de conhecimentos, saberes, práticas e representações, relacionadas com múltiplos modos de comunicação, diversas formas de estruturação da percepção e uma total transformação na construção das ações, das aspirações e dos imaginários coletivos. É precisamente neste ponto que as investigações sobre as interfaces comunicação-educação e, mais especificamente, a proposta educomunicativa, podem tornar-se úteis para o desenvolvimento teórico e metodológico da formação de professoras. Não porque venham a constituir uma solução simples e definitiva para os problemas existentes. Mas, porque são capazes de contribuir para esse debate de modo original, tanto pela recuperação crítica de experiências educativas historicamente conhecidas, empreendidas em espaços formais ou comunitários, quanto pela construção de uma nova abordagem transdisciplinar. Tomando a questão de modo mais amplo, não se trata apenas de pensar como a formação continuada pode favorecer a prática educomunicativa nas escolas, mas, também, como a Educomunicação pode promover a formação dos novos perfis profissionais e cidadãos desejados.

\section{a) Origens do campo}

As primeiras tentativas de aproximação entre Comunicação e Educação assumiram um caráter marcadamente instrumental. Na década de 50, Burrhus Skinner, com uma visão behaviorista, propôs o uso de

\footnotetext{
115 Jorge Huergo entende os horizontes culturais como formações que se pretendem puras e incontaminadas, e podem ser exemplificadas através da atitude de negação e denúncia que a escola assume frente aos meios e à cultura mediática. Também é de Huergo a proposta das "alfabetizações pós-modernas". Cf. HUERGO, Jorge A. Comunicación/ Educación: itinerarios transversales. In: VALDERRAMA, Carlos. Comunicación \& Educación. Bogotá: Universidad Central, 2000. p. 3-25.
} 
aparelhos mecânicos e elétricos no ensino. Sua preocupação era, basicamente, quantitativa: o aumento dos níveis de aprendizado por meio da equação estímulo-resposta. Não se punha em questão o tipo de relação educativa que se estabelecia a partir da introdução da tecnologia. Ao contrário: Skinner acreditava que a educação tornava uma cultura forte por meio da transmissão e do acúmulo de conhecimentos, aptidões e práticas sociais e éticas. O saber deveria ser fragmentado no maior número de unidades possível, de modo que, a cada etapa de assimilação, o estudante pudesse ser controlado e estimulado. Assim, ele desenvolveu as "máquinas de ensinar", cujo objetivo era proporcionar o reforço positivo aos alunos e assegurar que seus passos fossem dados segundo uma ordem cuidadosamente prescrita.

Contudo, a preocupação em relação à crescente influência dos meios de comunicação sobre a cultura e o comportamento dos jovens motivou, desde cedo, o surgimento de perspectivas mais críticas sobre as relações comunicação-educação. Nos anos 60, desenvolveram-se as primeiras experiências de educação para os meios. Elas eram inspiradas, principalmente, pelas teorias da indústria cultural, da psicanálise e dos aparelhos ideológicos do Estado. Sua abordagem enxergava crianças e jovens como vítimas indefesas dos meios e suas mensagens, suspeitando de sua capacidade crítica e da possibilidade de construírem um pensamento autônomo. O objetivo era ensinar aos alunos como discriminar os meios segundo sua suposta qualidade.

Ora, como afirma Francisco Sierra, essa educação para os meios tinha eficácia nula ao cair num "despotismo ilustrado". ${ }^{116}$ Em primeiro lugar, a premissa que a sustenta é a de que há uma hierarquia entre saberes e formas culturais, sendo necessário tutelar os estudantes para elevar-lhes o gosto. A cultura do educando, na qual a televisão vinha assumindo papel de centralidade, era marginalizada e negada no espaço escolar. Em segundo lugar, a visão psicanalítica, que contrapunha resistência ou negociação de sentido ao prazer da fruição das mensagens mediáticas, supõe serem a didática e o entretenimento mutuamente excludentes. A leitura crítica dos meios tornava-se, pois, uma experiência desprovida de satisfação. Finalmente, a compreensão estruturalista de que o sistema e sua lógica se impõem sobre os indivíduos, por meio de aparelhos ideológicos que os interpelam e condicionam suas ações, ignora as contradições e complexidades que atravessam os processos políticos e culturais.

\footnotetext{
${ }^{116}$ SIERRA, Francisco. El legado de Gramsci, p. 145-173.
} 
Embora seja possível mapear, ao redor do mundo e desde o início do século XX, inúmeras tentativas de aproximação entre meios de comunicação e educação, com abordagens que vão do uso do cinema como meio de difusão de um pensamento revolucionário até a mediação tecnológica no ensino, ${ }^{117}$ pretendo centrar minha atenção nas experiências latino-americanas destinadas a promover a apropriação crítica das tecnologias da comunicação e da informação pelo cidadão comum, na escola ou fora dela, a partir do viés cultural. Essa linha de investigação e intervenção social constitui a Educação para a Comunicação.

De acordo com Ismar de Oliveira Soares, a maioria dos programas de educação para os meios de comunicação, na América Latina, teve início entre meados dos anos 70 e princípios dos anos $80 .{ }^{118}$ Por essa época, operava-se uma revisão teórica profunda e de largo alcance, que deslocava do centro das análises o paradigma clássico da comunicação e as abordagens dos meios como difusores de inovações e extensão cultural. Entravam em pauta temas como o direito à comunicação, a comunicação como recurso, a comunicação horizontal e participativa, a planificação da comunicação e a preocupação com as origens e fluxos da notícia no contexto de uma nova ordem informativa mundial, dominada pelas grandes agências noticiosas. As análises estruturalistas, em voga no período, estudavam as mensagens para promover a decifração e o desvelamento de seus conteúdos ideológicos. Buscava-se promover a capacitação dos indivíduos para a leitura semiótica da linguagem audiovisual, para a leitura ideológica das mensagens e a formação de grupos para a mediação dos processos de recepção. Dentre os agentes institucionais que lideravam os projetos de intervenção, destacam-se a Unesco (propondo a educação para a recepção crítica, no bojo dos debates sobre o subdesenvolvimento) e a Igreja Católica, por meio dos grupos ligados à Teologia da Libertação. Nos anos 80, diante da explosão de movimentos populares e

\footnotetext{
117 Lembremos as experiências do cinema construtivista russo, de Eisenstein e Dziga Vertov, que, de maneiras divergentes, buscavam aproximar as questões políticas e culturais das massas camponesas e operárias, ou, ainda, a iniciativa de produção de filmes pelos revolucionários durante a guerra civil espanhola. No Brasil, conforme Adilson Citelli, já nas primeiras décadas do século XX houve tentativas de promover a educação por meio da comunicação: entre as décadas de 30 e 50, com Roquete Pinto e Anísio Teixeira, as rádios educadoras encampam o projeto de modernização do país por meio da educação e do enfrentamento do analfabetismo. (Cf. ClTELLI, A. Comunicação e educação: perspectivas. In: LOPES, M. I. V; MELO, J. M.; MOREIRA, S. V.; BRAGANÇA, A. (orgs) Pensamento comunicacional brasileiro. Intercom, São Paulo, 2004, p. 77-93.) Um levantamento das iniciativas de educação para os meios a partir dos anos 70 na Europa, América do Norte e América Latina, foi empreendido por Maria Verônica Rezende de Azevedo, cf. AZEVEDO, M. V. R. Telejornalismo e educação para a cidadania. São Paulo: Beca Produções Culturais, 2004.

118 SOARES, Ismar de Oliveira. Teoría y practica de la comunicación: incidencia sobre los proyectos de educación para los medios en América Latina. In: CENECA. Santiago, 1992, p. 273-289.
} 
sindicais, da derrocada da ditadura militar e do processo de redemocratização da sociedade brasileira, o interesse voltou-se para a luta por políticas democráticas de comunicação. Com o avanço das iniciativas neoliberais no país, a partir de meados da década, a educação para a comunicação passa a configurar-se como um campo de resistência cultural que procura articular ação pedagógica e vida cotidiana. Mantendo uma visão macrossocial das políticas de comunicação, ela firma o compromisso com a transformação da sociedade.

Nos anos 90, diante da difusão de novas mídias eletrônicas, os programas de educação para a comunicação assumem diferentes vertentes pedagógicas e linhas de pensamento, segundo as opções políticometodológicas dos agentes que os encampam. Dentre essas orientações, destacam-se as que conservam uma perspectiva crítica, incorporando as contribuições dos estudos sobre a pós-modernidade (García Canclini, Mattelart, Mário Kaplún); as que mantêm uma visão tecnicista da educação e buscam promover a sua aproximação com o mercado, legitimando as teses sobre o livre fluxo da informação; e as que defendem a organização dos atores sociais na batalha por uma nova comunicação, centrando esforços no desenvolvimento de cidadãos participativos, vigilantes e ativos na luta por reformas. Esses últimos estão pulverizados em instituições educativas, culturais, políticas, sindicais e agremiações, que buscam ventilar e democratizar o debate sobre a comunicação social. ${ }^{119}$

Compreendida, desde então, como ação social, a educação para a comunicação torna-se uma noção alargada - não se trata mais, apenas, de educação para os meios ou para a recepção, mas da criação de um ecossistema gerador de conhecimentos e de ações pedagógicas e políticas, que abarca os distintos campos da inter-relação Comunicação-Educação. ${ }^{120}$ Seu objetivo é o de formar homens e mulheres críticos e ativos frente aos diversos processos comunicativos em que estão inseridos, capazes, sobretudo, de se

\footnotetext{
119 Adilson Citelli identifica agentes que, no campo acadêmico, buscam aproximar Comunicação e Educação: em 1998, em São Paulo, o I Congresso Internacional sobre Comunicação e Educação reuniu cerca de 200 especialistas de todas as partes do mundo; no Paraná, a Universidade Estadual promove periodicamente simpósios sobre o tema; a Intercom instituiu, na sua estrutura, o Núcleo de Comunicação Educativa; na ECA/USP, o Departamento de Comunicações e Artes (CCA) mantém a linha de pesquisa em pós-graduação denominada Educomunicação, o Núcleo de Comunicação e Educação (NCE) e a Rede Brasileira de Educomunicadores, além da publicação da revista Comunicação e Educação; diversas universidades mantêm núcleos de pesquisa nessa área, como UFBA, Unicamp, Universidade Sagrado Coração de Bauru e a Universidade Federal do Paraná. (ClTELLI, A. Comunicação e educação: perspectivas.)

${ }^{120}$ SOARES, Ismar de Oliveira. Manifesto de la Educación para la Comunicación en los países en vías de desarrollo. La Coruña, España, 1995.
} 
afirmar frente aos aparatos de massa. Um horizonte utópico lhe serve de guia: que as pessoas se descubram como produtoras de cultura, apropriando-se dos recursos da informação e da comunicação. Nos espaços educativos, formais e não-formais, ela assume a tarefa de implementar fluxos comunicativos essencialmente democráticos e horizontais. Para isso, empenha-se em ativar as competências comunicativas e a experiência criativa dos sujeitos. Dentre os reptos que se colocam ao seu avanço, estão a promoção de alianças entre os diversos grupos envolvidos com esses objetivos; a mobilização social para a defesa dos direitos de acesso aos processos e recursos comunicativos; a formação de agentes educadores aptos a atuar como mediadores nas diversas instituições sociais e organizações populares; a tecedura de redes mundiais entre programas e projetos de educação para a comunicação; e o desenvolvimento de perspectivas verdadeiramente transversais ${ }^{121}$.

\section{b) Algumas definições}

A partir dessa proposição, e alimentando-se da tradição de pensamento voltada para a comunicação educativa, começou a configurar-se, na última década, um novo campo de intervenção social e pesquisa acadêmica, organizado em torno da idéia de estimular a criação de ecossistemas comunicativos abertos, com o compromisso ético de desenvolver a competência comunicativa dos cidadãos e ampliar o "coeficiente comunicativo" das ações educativas. Esse campo, que já lança as bases para estabelecer-se como objeto autônomo de pensamento, é a Educomunicação. ${ }^{122}$

\footnotetext{
121 HUERGO, J. Comunicación/ Educación: itinerarios transversales. O autor alerta que é preciso subverter a questão em torno da manutenção de um sentido hegemônico entre comunicação e educação (a recorrente pergunta: "educação para a comunicação" ou "comunicação para a educação"? - em que um elemento dessa relação é tomado como efeito do outro). Para ele, um projeto transversal de comunicação/educação poderia assumir as feições de um estudo cultural da comunicação na educação ou de uma pedagogia crítica das mediações culturais.

122 Pesquisa desenvolvida por Ismar de Oliveira Soares demonstrou que "efetivamente um novo campo do saber mostra indícios de sua existência, e que já pensa a si mesmo, produzindo uma meta-linguagem [...]". Não sendo uma nova disciplina, mas um paradigma discursivo transversal e transdisciplinar, desenvolve categorias analíticas próprias e é vivenciado na prática pela intervenção de atores sociais em áreas concretas. (SOARES, Ismar de Oliveira. Comunicação/Educação - emergência de um novo campo e o perfil de seus profissionais. Disponível em: <www.eca.usp.br/nucleos/nce/perfil_ismar.html> Acessado em 7 maio 2006.
} 
Definida por Ismar de Oliveira Soares como "o conjunto das ações inerentes ao planejamento, implementação e avaliação de processos, programas e produtos destinados a criar e a fortalecer ecossistemas comunicativos em espaços educativos presenciais ou virtuais", ${ }^{123}$ a Educomunicação desdobra-se em cinco áreas:

a) a educação para a comunicação, que, fundamentada nos estudos da recepção e nas reflexões sobre a relação entre produtores, o processo produtivo e a recepção das mensagens, resulta em ações de educação para a recepção crítica dos meios e na luta por políticas democráticas de comunicação;

b) a mediação tecnológica na educação, que trata das implicações trazidas pela introdução das tecnologias no cotidiano dos indivíduos e grupos e do seu uso nos processos educativos, presenciais ou a distância;

c) a gestão da comunicação em espaços educativos, que diz respeito diretamente à implementação dos referidos ecossistemas comunicativos;

d) a expressão comunicativa através das artes e

e) a reflexão epistemológica que fundamenta o campo.

Ao educomunicador, profissional que atua nesse espaço, coloca-se o desafio da formação de cidadãos críticos, participativos e inseridos em seu meio social. ${ }^{124}$ Em outras palavras, cabe a ele assessorar o sistema de meios de comunicação e o sistema educativo, implementando programas e projetos e pesquisando os fenômenos próprios da Educomunicação.

O perfil do educomunicador inclui conhecimentos (dos mecanismos que regem os processos comunicacionais, a recepção e o consumo de bens simbólicos, dos modos operatórios das tecnologias), habilidades (de incorporar novos saberes, visões de mundo e pontos de vista, de negociar os conflitos de interesse e agregar colaboradores), atitudes (de abertura para o diálogo e a diferença sociocultural, de disposição para a construção de um novo espaço público, de exercício de uma liderança não-autoritária rumo à mudança) e uma ética (do diálogo polifônico, do inacabamento dos discursos e da desdogmatização dos saberes).

${ }^{123}$ SOARES, Ismar de Oliveira. Metodologias da Educação para a Comunicação e gestão Comunicativa no Brasil e na América Latina, p. 115.

${ }^{124}$ Mídia e educação: perspectivas para a qualidade da informação. Brasília: MEC, 2000. p. 31. 


\section{c) A Educomunicação e a formação docente}

Considerando que é desejável e até mesmo necessário que a professora da escola pública integre, ao menos parcialmente, os atributos do educomunicador à sua identidade profissional, a Educomunicação tem um desafio a empreender: o de investigar como essa incorporação pode ser feita. Um dos caminhos é o de propor uma práxis formativa (intervenção - reflexão - prática - teoria...) que auxilie a: a) mergulhar no terreno empírico, onde o pesquisador-formador possa impregnar-se das mesmas circunstâncias onde a professora-educomunicadora deverá atuar; b) construir um quadro teórico transdisciplinar, aproximando comunicação, educação, linguagem, cultura, tecnologia, ética e política - que sirva como grade de leitura da realidade vivenciada; c) formular - aplicar - refinar uma metodologia de intervenção, alimentada pelas contribuições teóricas e experienciais da formação e da educação para a comunicação; e d) realimentar permanentemente esse processo de prática reflexiva.

Nesse sentido, iniciativas inovadoras têm sido empreendidas pelo Núcleo de Comunicação e Educação (NCE) da ECA/USP, destacando-se os projetos Educom.rádio (2001-2004) e Educom.TV (2002). O Educom.radio: educomunicação pelas ondas do rádio foi implementado em 455 escolas de ensino fundamental da rede municipal de São Paulo, envolvendo cerca de 11 mil pessoas, entre professores, funcionários, alunos e membros da comunidade escolar. Contratado pela Secretaria Municipal de Educação, o NCE ofereceu um curso de extensão que certificava docentes e funcionários das escolas, mas que incluía, entre seus participantes, alunos e membros da comunidade. Os encontros formativos configuravamse como palestras (acerca de temas específicos e transversais), oficinas e workshops sobre produção radiofônica, vídeo e jornal mural. As escolas participantes recebiam equipamentos com o objetivo de instalarem uma rádio no ambiente escolar, gerenciada em conjunto por alunos, docentes, funcionários e comunidade. O objetivo era criar um espaço de prática democrática na escola, incentivar a participação de todos os seus membros, resgatar a auto-estima dos alunos e ressignificar o espaço escolar e as relações de cada um com os meios de comunicação. As particularidades desse projeto são comentadas por Cláudia Lago e Patrícia Horta: 
Apesar de se constituir enquanto um curso de extensão, o educom.rádio supera, e muito, os limites de um curso de formação tradicional. Isso se explica em função dos princípios e objetivos que estão na raiz de sua formatação e que tentam unir dois vértices. Por um lado, a necessidade, expressa pela SME, de políticas de prevenção da violência dentro do ambiente escolar. Por outro, a linha teórico/ metodológica levada a cabo pelo NCE enquanto núcleo de pesquisa (e extensão) que iniciou em 1996 analisando a inter-relação entre os campos da Comunicação e da Educação, para depois passar a operar em relação ao que conceitua como campo da educomunicação, que se coloca como fio condutor dos princípios do projeto educom.rádio. ${ }^{125}$

O Educom.TV, por sua vez, foi desenvolvido no ano de 2002, com o propósito de oferecer aperfeiçoamento para 2250 professores e coordenadores de 1024 escolas da rede pública do Estado de São Paulo. A realização do projeto se deu por meio da modalidade de educação a distância, sendo que uma parte das aulas era presencial, incluindo seminários e oficinas de capacitação. Dos professores participantes, requisitou-se o compromisso com a elaboração de propostas de ações educomunicativas, a serem implementadas nas unidades de ensino. Também nessa formação, os alunos foram envolvidos, por meio de um projeto decorrente, o Tôdeolho.TV. De acordo com Ismar de Oliveira Soares, "Com o Educom.TV, o NCE-ECA/USP deu início a uma modalidade avançada de formação continuada de docentes das redes públicas de educação em todo o país." ${ }^{126}$ Nas diversas fases do curso, o conceito de educomunicação foi mobilizado para definir seus procedimentos internos, tais como a relação entre os membros da equipe, os dirigentes do curso, os prestadores de serviço e os cursistas.

Dadas as proporções dos programas de formação, gerou-se um importante volume de dados e informações, ainda não completamente esgotados nas pesquisas empreendidas desde então. Contudo, os projetos têm sido avaliados positivamente, o que demonstra tratar-se de um campo fértil para outras iniciativas e contribuições:

Os dados aferidos ao longo do processo de preparação e realização do projeto serão estudados pelos pesquisadores do NCE, nos próximos anos, permitindo que novas experiências possam ser realizadas. Uma primeira hipótese parece, contudo, estar comprovada: o conceito de edu-

\footnotetext{
${ }^{125}$ LAGO, C.; ALVES, P. H. Educom.rádio: uma política pública que pensa a mudança da prática pedagógica. Disponível em <http://www.usp.br/nce/aeducomunicacao/saibamais/textos>. Acessado em 10 out 2005.

126 SOARES, Ismar de Oliveira. EaD como prática educomunicativa: emoção e racionalidade operativa. Disponível em <http://www.usp.br/nce/aeducomunicacao/saibamais/textos>. Acessado em 10 out 2005.
} 
comunicação é um caminho viável de ser percorrido pelos que desejam rever suas práticas educativas. ${ }^{127}$

Na linha de pesquisa Educomunicação, o problema da formação docente é freqüentemente abordado, ora como tema principal, ora tangenciado na discussão do papel da professora no desenvolvimento de ações educomunicativas. É o caso da dissertação de Claudemir Viana, orientada pela Profa. Elza Dias Pacheco, cujo objetivo foi observar e analisar sistematicamente um processo de ensino-aprendizagem envolvendo a introdução de produtos mediáticos numa situação de ensino formal, tanto como estratégia pedagógica quanto como objeto de estudo. ${ }^{128} \mathrm{O}$ autor logrou descrever como ocorre o processo educomunicativo, atentando para os procedimentos pedagógicos aplicados e as mediações exercidas pelos professores em direção à construção do conhecimento pelo aluno.

A ressignificação do papel do professor e da escola é uma das preocupações de Maria Salete Prado Soares, em sua dissertação orientada por Adilson Citelli. ${ }^{129}$ Analisando as linguagens não-escolares que, acionando diferentes sistemas simbólicos, geram um novo sensorium e obrigam a escola a reorientar sua visão de saber e de educação, Salete busca identificar práticas pedagógicas mais dialógicas, planejadas coletivamente pelos docentes e que estimulem a expressão dos alunos nas novas linguagens e a formação de ecossistemas comunicativos. Em seu estudo de caso, a autora reconhece, na atuação de organizações não-governamentais, a possibilidade de ativar fluxos comunicacionais positivos na escola.

Já para Tania Amaral Oliveira, ${ }^{130}$ a formação de professores constituiu uma preocupação direta. Em sua dissertação de mestrado, orientada pelo Prof. Angelo Piovesan Neto, ela realizou um estudo de caso, a-

\footnotetext{
127 SOARES, I. O. EaD como prática educomunicativa. De fato, já começam a ser publicados os resultados, cf. ALVES, P. H. Educom.rádio: uma política pública em educomunicação. 2007, 229p. il. Tese (Doutorado). Escola de Comunicações e Artes da Universidade de São Paulo, São Paulo, 2007; FUNARI, C. V. A prática da mediação em processos educomunicacionais: o caso do projeto Educom.rádio. 2007, 2v. Dissertação (Mestrado). Escola de Comunicações e Artes da Universidade de São Paulo, São Paulo, 2007; LEÃO, Maria Izabel de Araújo. O papel da Internet nos projetos educomunicacionais do NCE/USP. 2008, 186p. il. Dissertação (Mestrado). Escola de Comunicações e Artes da Universidade de São Paulo, São Paulo, 2008.

${ }^{128}$ VIANA, Claudemir Edson. O processo educomunicacional: a mídia na escola. 2000, 237 p. Dissertação (Mestrado). Escola de Comunicações e Artes da Universidade de São Paulo, São Paulo, 2000.

129 SOARES, Maria Salete Prado. Processos comunicacionais em espaços educativos: estudos de caso sobre linguagens não escolares ativando ecossistemas comunicativos no projeto retratos do Butantã, realizado na escola Estadual Virgília de Carvalho Pinto. 2004, 182p. Dissertação (Mestrado). Escola de Comunicações e Artes da Universidade de São Paulo, São Paulo, 2004.

${ }^{130}$ OLIVEIRA, T. A. Uso da TV e do vídeo no espaço escolar: uma experiência de educomunicação. 2003, 225p. Dissertação (Mestrado). Escola de Comunicações e Artes da Universidade de São Paulo, São Paulo, 2003.
} 
nalisando os procedimentos aplicados por uma educadora para auxiliar seus colegas na inserção crítica e criativa de recursos como TV e vídeo em sala de aula. Do confronto entre a observação e a teoria, Tania chegou a um conjunto de "melhores procedimentos" para realizar essa inserção, cuja base está na açãoreflexão-ação freireana.

Outro exemplo é a tese de Maria Verônica Rezende de Azevedo, orientada pelo Prof. Ismar de Oliveira Soares. ${ }^{131}$ Seu trabalho, lançando luz sobre a formação continuada, compreende o professor como agente estimulador do diálogo dos jovens com os conteúdos veiculados pelos telejornais. A partir de uma experiência prática, Maria Verônica conclui que o docente em treinamento, atuando como educomunicador, pode ser um mediador entre a escola pública e um veículo de mídia, na proposição e coordenação de atividades de produção de mensagens pelos jovens alunos com o apoio técnico de uma emissora de TV local. Para ela, o formador tem a responsabilidade de trazer o aporte teórico às discussões coletivas e viabilizar ações de treinamento e aplicação prática na escola.

Merece destaque, ainda, Mídias e mediação escolar, de Maria Isabel Orofino, ${ }^{132}$ doutora em Ciências da Comunicação pela ECA-USP. Orofino desenvolve seu trabalho tendo como fundamentos a teoria da complexidade de Edgar Morin, os estudos culturais de Raymond Williams e Stuart Hall, a pedagogia de Paulo Freire, o campo da mídia-educação e a teoria das mediações de Jesús Martín-Barbero e Guillermo Orozco-Gomez. A autora propõe um duplo movimento para a construção de uma pedagogia participativa e libertadora: denunciar o quadro de perversidade política dos meios (seu fechamento à produção voltada para os interesses das comunidades) e anunciar a participação popular como intervenção criativa e ressignificação da cultura de mercado. Esse movimento constitui uma proposta política de construção de visibilidade para a imaginação e criatividade das crianças e adolescentes a partir do espaço escolar "como uma questão de direito à atualização e melhoria dos processos de ensino e de aprendizagem"133.

\footnotetext{
131 AZEVEDO, Maria Verônica Rezende de. Telejornalismo e educação para a cidadania: uma experiência de educomunicação. 2003, 257p. Tese (Doutorado). Escola de Comunicações e Artes da Universidade de São Paulo, São Paulo, 2003.

${ }^{132}$ OROFINO, Maria Isabel. Mídias e mediação escolar: pedagogia dos meios, participação e visibilidade. São Paulo: Cortez: Instituto Paulo Freire, 2005. (Guia da Escola Cidadã; v. 12).

${ }^{133} \mathrm{Idem}$, ibidem, p. 29.
} 
Orofino descreve o campo da mídia-educação como o espaço da teoria crítica. Ela envolve a ampliação de competências dos alunos nos diversos sistemas simbólicos - uma alfabetização para a mídia - que não exclua a escrita, mas se integre a ela. Esses estudos devem ser combinados com uma perspectiva multicultural, que compreenda o espaço ocupado pela mídia na relação com as demais dimensões constitutivas da cultura, dos sujeitos, das identidades e diferenças socioculturais, uma vez que na escola se encontram e se entrelaçam diversos sistemas simbólicos.

Entendendo as mediações como os percursos de produção de sentido (consumo cultural, apropriação, recusa ou resistência) que estruturam, configuram e reconfiguram a interação das audiências com os meios e a criação do sentido desta interação, a autora reconhece na escola um espaço privilegiado para potencializar esses processos. Se escola e TV competem pela socialização das crianças, as relações do telespectador com a mídia não são homogêneas e unívocas, mas múltiplas, envolvendo expectativas e gostos diferenciados, a partir da experiência sociocultural (mediações de classe, gênero, etnia, geração, religião, agremiações políticas, família, cultura de bairro, escola e pares). Cabe à escola, local de encontro dessas múltiplas culturas, abrir espaço para as mediações em jogo a partir do seu cenário, promovendo a polifonia. A mediação escolar deve ser potencializada, em vez de ser relegada ao espontaneísmo. Para que, efetivamente, ocorra a inclusão das práticas mediáticas de forma criativa e crítica na escola, é preciso atentar para a formação dos professores e defender a atuação do profissional de comunicação junto à prática escolar, como gestor/ educador para o uso dos meios. Para trazer o debate teórico da comunicação para o espaço escolar, Orofino propõe que os professores conheçam mais as teorias da comunicação, utilizando-as como suporte reflexivo para suas ações. Uma vez que não há fórmulas ou receitas prontas, o professor deve experimentar.

Um dos principais apontamentos feitos pela autora é o de que a pedagogia dos meios não pode ser desvinculada de um projeto político-pedagógico da escola. Sua proposta de uma pedagogia dos meios tem caráter prático e metodológico. Ela sugere a ampliação das mediações escolares por meio do consumo cultural crítico aliado à criação de estratégias de uso dos meios, sempre com foco na construção da cidadania ativa e participativa no contexto da comunidade na qual a escola se insere. A metodologia combi- 
na técnicas da pesquisa-ação ou ação cultural para a libertação (Paulo Freire), o estudo de recepção, o esboço etnográfico da comunidade e uma oficina de mídia-educação.

A leitura crítica da TV envolve a compreensão de sua linguagem híbrida, feita de formas culturais arcaicas, residuais e emergentes, de gêneros narrativos e formatos de programas que se entrecruzam num palimpsesto. A análise deve abranger dialeticamente tanto a dimensão formal quanto o conteúdo (desmascaramento das ideologias e questionamento da naturalização do sentido dominante de realidade), presentes nos três códigos de significação (texto, imagem e som). Abarca, ainda, o desenvolvimento das intertextualidades e conexões do "texto" televisivo com outras formas culturais, com outros produtos industriais, com a cultura oral e com a experiência social do sujeito. A recepção crítica explora as conexões entre os diversos segmentos da programação por meio das associações entre os fragmentos em fluxo. Na escola, o professor necessita planejar a oficina de mídia-educação tendo como foco três elementos: a dimensão estrutural (econômica) dos meios, a problematização das questões ideológicas para evitar uma leitura ingênua e a identificação das brechas e contradições no sistema.

O projeto prático desenvolvido pela pesquisadora trabalhou a linguagem da televisão, uma vez que, de acordo com ela, trata-se do meio mais difundido entre os alunos, e suas narrativas constituem a principal fonte de produtos culturais que eles consomem. Ela destaca o fato de que "a mídia dominante continua a atender aos interesses do mercado e não aos interesses dos telespectadores - muito menos aos anseios das crianças e adolescentes - enquanto cidadãos" ${ }^{134}$ Lembra que, por meio das representações dominantes, sustenta-se o ideário de uma sociedade de mercado que, além de excludente, incentiva o consumismo predatório e reproduz uma ordem classista e patriarcal. Ainda, destaca que grande parte da produção cultural televisiva não é planejada para as crianças, sendo necessário desenvolver quadros de análise para compreender como elas se apropriam desses produtos e buscar o aprofundamento e a produção de outros significados. Sem negar a realidade de produção e reprodução das desigualdades no campo cultural, a autora reconhece que nesse campo há contradições, conflitos e brechas, tanto na esfera da produção como na possibilidade da realização de leituras diferenciadas no âmbito da recepção.

${ }^{134}$ OFOFINO, M. I. Mídias e mediação escolar, p. 44. 
Cabe, portanto, à escola potencializar, trabalhar e desenvolver as mediações possíveis, articulando-se com outras organizações da sociedade civil.

Em sua proposta metodológica, o primeiro passo é a realização de um esboço etnográfico da comunidade em que se insere a escola - o que está de acordo com a proposta freireana. Além de compreender o contexto social e cultural da comunidade, é preciso observar a escola como um local de articulação dos movimentos sociais e identificar seu projeto político-pedagógico. O segundo passo é a realização de uma oficina de mídia-educação, que envolve debates e leitura crítica dos meios, estudos de recepção e, finalmente, o desenvolvimento de um projeto de produção de vídeo com a participação dos alunos. Esse vídeo deve originar-se de um tema gerador captado no universo temático da população e a pauta, definida com o grupo. A produção do roteiro é feita privilegiando a diversidade e liberdade de escolha de formatos e gêneros, de acordo com as preferências dos alunos. A pré-produção é uma etapa que estimula a cooperação entre os grupos. Os exercícios com a câmera propiciam a desmistificação da relação com o aparelho. A gravação dos produtos é uma oportunidade para os jovens se expressarem a respeito do problema e pensar sobre as próprias práticas. A veiculação, etapa final, revela a satisfação e o reconhecimento dos alunos pela participação na experiência e ainda possibilita a reflexão crítica sobre o próprio trabalho.

O trabalho de Maria Isabel Orofino traz importantes contribuições para uma pedagogia crítica dos meios. Ao destacar a escola como cenário de produção cultural, resgata o conceito de ação cultural no espaço escolar; identifica e explora o potencial subversivo e multiplicador do vídeo para propiciar aos jovens a oportunidade de elaborar contra-narrativas libertadoras; na criação coletiva e de co-autoria, rompe fronteiras e hierarquias e abre caminho para a criação e a arte; tematizando a formação das identidades e diferenças socioculturais, oferece uma plataforma para a construção reflexiva da visibilidade e da participação das minorias, conectando-as aos movimentos sociais pela cidadania, meio ambiente e direitos humanos; resgata a importância da memória social na construção das identidades. Esse tipo de ação propõe o debate sobre a criação de métodos democráticos na escola e a discussão de seu projeto político-pedagógico. Além disso, torna os sujeitos mais atentos aos direitos relativos à mídia: o de acesso igua- 
litário à tecnologia, mas também o de exercer o consumo reflexivo e de reivindicar uma programação que respeite seus interesses. $\mathrm{O}$ que pode, a princípio, parecer apenas uma ação local, num contexto limitado, adquire, efetivamente, repercussões na macro-esfera da vida social - o que dá consciência aos envolvidos da conexão entre a sua ação individual e a realidade global.

\section{d) Formação continuada como reeducação (cultural) para o uso da linguagem ${ }^{135}$}

Apresentado o quadro teórico que alimenta e dialoga com esta pesquisa, é possível propor uma abordagem sobre a formação de professoras em serviço a partir da Educomunicação, acreditando que este esforço pode contribuir para a geração de um novo ponto de vista sobre o tema.

Compreendida de maneira transdisciplinar, a formação docente é um processo comunicativo específico, que não pode ser resumido a um "curso" (canal) onde orientadores (emissores) transmitem conteúdos (mensagens) a um público-alvo (receptor passivo), ao qual caberia o papel de aplicar os preceitos recebidos com o mínimo de falhas (ruídos). Isso significaria considerar a linguagem operada como um veículo de idéias prontas e acabadas, e não como um ato criativo dos sujeitos envolvidos no processo educativo. Esse ponto de vista é o mesmo que resulta em avaliações do tipo: "as professoras estão aplicando exatamente aquilo que aprenderam durante o curso?", "o quão eficiente foi o curso para a mudança nas práticas pedagógicas?" ou, ainda "que resultados ou efeitos teve a formação em sala de aula?" Essas preocupações desconsideram o contexto concreto em que a formação opera - o ecossistema escolar e suas configurações. Nesta pesquisa não se trata disso: aqui, a formação em serviço é uma situação de comunicação mediada por elementos culturais e um exercício criativo da linguagem. Por isso, as perguntas mais importantes a fazer são: "que fatores interferem na apropriação das propostas?", "o que criam as professoras em formação?" e "como elas refletem sobre seus projetos?"

\footnotetext{
${ }^{135}$ A proposta de que se realize uma "reeducação para o uso da linguagem" é de Adilson Citelli. Cf. CITELLI, A. Comunicação e educação: a linguagem em movimento.
} 
A mediação cultural da formação de professoras em serviço implica que cada indivíduo detém uma capacidade diferenciada de apropriar-se dos saberes e tecnologias da comunicação e incorporá-los a suas práticas, dada por sua formação anterior, história de vida e hábitos culturais. Assim, os usos desenvolvidos pelos sujeitos serão múltiplos e a sua proficiência comunicativa crescerá à medida que forem capazes de dialogar entre si, compartilhando, no espaço coletivo, as suas descobertas. Quer no contexto privado, quer em situações de trabalho, ora as professoras irão utilizar os novos recursos para dar conta de atividades que já realizavam antes; ora irão desenvolver outras, explorando um potencial que as tecnologias anteriormente disponíveis não possuíam; ora poderão ousar soluções ainda impensadas. Seja como for, a prática constante com os meios e suas linguagens provocará uma reformulação de seus hábitos culturais e poderá transformar, em maior ou menor grau, aquilo que fazem e o que pensam sobre sua profissão - a sua identidade. Encarar a formação para o uso das tecnologias como um curso, treinamento ou instrumentalização é, portanto, extremamente empobrecedor. Essa concepção falha justamente ao fornecer uma visão teoricista, prévia à experimentação. É preciso incentivar o uso dos meios em situações concretas, nos contextos possíveis em que professoras atuam, e favorecer a invenção e cooperação entre elas. Sob essa perspectiva, a formação será o pontapé inicial de um processo que não tem fim, nem se torna obsoleto: aprender a aprender. Ao contrário dos treinamentos, cujos conteúdos, sobretudo em se tratando de tecnologias, rapidamente se tornam ultrapassados. Estou convicta de que não há outro modo efetivo de "aprender informática" ou incorporar qualquer tecnologia que não seja a experimentação constante numa rede colaborativa. Em lugar de aquisição de competências, há que se promover um diálogo entre proficiências.

Arranjo possível num contexto concreto, que se transforma permanentemente, a formação continuada a que me refiro nunca será uma "solução definitiva” para os problemas da escola, nem poderá ser convertida em fórmula massificada. Conseqüentemente, para o orientador do processo de formação continuada, o problema não é somente como desenvolver e reproduzir uma metodologia didática, mas conhecer o universo das professoras e auxiliá-las a introduzir os multimeios entre seus hábitos culturais, numa dinâmica coletiva. Quebrado o fetiche, afastado o medo da tecnologia, as professoras podem dar-lhe novos usos cotidianos. Dessa maneira, elas se tornam produtoras culturais. O grau de consciência acerca de como se dá esse processo é o que impede que essas mesmas educadoras estabeleçam relações monoló- 
gicas com seus alunos. A reflexividade é um elemento-chave para a transformação das práticas pedagógicas no sentido da dialogia e da criticidade. Interação, exercício, ação, a formação em serviço é práxis reflexiva. E ela só pode florescer no espaço coletivo, a partir de um uso desdogmatizante das linguagens e dos meios.

Essa "desdogmatização" a que me refiro é a introdução dos meios e suas linguagens no ambiente escolar, mas não como novos elementos tecnológicos, novas técnicas ou instrumentos de ensino, num velho arranjo de relações já dadas (e, normalmente, pouco democráticas). É a sua incorporação crítica e dialógica. Crítica porque questiona e transforma o equilíbrio de poder no ecossistema educativo, abrindo-o à participação dos diferentes atores que o compõem. Dialógica porque, constitutiva desse ecossistema, ela o converte em um campo de expressões múltiplas, polifônicas, onde, em lugar do preconceito e das hierarquias entre os "gostos" de alunos, pais, professoras, dirigentes e funcionários, promove hibridações, cria novas formas de comunicação, resgata bens culturais esquecidos e não legitimados, faz ouvir discursos silenciados e ver imagens antes invisíveis. Em outros termos, projeta nas tramas urbanas, sempre tão excludentes, os atores da periferia. Naturalmente, nada disso ocorre sem o surgimento de conflitos.

Fica claro, pois, que o sucesso desse tipo de formação não depende apenas dos sujeitos envolvidos e suas capacidades. Envolve a própria disposição do sistema escolar em democratizar-se (leia-se: vontade política de seus dirigentes e demais participantes). Isso não quer dizer que seja preciso esperar as condições ideais para implementar projetos educomunicativos nas escolas. Significa que os resultados obtidos só podem ser compreendidos em relação às estratégias adotadas pelos atores diante da estrutura que encontraram, como uma luta política e cultural: ora eles atuam livremente nas brechas do sistema, ora perdem espaços e sobrevivem clandestinamente, ora recuam e cedem para continuar subsistindo, e assim por diante. De uma maneira ou de outra, esses agentes já não são marginais ou excluídos, mas sujeitos inseridos no processo histórico. 


\section{O sistema de hipóteses}

A hipótese central desta pesquisa é que a formação continuada voltada para o trabalho com os meios de comunicação e suas linguagens configura-se pela articulação de três principais dimensões, a partir das quais seus limites e possibilidades podem ser investigados: a subjetiva (produção da significação pela docente), a estrutural (produção da hegemonia no espaço escolar) e a identitária/ coletiva (produção da legitimação do grupo de formação). Daí derivam as seguintes hipóteses secundárias:

a) A produção de um projeto pedagógico educomunicativo pela professora se dá quando ela, acionando suas proficiências comunicativas anteriores e ampliadas pela formação e suas matrizes culturais, recria a proposta formativa.

b) O contexto sociopolítico e econômico (da escola, do bairro, do município, etc.) constitui uma estrutura que limita a ação da educadora na medida em que a proposta formativa educomunicacional entra em contradição com o projeto político-pedagógico da escola ou as políticas educacionais mais gerais, e de acordo com a capacidade da professora de traçar estratégias de ação que provoquem o deslocamento das posições hegemônicas a partir de brechas no sistema.

c) A legitimação da proposta educomunicativa depende de como o grupo em formação constitui sua identidade no embate entre as ideologias profissionais compartilhadas com os pares, a consciência gerada na práxis educativa e as proposições teóricas e metodológicas do curso. Em outras palavras, do modo como as professoras criam visibilidade para o projeto que nasce quando, na socialização da proposta educomunicativa, caminham dos níveis mais fortuitos da consciência, onde se revelam as formações discursivas, estereótipos e preconceitos, em direção aos mais substanciais, nos quais operam a crítica dos padrões ideológicos anteriores. 


\section{Objetivos}

O objetivo geral da pesquisa é analisar as possibilidades e os limites da formação continuada de educadoras para a transformação da prática pedagógica em direção à incorporação crítica das linguagens e dos discursos mediáticos.

Os objetivos específicos são:

1. Em relação às dimensões subjetivas envolvidas na formação:

a) Identificar em que medida os meios e tecnologias da comunicação e as linguagens mediáticas estão presentes no cotidiano da professora (dentro e fora da escola) e como se dá o seu uso;

b) Caracterizar as proficiências comunicativas e as matrizes culturais das professoras e sua relação com os saberes acionados no processo de formação continuada;

c) Reconhecer e analisar os projetos pedagógicos educomunicativos produzidos pelas educadoras em formação continuada.

2. Em relação às dimensões estruturais:

a) Caracterizar o contexto sociopolítico e econômico escolar em termos de disponibilidade de recursos materiais e propostas político-educacionais;

b) Identificar as contradições entre o projeto político-pedagógico da escola, as políticas educacionais, os recursos materiais e as dimensões políticas envolvidas no projeto educomunicativo;

c) Reconhecer e analisar as estratégias de ação construídas pelas professoras em formação para implementação de seu projeto educacional. 
3. Em relação às dimensões coletivas de criação de identidade e produção de legitimação:

a) Identificar as ideologias profissionais subjacentes à consciência prática da profissional em formação;

b) Analisar as contradições entre as formulações teóricas e metodológicas do projeto de formação educomunicativo e os componentes da identidade profissional da educadora;

c) Reconhecer e caracterizar as novas identidades geradas pelo grupo em formação continuada e as estratégias de construção de visibilidade e legitimidade do projeto educomunicativo.

No plano teórico, este projeto visa a:

a) Discutir as possibilidades de construção de uma metodologia de pesquisa transdisciplinar para o campo da Educomunicação;

b) Desenvolver uma abordagem educomunicativa do problema da formação de educadoras em serviço;

c) Analisar os pressupostos teóricos e metodológicos para a implementação de cursos de formação continuada voltados para a prática educomunicativa.

Os objetivos práticos são:

a) Fornecer um painel analítico de projetos educomunicativos criados por professoras em formação;

b) Mapear ações efetivas desenvolvidas pelas educadoras para contornar problemas políticos e estruturais que dificultam a implementação de projetos educomunicativos no contexto escolar;

c) Traçar um quadro compreensivo das estratégias de legitimação produzidas pelo grupo em formação. 


\section{Procedimentos metodológicos}

Este projeto segue a proposta de Maria Immacolata V. de Lopes, de articulação da pesquisa em níveis e fases e de "construção de estratégias metodológicas com base em problemas concretos de comunicação identificados pelo gestor no sentido de chegar a uma intervenção fundamentada sobre esses mesmos problemas". ${ }^{136}$ Tendo já discutido as instâncias epistemológica e teórica, passemos à estruturação metódica e técnica da investigação.

\subsection{Delimitação do objeto empírico (amostragem)}

A construção do objeto empírico foi feita por meio do estudo de caso do curso Pedagogia da Imagem. A unidade básica de análise é a educadora, sujeito que articula os processos de produção de sentido na formação continuada, a partir de seus saberes profissionais, consciência prática e inserção sociocultural. O universo da pesquisa é composto por aquelas matriculadas nos anos de 2006 e 2007. Para o estudo em profundidade, foram escolhidas participantes de diversas regiões de Campinas, a fim de possibilitar o exame de diferentes contextos socioeconômicos e culturais.

Para compor a amostra, foram selecionadas professoras ou grupos de professoras de acordo com os seguintes critérios:

a) maturidade, consistência e abrangência dos projetos implementados nas escolas;

b) abertura do ambiente escolar à investigação das condições estruturais envolvidas no processo de formação;

c) capacidade de articulação de grupos em torno do projeto educomunicativo.

${ }^{136}$ LOPES, Maria Immacolata Vassallo de. Pesquisa e gestor: proposta de um modelo metodológico para a pesquisa de intervenção. In: BACCEGA, Maria Aparecida (org). Gestão de processos comunicacionais, p. 70. Cf. também, da mesma autora, Pesquisa em comunicação. 8. ed. São Paulo: Loyola, 2005. 
Foram selecionadas:

a) Profa. Walquíria Yara de Carvalho, da EMEF Correa de Mello, formada no curso em 2006;

b) Grupo de professoras da EMEF Edson Luís Lima Souto, participantes do projeto institucional de formação, desenvolvido em 2007, com o apoio da orientadora pedagógica Carla Feriani;

c) Grupo de professoras da EMEF Padre Leão Vallerie, inscritas no curso em 2007;

d) Grupo de professoras da EMEI Recanto da Alegria, também inscritas em 2007.

No mapa abaixo, vemos a localização dessas escolas, situadas nas regiões periféricas de Campinas.

Figura 2: Localização das escolas que integram o estudo na cidade de Campinas

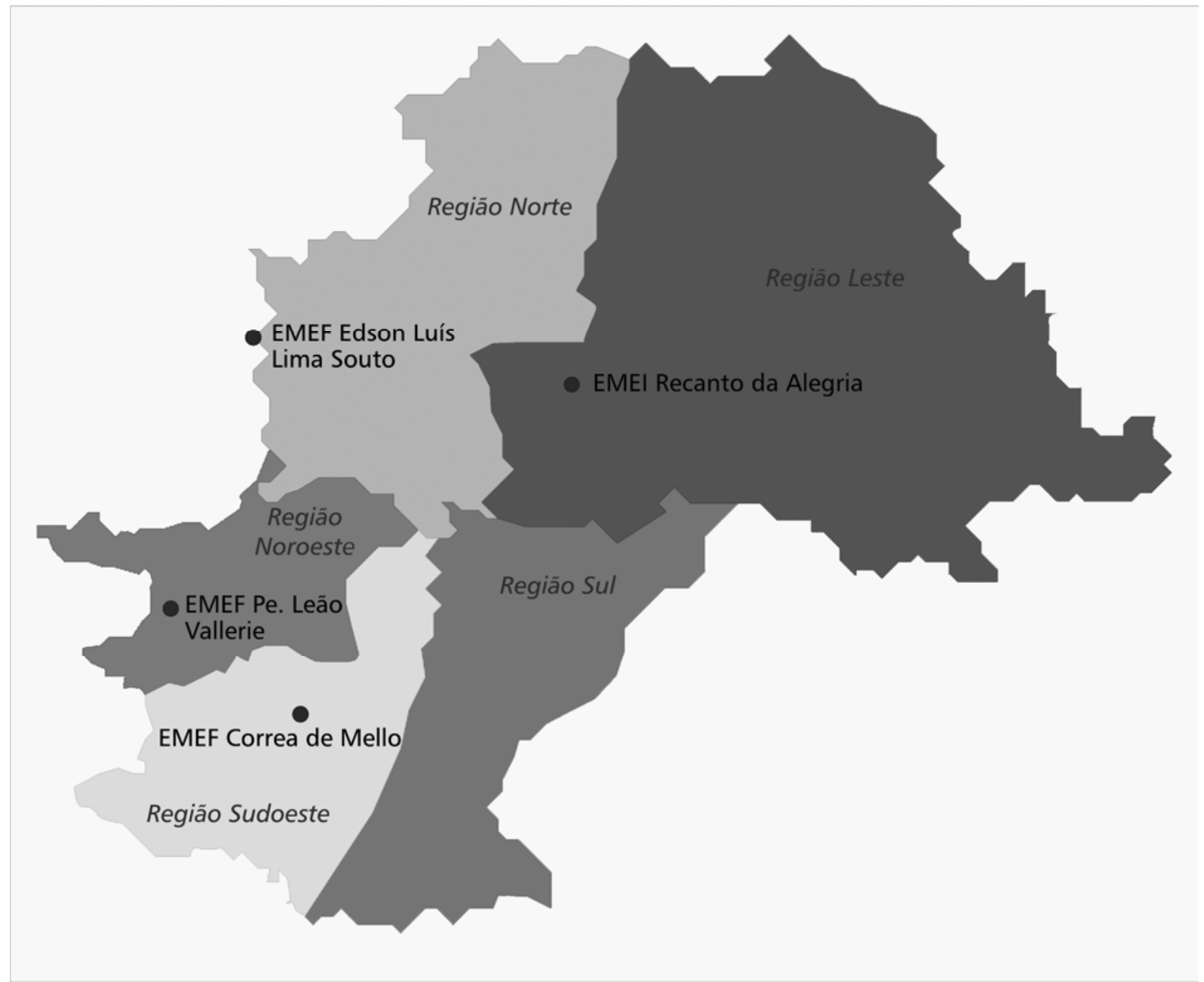




\subsection{Observação}

Os procedimentos de coleta consubstanciam uma estratégia multimetodológica cuja finalidade é observar o processo de formação de professoras em serviço como um fenômeno de comunicação. Assim, a reconstrução empírica do objeto foi feita pela investigação das três instâncias ou eixos da pesquisa - as dimensões subjetiva, estrutural e coletiva - a partir de três "lugares" da comunicação: o da recepção/ mediações, o da prática ou proposta formativa e o da produção de sentidos. O quadro a seguir evidencia a correspondência dessa estruturação com os objetivos da pesquisa.

Quadro 3: Estratégia da pesquisa para reconstrução empírica do objeto

\begin{tabular}{|c|c|c|c|}
\hline & \multicolumn{3}{|c|}{ Lugares } \\
\hline Eixos de investigação & Recepção/mediações & Prática formativa & Produção de sentidos \\
\hline Subjetivo & $\begin{array}{l}\text { Identificar em que medida } \\
\text { os MCM e tecnologias da } \\
\text { comunicação estão pre- } \\
\text { sentes no cotidiano da } \\
\text { professora e como se dá } \\
\text { seu uso. } \\
\text { Caracterizar as proficiên- } \\
\text { cias comunicativas e ma- } \\
\text { trizes culturais das educa- } \\
\text { doras. }\end{array}$ & $\begin{array}{l}\text { Explicitar as contradições en- } \\
\text { tre as proficiências comunica- } \\
\text { tivas acionadas no processo } \\
\text { de formação continuada e } \\
\text { aquelas trazidas pela profes- } \\
\text { sora. }\end{array}$ & $\begin{array}{l}\text { Reconhecer e analisar os } \\
\text { projetos pedagógicos edu- } \\
\text { comunicativos produzidos } \\
\text { pelas educadoras em for- } \\
\text { mação continuada. }\end{array}$ \\
\hline Estrutural & $\begin{array}{l}\text { Caracterizar o contexto } \\
\text { sociopolítico e econômico } \\
\text { escolar. }\end{array}$ & $\begin{array}{l}\text { Identificar as contradições } \\
\text { entre o projeto político- } \\
\text { pedagógico da escola, as po- } \\
\text { líticas educacionais, os recur- } \\
\text { sos materiais disponíveis e as } \\
\text { propostas educomunicativas. }\end{array}$ & $\begin{array}{l}\text { Reconhecer e analisar as } \\
\text { estratégias de ação cons- } \\
\text { truídas pelas professoras } \\
\text { em formação para imple- } \\
\text { mentação de seu projeto } \\
\text { educacional. }\end{array}$ \\
\hline Coletivo & $\begin{array}{l}\text { Identificar as ideologias } \\
\text { profissionais subjacentes à } \\
\text { consciência prática da } \\
\text { profissional em formação. }\end{array}$ & $\begin{array}{l}\text { Analisar as contradições entre } \\
\text { as formulações teóricas e me- } \\
\text { todológicas do projeto e os } \\
\text { componentes da identidade } \\
\text { profissional da educadora. }\end{array}$ & $\begin{array}{l}\text { Reconhecer e caracterizar } \\
\text { as novas identidades gera- } \\
\text { das pelo grupo em forma- } \\
\text { ção continuada e as estra- } \\
\text { tégias de construção de } \\
\text { visibilidade e legitimidade } \\
\text { do projeto educomunicati- } \\
\text { vo. }\end{array}$ \\
\hline
\end{tabular}


Cada um desses objetivos solicitou a aplicação de técnicas específicas de observação a diferentes amostras (ver quadro 4). Em síntese, para o trabalho com o universo das educadoras inscritas no curso Pedagogia da Imagem, foi feito o registro em vídeo e a transcrição dos encontros de professoras. Nesses momentos, freqüentemente são promovidas discussões que visam à troca de informações e experiências entre as participantes. Com o estímulo dos orientadores, as professoras deixam emergir expectativas, dificuldades, soluções, crenças, preconceitos, formulações ideológicas, consciência profissional, frustrações, estratégias, etc. capazes de apontar pistas de investigação e categorias que foram ponderadas por meio da aplicação de questionários e aprofundadas no trabalho com a amostragem de projetos. Junto a esse grupo menor, combinei o método etnográfico, as entrevistas semi-estruturadas e os registros dos projetos educomunicativos desenvolvidos em sala de aula. No eixo estrutural, além de buscar informações oficiais sobre as escolas, as professoras e as políticas educacionais do município, a pesquisa etnográfica incluiu o contexto do bairro onde se localiza a escola. Para complementar os dados de campo, foi feito um ensaio fotográfico sobre o espaços escolares e seu entorno.

Quadro 4: Técnicas de coleta e amostragem

\begin{tabular}{|c|c|c|}
\hline Eixo & Amostra & Técnicas \\
\hline \multirow[b]{2}{*}{ Subjetivo } & $\begin{array}{l}\text { Universo das professoras } \\
\text { inscritas no curso Pedagogia } \\
\text { da Imagem. }\end{array}$ & $\begin{array}{l}\text { 1. Pesquisa de fontes primárias (documental): transcrição dos regis- } \\
\text { tros em vídeo do curso Pedagogia da Imagem. } \\
\text { 2. Observação direta extensiva (questionário). }\end{array}$ \\
\hline & Amostra de professoras. & $\begin{array}{l}\text { 1. Observação direta intensiva (método etnográfico }+ \text { entrevista } \\
\text { semi-estruturada). } \\
\text { 2. Pesquisa de fontes primárias (documental): projetos e registro de } \\
\text { projetos desenvolvidos pelas professoras. }\end{array}$ \\
\hline \multirow{3}{*}{ Estrutural } & Rede Municipal de Ensino & $\begin{array}{l}\text { 1. Pesquisa de fontes primárias (documental): dados oficiais da Se- } \\
\text { cretaria Municipal de Educação. }\end{array}$ \\
\hline & $\begin{array}{l}\text { Universo das professoras } \\
\text { inscritas no curso Pedagogia } \\
\text { da Imagem. }\end{array}$ & $\begin{array}{l}\text { 1. Pesquisa de fontes primárias (documental): transcrição dos regis- } \\
\text { tros em vídeo do curso Pedagogia da Imagem. } \\
\text { 2. Observação direta extensiva (questionário). }\end{array}$ \\
\hline & Amostra de professoras. & $\begin{array}{l}\text { 1. Observação direta intensiva (método etnográfico + entrevista } \\
\text { semi-estruturada }+ \text { ensaio fotográfico). }\end{array}$ \\
\hline \multirow[t]{2}{*}{ Coletivo } & $\begin{array}{l}\text { Universo das professoras } \\
\text { inscritas no curso Pedagogia } \\
\text { da Imagem. }\end{array}$ & $\begin{array}{l}\text { 1. Pesquisa de fontes primárias (documental): transcrição dos regis- } \\
\text { tros em vídeo do curso Pedagogia da Imagem. } \\
\text { 2. Observação direta extensiva (questionário). }\end{array}$ \\
\hline & Amostra de professoras. & $\begin{array}{l}\text { 1. Observação direta intensiva (método etnográfico + entrevista } \\
\text { semi-estruturada). }\end{array}$ \\
\hline
\end{tabular}




\section{a) Problematizando os instrumentos de coleta}

Os registros em vídeo das discussões promovidas durante os encontros do curso Pedagogia da Imagem constituem uma situação comunicativa de produção discursiva, onde os sentidos do "texto" coletivo não são fechados pelos sujeitos participantes. Cada sessão não foi tomada isoladamente, mas como parte de uma prática discursiva mais ampla onde os significados são negociados e renegociados permanentemente. As discussões em grupo são uma prática performativa que aciona o habitus e a consciência prática dos atores, revelando suas inserções sociais e vinculações ideológicas. Coube a mim enfrentar o desafio de reconhecer, nesse jogo polifônico, os sistemas de significações e visões da realidade, as assimetrias nas relações sociais e os tipos de participação postos em cena pelas professoras. ${ }^{137}$

Os questionários foram aplicados às educadoras numa etapa posterior a discussões em grupo, a fim de se evitar a imposição de problemáticas alheias aos sujeitos pesquisados. Trata-se de um uso complementar dessas técnicas - em primeiro lugar, porque as dinâmicas coletivas me propiciaram assumir uma perspectiva de relativismo cultural e reflexividade na elaboração do questionário; em segundo lugar, porque o questionário permitiu identificar em que medida as posições defendidas nas discussões são compartilhadas pelo grupo ou refletem a predominância de certos participantes.

Do mesmo modo, a metodologia etnográfica e a entrevista semi-estruturada, aplicadas aos grupos de professoras selecionadas, funcionaram de maneira complementar. A etnografia permitiu captar a cotidianidade escolar, o que implicou recuperar conjuntos de atividades heterogêneas por natureza, empreendidas e articuladas pelos indivíduos, mas ao mesmo tempo impregnadas de conteúdo histórico. A entrevista semi-estruturada revelou a consciência discursiva dos atores a respeito do próprio fazer e das condições sociais em que estão inseridos, dando conta dos sentidos que thes atribuem.

${ }^{137}$ Questões especificas sobre o grupo de discussão são abordadas em CERVANTES BARBA, Cecília. El grupo de discusión: de la mercadotecnia al estudio de la cultura y la comunicación. VI Congresso ALAIC. Bolívia, 2002. 


\subsection{Preparação do material (pré-análise)}

Na pré-análise, os dados coletados foram organizados e confrontados pelo método da triangulação entre as informações relativas a processos e produtos centrados no sujeito, as referentes aos processos e produtos originados pela estrutura socioeconômica e cultural e os elementos produzidos pelo meio do sujeito. A utilização do método etnográfico permitiu rever, ampliar e alterar as categorias de análise à medida que as observações foram incorporadas e interpretadas. Como um parâmetro inicial, a partir dos recortes teóricos já enunciados, defini as seguintes categorias:

Quadro 5: Categorias de análise previstas

\begin{tabular}{|c|c|c|c|}
\hline & \multicolumn{3}{|c|}{ Lugares } \\
\hline Eixos & Recepção/mediações & Prática formativa & Produção de sentidos \\
\hline Subjetivo & $\begin{array}{l}\text { Proficiências comunicativas } \\
\text { Usos da comunicação } \\
\text { Matrizes culturais }\end{array}$ & $\begin{array}{l}\text { Saberes profissionais } \\
\text { Prescrição/ Construção } \\
\text { Contradições }\end{array}$ & $\begin{array}{l}\text { Autoria/ Motivação } \\
\text { Criatividade/ Prazer/ Risco } \\
\text { Experiência/ Inventividade }\end{array}$ \\
\hline Estrutural & $\begin{array}{l}\text { Cotidianidade/ Rotinização } \\
\text { Divisão do trabalho/ Poder } \\
\text { Projeto político-pedagógico }\end{array}$ & $\begin{array}{l}\text { Proposta ético-política da } \\
\text { formação } \\
\text { Contradições }\end{array}$ & $\begin{array}{l}\text { Resistência/ Reflexividade } \\
\text { Clandestinidade } \\
\text { Mudança/ Historicidade }\end{array}$ \\
\hline Coletivo & $\begin{array}{l}\text { Ideologias profissionais } \\
\text { Preconceitos/ Estereótipos } \\
\text { Consciência discursiva/ Prática }\end{array}$ & $\begin{array}{l}\text { Formulações teóricas e me- } \\
\text { todológicas/ Crítica } \\
\text { Contradições }\end{array}$ & $\begin{array}{l}\text { Identidade/ Reconhecimento } \\
\text { Visibilidade/ Invisibilidade } \\
\text { Legitimidade/ Julgamentos }\end{array}$ \\
\hline
\end{tabular}

\subsection{Análise}

A análise foi empreendida pelo método narrativo. Essa escolha foi feita tendo em mente a viabilidade e as vantagens de explorar as características desse gênero na construção do trabalho científico de natureza qualitativa $^{138}$ :

\footnotetext{
${ }_{138}$ BENJAMIN, W. O narrador. Considerações sobre a obra de Nikolai Leskov. In: Magia e técnica, arte e política; ensaios sobre literatura e história da cultura. 7. ed. São Paulo: Brasiliense, 1994.
} 
a) recuperando a experiência vivida pelos sujeitos envolvidos no processo de formação, a narrativa torna seu aprendizado comunicável;

b) seu senso prático e sua dimensão utilitária permitem ao leitor incorporar suas próprias experiências, o que faz do conhecimento um produto socialmente gerado;

c) ao estabelecer o distanciamento, a narrativa ensina lições que podem ser transpostas para outras situações (ao contrário do que ocorre com a informação, que só pode ser generalizável para contextos próximos/ semelhantes);

d) a narrativa é um produto coletivo e polifônico, uma vez que faz parte da constituição do sujeito que conta mas, simultaneamente, aciona a memória resultante de processos sócio-históricos. 

II Pedagogia da IMAgem: A CONSTRUÇÃO DE UM PROJETO EDUCOMUNICATIVO 

Não se creia que as lições que a vida ensina estão no ar, livres a voar, bastando que nossa boa vontade as leia. Elas não estão escritas e expostas. Compreendê-las demanda gestos de interpretação, sempre resultantes de diálogos entre o mundo da vida onde as ações acontecem e o mundo da cultura onde elas adquirem sentidos. Os sentidos não estão aí a bailar, soltos e solitários esperando seus interpretantes; as chaves com que se (re)constroem os sentidos são trabalhosas, demandam mãos hábeis no bordado, porque, às vezes insignificantes, nos escondem os elos necessários para (re)significar a vida. De novo, não apenas se aprende: produz-se o que se aprende.

Corinta Maria Grisolia Geraldie João Wanderley Geraldi ${ }^{139}$

A busca de sentidos para as ações que empreendemos é, muitas vezes, uma empreitada que nos lança em uma jornada árdua, de destinos insuspeitos e cuja trajetória decide-se menos pelos frágeis mapas que tomamos de apoio na partida que pelas linhas encontradas no percurso, com as quais vamos tecendo o nosso fio de Ariadne.

Assim tem sido minha experiência como agente cultural na Prefeitura Municipal de Campinas, desde que passei a me dedicar à construção do projeto Pedagogia da Imagem. Tendo como companheiros o professor e historiador Orestes Augusto Toledo e o agente cultural Batata (Ronaldo Simões Gomes), ousamos, em 2003, propor a criação de um grupo de trabalho de professoras da rede municipal, interessadas em explorar as linguagens da fotografia, do cinema, da TV e do vídeo em sala de aula. Ousamos, sim, porque na época não tínhamos a exata noção dos desafios com que iríamos deparar, nem do aprendizado que essa aventura nos proporcionaria.

Compartilhávamos uma percepção: a de que a esfera da comunicação, em especial pelo audiovisual, constitui hoje um espaço fundamental da ação cultural pública, contribuindo para a revelação das identidades ocultadas, para o despertar da autonomia e da autodeterminação dos sujeitos sociais e para o estabelecimento de relações mais democráticas no que se refere às condições de produção, fruição e circulação dos bens culturais. Procurávamos uma maneira de dividir nossas inquietações com pessoas que, trabalhando com crianças e adolescentes, nas mais diversas regiões da cidade, estivessem dispostas a realizar experiências de produção e discussão do audiovisual.

${ }^{139}$ GERALDI, C. M. G. e GERALDI, J. W. Saberes da lida, saberes da vida. In: LIMA, M. E. C. C.. Sentidos do trabalho, p. 10. 
Contamos com o apoio do Ceforma para divulgar nossa intenções. Pensávamos que a proposta atrairia não mais que uma dezena de educadoras. Estávamos muito enganados. Na primeira reunião, que convocáramos apenas para sondar o interesse do grupo, o improvisado auditório no Museu da Imagem e do Som ficou pequeno para cerca de cinqüenta professoras, diretoras e orientadoras pedagógicas cuja expectativa era, de imediato, iniciar um programa de formação continuada. (Três anos depois, em março de 2006, verificamos que o interesse pelo tema havia aumentado, com mais de uma centena de profissionais da educação inscrevendo-se para participar do curso).

Desde então, nosso esforço tem sido o de compreender os sentidos da formação continuada de professoras na área audiovisual, aproximarmo-nos da realidade das comunidades escolares e verificar que projetos, possibilidades e usos têm sido criados por esses agentes, que limites vêm se apresentando e que estratégias têm sido traçadas para contornar as dificuldades, vencer as frustrações e implementar ações efetivas. Temos também nos empenhado para sistematizar e consolidar teoricamente a nossa proposta, seja porque esse empreendimento nos ajuda a construir a legitimação de nossas ações junto aos órgãos municipais, seja pela seriedade do compromisso que assumimos com as educadoras que nos procuram - e compartilham conosco parte de seus saberes, de suas carreiras e de suas vidas.

Nossas reuniões semanais de planejamento são sempre oportunidades de autoformação, em que trocamos histórias, leituras, observações, experiências. As entrevistas individuais em profundidade e o grupo de discussão que promovi, para a elaboração deste capítulo, não foram diferentes: acabaram se constituindo em preciosos momentos de reflexividade e contribuíram para alargar a compreensão que cada um de nós tinha a respeito do projeto. Em encontros realizados no MIS, entrevistei Orestes e Batata; posteriormente, Orestes me entrevistou. O grupo de discussão, com a participação dos três integrantes, ocorreu em três sessões, totalizando quatro horas de gravação.

Apresentando os dados colhidos, minha tarefa não será a de explicar, teoricamente, o que constitui o projeto Pedagogia da Imagem. Antes, será a de buscar compreender como, a partir de trajetórias subjetivas diversas, em determinadas condições institucionais, nós, agentes envolvidos na sua proposição, passamos a, coletivamente, delinear e legitimar a nossa práxis cultural-educativa. 
Ao expor nossa proposta, meu objetivo não é apresentá-la como modelo ou exemplo a ser seguido como lembra o Professor Ismar de Oliveira Soares, não existe uma fórmula ou uma metodologia da Educomunicação - mas abri-la à análise e à construção de sentidos. Ir à prática, observá-la em sua complexidade, construir um conhecimento e, assim, torná-la práxis.

Procurarei ser o mais fiel possível às concepções do grupo, o que significa um esforço de não promover o fechamento discursivo a respeito do projeto, mas de registrar as diferentes visões que o alimentam. E, se a tanto não me faltar engenho e arte, concertá-las polifonicamente, como temos feito ao longo dos cinco últimos anos.

\section{Onde as vidas se encontram}

Para ensaiar a compreensão das propostas do curso Pedagogia da Imagem seria inútil recorrer, em primeiro lugar, a livros, teorias ou diretrizes institucionais. Esse trabalho não nasceu do engajamento do grupo em proposições acadêmicas ou de políticas públicas. Nasceu antes, nas nossas trajetórias pessoais, nas lições da vida, nas diferentes experiências moldadas pelas nossas inserções socioculturais, por vezes fragmentadas e assistemáticas, mas que nos permitiram, apesar das muitas diferenças, compartilhar uma visão de mundo e, sob uma dada circunstância, construir um projeto comum. A teoria nos serve, aqui, como um ponto de apoio e avaliação crítica das nossas premissas, impedindo-nos de cair num ativismo simplista e inconseqüente.

Reconstituir nossos passos, por meio das histórias de vida, não é uma tarefa de buscar as semelhanças entre nossos objetivos, formações ou crenças. É, ao contrário, entender a diversidade das nossas subjetividades, que, transpostas em diretrizes, metodologias e propostas práticas, fazem da Pedagogia da Imagem um projeto único. Por um lado, isso impede de tomá-la como fórmula ou modelo a ser seguido e, por outro lado, a torna singular e autoral. 
As entrevistas intensivas que fiz com os colegas Orestes e Batata, e a que concedi a Orestes foram, nesse sentido, reveladoras. ${ }^{140}$ Facilitados pela convivência respeitosa que estabelecemos ao longo dos anos, os diálogos explicitaram vínculos profundos de cada um de nós com as questões da imagem, da cultura e da participação política. Vínculos não apenas de natureza objetiva, social e profissional, mas também afetivos e existenciais. Optei pela entrevista não-diretiva, colocando, no centro do diálogo, o entrevistado. Solicitou-se a cada um que se identificasse, falando de sua formação, seu ingresso na carreira pública e seu interesse pela Pedagogia da Imagem. À medida que cada um desfiava o novelo das suas lembranças e esquecimentos, bordava também os significados dos fatos, como eram para si: trazendo-os novamente à luz, nos elucidávamos.

Os relatos que ouvi e contei procurarei agora narrar brevemente, no sentido que Ítalo Calvino deu à rapidez. ${ }^{141}$ Sua relevância reside no ponto em que as histórias pessoais se cruzam com a história humana, revelando as subjetividades formadas no encontro com o outro e com a cultura. Não se trata de uma simples contação de casos, mas de fazer a passagem do acontecimento à experiência, ${ }^{142}$ permitindo a compreensão de como chegamos a formar um grupo e propor o curso Pedagogia da Imagem.

\subsection{Uma paixão pelo cinema}

Orestes Augusto Toledo, historiador do Museu da Imagem e do Som de Campinas (MIS), é um colega tranqüilo, respeitoso e respeitado por todos no ambiente de trabalho. Não é para menos: há 16 anos radicado no MIS é ele quem coordena e põe em prática as atividades de exibição e debate de filmes, o núcleo de história oral em vídeo e uma série de grupos de discussão relacionados à produção de vídeo, à história do cinema e aos estudos culturais. Experiente, sempre aberto a colaborar em projetos audiovisu-

\footnotetext{
140 Para realizar as entrevistas, foi de grande utilidade e inspiração a leitura de MEDINA, Cremilda de Araújo. Entrevista: o diálogo possível. 4. ed. São Paulo: Ática, 2004.

141 "A rapidez de estilo e de pensamento quer dizer antes de mais nada agilidade, mobilidade, desenvoltura; qualidades essas que se combinam com uma escrita propensa a divagações, a saltar de um assunto para outro, a perder o fio do relato para reencontrá-lo ao fim de inumeráveis circunlóquios." CALVINO, Ítalo. Seis propostas para o próximo milênio. 2. ed. São Paulo: Companhia das Letras, 1990, p. 59.

${ }^{142} \mathrm{O}$ uso da narrativa como uma metodologia de construção do conhecimento nas produções acadêmicas é discutido em LIMA, M. E. C. C. Sentidos do trabalho, p. 47-48.
} 
ais, não seria exagero dizer que ele já se tornou uma referência na cidade. Vive cercado de jovens, nos cursos e orientações de trabalhos. Aparentemente introspectivo, quando encontra um interlocutor atento é capaz de conversar horas a fio e com propriedade, quando o assunto é cinema, vídeo ou a luta revolucionária. Tudo isso com uma sincera simplicidade e a humildade de quem se põe permanentemente disposto a encontrar o outro e aprender com ele.

Sentado à minha frente, ele conta, em voz mansa, sua formação e a carreira profissional. Fez o curso noturno de História na PUC Campinas, de 1973 a 1977, enquanto trabalhava em um banco. Já formado, em 78, iniciou a jornada típica do profissional de educação, dando aulas em duas ou três escolas num mesmo dia. Em 80 se efetivou na rede pública estadual. Dois anos depois, foi aprova-

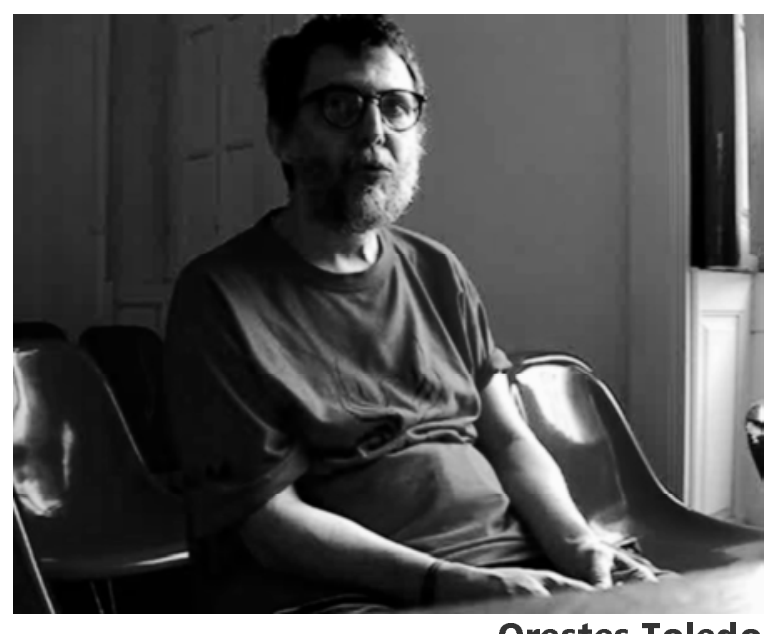

Orestes Toledo do em concurso para lecionar no período da noite na Escola Técnica Conselheiro Antônio Prado (Etecap), onde ainda trabalha. Em 89 prestou o concurso da Prefeitura de Campinas e foi atuar na estruturação da coordenadoria técnica do Conselho de Defesa do Patrimônio Cultural (Condepacc), que então estava sendo criado. Era responsável pelas pesquisas históricas que fundamentam os processos de tombamento. Sua intenção, no entanto, já era trabalhar no Museu da Imagem e do Som, aonde chega em 1990.

Sua relação com o Museu, explica Orestes, é muito anterior a essa data. É a própria relação com o cinema, uma relação que nasce com as experiências da infância e da adolescência. E, à medida que ele me revela sua paixão pelo cinema, a voz se entusiasma, o sorriso se abre e o pensamento vai saltando, ligeiro, entre as dobras da memória.

Orestes nasceu em Campinas, em 1954, herdando o nome do avô paterno, então falecido. Da família do pai, contador da Companhia Mogiana, conheceu a avó, uma espanhola já idosa e frágil, o irmão quinze anos mais velho, filho do primeiro casamento de seu pai, e os tios, todos solteiros: o único homem era 
rábula; das mulheres, uma delas cuidava da casa e outras duas eram educadoras. Uma, em especial, era alfabetizadora vocacionada, rodeada de crianças, ensinando as lições em casa. Costumava levar o sobrinho ao cinema e ao teatro, contava histórias, lhe dava livros com dedicatórias - relíquias até hoje mantidas. Sempre conversando sobre o que viam, comentando, estimulando. Pergunto se a opção de ser professor foi influenciada por ela. Orestes confirma: "eu diria que eu optei por ser professor até antes de ser historiador, porque era um ambiente que eu conhecia". Conhecia e amava: "paixão pela arte, cultura, literatura, essas coisas". Se a escola the parecia um jogo mental sem sentido, as tias the ensinaram que aprender podia ser uma coisa gostosa.

A maior parte da infância contudo, foi vivida junto à família da mãe, um núcleo numeroso de ferroviários que residiam na Vila Industrial. O avô, apaixonado pela ferrovia, e outros idosos da vizinhança contavam ao menino as lembranças dos tempos em que a Vila era chamada "o bairro vermelho", de quando as lutas operárias organizadas pelos imigrantes italianos eram duramente reprimidas pela polícia, ou dos carnavais que ali mesmo brincavam. A mãe tinha sido também operária. Depois de trabalhar nove anos na fábrica de fiação dos Matarazzo, concluiu os estudos no supletivo e conseguiu uma vaga no escritório da companhia, onde permaneceu por mais uma década. As lutas sociais, as reivindicações dos trabalhadores, as greves, tudo isso fazia parte do seu cotidiano. Eram a história viva. Foi, portanto, na Vila Industrial, que Orestes entendeu a essência da história: não é estudá-la; é fazê-la.

Na adolescência o cinema se tornou sua paixão. Era um período difícil: morando num bairro distante, já não convivia tanto com os primos e primas de sua idade. Sentia-se isolado. Duas coisas o salvaram: o futebol e o cinema. O primeiro era para ele uma boa metáfora do socialismo: um jogador é diferente do outro, cada um melhor em sua posição; o que importa é o espírito coletivo. Com ele se aprendem as regras da convivência: dizer não sem ofender, ouvir o não sem se sentir ofendido, admitir o erro, pedir desculpas, ter em consideração o bem da equipe. No futebol, ninguém vence sozinho. Já o cinema representava a possibilidade de imaginar, criar uma nova realidade, transportar-se para outros mundos. Uma necessidade existencial que trouxe um aprendizado prático, mas também político. 
Aos 11, 12 anos, Orestes freqüentava o cinema sozinho. Cinemas de bairro, que na época existiam até na periferia. Durante vários anos, ia quase toda noite e assistia às sessões duplas. Sem qualquer orientação, via e gostava de tudo. Hoje - revela - tem a clareza de como o cinema é importante para formar nossa cosmovisão, seja positiva ou negativamente: "a gente acaba criando certas visões estáticas, que impedem uma percepção mais clara sobre a dimensão real dos contatos humanos, muito mais complexos”. Daí a importância de receber outros estímulos, informações opostas, que provocam um curto circuito nessa rede de valores e percepções estáveis.

Esses estímulos vieram de um ambiente cultural diversificado. Avesso ao comportamento da maioria dos adolescentes de seu tempo, fãs da Jovem Guarda e do iê-iê-iê, Orestes preferia os livros. Acabou lendo, sem saber do que se tratava, os clássicos das literaturas francesa e russa. Ficou profundamente impactado com a leitura de Crime e castigo. Pela TV, acompanhou os festivais de música brasileira, O fino da bossa, viu surgir o Tropicalismo, os Doces bárbaros... Quando ouviu os Mutantes fundindo o moderno com a música caipira, foi tomado de perplexidade. Alguma coisa rompia os velhos rótulos e classificações: "até hoje, gosto de coisas de vanguarda. Coisas assim, que quebram a mesmice. Uma coisa meio diferente. Coisa que não entendo de cara”. Pela revista Realidade, ficou sabendo do movimento hippie nos Estados Unidos, do Festival de Woodstock, do movimento underground e da contracultura: estava mentalmente ligado a tudo aquilo: "o mundo é maior do que o que está aqui em volta".

No cinema do bairro, assistiu aos filmes do neo-realismo italiano, do cinema novo, do surrealismo. De uma postura assistemática, passou a anotar os nomes dos diretores das películas que lhe agradavam: Fassbinder, Buñuel, mais tarde Bergman e assim por diante. Agora, o fascínio pelo cinema se refinava em paixão pelo filme, pela linguagem do diretor e seu modo de contar a história.

Nesse período descobriu, por conta própria, como se produz cinema. O primeiro insight foi na aula de literatura. O professor leu em voz alta o conto de Guimarães Rosa, A hora e a vez de Augusto Matraga. No final do capítulo, havia um trecho do roteiro do filme, escrito por Roberto Santos. O professor não deu atenção ao roteiro, mas o formato diferente de contar a história chamou a atenção de Orestes, mesmo ele não tendo compreendido como aquilo funcionava. Algumas semanas depois, contudo, o filme en- 
trou em cartaz no cinema do bairro. Orestes se lembrou do roteiro: "então é assim que se faz um filme!" Outra revelação foi quando, lendo a revista Realidade, deparou com uma foto de Glauber Rocha no set de filmagem, junto a uma numerosa equipe de produção, dirigindo os atores em $O$ dragão da maldade contra o santo guerreiro. "Parecia óbvio, mas não era: eu tinha visto o filme, mas não tinha visto fora do quadro". Não tardou muito, descobriu em Campinas um grupo chamado Cinema experimental de fundo de quintal, de jovens cinéfilos que faziam experiências de linguagem em formato Super 8. Ao conhecê-lo, o líder do grupo entregou-lhe a câmera, deu umas instruções básicas e disse: "filma! Amanhã você volta e vamos revelar o que você fez." Entusiasmado, percebeu que aquela era também sua forma de expressão. Outra sensação impactante viria tempos depois, ao conhecer pessoalmente um diretor de cinema.

Quando entrou para a faculdade, no auge da ditadura militar, Orestes já possuía uma posição política definida. Engajou-se no movimento estudantil - na época dirigido por forças revolucionárias clandestinas - e logo percebeu a tarefa que lhe cabia: promover o cineclubismo. Tinha consciência de que o campo cultural era também um importante espaço de luta política, "infelizmente, em outras épocas mais valorizado do que hoje”.

O cineclube universitário funcionava clandestinamente. A PUC não autorizava a exibição de filmes. $\mathrm{O}$ fundador do Museu da Imagem e do Som, seu Henrique de Oliveira Júnior, emprestava o projetor 16 mm sem ter noção exata do que seria exibido. As películas proibidas eram conseguidas em acervos não declarados de distribuidoras situadas na Rua do Triunfo, a "boca do lixo”, em São Paulo. "Exibir os filmes era um ato revolucionário", define Orestes.

Por algum tempo, o movimento cineclubista contaria com alguns espaços significativos em Campinas: o Centro de Ciências, Letras e Artes, a Casa do DCE da Unicamp, o Cineclube Lampião, o barracão Evolução, o próprio MIS, cuja sala de exibição ficava no Centro de Convivência Cultural, o Ponto de Cinema e, mais tarde, o Cine Regente. Não tardaria e o cineclubismo seria ferozmente reprimido pelos agentes da ditadura. Na década de 80, coube ao MIS, sob a direção de Dayz Peixoto Fonseca, resgatar o espírito do movimento. No Cine-teatro Castro Mendes ela promovia, uma vez por mês, uma sessão com filmes de arte. A casa, com capacidade para 800 pessoas, freqüentemente lotava. 
Se a história do Museu da Imagem e do Som se pontua pela atuação de pessoas apaixonadas pelo audiovisual, desde o seu fundador, seu Henrique de Oliveira Júnior, incluindo diretores que se seguiram, como Dayz Peixoto, até os funcionários, técnicos projecionistas e educadores, estava claro para Orestes que era aquele o seu lugar. Quando ali chega, em 1990, durante o mandato municipal de Jacó Bittar, a diretriz para as ações culturais era promover sua descentralização. Foram anos de intensas atividades e de grande impulso à ação educativa.

As experiências que então se desenvolveram são precursoras da Pedagogia da Imagem. Além das exibições fixas na Sala Glauber Rocha, o MIS promovia, nos fins de semana, o cinema itinerante, com sessões de filmes $16 \mathrm{~mm}$ em escolas, espaços comunitários e sindicatos, seguidas de debates e explicações sobre a técnica. Não era simplesmente lazer ou educação. Havia uma questão de fundo que permeava aquele trabalho: a preocupação com a luta pela democratização dos meios de comunicação. Lendo o livro de Luiz Fernando Santoro, A imagem nas mãos: o vídeo popular no Brasil, (São Paulo: Editora Summus, 1989), Orestes tomou contato com uma realidade cultural latino-americana modificada pela introdução do videocassete e se impressionou com os relatos das experiências de utilização do vídeo nas lutas sociais populares, seja como registro histórico, instrumento didático ou um meio de realimentar o processo de mobilização. Lembrou que, em Campinas, tinha travado alguns contatos com a Central dos Movimentos Populares, ligada às Comunidades Eclesiais de Base, da ala progressista da Igreja Católica. $\mathrm{Na}$ época, anterior à popularização das filmadoras VHS e do videocassete, o grupo realizava uma produção audiovisual utilizando projetores de slides e aparelhos de som.

Sentiu que era importante desenvolver um trabalho nesse sentido. Teve o apoio de duas colegas, Tutu e Marilda. Decidiram promover a discussão sobre a televisão: criaram os teledebates. Gravavam programas de TV, escolhiam trechos e editavam, simulando, de maneira condensada, um dia da programação televisiva, desde a abertura, com os programas infantis, intercalando com os comerciais, passando pelos telejornais e novelas, até encerrar com programas humorísticos e de auditório. O vídeo final durava cerca de 20 minutos. Nos bairros, escolas e sindicatos, a equipe organizava sessões de exibição e discussão. Uma apostila era entregue no início da atividade, com algumas informações e perguntas. "Nunca teve, nem poderia ter, nem tem hoje, um proselitismo de respostas. As questões que a gente levantava eram 
questões provocativas". O objetivo era buscar aspectos do conteúdo e da linguagem que, descontextualizados da rotina de recepção, faziam refletir: "a dona-de-casa mais simples entendia tudo que tava por trás daquilo". Procurava-se evidenciar que a produção televisiva é uma construção, um recorte da realidade que começa na filmagem e se acentua na edição. "Eu acho até que a montagem, no sentido da manipulação de fragmentos que se articulam para formar um todo é o princípio central de todo o pensamento, de toda a nossa cosmovisão", justifica. Essas atividades eram chamadas Pedagogia da Imagem nome que, anos depois, iríamos resgatar para batizar o nosso projeto.

Quando o museu adquire uma câmera VHS, Orestes começa a utilizá-la experimentalmente nos projetos de história oral. Em pouco tempo, a novidade do equipamento se espalha pela cidade, dando origem a uma demanda inesperada de alguns setores sociais, das camadas populares e da Secretaria de Cultura, para o registro de diferentes atividades: rituais de candomblé (Projeto Candeias), apresentações de bandas alternativas (Bar Ilustrada), as manifestações da Central dos Movimentos Populares no Paço Municipal, algumas discussões sobre a criação de uma fundação municipal de cultura e assim por diante.

Logo Orestes perceberia: melhor que registrar as atividades das periferias seria permitir que os próprios moradores filmassem sua realidade, com a orientação e o apoio necessários. A metodologia privilegiava a participação de crianças e adolescentes e as decisões em equipe: na escolha do tema, na criação do roteiro, na definição dos enquadramentos e movimentos de câmera. Um processo moroso, mas necessário: "é como uma alfabetização, tem que ser um a um". Não tinha muita teoria, mas a prática fazia diferença: "o rapaz do Espaço Esperança uma vez me surpreendeu. Um rapaz simples, lá da periferia, ele falou assim: 'oh, agora eu não assisto mais o filme do jeito que eu assistia antes. Agora eu fico prestando atenção...' Então, quer dizer, ele começou a enxergar as coisas diferente”. Para a própria equipe do MIS foi também um aprendizado: o de que a leitura da imagem nasce da escrita da imagem. "Então começamos a perceber que não é só assistir à televisão, tem que fazer televisão. Não é só passar o filme. Tem que fazer o filme."

Nos bairros mais desassistidos de Campinas, como o Jardim São Marcos e o Santa Lúcia, as crianças queriam resgatar a história do bairro, para resgatarem a si próprias. Falavam: "vamos fazer um documen- 
tário do bairro, porque nós somos discriminados. A gente sai por aí, já perguntam: 'onde você mora? São Marcos? Ah, é bandido! Só sabe abrir cadeado’. Então vamos mostrar o outro lado do bairro”, conta Orestes. A experiência o marcou também pela profundidade das relações humanas que se desenrolavam diante da câmera: "era muita oralidade, quer dizer, muitas histórias de vidas, depoimentos..." As pessoas se abriam: "ficava um diálogo, sabe? Eu tenho a impressão de que em alguns momentos esqueciam lá da câmera ligada. Eles ficavam conversando com os meninos. Conheciam também, se conheciam”. Os encontros despertavam sua empatia e solidariedade: "eles queriam mostrar que a favela tinha trabalhador, tinha gente dando duro no batente, trabalhando na dificuldade, né, e contando mesmo, cada centavo no bolso, o que dá pra comer e o que não dá, e o sofrimento mesmo, o sofrimento de morar naquele local...”

O grande entrave era, e continua sendo hoje, o momento da edição. O museu não possuía uma ilha e os projetos ficavam meses à espera de alguma parceria que viabilizasse a finalização dos vídeos. As pessoas não viam o produto final e o aprendizado não se completava: "não podiam manipular o resultado e a produção de sentido é pela manipulação". Frustrado, Orestes dizia: "filmar sem editar é como fotografar sem revelar". Os grupos acabavam se desmobilizando e a exibição no bairro, etapa necessária para dar o retorno à comunidade, também não ocorria. "É um acumulo de frustrações. Por isso é que a gente fica agoniado e não desiste, sabe da prioridade da edição. E barateou o custo, agora não tem desculpa”.

A despeito da precariedade das condições técnicas, a Pedagogia da Imagem vai sobrevivendo. Citando Marco Bellocchi, cineasta italiano, Orestes explica: "antes do cinema existe o homem, o homem e sua visão sobre o mundo, sobre a sociedade, sobre si mesmo. As imagens expressam seu pensamento”. Para ele, portanto, a questão não é técnica, mas humanística. "Pedagogia da Imagem se aproxima cada vez mais, na minha visão, de uma pedagogia libertária. Ela não é desvinculada de um projeto histórico”. Trata-se de uma disputa no terreno do audiovisual, não apenas pela democratização da comunicação, mas também pela formação de quadros capazes de produzir um outro discurso. Lamenta que as forças de esquerda não dêem a devida atenção à questão cultural e, em particular, ao audiovisual. Nisso, teríamos muito a aprender com os países do mesmo continente: "pela pouca informação que eu tenho, o Brasil está muito atrasado em relação à questão na América Latina. Percebi isso com o FELCO, Festival Lati- 
noamericano de La Clase Obrera [....${ }^{143}$ Salvo engano meu, os movimentos na América Latina são os que mais dedicam importância a isso”.

Quando pensa no futuro da Pedagogia da Imagem, Orestes vislumbra caminhos. O primeiro é buscar as bases teóricas e as experiências históricas concretas. "Não vou inventar a roda, vou aperfeiçoar a roda. Não tem como negar a experiência acumulada, até pelos erros". E cita como exemplos a iniciativa anarquista da Confederação Nacional dos Trabalhadores de Barcelona (durante a guerra civil espanhola, os trabalhadores criaram uma cooperativa e produziram filmes) e a experiência do Centro Popular de Cultura (CPC) da UNE, com a produção do filme Cinco vezes favela, demonstrando que o espírito de uma pedagogia da imagem - ou Educomunicação - não é algo recente, mas possui uma tradição. O segundo caminho é a prática, "colocar a mão na massa" e filmar. Nesse ponto, o encontro entre teoria e prática se transforma em práxis.

Um terceiro item é o aprofundamento dos estudos sobre a recepção. Discutir como a produção audiovisual chega ao espectador - tanto fisicamente (a distribuição) quanto emocionalmente - porque sem ele, não existe cinema revolucionário. E essas discussões partem de experimentos de observação, alguns deles realizados com os próprios freqüentadores das sessões de cinema do MIS.

Finalmente, é preciso integrar-se com outras iniciativas semelhantes, especialmente as latinoamericanas. A experiência do FELCO foi muito importante. "Algumas pessoas assistiram aqui, ficaram até meio chocadas, mas foi bom. [...] Alguns até entenderam, falaram: 'não concordo com o ponto de vista mas eu percebi que é um ponto de vista’ [...]. Era isso que precisava!” É preciso respeitar a opinião do espectador: "Por que ele tem que gostar? É uma experiência estética necessária não gostar". Ela leva à reflexão. Daí a importância de se criar e preservar espaços onde uma pluralidade de pontos de vista possa se manifestar. "Existe um cinema que não disputa o mercado e não é feito apenas contra o mercado, ele é fora do mercado. Portanto, ele tem que construir a própria rede exibidora”. Não se trata de constituir novas empresas, mas de abrir espaços alternativos, nas escolas, comunidades, museus, enfim, locais onde

${ }^{143}$ O FELCO foi levado ao MIS Campinas em novembro de 2006. 
uma produção popular, feita de vozes freqüentemente apagadas, possa encontrar as pessoas e descolonizar nosso olhar.

\subsection{Um agitador cultural}

Batata gosta de ser chamado pelo apelido. "Ronaldo é minha identidade secreta, só minha mãe me chama assim”, costuma brincar. De fato, poucas pessoas seriam capazes de identificá-lo pelo nome, a despeito de ser uma figura marcante, muito conhecida por sua atuação política, cultural e universitária entre sua geração. Agente cultural há cinco anos na Prefeitura de Campinas, trabalha na Coordenadoria de Ação Cultural, sendo responsável por projetos descentralizados na região Norte da cidade. Lá, faz as coisas acontecerem, graças à sua capacidade de aglutinar colaboradores e entusiasmar pessoas. Assim, promove festivais de leitura, apresentações musicais, exposições fotográficas, incentiva grupos amadores de teatro, realiza exibições e debates de filmes e uma série de outros programas cuja marca é a continuidade. Anárquico, bem-humorado, idéias afiadas, está sempre questionando seus interlocutores para checar-lhes a consistência do pensamento. Durante a entrevista, diverte-se lembrando a juventude combativa em Campinas. Sem perceber, baixa a voz e quase sussurra quando o assunto é delicado. Fala pausadamente, colhendo as palavras com cuidado para dispô-las precisamente em seu lugar. Não é uma encenação: Batata é assim no dia-a-dia.

Peço que me fale de sua formação. Com um sorriso, se define eclético. “Tenho uma formação [...] que passa por Engenharia Elétrica, por Música, me graduei em Ciências Sociais e fiz pós-graduação de nível de mestrado, não completado, em História. Atuei como docente da Universidade de

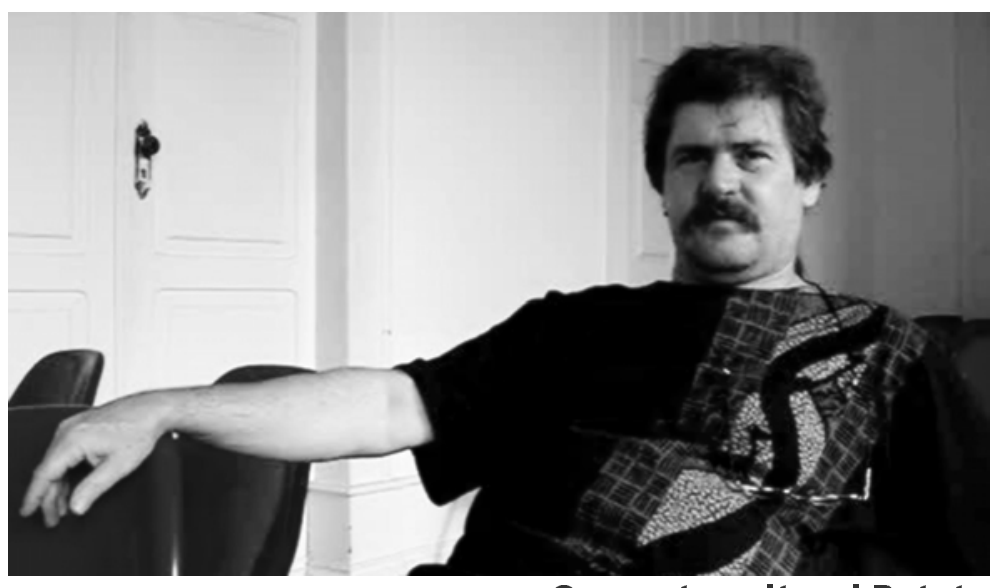

0 agente cultural Batata 
Maringá nas áreas de Ciências Sociais e História, durante sete anos." Não parou por aí: lidou com fotografia desde o início da faculdade, fez teatro universitário, cantou e regeu corais (regeu corais do Movimento Mário de Andrade e da Arquitetura da PUC Campinas, foi regente-assistente e orientou o trabalho de técnica vocal do Coral da Unicamp). Dono de restaurante, trabalhou como cozinheiro e gerente de casas de produtos culinários e lojas de conveniência durante outros sete anos. "Enfim, só isso de ecletismo".

Quero saber como começou sua aproximação ao campo cultural em Campinas. Foi ainda na juventude. Batata se preparava para o vestibular de Engenharia Elétrica, "por aqueles destinos de família: 'o menino é bom de conta, vai ser engenheiro.” Era 1970. De um lado, a contracultura estava em alta, guindada pelas inovações na MPB, as experiências do Teatro Arena e do Oficina, o Tropicalismo e a arquitetura modernista... De outro lado, o Brasil vivia o auge da ditadura militar, e seu pai era um preso político. Tudo aquilo mexia com suas convicções. Uma série de outras preocupações, como entender o processo histórico e cultural em que estava inserido, começavam a tomar-lhe a mente e desviar sua atenção para outros objetivos. “Quando eu entro na Unicamp, eu já entro com um pé fora da Engenharia”.

Ao iniciar a faculdade, soube que o maestro Benito Juarez, também recém-chegado, havia fundado o Coral da Unicamp. Batata se ofereceu como instrumentista. Benito lhe pediu para cantar. Começou então a estudar técnica vocal, teoria e análise musical. Em pouco tempo estaria aprendendo a regência de coro e permaneceria como seu discípulo até 1976, quando as dissensões políticas o afastariam do maestro. Enquanto aguardava a abertura do curso superior de Música, fazia disciplinas em Ciências Humanas e Pedagogia e atuava em grupos de teatro e atividades artísticas. Engajou-se no movimento estudantil, onde a atuação cultural se mostrava prioritária: "a ruptura política estava inviabilizada, a esquerda toda estava presa e, então, cabia à gente manter uma resistência e fazer um trabalho de rearticulação dos movimentos sociais".

Inspirados pelo trabalho de Benito Juarez, que ele próprio definira como "guerrilha musical", Batata e seus companheiros do movimento estudantil começaram a incentivar a ação cultural no campus, com o teatro de jornal, atividades literárias, apresentações musicais e encontros de grupos. Criaram na Univer- 
sidade um ritual que, a cada dois ou três meses, reunia artistas e grupos das mais diferentes manifestações artísticas. Batizaram-no Feira de Arte. Com o tempo, a atividade cresceu, ganhou a cidade, com dois importantes shows organizados em 72 e 73, chamados Musicampus, e depois se espalhou pelas universidades da região.

Diante da inexistência de equipamentos culturais públicos, a casa dos centros acadêmicos da Unicamp, na região central de Campinas, tornou-se um ponto de referência pelos eventos que ali se organizavam: apresentações de teatro, música, cinema, oficinas e palestras (Michel Foucault, em 1973, chegou a falar, clandestinamente, para uma platéia de cerca de 70 pessoas). Diversos grupos artísticos e culturais, que mais tarde se consolidariam, utilizavam a casa como espaço de ensaio e, assim, garantiam sua permanente movimentação.

Nessa época, Batata formou com os colegas um grupo de teatro, orientado por um professor de Ciência Política com experiência na linha do Living theatre. Montaram Os sete atos de loucura e nostalgia, uma peça sem palavras, que não pretendia fazer a discussão política "mas tinha uma intenção de discussão de todas as discriminações culturais”. A peça, apresentada ao longo de novembro de 1972, em uma quadra ao ar livre, foi posteriormente levada para a USP e, em 1973, apresentada num festival de teatro universitário em Campinas. Com isso, pontua, "a gente é posto no olho do furacão da discussão teatral no país, porque existia no meio estudantil uma hegemonia do teatro politizado didático, do teatro de jornal”. A polêmica, estabelecida com o grupo de teatro da Politécnica-USP, durou vários anos.

No Centro Acadêmico de Engenharia, Batata participou da organização de um grupo de fotógrafos universitários. Montaram um laboratório comunitário e o equipavam, ano a ano, graças aos cursos de iniciação que ofereciam. Geriam-no anarquicamente, o que não significa que fosse desorganizado. Ao contrário: durante vários anos, o Departamento de Multimeios do Instituto de Artes o utilizou para a realização de seus cursos. As reuniões eram feitas nas madrugadas de quinta-feira, numa república de estudantes. Em 1975, esse grupo originaria o Movimento Fotográfico (MoFo). Nele, discutiam-se as linhas de ação e as atividades comuns; em seguida, partia-se para a avaliação do trabalho de algum dos membros. A pluralidade dos projetos era assegurada: "o cara primeiro apresentava o que ele tinha pen- 
sado em fazer, e aí punha as fotos e a gente debatia no campo de projeção dele. Ninguém chegava: 'não, eu acho que ele tinha que fazer outra coisa'”. Assim, conviviam propostas desde o campo radicalmente formal até o da antropologia visual. O rigor técnico, porém, era uma exigência que garantia a qualidade das produções do MoFo. Com o passar do tempo, o grupo amadureceu e começou a expor nos espaços culturais da cidade. Mais tarde, nas manifestações estudantis e nas mobilizações populares, essas experiências de registro e exibição seriam aplicadas no campo político.

Simultaneamente, Batata seguia o trabalho de Benito Juarez com o Coral da Unicamp: o maestro ia cavando espaços no meio musical, até então asfixiado pelo establishment que ocupava os aparatos de governo, com uma produção elitizada e voltada para os interesses dos grupos políticos dominantes. $\mathrm{O}$ esforço de Benito the rendeu prêmios de referência cultural por vários anos consecutivos, e as portas oficiais foram-se abrindo.

Lauro Péricles, então prefeito de Campinas, começara a estruturar a área cultural da cidade. Em meados da década, dentre outros equipamentos públicos e instituições que criou, como o Museu da Imagem e do Som e o Observatório Astronômico Jean Nicolini, reinaugurou o Teatro Castro Mendes, profissionalizou a Orquestra Sinfônica, inaugurou o Centro de Convivência Cultural e a Concha Acústica e instituiu a Secretaria Municipal de Cultura. Com os novos espaços estabelecidos, o setor cultural campineiro começou a se reorganizar para enfrentar as disputas pelo seu uso e interferir na definição das políticas públicas. Na fase que se segue, a partir de 1977, o grupo de teatro universitário da Unicamp, articulado a outros grupos da cidade, forma a Federação Campineira de Teatro Amador e, a partir daí, constitui-se num agente mobilizador da luta pela democratização dos espaços recém-abertos.

Por essa época, no combate às crescentes pressões do governo militar, o movimento estudantil recrudescia. Os estudantes começavam a ir às ruas, para o enfrentamento da ditadura. A geração veterana que encabeçava o movimento, já formada, passou a militar nos movimentos sociais, abrindo espaço para o surgimento de outras lideranças. A atuação da nova geração do movimento estudantil extrapolou o âmbito universitário e passou a se relacionar com os demais movimentos sociais. Resultando desse processo, foi criado o jornal alternativo Repórter da Região. 
Durante o seu funcionamento, o jornal apoiou movimentos sindicais dos metalúrgicos, dos químicos, do setor da borracha, dos funcionários públicos da Unicamp e muitos outros. A mobilização popular que adquiriu maior projeção, contudo, foi o movimento das entidades de bairro. Era motivado, dentre outras razões, pela frustração das populações da periferia diante da quebra dos compromissos assumidos pelo então prefeito, Chico Amaral, durante a campanha eleitoral. Antes de se eleger, ele prometera "mundos e fundos" e, uma vez empossado, resistia às pressões do movimento. Sua recusa só fez acirrar os ânimos, de tal modo que, em 1979, uma grande manifestação tomou conta do Paço Municipal. Era a Assembléia do Povo. Três mil pessoas aguardaram ser atendidas pelo prefeito, as reivindicações em punho: Chico Amaral não cedeu. A multidão decidiu protocolar um documento e marcar uma data para retornar. 30 dias depois, estavam todos de volta e instituíram um novo procedimento. No saguão do Paço, montaram uma plenária onde os grupos populares podiam apresentar suas demandas e o poder público tinha que se explicar. "E ai do cara que pisasse nos tomates; tomava vaias monumentais", diverte-se Batata. A relação de poder se invertia à força: quem detinha a palavra era o povo, e era este quem a concedia ao poder público.

Naquele momento, o resgate das lutas sociais estava sendo feito no interior do MDB, com o apoio da ação pastoral da Igreja Católica. Em Campinas, organizou-se uma assessoria para articular as mobilizações emergentes. Participando desse processo, Batata atuou na área de comunicação. Seu trabalho era o de fazer circularem as informações entre os diversos movimentos. Elaborava releases, convocava a imprensa para a cobertura de manifestações e mutirões, produzia um jornal e fazia o registro fotográfico de todas as atividades. Durante as ações coletivas, as fotos eram expostas em “varais" e, assim, as pessoas envolvidas podiam se ver como parte ativa de tudo. Mais adiante, o grupo organizaria um audiovisual (apresentação de slides fotográficos, acompanhados de uma trilha sonora) com as imagens e sons registrados no movimento, e percorreria as favelas, nos finais de semana, fazendo projeções e debates. "Quem produz o audiovisual é um corpo de estudantes. Nós levamos o material, apresentamos, ouvimos, pegamos depoimentos [...]” A reconstituição do histórico do movimento, no entanto, seria elaborada juntamente com seus participantes. Essa atividade mantinha o debate aceso nas comunidades e acabaria originando um circuito de exibição de filmes sobre as greves do $\mathrm{ABC}$. 
A exibição do audiovisual teve um papel importante nesse momento de mobilização: "o trabalho de registro de imagem [...] reinveste no processo de criação de identidade social”. Ele estabelecia um nexo tanto político quanto cultural, pois a imagem se convertia num mecanismo de auto-reconhecimento e de construção de identidades. Identidades sociais e culturais dentro do campo das multiplicidades, reforça Batata. "Para eles o que antes era uma conotação negativa - ser favelado - vira uma conotação positiva: 'nós somos do movimento dos favelados'. E aí eles passam a atuar na cidade e todo o processo político é atravessado pelo movimento”.

$\mathrm{Na}$ assessoria, além da comunicação também haviam sido organizadas as assistências jurídica e urbanística. Desta última, participaram estudantes de arquitetura orientados pelos professores Tércia de Paoli e Toninho (Antônio da Costa Santos, que viria a ser prefeito de Campinas no ano 2000, assassinado em 2001). Naquele caldo, a cultura erudita dos acadêmicos fazia interface com a cultura popular. E os saberes do povo surpreendiam os universitários: "a Tércia falava assim: 'quando eu chego pra conversar com um desses caras que a associação me destaca, eu sei que é um cara conhecedor do processo de construção e medição de terra' [...] Então você começa a ver que tem todo um processo de produção de referências posto nos saberes populares".

Naquele instante, de reorganização partidária, o Movimento dos Favelados aderiu ao Partido dos Trabalhadores. As múltiplas tensões desse processo acabaram gerando disputas - principalmente pelo discurso do e sobre o movimento. Nem a esquerda católica, nem os políticos petistas conseguiram apreender a lógica que organizava o pensamento das lideranças populares. Era um discurso carregado de referências culturais e religiosas, estranhas ao tom racional e objetivo dos partidos. Fazia sentido nas favelas. "Mas a esquerda brasileira não tinha essa percepção, ela ainda estava perdida nos velhos dilemas leninistas”. Batata relata: “diziam que ‘aquela peãozada’ não tinha cultura política, saca? Porque não chegava com o discurso referenciado pela esquerda”.

"E então foi desse entrecruzamento que eu dei no que dei”, brinca Batata. Já formado em Ciências Sociais, começava a se preparar para cursar o mestrado em História, trabalhando em um projeto de pesquisa coordenado pelo Professor Carlos Rodrigues Brandão, sobre as formas de reprodução dos saberes po- 
pulares. Ainda na Unicamp, assessorou o setor de imagem do arquivo Edgar Leuenroth (um centro de memória dedicado a movimentos sociais), organizando acervos e microfilmando materiais. Seu projeto de mestrado trataria da emergência da memória social nos movimentos populares e do reinvestimento dessa memória nos próprios movimentos.

Batata recebe então um convite para lecionar na Universidade de Maringá como professor colaborador e lá permanece por sete anos. De volta a Campinas, abre um restaurante onde retoma a atividade de produção cultural: "os instrumentistas da música popular, todos, passavam pelo meu restaurante". A montanha-russa dos planos econômicos, porém, tornou a empreitada "uma tragédia", segundo ele próprio. Volta a atuar como cientista social, trabalha em projetos do Laboratório de Antropologia Biocultural da Faculdade de Educação Física da Unicamp, na produção de vídeos. Participa também de alguns projetos de pesquisa da PUC São Paulo. Um, em especial, sobre a presença da Rede Globo no mercado televisivo brasileiro, coordenado pelos doutores Gabriel Priolli e Sílvia Borelli, resultou na publicação do livro A deusa ferida. ${ }^{144}$ Entre idas e vindas, tinha montado e já encerrado as atividades de uma casa de produtos culinários e conveniências quando foi convocado pela Prefeitura para assumir o cargo de agente cultural, para o qual tinha sido aprovado em concurso alguns anos antes: "enfim, foi essa a trajetória até eu chegar aqui”.

\subsection{Minerando o eu}

Peço licença para contar também um pouco da minha história, enquanto tento reencontrar as experiências que me trouxeram onde estou. Nasci em Belo Horizonte, no ano de 1975. No solo de Minas forjei minha identidade: "Noventa por cento de ferro nas calçadas, oitenta por cento de ferro nas almas", como disse Drummond. Nos ares de Minas desfraldei meus sonhos: "Libertas quae sera tamen”, como quiseram os inconfidentes. Para conhecer-me é preciso minerar-me. Somente entre amigos revelo meus tesouros.

\footnotetext{
${ }^{144}$ BORELLI, Sílvia H. Simões; PRIOLLI, Gabriel (coord). A deusa ferida. Por que a TV Globo não é mais campeã absoluta de audiência. São Paulo: Summus, 2000.
} 
Venho de uma família simples: pai contador, mãe pedagoga, supervisora escolar. Minha irmã, a companheira e amiga. Criação rígida, mas amorosa. Vivíamos com o suficiente. Mais não precisava. O que a gente achava importante mesmo era ter educação. Não só a dos bancos de escola, mas também aquela da delicadeza com os outros. E, principalmente, não ser indiscreta. Talvez por isso é que falo pouco, mais observo. Gosto mesmo é de ouvir histórias.

Quando aprendi as letras, minha mãe me deu de presente uma coleção ilustrada; em cada livrinho uma dedicatória. Fiquei encantada com o gesto; o encanto nunca mais se quebrou. Na escola onde ela trabalhava, devorava a biblioteca. Lia com gosto, horas a fio. Principalmente nas férias. Aí, podia me transportar para longe. Brincadeiras eram muitas: boneca, casinha, escolinha, bola, bicicleta. Tudo compartilhado entre as irmãs. Meu pai ensinava jogos de tabuleiro. Quando possível, nos levava para passear: feira hippie, Pampulha, Parque Municipal, piquenique nas Mangabeiras, Praça da Liberdade, cidades históricas, gruta da Lapinha. Cinema, só de vez em quando: estava além do suficiente. Do radinho de pilha de minha mãe, vinham as notícias do mundo. Da TV, uma dose diária, em horários regulados: primeiro, as tarefas da escola. Passatempo bom era ver os álbuns de família, enquanto ouvia as lembranças dos pais.

Paixão maior, o desenho. Alguém achou bonitos meus primeiros rabiscos e, volta e meia, ganhava cadernos sem pauta, lápis de cor, canetinhas coloridas. Comecei a aperfeiçoar os traços. Vieram livros com técnicas de luz e sombra, volume, perspectiva... O desenho era meu refúgio, minha expressão, meu arejo. Construía com ele todos os mundos que eu pudesse imaginar. Minha avó guardou para mim uma folhinha com figuras do Monet (eu não sabia quem era, mas apreciava as pinturas). Uma tia trazia figuras recortadas de cartões de Natal que comecei a colecionar. No verso, era comum encontrar o nome das obras e dos autores: Ticciano, Da Vinci, Raffaello, Velásquez, Picasso, Portinari e muitos outros que não me recordo mais. Depois vieram umas gravuras japonesas, outras naifs, outras populares. Comecei a tomar gosto pelo diferente. De tanto rever as imagens, elas se tornaram parte de mim, inscritas no meu acervo imaginário.

Passei a cultivar a paixão pela arte. Não que achasse importante: me era necessária como o ar. Visitando com minha mãe uma exposição no Palácio das Artes, deparei com algo inusitado: grandes chapas de 
metal desgastadas pelo tempo, cobertas de pigmentos de ferro. Nunca tinha visto nada parecido! Tão bonito, tão forte. A cor era a mesma do solo de Minas, vermelha. Imediatamente me reconheci. Descobri, naquele instante, que a arte podia também me dizer quem sou.

Na escola, inventava modos diferentes de apresentar os trabalhos: montar uma peça de teatro, gravar um vídeo. Certa vez, propus à professora de história que nos deixasse fazer um vídeo no lugar do trabalho escrito. Tínhamos lido Agosto, de Rubem Fonseca, e a história nos permitia fazer uma reconstituição de época. Com a ajuda dos colegas, montei o roteiro, como uma programação de TV. Havia um telejornal, talk-show, comerciais e até uma novela. Tudo girando em torno do tema em questão, os acontecimentos históricos relacionados à morte de Getúlio Vargas. Uma colega trouxe a câmera filmadora. A turma toda se engajou. Um garoto editou a fita, juntando dois videocassetes. Fizemos tudo sem orientação, tivemos tanto trabalho quanto prazer. A experiência nunca mais foi esquecida.

Não me recordo, exatamente, quando decidi ser publicitária. Sei que meu desejo era atuar na área de criação. Ao entrar na UFMG, em 1993, as perspectivas se multiplicaram. Aprendi a produzir vídeos, fotografias, trilhas de rádio, textos publicitários. O professor de redação, a propósito, havia tentado nos inculcar algumas fórmulas, velhas e sem-sentido: textos longos, com uma estrutura rígida, repetindo o maior número possível de vezes o nome do produto. A turma toda reagiu: as regras não eram criativas e, além do mais, pareciam subestimar a inteligência do leitor. As polêmicas que travávamos pareciam intermináveis: nenhum dos lados queria ceder. O marketing era outra vertente interessante, bem diferente do estereótipo que até então fazíamos da profissão: discutia-se a ética e a responsabilidade, a construção de relações sustentáveis e a visão de longo prazo. Havia ainda a área teórica, que foi uma das experiências mais valiosas para minha formação humanística, o desenvolvimento do pensamento autônomo e da visão crítica. E, finalmente, a produção e criação gráfica, minha grande paixão.

Já no primeiro período, tentei conseguir um estágio. Candidatei-me a uma vaga na Coordenadoria de Comunicação da Universidade. Na entrevista, perguntaram-me se conhecia editoração eletrônica. Nunca tinha mexido em um computador. No dia seguinte, tratei de procurar um bom curso. Fiz a iniciação ao Page Maker, software para criação de publicações. Daí para frente, fui aprendendo com os cole- 
gas, no laboratório da faculdade. Dentre os iniciados, havia uma cultura de cooperação que promovia a troca de experiências. Logo estava trabalhando com o Corel Draw, fazendo em minutos o que manualmente levaria horas. Tomei gosto pela informática, pela rapidez com que os processos estavam evoluindo. E a velocidade era tal que, quando tive aulas de desenho publicitário, a professora aprendeu conosco os macetes da editoração, enquanto nos ensinava, a título de curiosidade histórica, os processos que o mercado acabara de pôr em extinção.

No segundo período, iniciei um estágio na Faculdade de Farmácia; era responsável pela comunicação interna: pequenos boletins, cartazes, rotinas tranqüilas. No ano seguinte, surgiu uma grande oportunidade: dois dos mais respeitados professores do Departamento de Comunicação Social, os doutores Maria Céres Pimenta Spínola Castro e Paulo Bernardo Vaz, estavam selecionando alunos interessados em participar da Iniciação Científica, ao longo de dois anos. Conduziriam um projeto integrado sobre o nascimento da imprensa belo-horizontina, com financiamento do CNPq. Eram vésperas das comemorações do centenário de Belo Horizonte e a Biblioteca da UFMG havia recebido um precioso acervo de jornais, cuidadosamente formado, durante décadas, por um amante da imprensa. Nossa tarefa era ir aos jornais, identificá-los, descrevê-los e tentar reconstituir, na leitura daquelas páginas amarelecidas, a dinâmica social da capital recém-inaugurada. Além disso, cada um dos bolsistas - eram seis, ao todo - deveria conduzir uma pesquisa individual, com orientação dos coordenadores.

Começamos o trabalho indo à Biblioteca Central, onde os jornais podiam ser consultados, em salas especiais. Aos poucos, a leitura conquistava o interesse. Os trechos importantes eram copiados manualmente. Logo as peças do quebra-cabeça começaram a se encaixar. Íamos identificando os atores sociais, os interesses, as disputas, os fatos pitorescos, os costumes... A Belo Horizonte-menina ressurgia, como num holograma - um tanto incompleto, é verdade - dos nossos relatos entusiasmados nas reuniões semanais.

Minha primeira intenção foi trabalhar com os pequenos jornais, aqueles que, aparentemente, seriam os menos significativos. Intuía que, nas folhas alternativas, de estudantes, operários e tipógrafos, vozes silenciadas me contariam uma outra versão da história. Não me enganara. Um dos grandes achados da pes- 
quisa, que me proporcionou um insight, foi um editorial d'O Operario, escrito por Donato Donati, um imigrante italiano, presidente da Liga Operária de Belo Horizonte. Nele, o líder trabalhador expressava seu inconformismo com o "silêncio sepulcral" da imprensa mineira em relação às manifestações da Liga. Dizia haver uma conspiração do silêncio em torno do movimento. De fato, constatei, não fossem as cinco edições que a Liga conseguira publicar, a história jamais registraria sua existência. Compreendi que a essa tentativa de apagamento simbólico correspondiam outras formas de apagamento: o físico (pelo planejamento urbanístico e pela estrutura de transportes, as camadas populares eram banidas da região central da cidade) e o político (por meio de práticas autoritárias, as elites dominantes sistematicamente ignoravam as reivindicações e lutas populares). Nasceu aí meu primeiro tema de pesquisa: o processo de formação do espaço público durante os primeiros anos de existência da capital. Apresentado na Semana de Iniciação Científica da UFMG, o trabalho foi selecionado entre os melhores da área de Ciências Humanas.

Paralelamente à pesquisa, comecei a desenvolver projetos gráficos para jornais institucionais. Os clientes eram, em sua maioria, grandes empresas dos setores da mineração, aço e siderurgia: Samarco, Acesita, Açominas, Belgo-Mineira, Sibra e Companhia Paulista de Ferro-Ligas, entre outros. Eram publicações dedicadas, geralmente, ao público interno e, em menor proporção, às comunidades em torno das fábricas. Tinha, aí, a oportunidade de religar meu trabalho de pesquisa com a prática profissional. Junto às assessorias responsáveis pela linha editorial, tentava influenciar, e via de regra era bem sucedida, no sentido da valorização do elemento humano. Em primeiro lugar, não era porque se tratava de um jornal interno que tinha que ser feio e mal-cuidado. Precisava ser ilustrado, trazer fotos de qualidade, preferencialmente mostrar as pessoas nos seus contextos de trabalho (nada de fotos posadas) e contar suas histórias. Era preciso respeitar também os hábitos e práticas de leitura dos destinatários: letras não muito pequenas nem grandes, mas com um entrelinhamento suficiente para arejar a página e tornar o texto mais ligeiro. E, acima de tudo: nunca subestimar o leitor, infantilizá-lo ou idiotizá-lo. As publicações pareciam atingir os objetivos: numa das empresas, a assessora de comunicação me relatou o telefonema recebido de um trabalhador, que agradecia pelo jornal e confessava, em tantos anos de vida na fábrica, nunca ter se sentido tão valorizado quanto no momento em que recebeu aquela publicação. 


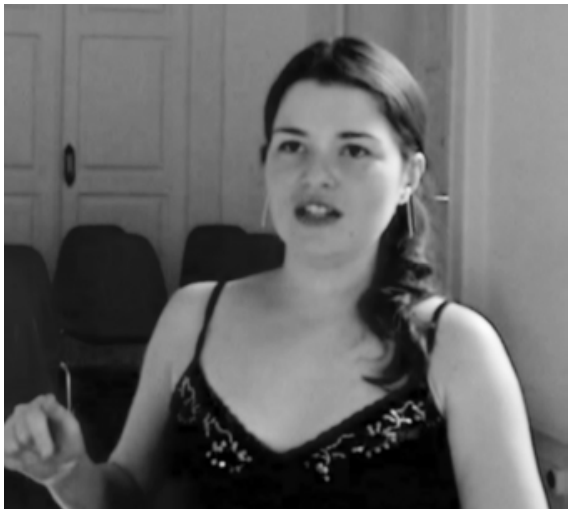

Pesquisa acadêmica em diálogo com a sociedade

O ano seguinte, 1996, era o da finalização do curso. A experiência de Iniciação Científica forneceu-me o material para a monografia de conclusão. Mais uma vez, tratei de equilibrar meus interesses de estudo e profissionais. Decidi investigar os projetos gráficos dos jornais, as inovações técnicas subjacentes às suas mudanças e os vínculos históricos e sociais correspondentes a essas transformações. Novamente, a pesquisa foi premiada na Semana de Iniciação Científica da UFMG. Passadas as festas da formatura, o projeto de pesquisa ia atingindo sua reta final. No ano seguinte, iniciaram-se as comemorações pelo centenário de Belo Horizonte. Os orientadores haviam previsto lançar um livro, condensando os projetos desenvolvidos pelos bolsistas. Fiquei responsável pela organização do material, o projeto gráfico, a diagramação e a produção, com o apoio do professor Paulo Bernardo. O lançamento da publicação, intitulada Folhas do Tempo, ${ }^{145}$ integrou as festividades oficiais. A Prefeitura Municipal decidiu lançar uma cartilha para as crianças, contando alguns aspectos da história da cidade. Indicada pela orientadora Maria Céres, redigi o texto e diagramei o material. A pequena publicação foi amplamente distribuída nas escolas. ${ }^{146}$

Formada, continuei trabalhando como free-lance na criação de projetos gráficos e diagramação de jornais, livros e outras publicações. Sentia, entretanto que o trabalho vinha se tornando repetitivo. Queria ampliar meus conhecimentos a respeito das novas tecnologias, em especial a Internet e a multimídia. Para tristeza da família, em 1998 decidi me mudar para Campinas, onde passei a freqüentar as disciplinas do curso de Multimeios da Unicamp. Além dos cursos ligados à área informática, estudei história e linguagem do cinema e produção de vídeo. Ainda como autônoma, desenvolvi alguns projetos de website, dentre os quais o do Governo do Estado de Minas Gerais, da Associação Nacional dos Procuradores da República e o do Comitê pela Democratização da Informática - SP (hoje já substituídos por novas versões). Planejei o design de algumas intranets corporativas. Junto ao Núcleo de Informática Aplicada à Educação (NIED), da Unicamp, assessorei a montagem de aplicativos multimídia.

\footnotetext{
${ }^{145}$ CASTRO, M. C. P. S. e VAZ, P. B. F. Folhas do tempo; imprensa e cotidiano em Belo Horizonte. 1895-1926. Belo Horizonte: UFMG; Associação Mineira de Imprensa; Prefeitura Municipal de Belo Horizonte, 1997.

${ }^{146}$ SIQUEIRA, J. BH 100 anos; uma lição da História. Belo Horizonte: Prefeitura de Belo Horizonte, 1997.
} 
Todo esse trabalho me conduziu a uma empresa desenvolvedora de sistemas corporativos, sediada em Limeira. Contratada inicialmente para implementar modificações no seu website, começo a ganhar espaço na área de comunicação e um ano depois sou promovida à gerência de marketing. Diante do novo desafio, optei por fazer um curso de especialização em Marketing de Serviços (MBA). Foi uma época de grande aprendizado sobre administração e tecnologias, mas também sobre relações humanas, já que tinha de lidar com uma equipe relativamente numerosa. Procurava estimular a participação criativa dos colegas, valorizando o trabalho em equipe e a visibilidade de todos os seus membros. Fiz grandes amizades, realizei projetos bem-sucedidos.

Contudo, a vida dentro da empresa, trancada em um escritório frio e impessoal (quase um não-lugar), parecia artificial. Sentia-me competente, mas não feliz. Faltava-me algo. Fazia cada vez menos sentido trabalhar em um ritmo mais e mais intenso, estressante, tendo como obrigação priorizar a racionalidade técnica sobre o fator humano, num ambiente onde a atitude competitiva e a autopromoção são vistos como mais importantes que a colaboração e o reconhecimento coletivo. Comecei a repensar o rumo da minha vida profissional. Acreditava que atuar na área cultural seria prazeroso e me permitiria estar em contato com atividades apaixonantes. Quando surgiu o edital para a contratação de agentes culturais pela Prefeitura de Campinas, não foi difícil tomar uma decisão. Prestei o concurso público, fui aprovada e empossada na Coordenadoria de Ação Cultural (CAC), em outubro de 2002. Começaria, então, uma nova caminhada.

Os primeiros tempos foram difíceis: um momento de reconstituir minha identidade. Aceitar-me funcionária pública (algo que no mercado é quase sinônimo de incompetência e inutilidade), confrontarme com a estrutura burocrática e seus meandros, compreender os ritmos diferenciados do setor (demasiadamente lentos para quem se acostumara ao ramo de tecnologia), adaptar-me a novas rotinas. Mas o desafio maior era compreender o que é ser uma agente cultural. Nesse sentido, o funcionamento da CAC não me auxiliou: a falta de diretrizes claras para o setor deixava confusos até mesmo os militantes culturais experientes, que ali atuavam como assessores. Eram constantes os questionamentos sobre o que se esperava dos agentes e que políticas culturais deveriam ser implementadas. Predominavam ações isoladas e eventos, em detrimento de projetos e propostas de longo alcance. Naquele momento, a minha 
formação acadêmica também pareceu ser de pouca valia (só mais tarde, no desenvolvimento da Pedagogia da Imagem, conseguiria reintegrar meus saberes e vivências à minha nova profissão). Dessa fase, ficaram as amizades e os contatos com os militantes culturais, a experiência de uma formação coletiva, feita nas discussões em grupo, e um primeiro reconhecimento da cidade, das periferias e dos equipamentos públicos municipais. Já identificava, também, algumas dimensões essenciais da ação cultural: a orientação para a democratização do acesso aos bens culturais, a descentralização da ação, o respeito às características das comunidades com as quais interagia, a intersetorialidade, a formação de redes e a priorização de programas contínuos, em vez de ações isoladas.

Com a consolidação do projeto Pedagogia da Imagem, fui estreitando o relacionamento com o Museu da Imagem e do Som. Percebi que, a partir de um setor estruturado e dotado de melhores recursos, poderia desenvolver uma ação cultural mais efetiva. Transferi-me para lá no final de 2004, logo após a reinauguração de sua sede, o recém-restaurado Palácio dos Azulejos. Novos desafios, novos saberes necessários: a missão de um museu, princípios da museologia, preservação da memória, produção da história, formação de público, comunicação museal... Dessa vez, o aprendizado foi mais fácil. No MIS, havia uma equipe qualificada e um clima de colaboração, com reuniões semanais, discussões abertas e uma atitude reflexiva, que me permitiram reconhecer o terreno, identificar fontes de conhecimento (autores, instituições, eventos científicos) e, assim, tornar-me agente cultural. Devo muito aos colegas, sobretudo Orestes, Batata, Sônia Fardin e Mirna Vasconcellos, à então chefe de setor, Adriana Maciel, e também aos técnicos Francisco Rossi e Manoel Silva, pela generosidade de compartilhar comigo seus saberes e, juntos, criarmos um projeto de museu, essencialmente plural e democrático. Infelizmente, as circunstâncias já não são as mesmas, e muitos daqueles companheiros estão afastados do museu. Para os que, como eu, permanecem, resta a persistência e a disposição de manter viva nossa utopia.

Atuando como agente cultural, indo às periferias, descobrindo pessoas e suas histórias, nos abraços e nos sorrisos, nos sofrimentos e na esperança, descobri minha identidade profissional e meu ideal de vida. Sei o que me faltava antes: um sentido para o trabalho. Hoje reconheço que meu engajamento é na luta para que todos os cidadãos possam fazer valer seu direito à cultura, ao auto-reconhecimento, à construção de sua identidade. Resistindo às tentativas de apagamento, escrevendo a sua história. 


\section{Da experiência ao pensamento: princípios e práticas da Pedagogia da Imagem}

Tendo compartilhado nossas histórias de vida, Orestes, Batata e eu somos capazes de compreender como e porque a Pedagogia da Imagem se configura na sua maneira particular. Voltando minha atenção para questões mais específicas, promovi três sessões de discussão em grupo nos dias 5, 9 e 23 de março de 2007, na sala do MIS onde ocorre o curso. As sessões foram gravadas em vídeo digital, sem a presença de outras pessoas que não os três proponentes. No roteiro semi-estruturado, que elaborei após as entrevistas em profundidade realizadas com cada um, busquei que nos pronunciássemos sobre: a) as nossas intenções e o significado que atribuímos à Pedagogia da Imagem; b) as influências teóricas que fundamentam nossa ação; c) os pontos característicos da nossa metodologia de trabalho; d) as condições de realização do nosso trabalho e o modo como temos lidado com a estrutura municipal; e) as ações que desenvolvemos para conferir legitimidade ao programa ef) nossas expectativas e planos para a continuidade do projeto. Este capítulo é uma tentativa de alinhavar as idéias presentes em nosso diálogo, referentes à dimensão de significação do programa. Por vezes, entre as falas, surgem contradições e divergências, que procurei não aplainar, visto que expressam o nível de amadurecimento das nossas formulações, ainda em construção.

Em primeiro lugar, o que queremos dizer com o termo "Pedagogia da Imagem"? A título de registro pois o que me interessa aqui é examinar a proposta de formação continuada de professoras - é preciso esclarecer que a Pedagogia da Imagem ultrapassa e antecede o curso de formação continuada. Ultrapassa como concepção da ação educativa do Museu da Imagem e do Som, que não se restringe à iniciativa de formação de professoras, nem está limitada a esse público. E antecede porque, ao estruturá-la e conferir-lhe esse nome, estávamos recuperando uma experiência desenvolvida pela equipe do MIS, na década de 90, que se encontrava suspensa pela exoneração ou dispersão de seus participantes em outros setores da Prefeitura. Esse resgate não foi simples repetição, mas uma análise e reformulação crítica dos objetivos e estratégias de ação. Há uma década e meia, a Pedagogia da Imagem no MIS era uma atividade que consistia em promover debates sobre material televisivo previamente gravado e editado, em escolas, centros comunitários, sindicatos e outras entidades. Seu objetivo era, de fato, ativar a "leitura crítica" dos 
telespectadores e desvendar algumas das armadilhas ideológicas presentes nas mensagens mediáticas. Ora, não é necessário me alongar na argumentação a respeito das limitações desses procedimentos, tanto do ponto de vista teórico quanto pragmático. Devo ressaltar, no entanto, que compartilhamos hoje uma outra visão sobre o processo comunicativo, em especial, o papel do receptor. Esse entendimento, ancorado não apenas na teoria das mediações, mas também na observação do comportamento do público que freqüenta as sessões de cinema do MIS, nos permite afirmar que a leitura crítica de uma mensagem vai muito além do desvendamento de seus conteúdos ideológicos, abarcando, ainda, uma percepção dos elementos de linguagem que a compõem. O diálogo, no exercício coletivo da audiência, é crucial para a ativação da criticidade do receptor. Ele leva o espectador a compreender, imediatamente, o seu caráter de construção: a linguagem para além de veículo de idéias ou representação da realidade. Delineia-se, assim, um primeiro aspecto da pedagogia da imagem: pela leitura de imagens é possível compreender a natureza social, interativa e criativa da linguagem. Efetivamente, a leitura coletiva constrói as imagens, o seu significado:

Batata: $\quad[. .$.$] a recepção não é plana, não é dada, não éa reprodução do produto.$

Orestes: $\quad$ O espectador não é um recipiente vazio.

Batata: $\quad$ Exato. [...]

Orestes: [... para ] você ter uma leitura crítica da imagem você tem que ter uma escrita crítica da imagem. Ea ́i como é que fica o papel da recepção? Acho que essa é uma referência importante. Não é só a linguagem do sujeito que fala. Mas o que ouve também é sujeito. E ele não é passivo. A gente percebe até nessa sala quando exibe o filme e faz o debate. Como são surpreendentes as diferentes leituras que cada um faz, de acordo com seu repertório[...].

Batata: $\quad$ E de acordo com o campo de significados que uma obra visual dá.

Orestes: $\quad$ Exato.

Batata: [...] são múltiplas narrativas se sobrepondo. Não é só a narrativa do roteiro com seu texto, seus meandros, a sua linearidade de ação. [... Você vai compondo uma série de outros campos de significado em cenário, em vestimenta, em ações paralelas [...], em sobreposição de...

Orestes: $\quad$ O espectador cria. Por isso que eu digo que exibir filmes, fazer debates, é fazer cinema. [...] O espectador, quando dialoga [...] com o filme, percebe o discurso, e essa construção, e as várias sobreposições de linguagens. E também, no diálogo e na interação com o outro, ele estáfazendo o filme.

Nossa proposta atual tem como fundamento a convicção de que a leitura crítica da imagem se desenvolve também pela sua "escrita". No processo da criação, o aprendiz necessita ter acesso à "gramática audiovisual", aos códigos de linguagem do cinema e do vídeo - enquadramentos, planos, angulações de câmera, passagens, pontos de vista, entre outros. Se tais códigos vêm sendo construídos historicamente, 
a exibição e estudo dos "clássicos" do cinema se justifica, aqui, não por uma suposta necessidade de "elevar o gosto" dos alunos, mas porque permite a compreensão de como a linguagem audiovisual foi sendo definida e modificada pela inventividade de inúmeros autores. Ao experimentar esses conceitos na sua criação, o sujeito percebe que cada escolha provoca um efeito de sentido diferente. Como espectador, portanto, ele se torna apto a identificar as decisões do produtor e a interpretar suas intenções. Conseqüentemente, ao realizar a Pedagogia da Imagem, a escola pode promover a apropriação de um vasto patrimônio cultural, consolidado na produção cinematográfica nacional e internacional, bem como da gramática imagética, exibindo, contextualizando e analisando filmes e produtos televisivos e incentivando a filmagem e edição de produções próprias.

Se aceitamos as imagens como um discurso construído por meio de sucessivas escolhas criativas, devemos supor a existência de um emissor. Um sujeito que não existe no vazio ou no abstrato, mas que fala a partir de um lugar social, de um campo ideológico e que possui um projeto de poder - mais ou menos participativo e democrático. Ler criticamente as mensagens requer, pois, fazer a crítica das suas fontes identificá-las, confrontá-las, avaliá-las, validá-las, compartilhá-las. Sobretudo, diversificá-las para que o sujeito não se torne refém de um pensamento único:

Juliana: $\quad[. .$.$] Nessa sociedade da informação, tendo se disseminado inúmeras fontes sem rigor$ [...], a leitura crítica passa pela forma como as pessoas vão saber selecionar fontes de informação, identificar os pontos de vista [...], o ponto de partida de cada uma dessas fontes. [...] Saber selecionar as fontes [...] é uma parte importante da Pedagogia da Imagem. Isso faz parte da leitura crítica, não é só a questão do conteúdo em si, mas avaliar a fonte como um todo, [...] validar as fontes, compartilhar fontes.

Orestes: $\quad$ Porque [...] o discurso único se torna único também pela saturação de uma multiplicidade de supostas fontes diferentes. [...] A fonte é diferente não só pelo meio que ela utiliza, mas pelo conteúdo também. Então, [...] ou você tem um discurso único ou tem tantos, tantos, [que] você fica saturado, você não consegue nem processar a informação, nem filtrar.

Aos poucos, vamos especificando e tornando mais complexo o sentido da criticidade na Pedagogia da Imagem. Um aspecto importante é a "desnaturalização" do olhar, isto é, não tomar as imagens ou os simulacros pela própria realidade. A pergunta a ser feita à imagem não é a da "verificação" da correspondência entre ela e o real, mas que intenções e projetos de poder existem por trás de cada construção. A importância desse questionamento para o discurso educativo é fundamental. Sem ele, a incorporação das tecnologias da informação e da comunicação às práticas pedagógicas se torna uma maneira de subs- 


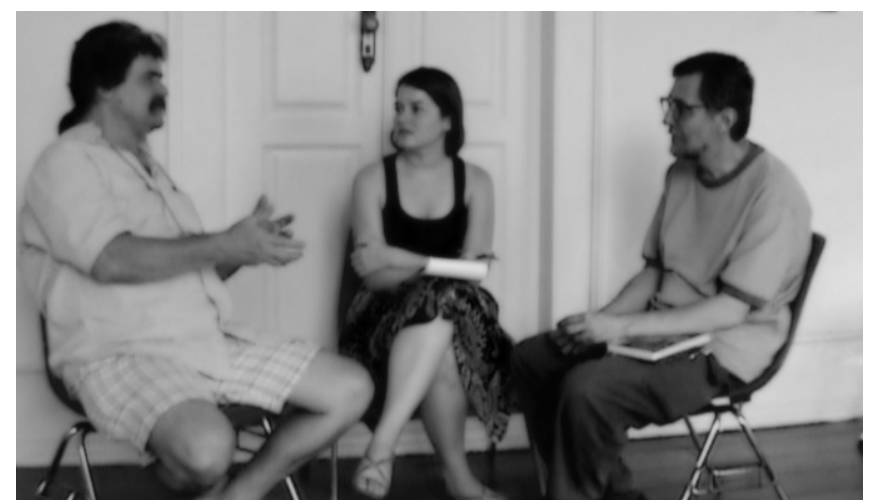

Grupo de discussão tituir a elaboração conceitual por um fluxo agradável de imagens a serem fruídas contínua e ingenuamente, aceitas dogmaticamente como "verdade". O perigo está em tomar o conhecimento escolar não como construção baseada na experiência coletiva, mas como informação pronta e neutra, a ser acumulada

bancariamente:

Juliana: $\quad$ Eu acho que [...] uma das fontes importantes [...] é a teoria da linguagem.

Batata: $\quad[. .$.$] A teoria da linguagem [...] é a que desmonta o naturalismo [...] da produção visual.$ Quer dizer: "isso não é um cachimbo". O paradigma do...

Juliana: Magritte.

Batata: $\quad$...do Magritte.

Orestes: $\quad$ Isso é fundamental. Que essa construção de simulacro [...] é muito em cima do naturalismo.

$[\ldots]$

Batata: $\quad$ Então, mas [...] você vai precisar da bagagem literária, científica, pra produzir o material imagético. Agora, pra ser o espectador, não. E, de certa maneira, quer dizer, aquela discussão...

Juliana: Depende, né?

Orestes: $\quad$ Depende do conteúdo da imagem...

Batata: $\quad$ Aquela discussão que a Maria Rita Kehl faz da fruição [da TV], do objeto do prazer que se apresenta enquanto uma obra completa e fechada, que não cabe interferência dentro do processo dela, como você interfere no livro, que você, enfim, volta na página anterior, vê... Quer dizer, dentro dum produto imagético [...] a coisa flui pra você continuamente. E ele [o espectador] vê enquanto produto fechado. [...] $]^{147}$ Fazer a crítica dele, de qualquer produto cultural, [...] a cultura faz. Agora, isso pode ser mais ou menos incisivo. A escola tradicional, não preocupada com a Pedagogia da Imagem, o quê que ela pode fazer? A substituição de determinados conteúdos por produtos fluidos. E que vão ser e que são ministrados aos alunos como obras completas que dão conta de determinado conteúdo. Então: "ah, vê lá aquele filminho e hoje não tem aula". Quer dizer, isso é uma maneira acrítica de trabalhar com as

\footnotetext{
${ }^{147} \mathrm{KHEL}$, Maria Rita. Imaginar e pensar. In: NOVAES, Adauto. (org) Rede imaginária: televisão e democracia. 2. ed. São Paulo: Companhia das Letras: Secretaria Municipal de Cultura, 1999, p. 60 - 72 . Essa noção de que o produto televisivo é fechado, isto é, um fluxo ininterrupto no qual o espectador não pode interferir, talvez ainda fosse cabível no princípio dos anos 90, quando o artigo foi escrito. Mas, agora, é contrariada pela constatação de que o espectador foi desenvolvendo, efetivamente, hábitos culturais mais complexos em relação à recepção televisiva - graças, em parte, à evolução tecnológica. Ele pode, hoje, "zapear" entre múltiplos canais, assistindo dois ou mais programas ao mesmo tempo, redefinindo o ritmo das imagens, recortando e recriando as narrativas ao seu gosto. Sem contar a possibilidade de gravação, edição e compartilhamento de programas em vídeo, DVD ou pela Internet, em sítios como Youtube. O alerta que Batata faz em relação ao (mau) uso das imagens na escola, contudo, não pode ser ignorado. É o que José Manuel Moran chama de usar o vídeo como "tapa-buraco". Cf. MORAN, J. M. O vídeo na sala de aula. Revista Comunicação \& Educação. São Paulo: ECA: Ed. Moderna, n. 2, jan-abr. de 1995. p. 27 a 35.
} 
imagens. E de tentar suprir as suas lacunas de abordagem de determinados conteúdos [...], substituindo [a discussão] por um produto acabado.

Juliana: $\quad[. .$.$] eu tenho um problema com esse tipo de concepção pelo próprio conceito de lin-$ guagem que está subentendido. Porque $[. . . \mathrm{em}]$ qualquer produção de sentido não existe nunca um produto acabado. E um garoto que estiver assistindo [um vídeo ... não desliga ali do mundo, do seu universo, das outras inserções [...] que ele tem. Ele pode ser, por exemplo, [...] militante, sei lá, e ele vai ler aquilo de outra forma.

Batata: $\quad$ Eu não tô falando que o projeto [...] é aplicado plenamente, quer dizer, a cultura vai fazer a crítica, de alguma maneira, tá? Agora, se você estabelece a substituição do processo pedagógico [...] - o que antes [...] se estruturava em cima do livro-texto - por um produto imagético fechadinho, ou pela aula com datashow, $[. .$.$] mistura imagens, pequenos textos... quer dizer, faz um simulacro do conteúdo$ que tem que ser ministrado...

Juliana: $\quad[. .$.$] mascara a educação bancária com novas tecnologias...$

Batata: Exatamente, com novos rótulos, e aí você ilustra o simulacro, preenche as lacunas dele com algumas imagens. [...] Quer dizer, [...] esse tipo de uso da imagem [...]é um tipo que substitui uma elaboração intelectualizada por produções de figuras.

$[\ldots]$

Juliana: $\quad$ Porque está por trás uma questão do exercício de poder. [...] Quer dizer, a importância da Pedagogia da Imagem também é pra questionar e...

Orestes: A pedagogia da imagem é libertária.

Juliana: Libertária.

Orestes: $\quad$ Senão, não é nem pedagogia. Esse simulacro é dominação. E não ter acesso a esse capital, não ter o domínio da técnica, é impedir as pessoas de também formularem o seu discurso audiovisual. Agora, o discurso verbal, o discurso escrito, o discurso visual são um discurso, e enquanto discurso eles são um projeto, ou seja, são uma certa concepção, de um certo ângulo, que leva para uma determinada direção, porque é ação. Não é mera contemplação. A perspectiva de projeto - aquilo que não é, mas pode vir a ser - é que dá o sentido desse capital cultural, do acesso a essa tecnologia, de romper com o simulacro. A existência de um projeto. E é interação social, é coletivo, não é um ato solitário.

Batata: Claro. Então, quer dizer: é recompor no coletivo o processo de desmonte desses produtos, de análise crítica deles.

A incorporação dos meios às práticas pedagógicas somente se configura como um projeto emancipador e libertário - portanto, uma Pedagogia da Imagem - se vai além da sedu- ção da tecnologia e da imagem. Seu foco é a construção de saberes pelo constante questionamento da informação, pela observação empírica do real e seu confronto com a teoria, e não pela acumulação do já dado. A produção de vídeo na escola é uma forma de investigação da realidade do aluno, por ele mesmo e por suas educadoras:

Orestes: $\quad$ [...] A facilidade de pegar a câmera e começar a filmar [...] não significa grande coisa. Simplesmente isso. [...] Não é só o deslumbramento com a tecnologia, com a informação, com o equipamento. Não tem como abandonar o conhecimento científico, o conhecimento teórico.

Juliana: $\quad[. .$.$] Então o que está por trás da Pedagogia da Imagem, antes de tudo, é uma "pedago-$ gia do conhecimento", né? 
Orestes: $\quad$ Sim. [...] Inclusive, o conhecimento para usar essa tecnologia não é um conhecimento exclusivamente tecnológico.

Batata: Com certeza. Quer dizer: o conhecimento tecnológico, para se legitimar, precisa tentar estabelecer um nexo de referência com as tradições culturais que estão sendo usadas. Senão ele vira uma bolha [...]. Passou cinco, dez anos ele não existe mais. Quer dizer, existe o mesmo tipo de coisa, o mesmo tipo de produto, mas de repente aquela configuração, puf... se esvaneceu. [...] É o acúmulo de cenários desvanecidos da sociedade pós-moderna tecnológica, que, enfim, fica produzindo referências que no fundo não são referências, são...

Juliana: $\quad$ E aí começa a produzir dogmas, verdades incontestáveis, em vez de realmente buscar as fontes da informação e questionar aquilo que está sendo dito.

É fato que as mudanças trazidas pelas atuais tecnologias da informação e da comunicação, quer pela proliferação de fontes, quer pelo descentramento da palavra escrita em relação à difusão do conhecimento, criam obstáculos, senão tornam mesmo impossível à escola continuar tratando o saber como coleção finita, pronta e acabada de informações, cujo principal repositório é a educadora. Esta, agora, terá de assumir um novo papel:

Batata: $\quad[. .$.$] O principal elemento eu acho que tá lá naquele texto da Dulce analisando os dile-$ mas da pedagogia tradicional na sociedade midiática ${ }^{148}$. Quer dizer, como é que um professor vai enfrentar com cuspe e giz todo um processo de circulação de informações que se faz independente dele, dentro dos meios sociais de produção do saber? Então, foi esvaziada pela mídia [...] a figura do professor. E os alunos vão ter um referenciamento de informações muito maior do que aquilo que muitas vezes o professor está trazendo no seu programa, no seu livro didático, no seu campo de saberes. [...] De repente, uma criança viu um "Mundo Animal" que fala sobre a vida dos cangurus e o professor vai falar do canguru, uma coisa que ele não tem muita segurança, e a criança pode saber muito mais que ele a fisiologia, a morfologia, a ecologia do canguru. E então esse processo de esvaziamento do professor como fonte tradicional de repasse de um saber sistematizado tem que ser recuperado com a incorporação dessas outras fontes de informação. Assim como o pensamento enciclopédico esvazia o ensino religioso, [...] esse enciclopedismo banalizante imagético [...] esvazia o trabalho e o saber tradicional sistematizado no processo pedagógico. [...] Então, repensar essa a relação de ensino e aprendizagem com [...] a inclusão dessas novas fontes de informação, fontes acríticas, [...] vai reconfigurar a figura do professor como aquele que vai trabalhar com os alunos a crítica das fontes. E não mais buscar ser a fonte privilegiada das informações verídicas.

A crítica das fontes pela revelação de suas contradições é o passo essencial para a desdogmatização dos discursos e da própria consciência. Congelados, estes se tornam meros simulacros da realidade, efêmeros na sua duração, mas efetivos como instrumento de exercício de poder. A Pedagogia da Imagem, portanto, também é a pedagogia do conflito. Ao contrário do que alguns possam imaginar, a ocultação da

148 CAMARGO, Dulce Maria Pompêo de. Conhecimento escolar: o mito da fronteira entre a ciência e a cultura. IN; VEIGA, I. e CASTANHO, M.E. (orgs.) Pedagogia universitária: a aula em foco. Campinas: Papirus, 2000. 
contradição não produz a harmonia social, mas a exclusão e o silenciamento das posições nãohegemônicas. Revelá-la, denunciá-la, é o primeiro passo para se anunciar a necessidade e a possibilidade de um outro arranjo social, mais justo e solidário:

Juliana: $\quad[. .$.$] Eu acho que a gente está discutindo aqui a questão da consciência. Como surge a$ consciência? E eu penso que existem algumas condições. Primeiro são as inserções sociais do indivíduo: quanto mais ricas elas forem, maior o desenvolvimento dessa consciência, [... mais ampla] vai ser a sua visão de mundo, etc. [...]

Batata: $\quad$ Ricas culturalmente $[\ldots .$.

Juliana: $\quad$ Variadas, diversas [...]

Orestes: $\quad$ Em dois aspectos: ricas culturalmente - e essa riqueza cultural é controvérsia, não são apenas visões diferentes, são visões excludentes. Visões que se chocam, que se opõem. Que aí dá um atrito.

Juliana: $\quad$ É uma ampliação. Saber [...] que a sua visão é um ponto de vista. [...] E que existem outros contrários. [...] Não quer dizer que o seu tem que prevalecer. Então, a consciência, antes de tudo, é a consciência do seu lugar no mundo, de onde parte a sua visão e as visões dos outros. E [...] acho que o segundo elemento importante para o desenvolvimento da consciência é a questão da linguagem. Porque sem isso não há comunicação, não se pode desenvolver a consciência. A linguagem é a base da consciência, é a matéria da consciência. Então, esses dois elementos aí, a linguagem e o social, o social eu vejo [que se desenvolve] com o processo da educação. Não [...] a escola tradicionalmente envolvida, mas a educação que se faz com o outro. E a linguagem que [... se desenvolve na] Pedagogia da Imagem, esse exercício da linguagem. $\mathrm{O}$ exercício não só de um meio, de uma tecnologia, mas de saber que é um discurso construído, que tem um ponto de vista, que é essencialmente limitado, [como] todos os pontos de vista são.

$[\ldots]$

Batata: $\quad$ [...] São campos de representação que constroem a consciência social. [...] Então, quando a gente fala que o processo de construção de consciência está dentro do processo de luta social [...], são matrizes de representação que estão se debatendo. [...] Umas mais acabadas no sentido de estarem apontando horizontes, enfim, uma providência histórica para a sociedade que há nesse embate. [...] Agora, quer quem participa, quer quem não participa do embate principal dentro da ordem social tem elaborações que representam a ordem social. [...] É exatamente o debate entre essas representações que constitui o campo da cultura. A intenção da sociedade midiática é esvaziar esse debate e estabelecer um discurso de imagens que de certa maneira representem a ordem social sem conflito. Quer dizer, então, [que] entronizar o conflito nesse processo de representação [...] é a maneira de desmontar o ardil da dominação que a sociedade midiática estabelece.

Orestes: $\quad$ E não é um conflito só de consciência social. Toda consciência é uma representação. Mas não só de grupos sociais. Eu acho que esse conflito existe no interior de cada consciência. Não há uma consciência. [...] Todo mundo tem consciência. Agora, a questão [é] que [se] procura neutralizar o conflito também no interior da própria pessoa. Porque a consciência não é um nirvana, um estado de graça, mas, na verdade, é você acirrar as contradições que há dentro de você. [...] Fazer essa neutralização de conflitos, [...] do ponto de vista social, aí é difícil, porque os embates ocorrem: aí é mais um ocultamento. Mas há um processo de asfixia, de destruição do conflito interno. Aí o que acontece? Os que vão pro embate... (estou falando de quem supostamente tem consciência de classe e luta) eles vão cair numa armadilha. Por quê? Porque eles acabam tentando só substituir o rótulo, digamos assim. Porque não está instalado dentro dele o conflito. Cai numa postura sectária. Dogmática. Como se fosse a verdade. 
Batata: Mas o problema é que no debate contemporâneo a questão da verdade não está posta. O que está posto é qual é o simulacro que é aceitável. É essa. Porque você não vai ter o procedimento da observação, da checagem com os critérios de verdade, para estabelecer um campo de objetividade. Não, você vai ter uma construção de objetos que são simulacros da representação social, [...] que, de certa maneira, vão se tornar os elementos a partir dos quais as pessoas criam suas referências. [...]

Orestes: Não ocorre a transformação que você está falando. [...] Os anarquistas falavam assim: "olha, pessoal, a questão não é tirar a foto do Cristo e colocar a foto do Bakunin na sala de aula. Está errado isso." [...] Não é essa a questão - de ficar só no simulacro.

Batata: Não. [E] a diferença é que [a imagem-simulacro...] não tem uma permanência; ela vai ser substituída caoticamente pra ser o simulacro do momento, que dê conta dos elementos que emergem em cada uma das construções, em cada um dos momentos. E, então, eu acho que é esse o embate da desconstrução: [... ele] não passa por um critério de verdade; passa por uma demolição dos simulacros. Quer dizer, você revelar o caráter de cenário. [...]

É justamente por preocupar-se com o desenvolvimento crítico do pensamento que a proposta de uma Pedagogia da Imagem não pretende substituir, no espaço escolar, a expressão verbal, a leitura e a escrita, muito menos sepultar o conhecimento científico:

Orestes: $\quad$ Eu acho que a questão da Pedagogia da Imagem tem uma discussão sobre a questão da Pedagogia, independente ou anterior até à questão da imagem. E aí eu tenho algumas dúvidas, [...] se o discurso audiovisual é um discurso que pode ter o mesmo rigor científico, ou mesmo a construção do pensamento, a estruturação do raciocínio do que [...] palavra escrita. Eu tenho a tendência a achar que uma coisa não substitui a outra. Porque quando você produz a imagem, não abandona a palavra escrita. $\mathrm{Eu}$ acho até que estimula, no sentido de que [se] você vai produzir uma imagem, tem que fazer o argumento, o roteiro, tem uma herança dramatúrgica. [...] Eu tenho uma certa aversão a endeusar a imagem ou as novas tecnologias no sentido de achar que elas possam substituir [o verbal...]. Então, eu, falando, assim, de forma até radical, não acho que o professor deva abandonar o texto. Nem abandonar o texto escrito, nem abandonar o acúmulo de produção literária, filosófica, científica. Eu acho que esse acúmulo é que permite a construção de uma imagem, apesar dos seus limites, talvez, com alguma criticidade. Não é uma coisa substituindo a outra.

A Pedagogia da Imagem não vem para estabelecer uma competição entre essas diferentes linguagens, mas ampliar repertórios e a proficiência dos sujeitos no trato com elas. Espera-se que, com isso, eles sejam capazes de transitar, com desenvoltura, entre diferentes esferas socioculturais, e que possam interferir cada vez mais nos cenários políticos em que estão inseridos:

Juliana: $\quad$ [...] Um aspecto importante também da Pedagogia [da Imagem] é esse: [...] desenvolver as competências dessas pessoas que participam, para [...] que elas também saibam transitar entre os diversos ambientes, os diversos círculos [socioculturais]... 
Batata: $\quad$ É o projeto dos quilombos com antena parabólica do $\mathrm{TC}^{149}$.

Juliana: $\quad[. .$.$] Antes de ser uma Pedagogia da Imagem, a gente pode pensar [...na] importância de$ qualquer processo educativo [...], e qual o papel, o peso dos meios, das tecnologias nesse processo. Primeiro, porque cada tecnologia vai funcionando mesmo como uma extensão da nossa percepção, e vai transformando a nossa forma de produzir o conhecimento. [...] Eu acho que a gente não deve encarar como uma questão dicotômica do tipo: ou os meios e a imagem ou a palavra e o conhecimento. Eu acho que a importância da Pedagogia da Imagem é justamente saber conjugar as duas coisas, para que não se fique só no simulacro e se possa resgatar o discurso, resgatar o pensamento, e tudo mais. [...] A importância da educação, de qualquer processo de aprendizado, é a possibilidade de que o sujeito que participa desse processo [... possa] transitar por diferentes esferas, compreender o maior número possível de discursos, formular o seu discurso no maior número possível de esferas[...]. Então [...] a importância da imagem, da Pedagogia da Imagem, é que ela seja ampliadora dessas inserções sociais, dessa diversidade cultural a que o aluno ou o aprendiz possa ter acesso. Quer dizer, uma educação que não considera as novas tecnologias, os novos meios, está privando aquela pessoa, o aluno, o aprendiz, da possibilidade de lidar com aquele instrumento para se apropriar de bens culturais e produzir também. [...]

Podemos, então, sintetizar o sentido da nossa Pedagogia da Imagem em uma chave dupla: promover a apropriação crítica e dialógica das tecnologias da comunicação e informação e suas linguagens. Crítica que inclui: a compreensão da imagem e da própria linguagem como construções sociais; a apreensão dos elementos da gramática audiovisual pelo exercício da produção de imagens e essa produção como proposta de investigação da realidade do aprendiz; a desnaturalização, sensibilização e politização do olhar; a desdogmatização das consciências e discursos pela análise das fontes em seu rigor, em seus projetos de poder e nos conflitos que elas revelam; a superação da abordagem bancária do conhecimento e dos educadores como transmissores de conteúdos; a apropriação das tecnologias e repertórios culturais como um processo educativo de ampliação das proficiências dos sujeitos e de seu potencial comunicativo. Dialogia que se exerce no diálogo entre os sujeitos, aspirando a ampliar sua capacidade de comunicar-se dentro do seu grupo e com outros grupos socioculturais; e que não almeja impor uma lógica ou pensamento único, uma só interpretação, consciência ou leitura das imagens e do mundo, mas promover a compreensão e o respeito pelas diversas lógicas e sensibilidades que organizam e dão sentido à existência social.

\footnotetext{
${ }^{149}$ Batata está se referindo ao Projeto Mocambos, da Casa de Cultura Tainã, em Campinas. "TC" é a forma como é conhecido um de seus fundadores, Antônio Carlos. O Projeto Mocambos, que tem apoio do Governo Federal, integra, por meio de uma rede via satélite, centros de comunicação instalados em remanescentes de quilombos em todo o território nacional. Esse projeto demonstra a possibilidade de conjugar as raízes mais profundas da cultura popular com a tecnologia digital, ampliando a capacidade das comunidades quilombolas desenvolverem ações em cooperação para resolução de problemas comuns, promoção do intercâmbio cultural e união de forças nas lutas políticas.
} 
No campo teórico, nossa formulação não pretende ser inédita, mas uma reinterpretação e atualização 150 de formulações já existentes e que nos inspiram, nas situações concretas que vivenciamos. A principal delas é a Pedagogia do Oprimido, de Paulo Freire. Batata especifica: "[...] o quê do Paulo Freire? O ensino enquanto ação coletiva, enquanto projeto investigatório. Principalmente isso, voltado para as temáticas que emergem dentro das micro-regiões, das micro-comunidades”. Orestes encontra raízes mais profundas: "[...] a teoria e experiência histórica da chamada Pedagogia Libertária, ligada às experiências anarquistas".

As discussões em grupo também esclareceram nossas motivações e intenções. No cadinho das lutas diárias, onde se fundem os embates e os sonhos que tivemos, forjou-se uma utopia pela qual acreditamos que vale a pena trabalhar. Utopia, sim, tomada como a possibilidade da invenção, da construção de uma outra realidade. Cravada com os dois pés no chão, vinculada a um entendimento do processo histórico atual, mas com os olhos voltados a um projeto de sociedade - não necessariamente único, mas imprescindivelmente humanizador. Orestes traduz: "Essa discussão da linguagem, da Pedagogia da Imagem, do audiovisual, eu acho que é um meio, não um fim em si mesmo”.

Orestes: $\quad$ E eu vejo um aspecto [...] da Pedagogia da Imagem, que é a necessidade de compreender o discurso audiovisual, a leitura, no sentido da consciência crítica, [...] para poder participar de um processo de construção da história. Então, a leitura e a escrita da imagem fornecem condições [...] para que as pessoas possam assumir um papel de sujeito da história. [...] Essa discussão sobre a linguagem audiovisual é no sentido de se apropriar dessa gramática audiovisual, numa perspectiva de transformação histórica. [...] A questão da Pedagogia da Imagem, na minha ótica, está ligada à luta de classes, é uma ferramenta, um instrumento desse processo de luta, de um outro projeto histórico, de uma transformação da sociedade. [...] Portanto, a minha ótica é bem militante. [...] E por isso que é importante na escola. Não na escola enquanto instituição atrelada ao Estado, mas como um espaço de encontro entre as pessoas, e que possa colocar essa discussão de formação da consciência. [...

\footnotetext{
${ }^{150}$ Atualização, aqui, não significa que as proposições teóricas originais tenham se tornado obsoletas. Ao contrário, permanecem mais contemporâneas e necessárias que nunca. Utilizo o termo no sentido em que tais proposições são uma virtualidade, como definiu Pierre Lévy: "[...] é virtual o que existe em potência e não em ato [...], o virtual é como o complexo problemático, o nó de tendências ou de forças que acompanha uma situação, um acontecimento, um objeto ou uma entidade qualquer, e que chama um processo de resolução: a atualização". A Pedagogia da Imagem é, pois, uma atualização (já existiram e podem existir outras) das concepções que nos inspiraram, pois são uma solução concreta que encontramos para os problemas que elas nos apresentam: "A atualização é criação, invenção de uma forma a partir de uma configuração dinâmica de forças e finalidades [...]: uma produção de qualidades novas, uma transformação das idéias, um verdadeiro devir que alimenta de volta o virtual." Se nossas interpretações não são exatamente fiéis, é porque "[...] o atual em nada se assemelha ao virtual: responde-Ihe". (Cf. LÉVY, Pierre. O que é o virtual? São Paulo: Ed. 34, 1997, p. 1517.)
} 
Juliana: $\quad$ Eu vejo [...] que essa consciência, hoje, precisa ser, pela sobrevivência da espécie humana, [...] altermundista. Um outro mundo tem que ser possível. Ela não pode ser mais essa consciência reafirmadora. Porque a gente já está aí vendo [...] que esse modelo que vem vindo até agora é insustentável. Então eu acho que [precisamos promover] essa consciência de que, primeiro, não podemos repetir os mesmos erros nem continuar na mesma corrente; segundo, [...] essa transformação tem que vir com a participação daqueles que até então foram excluídos. [...] Pra mim, a Pedagogia da Imagem não pode ser outra coisa, senão começar a traçar uma outra via, e que essa via seja traçada com a participação daqueles que até hoje foram excluídos. Então eles têm que estar habilitados a participar, [...] conquistando o seu espaço com suas habilidades[...].

Batata: $\quad[. .$.$] A composição do processo de dominação na sociedade contemporânea tá no con-$ trole da informação. E isso é uma unanimidade para nós. E desmontar esse aparato significa você transformar revolucionariamente a sociedade, não na perspectiva da revolução francesa, nem na perspectiva da revolução leninista, mas na perspectiva, talvez, de uma transformação que vá gerando conflitos internamente e recompondo o processo de dominação em outros dilemas. A legitimação dos poderes dentro das sociedades contemporâneas que se pensam democráticas ou que têm o seu referencial no jogo político da democracia nos aponta para um processo de construção das imagens dos grupos que estão [...] postulando participação nos espaços de poder. Primeiro, [havia] o discurso de referenciação classista ao controle da palavra escrita, ao controle da produção do jornal, o controle dos espaços legítimos de pronunciamento dos discursos de poder. [...] Esse lugar, a partir dos anos 60, 70, é deslocado para um outro lugar do pronunciamento dos discursos, que é o lugar onde você costura imagens à fala verbal, coloquial. Você passa a elaborar um novo projeto de comunicação, muito mais centralizado e que, de certa maneira, vem esvaziar o processo do embate político a partir do discurso retórico e estabelece o surgimento de um novo processo de comunicação, ancorado na imagem, e que esvazia, de uma certa maneira, o conhecimento tradicional da sociedade. Então, nesse processo, são gerados os novos ícones que vêm substituir, de maneira cristalizada, o espaço que antes era colocado para o confronto das idéias, dos embates retóricos. Então, o domínio desse modo de produção desses ícones da sociedade contemporânea acho que é o objeto que a Pedagogia da Imagem vai se debruçar.

A Pedagogia da Imagem é, para nós, um projeto político que se traduz, antes de mais nada, no reconhecimento da posição de centralidade ocupada pelos meios de comunicação e pelas linguagens audiovisuais na distribuição das relações de visibilidade social e no processo de constituição de identidades culturais, condições essenciais para a participação democrática. Se aceitamos, como propõe Daniel Innerarity, que hoje poder é poder ser visto ("o poder está no rosto"), ${ }^{151}$ temos que questionar os procedimentos de apagamento simbólico de certos sujeitos sociais nos espaços públicos mediatizados. Para que a perspectiva plural seja preservada, é necessário que os diferentes pontos de vista tenham garantida a possibilidade de se manifestar por si próprios, serem autodeterminados, sem a tutela das vozes hegemônicas - quer de direita ou de esquerda. Nossa primeira tarefa consiste, portanto, em promover o direito à elaboração

${ }^{151}$ INNERARITY, Daniel. A transformação da política. Lisboa:Teorema, 2005. 
da própria imagem por aqueles que, historicamente, têm sido silenciados e ocultados. ${ }^{152}$ Essa ação se insere num contexto mais amplo, de luta dos diversos setores sociais pela criação de canais alternativos de comunicação e pela democratização dos espaços já existentes, onde os diferentes atores possam expressar suas visões de mundo e defender seus interesses, numa perspectiva plural.

Juliana: $\quad$ [... Quero ressaltar $]$ o quão importante é, num cenário social, político, que os grupos e os atores sociais disponham de uma imagem e de uma voz. [... Mas eles] não têm o seu espaço nesses meios hegemônicos, na TV, no rádio, etc. [A Pedagogia da Imagem tem como objetivo...] que eles possam, primeiro, realizar a leitura crítica daquilo que chega, e [...] se perguntar a que serve esse tipo de imagem. Segundo ponto é que eles saibam também usar os recursos da comunicação, desenvolver as suas competências comunicativas para saber também formular as suas propostas e encontrar espaços alternativos para veicular a sua imagem. Então está relacionado [...] a criar canais alternativos. [...] Seja a escola, seja o bairro, sejam os pequenos grupos, até o círculo familiar. Não importa. Onde houver esses canais eu acho que essas seriam algumas tarefas da Pedagogia da Imagem.

[...]

Batata: $\quad[. .$.$] Ser mostrado significa ter existência e não mais se pronunciar.[É...] você aparecer$ enquanto um [...] suporte de significados dentro da nova iconografia. Então, a luta é pela elaboração desses ícones, [...] desmontar o monolitismo dessas configurações e mostrar que por trás dele existe ainda o conflito histórico. [...] Revelar o conflito, desmontando a linguagem da construção dos ícones, é a maneira como a gente [...repõe] a contradição dentro desse campo contemporâneo da produção dos significados. [...] O embate principal que nós vamos ter nessa década é o embate sobre o controle dos meios de emissão de imagem ou a descentralização dele total através da universalização, da proliferação da comunicação através da Internet. [...] É esse o jogo onde a gente entra [...]: tirar o processo educacional do século XIX e jogar no século XXI. [...] É o nosso desafio. Fazendo esse trabalho com agentes pedagógicos do sistema público, principalmente, que no sistema privado isso está sendo trabalhado.

Orestes: [...] A discussão da mídia, da comunicação social, não é uma discussão desplugada, desligada desse embate [econômico] concreto que existe. [...] Então, o domínio da linguagem é o domínio de luta, de combate. [... Momentaneamente, eu acho que o] domínio dessa gramática audiovisual [...] não é por si mesmo conscientizador, se ele estiver desligado da luta concreta, dos embates sociais e dos projetos históricos colocados. [...] O que existem de fato são pessoas, nos quatro cantos do mundo, [...] que, bem ou mal, aos trancos e barrancos, estão em movimento. Elas não aceitam aquele dado como uma coisa completa e estão tentando fazer alguma coisa de forma plural [...]. Têm um mínimo de indignação e canalizam isso para uma luta coletiva e organizada. Não é uma insatisfação pessoal, não é um descontentamento pessoal. [...] Não é um delírio meu. Essas pessoas existem. Cruzo com elas por aí. Só que o que me preocupa é que essas pessoas são [...] despreparadas e até não conseguem dar a importância devida a essa linguagem audiovisual [...].

Juliana: $\quad[. .$.$] A questão do pluralismo que se coloca é que os diversos grupos sejam capazes de$ elaborar as suas demandas, colocar [publicamente] as suas demandas, e que eles sejam ouvidos. E que a

\footnotetext{
152 Não queremos com isso negar o valor da mediação competente do profissional de comunicação social. Ao contrário: a atuação qualificada e eticamente comprometida com os valores da dialogia se faz cada vez mais necessária e possível. "Partilhar a visão de mundo do outro, dela extrair a utopia humana e ceder a competência técnica e científica para uma narrativa solidária não é uma miragem, é uma possibilidade". MEDINA, Cremilda. Símbolos e narrativas: rodízio 97 na cobertura jornalística. São Paulo: Secretaria do Meio Ambiente, 1998. p. 20.
} 
esfera política seja capaz de negociar com os diversos pontos de vista [...] para que se minimize e se contorne o aspecto da exclusão, para que não haja tanto o apagamento dos outros atores.

Orestes: $\quad$ Não sejam sempre os mesmos.

Juliana: $\quad[. .$.$] E que haja mecanismos compensatórios.$

Orestes: [... Para chegar a essa situação há pré-requisitos: a pessoa excluída da esfera da comunicação] não está apta para entrar nesse espaço de debate público.

Juliana: $\quad$ Ela não desenvolveu as competências comunicativas necessárias para se colocar nesse lugar de debate.

Batata: $\quad$ Mas ela é habilitada a raspar as cores para o mofo aparecer. [...] Ela vai sempre cutucar o cenário, falar: "Epa! Por que não se move?"

Orestes: $\quad$ Sim. Por isso que não se pode desistir nunca.

Um segundo aspecto desse pressuposto é a compreensão do caráter aberto e móvel das identidades socioculturais. ${ }^{153}$ Em outras palavras, a Pedagogia da Imagem não deve tomar os media exclusivamente como um fator desagregador de identidades, mas um elemento por meio do qual as coletividades assimilam novos conteúdos e tecnologias, os inserem nas culturas do cotidiano e reinvestem em novas configurações de identidade e auto-reconhecimento. As identidades e a cultura são, pois, contextualizadas sócio-historicamente. Difundir, fazer dialogar, hibridizar e pluralizar os bens culturais (materiais e imateriais) é o que alimenta as atuais estratégias de resistência à homogeneização proposta pelo mercado globalizado.

Batata: [...] Para além do jogo da militância, o entendimento da linguagem está posto hoje como a alfabetização estava posta há 50 anos atrás. Quer dizer, é uma capacitação da população a desmontar o discurso através do qual se cria uma iconografia do poder, se criam os referenciais de constrangimento cultural à manifestação da pluralidade. O padrão, hoje, dentro da representação da cultura de classe, é uma homogeneização, via mercado de consumo e mercado cultural, das formas de representação da sociedade. Porque, antes, você ainda tinha valores culturais guetificados, de nacionalidades distintas, de culturas subalternas, que se reproduziam independente da presença do discurso de dominação. [...] Então, desmontar a estratégia desses emissores [hegemônicos] é habilitar o cidadão a exercer a crítica e a produzir o seu discurso independente de ele ser militante ou não.

Juliana: $\quad$ E fazer circular esse discurso.

Orestes: $\quad[. .$.$] Isso sem dúvida. [...] Mas o problema da hegemonia antecede a isso. Por isso que$ eu digo: a televisão não aliena. Lógico que não aliena. Ela reforça uma alienação já existente. Porque se essa criança tiver acesso a outras informações, se é colocada no espaço da escola com visões antagônicas, tem a oportunidade de expressar a sua individualidade, a sua forma de comunicação artística, que efeito terá a televisão? Eu estou falando agora, até, como pai, em relação aos filhos, porque nunca proibi de assistir a qualquer programa que quisesse. Então não é aí que está o problema.

${ }^{153}$ Cf. FERIN, Isabel. Comunicação e culturas do quotidiano. Lisboa: Quimera, 2002. 
Hic et nunc, a Pedagogia da Imagem adquire concretude na luta pela democratização da comunicação social e do acesso aos bens culturais, na garantia do direito de fruir e produzir a cultura, de conhecer e se apropriar do capital cultural coletivo. Como lembra García Canclini, não basta que os bens culturais estejam disponíveis livremente a todos, se as suas possibilidades de uso são desigualmente distribuídas. ${ }^{154}$ Os bens culturais acumulados, conforme já havia demonstrado Bourdieu, não pertencem realmente a todos, mas àqueles que dispõem dos meios para decifrá-los e se apropriarem deles, intelectual e sensivelmente. Daí a urgência de uma ação cultural educativa que contribua para a redução das desigualdades entre as classes, por meio da socialização dos códigos e procedimentos de escrita e leitura de imagens.

Para que isso seja possível, é forçoso assumir a crítica da concentração dos meios de produção e difusão da informação nas mãos de uma minoria. ${ }^{155}$ Uma pedagogia libertária pela imagem não pode ser bemsucedida quando o livre acesso à informação - e à contra-informação - é dificultado pela escassez ou inacessibilidade de fontes alternativas. O choque entre pontos de vista, nos conteúdos e nas estéticas, é um requisito para provocar a abertura do pensamento, a quebra de estereótipos, a ampliação das mundivisões e para desenvolver a capacidade de avaliar e selecionar as próprias fontes. Assim, uma tarefa prioritária é a de estimular e alimentar as redes alternativas de produção, circulação e discussão do audiovisual, em todas as suas formas. As políticas públicas de ação cultural não podem ignorar essas considerações.

Juliana: [...] É importante [que se coloque a Pedagogia da Imagem...] como uma conquista, sempre. Porque esse espaço de reivindicação não vai ser dado. São esses grupos que têm que estar permanentemente à busca...

Orestes: $\quad$ E isso é uma luta. [...]

Finalmente, tendo em vista, ainda, a questão das diferentes capacidades de apropriação do capital cultural, impõe-se à Pedagogia da Imagem o caráter eminentemente prático, ou melhor, de práxis. É preciso levar em conta que emergirão diferentes formas de produzir e apresentar as imagens, conforme lembra Marco Bellocchi: "antes do cinema existe o homem, o homem e sua visão sobre o mundo, sobre a sociedade, sobre si mesmo". O princípio da Pedagogia da Imagem não pode ser teórico, nem prescritivo, ba-

\footnotetext{
154 GARCÍA CANCLINI, Néstor. As culturas populares no capitalismo. São Paulo: Brasiliense, 1983.

${ }^{155}$ Essa posição parece ser compartilhada por FERIN, I. Comunicação e culturas do quotidiano, p. 151.
} 
seando-se no estabelecimento de padrões técnicos ou estéticos, modelos, formulações. Ao contrário, deve ser o de estimular a diversidade de experiências e de verificar os múltiplos usos que os sujeitos desenvolvem, de maneira autoral. Garantir a polifonia dos projetos significa promover o não-fechamento estético e o estabelecimento de um compromisso ético de respeito ao outro e à sua visão de mundo. Da sistematização das experiências e do exercício crítico, pode nascer uma teoria que realimente e qualifique a prática, impedindo-nos de cair no ativismo inócuo ou na cristalização de procedimentos.

\subsection{Desafios cotidianos: a construção metodológica da Pedagogia da Imagem}

A atualização dos princípios e intenções enunciados, num programa de formação continuada de professoras, traduz-se num objetivo aparentemente simples: promover a incorporação crítica e dialógica dos meios de comunicação e suas linguagens em sala de aula. A questão envolve, porém, uma série de desafios e algumas armadilhas às quais precisamos escapar. Por isso, a nossa metodologia de trabalho é objeto permanente de discussão e revisão. A programação dos cursos, cumprindo alguns critérios básicos, foi sendo construída, ano a ano, para atender, ao mesmo tempo, expectativas das educadoras e requisitos que traçamos para a formação. Assim, de cada grupo que se constitui, é necessário traçar o perfil, conhecer as potencialidades e dificuldades no trato com os meios e fazer adaptações às atividades e dinâmicas mediadoras da aprendizagem.

Batata: $\quad[. ..] \mathrm{O}$ [curso] Pedagogia da Imagem, de certa maneira, vai se configurando a cada edição e vai assumindo uma cara. E ele tem no seu bojo a intenção do trato da linguagem visual e de analisar a maneira como a linguagem visual é inserida no processo educacional.

$[\ldots]$

Juliana: A Pedagogia da Imagem - acho que é importante ressaltar isso: ela não pode ser transmissão de informação. Por isso, ela não pode ser pensada no abstrato, para qualquer tipo de grupo. Cada grupo que a gente vai atender [...] tem a sua visão, tem as suas necessidades e vai desenvolver usos [próprios].

O programa atual, que se consolidou a partir de 2006 (vide Anexo B), tem como eixo a discussão sobre os usos dos meios e suas linguagens na escola - o que é feito, como é feito, por quem, que tipo de relação 
pedagógica se estabelece nessas situações - e a instigação das educadoras para que criem novas possibilidades no espaço escolar. Nós, orientadores, não decidimos o que deve ser produzido: cada participan-

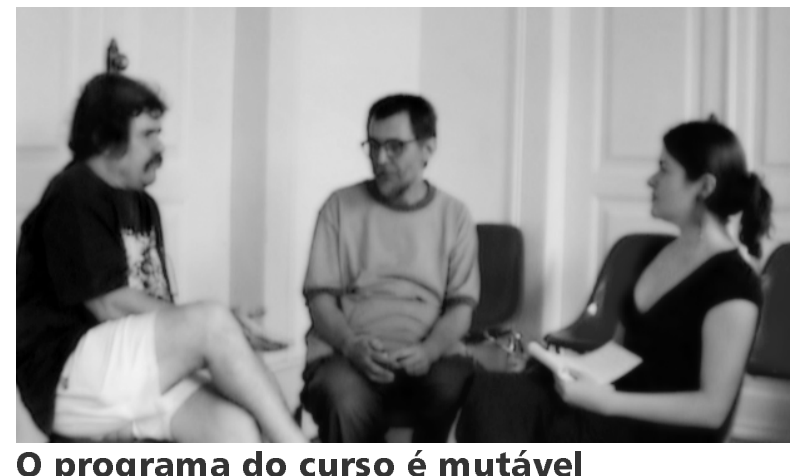
te deve reconhecer, no seu ambiente de trabalho, os recursos existentes, as políticas de utilização dos mesmos, as limitações de tempo e espaço, os interesses diferenciados dos alunos e as possibilidades de desenvolvimento de um projeto audiovisual. O que fornecemos é um panorama de diferentes linguagens (fotografia, vídeo, cinema) e sugestões de aplicação: o registro e preservação da memória da escola, a aproximação com a comunidade por meio de passeios fotográficos pelo bairro e exposições, o uso do vídeo para o estudo do meio, a produção de material didático em audiovisual, a realização de sessões de cinema abertas à comunidade... Não é preciso ir muito longe: em geral, as educadoras logo se identificam com uma ou outra linguagem e rapidamente imaginam um projeto no qual poderiam aplicá-la. Para algumas, fotografar ou fazer um vídeo sobre ou com os alunos já é um sonho antigo. As discussões coletivas sobre o que planejam desenvolver na escola contagiam positivamente as colegas mais receosas. Os relatos sobre as dificuldades que surgem pelo caminho não deságuam na lamentação: o grupo troca experiências e sugere saídas. Nesse momento, como animadores, nosso papel é o de acompanhar cada um desses processos e suas metodologias, oferecendo orientações mais específicas, materiais de apoio, assistência técnica mas, sobretudo, respaldo no ambiente escolar, auxiliando a professora na negociação junto às pares, orientadoras pedagógicas e diretoras, tanto para que se compreenda a importância do projeto quanto para que a unidade garanta suas condições de realização.

Isso quer dizer que a formação não se limita ao encontro semanal no MIS, mas se desdobra em inúmeras visitas aos espaços educativos. É algo trabalhoso, mas não impossível: os projetos têm níveis de complexidade diferenciados e há professoras com maior autonomia e desenvoltura no trato com os meios. Além disso, incentivamos a realização de trabalhos em equipe por profissionais da mesma escola. Com o tempo, esse acompanhamento in loco mostrou-se essencial, não apenas para que os projetos desenvolvidos fossem bem-sucedidos, mas principalmente para que nós, agentes da Secretaria de Cultura, conhecêssemos mais a fundo o funcionamento das escolas e a estrutura da Secretaria de Educação, cujas de- 
terminações criam condições mais ou menos favoráveis à implantação da Pedagogia da Imagem pelas docentes. Dessa maneira, descobrimos que umas portas se abrem na sala de aula; algumas, na diretoria e outras, ainda, nas instâncias que centralizam as decisões da SME. Fomos desenvolvendo a convicção de que a formação não é um processo de treinamento, instrução ou capacitação de professoras: ela envolve, necessariamente, a compreensão e facilitação de suas condições de trabalho. Não tivéssemos extrapolado os muros do museu, a Pedagogia da Imagem já teria naufragado como possibilidade concreta de produção audiovisual na escola pública.

Esta foi-se mostrando, cada vez mais, um espaço contraditório. Por um lado, burocratizada, cheia de normas, regras, restrições, prescrições e, por outro, um lugar ora distante, ora invisível, às vezes esquecido, com inúmeros pontos cegos para o controle central. Um território onde os diferentes atores encontram brechas para negociar ou ignorar os limites, cavando um campo de autonomia para sonhar e produzir.

Batata: A questão da escola está posta desde sempre. Quer dizer: a readequação dela enquanto correia de transmissão de um conhecimento operatório ou de iniciadora da criança e do jovem nas tradições acumuladas socialmente, essa é a polêmica que vai permanecer [...]. A outra é se o método é o de pensar o conhecimento enquanto coisa em elaboração ou enquanto a enciclopédia cristalizada. [...]

Orestes: $\quad$ E, num certo sentido, a escola pública, pelo estado de abandono e também pela própria formação do professor, não cumpre nem a função já questionável de transmissão. Então, quê que faz? Por que se reúnem naquele espaço os jovens e os professores? O que eles tão fazendo?

Juliana: $\quad$ Eu vejo a escola como um espaço altamente contraditório. [...] Se existe uma intenção de controle, ela não se exerce [completamente], pelo abandono das escolas. [...] O discurso oficial é o discurso da libertação, da inclusão, da produção de conhecimento, que é um discurso que não se realiza [também...] pelo abandono... [...] E ao mesmo tempo, os professores [...] pela própria condição de abandono em que estão, teriam possibilidade, quer dizer, existe, aí, a possibilidade de haver uma transgressão, de [...] se produzir um outro tipo de educação. Justamente pela brecha [...] enorme que esse controle deixaria.

Orestes: $\quad$ Por isso que é um espaço, como você falou, da contradição. Ela é um espaço, inclusive, de disputa hegemônica. O problema é que isso depende da inserção da escola na comunidade, nos movimentos sociais, na formação dos professores, e isso é algo que a estrutura administrativa estatal engessa. Começa na formação dos professores, depois no exercício da prática docente. Há uma canalização de qualquer forma de insatisfação, no sentido apenas pessoal de ceticismo, descrença...

Juliana: Mas quando a gente vai lá na escola, parece que é uma lupa que a gente coloca. E [...] a gente encontra pessoas que, mesmo com a dificuldade de formação, dificuldades de expressão mesmo, escrita, oral, [estão...] interessadas em trabalhar, e dispostas a se integrar mais com a comunidade.

Orestes: $\quad$ Por isso é que é um espaço de contradição. Mas [...] é uma ação, se não for articulada de forma mais engajada, [...] quixotesca. Porque se a percepção [ou... a ação do educador é movida por 
ilusões, sem uma compreensão crítica de toda a engrenagem, de todo o sistema, ou pela visão tradicional, de transmissão de saber, ela vai cair na decepção, e a decepção é o primeiro passo para o ceticismo. Mas, digamos, é [...] um espaço de disputa de hegemonia. Eé interessante porque [...] o poder dominante atua [...] de forma desorganizada, [...] inorgânica. Ou seja, agindo como estrutura, como política educacional, para desorganizar. [...] Mas eu não tenho uma visão pessimista. Senão, não estaria na escola. Eu acho que é uma trincheira valiosa de luta para acirrar a contradição. [...] Em que local hoje se encontram tantos jovens, tantas crianças, numa interação social? Não é só a aula, que às vezes eles aprendem mais é no pátio, nos corredores, em atividades extraclasse que rompem um pouco com a hierarquia. [...] Mas é o espaço do conflito, você colocou bem, e é um conflito, uma contradição, para ser acirrada.

Por vezes, é o próprio desenvolvimento de um projeto de Pedagogia da Imagem que gera tais conflitos no ambiente escolar.

Orestes: Já provoca um certo abalo na rigidez. Nós percebemos isso: já começou a tumultuar porque já pega a câmera que tá no armário. Já começa a colocar a câmera na mão do aluno: o aluno vai quebrar? Não vai quebrar? Começa a fazer atividade fora daquele absurdo de aula (deu o sinal, terminou), em cima de projeto. Até o fato do aluno formar um trabalho em equipe, ter tarefas diferentes, a hora da discussão, a hora de ouvir, a hora de falar e se apropriando também dessa herança cultural. [...]

Batata: $\quad[. .$.$] Mas o movimento mais fácil, que é utilizado como alforria, auto-alforria dos pro-$ fessores perante o seu trabalho, é o "põe o filme aí e deixa esses moleques"...

Orestes: "Então vamos lá pra assistir, pra se divertir". Como se aquilo não fosse um conhecimento, se não tivesse um discurso, um sujeito discursando, como se não fosse uma construção da linguagem.

Juliana: $\quad$ Vendo de uma outra forma, isso é uma maneira do professor reagir - quer dizer, de uma maneira não-qualificada, mas é uma reação a essa opressão que ele sente, a essa frustração constante, à falta de recursos, à falta de reconhecimento, à falta de condições. O que seria importante é que ele percebesse tudo isso e tivesse um outro tipo de reação.

Nesse momento, a atuação dos orientadores é decisiva: estimular a reflexividade das professoras sobre seu trabalho, numa discussão que supere as reclamações sobre as dificuldades cotidianas, a descrença, o ceticismo e faça (re)emergirem os sentidos de sua atuação profissional. Nesse espaço coletivo, elas reencontram e reafirmam sua identidade de educadoras. Algumas vezes, não se consegue atingir essa organicidade no espaço da escola, contaminado por conflitos e relações interpessoais autoritárias, opressivas. O ambiente da formação no museu, povoado de novos rostos, novas interações, torna-se um arejo e propicia uma reavaliação e asserção de (outras?) práticas, valores e ideologias profissionais.

Orestes: $\quad$ A Pedagogia da Imagem atua também, me parece, observando aqui esses anos, num certo sentido [...] de organizar o que está muito disperso. Porque, de repente [...] você tem um aqui na escola, um pouquinho ali, que está no limite de romper com essa postura passiva, submissa. Aí numa ou- 
tra escola tem um outro também. E de certa forma eles se encontram aqui. E dialogam. E começam a perceber que a ação deles não é uma ação isolada. Tem um espaço de discussão e reflexão coletiva. E essas experiências precisam circular. Eu acho que a ida às escolas, para fazer um projeto específico na escola, em audiovisual, não é um gueto. É rede, no sentido de ramificar até criar um circuito exibidor nas escolas. A escola A fez um vídeo lá, vai passar na B, C, D... Quem não fez fica estimulado a fazer. [...] Porque a ação pontual, isolada, mesmo que seja de acirrar conflito, tem alcance limitado. Agora, quando você articula, aí os professores começam a perceber que não são alguns professores, algumas escolas: isso é mundial. Tem uma rede aí [...]. Então eu acho que o que precisa é [...] usar do que a imagem permite em termos [...] de permitir diálogo e de conhecer experiências diferentes. [... O professor]não está sozinho. Ele tem que ser um nó dentro dessa rede. E há essa rede.

A falta de organicidade não se dá somente entre as professoras. Está, principalmente, no sistema e na unidade escolar, que nem sempre reconhecem a necessidade de uma Pedagogia da Imagem e tratam a formação, algumas vezes, de maneira pouco profissional. Isso pode ser notado no modo como os cursos são oferecidos e como são feitas as inscrições. Em relação à oferta, não é garantido que a educadora perceba remuneração pela sua participação em cursos. Freqüentadoras da mesma turma costumam estar em situações diferentes, até mesmo no que diz respeito ao direito de receberem certificados de conclusão de curso ou apenas declarações de participação. A questão de fundo, aqui, é assumir a formação permanente como um componente do trabalho docente e não como um benefício ou requisito do qual a professora tem de dar conta por si só. Esse entendimento gera conseqüências no que diz respeito a quem assume a responsabilidade pela formação continuada e, por conseguinte, no perfil profissional que se configura no quadro geral das professoras municipais. Não nos consta que tenha havido algum tipo de sondagem sobre o perfil das docentes em exercício, especialmente de seus conhecimentos e habilidades que não se relacionam diretamente à formação acadêmica, com vistas ao planejamento do leque de cursos a serem disponibilizados anualmente. Ainda que tivesse sido feita, a discrepância entre o número, a variedade, as temáticas e o enfoque dos cursos e GTs, nos últimos anos (vide Anexo A), demonstraria que a interpretação dos resultados, em cada período, levara a conclusões diametralmente opostas. Ora o cardápio é variado, denotando uma preocupação com uma formação "integral" do profissional, ora exagera na amplitude e perde o foco e, finalmente, dá uma guinada em direção a uma abordagem instrumentalizante. O problema vai mais adiante: a despeito da boa-vontade e dos esforços de seus profissionais, o processo de acompanhamento dos cursos pelo Ceforma é frágil, baseado apenas em relatórios semestrais padronizados, preenchidos pelos próprios ofertantes. Da mesma maneira, a avaliação sobre a pertinência de cada curso tem sido, nos últimos anos, pouco transparente, baseada em crité- 
rios desconhecidos, e as conclusões parecem ignorar as opiniões das próprias professoras, expressas nos formulários que preenchem duas vezes por ano. Em algumas áreas temáticas (talvez consideradas menos relevantes), nem a SME, nem as escolas possuem informação sobre quantas professoras, em cada unidade, deveriam ser formadas para atender a projetos que se pretenda implementar. Tudo depende da vontade das educadoras, que decidem o que querem cursar, e quando. Antes assim: a elas a Pedagogia da Imagem deve sua subsistência.

Batata: $\quad$ A minha avaliação é que o maior problema que a gente enfrentou [...] é que esse espaço de formação dos professores não costuma manter um vínculo orgânico com a atividade do professor dentro da escola. Então vira um espaço meio do... "bem, as minhas horas de formação [são] para eu fazer o que está na minha cabeça" Quer dizer, não é um processo onde a escola faça a opção por um certo campo de saberes que o professor vai trabalhar, enfim, absorver esses saberes, desenvolver esses saberes e trazer esses saberes pra dentro da escola, pra que, enfim, ele seja um fator de multiplicação. A gente, de certa maneira, tem que investir na possibilidade de que o voluntarismo de determinados professores faça com que, localizadamente, dentro de uma escola ou de outra, aconteçam determinados projetos. Então o nosso encaminhamento, ao longo desses quatro anos, foi de tentar fazer com que ele assuma um caráter institucional, pra fazer com que a atividade desenvolvida aqui tenha uma repercussão dentro da escola. Agora, se a gente olha o cotidiano da escola, [...] onde os professores são colocados numa seqüência de atividades em que a reflexão e o planejamento não têm muito espaço, muito menos a formação, e muito menos ainda o desenvolvimento de atividades extraclasse, isso acaba virando mais um campo do voluntarismo. Quer dizer, aqueles que vestem a camisa, assumem o processo fora da sua jornada, levam adiante. Ou aqueles que se integram dentro do corpo diretivo da escola e conseguem fazer daquilo uma diretriz da atividade docente, conseguem fazer barulho. Mas não existe dentro do ensino público a perspectiva de uma formação extracurricular com o desenvolvimento de atividades do plano cultural, uma pedagogia que se aproprie do elemento cultural pra fazer disso conteúdos da escola, fazer disso campo da formação escolar. Então, eu acho que esse é o maior nó que a gente começou agora a enfrentar, com a nossa intromissão dentro do espaço escolar.

Orestes: $\quad$ E que Pedagogia da Imagem não é uma política pública. Nem na Secretaria de Educação, muito menos na Secretaria de Cultura. E a Pedagogia da Imagem, me parece que ela tem uma concepção pedagógica que se choca com a pedagogia oficial aí existente.

A formação se torna, então, um espaço de profissionalização, mas a cargo apenas ou majoritariamente, da professora. O enraizamento e continuidade de programas como a Pedagogia da Imagem, na escola, ficam condicionados, assim, à disposição de alguns sujeitos.

Batata: $\quad[. .$.$] Esse professor é incumbido de um processo... A escola não tem uma estratégia de$ encaminhamento dos seus quadros para os cursos, não é um processo institucional. É um processo: "ah, eu tô a fim, eu vou". É um jogo de toma-lá-dá-cá dentro da escola, de trocas, de: "quem pode ir fazer o curso?” Aí quem pode é quem está fora da sala de aula. [...]Então localizar isso é importante pra você a- 
postar estrategicamente onde o programa vai investir, no sentido de capacitar aquela escola pra se inserir de maneira mais ativa dentro do programa.

Por essa razão, tem sido relativamente lenta a difusão do Programa pelas escolas. Também por esse motivo, o modelo clínico de formação é fundamental na articulação dos esforços das educadoras envolvidas, auxiliando-as na resolução de problemas e na sistematização de metodologias de trabalho próprias, adaptadas a suas necessidades.

Juliana: $\quad[. .$.$] O diferencial do nosso trabalho [...] é fazer esse acompanhamento daquilo que o$ professor criar na escola dele. [Não vamos...] levar um modelo do que o professor vai fazer na escola, dar receitinha para o professor. Que aí é aquilo que a gente falou: substitui uma receita por outra e continua a mesma repetição. [...] O interessante do nosso projeto é isso: aqui é um momento em que eles se introduzem e despertam [para o trabalho com o audiovisual...], para num momento seguinte a gente dar suporte e apoio pra criação deles.

Perde-se por um lado, ganha-se por outro: esses sujeitos articulados são agentes de luta, conquistam diaa-dia sua autonomia, tornam-se protagonistas do processo educativo - e ao compreenderem sua situação, transformam sua relação com os alunos e com a comunidade. Pela força das circunstâncias, a Pedagogia da Imagem constrói-se, assim, "de baixo para cima”:

Juliana: $\quad$ Eu imagino que esse tipo de ação, como a gente tem começado, de baixo pra cima [...] tem um potencial transformador muito maior. [...] Até porque os professores já estão cansados dessas idéias que vêm do dia pra noite e aí eles não se engajam, quer dizer, não partem deles, eles não são envolvidos, não acreditam mais. Eu acho que essa ação que a gente tem feito, descentralizada, pode [...] criar um volume tão grande dessas produções que isso vai ter que ser reconhecido e aí pode ser destinado recurso para cada escola. Mas é um outro tipo de estratégia, que não é uma diretriz central, mas cada escola poderia fazer a sua Pedagogia da Imagem, o seu projeto específico, diferente e ligado à sua comunidade, e não de cima pra baixo. Que aí, sim, seria uma coisa de longo prazo.

Orestes: $\quad$ E altera também a relação educador-educando, professor-aluno.

Juliana: $\quad$ E comunidade-poder.

Orestes: $\quad$ Todos são protagonistas. Todos são sujeitos do processo.

O protagonismo e o envolvimento ativo de educadoras e educandos nos processos de produção e leitura do audiovisual constituem a principal diretriz do nosso curso. A construção dessa autonomia começa na relação conosco. Em torno da roda de discussão, damos as boas-vindas às professoras, propomos a pauta do dia. Enquanto as participantes vão chegando, colocamos em circulação matérias de revistas 
como Caros Amigos, Carta Capital, Revista do Brasil e do jornal Brasil de Fato, além de informações sobre exposições, filmes e agenda cultural de caráter popular em Campinas. Há espaço para relatos, informes e resolução de dúvidas. Em geral, há um artigo que deflagra o debate ou um vídeo que motiva a participação. Frente a esses textos, a postura não é de aceitação passiva, mas de confronto com a experiência. Todas são estimuladas a se pronunciar. Quando uma ou outra pessoa tende a monopolizar o debate, propomos dinâmicas diferentes, como a organização de pequenos grupos e a apresentação das conclusões para o conjunto da turma. Assumimos um papel de orientação - e não de prescrição. Por isso, quando não estamos de acordo com alguma opinião, não a rechaçamos. Expomos um ponto de vista, mas não detemos a última palavra. Acreditamos que transformar ideologias profissionais arraigadas e quebrar preconceitos não é uma questão que se resolve pelo discurso. Preferimos propor experiências diferenciadas e trazer informações que se choquem com idéias cristalizadas. Assim é que funcionam atividades propostas às professoras, como pesquisar os hábitos culturais dos alunos, fazer passeios fotográficos pelo bairro onde se localiza a escola, visitar um Ponto de Cultura ou trazer um integrante do movimento hiphop ou das rádios comunitárias para dialogar com as educadoras. Outro recurso importante é a exibição de filmes provocadores, sempre inseridos em uma dinâmica que pretende chamar a atenção das participantes para temas específicos e para os recursos de linguagem empregados, sem cair no vazio ou no entretenimento puro.

Juliana: No caso dos professores, [a Pedagogia da Imagem] também entra em choque com uma série de concepções, de preconceitos que eles tinham, da consciência profissional, da ideologia profissional. E é preciso ele estar muito seguro, legitimar a sua nova prática, para que ele abra mão daquela prática anterior, que é a hegemônica, que é a que todo mundo faz. Porque ir contra a corrente é difícil.

Orestes: $\quad$ Agora, você aí tem dois desafios: primeiro, a discussão do conteúdo e, depois, relacionado à Pedagogia da Imagem, tem que discutir a linguagem. Agora, exibe o filme, a reação de cada professor é reveladora sobre sua história de vida, cosmovisão, visão de mundo. Aí que entra o outro desafio maior, que é romper com essa postura passiva do espectador.

Juliana: De entretenimento?

Orestes: $\quad$ É [...]. Ali que entra a necessidade de preparar essa exibição, com alguns temas geradores de conflitos, de provocações. Então eu acho que é uma experiência, seria um estudo, num caso específico, de recepção.

No desenvolvimento do projeto prático, é a educadora quem escolhe a linguagem e o tema a ser trabalhado. Insistimos apenas que haja o envolvimento ativo dos alunos, desde a escolha do tema até a operacionalização da produção. $\mathrm{O}$ acompanhamento dos projetos, além das visitas às escolas, é feito por meio 
de relatos coletivos, permitindo a troca de experiências. Os conhecimentos construídos ao longo do ano são sistematizados em sessões no final de cada semestre.

Orestes: $\quad$ É... eu acho que a força e a disseminação é quando o próprio professor, os próprios alunos, a comunidade envolvida, se sentem sujeitos do processo, se sentem agentes. A gente só acirra a contradição, só fornece os elementos, eles é que constroem. Daí que eu acho interessante essa pluralidade. Não é um modelo único, todas as escolas. Não. Há um aspecto único, no sentido libertário, da inserção nas lutas sociais e na produção da tecnologia, mas há especificidade, há aquilo que é próprio daquela comunidade, daquela escola, da história daquelas pessoas.

Juliana: $\quad$ Esse, na verdade, é um dos elementos fundamentais da nossa Pedagogia da Imagem. [...] A construção pelos sujeitos que participam dela. E eu acho também que essa procura dos professores demonstra um esgotamento [...] desses modelos e fórmulas prontos, desse tipo de pedagogia já desgastado. [...]

Orestes: $\quad$ Agora, é um processo realmente de formiguinha. E aí está a força. Porque é um processo. [...] Então isso é uma coisa que se ramifica. E vai se incorporando e assumindo formas, feições próprias, de acordo com os agentes sociais, as pessoas que estão inseridas nisso. Isso é interessante porque você não vai substituir uma mídia pela outra. Não é uma questão de substituir um padrão pelo outro. É no sentido de pulverizar mesmo, é plural. E cada um se apropria de uma forma.

Construímos, assim, uma atmosfera de respeito e amizade. A mesma que esperamos que as professoras possam construir com seus alunos. Não abdicamos do papel de orientadores do processo. Apenas não pretendemos controlá-lo, roubando a iniciativa das professoras. Organizamos dinâmicas de experimentação dos equipamentos de produção e exibição de imagem - câmera fotográfica, filmadora VHS ou digital, videocassete, DVD player e datashow. Tiramos as dúvidas sobre o seu funcionamento, desmistificando o que as educadoras costumam chamar de "parafernália". Enfatizamos também que não se trata só de apertar botões, mas de observar e compor a imagem, alterando a maneira como elas são produzidas: em vez de um olhar ingênuo ou disperso, um olhar que recorta o espaço e constrói um discurso sobre os acontecimentos que pretende narrar, a partir de um ponto de vista. Na orientação dos projetos, passo a passo, vamos introduzindo conceitos e técnicas relativas ao processo de concepção, produção e finalização de vídeo, tais como: elaboração de story-line, argumento, roteiro, story-board, roteiro decupado ou técnico, minutagem, roteiro de edição. Informamos, ainda, sobre a configuração de equipamentos e software necessários e suficientes para a criação audiovisual na escola ou em casa. As participantes percebem que, atualmente, não é preciso muito mais que um computador atualizado, com uma ou duas placas especiais, de baixo custo, para começar a realizar os próprios filmes, especialmente quando se utiliza o software livre, gratuito. O objetivo não é formá-las profissionais de comunicação, mas educadoras 
com referências suficientes para orientar um projeto de experimentação em audiovisual com seus alunos. Ao final do ano, a diferença é notada não apenas no número de professoras que tiraram suas câmeras do armário, adquiriram filmadoras e ampliaram o uso do computador, mas também na qualidade das imagens produzidas e na incorporação de elementos audiovisuais à prática pedagógica.

Há, ainda, espaço para levantarmos e discutirmos temas transversais, como diversidade étnica, violência, cultura popular, meio ambiente e as culturas urbanas jovens. A intenção é observar como esses tópicos são abordados pelos meios de comunicação e buscar pontos de vista diferenciados, que tornem mais complexa a visão das professoras sobre o assunto. Trazemos professores da Unicamp para apresentações, fotógrafos, rappers, militantes de movimentos de afirmação da identidade étnica e de organização cultural e comunitária. Exibimos suas produções audiovisuais e documentários, de modo de as educadoras percebam que, em diversos segmentos da sociedade, o vídeo já é uma forma de expressão cultural e manifestação política, e que sua produção não está mais restrita à esfera profissional dos grandes grupos de mídia - conseqüentemente, não há porquê a escola ignorá-lo.

A partir de nossa experiência e, principalmente, da pesquisa sobre o perfil sociocultural das professoras, por meio de questionário e grupo de discussão, realizados no início de cada ano, fomos levados a refletir que a incorporação de novas tecnologias e linguagens na escola é uma mudança que requer, antes de tudo, a mobilização e luta política das educadoras pela valorização de seu trabalho. O processo de formação continuada não pode pretender alcançar resultados positivos ignorando nem as determinações estruturais, nem as condições socioculturais das educadoras, muito menos se impor apesar delas. Isso porque não se trata apenas de fornecer-lhes habilidades técnicas, mas de acionar e potencializar sua proficiência comunicativa. A formação deve mobilizar vivências e experiências das professoras, estimular a experimentação de novas formas de organizar o conhecimento, fruir e produzir cultura. Como fazê-lo dentro de possibilidades restritas econômica e culturalmente?

É justamente em sala de aula que a pouca familiaridade das docentes com a tecnologia - não apenas no nível operatório, mas sobretudo lógico, estético, epistemológico, etc. - transforma-se em dificuldade para dialogar com os alunos nos termos que propõe Paulo Freire: "este encontro dos homens, mediatiza- 
dos pelo mundo, para pronunciá-lo". ${ }^{156}$ Frente a essa situação, nós orientadores temos que nos manter extremamente flexíveis, respeitando os diferentes ritmos de aprendizado das professoras e a diversidade na construção dos seus projetos. Não é fácil, mas é enriquecedor.

Os debates sobre a prática docente, promovidos ao longo do curso, têm sido muito importantes para revelar os desafios que a formação continuada deve encarar, se aceitamos como ponto de partida as duas dimensões da práxis: ação e reflexão. ${ }^{157} \mathrm{O}$ primeiro é a superação da dicotomia "nós-eles", educadoraeducando, que sobressai nas falas das professoras. A música deles, a apresentação deles, a gíria deles, o espaço deles, o que eles gostam, o que eles querem: a professora coloca-se quase sempre à parte, resguardando a posição hierárquica de quem deve realizar as escolhas pelos alunos, conduzindo o processo de aprendizagem. É a professora quem define o vídeo a ser exibido ("porque se você deixa..."), o tipo de música que deve ser ouvido ("senão todo mundo quer só escutar o mesmo"), e isso a coloca em confronto direto com o aluno ("da $5^{\mathrm{a}}$. à $8^{\mathrm{a}}$. série foi mais resistente, mas conseguiu”; "é uma discussão onde os professores às vezes cedem um pouquinho, a direção cede, mas é complicada"; "você faz um acordo com eles"). Contradição que uma participante do curso foi capaz de apontar, reconhecendo as implicações políticas dessa postura:

...eu acho que essa é a quebra, essa é a liberdade que os alunos têm, não só os alunos, como outros segmentos têm, de manifestar aquilo que eles querem, a forma que eles entendem de fazer a leitura de mundo, das coisas que são interessantes para eles, né. Com os adultos também acontece da mesma forma.

A ruptura de velhas concepções que pesam sobre o trabalho da professora - lado a lado com a construção de referências mais positivas - também deve ser explorada na formação: que ensino e prazer não se misturam, que o aprendizado deve estar marcado pela transmissão de um conteúdo, que o bom mestre mantém tudo sob controle (isto é, previsto em seu planejamento), que a sala de aula não é lugar para ex-

\footnotetext{
${ }^{156}$ FREIRE, Paulo. Pedagogia do oprimido, p. 78.

157 Os encontros iniciais de 2006 do curso Pedagogia da Imagem, onde as professoras expunham suas expectativas, hábitos de uso de tecnologias e linguagens mediáticas, dificuldades, experiências bem-sucedidas e suas práticas educativas em geral, foram gravados e posteriormente transcritos para análise. Trechos selecionados foram levados para a discussão do grupo, com o intuito de problematizar suas práticas. As citações empregadas nesta parte do texto referem-se a tais transcrições. O sigilo dos nomes das professoras foi resguardado.
} 
perimentação metodológica e quebra de rotinas. Concepções que podem revelar porque os media não são bem-vindos no espaço onde supostamente deve reinar a professora:

A gente costuma fazer uma programação e todo bom educador procura inclusive selecionar o tipo de filme que vai passar para as crianças. E eu acredito assim, que entre nós educadores, nós temos uma certa resistência com essas linguagens que chegam às vezes na sala de aula, porque parece que ela mexe um pouco com a nossa organização, com o nosso planejamento.

Concepções que também tornam a própria Pedagogia da Imagem um elemento perturbador no espaço da sala de aula:

Orestes: $\quad$ [...A ] Pedagogia da Imagem é um elemento perturbador no espaço escolar. Não só exibir filmes, não só pegar câmera, não só filmar, mas [...] o mais importante na Pedagogia da Imagem é o professor como protagonista, sujeito. E a dificuldade do professor é romper a hierarquia de domínio. Qual a visão que ele tem? Quando começa a Pedagogia da Imagem, "vamos fazer um vídeo aqui com os alunos"... até pra poder viabilizar [...], mudou da sala de aula. Mudou aquele tipo de saber. De repente, o aluno pega a câmera e ele tem mais facilidade de manusear que o professor. Já abala o professor. Depois vai estabelecer um diálogo diferente, em relação à tradição da relação professor-aluno. Então, é perturbador pro próprio professor. [...] Não é o domínio do processo. Ele é o agente, ele tem um papel, um papel importante, mas ele não tem o domínio do processo. Então, é interessante porque o professor, num primeiro momento, pode ser motivado pela Pedagogia da Imagem porque é uma novidade, uma coisa diferente. A gente percebeu muitas vezes os professores querem muito... como se fosse assim... aprender a Pedagogia da Imagem para poder dar aula melhor, do mesmo jeito que sempre deu, no sentido convencional. É como se fosse assim: do giz à câmera, é a mesma coisa. Só que do giz ele ainda pode ter o monopólio. Da câmera não dá. Aí não tem jeito. Por isso que é um elemento perturbador e a maior perturbação começa com o professor.

Outra questão que necessita ser encarada no processo da formação continuada são as dificuldades vividas no ambiente escolar: o isolamento do profissional, a descontinuidade de projetos e políticas, a baixa motivação e auto-estima da professora, os problemas estruturais da escola, a inadequação das condições de trabalho. Conhecedoras dos limites existentes nesse ambiente, as educadoras muitas vezes resistem à mudança por responsabilidade em relação ao aluno. Têm receio de criar elevadas expectativas e, ao final, não corresponderem a elas, seja porque a infraestrutura da escola é insuficiente, porque conflitos interpessoais tornam o trabalho desgastante ou porque ainda não conhecem todo o processo. Temos que lidar com essas ansiedades e medos, tranqüilizando e motivando as participantes. Nosso papel não é o de impor uma nova prática a todo custo. Precisamos desenvolver uma postura compreensiva, que nos habilite a ler os cenários escolares, detectar as possibilidades de ação, os pontos negociáveis e, sim, fazer o 
enfrentamento das resistências assertivamente, sem arrogância. Além disso, mais uma vez, ressaltamos, trata-se de despertar a professora para a importância de sua mobilização e luta política, no que diz respeito ao reconhecimento do trabalho docente. Os obstáculos não devem justificar a acomodação ou o conformismo; a resignação é uma morte cotidiana: “A liberdade, que é uma conquista, e não uma doação, exige uma permanente busca. [...] Na medida em que, para dominar, se esforçam por deter a ânsia de busca, a inquietação, o poder de criar, que caracterizam a vida, os opressores matam a vida."158

Há, ainda, que revelar e escapar às armadilhas no trabalho de formação. Por vezes, a professora tem a expectativa de encontrar, no curso, a fórmula mágica que a ajudará a superar as dificuldades, a habilidade técnica necessária para recuperar o controle perdido sobre os alunos, ou a possibilidade de ilustrar de maneira moderna os conteúdos de uma educação bancária (“...é para tornar a aula mais agradável, dinâmica. E o aluno mais interessado... Então precisamos descobrir novas coisas que chamem a atenção, que façam com que ele se interesse pelo conteúdo a ser apresentado...”). Os formadores devem manterse alertas para problematizar essas expectativas junto às educadoras.

Finalmente, é preciso auxiliar a professora a mapear e sistematizar os caminhos trilhados na direção da constituição da sala de aula como um espaço comunicativo mais democrático, que acolha a diversidade cultural e estimule os alunos. Percursos que são fáceis de se reconhecer, na alegria dos que participaram da caminhada:

[...] a produção deles foi além do que eu imaginava. Eles gostavam tanto de trabalhar. E alguns trouxeram até disquete com imagem [...] e outras músicas [...] alguns fizeram poesias. Então foi um trabalho assim muito diversificado, valeu a pena, foi muito gostoso.

Os alunos fizeram um rap sobre a água, foi muito bonito, muito bacana. Eles vestiram de maloqueiro, assim, com touca na cabeça, dançaram [...]

O encontro final de 2007, em forma de confraternização no MIS, onde as educadoras exibiram suas produções em vídeo, foi revelador. Após tanto minerar, tínhamos encontrado ouro. Ele reluzia nos olhos e sorrisos das professoras, que trouxeram alguns alunos, filhos e irmãos para sua avant-premiére. Era nítida

${ }^{158}$ FREIRE, Paulo. Pedagogia do oprimido, p. 47. 
sua satisfação ao apresentarem, empolgadas, extrovertidas, suas produções e seu processo de criação. Não nos restou dúvidas de que a experiência foi libertadora. Como disse Oswald de Andrade, "a alegria é a prova dos nove"159.

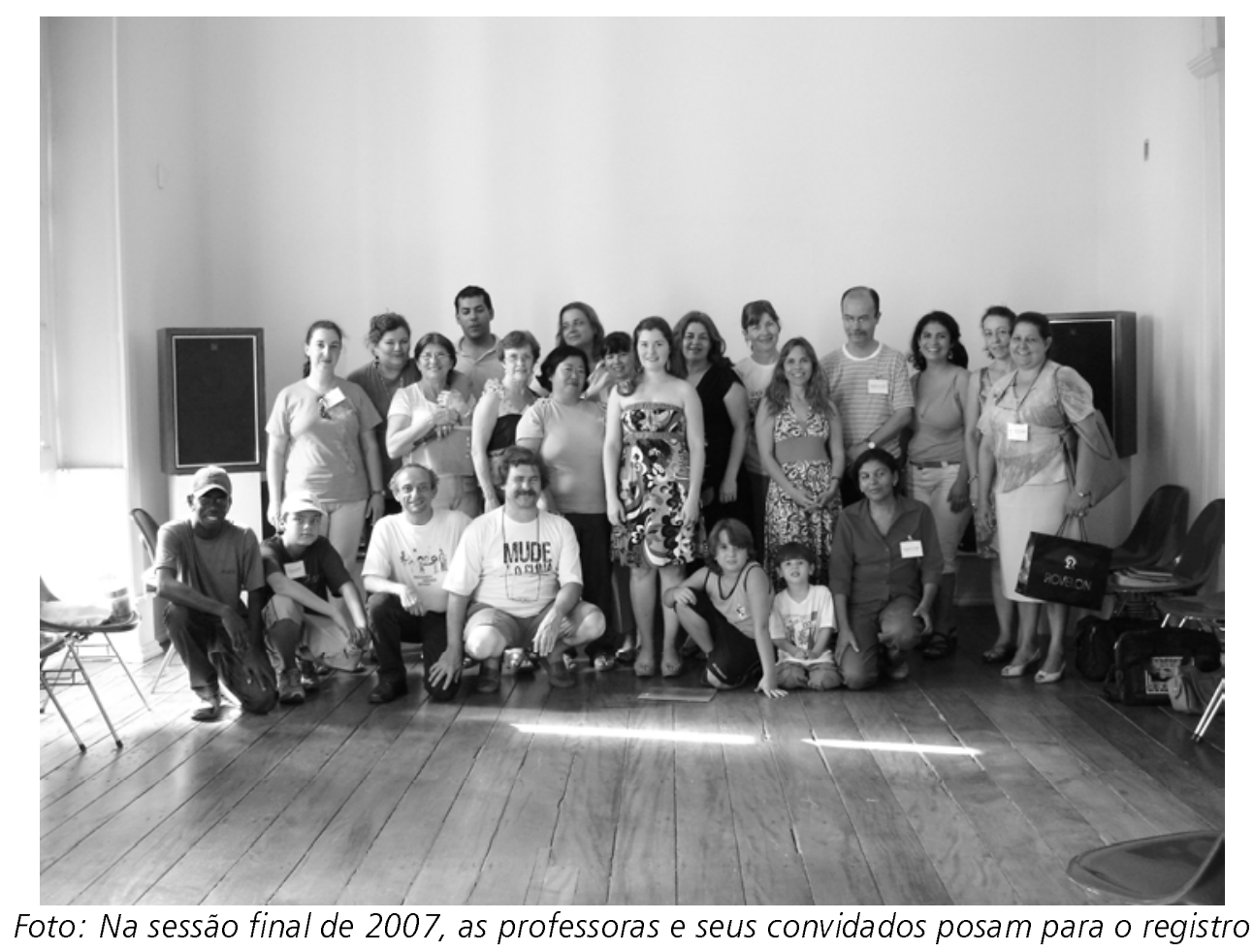

\subsection{Criações autorais, plurais: breve relato dos projetos desenvolvidos}

Em 2006 e 2007 foram realizados os seguintes projetos pelas educadoras participantes do curso:

\section{Em CEMEIs (creches):}

Anna Paula Silva, da CEMEI Corujinha (Jardim Ademar de Barros), trabalhou os registros das atividades ligadas ao Projeto Etnia, desenvolvido na escola, para apresentação no Seminário de Educação. O trabalho com as crianças procurou valorizar a arte e a criatividade dos povos africanos, resgatando a tradição da pintura em tecido. As crianças, com idades entre cinco e seis anos, fizeram panôs e desfilaram suas criações na escola. O vídeo produzido por Anna Paula documentou esse processo pedagógico e foi

\footnotetext{
${ }^{159}$ ANDRADE, Oswald. Manifesto Antropofágico. Revista Antropofágica. São Paulo, n. 1, ano 1, maio, 1928.
} 
posteriormente utilizado como mediação da discussão com pais, ao ser exibido em reunião específica. (2006)

Sônia Ferreira, da CEMEI Brasília Byngton Egídio Martins (Vila Padre Anchieta), filmou o dia-a-dia das crianças do Agrupamento 2 na creche. O material foi utilizado na reunião com os pais para discutir o desenvolvimento das crianças e seu aprendizado na escola. (2006)

Cláudia Ripari Chiachio, da Cemei Catharina Milani Manarini (Jardim Bandeiras II) também documentou, pela fotografia, as atividades realizadas pelas crianças durante o período escolar, com o objetivo de dialogar com os pais sobre o papel da escola. As fotos foram editadas em um clipe, "A criança na escola”, entregue a cada família, ao final do ano. (2007)

Em EMEIs (pré-escola):

Kelly Cristiane da Silva de Almeida, da EMEI Profa. Helena Novaes Rodrigues (Jardim Vista Alegre), filmou a rotina do Agrupamento III, para levar ao conhecimento da comunidade as atividades desenvolvidas com as crianças. (2006)

Da EMEI Recanto da Alegria (Parque São Quirino), as professoras Analice Gomes de Lima Dias e Tânia Cristina Costa participaram do curso em 2007, produzindo dois documentários: "Minha vida é assim na escola" e "Passagens", além da documentação fotográfica das atividades pedagógicas. Transformaram o espaço da escola, até então resistente à incorporação de recursos tecnológicos, com a introdução de computadores em algumas salas de aula e com o uso intensivo da câmera fotográfica digital. Em 2008, desenvolveram o Projeto Memória, com o objetivo de organizar a memória da escola e compartilhar com a comunidade conhecimentos sobre produção, organização e preservação de acervos de fotografia. Foi realizado um curso de fotografia digital para a comunidade, com a promoção de passeios fotográficos pelo bairro, resultando na discussão das transformações por que passou a região e em uma exposição fotográfica ao final do ano. 
Maria da Conceição dos Santos, professora da EMEI Padre Anchieta II (Vila Padre Anchieta II), elaborou seu projeto a partir da preocupação manifestada pelos pais enquanto as crianças estão na escola. Seu vídeo “Interação com maternal”, finalizado em 2007, teve como objetivo levar a família a refletir sobre as interações que os filhos exercitam na EMEI, sobretudo como elas reagem aos diversos estímulos e como se vêem nas imagens.

\section{Nas EMEFs (ensino fundamental):}

Ana Maria de Oliveira Tellaroli, da EMEF Dulce Bento Nascimento (bairro Guará, em Barão Geraldo), trabalhou o filme Kiriku e a feiticeira com seus alunos da 2a. série A. O trabalho também fazia parte do projeto "A cor da cultura", de valorização da identidade e diversidade étnica. Inspiradas pelo filme, as crianças criaram uma dança utilizando a semente do flamboyant como um instrumento musical. Toda a atividade foi gravada em vídeo pela professora, resultando num documentário (ano de 2006). Em 2008, a escola, já sensibilizada pelo trabalho desta e outras professoras, acolheu o programa Pedagogia da Imagem para o desenvolvimento de atividade de produção de vídeo, em grupos mistos de professoras e alunos. Estão sendo produzidos documentários sobre o meio ambiente do bairro Guará, sobre a história da escola e sobre o cotidiano do trabalho dos alunos da Educação de Jovens e Adultos (EJA).

Maria das Graças Gomes da Cruz, a Gracinha da EMEF Edson Luis Lima Souto (Vila San Martin), desenvolveu um projeto que valoriza os saberes populares, por meio da pesquisa sobre o uso das ervas medicinais. A participação das crianças da terceira série, pesquisando, trazendo de casa as plantas e explicando sua utilização terapêutica, foi filmada pela professora. O trabalho estava integrado ao projeto "A cor da cultura”, de valorização da diversidade étnica e da identidade dos afro-descendentes. (2006)

No ano seguinte, a mesma EMEF Edson Luis Lima Souto solicitou-nos uma programação de formação em Pedagogia da Imagem, durante os TDCs (horas de trabalho docente coletivo). Um grupo de 14 professoras, lideradas pela orientadora pedagógica Carla Feriani (que fizera o curso em 2005), com o apoio da direção da escola, iniciou atividade voltada para trabalhar os recursos e usos da comunicação no espaço escolar. Produziram vídeos de registro do trabalho pedagógico e de documentação da história e dos recursos do bairro, como áreas de lazer e serviços públicos disponíveis aos moradores, e sobre a 
realidade de ex-alunos da escola. Enfrentaram dificuldades para a edição das imagens, uma vez que a infra-estrutura de informática da escola era precária e não pôde ser atualizada por motivos que fugiram ao controle das participantes. (2007)

Walquíria Yara de Carvalho, da EMEF Correa de Mello (Parque Universitário Viracopos), freqüentou o curso do MIS em 2006 e trabalhou com os alunos de terceira e sétima séries a temática do folclore. Os alunos da sétima série fizeram a oficina de filmagem e foram os responsáveis pelas gravações das apresentações de teatro, dança e música da terceira série. Em 2007, ela consolidou o trabalho como um projeto da EMEF, orientou duas turmas de alunos da segunda fase do ensino fundamental $\left(5^{\text {as }}\right.$ e $6^{\text {as }}, 7^{\text {as }}$ e $8^{\text {as }}$ séries) com o objetivo de desenvolver o potencial comunicativo e crítico dos alunos. Criou uma metodologia de trabalho própria, onde os alunos se reúnem, discutem o que querem fazer e se organizam para planejar e executar as tarefas. Seus grupos, além de fazerem a documentação permanente do cotidiano da escola, em vídeo, (festas, atividades especiais, festivais, jogos estudantis, feiras, atividades culturais, passeios e estudos de meio), criaram um blog da escola, publicam um jornal que está em sua terceira edição e produzem documentários. Em 2008, o projeto foi ampliado e passou a incluir também a criação de desenhos animados (sobre o meio ambiente). Além de exibir e debater filmes com as crianças, Walquíria leva à escola profissionais da área de comunicação para conversar com os alunos e promove visitas técnicas a casas de cultura, faculdades, museus e estúdios.

A EMEF Domingos Zatti, localizada no Parque Fazendinha, abriu-se para a comunidade, realizando exibições e debates de filmes, às quartas-feiras, das 15 às 17h. (2006) No ano seguinte, a Orientadora Pedagógica Rosemary Pontes participou do curso no MIS e produziu um documentário sobre o cotidiano da EMEF ("Momentos Zatti"). Continuamos em contato com a escola, realizando atividades culturais, de maneira pontual.

Na EMEF Odila Maia Rocha Brito, no Jardim São Domingos, a professora Sandra Dias Pacheco e a exaluna Edilaine Freitas criaram um projeto na área de vídeo para estimular a participação dos moradores do bairro nas questões ligadas ao meio ambiente e ao lazer. Foram feitas exibições e debates de filmes e produção de um documentário sobre a região com a participação ativa de alunos. (2007) 
Heloísa Pala de Lima Antonialli, professora de Educação Artística da EMEF Benevenuto Torres (Jardim São José), filmou o processo de escolha de um mascote da escola, comemorativo dos 30 anos da instituição, e entrevistou o aluno da $5^{a}$ série, vencedor do concurso de desenhos. (2006)

Margarete Morgante e Hortêncio Pedro Antônio, da EMEF Oziel Alves Pereira (Parque Oziel), orientaram seus alunos na realização de pesquisas, entrevistas e gravações de atividades. As crianças registraram o trabalho de criação de um sistema alternativo de aquecimento solar, apresentado na Feira de Ciências. (2006) Em 2008, Hortêncio transferiu-se para a EMEF Pe. Leão Vallerie, onde a Pedagogia da Imagem desenvolve atividades de formação de professores e alunos em audiovisual.

Da EMEF Pe. Leão Vallerie. (Parque Valença), uma turma de três professoras e duas orientadoras pedagógicas fizeram o curso do MIS em 2007. Dentre os projetos resultantes, destacam-se: documentação das atividades pedagógicas na área de ciências, produção de documentários sobre a escola, seu entorno e meio ambiente, pelos próprios estudantes ("Água” e "Caminhos do Valença”); suporte a projetos como Orientação e Educação Sexual, Teatro, Teatro de Fantoches; projeto de educação patrimonial e adaptação de obras literárias em vídeo; formação de docentes para uso de equipamentos de audiovisual e aquisição de equipamentos para edição de imagens digitais no laboratório de informática da escola.

A Orientadora Pedagógica (OP) Elenir Castanho, da EMEF Edson Luís Chaves (Jardim Santa Rosa), participou do curso em 2007, produzindo um videoclipe motivacional para sua equipe e as colegas da região noroeste ("Enquanto houver sol"). Em 2008, levou o projeto para dentro da escola, com o suporte do MIS. Foram formados grupos mistos de professoras e alunos que cooperam para a produção de documentários sobre o cotidiano e a história da escola no bairro e a história de vida de ex-alunos e sua relação com a EMEF.

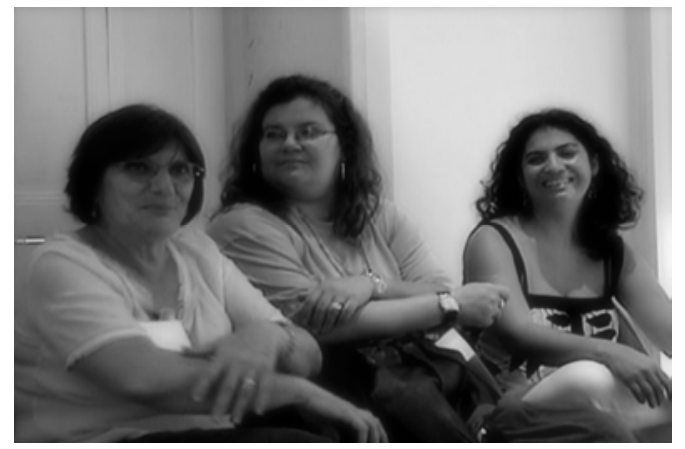

As orientadoras pedagógicas Elenir Castanho (EMEF Edson Luís Chaves), Sara Bueno (EMEF Pe. Leão Vallerie) e Maria de Lourdes Gomes da Silva (EMEF Pe. José Narciso Vieira Ehrenberg) participaram do curso em 2007 e levaram a Pedagogia da Imagem para suas escolas, em 2008. A foto foi tirada na sessão final de 2007. 
A OP Maria de Lourdes Gomes da Silva, da EMEF Pe.José Narciso Vieira Ehrenberg (Jardim São Marcos), participou do curso no MIS em 2007. Produziu um documentário sobre o cotidiano escolar ("Escola: lugar de histórias e aprendizagens") e atuou como multiplicadora junto às professoras, o que resultou na produção de um vídeo didático sobre a teoria de Charles Darwin. Em 2008, formou um grupo misto de professoras e alunos para formação em produção audiovisual na escola. Está sendo produzido um docu-drama sobre o bairro São Marcos, sua história, os grupos culturais e os recursos existentes para inclusão social.

Neide Moredo Molan, da EMEF Francisco Ponzio Sobrinho (bairro Santa Odila), produziu com as crianças da quarta-série um vídeo didático sobre "As regiões do Brasil”. As crianças ficaram responsáveis pela pesquisa das informações e imagens, enquanto a professora responsabilizou-se pelo roteiro e edição do material. Além das informações didáticas, ao final do vídeo aparecem diversas fotografias que documentam o trabalho de pesquisa realizado pelos alunos. (2007)

Rosânia de Fátima Tavares, professora de terceira série na EMEF Virgínia Mendes Vasconcellos (Jardim Maria Rosa), além de exibir e debater filmes sobre temáticas específicas com seus alunos, produziu um vídeo que relata afetivamente os acontecimentos marcantes do ano de 2007 para a sua turma. "Lembranças", roteirizado e editado pela

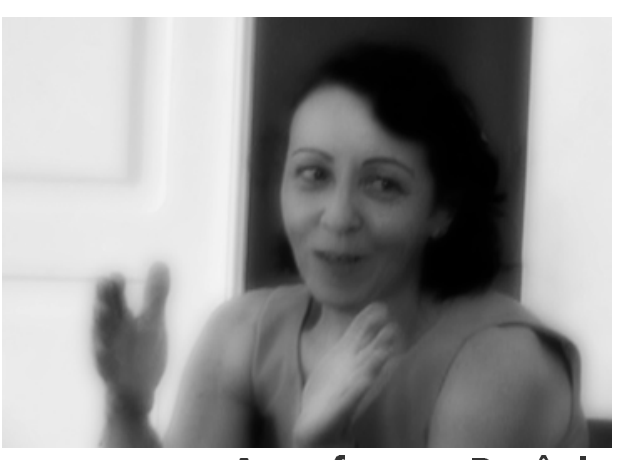

A professora Rosânia professora, traz produções das crianças, como fotografias, desenhos e pequenos poemas.

Finalmente, o professor de história Alberto Eugênio Nasiasene, da EMEF Raul Pilla (Jardim Flamboyant), foi um dos participantes mais entusiasmados com a descoberta do audiovisual. Produziu dezenas de pequenos clipes e documentários para servirem de material de apoio didático às suas aulas ("Grito dos Excluídos", "Mercado de Escravos", "Tráfico Atlântico de Escravos”, "Vladimir Carvalho e sua obra”, entre outros). Além disso, documentou o início do ano letivo, os projetos existentes na escola, como "Fanfarra" e "Comunidade em Ação", eventos como o campeonato de futebol do EJA, o desfile da escola no 7 de Setembro, na Av. Francisco Glicério, a festa junina e a formatura de seus alunos. Em 2008 conti- 


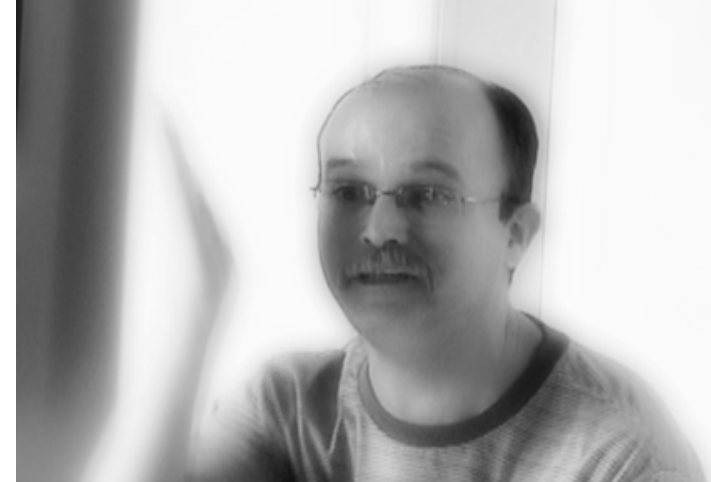

Alberto Nasiasene

nua sua produção, envolvendo os alunos na criação de vídeos e fotografias que documentam seu cotidiano. (2007)

Como se pode notar, os projetos são os mais variados, não seguindo um formato único ou qualquer outro padrão. Cada um tem a marca da subjetividade de suas criadoras, bem como das possibilidades concretas determinadas pelo contexto escolar. Não é possível classificá-los apenas pelo exame das temáticas ou sua breve descrição. Os sentidos e as dimensões que adquirem nas comunidades onde foram gestados só podem ser compreendidos a partir de um estudo de recepção, feito com base em exibições e debates com a participação de educadoras, alunos, familiares, gestores e funcionários da escola. Sem dúvida, merecem uma investigação aprofundada, pelo que condensam a respeito de como esses sujeitos vêem a si mesmos, à escola e à comunidade. Não é esse o meu objetivo agora; quero apenas ressaltar a riqueza latente nesse campo. Por isso, limito-me a apresentar algumas dessas produções numa coletânea em DVD, anexada à dissertação.

\section{0 contexto institucional}

O elemento subjetivo, embora determinante na configuração das práticas e dos princípios da Pedagogia da Imagem, por si só não seria suficiente para fazer surgir, concretamente, o projeto. $\mathrm{O}$ fator detonador da sua implementação se encontra no contexto institucional, na dialética entre a contingência política que permitiu a emergência da proposta e a estratégia por meio da qual nossa equipe vai cavando os espaços para atuação.

Em 2003, um grupo de agentes e assessores da Coordenadoria de Ação Cultural (CAC) provoca uma discussão sobre as diretrizes da ação descentralizada na cidade. Até aquele momento, os agentes culturais eram lotados em regiões específicas e trabalhavam, de maneira isolada, em projetos de natureza diferenciada. A realização de um festival de teatro de bonecos introduziu, naquele cenário, uma perspectiva 
diferente: a possibilidade de projetos transversais (que abarcassem todas as regiões da cidade) darem suporte e diversificarem o leque de opções para os agentes descentralizados.

A coordenadoria propôs, então, aos agentes, que elaborassem programas, de natureza permanente, aplicáveis a todas as regiões da cidade. Dentre os vários recortes indicados, o programa de multimeios coube à agente Isabel Pagano, por sua atuação na área de fotografia.

Isabel desenvolveu o Programa CLIC - Cultura, Lazer, Informação e Cidadania, que abrangia projetos como realização de oficinas de fotografia e vídeo, exibição e debate de filmes, incentivo a produções de cinema, entre outras atividades. Em linhas gerais, tinha inspiração nos princípios da Media Litteracy (alfabetização para a mídia) norte-americana. Para o planejamento das ações, ela tinha feito um levantamento de setores da Secretaria de Cultura capazes de oferecer apoio ao programa e, assim, entrou em contato com Orestes, no Museu da Imagem e do Som. Orestes contou-lhe as experiências anteriores em produção de vídeo e Pedagogia da Imagem. Na época, esses projetos estavam paralisados pelo fato de a equipe que o auxiliava ter-se dispersado por outros departamentos.

Atraída pelo tema, ofereço-me para colaborar com Isabel na implementação do programa. Ela me apresenta Orestes e, ao inteirar-me das propostas da Pedagogia da Imagem, me entusiasmo. Estávamos decididos a iniciar uma ação. Conversamos com o Batata, então coordenador da CAC. Também ele se interessou e, logo que se desvencilhou do cargo de chefia, passou a integrar o grupo. O segundo semestre do ano já se iniciava.

Em equipe, optamos por realizar uma atividade com agentes multiplicadores - de preferência, professoras das escolas públicas. Seria uma maneira de ampliar rapidamente o alcance do projeto. Ponderamos que era necessário reunir um grupo de docentes interessadas e levantar seus objetivos e suas expectativas, a fim de construir a proposta conjuntamente. Decidimos, então, contactar o setor da Secretaria Municipal de Educação responsável pela realização de cursos para as professoras, o Ceforma. Uma falha na comunicação fez com que se divulgasse às professoras que estava sendo aberto um Grupo de Trabalho (modalidade de atividade de formação em que as professoras têm as horas remuneradas, mas não rece- 
bem certificado por participação). Assim, no dia marcado, fomos surpreendidos com a presença de mais de 50 professoras, ávidas por iniciar um curso.

Não podíamos perder a oportunidade de reunir tantas interessadas. Levantamos suas expectativas e rapidamente nos organizamos, montando um programa de curso. Para objetivar-se, o projeto teve de se adequar às determinações do Ceforma. Percebemos que isso era fundamental, pois o reconhecimento oficial da atividade de formação é um fator decisivo para muitas professoras participarem da atividade. A duração do curso era semestral e o foco inicial estava na leitura crítica da mídia.

No início de 2004, a Secretaria Municipal de Assistência Social nos convoca para levar adiante uma missão quase impossível: em cerca de dois meses, deveríamos capacitar as monitoras dos núcleos espalhados pela periferia de Campinas na produção de fotografias. Estas, por sua vez, seriam multiplicadoras junto aos adolescentes atendidos. $\mathrm{O}$ objetivo era que os meninos e meninas produzissem um álbum com 230 fotos, comemorativo do aniversário da cidade. As 50 melhores fotos seriam ampliadas em grande formato e comporiam uma exposição no Centro de Convivência Cultural, cuja abertura, no dia 14 de julho, contaria com a presença da Prefeita. Contra todas as adversidades (tempo escasso, equipamento precário, falta de experiência das monitoras e crianças no trato com a fotografia e sua linguagem), o projeto foi um sucesso, em todos os sentidos.

O resultado alcançado nos entusiasmou a todos e percebemos que uma metodologia semelhante poderia ser empregada com as professoras. Nessa época, Isabel Pagano tinha assumido a diretoria do Museu de Arte Contemporânea e deixara o grupo. No segundo semestre, procuramos estimular o desenvolvimento de projetos nas escolas, mas o período de seis meses para muitas docentes não era suficiente para o planejamento e a aplicação prática. Decidimos que, no ano seguinte, o curso teria duração anual.

Em 2005, os primeiros projetos práticos são implementados pelas professoras. No segundo semestre, vasculhando a Internet, entro em contato com a linha de pesquisa Educomunicação, da ECA-USP. Começo a freqüentar a pós-graduação, como aluna especial. Compartilho com os colegas as leituras e discussões de aula, trazendo importantes contribuições para o aperfeiçoamento do programa que, no 
ano seguinte, adquire as feições já descritas. A influência do pensamento educomunicativo na transformação de nossa abordagem teórica e na metodologia de trabalho é reconhecida por todos os coordenadores.

Orestes: $\quad$ Agora, na minha opinião, se a vinda de vocês dois foi um salto, eu acho que dentro desse salto teve um salto ainda maior. Pelo menos, na minha visão, eu acho que foi... Eu senti uma mudança - e diria até de radicalidade política - a partir do momento em que a Juliana foi lá em São Paulo, a Educomunicação, e colocou a Pedagogia da Imagem com Paulo Freire. E aí avançou: o professor ser o sujeito. E também abriu pra fase atual, que é os alunos serem sujeitos. E é isso que justifica a intervenção pontual, no espaço escolar. Pelo menos pra mim, ficou muito mais claro qual é o nosso papel nesse processo. Porque eu estava mais preso à questão da imagem. E mais desplugado, não fazendo a conexão com a Pedagogia. Porque a gente pensa mais a imagem, eu sou mais ligado à imagem, mas não acho que [baste] como método de trabalho, como concepção filosófica, política do trabalho. Agora eu acho que a Pedagogia realmente vem antes da imagem. É a questão central, e até os nossos seminários de estudos têm sempre uma ligação com a Pedagogia...

Juliana: Que tipo de educação se faz com a imagem.

Orestes: Isto. Exatamente. Acho que há até a necessidade de radicalizar ainda mais do ponto de vista da discussão teórica da pedagogia.

A influência da Educomunicação sobre nossa forma de trabalhar não é apenas teórica ou intelectual. Ela modificou profundamente minha visão de mundo e se expressa também em atitudes. Tornamo-nos vigilantes em relação às nossas ansiedades, para que as professoras tenham garantida sua palavra, o tempoespaço em que podem se pronunciar livremente, e para que a relação de formação não seja marcada pela prevalência de nossas vozes e mundivisões.

Orestes: $\quad$ Eu acredito que essa mudança está relacionada ao amadurecimento do conceito de pedagogia, à Educomunicação, ao Paulo Freire. [...] Eu senti uma mudança em nós mesmos. Na nossa maneira de se relacionar com os professores. E da equipe aqui eu acho que eu sou o que tem mais dificuldade de se enquadrar nesse esquema, porque isso pressupõe você não ser afoito em expor seu ponto de vista. Eu normalmente exponho o meu ponto de vista antes de fazer qualquer coisa. E o ideal é fazer as coisas e não fazer com que seu ponto de vista fique exposto, até chegar o momento em que você deixa claro. Então, por isso, há a necessidade de aprofundar. [...] [grifo meu]

Essa guinada que exercemos sobre a Pedagogia da Imagem refletiu-se na adoção de um modelo clínico de formação, no acompanhamento dos projetos realizados no espaço escolar.

Juliana: $\quad$ A formação não é o que acontece aqui. Formação, eu vejo hoje, é, por exemplo, o que a Walquíria está tentando fazer lá, é o esforço dela de criar alguma coisa diferente na escola, de romper 
padrões até dentro do próprio pensamento do aluno também. Pra mim, mudou muito depois que eu fui estudar e ver uma outra perspectiva crítica, porque antes eu ficava completamente frustrada.,[...] porque eu achava que o espaço da formação era aqui. Quando eu vi que a questão não era [...] quanto que a gente capacita o professor, não: é o quanto o professor cria. Aí a gente vai na escola e começa a ver as coisas acontecerem, funcionarem. Vê também os embates com a estrutura, com essas mentalidades fechadas. [...] O salto é essa mudança de ponto de vista, é a mudança de paradigma. [...] Do informacional para o comunicacional. [...] Foi uma questão de metodologia também, porque a metodologia tem que se adequar ao paradigma a que você se vincula. [...] E uma contribuição importante que essa minha saída pra USP [provocou...] foi olhar para o curso de uma maneira diferente mesmo. Da gente estruturar. No início eu realmente tava muito perdida [...]. A gente tentava fazer uma abordagem da comunicação pelo lado teórico e acho que a gente não conseguia ainda dialogar com a realidade do professor. Então fazer a leitura de Paulo Freire, de outros da Educomunicação, de outros livros também, apontou pra entender o quê que é a formação, a realidade do professor, da escola.

Embora estruturada teórica e metodologicamente, permanentemente avaliada, consolidada, com repercussões nas escolas e mantendo continuidade e regularidade, a Pedagogia da Imagem não se tornou uma política pública.

Juliana: [...] Não é uma política pública mas é uma ação que tem características de. Porque ela é de longo prazo, ela é planejada, tem avaliação constante, a gente está sempre melhorando... Então não vamos hoje fazer tal coisa e amanhã a gente vai fazer outra coisa. Não: é um trabalho que vem sendo construído. E que tem um futuro. [...] E aí que eu falo que é um ponto fraco nosso, mas também é um ponto forte, porque não ser uma política pública nos possibilita essa liberdade de criar e possibilita também ao professor... De repente ele vem aqui não porque ele está sendo obrigado, descrente e tudo mais. Mas ele vem por vontade própria mesmo. Então mesmo que ele chegue aqui simplesmente para arejar, aqui ele descobre uma outra possibilidade de trabalho.

Nem a Secretaria de Cultura, nem a Secretaria de Educação assumiram o programa oficialmente, responsabilizando-se pela sua viabilização, garantindo recursos para sua efetivação nas escolas. Pela sua proposta libertária, isso pode ser compreendido.

Orestes: $\quad[. .$.$] Eu acho que [o modo como a Pedagogia da Imagem se ramifica] demonstra que$ isso é uma luta [...]. E também está ligado à maneira como se coloca a Pedagogia da Imagem, não só do ponto de vista de não ser institucionalizada de cima pra baixo como política pública - porque aí é instrumentalizado para outros fins -, como também pelo fato de ser libertária, nessa fundamentação do Paulo Freire: nem dar receita pronta e nem nos colocarmos como messias, salvadores... não!

Nossa relativa liberdade de ação traz, a contrapeso, dificuldades operacionais. A falta de recursos talvez seja o obstáculo mais simples a ser vencido. 
Juliana: Vocês falaram que a Pedagogia da Imagem não é uma política pública. Não é, e por isso a gente enfrenta bastante dificuldade. Eu acho que a gente conseguiu sobreviver até hoje com muito trabalho, é evidente, mas com uma boa pitada de sorte, e também graças ao fato de a gente ter sido completamente ignorado.

Orestes: $\quad$ Mas eu acho que uma coisa importante a registrar é que dentro da máquina estatal a açãoésempre na corda bamba.

Juliana: $\quad$ Agindo entre as brechas...

Orestes: $\quad$ Vive sempre sob ameaça de descontinuidade. Não é fácil.

Juliana: $\quad$ Você nunca sabe o que vão determinar para você amanhã.

Orestes: $\quad$ Eu acho que esse grau de incerteza é bom ter clareza sobre ele para tentar antecipar-se aos fatos.

Batata: $\quad$ Então, mas a gente fez isso. Sempre. [...] De certa maneira, a gente foi costurando sempre de fora pra dentro o projeto.

Juliana: $\quad$ Para ganhar legitimidade junto ao público, para se tornar um projeto tão maior...

Batata: $\quad$ E aí assim... [...] Por que nós não fomos mexidos no atual jogo? Do jeito que está a coisa? Mal-parada? Por que não mexeram na gente?

Juliana: É, eu não sei. Eu até agora não sei. Eu tenho pesadelos toda noite com a possibilidade de amanhã eles me tirarem do projeto.

Orestes: $\quad$ A gente convive com essa ameaça, me sinto assim, como se fala, com a espada o tempo todo, eu não me sinto tranqüilo. [...] E [...] eu tenho que fazer um esforço pessoal muito grande para não ser dominado pelo desespero. Que jogo triste! [...] É uma engrenagem que tritura muito, é preciso ter uma resistência, eu diria, pessoal, política... É difícil de ter. [...] Eu acho que aí acrescenta-se uma outra contribuição que é ter essa visão política, isso que você fala agora, que você sempre tem dito, pelo menos para mim serve como antídoto ao desespero. Porque as suas articulações [refere-se ao Batata] são concretas, acho que a Pedagogia depende, eu acho que é importante saber disso, infelizmente, eu acho, depende das articulações.

Ao longo desse período, o escasso apoio institucional, a carência de recursos e a precariedade das condições técnicas do Museu da Imagem e do Som trouxeram dificuldades, mas não impediram a continuidade do trabalho. Diante dos obstáculos, nossa reação não tem sido o desânimo, mas a agilidade na busca de alternativas.

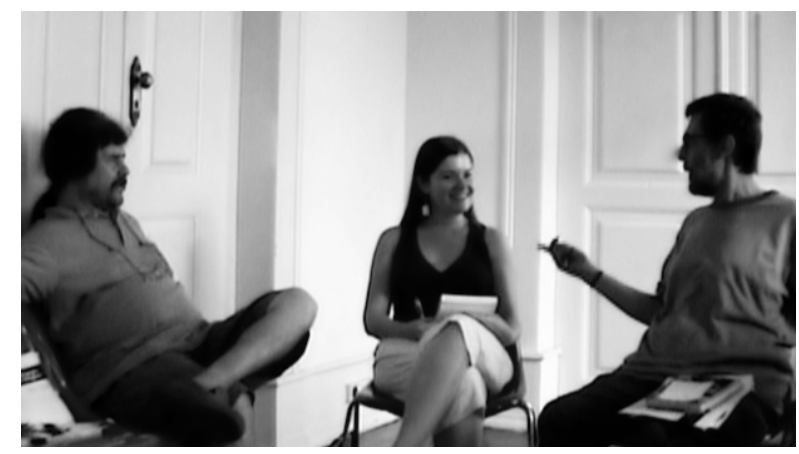

Frente aos obstáculos, nossa atitude é de resistência

Um exemplo é o problema da edição de vídeo. A ilha de edição do MIS, nossa primeira opção, esteve fora de funcionamento por mais de dois anos. Cientes da prioridade da edição para o aprendizado do vídeo e percebendo que o problema não tinha sensibilizado a administração, fomos ao mercado e descobrimos que, atualmente, a um custo relativamente baixo, é possível montar uma ilha de edição básica. 
Verificamos que essas configurações eram suficientes para o aprendizado e a prática nas escolas. Chegamos a sugerir a atualização de um dos computadores do laboratório de informática e descobrimos que essa decisão não pode ser tomada pela direção. Os laboratórios só podem ser modificados pelo Núcleo Técnico Educacional (NTE), com aprovação do Departamento Pedagógico (DEPE). Fomos, então, negociar com essas instâncias. Apresentamos nosso projeto, argumentamos sobre a importância de as escolas editarem o próprio material e, modestamente, expusemos a necessidade de atualizar ou adquirir um computador, apenas nas escolas que já participam do projeto, para que pudesse ser usado como ilha de edição pelos alunos. Dissemos da possibilidade de se utilizar o software livre e da disponibilidade da equipe da Casa de Cultura Tainã (com quem também negociáramos) realizar o treinamento de professores e alunos para uso do programa gratuito de edição de vídeo.

No final de 2007, conseguimos que se reunissem as equipes do NTE e da Casa Tainã. O choque cultural foi visível. De um lado, os jovens, com seus colares de contas e dreads no cabelo, acenando com a possibilidade de que os estudantes desmistificassem a "caixa preta" da CPU. Diziam que, para aprender informática, é preciso que se perca o medo do equipamento, aprendendo a montar e desmontar o computador, a programar, a consertar o que está estragado e, eventualmente, fazer a "meta-reciclagem" do que não funciona mais, montando equipamentos com partes daqueles que estão danificados. "Isso é uma solução”, dissemos. "Há escolas em que os laboratórios estão parados por falta de mouse ou porque alguma coisa foi apenas desconfigurada." Do outro lado, porém, estavam as educadoras, bem intencionadas e cheias de boa-vontade, é certo, mas principalmente preocupadas com a falta de controle sobre os laboratórios, a que tal atitude levaria. Houve disposição para discutir o tipo de software que poderia ser incluído numa futura distribuição às escolas. Não foi surpresa quando, tempos depois, soubemos que o convênio com a Casa Tainã não decolara. Junto ao DEPE, ainda procuramos negociar a aquisição dos equipamentos para o laboratório de informática. A atualização do conjunto - fomos informados só está prevista para depois de 2009 e a aquisição imediata de um computador ficaria inviabilizada, uma vez que os fornecedores costumam elevar seus preços para compensar a demora no pagamento feito pela Prefeitura! Em síntese: as instâncias superiores da SME nada poderiam fazer, pelo menos, por enquanto. 
Atualmente, temos recomendado às professoras e às diretorias das escolas interessadas em realizar o trabalho de vídeo que façam a adaptação de um dos equipamentos existentes na escola ou adquiram um computador específico para essa finalidade, a ser disponibilizado no laboratório de informática para professoras e alunos. A solução proposta é viável, uma vez que as escolas hoje possuem uma verba disponível e autonomia para decidir o destino de pequenos investimentos como este.

Outro exemplo, bastante significativo, foi a transformação da política de remuneração das professoras municipais, a partir da vigência de um novo plano de cargos, carreiras e salários. Já mencionei anteriormente como isso afetou a formação continuada. O que ainda cabe dizer, aqui, é que, em 2008, inviabilizada a oferta do curso Pedagogia da Imagem por meio do Ceforma, articulamos a realização de turmas diretamente nas escolas, com participação de alunos e educadoras.

Assim, posso dizer que a nossa capacidade de responder às contingências impostas pela estrutura institucional (tanto positivas quanto negativas) e as estratégias por meio das quais encontramos brechas no sistema têm permitido ao projeto manter-se vivo e a cada ano mais consistente.

\section{Práticas de legitimação}

Para a consolidação da Pedagogia da Imagem, tão importante quanto encontrar brechas no sistema é promover ações de legitimação do programa. Isso está diretamente ligado à qualidade das atividades propostas e, na mesma proporção, à capacidade de dar-lhe visibilidade e conquistar apoio social. A divulgação do projeto acontece por nossa iniciativa, visitando periodicamente os NAEDs (Núcleo de Ação Educativa Descentralizada) e escolas, e pela própria rede informal de participantes. São inúmeras as ocasiões em que, numa reunião com educadoras, surge um comentário positivo sobre o projeto.

Batata: $\quad$ Eu tenho um exemplo disso que a Juliana estava falando, desse disseminar... Na reunião de quarta-feira, que foi no NAED, [...] tinha uma reunião na entrada da NAED, de professoras. [...]E aí, na hora que eu estava entrando, uma professora que era da Edson Souto estava contando: "vocês não 
sabem o que vai acontecer na nossa escola! O pessoal do MIS vai levar pra lá o Pedagogia da Imagem e nós vamos fazer um negócio assim, assado..." E eu não conhecia aquela professora. [...] O assunto estava pautado numa mesa com umas sete, oito pessoas. Cada uma me pareceu que eram de várias escolas ali presentes, da região Norte. E então, a Rose do Zatti me falou que, na reunião dos Orientadores Pedagógicos, a Carla levou a nossa proposta e ficou todo mundo também querendo desenvolver algo parecido. Quer dizer, isso vira [...] um processo de divulgação. Não é por acaso que nós tivemos 105 inscrições no ano passado. [...] Então, entrando pra história da legitimação do projeto, essa colocação na rede, na base da rede, direto com os professores, direto com as escolas...

Juliana: $\quad$ Construindo participativamente...

Batata: $\quad$...cria uma ressonância pro projeto que...

Juliana: Que ele não tem esse viés. [faz um gesto com a mão: de cima pra baixo]

Orestes: $\quad$ Eu tenho um exemplo disso. Eu tenho uma ex-aluna, que estudou lá na EMEF Odila Maia, e a Sandra, professora de educação artística, que fez o curso aqui há uns dois anos. Agora está fazendo o projeto lá na escola, junto com essa aluna minha. [...] Eu acho que esse sentido da ramificação [demonstra...] que isso não é fantasia nossa, existe de fato, é concreto, uma demanda [...]

A continuidade das ações, num cenário onde a instabilidade e a impermanência de propostas são a norma, é um diferencial para que a Pedagogia da Imagem se torne uma referência para as professoras. Mais importante do que ter respostas definitivas (o que não há) é constituir um espaço aberto ao questionamento e reflexividade sobre a prática.

Orestes: $\quad$ Tem essa questão do educador ter um espaço de discussão e reflexão sobre a própria imagem, porque se ele não discute isso, como é que ele vai discutir com o aluno, se ele próprio, entre eles, não discutem? Depois, isso leva a uma mudança na utilização da imagem no espaço escolar, em termos de exibição de filmes, e o passo seguinte é a produção. Agora, não sendo uma política pública, fica amarrado a uma estrutura burocrática, administrativa, que não existe pra viabilizar essa discussão. Aí é a descontinuidade, o professor vem e não continua.

Fator imprescindível para a organicidade entre formação e aplicação em sala de aula é que se consolidem as atividades nas escolas.

Orestes: $\quad[. .$.$] Do ano passado para esse ano foi dado um outro salto fantástico, que é essa inter-$ venção pontual na escola. É uma maneira de enfrentar o que o Batata falou, dos entraves burocráticos, da descontinuidade. De certa forma, a Pedagogia da Imagem aqui deve continuar existindo, o professor vê lá: "Pedagogia da Imagem, quero fazer". Chega aqui, assiste filmes, começa a fazer análise dos filmes, tem debates, tem discussão, tem texto para ler, seminários, tal... Trazem outras pessoas, sempre discutindo a construção do discurso, desconstruindo, construindo o discurso. Eu acho que isso funciona como uma espécie de porta de entrada, [...] uma oportunidade para que todos tenham acesso a isso, possam pensar sobre isso. Agora, desses todos que aqui comparecem é nosso papel fazer o que foi feito no ano passado: identificar aqueles que vão para a prática. Não é só [...] vir aqui, aprender algumas coisas, [...] mas quem vem aqui também começa a perceber a necessidade do passo seguinte. E o passo seguinte é 
múltiplo, essa intervenção pontual na escola e a produção, [...] que possa até percorrer outras escolas e servir de estímulo para que mais escolas se envolvam. Mas esse é um outro passo que eu acho que é difícil fazer sem ter o anterior. Agora eu acho que, depois, a realidade vai impor novos passos. O importante é perceber o avanço. [...] Não pode ser descontínuo. [...] Tem que ir. E a produção no espaço escolar, com professores que já freqüentaram a Pedagogia da Imagem no museu e [...] nessa visão transformadora no espaço escolar.

A atividade na escola também mobiliza as comunidades em que se inserem. Nesse sentido, os relatos das professoras são animadores. Elas confirmam que o uso do audiovisual promove a aproximação e transforma a relação entre a escola e sua comunidade. Nas reuniões de pais, por exemplo, o uso da fotografia e do vídeo tem contribuído para aumentar seu interesse e sua participação ${ }^{160}$ :

$\mathrm{Eu}$ acho que aumenta até a freqüência dos pais, na assembléia de pais. Porque aquelas reuniões que normalmente são só comentadas, ou só verbalizadas, ou mesmo para comentar o pedagógico, ou para falar sobre o trabalho, eles acham cansativo, eles começam a olhar no relógio, sabe. Então eu acho que quando você apresenta algo que seja mesmo visual, chama muito mais a atenção e a freqüência acaba ficando maior mesmo. Porque aí entendem.

O depoimento da professora chama a atenção para a necessidade de se criar uma linguagem comum entre a escola e sua comunidade, processo no qual o audiovisual pode colaborar:

Você acaba introduzindo algumas palavras pra comunidade (...). Às vezes você fala "estudo do meio", você fala "passeio". Ah! Passeio é passeio. Passeio não é igual a estudo do meio. Mas se você vai apresentar fotos, ou um vídeo, vai mostrando as fotos e fala "estudo do meio", vai criando a noção.

A criação de vínculos mais profundos com a comunidade, pelo simples fato do audiovisual permitir seu auto-reconhecimento, é outra contribuição valiosa dos projetos:

Eu sempre trabalho numa comunidade onde tem uma baixa auto-estima, né, e quando a escola e a comunidade se vê, ela tem uma coisa assim, como uma atenção. Você vê a filmagem do seu filho lá, brincando, fazendo aquele filme, você vê o resultado da produção final fotografado, você joga no data-show, aumenta a auto-estima dela. Você acaba criando o vínculo com o bairro, levando isso à comunidade escolar. É: a escola é boa, então por conseguinte, né, a comunidade também faz parte dessa escola. Então eu acho muito importante o registro audiovisual pra auto-estima do aluno, da comunidade, de uma forma muito positiva.

\footnotetext{
160 Os depoimentos apresentados nesta parte foram gravados na sessão de sistematização das práticas, no dia 7 de novembro de 2006.
} 
Um outro lugar de legitimação é a permanente sistematização das práticas, gerando uma produção teórica própria, e permitindo a ampla divulgação dos achados do grupo. Isso nos insere em uma rede de agentes educomunicadores, que buscam alternativas para a democratização da comunicação social.

Juliana: $\quad$...A importância da gente não ficar no isolamento. Tanto a gente pesquisar, sair para arejar, para tentar ver aqueles problemas de uma maneira nova, procurar outros pontos de vista e [...] estudar e trazer livros, mas também a gente expor nosso trabalho nos congressos, nos seminários.

Tendo esse objetivo em vista, iniciamos, em 2005, o trabalho de "extroversão" do projeto, apresentandoo no Encontro de Educadores promovido pela APEOESP de Campinas. Em 2006, a Pedagogia da Imagem foi apresentada no Seminário Regional de Mídia e Educação, realizado em Americana, e na Semana de Educação da Faculdade de Educação da USP. Em 2007, estivemos no VI Simpósio do Laboratório de Gestão Educacional da Faculdade de Educação da Unicamp e no $16^{\circ}$ Congresso de Leitura do Brasil, promovido pela Associação de Leitura do Brasil e FE-Unicamp. Esses momentos de exposição do trabalho são valiosos, sobretudo, pela avaliação crítica por agentes externos qualificados, pela troca de experiências com grupos que realizam trabalhos semelhantes e pelo estabelecimento de uma rede de colaborações. O diálogo permanente eleva a qualidade de nossa proposta e nos dá mais segurança para atuar internamente, na Secretaria de Cultura. Os resultados práticos obtidos e o capital teórico acumulado nos fortalecem nos embates com a instituição, fornecendo a munição necessária para a defesa do projeto em situações críticas.

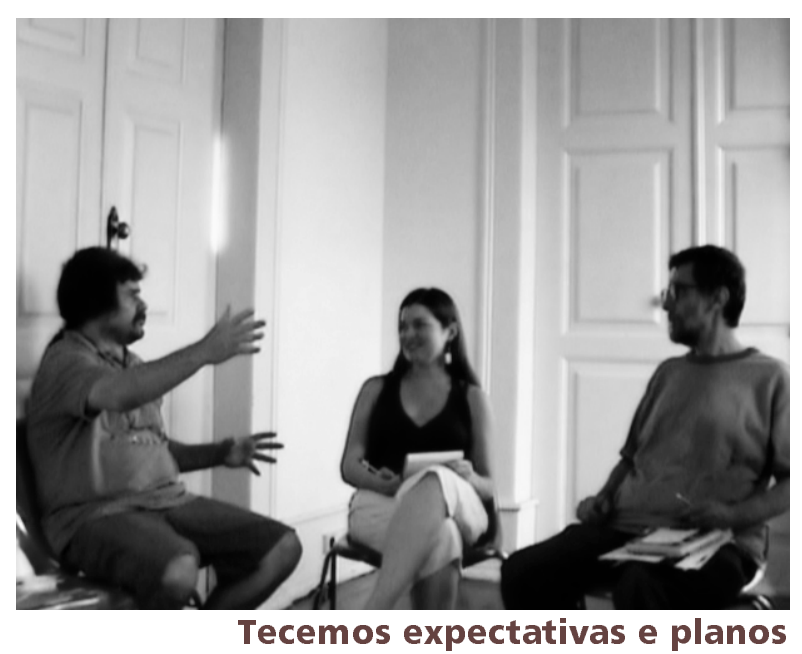

Batata: $\quad[. .$.$] Tem esse lance do nosso compromisso com a rede e da gente fazer [a articula-$ ção...] horizontal, tem o lance de costurar dentro da máquina e tem esse lance do respaldo intelectual. $[\ldots]$

Juliana: $\quad$ É, porque [...] se não houvesse esse trabalho, se não houvesse um pensamento por trás disso, não ia adiantar a costura política. Agora, todas essas coisas sem a costura política também...

Orestes: $\quad$ Então, é um tripé. Se tirar um pé... tem que ter os três pés. [...]

Orestes sintetiza nossa compreensão sobre os fatores que legitimam a Pedagogia da Imagem: 
Orestes: $\quad$ É um trabalho assim, em equipe. Mas é como você falou, um trabalho em si mesmo, de inserção na rede, com o professorado. O trabalho efetivo existe. Ele responde a uma necessidade concreta. Não é voluntarismo pessoal. É uma necessidade. A gente tenta enfrentar. Mas é uma realidade. Tem o respaldo intelectual, [...] é uma coisa que tem solidez. E tem essa articulação política, e saber perceber as conjunturas como elas vão se articulando. Eu acho que do ponto de vista histórico é importante [... ter] consciência disso, desse jogo, que é sempre instável. [...] É difícil mexer também. Que aí há a repercussão, o risco... É uma seriedade intrínseca, pela própria bagagem intelectual e [...] essa intersecção do que é construção coletiva, sem anular a óptica e a perspectiva de cada um.

Inerentes à perspectiva da legitimação e da continuidade do projeto são o formular expectativas e o tecer planos para o futuro. De modo imediato, nossos objetivos são a incorporação da rede das escolas estaduais de Campinas ao projeto e a rearticulação com o Ceforma. De maneira mais ampla, voltamos nosso olhar para o horizonte, e nele enxergamos a utopia.

Orestes: $\quad$ [...] Quando [se] tem uma inserção maior dentro da escola, eu acho que muda até a expectativa, o objetivo, o que se espera. [...] O fato de você esperar alguma coisa não significa impor essa coisa. [...] Para você fazer a depois a avaliação, é em função daquilo que se esperava. [E...] também o que se espera ajuda a nos relacionar com essas experiências diferenciadas de cada escola. O que há em comum e o que há de específico em cada escola? Então, [...] o que se espera?

Juliana: $\quad$ Ah, apesar de querer ver o que os professores vão fazer, eu tenho algumas expectativas. Primeiro, que os professores percam cada vez mais o medo de trabalhar com a tecnologia. Percebam que não é [...] um monstro, bicho de sete cabeças. Segundo, eu espero que seja uma maneira da escola se abrir mais pra comunidade. Seja indo com as crianças fazer uma entrevista, sair daquele mundo dos conteúdos dos livros, [...] interagir, dialogar com a comunidade, seja através da própria criança que mora ali. [...] Terceiro, que realmente os alunos sejam os protagonistas, porque eu acho até que quando o professor começa a trabalhar, vai ser inevitável, porque os alunos vão tomar a frente.

Batata: [...] A questão não é quem toma a frente, é o professor conseguir perceber qual é a função dele num processo de produção complexo e coletivizado. [...] O lance da gente acompanhar é exatamente pra cacifar os caras, falar: "o seu jogo é outro". Quer dizer, você não é o...

Juliana: $\quad$ O dono da palavra.

Batata: $\quad$ É. Você não é o...

Orestes: Não é o monólogo, né.

Batata: $\quad$... como é que se diz, o proferidor da narrativa. Você é outra coisa. Quer dizer, você vai ter que atuar no processo de coordenação das iniciativas [...], ir buscar a solução pros problemas que aparecerem. A nossa função vai ser essa, de fazer essa assessoria aí, pra ele não se sentir acuado e sem saídas para determinadas situações.

Orestes: $\quad$ E você redefine o papel dele, redefine a relação dele com o aluno, conseqüentemente muda o papel do aluno. Agora, eu tenho uma outra expectativa assim, mas expectativa, não é ilusão, então não tem decepção. Mas é altíssima. Porque [...] o que justifica o meu engajamento na Pedagogia da Imagem, eu sempre tenho a expectativa de que nesse amplo universo, que vai se ampliando cada vez mais, na medida em que você rompe com o cabresto, vai soltando pro pasto livre. Eu tenho sempre a expectativa de que realmente a quantidade de pessoas, com visão crítica do sistema que nós vivemos e que possa se engajar na luta pela transformação desse sistema capitalista, e na trincheira que está muito des- 
guarnecida da cultura, e com essa arma muito abandonada que é o audiovisual. Então eu estou vislumbrando que alguns desses professores, alguns desses alunos, terão uma perspectiva que não é imediatista, mas é um engajamento, ampliando o horizonte, entrando nessa rede mundial, fazendo parte dessa unidade plural, múltipla e cheia de conflitos internos, mas que espelhe uma posição. E que até coisas concretas, democratização dos meios de comunicação de massa, o controle social, TV digital, que essas questões passem a ser preocupações e que eles se posicionem diante dessa luta, desse embate. [...] Então, nesse universo que se abre, nessas portas, janelas que se abrem, eu acho que tem graus diferentes e todos os graus são importantes, até o professor que tirou a câmera empoeirada do armário e não teve medo da câmera quebrar, eu acho que isso é o início de um processo. E que, nessa abertura, alguns façam dessa luta até o sentido da sua vida. Porque se fica trancado no armário, e se a cabeça da pessoa está trancada também, não vai. Você tem que abrir e ver o que acontece quando abre tudo isso. Então a questão é abrir e depois ver o que acontece. Tenho expectativa, esse depois, o que acontece, vai ampliando a quantidade de militantes culturais engajados nas trincheiras: audiovisual, uma leitura crítica... [...]

Juliana: $\quad$ Acho que uma coisa importante também é que esses alunos possam no futuro ter mais interesse pelo coletivo.

Batata: É, na medida em que vivenciem processos coletivizados, vão aprender, isso é um aprendizado. Quer dizer, pode começar na gang ou numa produção de vídeo. [...]

Juliana: $\quad$ Eu imagino, [...] não sei quanto tempo vai levar isso.. Mas pra gente crescer com esse trabalho, ter o curso aqui, continuar esse acompanhamento nas escolas, que haja mais escolas, e cada vez mais engajadas [...] para chegar a um volume tal que a própria realidade vai se impor e aí ver a Prefeitura reconhecer, a Secretaria reconhecer isso como uma política pública já implementada. [...]

Orestes: $\quad$ E você está falando no sentido, acho que é interessante, que você fica provocando uma agitação nas águas paradas pra criar demandas. [...] Quando falo política pública eu penso outro Estado. Vindo de baixo pra cima. Uma pressão do povo.

Batata: $\quad$ [...] A questão dos seminários eu acho que aponta pra uma perspectiva. [...] A gente tendo o curso assentado, ter os seminários encaminhados, a gente pode vir a abrigar um programa de pós-graduação lato sensu. Fazendo convênio com algumas outras instituições, ou a Unicamp, ou a USP ou PUC São Paulo, desenvolve aí um curso de especialização. Isso é uma maneira de você apontar a longo prazo, que além de você proliferar ações, você cria um espaço onde você pode fazer com que se aprofundem as discussões conceituais...

Juliana: $\quad \mathrm{E}[. .$.$] formar os nossos multiplicadores. [...]$

Orestes: É uma teoria que vai dentro da prática e a prática se fortalece com a teoria. Por isso que é práxis. Nesse sentido. Não é um teoricismo diletante, não é um praticismo voluntarista...

Juliana: $\quad E[. .$.$] esses professores que tão começando a fazer hoje são um potencial...$

Batata: $\quad$ Isso... [...] Vamos ver quem na rede é titulado, que possa ajudar a estruturar isso e pôr de pé.

Juliana: $\quad$ Abre também uma possibilidade de uma reflexão teórica que a gente não tem muito como explorar aqui [...].

Orestes: $\quad$ E [...] essa fundamentação teórica é uma necessidade. E vejo a questão do seminário como uma etapa realmente de produção teórica. Isso que é interessante. [...] A análise da inserção concreta na escola vai colocar novas questões teóricas. Para dar respostas a essas novas questões, a gente começa a dialogar, por isso que é interessante, porque faz uma ponte entre o que é produção teórica, até o acadêmico, com a realidade concreta lá da escola, de mudar aquele espaço escolar. [...]

Juliana: $\quad$ E uma expectativa que eu também tenho é que esse trabalho nas escolas [...] seja o início de uma coisa que lá na USP eles chamam de gestão comunicativa no espaço educativo, ou seja, que a gente possa começar a lançar ali uma semente para mudar as formas de comunicação.[...] Vai ser mais 
aberto, mais participativo, menos autoritário. E principalmente da relação da comunidade com a escola. [...] Avançar para esse segundo estágio da comunicação.

Orestes: $\quad$ Eu acho que isso aí você tocou num outro ponto importante. Não pode pensar a escola só professor-aluno. Tem que pensar a inserção dela na comunidade e a comunidade dentro dela. Não tem como separar. A força está realmente na comunidade.

Por meio destes relatos e análises, tentei reconstituir um caminho possível para a compreensão de como a proposta da Pedagogia da Imagem tem se estruturado, a partir do momento em que foi concebida. Projeto coletivo, em construção permanente, não me cabe, aqui, antecipar uma conclusão. Avessos ao fechamento dos discursos, Orestes, Batata e eu sabemos que o que dá sentido ao nosso trabalho não são nossas intenções, tampouco as interpretações que produzimos sobre elas. A Pedagogia da Imagem se realiza, de fato, nos desdobramentos que lhe dão as professoras, cada uma a seu modo, na lida cotidiana. Eis, então, o que passo a relatar nas páginas seguintes. 

III AS MEDIAÇÕES DA FORMAÇÃO 



\section{Formar-se professora, tornar-se professora}

Dentre os elementos subjetivos que contribuem para a construção da identidade das professoras, a formação - inicial ou continuada - é fator fundamental, mas não o único. Ele se mescla com a história de vida, as inserções socioculturais, os desejos e expectativas que fizeram cada uma delas escolher a profissão, e a experiência cotidiana, na qual essa opção se reafirma e se redefine. No convívio com as educadoras percebi que, se a formação é o requisito para a entrada nesse ofício, é a práxis que as faz profissionais. Prática que condensa múltiplos conhecimentos e uma compreensão do meio em que se realiza e se consubstancia num projeto pedagógico singular.

Ser professora era desejo de muitas; algumas outras sonharam caminhos diversos, mas enfrentaram circunstâncias que não lhes permitiram segui-los. Nos cursos normais ou de pedagogia,formaram-se. Entretanto, foi no exercício em salas de aula, na vivência com os estudantes, que se tornaram professoras, assumiram a profissão e se engajaram nela. Essa constatação parece fazer parte de sua consciência prática: sabida e sentida, é, no entanto, indizível, inexplicável para elas. Nas reticências e nos silêncios, elas apenas confirmam: "sou professora... sou professora".

Narrando os encontros iniciais com as participantes do curso Pedagogia da Imagem, procurarei as pistas para reconstituir e, no que for possível, traduzir esse sentido complexo. Voltarei aos primeiros contatos que tivemos, de onde pretendo trazer: como essas educadoras se vêem, o que esperam da formação, que desafios os meios e suas linguagens representam para elas, o que buscam para se tornarem a educadora que julgam necessária na escola de hoje. Das sessões subseqüentes, busco entender como os meios audiovisuais e a informática entram em suas vidas, sua formação e seus hábitos culturais. Finalmente, apresento as professoras cujos projetos acompanhei em profundidade. Sem uma preocupação cronológica, agrupei os depoimentos de 2006 e 2007, mantendo os nomes das professoras em sigilo, quando preciso. Vamos, então, ao começo da história... 
Principia o ano e, com ele, nosso trabalho. É sempre com entusiasmo que preparamos a proposta de formação apresentada ao Ceforma. Por volta de março, as informações gerais sobre os cursos estarão publicadas no Diário Oficial e chegarão às escolas para a inscrição das educadoras. Não nos contentamos com essa divulgação sucinta. Logo nos primeiros anos, vimos que muitas pessoas nos procuravam sem ter clareza a respeito dos nossos objetivos. Decidimos, então, expor nossas intenções pessoalmente. Entramos em contato com cada Núcleo de Ação Educativa Descentralizada e solicitamos 10 a 15 minutos das reuniões com diretoras e orientadoras pedagógicas. É o suficiente para nos apresentarmos, despertarmos a atenção e o interesse das educadoras, explicar do que trata o curso, responder às dúvidas e distribuir um folheto com informações e nosso contato, para circular nas escolas. Em algumas unidades, somos convidados a promover uma dinâmica nas reuniões de TDC (trabalho docente coletivo).

Foi assim que começamos o trabalho na EMEF Edson Luís Lima Souto. A orientadora Carla, que havia freqüentado o grupo da Pedagogia da Imagem em 2005, estava interessada em que o grupo de docentes da escola incorporasse o trabalho com as linguagens audiovisuais em suas propostas pedagógicas. Convocou-nos a participar de um TDC, com o objetivo de despertar as professoras para a importância de desenvolverem esse tipo de atividade com os estudantes e de animá-las a fazer o curso no MIS. Já havia uma disposição favorável entre as educadoras da escola e algumas possuíam experiência ou conhecimento teórico no assunto. Faltava apenas a definição, por parte da EMEF, de investir na formação e infra-estrutura, com vistas à implementação de um projeto em audiovisual - era o que se pretendia então.

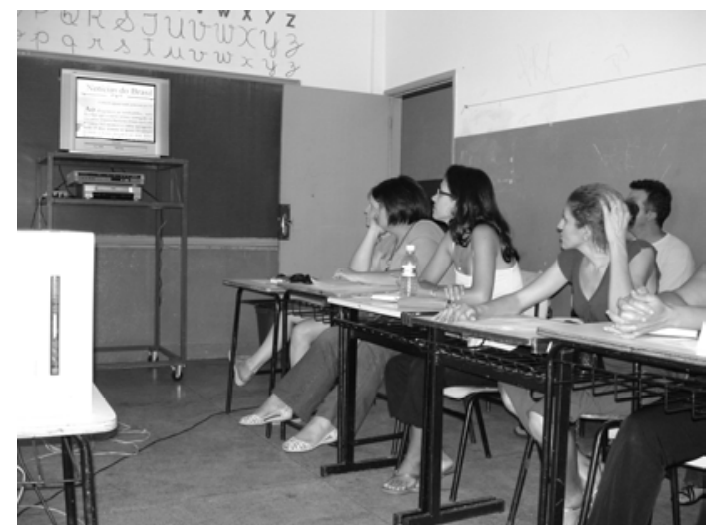

Professoras da EMEF Edson Luís Lima Souto assistem ao curta Poráo
Aceitamos o convite e, na dinâmica, exibimos o curta Porão ${ }^{161}$ e debatemos com as educadoras questões em torno do tema "educação e cidadania". Abordamos o processo de formação das periferias de Campinas, a violência urbana e a maneira como a educação bancária reproduz as exclusões e violências em sala de aula, em contraponto com a educação dialógica, voltada para formar cidadãos críticos e participativos.

\footnotetext{
${ }^{161}$ PORÃO. Direção Fernando Mozart. Rio de Janeiro: Expressão Filmes, 2003. 15 min.
} 
As intervenções das docentes nos mostraram que o tema era bastante relevante no contexto escolar. $\mathrm{O}$ bairro San Martin, onde se localiza a EMEF, está situado nos limites da cidade e sofre, como tantos outros, com sua invisibilidade e abandono. Enquanto uma parte está urbanizada e dispõe de bons serviços, as áreas mais isoladas convivem com condições precárias de vida e o tráfico de drogas. Nas vizinhanças da escola, diversas rodovias e um terminal intermodal de cargas colocam o local na rota da exploração sexual de crianças e adolescentes. A poucos quilômetros dali, ergueu-se uma grande unidade da Febem, sob o protesto e o medo dos moradores. Esse conjunto de fatores lança o estigma do preconceito e da discriminação sobre os habitantes do bairro, avançando também dentro do espaço escolar.

A despeito de sua importância, porém, o tema chocou algumas educadoras, deixando patente que ainda careciam de chaves de interpretação dessa realidade, bem como de maneiras adequadas de tratar o problema, cada vez mais presente na escola. A pergunta de uma professora, após assistir ao vídeo, foi reveladora dessa situação: "Sempre houve violência no mundo. Mas pros adolescentes,

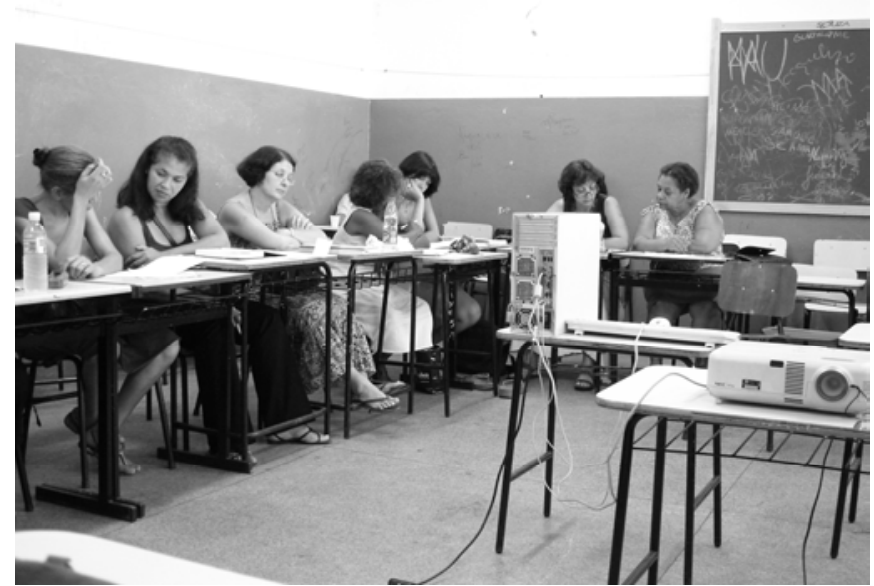

Durante a dinâmica, as educadoras lêem um trecho de Pedagogia do Oprimido como a gente trabalha isso?" O preconceito e a falta de instrumentos que auxiliem a educadora no trato com essas situações aumentam sua distância em relação aos estudantes, tornando impossível a dialogicidade da ação educativa. Foi a professora Luciane que despertou para esse fato, mostrando que as diferenças não podem se traduzir em desigualdades:

[...] Quando terminou o filme eu falei: nossa Graça, que pesado, né? [...] Mas, assim, talvez eu tô imaginando isso como uma reflexão nossa, eu não imaginei mesmo passando para os alunos, porque isso é a realidade deles, a gente sabe que é. Não é a nossa realidade. Então, talvez, pra nossa reflexão, até pra gente mudar o nosso paradigma, o que a gente trabalha em sala de aula com os alunos, da onde a gente fala [faz um gesto levantando a mão direita] se a gente tentar tá aqui, ó, tentando entender [e a mão direita vai baixando e a esquerda vai subindo]... Não que a gente vai passar a mão na cabeça de aluno, mas, assim, a gente ter essa noção exata do que é essa vida deles, totalmente diferente da nossa, pra quando a gente tá planejando uma aula... Eu sei que vocês vieram da área da cultura aí, mas, assim, já pensando na sala de aula, quando a gente tá planejando um conteúdo, pensando num conteúdo, a gente entender um pouquinho mais dessa realidade que é tão distante da gente e pra eles é tão próxima, é tão cotidiana, como você colocou. 
Então, talvez, até, como hoje começa o nosso planejamento, um momento assim, de reflexão mesmo, da gente colocar os pezinhos no chão, ainda mais que a gente chegou de férias, de viagem, de descanso, de um mundo assim, tão, tão, tão distante deles, da realidade deles, pra gente refletir um pouco. Eu peguei mais esse caminho aí. [grifo meu]

De modo geral, as professoras presentes perceberam a dinâmica com audiovisual como um importante instrumento de trabalho, capaz de despertar o interesse, motivar a participação no debate e trazer novos elementos ou perspectivas para a discussão em sala de aula. Entusiasmadas, disseram querer participar do curso no MIS, mas ressaltaram as dificuldades em relação à distância e aos horários disponíveis. Luciane, a mais animada, propôs a formação de uma turma dentro da escola. "Verifique quantas estão interessadas e, se houver um número razoável, atenderemos vocês aqui”, respondi, após consultar a orientadora pedagógica, Carla. A fim de viabilizar o trabalho com alunos, a escola deveria adaptar alguns computadores do laboratório de informática ou disponibilizar outro equipamento para edição de imagens. Carla estava de acordo e ainda ponderou: a EMEF estava de mudança para um novo prédio. Assim que esse processo fosse concluído, os encontros da Pedagogia da Imagem começariam. Enquanto isso, a turma seria formada e as adaptações, providenciadas.

\subsection{As expectativas e os sentidos da formação para as professoras}

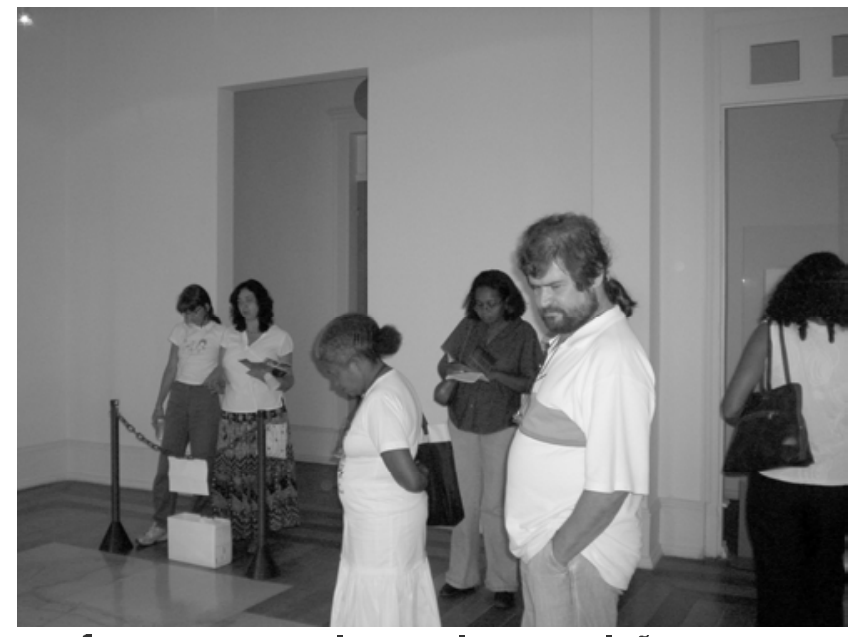

Professoras passeiam pela exposição temporária Cartografia Histórica de Campinas (2006)
Em 2006, o Ceforma autorizou o início das atividades de formação no princípio de março. No ano seguinte, com a (conturbada e parcial) informatização do processo de inscrição e a ampliação da oferta de cursos, a inauguração das turmas ocorreu apenas em meados de abril (a data coincidiu com o início da formação na EMEF Edson Luís Lima Souto). No MIS, recebemos as educadoras ciceroneando- 
as pelo museu, e lhes demos as boas-vindas com uma performance teatral, protagonizada pelo colega Joaquim Andrade. De volta à sala de projeções, ouvimos as apresentações das professoras, suas motivações e expectativas em relação ao curso e suas experiências com uso da imagem.

Via de regra, as professoras nos procuram porque percebem a necessidade de transformar o seu trabalho em sala de aula e enxergam no audiovisual uma possibilidade de desempenhá-lo de uma maneira mais satisfatória e proveitosa para os estudantes. Elas identificam a abordagem pela imagem ao novo, algo que "dá certo", em contraponto às metodologias disciplinares

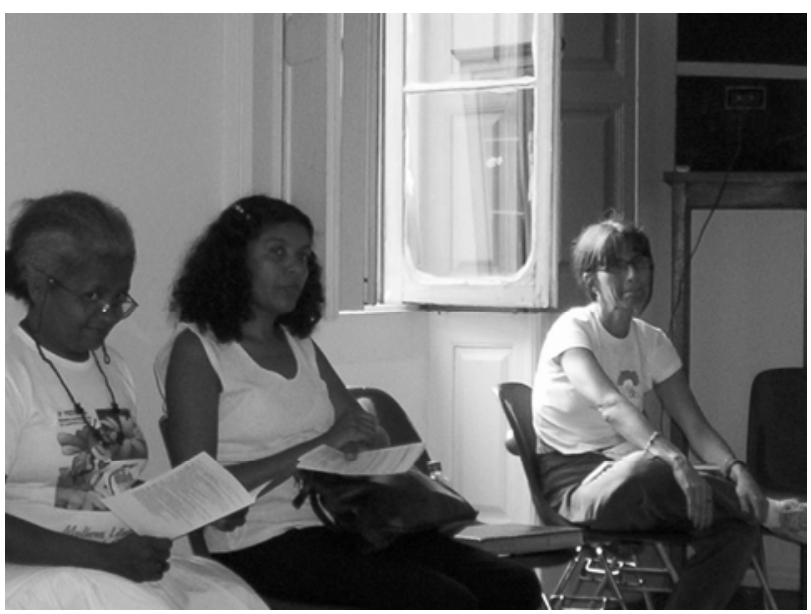

Gracinha, Conceição e Sônia (2006) usuais: ${ }^{162}$

[...] Eu estou aqui com a grande expectativa de aprender como trabalhar e modificar o meu trabalho. Meu objetivo aqui é esse. [...] E estou aqui para aprender e conhecer novas formas de melhorar o trabalho em sala de aula.

Eu vim aqui mais pra aprender. Porque, em 2004, eu queria fazer o Pedagogia da Imagem, [...] e aprender a mexer com a filmadora, enfim, um trabalho diferenciado na sala de aula. A gente tem mais curiosidade de fazer o curso e aprender, [...] fazer alguma coisa, assim, diferente com o aluno.

[...] Eu tô aqui, assim, pra fazer esse trabalho novo, essa proposta nova, [...] pra mim sair da mesmice [sic ...] que a gente sempre faz, [...] que é letramento. Então, fazer uma coisa diferente, gostosa.

[...] A nossa expectativa do Leão [EMEF Pe. Leão Vallerie] é que a gente produza algo muito bom lá na escola.

É, acho que é uma área assim que dá certo, independente de faixa etária dos alunos. Funciona muito bem com os adolescentes, que nós temos bastante na escola, e com os adultos também. Tem funcionado muito bem.

Eu vim nesse curso [sic] porque eu queria fazer uma coisa diferente. Normalmente a gente que é da área [de] biológicas sempre escolhe a área de Biologia e não quer mudar. Como a gente tá mexendo com

162 Nesta parte da dissertação, estão depoimentos recolhidos nas sessões de 14 e 21 de março de 2006 (no MIS), 2 e 16 de abril de 2007 (na EMEF Edson Luís Lima Souto) e 17 e 24 de abril de 2007 (no MIS). Os grifos nas passagens transcritas são sempre meus. Mantive o tom coloquial do discurso das professoras, sem efetuar correções, apenas suprimindo repetições. 
adolescente, mexendo com adulto, eu achei interessante fazer uma coisa diferente, pra que eles estejam mais motivados e eu aprendendo também $[. .$.$] .$

Eu, assim que vi a Pedagogia da Imagem, o curso, eu de cara, assim, já me identifiquei, pra poder tá levando subsídios, pra poder tá enriquecendo e até mesmo podendo ajudar melhor as atividades da escola, principalmente porque nós trabalhamos com projetos. Então pra mim veio de encontro às perspectivas do nosso projeto na escola [sic].

$\mathrm{Na}$ fala de algumas educadoras, é possível sentir uma certa angústia em relação à necessidade de mudança. Não se trata apenas de aperfeiçoar uma prática, mas de buscar saídas urgentes para situações conflituosas (semelhantes, talvez, às que encontramos na EMEF Edson Luís Lima Souto), que fogem ao previsto e para as quais antigas soluções não funcionam mais:

[...] Obviamente a gente tem que... se reciclar não, porque a gente não é lixo, né? A gente tem que olhar pra um outro enfoque, pra conseguir fazer um meio de campo legal. E a imagem eu acho que vai conseguir isso. Sabe? [...] A minha esperança é através da imagem a gente conseguir um consenso. [...] São novos desafios que a gente vem enfrentando, eu tenho sentido há dois anos, e um curso arrojado como esse eu espero que me dê elementos e respostas pra gente formar um meio de campo legal. Nem lá nem cá, né? É isso aí.

[...] São coisas que eu acho que hoje nós, enquanto educadores, nós temos que abrir o nosso olhar. Chega de ficar tent... só, sabe? As questões matemáticas, a linguagem lá, que é a escrita, que na realidade é um contraponto que a gente tá discutindo dentro da educação: por que só valorizar a parte escrita? [...] Então eu acho que a gente tem que ter esse olhar mais amplo. [...] Em prol desse aluno que tá aí e que tem um monte que a gente não tá sabendo como fazer com eles. A grande realidade nossa, acho que a de todas as escolas, nós estamos com um alunado que a gente não tá sabendo direito o que fazer com eles. Só que ele vem pra escola. Se ele vem pra escola, nós enquanto profissionais temos que saber o que fazer com eles. De uma maneira adequada, coerente e profissional, né? É por aí.

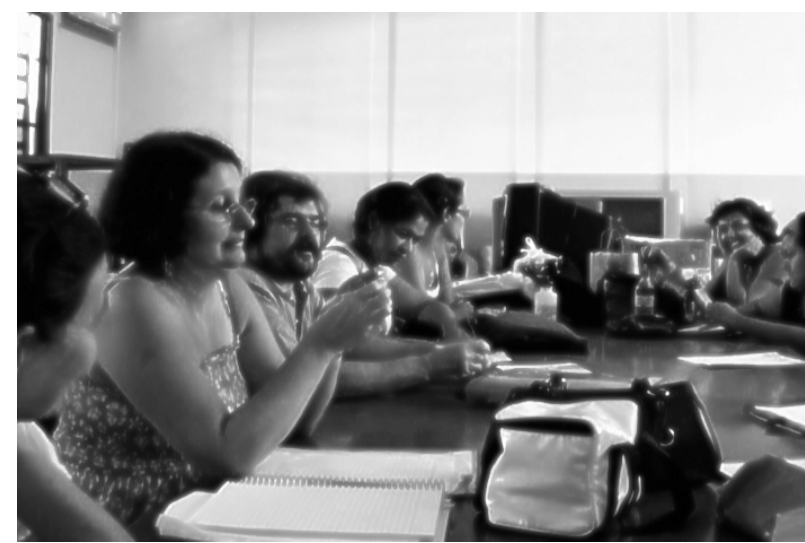

Na EMEF Edson Luís Lima Souto, a primeira sessão é dedicada a conhecermos as expectativas das educadoras
Frente à necessidade de realizar seu trabalho em um contexto sociocultural transformado, a que as metodologias usuais parecem não mais responder (de acordo com as falas, elas não motivam os alunos, geram conflitos entre grupos com diferentes padrões de aprendizagem e não abrangem as diversas linguagens que permeiam a vida dos estudantes), as educadoras estão em busca de 
novos subsídios. É compreensível que percebam a imagem e as tecnologias da comunicação e da informação, que também alcançam o status de novidade no meio social, como uma possibilidade de transformação de seu exercício profissional. Ao audiovisual e ao multimídia, elas atribuem características positivas. A primeira delas é "ser novo": o novo atrai a curiosidade, especialmente dos jovens, e torna-se um ponto através do qual se pode iniciar um diálogo com os estudantes:

- Sempre coisa nova pra eles [alunos]. Eles gostam do novo.

- Mas quem não gosta?

Eu sou Marli, também de Português, também da escola Padre Leão. Eu gosto muito de cinema, gosto de trabalhar filmes com meus alunos, filmes brasileiros. Filmes estrangeiros eu não costumo passar pra eles não. Só os brasileiros. Eu percebo que eles gostam muito, é uma atividade que todos prestam muita atenção quando eu passo um filme e fazem as atividades depois, debates.

Esse "novo" é, ainda, atual, isto é, funciona, acontece, vige e se realiza no presente e se enquadra no caráter da nossa época; mas também é manifestação efetiva, real (opondo-se ao que é apenas potencial). ${ }^{163}$ Por serem contemporâneos, o audiovisual e as tecnologias da informação e da comunicação integram a nossa cultura. Incorporá-los ao trabalho em sala de aula permite restabelecer o diálogo com aluno - não apenas com base em conteúdos didáticos, mas, sobretudo, pelo viés cultural:

Eu acho que não tem mais nada tão atual como a imagem [...]. A gente tem que fazer as releituras das imagens. Daqui pra frente é imagem, imagem, imagem. Então precisamos nos atualizar em cima disso. E eu acho que a releitura, desde a criança até o infinito, a gente tem que fazer releitura de imagens. Isso é importante, inclusive, pra divulgar a cultura. Acho que quando a gente sabe fazer essa leitura, a gente divulga e é fácil de trabalhar a cultura com a criança, com adulto.

Linguagem que permite a comunicabilidade da cultura, como lembrou a educadora, a imagem é também meio de realizar o seu registro, preservação e transmissão às gerações futuras. O audiovisual e o multimídia são percebidos como ferramentas para produção da memória coletiva da escola e mesmo da cidade, do auto-reconhecimento pelos estudan-

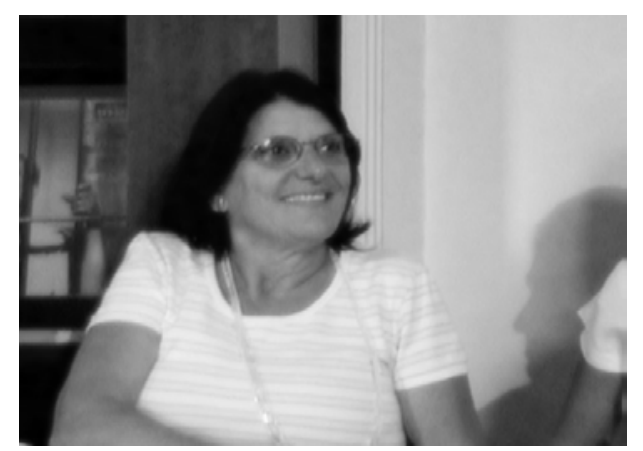

Elenir Castanho, OP (2007)

163 CALDAS AULETE, Francisco J.; VALENTE, Antonio Lopes dos Santos. Dicionário contemporâneo da língua portuguesa Caldas Aulete. Edição brasileira original: Hamílcar de Garcia, 2007. Atual. 
tes e, ainda, de reconstituição afetiva da trajetória e da identidade da própria educadora:

[...] me interesso muito por esse tipo de trabalho porque eu já trabalhei com história e sei a importância que é isso pra memória, isso pra história e até pra história da educação e [...] história da cidade [...].

[...] Eu gosto desse registro da memória amorosa, então eu tenho os registros de cada ano, dos trabalhos, dos projetos que eu trabalho. [...] Mas o registro é muito importante. Porque após os eventos - que a gente tem o hábito de sair com os alunos nas atividades culturais - a gente monta painéis na escola, nos quadros, e eles gostam de apreciar e a gente também vai tendo essa memória amorosa das turmas que vão passando por nós.

Na medida em que se torna objeto de reflexão, para além do simples fazer, a produção de imagens constitui, ainda, uma prática educativa que aguça a sensibilidade, o pensamento e a criticidade do educando:

Essa questão da imagem sempre me atraiu. [...] E, assim, eu acho legal essa coisa de manusear os equipamentos, explorar o que vem depois [...] que você manuseou. Eu acho legal essa coisa assim: o resultado, o quê que eu produzi: tentei uma coisa, fiz outra, ou aquilo foi de acordo com o que eu tinha pensado? Essa coisa, o que vem depois, pra mim é que aguça [...] a capacidade de olhar também o mundo, não só as imagens.

Uma certa visão ingênua permeia a fala de algumas educadoras em relação ao audiovisual. Ao identificálo com "o novo", elas se arriscam a cair na armadilha do discurso modernizador - onde o contemporâneo sempre deve substituir o antigo, tornado obsoleto, irremediavelmente ultrapassado. Com isso, o foco da ação educativa recai sobre os meios, em vez de fixar-se sobre as relações entre os agentes. O perigo está em buscar na tecnologia maneiras mais atraentes de reproduzir uma educação bancária, de transmissão de conteúdos:

Olha, é para tornar a aula mais agradável, dinâmica. E o aluno mais interessado. Porque é complicado, nossas salas são normalmente numerosas, e nós temos que buscar formas diferentes pra estar desenvolvendo o nosso trabalho em sala de aula. Então você procura descobrir novas coisas que chamem a atenção, que faça com que ele se interesse pelo conteúdo a ser apresentado...

É cativá-los. O noturno era extremamente prazeroso até pouquíssimo tempo atrás. [...] Continua, mas agora já tem os percalços. Por quê? Porque a gente lidava com adulto e adulto não te dá problema de disciplina, comportamento: você fala, eles ouvem, eles perguntam. Era uma relação assim quase que de igual pra igual, né? Agora, a gente tem muito adolescente de noite. A gente tá se deparando com embate: é velhos $\mathrm{x}$ moços, moços x velhos. 
O meu objetivo é [...] ter mais recurso para trabalhar com os alunos, poder registrar mais o trabalho deles, e eu querendo aprender um pouco mais isso. [...] Trabalhar mais com filme, como trabalha... A gente sempre passa filmes, mas [...] ter um trabalho mais sistemático, [...] mais moderno...

Essa perspectiva, entretanto, não é única entre as professoras. Ouso dizer que não chega a ser predominante. A busca unânime e angustiada de novas formas de trabalho talvez seja um indício de seu anseio por estabelecer um diálogo com os alunos:

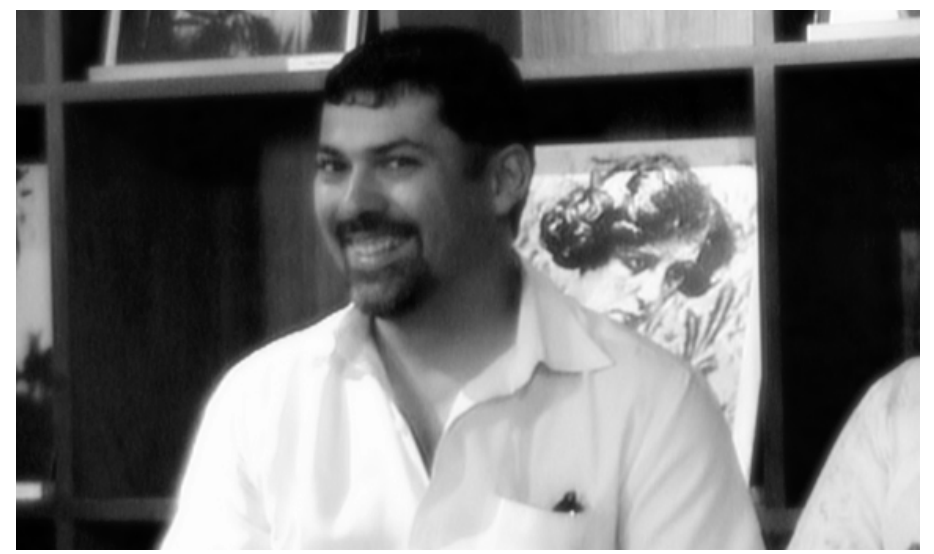

Professor Rubens (2007)

- O que você gostaria de fazer com a câmera, com os seus alunos?

- Ah, eu gostaria de poder mostrar pra eles [...] as coisas mais interessantes, o que eles se interessam, o dia-a-dia deles. É... procurar, pesquisar, entendeu? Porque a pesquisa é a coisa mais gostosa que tem, desde que você se interesse pelo assunto, que seja seu, você vai embora. Agora, se não é um assunto que te interessa, se é uma coisa imposta pra você, cê não tem interesse.

- E você acha então que através desses meios, da câmera, [...] do computador, você consegue despertar o interesse do aluno [...]?

- Com certeza! Ele aprende porque [...] você tá deixando ele pesquisar uma coisa que interesse a ele. Não está impondo para ele o que você quer. Você tem que deixar ele pesquisar o assunto que interessa a ele.

- Rompe também um pouco a hierarquia professor-aluno, nesse momento [...]? [...]

- Éverdade!

- E como você se sente em relação a isso, quando essa hierarquia rompe? [...]

- É interação mesmo. É maravilhoso. Por isso que eu quero aprender mais. Para poder deixar o aluno trabalhar junto com você. Conseguir pesquisar...

Eles [os estudantes] são espertos, né, eles pegam, eles fazem isso, fazem aquilo. Eu [...] achei muito interessante e tenho... eh, esperança, né, que isso possa mudar [... até o relacionamento pra trabalhar alguma coisa diferenciada dentro da minha área, tá?

Entretanto, a compreensão das educadoras sobre as possibilidades que o audiovisual oferece para a transformação de seu trabalho é, muitas vezes, vaga, imprecisa. Sua expectativa em relação ao curso é, portanto, identificá-las, discuti-las e compreendê-las.

Desde o ano passado a gente tem feito o registro [...] das atividades das crianças em sala de aula, e a gente queria - eu e a outra professora que tá de licença gestante - [...] sempre teve vontade de ampliar esse uso 
da foto, mesmo de filmagem, na sala de aula e a intenção de procurar um curso pra ver quais as possibilidades. Eu sempre usei também vídeo, [...] filme, desenho [...].

Aquelas que estão mais familiarizadas com o ambiente acadêmico, contudo, possuem clareza sobre o que pretendem realizar e percebem a formação como um espaço de pesquisa, de experimentação e reflexão, com vistas a renovar a prática pedagógica:

Meu nome é Analice. [...] Em 2005 eu fui pra Itália. Cheguei lá, conheci todo o trabalho que eles fazem baseado em Paulo Freire, [...] e aí quando eu voltei pra Campinas eu fiquei apaixonada por Campinas, porque Campinas tem tudo pra ser o que tem lá e não é, né? Por quê? Por que a gente não se mexe, por que a gente não mostra, por que a gente não aponta? [...] A minha escola é uma escola fantástica, porque eu escolhi essa escola, o Recanto da Alegria. [...] Quando eu fui pra lá eu fiquei encantada com aquele monte de foto, e inclusive comecei um trabalho, mas sozinha, né? Uma andorinha só não faz verão. Então aí esse Pedagogia da Imagem a gente pretende tá fazendo dentro mesmo do nosso projeto [memória] pra nos dar ferramentas pra que a gente possa tratar essas imagens, essas histórias e colocar [...] pra fora [...]. Então, cês vão me ajudar [...] nesse sentido, pra gente poder fazer uma coisa simples, né, nada assim de muito grande, mas fazer, contar a nossa história, que é isso que tá faltando. [...] Eu trabalho com crianças de três a quatro [anos...]. E também a questão do registro [...] pra gente é muito importante. Uma reunião de pais, cê pode tá mostrando pra eles [...] a dinâmica da escola, né, como é que eles são. Tudo isso é muito gostoso. Ajuda, é uma ferramenta pro trabalho da gente. Tem coisa que cê não consegue contar. Mas você consegue mostrar através de uma imagem. É mais ou menos isso.

Oi, eu sou o Rubens, também sou da escola Padre Leão Vallerie e pretendo trabalhar com essa Pedagogia da Imagem junto aos alunos com produção de fotos, de textos, filmes [... e] buscar hoje na imagem o que o aluno representa pra gente e principalmente o que a gente representa pra ele, porque quando você foca uma imagem, você diz o que você pensa sobre aquilo [...] indiretamente. Então a minha idéia seria buscar nos alunos essa auto-imagem, que o professor tem assim meio em falta dentro dos meios que a gente tá sempre em contato. Então já que o professor tem uma falha nessa comunicação com o visual, [...] vamos buscar uma resposta pra isso. Vamos fazer pesquisa.

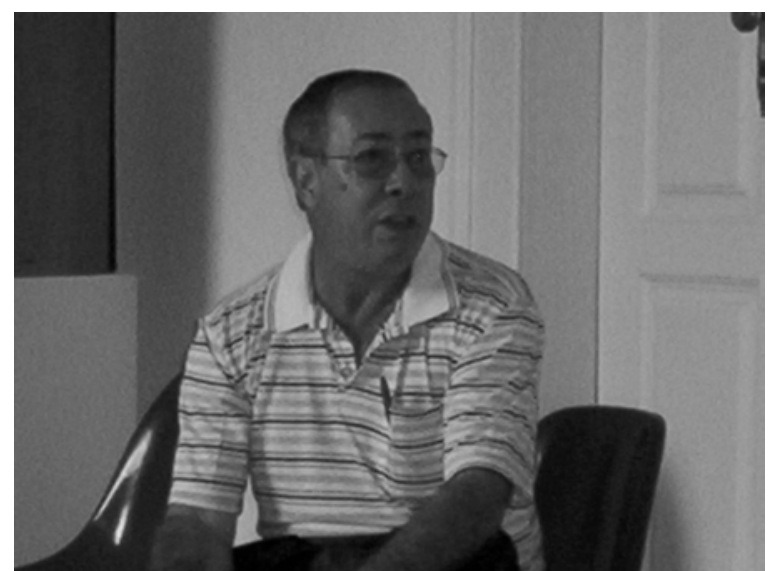

Professor Hortêncio já havia desenvolvido projetos de vídeo com alunos (2006)
A primeira dificuldade enfrentada pelas educadoras - e que elas esperam superar com o curso - é o trato com os equipamentos, os quais costumam denominar "parafernália". Com bom humor, às vezes resignação, elas relatam sua relação de amor e ódio com as máquinas digitais. Sua vinda ao grupo de formação demonstra consciência de que precisam vencer seus receios e limitações. 
Computador eu amo de paixão: mexo, sem fazer curso, sem fazer nada... Mas a máquina fotográfica na minha mão é um desastre! Quem tem perna que se cuide, e cabeça também. A digital, então, nem comenta!

Me dá uma máquina fotográfica e eu me perco com ela e, se tirar uma foto, eu acabo perdendo a foto. Me dá um datashow e eu se não tiver o [...cita o nome de um professor] lá não tem datashow. È tudo muito complicado pra mim, porque eu nunca tive intimidade com esse material. Agora, como orientadora pedagógica, eu tenho que utilizar esse material, porque se a orientadora não usa é muito complicado. Vai fazer uma avaliação dos professores e se não vem alguém lá pra manusear toda essa parafernália, eu não faço nada. Então eu gostaria muito de aprender, de inclusive trabalhar com isso nos planejamentos dos professores, dar sugestões, sugerir, poder ajudar a quem também não sabe, e aprender né, aqui, e auxiliar aqueles que como eu se perdem no meio de tudo isso. Porque eu sou professora de Português e eu sei a importância da linguagem, não é? E sei que a linguagem não é só a linguagem escrita, mas existem aí diversas linguagens, e a imagem, o som estão ligados a isto. Então tem que ser explorado dentro das escolas [...] e eu como orientadora tenho que dar um jeito de também fazer isso no dia-a-dia do meu trabalho. É isso.

Eu sou professora de $1^{\text {a }}$ a $4^{\text {a }}$. série. E eu não tenho hábito de trabalhar com nada disso, com imagens, com ritmos. [...] Esse ano estou com a $4^{a}$. série. [...] E não sei lidar com nenhuma dessas... com vídeo, com filmadora, mesmo máquina fotográfica, eu tenho uma certa dificuldade. Eu prefiro não usar.

Eu gosto, né, de tirar fotos, mas eu não sei fazer nada daquilo. Eu quero aprender numa máquina fotográfica quais são os recursos [...], porque eu sei [...] que a máquina tem recursos, [mas...] cê não sabe como utilizar.

- Essa máquina fotográfica que a gente ganhou, a gente precisa saber usar, porque eu fui usar num aniversário e ficou péssimo. Olha!

- Ela é digital?

- É digital, que a gente ganhou num curso que a gente fez, né. Mas foi horrível [...]. Não tava dando certo. Tremia. Tremia toda a imagem. Quem sabe eles ajudam a gente a usar ela, porque... ah, nem li manual, não gosto de manual...

Meu objetivo é aprender um pouco mais, é dominar um pouco mais a questão da fotografia. Eu fico um pouco perdida ainda com a com essa tecnologia. Então, como ela disse, vão montar o datashow, me perco um pouco...

Para algumas professoras, a dificuldade se converte em medo de danificar as máquinas. Elas sabem o quanto é difícil obter recursos e equipamentos nas escolas e o quão escassas são as verbas para manutenção, mas também têm receio de enfrentar constrangimentos ou ter de arcar com as despesas de um possível conserto.

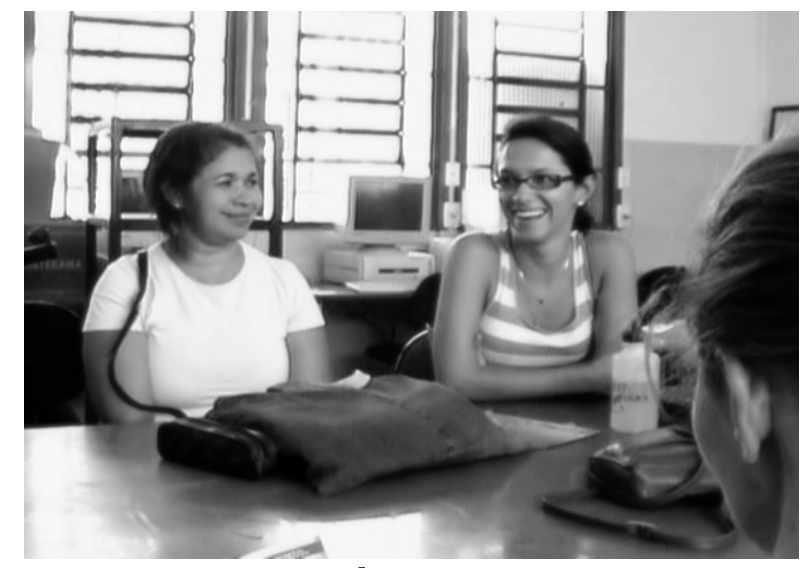

Professoras Roseli e Roberta 
Então, eu vim [... porque] eu gostaria também de aprender mais como mexer com a câmera, né, porque quanto ao acesso ao material, [...] a escola tem. Mas é o tal negócio: como a gente não sabe muito assim, trabalhar com a câmera, então a gente tem aquele certo medo de quebrar qualquer coisa... E depois, né? É complicado isso aí. Então eu não pego nada na escola. Não que não tenha. Tem tudo na escola. É. Mas eu não pego por isso: tenho medo mesmo de quebrar. Estou aqui para aprender, [...] pra gente conseguir mexer melhor, trabalhar com a câmera [...]. Por isso que eu pensei em fazer o curso.

A gente tem muito medo de mexer nas coisas, de acontecer alguma... o medo da gente. Da máquina fotográfica agora eu sei, mas os meus alunos também precisam me ajudar até na maquina digital.

O medo, porém, é um passo para a resistência, uma atitude quase inexplicável:

Apesar de ser apaixonada por arte, cinema, teatro, por tudo, [...] não tenho grandes familiaridades ainda com datashow, com computador, com todos esses recursos tecnológicos. Apesar de ser apaixonada por esses, eu tenho uma certa resistência de trabalhar com eles.

- Que recursos você usa normalmente com seus alunos?

- Olha, normalmente, mais [...] folhas mimeografadas, xerocadas, lousa, livro, textos... Filmes, muito poucos. Porque nós trabalhamos cada ano numa série, $1^{a}$ série, $2^{\mathrm{a}}, 3^{\mathrm{a}}, 4^{\mathrm{a}}$. E às vezes trabalhamos por área, e às vezes não. Aí depende. Então nós não temos o hábito. E também as escolas, né, conforme a escola que nós estamos não tem [...] ou se tem às vezes o aparelho tá com problema, existe uma certa restrição de uso.

- Nessa escola em que você está agora, tem câmera fotográfica, filmadora?

- Temos muitos recursos. Na minha escola, que [é] muito privilegiada. É uma escola que tem no Parque Industrial. É uma escola que tudo que você pensar tem. Só que nós não sabemos trabalhar.

- E vocês têm autorização para usar?

- Temos, nós de $1^{a}$ a $4^{a}$. Professores de $5^{a}$ a $8^{a}$ já têm outra postura, eles já conhecem muito mais do que nós. Mas nós de $1^{\text {a a }} 4^{\mathrm{a}}$ nós temos uma certa dificuldade de usar esses meios.

- Computador: tem sala de computador?

- Tem, tem. Nós podemos usar tudo que tem na escola. É permitido o uso sim.

- E os alunos? Se vocês desenvolverem um projeto em que os alunos vão tirar fotos, eles podem usar a câmera da escola?

- Podem, com certeza. Podem sim. Nós temos todo o apoio.

A maioria das educadoras, contudo, não se sente confortável nesta situação. Elas identificam essa falta de habilidade no trato das tecnologias com um "atraso" e, portanto, atribuem a si o indesejável sentido de obsoletas:

Por quê que eu vim? Eu vim porque enquanto o mundo anda de boeing, eu ando de jegue. É muito complicado isso.

Sou [...] um pouco jurássica, então queria me atualizar melhor nessa área. 
É ao buscarem ajuda que admitem sua acomodação e se sentem até "envergonhadas". Elas reputam o próprio comodismo ao fato de receberem ajuda de pessoas familiarizadas com os equipamentos, sejam alunos, outras professoras ou os filhos. Sabem que esse auxílio permite que o seu trabalho não seja sempre prejudicado. Entretanto, percebem que conquistar autonomia neste campo irá lhes proporcionar mais liberdade, rapidez e desenvoltura:

Nós temos a filmadora. Por exemplo, eu tava fazendo um evento, um jogral com os alunos. A professora sabe que eu não sei registrar, já se prontificou, já apareceu, já ligou a máquina, já veio me auxiliar. Então isso tudo é muito bom. E com isso, como a gente corre muito, a gente acaba encostando o corpo. Que em casa, os adolescentes têm mais tempo. A gente tem o serviço pra fazer, tem as coisas da escola pra providenciar, acha muito mais prático se eu tenho os filhos já jovens, oh, me faz isso, digita isso pra mim. Pra mim, me ajuda muito e eu levo esse auxílio e ao mesmo tempo eu vou me postergando, postergando de aprender. É uma necessidade, porque não é todo momento que eu posso pedir socorro, que vou ter alguém lá pra me ajudar. Então esse fato da gente ter essa independência, isso nos liberta. Eu acho assim, que eu vou me sentir muito mais feliz de poder eu mesma pegar uma filmadora [...] e dar conta do recado. Eu acho que eu vou ser muito mais feliz e mais corajosa de encarar né, esses aparelhos eletroeletrônicos. Que eu sou de outra geração, então a dificuldade não é como eles. Eu tenho muito receio de mexer no botão e danificar, e isso não acontece com os jovens. Então a gente pensa três vezes antes de apertar um botão.

A gente tira fotografia. Mesmo que fique uma droga, mas a gente tira. Se não sabe, pede pros alunos, pelo amor de Deus. Eles dão um help. Mas eu devo confessar que eu sou acomodada na coisa. Eu tenho duas filhas. Quando eu preciso, eu peço pra elas e daqui a pouco tá na hora de criar vergonha, né? Acho que já chegou [essa hora].

Eu me perturbo quando, por exemplo, nós temos um evento. Aí chega a [...] bendita hora de filmar, fotografar ou então usar o datashow. Ninguém sabe. E isso, eu, [...] como diretora, me sinto extremamente incomodada. Então eu falei: dessa vez, já que ninguém vai... Ninguém vai? Não, ninguém vai. Eu vou. Uma que eu gosto, adoro filmes, adoro fotos, né, e eu acho, eu sinto essa necessidade, essa carência que tem na minha escola.

Eu escolhi esse curso pelo fato de [que] realmente eu quero aprender a usar tanto a máquina digital como a filmadora e datashow. Mas o fato de eu não saber usar não [...] impede que eu utilize e registre as atividades que eu desenvolvo com os alunos. Porque na minha escola a maior parte eles têm o domínio. Então meus alunos montam datashow quando a aula é com datashow, minha filha me ajuda com o CD. [...] Eu uso a [câmera fotográfica] digital, mas eu só registro, só aperto. Eu não sei passar pro computador, e não sei também passar pro papel. Eu não sei. Aí eu peço auxílio pra minha filha, que é publicitária. Então eu acho que esse fato me fez acomodar e eu fui deixando. [...] Sou metódica, gosto de organizar e às vezes tem alguns trabalhos que eu tenho que ficar pedindo e me sinto constrangida: "olha eu quero aquelas imagens, não esqueça de separar pra mim”. Então eu me sinto muito impotente nesse fato, porque quero as imagens e fico nessa dependência de conseguir pra colocar do jeito que eu quero.

Não tenho intimidade com a máquina fotográfica, com aparelhos, com imagem é uma dificuldade, tudo. Eu falei, não, dessa vez eu vou enfrentar, né, o bicho assim, pegar pelo rabo mesmo porque não dá pra 
você ficar numa sala só pedindo, oh, fulano, cê me ajuda aquilo, cê me ajuda? Não dá, né? Chega um momento que a gente tem que se virar.

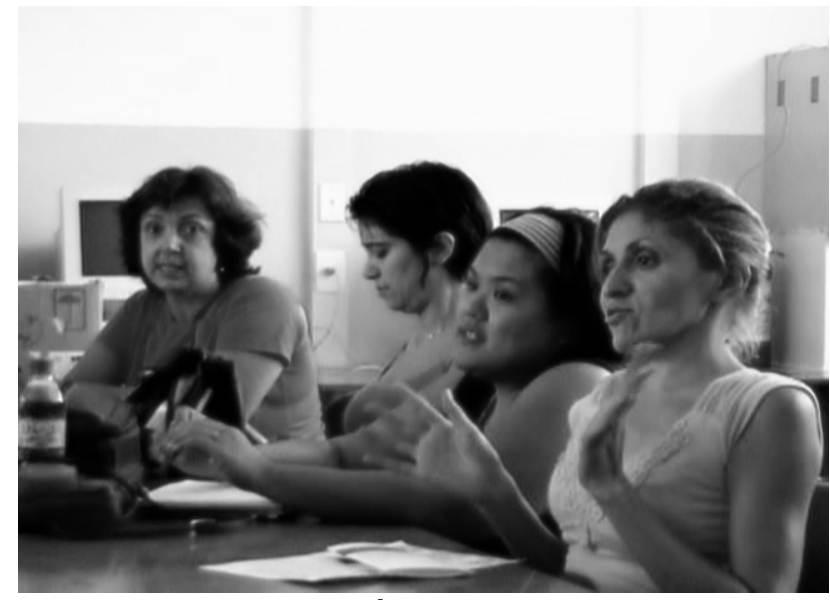

Rosaura, Luciane, Tiê e Lieci
Outras vezes, o desconforto das educadoras é causado pelo isolamento e pela insegurança que seu não-saber provoca. Os projetos especiais desenvolvidos nas escolas sempre motivam e entusiasmam as professoras. Entretanto, aquelas que não lidam bem com certos recursos tecnológicos são postas de lado ou deixadas para trás nessas atividades. Buscar essas proficiências que

lhes faltam é uma maneira de tentar se integrar a um grupo mais dinâmico e interessante, recuperando uma dimensão importante de sua identidade profissional - a auto-estima e o reconhecimento coletivo:

O ano passado eu tava numa outra escola [...] e eles tinham um projeto bárbaro lá, que era a preservação do patrimônio. Então como ali é APA, né, uma área de proteção ambiental, [...] a gente fez muita filmagem ali naquela trilha, em tudo aquilo. Como eu não era dada com todo esse instrumento tecnológico en ficava numa outra parte, né. E foi apaixonante, todos aqueles dados. Foi um projeto maravilhoso. [...] Tô aqui [...] pra aprender também.

Em 2004, uma colega fez o curso e nós montamos o projeto na escola, o ensino da imagem. Só que era um pessoal que vinha pra cá. [...] Eles tinham um ânimo medonho. A gente foi no museu, nós fomos lá ver, sabe, estátuas, fez o que pôde e o que não pôde com as crianças. Mas com os alunos mesmo. [...] Fomos em vários pontos. Nós andamos muito. E fomos nuns sete pontos, num dia só. Eles adoraram. Ver a professora explicando como se via a imagem, como é que se lia aquela estátua. Eles ficavam assim encantados. Eu mesmo. Analisar o casarão, olhar, parar em frente e admirar. Porque é lindo, né, esse estímulo de olhar. E eu fiquei encantada. [...] Eu falei: gente do céu, eu acho que eu não consigo ler um negócio desses! Mas contagiava. Tudo! Aí depois, com a câmera digital, hoje em dia, dá pra gente enxergar várias dimensões diferentes. Aí foi contagiando a gente. Aí vim. Não sei se eu vou aprender. Que isso aí pra mimé bicho de sete cabeças. [Risos da turma] Jesus! Lá em casa eu mexo, mexo no computador, tal, mas brigo com ele direto. [...] Ah... é complicado pra gente. A coisa evoluiu muito rápido. E na escola tem... esses passeios todos que a gente fez, a professora tá filmando, os outros com a máquina digital, a gente tem. Agora tem um projeto muito legal mesmo. Entramos até num concurso aí, né. Eles: eu não. Eu vou atrás dos meninos. Mas é: a criança olha, mas ensinar a criança a olhar, a ver a imagem, a refletir, falar sobre ela, é uma delícia. Porque aí eles começam a ver [...] um monte de coisas.

O aprendizado do uso de equipamentos de produção de imagem, porém, não é o único interesse das educadoras no curso Pedagogia da Imagem. Muitas estão atentas à natureza da relação pedagógica que 
se estabelece num projeto audiovisual, buscando uma metodologia para explorar a imagem em sala de aula, seja em projetos extracurriculares ou na abordagem disciplinar.

Enxergar a educação de um jeito também estimulante, quer dizer, outras formas de ver o caminho da aprendizagem.

Talvez, refletir um pouco mais no cotidiano da escola sobre as imagens, tá mais atenta a essa questão da imagem no cotidiano da escola.

Por se tratar de Pedagogia da Imagem, eu quis saber qual que é a relação da imagem na educação, pra mim poder levar pra escola também [sic].

Eu estou aqui $[. .$.$] também pra ver se a gente faz um projeto.$

Me despertou também pra isso [...] da imagem, como trabalhar com a imagem.

Eu me interesso em saber, [...] principalmente, [...] a questão de trabalhar com filmes, com temas dos filmes. Eu acho muito interessante saber aproveitar mais a questão dos filmes que a gente pode tá apresentando dentro da sala.

O motivo de eu assim, tá fazendo esse curso é que naquele dia que você veio lá, tocou com uma coisa que eu gosto, não só com a imagem contemporânea, mas com o contexto histórico. [...] Então eu sempre gostei de fazer esse paralelo: passado-presente e o que tá acontecendo. [...] Eu sempre gostei de trabalhar com a imagem na forma de desenho, [...] eu sempre passei isso pros alunos.

- Esperamos que o curso nos ajude na questão do vídeo como produção.

- Que seja um apoio, né, e não um descanso, né. [...]

- Que não vire um lazer, e faça parte do conteúdo.

- É lazer também.

A partir das expectativas apresentadas, podemos depreender alguns dos significados que a formação adquire para as professoras. Em primeiro lugar, trata-se de um espaço de profissionalização e reflexão sobre a prática. Na maioria das vezes, rejeitando a idéia de “reciclagem”, mera capacitação ou atualização, elas buscam na educação continuada saberes teóricos e práticos, metodológicos e técnicos para continuar exercendo sua profissão num cenário transformado ou, antes, para satisfazer uma exigência imposta pela visão crítica que elas próprias possuem sobre o seu fazer. O que mais explicaria a grande procura por tal curso se, como já mencionamos, as instituições de ensino municipal não possuem uma diretriz que encaminhe a formação de quadros para desenvolvimento de projetos específicos em audiovisual, tampouco estão plenamente equipadas ou informatizadas no que diz respeito a suas rotinas mais simples, que 
dirá para produção de imagens? Certamente não são o comodismo, a resistência e o descompromisso que costumam ser levianamente atribuídos às educadoras. Se a formação em serviço é uma brecha no cotidiano, onde a professora pode colocar-se em dia com o novo, não seria porque seu fazer deixou de ser verdadeiramente práxis, ao ter seus tempos-espaços rigidamente controlados por uma burocracia que valoriza exclusivamente os momentos-produtividade em sala de aula, isto é, de transmissão de conteúdos, ignorando os aprendizados que podem ocorrer no desenvolvimento de projetos extra classe, transversais, de caráter cultural? Não seria porque essa mesma burocracia ignora que também o educador precisa educar-se constantemente, fazendo de seu trabalho um permanente objeto de investigação?

Desse primeiro significado, decorre o segundo: a formação é um espaço coletivo para as professoras, e não simplesmente uma fonte onde vão buscar soluções individuais. Esse sentido se revela na medida em que as educadoras buscam no curso saberes que as integrem em determinados grupos dentro das escolas - aqueles que desenvolvem projetos interessantes, aqueles que compartilham certos conhecimentos e práticas, aqueles que são vistos como dinâmicos, criativos. É isso que podemos ler nos seus depoimentos:

Meu nome é Tânia, eu sou da EMEI Recanto da Alegria, trabalho com crianças de cinco anos. Vim influenciada [...] pela minha colega de trabalho, a Analice. Ela que me falou desse curso, e como a gente tá fazendo parte do Projeto Memória na escola, e todo o resgate histórico já foi feito, a gente tem muita foto, trabalhamos muito com foto e agora estamos com [...] máquina digital, os CDs e tal. Ela tem um pouco [...] mais capacitação nessa área do que eu, e ela também é muito dinâmica [...]. Então, quer dizer, a gente juntas, né, fazendo um curso assim, a gente vai poder trocar mais, vai poder tá levando pra escola e fazendo um trabalho [...] mais adequado na escola. Por isso eu vim.

Eu já queria ter feito faz um tempo. Desde o primeiro curso que foi oferecido eu fiquei tentando encaixar na agenda, mas não tinha dado ainda. E aí depois algumas pessoas fizeram e gostaram. Fizeram propaganda.

Colega virou pra mim e falou assim: cê já fez a inscrição no curso? Eu falei: não. Ele falou: olha, tem um monte de gente da escola que vai num curso de terça-feira e promete ser uma coisa assim... muito diferente. Cê quer? Eu falei: ah, [...] eu quero. Faz minha inscrição. [...] Então por quê que eu vim? Primeiro pelo convite. Segundo, mais ou menos porque a gente se sente amparada: tem um grupo grande...

E eu também vim influenciada por um professor da escola que fez a última edição, que ficou apaixonado pelo curso, professor Celso, e [...] principalmente eu vim com meu olhar observador, que eu sou muito observadora. Então eu quero aproveitar esse olhar pra tá trabalhando nessa Pedagogia da Imagem. 
Eu vejo assim como uma grande gratificação para nós. É bom conhecer também [...] colegas novos, nas oficinas que a gente procura estar fazendo [sic].

Esse aspecto coletivo da formação também é denotado pelo hábito que as professoras possuem de compartilhar informações a respeito dos cursos que freqüentam. Elas indicam para as colegas aqueles que acham válidos, fornecendo referências concretas dos trabalhos desenvolvidos e das aplicações geradas em sala de aula. Dessa maneira, cria-se uma rede informal que orienta as escolhas das educadoras para sua formação continuada, legitimando e fortalecendo as iniciativas que, de seu ponto de vista, merecem continuidade, ao passo que propostas menos sérias ou com aproveitamento limitado não encontram ressonância nesse canal. Por isso, as referências de outras educadoras têm um peso importante na opção por um curso ou GT:

Eu vim meio que influenciada por uma pessoa que já fez o curso aqui com vocês o ano passado. Ela falou tanto, falou tão bem, que eu fiquei assim curiosa e acredito que seja uma coisa que eu vá aplicar bastante.

A Rosângela [...] tinha feito o curso em 2005, tinha falado muito bem do curso e aí eu tô tentando fazer o curso desde 2006.

Quem me falou do curso foi uma professora que trabalha comigo, a professora Walquíria, que fez o curso o ano passado e aí despertou um certo interesse.

Um terceiro e importante significado da formação surge na fala de algumas professoras, de maneira incomum, como se necessitasse licença ou justificativa. Trata-se da dimensão existencial, inerente a todo processo educativo, mas à qual as educadoras parecem sentir que não têm direito. Percebendo-se instrumentos educativos dos alunos (e não sujeitos em relação com outros sujeitos), poucas têm a coragem de assumir a necessidade e o desejo de ser mais, crescer como seres humanos, alimentar sua subjetividade no encontro com o outro e com outros saberes. Quando o fazem, declaram-se "egoístas", provocando, entre as companheiras, olhares de espanto e queixos caídos.

Eu acho que eu sou a única egoísta do grupo, porque eu vim fazer o curso por mim mesmo. Não foi pelos meus alunos, não. Eu gosto de imagem, gosto de fotografia, gosto de filme... Até filme ruim eu vejo até o fim. [...] Pra fins pessoais. Se der, eu uso na escola.

Eu sou [...] professor de história, e na verdade [...] quando eu escolhi o curso eu pensei mais em mim mesmo, porque eu gosto muito de imagens. Sou deficiente visual, por isso que eu gosto, é tão importante pra 
mim: eu só enxergo com o olho esquerdo e, mesmo assim, eu sou míope dele. Então pra minha vida, a imagem é central. Eu trabalho com fotografia e com os alunos eu uso muito. Mas eu não tava pensando neles, tava pensando em mim, porque se eu não estou aprendendo alguma coisa então não adianta eu levar pra sala de aula. Tem que começar por mim mesmo. A minha expectativa é isso: conhecer pessoas novas, aprender mais sobre fotografia, e como sou professor de história, a foto é encarada como documento histórico. Nós usamos muito fotografia, mesmo os livros didáticos, datashow, Internet, foto digital. [...] Mas também tô feliz mesmo, porque é a primeira vez que a escola nos liberou pra que a gente fizesse os TDPRs fora da escola. E é sempre preferível fazer aquilo que a gente quer do que ficar lá preso na escola, sem conhecer pessoas novas e sem ver coisas novas. Então nesse sentido eu sou egoista mesmo. Eu preciso crescer como ser humano primeiro.

O professor de história tem razão: a justa preocupação com a melhoria da educação, com a aplicação dos princípios da formação continuada em sala de aula e com o desenvolvimento de projetos pedagógicos que incluam os estudantes não deve resultar na anulação do sujeito docente. Como podemos pretender estabelecer um processo educativo emancipador a partir de um educador coisificado, sem direito ao autodesenvolvimento? O sentido existencial da formação precisa sair da clandestinidade a que o forçaram as concepções bancárias da educação, declarando-se legítimo, afirmando-se sem receio.

Finalmente, não posso deixar de mencionar que uma pequena parcela de professoras nos procura por razões menos consistentes, como curiosidade ou possibilidade de encaixar a formação na sua grade de horários:

Eu fiz a opção por esse curso assim eh, pelo dia. Cabe dentro do meu horário e achei muito interessante o curso em si, né? Pedagogia da Imagem eu acho que casa um pouco com o que a gente trabalha. E por curiosidade também.

A minha intenção de fazer o curso também coincidiu que terça-feira é um dia que eu tenho livre.

Às vezes é por conta de horário: você tem que se encaixar em algum desses horários, né? Também isso.

As frágeis motivações dessas educadoras em relação à formação continuada mostram-nos que, ao caírem na rotina e se isolarem, as professoras acabam contando com menos instrumentos para fazer a leitura dos cenários em que atuam e dirigirem seus esforços de estudos para áreas temáticas e metodológicas potencialmente mais necessárias. Embora o convívio com as colegas e os formadores possa ser de grande valia na superação desse retraimento e para a reinserção dessas educadoras num processo coletivo de profissionalização, muitas delas abandonam o curso logo no início. 
A elevada evasão dos cursos de formação ${ }^{164}$ também pode ser explicada por inúmeros fatores, como transferências de escola e mudança de horário, determinações institucionais (como no caso citado por uma professora: "O ano passado eu fui até na primeira reunião, tentei participar, mas depois eu fui obrigada a participar de um curso, porque eu estava na primeira série, e que chamava Letra Viva. [...] Então aí não coincidiu, eu não podia fazer, aí eu não dei seqüência, fui só na primeira reunião."), impossibilidade de conciliar as tarefas da formação no horário de trabalho, a sobrecarga gerada pela dupla jornada professora-mãe, além de problemas de saúde e questões pessoais. Humildemente, há que se reconhecer, ainda, no caso específico da Pedagogia da Imagem, que existem educadoras que não se identificam com a nossa proposta, seja porque as condições da escola são precárias demais para se tentar implementá-la, seja porque não abrimos mão de alguns fundamentos, como o desenvolvimento de um projeto na escola, o protagonismo dos estudantes, a abertura para a comunidade, o despojamento de preconceitos socioculturais, a fundamentação teórica e reflexão sobre a prática e o posicionamento ético e político.

\subsection{A experiência das professoras no uso do vídeo e outras linguagens}

O trabalho com o audiovisual, em salas de aula, necessita ser mais sistematizado, analisado e discutido com as professoras. A despeito de reconhecerem que essa linguagem faz parte do nosso cotidiano (“[...] Hoje já não é mais tão novidade, né? [...] Hoje em dia a gente já tá bem [...] acostumado com a questão de trabalhar o vídeo”), as educadoras nem sempre são capazes de identificar situações em que a empregam. Mencionam "algumas coisas pontuais, da gente olhar e estar trabalhando com alguma imagem junto com os professores, de observação mesmo de imagem, mas nada assim... mais pedagógico, assim, não." Quando, porém, insistimos em buscar os relatos de quaisquer experiências, vão surgindo diferentes usos e concepções do audiovisual. Revelam-se também suas dúvidas, críticas, tentativas, bloqueios e

\footnotetext{
${ }^{164}$ Refiro-me aos cursos de formação oferecidos pelo Ceforma e não somente ao Pedagogia da Imagem, pois, nas ocasiões em que os ofertantes se reuniam, o tema da alta evasão era abordado e mostrava-se um problema comum a todos, não sendo mais grave no nosso caso que nos demais.
} 
dificuldades. É a partir do debate entre essas diferentes visões que vamos, no curso, construir uma metodologia para a abordagem pedagógica dos meios de comunicação e tecnologias da informação. ${ }^{165}$

A primeira e mais comum utilização do audiovisual na escola é a exibição de vídeos e DVDs, de acordo com a enquete realizada com as professoras das turmas de 2006, 2007 e da EMEF Edson Luís Lima Souto, sobre os recursos que empregaram nos anos anteriores ${ }^{166}$ :

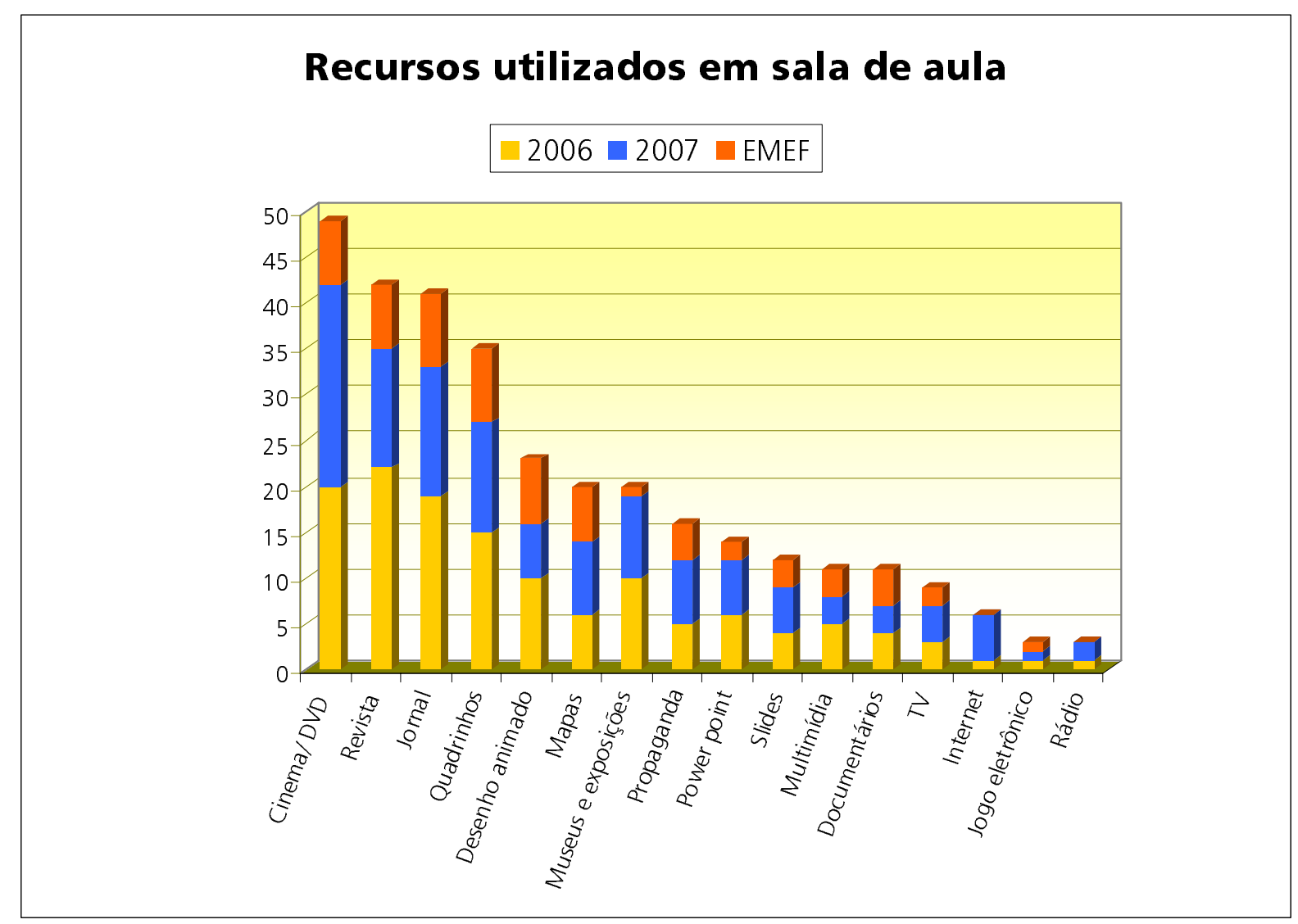

Os dados mostram, contudo, que o material impresso (somando-se revistas, jornais, quadrinhos, mapas e mesmo slides) é ainda mais presente que o audiovisual (incluindo cinema, DVDs, desenhos animados, propagandas, documentários, TV e rádio), ficando à frente dos recursos da informática (apresenta-

\footnotetext{
165 Os dados dos questionários e discussões aqui apresentados foram coletados nos primeiros encontros com as professoras. Portanto, referem-se à sua experiência antes de cursar a Pedagogia da Imagem.

${ }^{166} \mathrm{Em}$ 14/03/2006 e 23 e 24/04/2007, foram aplicados questionários às professoras participantes do curso Pedagogia da Imagem no MIS e na EMEF Edson Luís Lima Souto. Os resultados, após tabulados, foram discutidos com as educadoras nos encontros de 28/03/2006 e 14 e 15/04/2007.
} 
ções em Power Point, multimídia, Internet e jogos eletrônicos). Em último lugar, estão as atividades culturais, como visitas a museus e exposições.

O gráfico anterior não mostra, porém, como são utilizados esses recursos. A freqüência de utilização do material em vídeo ou DVD é, em geral, baixa: um a três filmes por ano:

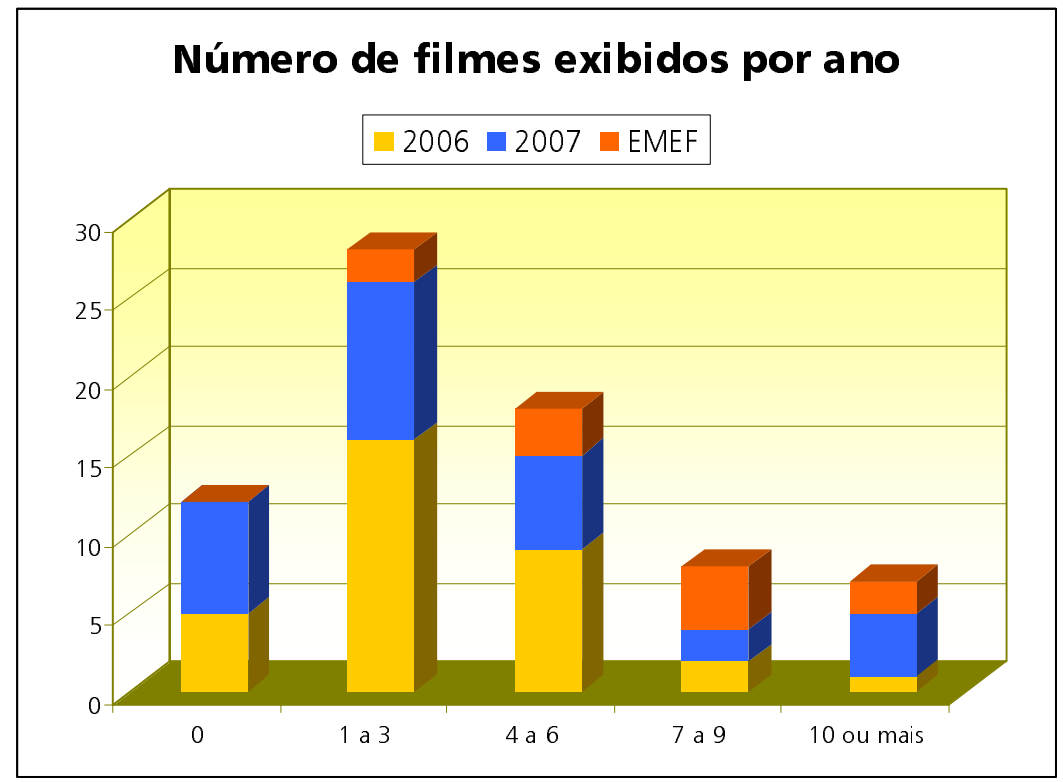

Ao responderem o questionário, as professoras afirmaram, em sua maioria, realizar debates sobre o filme após a exibição.

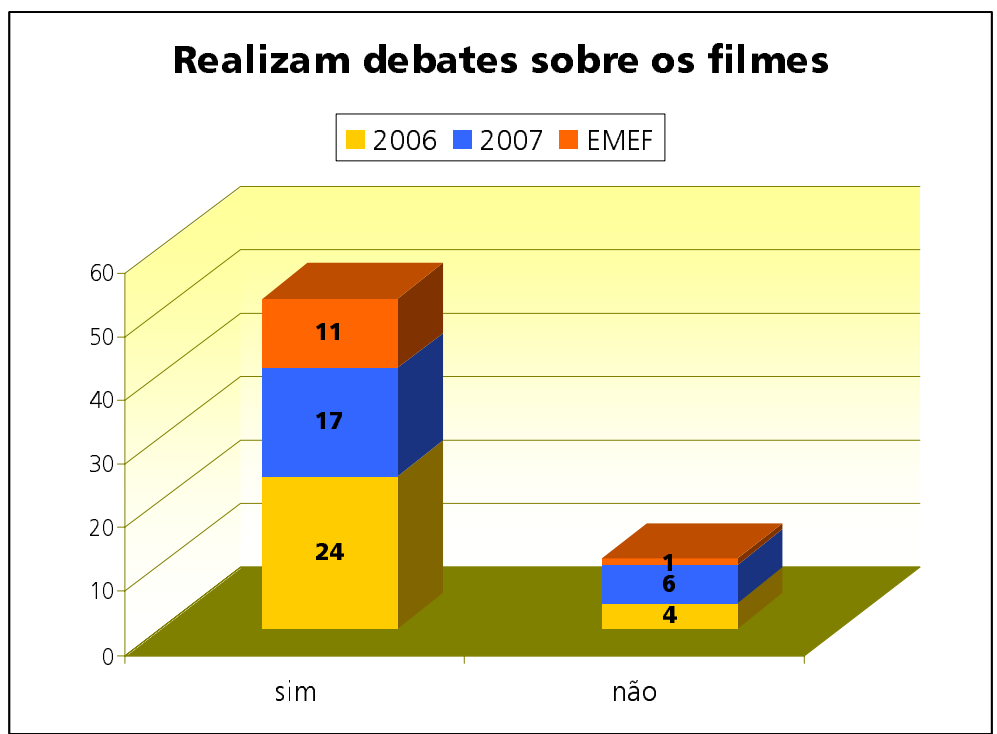


O papel que assumem, freqüentemente, nessas situações, é o de fechamento e validação do discurso sobre o filme, exemplificado pela fala da professora:

Bom, projeto assim, na escola, com imagem eu nunca fiz nada. Eu sempre faço é o seguinte: [...] levar vídeo na sala de aula. [...] Olha, geralmente eu levo. [...] Primeiro, assim, eu não falo nada. Deixo eles assistirem, para ter a opinião deles, saber o que eles acharam, se gostaram, não gostaram. Porque eu acho que importante primeiro é saber o que eles [...] viram, o que eles entenderam. Aí, depois [é] que eu exponho, mas a partir do que eles falaram.

O depoimento revela a intenção de se estabelecer um diálogo democrático com os estudantes, deixando que eles se expressem livremente. Entretanto, ao realizar a sua fala, ao final do debate, a professora corre o risco de invalidar, com sua autoridade, as opiniões destoantes da sua ou da maioria da classe. Torna-se populista, ouvindo os alunos para, afinal, tutelá-los. Não é isso que, em geral, ocorre na dinâmica bancária da interpretação de textos?

A intervenção antes, durante ou após a exibição de DVDs é considerada necessária por todos, especialmente quando se trata de vincular o audiovisual a um conteúdo de sala de aula. Entretanto, aqui e ali vão surgindo depoimentos que contradizem a afirmação de que o filme é sempre explorado em debates. Afloram também as dúvidas e controvérsias sobre como as discussões devem ser conduzidas.

A intervenção do professor [...] antes do vídeo, [...] durante a exibição do vídeo e depois da exibição do vídeo, [...] como é que ela acontece? [...] Às vezes eu acho que a gente peca em achar que fala sozinho o vídeo... e às vezes ele fala mesmo. E às vezes até tem que deixar. Mas eu acho que, pensando numa situação [...] pedagógica, eu acho que essa preparação, essa intervenção durante [...] (se couber no durante, porque eu acho que em alguns vídeos não cabe isso), mas, assim, se couber no durante, e no depois, como é que se discute isso depois no grupo de alunos?

- Isso se dilui, [a leitura crítica] se dilui, no dia-a-dia, quando você não faz [...] essa retomada e releitura. Talvez todo mundo segue o fluxo [de sentido proposto pelo filme] porque o fluxo não foi interrompido. À medida que você interrompe esse fluxo, essa inércia, [...] e aí pede só a opinião, às vezes não precisa nem uma análise profunda, crítica, [...] mas só de você saber o que um pensa, o que outro pensa, confrontar as idéias, talvez isso já seja [...]. Agora, se isso não se faz, [...] aí segue mesmo. [...]

- Senso crítico não é espontâneo. Ele até tem a sua espontaneidade. Agora, aí é que é o papel do professor mesmo. O professor é que tem que ter feito essa leitura antes. Por isso que eu não gosto de levar qualquer filme. Só porque eles querem. Eu até posso levar lá algum que eles sugeriram. Mas não é só porque eles querem. Aí, o meu caso como professor de história, [...] eu dou essa prioridade, tem que ter algum conteúdo de história. E o conteúdo também tem que ser analisado criticamente. Como você falou. Aquilo não é a realidade. É uma construção, é uma representação sobre qualquer realidade histórica, mesmo presen- 
te ou que esteja no passado. Ou no futuro, que é o caso do Matrix. O conteúdo tem que ser sim. E quem faz isso primeiro éo professor. Se ele não tem essa segurança, não adianta. Ele tem que ensinar o aluno.

Só pra fechar [minha fala]: a questão dos saberes, o quanto a gente aprende com eles [estudantes] e eles às vezes apontam algumas coisas que a gente não viu [...]. Eu não vou saber falar ipsis literis, mas tem um pensamento do Paulo Freire que fala desses saberes diferentes, é alguma coisa: "ninguém sabe nada, ninguém sabe tudo, todos nós sabemos alguma coisa, com isso aprendemos sempre". Então essa questão da gente estar disposto a aprender com o aluno, porque nós sabemos ler e escrever, a maioria tá aqui pra alfabetizar. Então pressupõe-se que nós vamos ensiná-los a ler e escrever, mas eles trazem tantos conhecimentos que a gente pode aprender, vendo um vídeo, por exemplo, eles podem trazer experiências que a gente não tinha atentado. Então, essa questão de ninguém detém todo o saber, né, são saberes diferentes mesmo que eles podem nos chamar a atenção num vídeo, num filme que nós não percebemos.

A primeira professora reconhece que, nem sempre, os vídeos são discutidos com os estudantes e se pergunta como e quando a educadora deve intervir. A segunda propõe que o fluxo da exibição seja interrompido para que os educandos possam se expressar sobre o que viram e, eventualmente, questioná-lo. O terceiro professor já se posiciona, de maneira firme, favoravelmente à leitura crítica que desconstrua o discurso. Para ele, essa tarefa cabe, em primeiro lugar, ao docente. Este é quem deve conduzir o aluno. Aqui, os papéis da relação ensino-aprendizagem estão muito bem definidos e apartados. É, porém, a última fala, proferida por Luciane, que desata o nó que aprisiona o pensamento de muitas educadoras. Ao assumir a postura de quem sabe tudo, a professora torna-se a responsável por validar as falas dos alunos, sendo necessário, para tanto, que tenha se preparado para a exibição, desvendando previamente "todos" os significados contidos no filme. Como se isso fosse possível! Entretanto, quando se tem a consciência de que os sentidos não são conteúdos fixos e congelados, mas uma interminável negociação, e de que educador e educando estão permanentemente ensinando e aprendendo uns com os outros, é possível adotar uma postura verdadeiramente dialógica e polifônica. Aqui, os discursos nunca são fechados e acabados e os interlocutores possuem igual capacidade de intervenção no debate.

Existe, porém, um problema mais grave do que a postura inadequada nos debates a respeito dos filmes: é o seu uso como "tapa-buraco" ${ }^{167}$, isto é, sem finalidade pedagógica ou recreativa, apenas para ocupar o tempo das crianças e adolescentes quando uma professora falta ou quando há poucos alunos em classe:

${ }^{167}$ Cf. MORAN, J. M. O vídeo na sala de aula. 
- O que me marcou muito [na leitura do texto de J. M. Moran] foi: usos inadequados em aula. [...] O quê que a gente vê? A gente tem um recurso maravilhoso nas escolas e tudo que a gente vê é que ele é sempre usado da maneira mais errada possivel. Tudo errado. [...

- Dá um exemplo.

- Choveu, não tem parque... [...]

- Sempre o tapa-buraco?

- É um tapa-buraco, né? Então quê que acontece? Que mensagem você passa, por exemplo, no nosso caso, nós temos crianças. Que mensagem você passa pra um grupo de crianças quando você vai pra sala do vídeo? Primeiro que o que eles mais gostavam, gostam de fazer é o parque, né? Cê tá levando pro vídeo. Então eles vão ficando com ódio do vídeo porque sabe que o dia que vai pro vídeo é que não dá prafazer uma coisa... porque o vídeo é maravilhoso, mas pra uma criança, muito melhor ficar num tanque de areia, né? Eles adoram o vídeo, por exemplo, pra se ver. E eles têm uma coisa muito interessante, assim, quando vêem um filme, eu sou aquele, eu sou aquele, então a identificação. [...] Cê não consegue nem ver o filme porque uma é a princesa, o outro é um... eles têm essa coisa da identificação.

Eu achei muito interessante uma coisa que, assim, pesquisa há tanto tempo isso. A gente, o recurso tá aí, a gente não usa. [...] A gente tem tanto medo do equipamento na escola, a gente usa de tudo quanto é jeito, menos do jeito que vá acrescentar alguma coisa.

- O vídeo, assim, ele é lazer também. É [...] que a gente tá aproveitando esse lazer [...] pra tá passando informação. Só que a gente faz uma pesquisa na sala de aula, toda criança tem a televisão, tem o vídeo ou DVD. Então, o lazer ele já tem como [...]. Então, a gente quer aproveitar a sala de aula pra ver vídeo pra uma aprendizagem assim bacana. [...]

- Vamos debater um pouquinho esse tema, do lazer e da aprendizagem. Será que uma coisa tá separada da outra...

- Não.

- ...ou as crianças aprendem enquanto estão no lazer também?

- É, só que eu acho errado assim, a maneira que tá sendo usado, por exemplo, [...] às vezes vem pouco aluno, é um feriado então escolhe-se um filme rapidinho pra pôr pro aluno. Daí eles começam assim: "ô, vamos pra sala de vídeo, vamos assistir filme, pega um filme lá?” E daí eu percebo que eles [...] nem assistem. Eles formam rodinhas assim e ficam conversando, certo? Então não tem nem um interesse e geralmente o filme eles já assistiram, porque, sabe, é filme já assistido que eles têm acesso, sim, embora sejam pobres, eles vão a cinema, pega fita, certo?

A fala da última professora ("escolhe-se um filme rapidinho") remete à questão dos acervos audiovisuais nas escolas. Esses, quando existem, são diminutos e qualitativamente pobres. Abrangem normalmente uns poucos filmes didáticos e outros de ficção norte-americana, típicos do circuito comercial. Aqui, o nó não está num juízo de valor sobre a qualidade estética destes filmes, mas no fato apontado pela professora: são filmes aos quais as crianças e adolescentes, de qualquer classe social, têm acesso fácil por meio da TV aberta. Assim, não representam novidade ou interesse e, portanto, não contribuem para a ampliação e diversificação de seus repertórios sobre o cinema. A inexistência de bons acervos escolares de vídeo 
expressa o grau de importância que esse material possui para as educadoras e, sobretudo, para aqueles que planejam e distribuem recursos.

Outro fator que prejudica a escolha de DVDs para exibição aos alunos é o desconhecimento da coleção de vídeos da escola. As fitas e os discos existentes são mantidos em armários fechados, geralmente, na sala da direção ou da orientadora pedagógica, e não na biblioteca, onde poderiam compor uma seção audiovisual, com diversos materiais de referência e informações que facilitassem a busca e a seleção pelas professoras. Eles também não ficam à disposição alunos, para serem consultados, quando necessário.

- Uma outra questão que vocês falaram aí, que eu achei interessante, é de conhecer o acervo da escola. Vocês todas sabem o quê que tem na escola, o quê que não tem?

- Eu não sei, tem algumas coisas que...

- A gente até conhece porque são poucas [...], tem pouca. Aí é o caso, no projeto pedagógico da escola precisaria elaborar o que tem, pedir o que falta [...].

- Falar verdade, eu não tô sabendo nem pedir, sabe? Eu acho assim, eu preciso ter um conhecimento melhor.

$\mathrm{Na}$ falta de acervos adequados e diante da fragilidade das propostas de utilização do vídeo, as exibições acabam se constituindo em uma situação conflituosa entre professoras e alunos. A escolha dos filmes torna-se uma questão de gosto pessoal, a respeito do qual as opiniões nunca convergem. As diferenças culturais nem sempre são compreendidas. Estabelece-se uma queda de braço, onde o mais forte tem a última palavra e decide com base em seus preconceitos:

Os alunos do bairro, assim de periferia, às vezes nunca foram ao cinema, né, não conhecem, não sabem nada.

- Eles que escolhem o filme ou você que escolhe?

- Geralmente eu escolho.

- Você escolhe? Qual o critério?

- Eu escolho, porque se você deixa....... O que eu conheço eu acabo levando. Mas se você deixar pra eles, eles querem o filme de aventura, né, filmes comerciais, e a gente acaba querendo que eles... [...] A gente acaba escolhendo. A mesma coisa música. Você pode até, assim, você faz um acordo com eles: a gente escutar o que eles querem, mas depois, também, numa próxima [vez], é o que a gente quer. Tem que ter uma troca.

[Professoras manifestam-se concordando.]

- E como é que você vê os vídeos que eles gostam e as músicas que eles gostam? O que você acha? 
- O que eles gostam é o que está aí, o que a TV mostra pra eles, né, o que tá aí [...]. Então as meninas que dançavam [...] lá, eles queriam aqueles... eu sei até aqueles... funk lá tudo, né, porque tive que ouvir..

- Já trabalhou uma letra de funk na sala de aula?

- É, já com eles. Aí você tem que ouvir, né, deixar assim na aula. É: tudo bem, vou ouvir o que vocês querem. Nós todos vamos ouvir o que vocês querem, o quê que é essa música para vocês. Aí depois numa próxima aí nessa hora, né, vocês vão ouvir uma... outros tipos de música, né [...]. Eles até, [...] depois, falam pra mim que até que é legal [...]. A gente tem que ouvir outras coisas também.

... Às vezes você tem algum impasse, [...] alguns elementos que convivem no meio de campo, não é tão tranqüilo. E com relação à fita, esse eu acho que é o maior problema. Normalmente, o jovem ele só quer ver filme violento, né? Então essa discussão do consenso do que poder assistir é complicada também. É uma discussão onde os professores às vezes cedem um pouquinho, a direção cede, mas é complicada. A questão do vídeo é uma das questões mais complicadas de se gerenciar, porque sempre a gente quer tá ligando ao pedagógico e muitas vezes o aluno quer somente pelo prazer só de assistir, né? E a escola tem aquela preocupação de tar sempre amarrando alguma coisa ou mesmo com o lazer.

Se você, por exemplo, passa no vídeo ah, um dia que eles tiveram na escola, aí tudo bem, é diferente. Mas se você passa um desenho... [...] Eu brinco muito, tem gente que passa bastante Xuxa, né? [...] Mas aí também eu tava lendo sobre isso, [...] que eu tenho coisas que eu tenho aversão, eu como pessoa, mas eu também tenho que usar aquilo e discutir por quê que aquilo me causa aversão. Ou tentar fazer a criança ter uma visão crítica, estudar. Eu tento fazer isso com meu filho, né, porque eu não tô o tempo todo com ele. Ele tem o controle da televisão nas mãos. [...] Mas são os usos que a gente faz, de televisão, de vídeo, com aluno, com filho, né? A gente tem que admitir tudo isso.

Eu sou professor de história. Não tenho nada contra uma vez ou outra um vídeo como diversão. Pra relaxar mesmo, quer dizer, uma comédia ou muita pancadaria, muito sangue, pra uma clientela entre aspas, favelada. Então o que interessa pra eles é isso, a pancadaria, édrogas, a leitura que eles fazem do vídeo é completamente diferente da nossa, o bandido muitas vezes é o herói deles e não é o que nós pensamos. [...] Pois tem que dar aula, mas não é assim... querem ver educadamente. É um tumulto terrível, se você bobear eles passam pra cima de você. Então você tem que se impor mesmo. Tem que impor, não é, exercer às vezes disso não é ser autoritário. Por quê? Pra eles ficarem só no mundinho deles? Não, minha função como professor de história é ampliar esse horizonte. Agora, a partir de onde eles estão. Não desprezo rap, ou hip-hop ou a pancadaria, ou só filme que tem conteúdo de coisa de periferia, de bandidagem ou Harlem do Nova Iorque, que é o que eles gostam. Que tem muita ação, muita ação, muita ação, pouca reflexão. Eu começo por isso. Mas não quero ficar só nisso. Então quando levo uma aula pra dar através do vídeo, nem sempre eu encaro aquilo como uma complementação. Pra mim a aula é aquilo, é a imagem. Não é uma complementação. É o problema que eu tô colocando e que eu sei que vai chocar. Então aí muitas vezes no começo eu, no jogo de cintura, eu me sentia derrotado, eu não conseguia levar. Mas depois fui insistindo, no ano passado, por exemplo, eu levei Deus e o diabo na terra do sol, que é um preto e branco, não tem ação... Não tem? Até tem, mas não no ritmo que eles tão acostumados. E deu certo, não sei porquê. Porque eu já aprendi a firmeza, depois de tanto tempo com esses alunos. Deu certo. Mas com essa proposta que tá aqui no texto, é análise. Análise não é fácil, não. Por isso que eles não gostam de ler. É porque dá trabalho. [...] Tem atividade que dê mais trabalho do que forçar o cérebro a pensar, a se exercer?

As professoras parecem como que aprisionadas por esta situação, sem encontrar solução para o conflito: deixar os alunos assistirem ao que gostam, mesmo que isso lhes cause "aversão", impor suas escolhas e 
arriscar que a atividade naufrague ou negociar um revezamento? A saída não está em qualquer dessas opções, mas em perceber que a finalidade de exibir filmes é promover a ampliação de repertórios culturais (e não a elevação do gosto dos estudantes) e a apropriação dos elementos da linguagem audiovisual - elementos esses historicamente construídos. É preciso, ainda, compreender o que há de educativo no processo pluralista de tomada de decisões:

- Quando ele perguntou como se trabalha as informações, eu falei: nossa, mas isso é muito tranqüilo! Eu só queria citar um exemplo, [...] que a gente costuma fazer uma programação e todo bom educador procura inclusive selecionar o tipo de filme que vai passar para as crianças, e eu acredito, assim, que entre nós, educadores, nós temos uma certa resistência com essas linguagens que chegam às vezes na sala de aula, porque parece que ela mexe um pouco com a nossa organização, com o nosso planejamento e às vezes a gente...

- Incomoda...

- Incomoda, às vezes, e a gente começa a ter uma certa resistência. Eu não sei se todos, são todos? Mas eu tenho conversado com muitos e isso também em mim era presente e eu fui quebrando isso com o tempo. [...]. Então eu acho que é aí que tá: a gente tentar trabalhar essa informação que ele trouxe para dentro da sala de aula, você não proibir e todo mundo assistir. [...] Mas eu acho que essa é a quebra, essaé a liberdade que os alunos têm, não só os alunos como outros segmentos têm de manifestar aquilo que eles querem, a forma que eles entendem de fazer a leitura de mundo, das coisas que são interessantes para eles né. Com os adultos também acontece da mesma forma. Eu tenho escolhido o filme porque eu tenho dois [...] deficientes auditivos na sala e eu fico preocupada para que elas também possam participar. Mas muitas vezes eles trazem e aí acaba sendo uma coisa legal. Às vezes dá para amarrar pedagogicamente, às vezes não dá e no futuro talvez dá para amarrar. Eu acho assim, é... nós estarmos respeitando e aceitando diferentes linguagens, porque mudou muito, né, o perfil do aluno mudou muito. [...] E aquele planejamento, aquela idéia que eu tinha, né, [...] ela caiu por terra, porque eles tão muito além do que eu esperava.

A compreensão dos diferentes hábitos culturais dos estudantes é importante não apenas para a escolha da temática e do gênero dos filmes a serem exibidos, como também para a análise dos aspectos referentes à recepção (idioma, legendas ou dublagem, ritmo, duração do filme). Os alunos estão mais familiarizados com a recepção televisiva que a cinematográfica. Isso significa que assistem preferencialmente aos filmes dublados, cuja apresentação não é contínua, mas recortada por intervalos regulares. Além disso, a pequena tela numa sala iluminada (costuma ser assim também nas salas de aula) disputa a atenção dos espectadores com outros elementos do ambiente, favorecendo brincadeiras e comentários paralelos. Em vez de lutar contra essas circunstâncias, as professoras poderiam lhes tirar proveito, fazendo pausas em momentos-chave e propondo pequenas discussões. 
- Eu percebi que [...] quando foi [...] vídeo [...] com legenda, eles têm dificuldades, sabe? E eu percebi [...] que uma parte assistiu, uma parte perdia. [...] Não pode ser longo, [...] porque eles perderam o interesse [...]. Mas quando tinha os diálogos importantes, que eles deveriam prestar atenção, se dispersavam. [...] Principalmente no legendado. E no outro, quando não é legendado [...] eu percebi [que...] eles começaram: zuzuzuzuzu... conversava, a gente não escutava também. Porque eles têm um curto espaço de interesse, sabe? Então se é pra passar uma coisa longa, deve passar em duas ou três etapas e nunca passar assim, sem planejamento, não. Eu acho que tem que ter tempo, na minha opinião, pra planejar atividade, porque de quinta a oitava pra banalizar a coisa... daí quando a gente for passar um negócio com seriedade, eles estão tão acostumados nesse tapa-buraco que daí... Eu penso assim. Não sei se eu tô certa ou tô errada... [...]

- [...] Então como nós poderíamos [...] discutir essa questão, [...] do que prende atenção do aluno, por quanto tempo? Daí a gente pensa num vídeo pra criança. A gente repara: pros pequenos o vídeo nunca é [longo]- eu nunca consegui lembrar de algum de duas horas, só pra criança mesmo. A maioria é uma hora e vinte, uma hora e quinze, então, já é menor. Mas [...] imagine pra quinta a oitava, pegar um filme [...] de duas horas, [...] num grupão de colegas que têm vários interesses, pra eles ficarem duas horas sentados assistindo. A gente até discutiu isso, talvez assim, quando for passar um vídeo, um tema, dividir em duas vezes, num dia passa uma parte, no outro dia, retomando, faz uma discussão dessa primeira parte e continua. Porque duas horas, às vezes, o professor quer usar pra matéria. [...] Nem a gente, adulto, conseguia se ater ao conteúdo total. Então imagine os nossos alunos pequenos, de primeira a quarta, e os de quinta a oitava. [...] Que o próprio texto [de Moran] coloca da rapidez dos clipes, da linguagem, quê que mais prende a atenção do aluno? Sempre um pelo menos, na classe, tem, eu achei incrível, aqui tem TV a cabo ou TV paga. Então se um tem, eles combinam final de semana pra ir assistir exatamente os clipes. Então é uma coisa que chama muito a atenção.

- A gente tem vídeos bons, às vezes, mas é legendado. O legendado pra gente é assim: cê tem uma classe lá, tem alunos ótimos. E eles entendem rápido. Mas tem alunos da gente que não entende. Tem dificuldade na leitura. Principalmente do EJA. Então cê já tem que descartar. Não pode, às vezes, cê até acaba emprestando pro aluno, porque o aluno chega: “mas professora, a senhora tem aí? É da senhora?" É meu, porque a gente acaba comprando o material da gente. Então a gente tem que tomar cuidado, principalmente que [...] tem que ser dublado. E também o tempo de duração eu reparei que não pode ser uma coisa longa. Porque fica uma coisa cansativa pra eles.

Uma professora pergunta:

- Mas que série que eles não conseguem acompanhar o legendado? Só por curiosidade...

- [...] Pode ser na sétima e na oitava. [...] E é outra coisa: a linguagem deles. Às vezes a gente pega o vídeo e assiste em casa. A linguagem pra mim é fácil. Pro meu aluno bom é fácil. Mas tem aluno que tem uma dificuldade de entender. Então, depois que cê passou cê vai questionar com eles. Então eles falam: "ai, dona, mas não entendo essa palavra”. Daí volta de novo, para o vídeo. Daí aqueles bom vão de novo, né? [...] Eu falei: nossa, que decepção! Que a classe, metade falou: "ah, oh, dona, tem que ser dublado, não pode ser legend...” Aí cê entendeu? Então eu fico assim. [...]

Outra professora interfere:

- Eu acho que todos nós somos leitores e bons leitores. Agora, eu faço uma pergunta: quantas vezes nós vamos ao cinema e tem cena que a gente não consegue ler até o final porque não dá tempo? A cena é rápida demais e a gente não consegue ler. Ou será que só acontece comigo isso? Eu acho que com a maior parte de nós [olha para a turma que está concordando]. Então a gente também não pode achar, não pode, assim, culpar o aluno, que o aluno somente também não saiba ler. Porque às vezes também não tem o hábito de fazer aquele acompanhamento rápido de ler. 
A agilidade para acompanhar legendas é um hábito cultural que se adquire com a prática. Entretanto, o problema que as professoras apontam também abrange a dificuldade geral de leitura, compreensão de textos e de vocabulário. Durante as sessões da Pedagogia da Imagem, as educadoras voltaram a discussão para o sistema de aprovação automática que, se não foi adotado oficialmente na rede municipal, realiza-se, na prática, por meio de inúmeros mecanismos que dificultam ou impedem a reprovação dos estudantes, sem, no entanto, ajudá-los a vencer as lacunas de aprendizagem. Para além dessa questão, porém, existe o fato de que todo produto audiovisual compõe um sistema simbólico complexo, que supõe diferentes níveis de leitura. A dinâmica de exibição do vídeo, portanto, exige voltar ao material algumas vezes para que os estudantes possam desmembrar esse palimpsesto em diferentes significados - o que nem sempre é feito, pela impaciência dos alunos tidos pelas professoras como "bons" ou pelas limitações de tempo. A solução poderia estar em tornar o material acessível aos alunos, por meio de empréstimo de cópias para estudo:

Tem uma professora que sempre fala isso: pros alunos, seria bem interessante (mas a gente sabe que não é muito real pro dia-a-dia do cotidiano escolar) [...] assistir, ver um vídeo, um filme, o máximo de vezes possível. Porque a cada vez [...] tem uma coisa que eu não tinha percebido na primeira, segunda, terceira, na décima vez. Então imagine pro aluno, [...] várias imagens, informações, falas pro aluno ver e a gente já pedir pra ele uma produção. Sendo que é, assim, uma novidade pro aluno, se o filme é novo, né, que ele nunca tenha visto. [...] Se possível, é estar revendo, antes de solicitar [redações, trabalhos sobre o filme] ou até pra avaliar o aluno [...]. Então essa é uma coisa de estar tendo a possibilidade ou dar a oportunidade, de repente, até, emprestar, combinar com o aluno, olha empresto para um grupinho tá assistindo novamente em casa, na casa de alguém que tem e tal...

Uma segunda forma bastante freqüente de emprego do audiovisual na escola é o registro de eventos e atividades pedagógicas por meio de câmeras fotográficas e, em alguns casos, filmadoras. É o que revelam os dados do questionário aplicado às educadoras: 

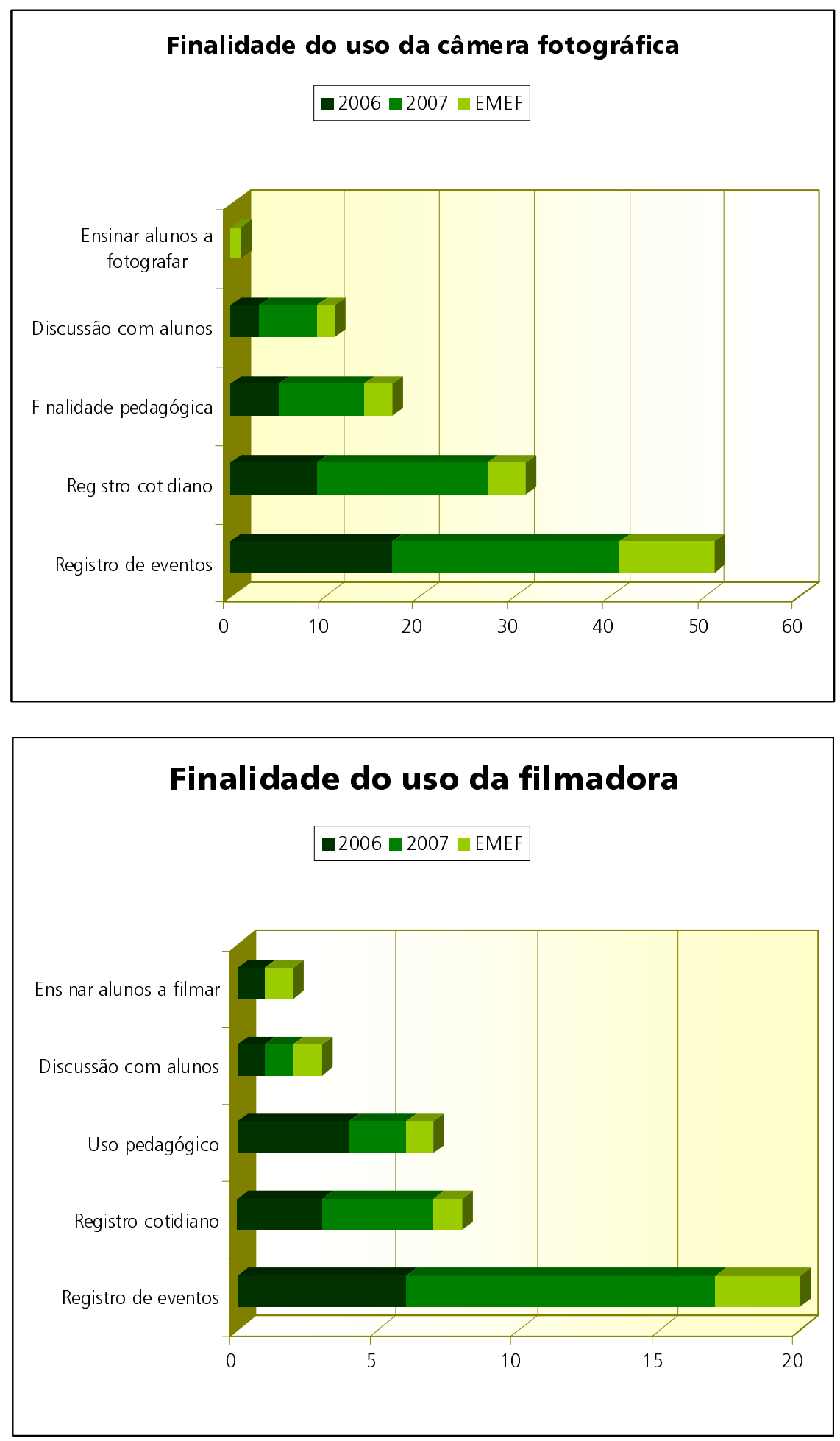

Esses equipamentos, quando são utilizados, destinam-se prioritariamente aos fins de memória das festas, estudos do meio e atividades em sala de aula. Em segundo lugar, vem o uso pedagógico, isto é, aplicação das fotografias e vídeos em projetos específicos ou no ensino de algum conteúdo disciplinar. Esses recursos, entretanto, são raras vezes aproveitados para promover a discussão com os estudantes a respeito 
das imagens e quase nunca para que eles aprendam a fotografar e filmar. Os depoimentos das educadoras reforçam esse uso:

Eu trabalho com educação infantil, e desde que surgiu [...] a máquina digital, eu acho [...] que foi uma das melhores invenções, porque aí não parei mais de tirar fotos. E acho legal tá armazenando. Então na minha escola a gente sempre registra todos os momentos, [...] os mais importantes, principalmente lá em sala de aula, os projetos, os passeios. E tudo que a gente registra em foto, aí no fim do ano a gente faz um CD pra cada criança, depois, levar pra casa. [...] E também eu apresento sempre pra criança tudo que eu registro. [...] Então tem a TV lá na sala de exibição, o vídeo, né, o DVD, e aí eu coloco as imagens, e eles adoram se ver. A gente trabalha [...], eles se sentem [...] valorizados e é uma forma [...], quando eu faço reunião de pais, de tá contando, eles tarem percebendo como que é o dia-a-dia na escola, o quê que o filho dele faz. Porque não é só aquele registro na folhinha não, tem coisa muito mais interessante que eles fazem que aquele registro em folha. E é uma coisa [...] que valoriza também o nosso trabalho, que eu acho [...] que é um registro que fica pra sempre. [...] A gente escreve, mas a imagem, ela tá ali. E fica muito bonito.

Eu lembrei de uma experiência interessante, que no folclore nós [...] formamos um coral de músicas que a gente considera que seja da época. [...] As músicas ficaram muito bonitas e o lanche foi mais ainda. E essa atividade foi filmada. Por isso eu acho [...] interessante aprender a lidar com essa questão da imagem. [...] Na semana seguinte, pelo menos, na minha turma assistiu. Como eles ficam felizes vendo eles filmados!

- Nós filmamos muito as crianças e agora a gente descobriu que dá para projetar no datashow.

- Ah! - fazem as professoras em coro.

- E aí fica aquela parede imensa e a criançada se vendo. Então, não é mais só o recurso de se ver na televisão, né, mas de se ver de uma forma projetada, grande, maravilhosa [...]. E eles ficam assim, extasiados, principalmente as crianças pequenininhas, de 2 anos, de 3 anos. Quando eles se vêem projetados naquele tamanho, numa tela de cinema, eles correm para a parede para se abraçar. [Risos gerais] Então é muito divertido de ver o impacto [...] que causa a imagem e mais ainda a imagem de si próprio, né? E os pais [...], toda vez que a gente faz projeção da criançada, é aquele fuá, aquele auê. Então é muito bacana [...]. As crianças gostam [...] de serem retratadas e de se assistirem muitas vezes.

Eu tenho a minha filmadora, que eu geralmente uso para filmar as crianças no início [do ano], quando elas entram [para a escola]. As atividades que elas fazem... Aí, lá pro meio do ano, eu filmo elas e mostro, pra no final do ano, quando eu converso com os pais, eu tar passando pra eles, para eles verem como que os filhos estão, pra eles se sentirem mais seguros. Porque eu tô com crianças pequenas, tem de três anos, tem que vai completar quatro anos em dezembro. Então, muitas vezes, os pais chegam e não sabem, deixam o filho lá e ficam olhando na porta. Fica triste, achando que vai acontecer alguma coisa terrível com o filho dele, né? Às vezes, o filho já vem chorando. Então, isso a gente vai passar um pouco de segurança pra eles também. 
Embora seja bastante citado pelas professoras, o registro em foto ou vídeo é limitado quantitativa e qualitativamente. Vejamos o número de álbuns produzidos, a destinação dada às imagens e a participação dos alunos nesse processo:

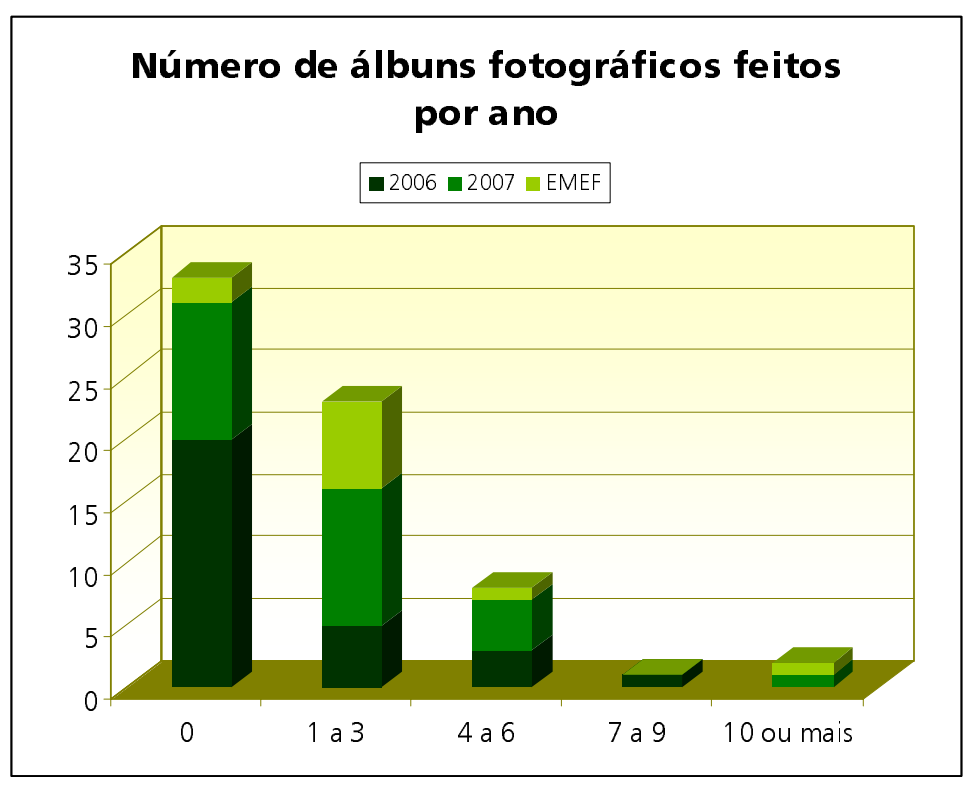

A maioria das professoras pesquisadas não havia produzido "álbuns" fotográficos impressos ou digitais no ano anterior, enquanto as que o fizeram fotografaram até 3 vezes ao ano. Em parte, esses dados podem ser explicados pelo fato de que, até 2006, prevaleciam nas escolas os equipamentos analógicos, que envolviam custos de aquisição de filmes, revelação e impressão das fotos. De 2007 em diante, temos observado que a disseminação das câmeras fotográficas digitais nas escolas e entre as educadoras vem alterando esse quadro.

A destinação dada às fotografias é, em geral, a exposição em murais ou a exibição aos pais durante as reuniões, após o que as imagens são armazenadas, normalmente, sem uma organização e catalogação que permita, futuramente, a correta identificação dos registros. $\mathrm{O}$ mesmo acontece com as fitas de vídeo produzidas. Em raras situações a geração do material está vinculada a um projeto pedagógico. Os debates durante os encontros da Pedagogia da Imagem suscitaram o questionamento dessa realidade:

Uma coisa que é sugerido [pelo texto em estudo] e que [...] eu acho legal tá discutindo, [é] a possibilidade de utilização do vídeo como documentação. [...] Eu parei e fiquei pensando assim: [...] a gente não 
utiliza na escola, na vivência da escola. Ou então utiliza assim: festa junina, apresentação do dia do não sei das quantas, [...] um evento "x" na escola. Aí vai lá a OP, [...] filma tudo e, no máximo, no máximo, na reunião seguinte a gente vê junto esse registro. Ponto. Guarda, isso, [...] na melhor das hipóteses, etiqueta: festa junina 2006, armarinho lá. Então eu fiquei pensando nisso: [...] como é que a gente poderia, e mesmo as fotografias. Em geral, se você for fazer uma pesquisa de como é que é o acervo fotográfico das escolas, assim, se a gente fizer uma rodada aqui, [...] o tipo de fotografia que se tira e que utilização se faz dessas fotografias, cê vai ver [...] que em geral é de evento, [...] na maioria das vezes, e não se utiliza. [...] Daí [...] é só uma questão da gente pensar por que será [...] que acontece dessa forma, [...] como é que a gente muda essa situação.

Em vista desses usos, a participação dos alunos na produção do material audiovisual é reduzida:

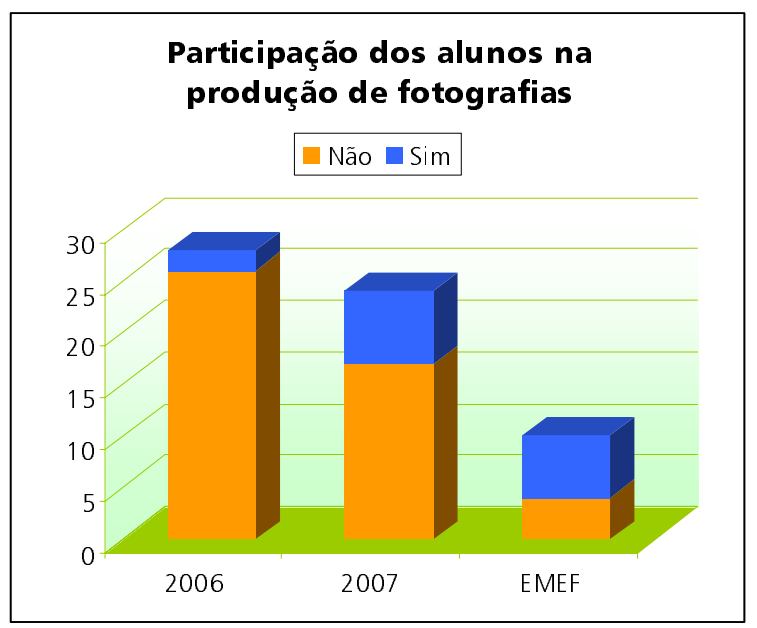

No que diz respeito aos registros e projetos em vídeo, a disponibilidade de câmeras não é um problema para a maioria das escolas e sim o seu uso pelas educadoras. Os dados revelam que o equipamento existente em cerca de $70 \%$ das instituições não é aproveitado:
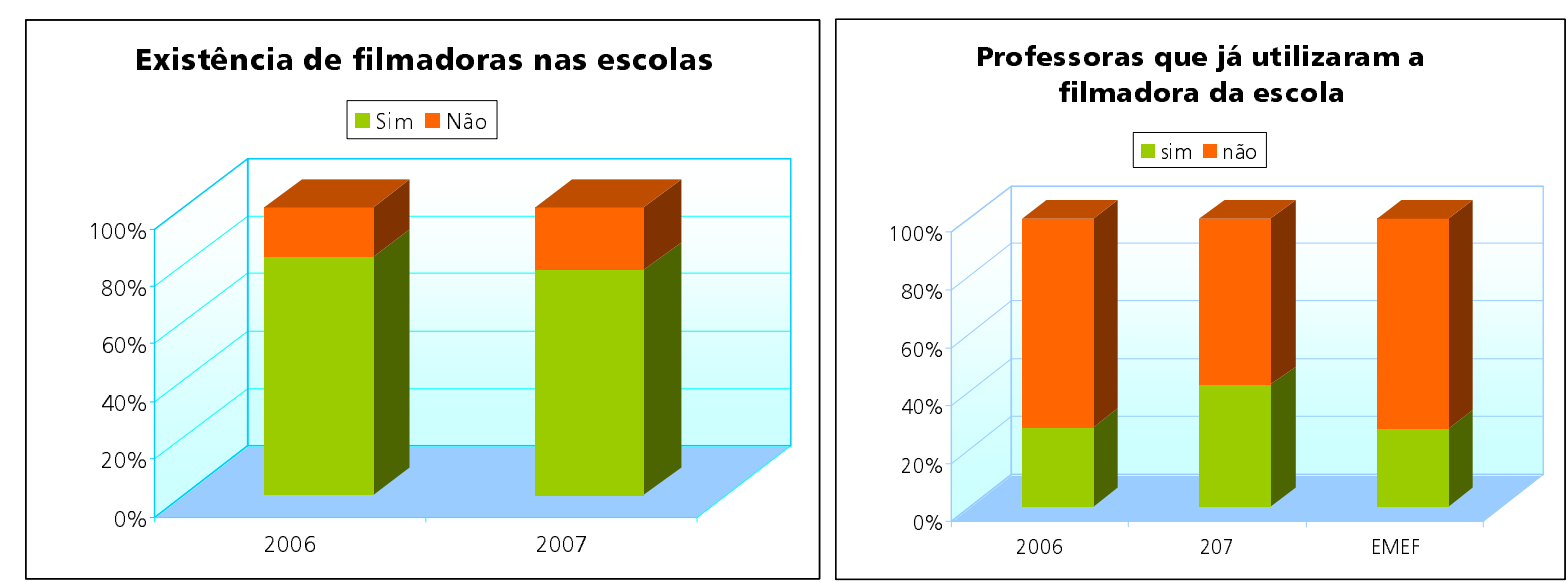

* Obs.: A EMEF Edson Luís Lima Souto possui duas filmadoras: VHSc e Hi8, sendo que esta última nunca havia sido usada. 
Os projetos nos quais esse recurso é empregado têm natureza diversificada. Um exemplo é a história oral das comunidades:

O ano passado eu fiz uma entrevista com a Albertina [moradora do bairro]. Na verdade, o objetivo era a história aqui do bairro [...]. Aí a gente ficou observando [a gravação...] da entrevista, o tom de voz da criança e a resposta da dona Albertina, e que, depois disso, nós fomos visitar a creche e lá ela se expunha [...] com maior desinibição, ela dava melhor o histórico. [...] E nós chegamos à conclusão que no momento de ser gravado, a pessoa fica nervosa e reduz a resposta e que lá, pessoalmente, fora do vídeo, é bem mais produtivo.

A fala da professora demonstra que a filmagem foi empregada sem o conhecimento da metodologia da história oral e das técnicas de abordagem da entrevistada, que poderiam deixá-la mais familiarizada com o equipamento e à vontade para contar sua história em frente à câmera.

Outra possibilidade citada foi a utilização da gravação como "vídeo-espelho" (filma-se a atividade da professora e ela, posteriormente, assiste à própria atuação, com finalidade de estudo, auto-análise e mudança de atitudes e comportamentos):

Eu não usei, eu necessariamente não usei, [...] mas eu já me senti avaliada, [...] uma professora, [...] ela fez mestrado, [...] assistindo às minhas aulas, gravando e logo depois que ela gravava, ela discutia comigo. Então é muito interessante. Porque primeiro cê não se reconhece lá, a voz não é a sua, então é horrível, cê acha assim, nossa! Aí eu vi o tanto que eu falava errr... errr... errr..., né? [...] A postura, entendeu? As coisas que eu falava muitas vezes pros alunos, e que outro aluno tava perguntando outra coisa, sabe? $\mathrm{O}$ tanto que eu ficava [...] atenta a algumas coisas e outras não... Nossa, ela ficou oito semanas na minha sala. Mas da terceira em diante eu fui melhorando, a postura minha diante do vídeo foi melhorando, entendeu? Mesmo porque eu esqueci [que a estava câmera ligada]. Mesmo enquanto professora eu mudei muitas atitudes. Porque é um espelho mesmo, sabe, você fica muito estranha naquilo. É uma coisa muito engraçada. [...] Agora, eu garanto pra vocês, filmar [...] e depois mostrar a gente falando, isso é um aprendizado fora de série. [...] Tinha [...] aluno [...] que ficava uns santos. A minha classe parecia uma classe de anjos porque estava sendo filmado. [...] No início. No início. Eles: nossa, ela tá filmando, então quer dizer, alguém vai mostrar, alguém vai ver. Eles ficavam, eles faziam todas as regras, levantava mãozinha: professora dá licença. No final, eles tavam indo lá, pegando a câmera na mão [...] e filmando o outro. No começo, eles achavam assim, ficava inibido também. Só depois acostumaram.

As colegas que ouviam o relato da professora manifestaram estranheza e desconforto com a idéia de serem filmadas, mesmo para uma auto-avaliação individual. Discutimos com elas as razões de sua inibição frente às câmeras: 
- A inibição do professor [...], será que não tem a ver com uma idéia que diz: o professor tem que saber tudo, o professor não pode ter uma falha, o professor tem que ser perfeito, tem que dar conta de tudo? Será que não é um pouco por causa disso?

- Eu acho - respondeu a professora. Eu acho ou tenho quase certeza. A gente não tem uma noção como que a gente é.

- Essa concepção é uma concepção enciclopédica. Que aquele que ensina tem que ter o controle de todos os assuntos...

- Você não é professora? É assim que eles perguntam. [...] Ou então: Você é professora, vem aqui e explica isso pra mim.

- Então, é, no fundo, uma concepção de que existe uma fonte dos saberes [...] e que você é um veículo de irrigação: você bebeu na fonte e passa a fonte adiante. Quer dizer, é o canal. E [...] não se pensa o saber como um processo que é elaborado coletivamente.

- Não, cê tá certíssimo.

Finalmente, surgiram algumas tentativas de utilização do vídeo em atividades pedagógicas com características educomunicativas, como o protagonismo dos estudantes e ação por projetos. Essas experiências são, ainda, autorais, isto é, criações singulares das educadoras, conforme demonstra o depoimento:

Eu há algum tempo desenvolvi [...] o projeto vídeo-escola, uma criação minha, o meu projeto que deu tão certo, né? [...]. Nós filmávamos, foi feito gravações, foi feito escolha [de] músicas, gravamos músicas, textos, filmamos desenho animado, computador, o aluno fez desenho animado [...]. O tema era sobre a água [e o] meio ambiente. E foi muito interessante, [...] porque a produção deles foi além do que eu imaginava. Eles gostavam tanto de trabalhar! [...] Então foi um trabalho assim, muito diversificado, valeu a pena, foi muito gostoso. O resultado foi excelente. O detalhe, né, que o pessoal já dominava a informática. Então o nosso trabalho era levar o material para a sala de informática, produzir uma apostila, que ficou na escola [...]. Os alunos fizeram um rap sobre a água, foi muito bonito, muito bacana. Eles vestiram de maloqueiro assim com touca na cabeça, dançaram. [...] Eu que realizei esse trabalho, foi muito gostoso. Aí no ano seguinte eu falei, bom, agora falar da água de novo? [...] É cansativo. Aí eu falei, vamos falar sobre a história da cidade de Campinas. Eles conheciam muito pouco sobre a história da cidade. Então visitamos o museu Carlos Gomes, [...] foi filmado fotos antigas, pesquisa de CDs, com músicas antigas. [...] Mas foi muito interessante. [...] A orientadora pedagógica tava acompanhando o projeto, aí dava umas dicas.

O entusiasmo com o sucesso da iniciativa, perceptível na fala desse professor, pode ser creditado ao envolvimento dos estudantes e ao fato de perceber-se autor da proposta educativa. Isso o motiva a dar continuidade ao projeto nos anos subseqüentes e a buscar mais subsídios para seu trabalho na formação continuada. Entretanto, a maioria das ações empreendidas pelas educadoras constitui-se de atividades esporádicas, sem outros desdobramentos no cotidiano das escolas: 
- Eu tenho uma filmadora, agora queria comprar uma melhor, né. Eu tenho aquela grandona, sabe, que põe a fita de vídeo, né, e agora só que máquina digital não tenho ainda. E eu gosto muito de fotografia e de vídeo, sempre gostei, sabe. Embora eu tenha problema visual, eu até que eu acho que eu acerto bem. - Você [...] usa isso com os alunos?

- Não. É, eu já usei sim, na outra escola. Aqui não. Porque eu levei a máquina grande, eu fiz um jornal falado com eles. Filmei, sabe? Eles se assistiram depois, foi muito legal, sabe? Mas foi assim tudo sem técnica. O som era muito ruim, mas eles gostaram. Nossa! Eles viram os defeitos também. [...] Foi muito produtivo. Aqui nessa escola eu não utilizei ainda não. Tem professora que já fez [...] um audiovisual. É muito legal.

Existem muitos fatores que dificultam o desenvolvimento de um trabalho efetivo com os meios e suas linguagens no ambiente escolar. O primeiro é o acesso aos equipamentos de produção de imagem. Embora grande parte das unidades disponha de câmera fotográfica e filmadora, as professoras não têm o hábito de agendá-las para utilização. Preferem trazer equipamentos próprios para ter maior liberdade de ação. Isso parece estar relacionado tanto à escassez de aparelhos e à desorganização de seu agendamento quanto à necessidade de improvisar para responder a situações inusitadas, tendo em vista o caráter nãosistemático do uso da imagem na escola e o desconhecimento das técnicas e metodologias de criação em audiovisual, que envolvem planejamento detalhado, trabalho em equipe e confiabilidade no grupo de apoio técnico (elementos com que a professora não conta).

Nós temos [...] datashow, e tem uma câmera da escola, mas eu uso a minha mesmo.

Eu nunca pego a máquina - pra falar a verdade - da escola. Se eu tiro alguma foto eu trago lá de casa, né? [...] Porque tem uma certa burocracia lá pra pegar a filmadora, pra pegar máquina, né? Tem umas exigências. [...] Mas agora, a partir daqui, [...] eu vou começar, eu também, a correr atrás da máquina [...]. Saber onde é que guarda, onde é que está, [...] para poder estar registrando.

- Lá tem os mesmos recursos. Só que pra usar também é bem limitado.

- Por quê? Quais são essas limitações?

- Então, [...] só tem, ó, uma máquina de foto. Quando você procura você não encontra, porque se você quer num determinado momento, você procura...

- Tem um agendamento?

- Não. Ela fica à disposição. Mas aí tem GTs, então o pessoal, dependendo do GT que está fazendo, utiliza. Então nós não temos...

Ah, olha, falar aula de informática pra eles [estudantes] é tudo! Adoram informática, né? [...] Querem ir pra sala de informática e não vê a hora que chega. "Só um dia?" [- eles perguntam]. Eu falei: "só um dia na semana, porque a escola é grande, então não dá pra ir mais”. 
Depois [a professora...] copia [o texto] pra gente, que a escola não tem xérox. [O marido da professora citada tinha uma loja copiadora à qual as colegas recorriam para produzir seus materiais.]

A inexistência de profissionais de apoio técnico nas escolas também se reflete na falta de manutenção dos equipamentos. Muitas vezes, problemas corriqueiros impedem estudantes e professoras de utilizálos regularmente, comprometendo projetos que dependam dessas máquinas.

- A nossa escola tem uma professora só pra atender computação. É 20 alunos. Menina fica no computador, os moleques ficam tudo sem fazer, aquele dia não. Nossa, hoje as meninas falaram: "amanhã tem computação, amanhã é dia dos moleque, nós vamos fazer o quê, dona?” É, 15 dias! O que você vê no computador? Quebrado, quebrado, quebrado! Quebrado assim: um é mouse, o outro é do deficiente, mas não foi ligado, o outro é... é absurdo!

- Manutenção. Problema de manutenção. Será que o dinheiro do conta-escola pode ser usado pra isso? Outra professora, da mesma unidade, completa:

- Deve ter uns 20 computadores e alguns estão com problemas e os da educação especial, que [...] não é pros outros usarem mesmo. Mas como ainda não tá instalado, o aluno [... especial] senta em qualquer computador [não adaptado].

Os empecilhos se estendem às condições gerais da escola, marcadamente a inadequação dos espaços físicos para o desempenho de atividades extraclasse. Nota-se que, na maior parte dos casos, as construções foram estritamente planejadas para atender alunos nas salas de aula, sem considerar a possibilidade de haver ambientes de encontro e trabalho em grupo, auditórios, anfiteatros, salas multiuso. Vemos também que muitas escolas abrigam mais estudantes do que a sua capacidade, organizando as turmas em quatro turnos sem intervalos (das 7 às $11 \mathrm{~h}$, das 11 às $15 \mathrm{~h}$, das 15 às 19 e das 19 às 23h). Conseqüentemente, as crianças e adolescentes só podem permanecer ali no estrito horário das aulas.

- Sou professora de quarta série, no Francisco Ponzio Sobrinho. É uma escola pequena, não tem espaço físico, é só sala de aula. Então fica bastante difícil trabalhar só dentro de sala de aula. Até pra Educação Física nós somos obrigadas a sair da escola pra ir num local pra fazer uma atividade física. [...] E, então, o trabalho é totalmente feito dentro de sala de aula. [...] Biblioteca pequena, não tem computador, não tem nada. Então eu acho assim que a gente precisa dinamizar alguma coisa além do que eles possuem. É pouco: livro didático, [...] livros de história e eu sempre levo jornal, a gente procura analisar as fotografias do jornal, o quê que tá aparecendo... Mas é só o que nós temos. Então o motivo da minha vinda é ver se eu consigo dinamizar. Se conseguimos fazer alguma coisa a mais pelos alunos da escola. A escola é boa. [...] Infelizmente é o espaço físico mesmo que prejudica a escola.

- E os equipamentos? Tem lá na escola câmera? 
- Nós, não. O que nós temos é só uma televisão que é colocada em um carrinho e que a gente leva pra sala de aula, pra eles poderem assistir filme, né? A gente faz comentários, faz trabalhinhos com eles, [...] mas não tem equipamento nenhum.

- Nem laboratório de informática?

- Nada. Não tem espaço físico pra nada.

- Em que bairro é sua escola?

- É no Jardim Santa Odila. É na Rua Abolição [... curiosamente, a escola não fica muito afastada do Centro, e o bairro onde se localiza não é dos mais carentes de Campinas].

Eu [...] sou professora de Ciências, pertenço à escola Maria Pavanati Fávaro. Ela é no Jardim São Cristóvão, é próxima ao aeroporto. É uma escola bem distante e é uma escola também que nós temos pouco espaço físico e trabalhamos em quatro turnos. Nem dá pra ventilar a escola: sai uma turma entra outra. Começa às sete, termina às onze.

Batata estava sugerindo uma certa atividade cultural:

- Então, isso pode ser feito numa sala de aula, ou na quadra, ou no anfiteatro da escola nova, que cabem 500 alunos.

Risos e comentários coletivos desconcertam o interlocutor:

- Não tem um anfiteatro?

Esse tipo de espaço não fora incluído no projeto de uma escola recém-inaugurada.

A organização dos espaços privilegia os momentos de aula, relegando as atividades culturais ao segundo plano. É assim que bibliotecas, salas de vídeo e de informática deixam de ser vistos como requisitos básicos para o funcionamento de uma escola e, sempre que surge uma emergência, esses locais são transformados em depósitos provisórios, desativados por um longo período. Os projetos extraclasse também são os primeiros a serem interrompidos, quando a rede decide reduzir custos.

Agora nós estamos com um problema lá, de não poder usar a sala de vídeo. Então, este ano, por enquanto, não usamos. Mas eu pretendo retomar. Assim que a sala for liberada eu pretendo retomar as atividades.

Essa cultura popular, ela acontecia, assim, no contexto da escola, mais praticamente no projeto Escola é Nossa, que é uma pena que esse ano não tá acontecendo né? Então, assim, até o ano passado, nós tínhamos lá pessoal do hip hop, do rap, o que mais? Do teatro, [...] entre outros. E esse ano até agora não está acontecendo, e os professores que tinham jornada especial, que também agora [...] não temos... Então, assim, os eventos da escola, até o ano passado, nós tínhamos a colaboração desse pessoal do Escola é Nossa, né? E agora ainda tá mais restrito, vamos ver como vai ser.

O modo como são reguladas as horas de trabalho das professoras é um fator gerador de ansiedade e, às vezes, desespero. As educadoras manifestam que lhes falta tempo para desempenhar atividades que elas tomam como necessárias, e se angustiam por não saber como produzi-lo. 
Geralmente, quando eu levo um vídeo, eu levo para dar aulas. E nunca dá tempo, porque não tem carga horária [...] que dê um filme inteiro. Então é pedaços do filme mesmo.

Eu fico imaginando como que eu vou dar conta de toda a informação de documentação do meu dia-a-dia, como que eu tenho que me organizar, que tempo que eu vou ter, né? Quê que eu posso tá fazendo pra eu contar, de repente, [em] cinco minutos, o que aconteceu num dia de aula? [...] Como é que eu vou? Então isso que fica me mexendo comigo também. Porque é tanta informação que chega uma hora que dá um desespero, cê vai se afogar, né? Mas é possível.

Eu não dou conta de dar aula em três horas e meia, eu não consigo, tem que ser sete horas de aula. Eu dou aula pro terceiro ano, antiga segunda série. Tenho alunos de oito a treze anos, não alfabetizados, 100\% pra alfabetizar, dois deficientes auditivos, um mental, vários outros com neuros e neuras, e tô chegando na escola nova, sem carteira, sem cadeira, marcando um teste pra amanhã. Tô no setor de reabilitação da Prefeitura. Querem me tirar da sala de aula, eu tô lutando pra não sair [...] e tô nos nervos...

Nesse contexto estressante, a professora sente-se desestimulada a envolver-se em projetos extraclasse.

Quando uma colega solicita ajuda, em vez de solidariedade, encontra o isolamento:

- Olha, engraçado, que eu falo assim: alguém quer participar do projeto? [...]

- Mas você era professor de língua portuguesa [...] e tava trabalhando com um tema que envolvia ciências, envolvia geografia... e esses professores? Se envolveram? [...]

- Não, alguns falavam assim, né: você tá ganhando pra isso. Você tá ganhando pra isso. [O professor insistia:] "Olha, você não quer participar do projeto? É engraçado, é interessante, ajuda os alunos, né, é uma pesquisa”.

Apesar do apelo, ninguém quis auxiliá-lo.

O desenvolvimento de ações educomunicativas esbarra, ainda, em outro tipo de obstáculos: as contradições e resquícios de um pensamento autoritário e arbitrário:

A realidade é complicada. [...] Tem alunos que não tem o que fazer mesmo, que a solução não é dentro da escola. Isso é um outro problema, não é a escola que vai resolver.

Batata perguntava às professoras sobre o uso dos equipamentos de vídeo e foto. Diante da negativa da maioria, que mencionava apenas a realização de festas, disparou o que era para ser uma piada:

- E a palmatória, quantas usam? E não é um material exótico...

- Está em desuso - disse uma professora, ao que uma outra emendou:

- Devia ser retornado, porque está difícil. Na minha escola nós fazemos isso também.

- Palmatória ou...? - Meio espantado, Batata saiu-se com esta e arrancou risos gerais. A professora não se conteve:

- Infelizmente não. De fazer festinhas com eles, sabe? De ah... fazer a festa do dia dos namorados [...]- e sua contradição espantou a todos:

- Pode? 
- Pode. Isso, qualquer motivo, né? Páscoa... Qualquer motivo é motivo para... para eles estarem em festa. Então nós temos o aparelho de som, eles trazem os próprios CDs, então a gente faz [...] um pouco [...] de cada ritmo, porque senão todo mundo quer só escutar o mesmo. E eles dançam, e nós temos coral, apresentação de coral. Nós temos um coral em Inglês, que a professora de Inglês ensaia, então todo evento há uma apresentação de todos os projetos da escola, inclusive o projeto de dança do ventre que tem na minha escola, muito bonito. [...] Então a gente faz muita festa. Dá aula também. Mas dá muita festa também. Que eu acho que isso é o convívio. É importante para eles e para a gente também.

O projeto alimentar foi um projeto [...] maravilhoso que nós fizemos, porque a necessidade de mudar tudo aquilo que as crianças não tinham hábito alimentar, higiene [...]. Aí foi sentado com a equipe gestora tudo para mudar aquela... Aí veio uma idéia de uma professora de colocar música ambiental, música ambiente para refeição. Aí cê conversa com o aluno, lógico que ele não vai querer Bach e Beethoven, né, ele vai querer as músicas da praia dele. Aí a $5^{\text {a a }} 8^{\text {a }}$ foi mais resistente, mas conseguiu: "Olha, a música de vocês vai ter o dia para ser ouvida essa música. Mas, na refeição, vocês vão ouvir música que vocês não conhecem". Aí o diretor da noite, do jovem e adulto, ele fez uma coisa sui generis, que eu achei bárbara: aboliu o sinal. O sinal era uma música. Na hora de sair pro lanche era uma música, e não era música deles, que eles tinham um dia da música deles. Todos tinham: $1^{\mathrm{a}}$ a $4^{\mathrm{a}}$, todos tinham o dia da sua música, o dia que cê podia trazer o seu $\mathrm{CD}$, mas tinha o dia que eles tinham que ouvir músicas diferentes. Eu achei que não ia funcionar. Imagina o adulto tocar música para ele entrar. Mas ele preferia ouvir aquilo do que aquela sirene, né? Então foi uma coisa fantástica.

As falas deixam fluir, despercebidos pelas professoras, modelos autoritários de pensamento. A primeira sugere que certos problemas de comportamento dos estudantes são casos de polícia. A segunda se perde entre a intenção de demonstrar um pensamento liberal (as crianças podem comemorar o dia dos namorados, aprender dança do ventre e participar de muitas festas na escola) e o desejo de reprimir e disciplinar os alunos. Além disso, coloca em oposição momentos que deveriam ser complementares na sua função educativa - a festa e a aula. Por sua vez, a terceira retrata a atitude típica do "invasor cultural", na medida em que, ao ignorar por que um grupo age de determinada forma, e julgando-o inferior a si, determina que ele não possui cultura, hábitos alimentares e higiene e que, por isso, deve incuti-los às crianças. Ainda, encanta-se com um artifício "suave" de exercício de controle (a música que substitui a sirene), sem se dar conta de que o essencial não foi alterado (os estudantes não conquistaram qualquer autonomia sobre a decisão de entrar ou não na classe, nem podem escolher o que desejam fazer).

Finalmente, para incorporar crítica e dialogicamente os meios e suas linguagens em sala de aula, a educadora tem que vencer o obstáculo da falta de formação específica, que concilie a teoria e a prática: 
-Eu gosto e não sou formada em nada. Tô fazendo na verdade uma especialização na Formação de Professores em tecnologia, mas é na parte pedagógica. O pouco que eu sei de tecnologia prática é aprendendo, não fiz curso. Esse vai ser o meu primeiro curso oficial. Porque à noite é só teoria. [... É é um curso de Pedagogia, a gente trabalha tecnologia e educação, mas é a parte teórica e pedagógica mesmo e não técnica. E vou adorar aprender então algumas coisas com vocês. [...]

O curso que eu fiz - que eu fiz de Letras, na parte de Literatura - a gente não trabalhava com imagem. [...] Então tá faltando um pouco introduzir essa parte tecnológica.

Quando e como foram formadas essas professoras e quais os seus hábitos de uso das tecnologias de informação e comunicação é o que procurei descobrir com a aplicação de um questionário. Os dados coletados me auxiliaram a compor seus perfis profissionais e socioculturais.

\subsection{Revelando os perfis profissionais}

Responderam ao questionário 79 participantes do curso Pedagogia da Imagem (respectivamente, 35, 32 e 12 pessoas, nos anos de 2006 e 2007, no MIS e na EMEF Edson Luís Lima Souto). A pesquisa revelou que as educadoras, em sua maioria, estão na metade final de sua carreira. São, geralmente, mulheres (a média de homens é de 2 por turma) acima dos 45 anos (tivemos algumas na faixa dos 60), que ultrapassaram os 15 anos de exercício profissional (parte delas está mesmo próxima da aposentadoria) e cuja formação não abrangia as linguagens audiovisuais (pouco mais de 50\% dos casos). Vejamos:

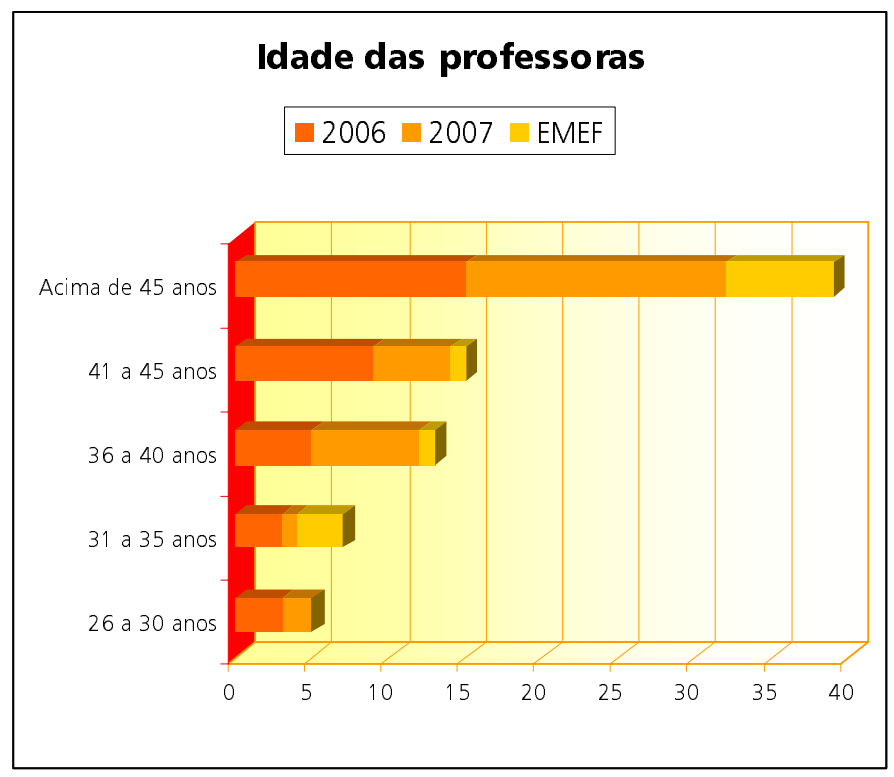




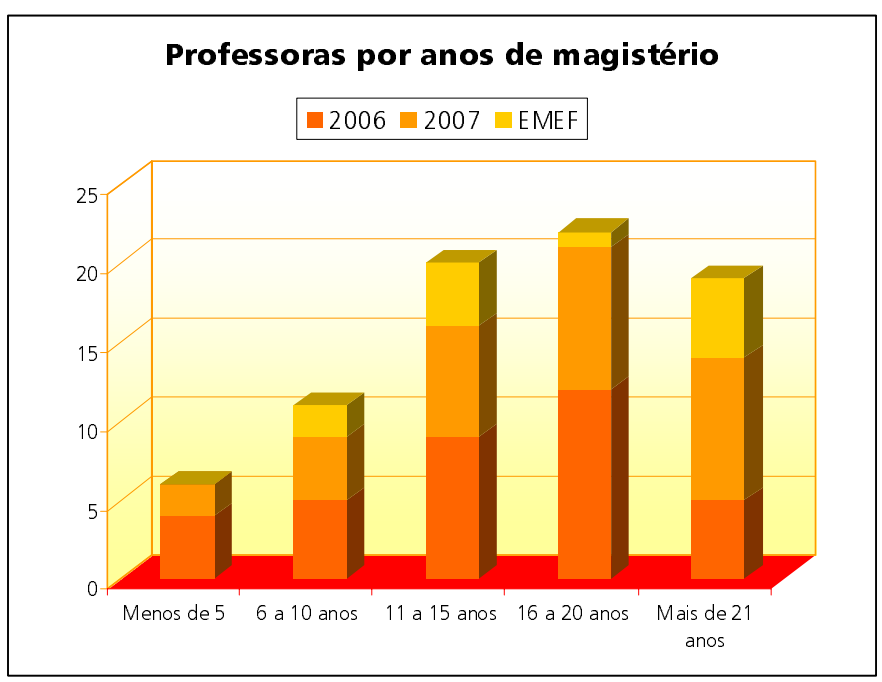

Apresentamos os resultados do questionário às professoras e realizamos um debate para que os dados fossem contextualizados. Indagamos a razão da procura por cursos de formação continuada por educadoras com tantos anos de magistério. Seria pela composição dos quadros da rede municipal, formada por contratações mais antigas, ou porque as recém-formadas e concursadas não sentem logo cedo a necessidade de retornar aos estudos? As respostas que obtivemos incluem fatores pessoais, institucionais e de legitimação. Segundo as participantes, quando mais jovens, dedicam-se mais à família e aos filhos pequenos, não dispondo de tempo para investir na formação em serviço. Para algumas, a forma de divulgação dos cursos é limitada e, ao entrar na rede, as educadoras desconhecem as opções e serviços que estão à sua disposição. Somente com o passar do tempo vão ganhando desenvoltura para usufruir desses direitos. Outras lembraram que os concursos públicos para o município têm um grau alto de exigência, favorecendo a entrada de docentes com maior experiência e, portanto, idade mais elevada. A estabilidade e certas características da rede municipal, em contraponto à estadual, estimulam as efetivas a permanecerem até sua aposentadoria. Finalmente, apontou-se o problema da credibilidade dos cursos de formação oferecidos pelo Ceforma e a necessidade de se ter referências antes de investir em uma formação.

- Geralmente a pessoa acaba procurando quando os filhos cresceram um pouco e podem voltar a se aperfeiçoar.

- Também. [...] Isso também é uma outra possibilidade que não permite que... [...]

- Eu acho que esse ano, o que contribuiu um pouquinho pras pessoas se mobilizarem mais pra tá fazendo os cursos foi a maneira como eles foram organizados, como eles foram oferecidos - esse curso e os outros. Então a gente percebe que vários colegas, várias pessoas se mobilizaram pra fazer. Nos outros anos tiveram os cursos, eu participei de alguns cursos, foram oferecidos, sempre foram oferecidos. Só que esse ano, particularmente, eu acho que foi feito de uma maneira mais organizada. Então dá impres- 
são, né, e assim, deu mais credibilidade, as pessoas começaram também a um contaminar o outro, um contar pro outro, esse curso especificamente já é um curso que tem tradição, né? A gente já ouviu falar... tem curso que fica todo mundo assim, sem saber se vai, se não vai. Agora tem cursos que cê já ouviu falar, já sabe que tem retorno. [...] Agora quanto à idade, né, que é isso que cê perguntou, eu acho também que porque agora que a gente também com esse tempo de magistério que a gente também consegue [...] desfrutar do que tem na rede. Porque é o que a Eliete falou, de repente antes, não só os filhos, mas uma série de outras situações do trabalho mesmo...

- Dentro também não é informado...

- Não.

- Isso, exatamente, a gente fica perdido. Então eu mesma. Eu acho que agora é que eu tenho um pouquinho mais de desenvoltura, assim, na rede. [...]

- Agora, por que tem mais professores, dois terços, né, com mais de quarenta anos, é isso?

- Não só mais de quarenta anos, mas também com um grande número de anos no magistério da prefeitura.

- Isso tem a ver com a estrutura legal mesmo. Professora se aposenta com 25 anos. Mas como em 98 mudou...

- Isso, isso também.

- ...não é só os 25, tem que ter também a idade mínima. Então, o seguinte: na rede é muito difícil você entrar como professor efetivo. Por quê? Concursos tem. [...] É difícil entrar, os concursos são muito concorridos e apenas poucas vagas. Porque não é uma rede tão grande assim. Por exemplo, de $5^{\mathrm{a}}$ a $8^{\mathrm{a}}$ série, se não me engano, por volta de 30 escolas que têm $5^{\text {a a }} 8^{\text {a }}$ série. E geralmente, no meu caso, sou professor de história, é um ou no máximo dois por escola. Se tem dois, você não consegue completar a carga horária porque não tem tantas classes assim. Até na minha escola, não é que a gente tá com superlotação, porque nós resistimos, nós, essa é uma rede que tem uma dinâmica própria. Ela não é a mesma rede do estado.

- Isso é verdade. É fato.

- E nós, qualificação dessa rede, [...] é alta. O que tem mestres e doutores dando aula pra quinta a oitava série ou ensino infantil ou de $1^{\text {a a }} 4^{\text {a }}$, é muito grande. Então a capacidade de resistência [...] a certas políticas que querem nos impor à força é grande. E porque tem uma vantagem qualitativa. Como é em menor escala, a gente sabe quem é o secretário que está - atualmente, né, porque a rede fica, os secretários vão e vêm. As administrações vão e vêm, mas a rede fica. Ela tem essas instabilidades. Primeiro, porque quem começou a dar aulas 20 anos atrás não vai: geralmente continua, porque vai ficar até se aposentar. As vagas são poucas.

A quase totalidade das professoras possui nível superior, mas, apesar de seus muitos anos de magistério, um número elevado graduou-se após 1991. Na amostra, são poucas as que possuem pós-graduação normalmente, especialização ou mestrado. 

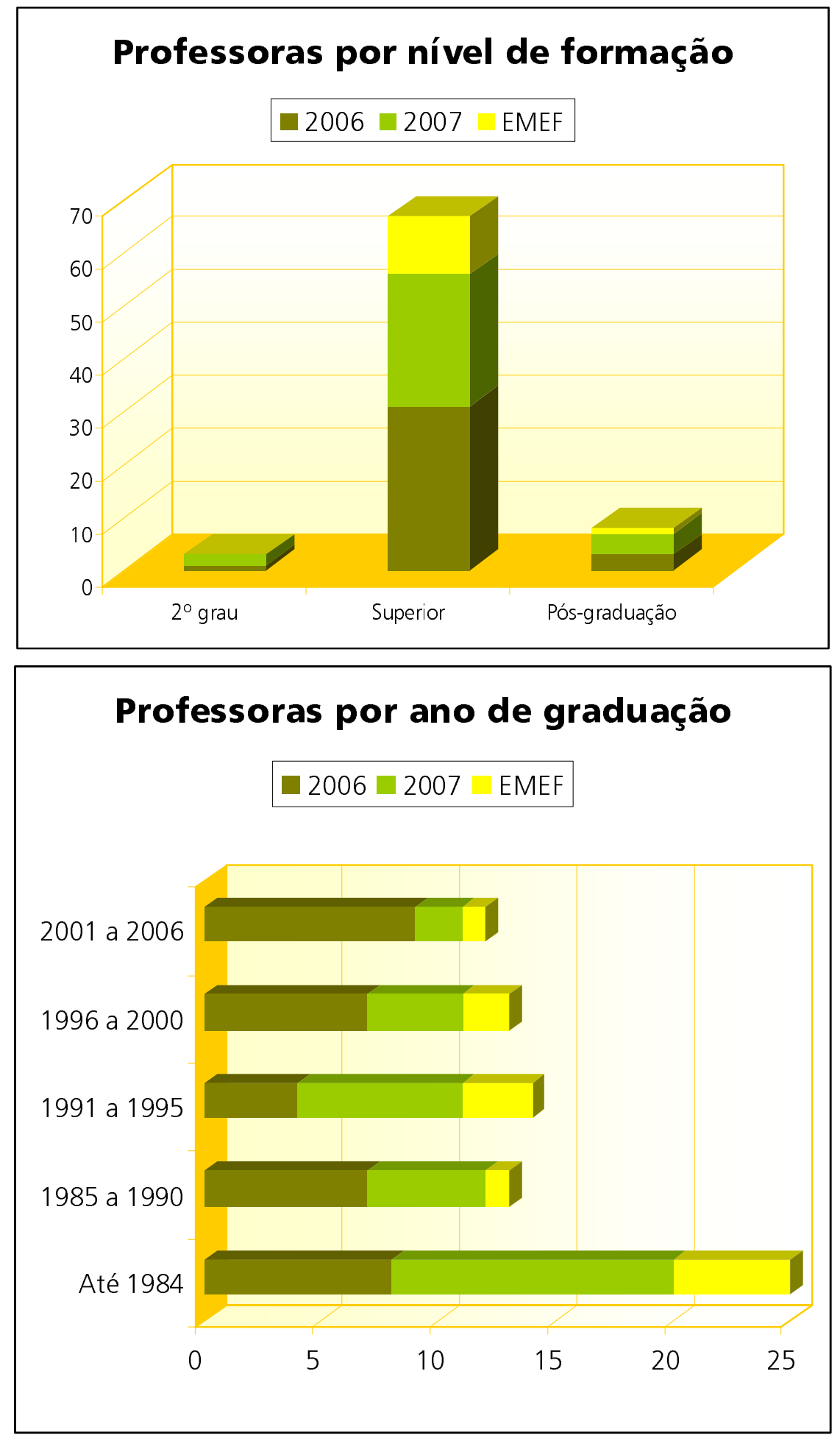

A graduação relativamente recente pode explicar por que quase metade delas afirmou ter recebido algum tipo de formação em linguagens audiovisuais. As mais citadas são artes, vídeo/ TV e informática. No caso do vídeo, os dados referem-se, geralmente, à exibição e não à produção. Fotografia, rádio e multimídia são as linguagens menos presentes na formação das educadoras entrevistadas. 

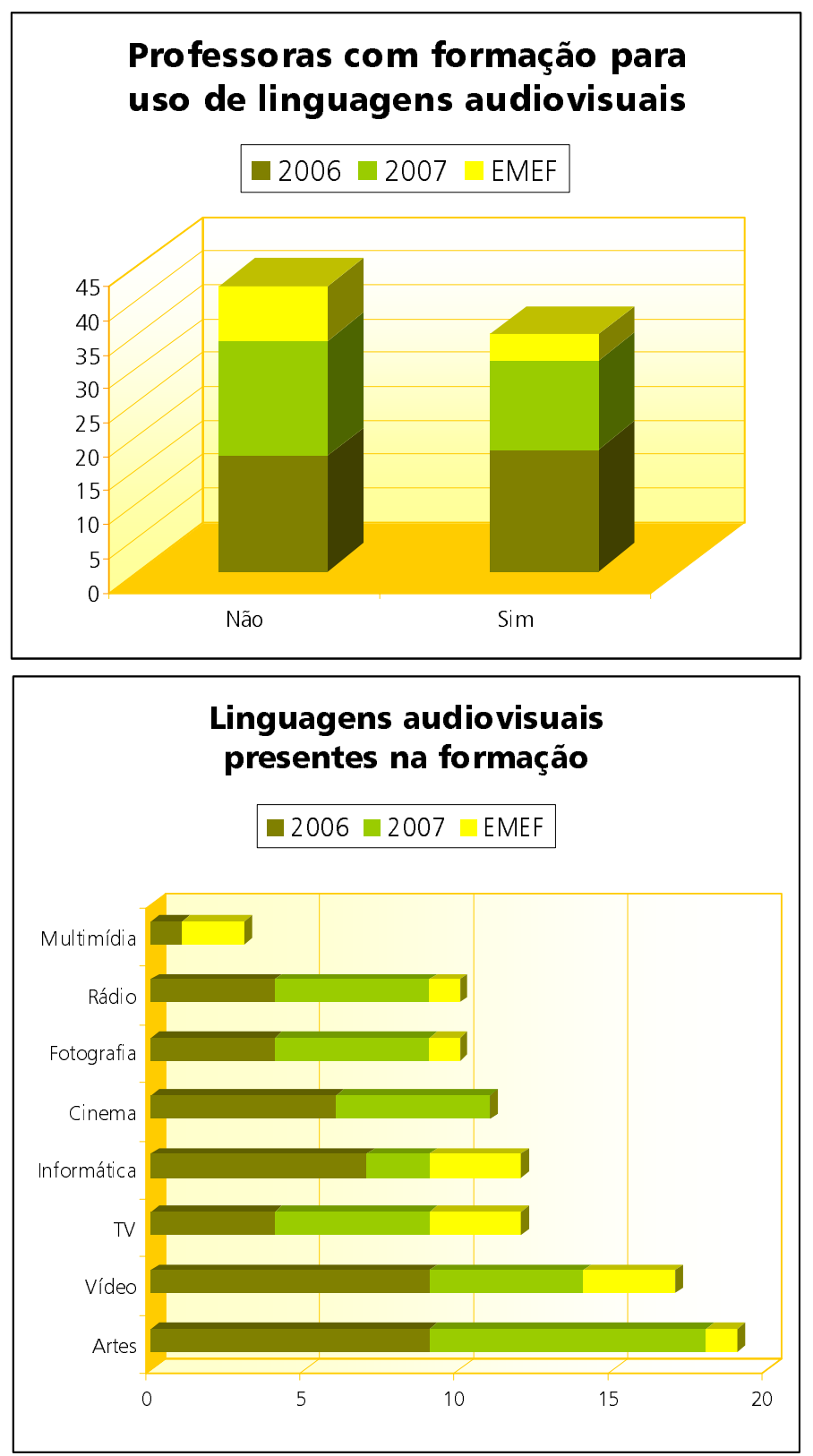

Algumas professoras formadas a partir de 1991 tiveram a oportunidade de experimentar a produção de vídeo durante a faculdade. Suas idéias inovadoras e iniciativas de mudança encontram resistência no espaço escolar, onde precisam negociar pacientemente com as mais antigas, que não dominam a técnica do audiovisual, mas dispõem de prestígio e influência sobre o grupo:

- Durante a graduação, a gente tinha um pouco isso [produção de vídeo] e daí quando eu fui trabalhar com as crianças aí eu quis lançar mão, mas a resistência era tão grande no grupo que eu participava que eu fui deixando de lado. A ponto de chegar no dia da apresentação do dia das mães e a diretora falar: "não, cê não vai apresentar". [...] Então, assim, isso foi me tolhendo demais. Ano passado eu tentei, eu queria fazer um DVD pra dar de presente pros pais, também fui tolhida. [...] Eu falei: "não vai custar nada”, mas assim, as pessoas não querem nem ouvir você falar. E assim: ou faz pra escola inteira ou não vai 
fazer pra uma sala só. Então é um movimento. E tem que respeitar, e tem que esperar. Que agora, graças a Deus, as pessoas tão se abrindo pra isso. Tem que esperar, né?

- Por isso que eu acho interessante quando tem diretoras, orientadoras, vices, aqui no Pedagogia, porque, geralmente, quem participa aqui leva pra escola esse outro...

- Mas mesmo quando tem diretora, às vezes, cê vai encontrar grupos de professores que vai achar [...]: "ah, por que a diretora tá querendo cobrar da gente?" Às vezes é até pior: a diretora, às vezes chega, quer dar a idéia, vai achar que é cobrança, né? Então, assim, a gente tem que ter paciência, vai chegar um tempo em que vai dar tudo certo.

Nas turmas de 2006 e da EMEF Edson Luís Lima Souto, prevaleciam as professoras polivalentes (educação infantil e primeira fase do ensino fundamental). Na classe de 2007, houve um equilíbrio entre estas e as especialistas em disciplinas (segunda fase do ensino fundamental).
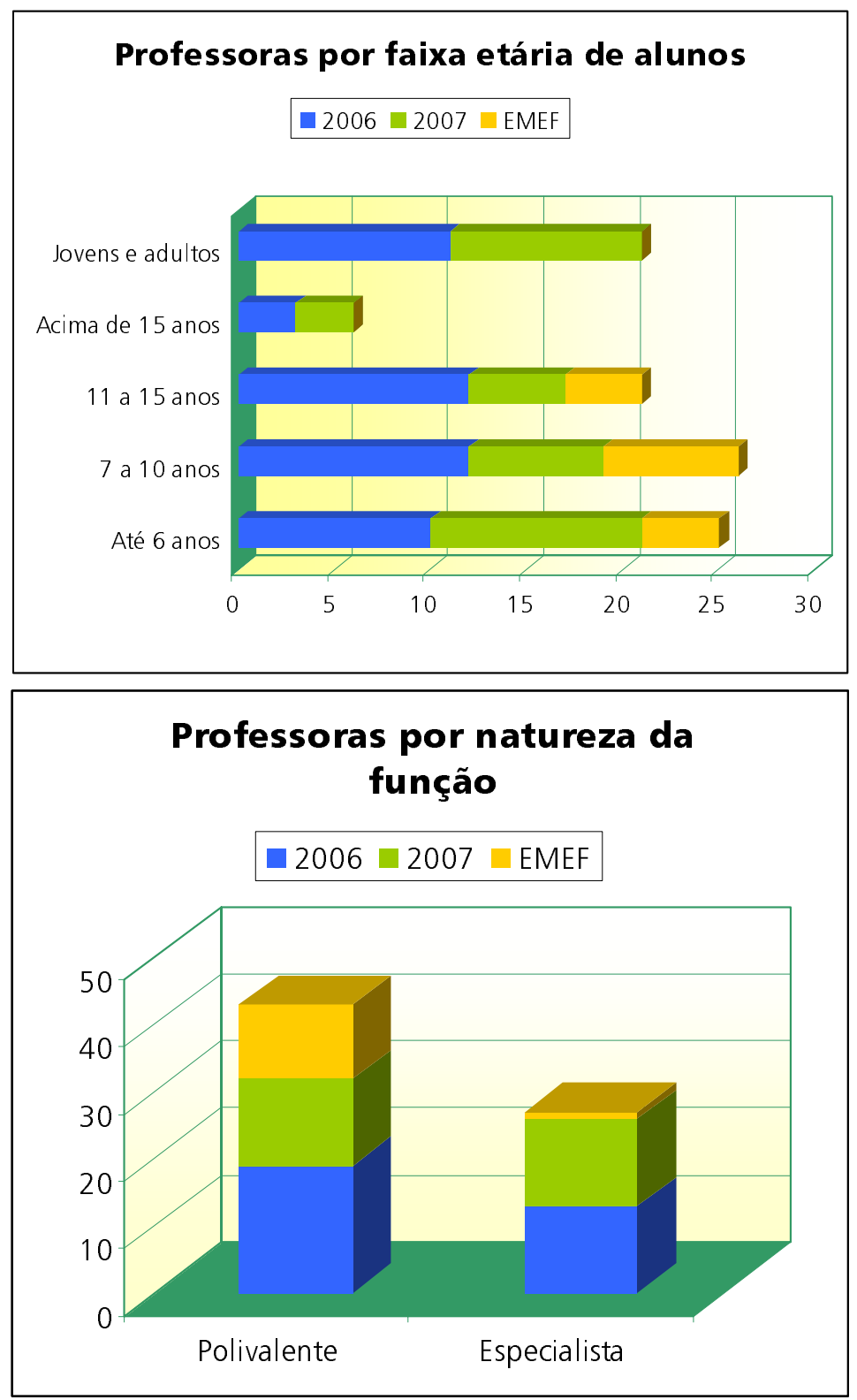
Tomando como base os dados apresentados, pode-se concluir que, na sua formação inicial, as professoras ingressantes na Pedagogia da Imagem não tiveram oportunidade de incorporar os meios de comunicação e as tecnologias da informação à sua metodologia de trabalho. A maioria foi desenvolvendo os hábitos de uso dessas linguagens na fase adulta e na maturidade. Foi preciso que elas se adaptassem, ajustando suas antigas práticas a uma nova realidade tecnológica - algumas com maior desenvoltura que outras. Os alunos com quem trabalham, ao contrário, nasceram e vivem em um mundo onde essas mesmas tecnologias fazem parte do cotidiano. Os equipamentos digitais, com sua organização e seus conteúdos específicos, estão intrinsecamente relacionados aos seus modos de lazer, informação e estudo. Pareceu-me delinear-se, aí, um provável choque cultural. A investigação dos perfis socioculturais das professoras ajudou-me a compor mais detalhadamente esse quadro.

\subsection{Práticas de consumo cultural}

Em relação aos hábitos culturais, pesquisei a audiência de TV e de rádio, uso de videocassete e DVD, o domínio da informática, o uso da Internet, a freqüência ao cinema, teatro, a leitura de jornais, revistas e livros e a produção de imagens em fotografia e vídeo.

a) o uso da TV

\begin{tabular}{lccc}
\hline \multicolumn{4}{c}{ Professoras que possuem TV } \\
\hline & 2006 & 2007 & EMEF \\
\hline Possuem & 31 & 31 & 10 \\
\hline Não possuem & 1 & 0 & 0 \\
\hline N/responderam & 3 & 1 & 2 \\
\hline
\end{tabular}

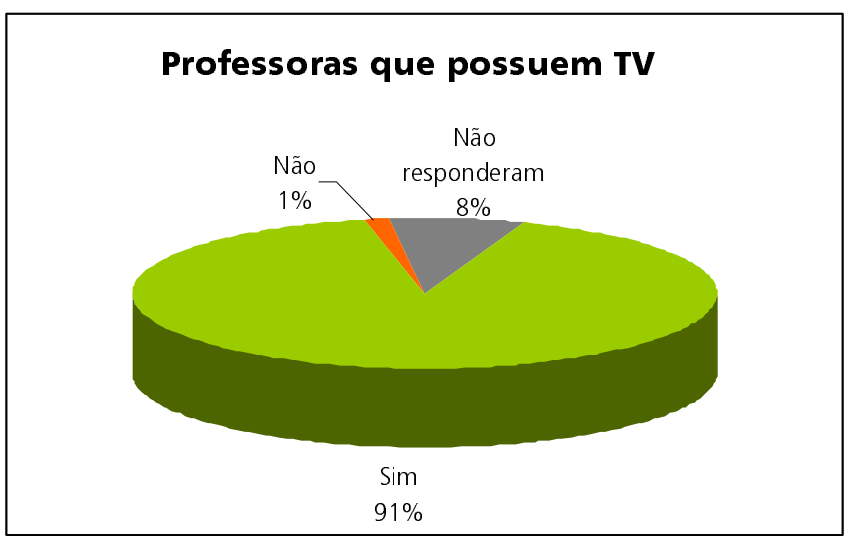




\begin{tabular}{lccc}
\hline \multicolumn{4}{c}{ Número de aparelhos de TV } \\
\hline & 2006 & 2007 & EMEF \\
\hline 1 & 9 & 10 & 5 \\
\hline 2 & 10 & 10 & 3 \\
\hline 3 ou mais & 12 & 11 & 1 \\
\hline N/responderam & 4 & 0 & 2 \\
\hline
\end{tabular}

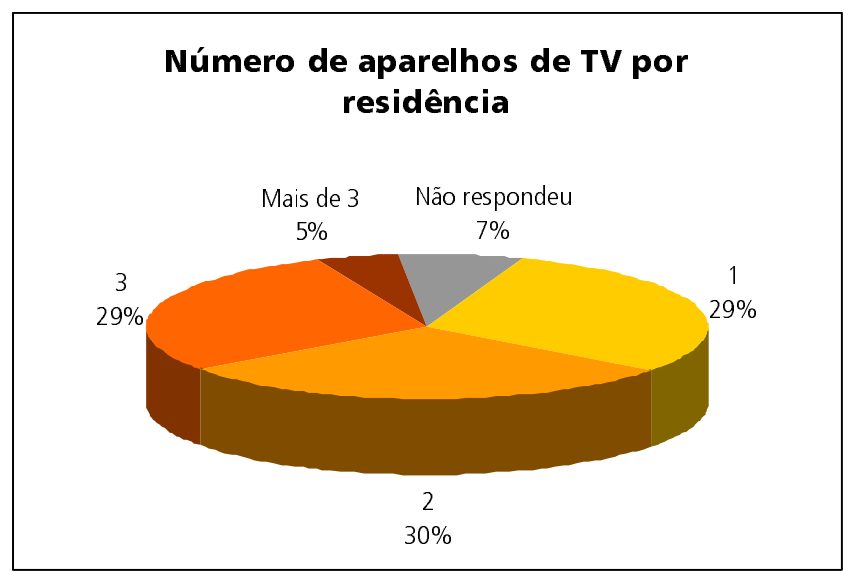

A televisão está presente em $91 \%$ das residências das professoras, sendo que em $64 \%$ dos casos há mais de um aparelho. A audiência é, muitas vezes, uma prática coletiva, visto que muitos equipamentos se localizam em salas e áreas comuns das casas (copa ou cozinha).
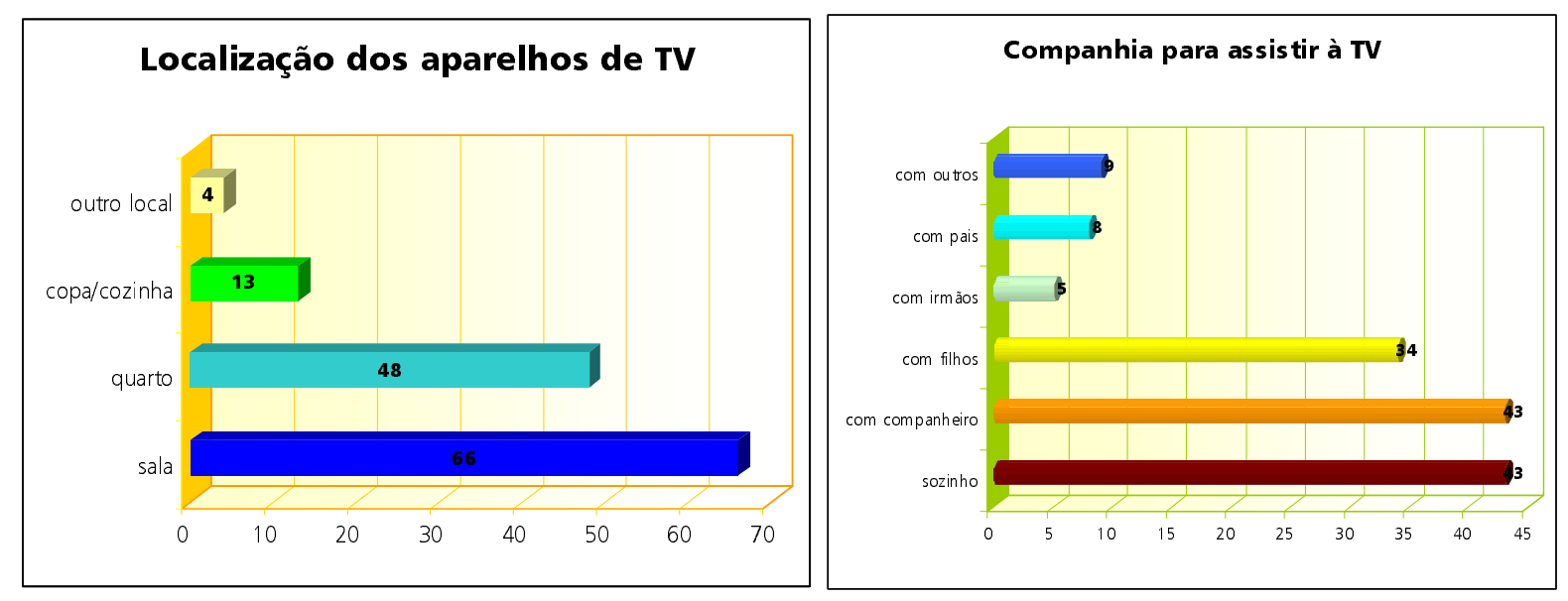

Assiste-se à TV, preferencialmente, à noite. Nos fins de semana há um aumento do número de horas dedicadas à atividade. A maioria fica, em média, duas horas por dia ou mais em frente ao aparelho.
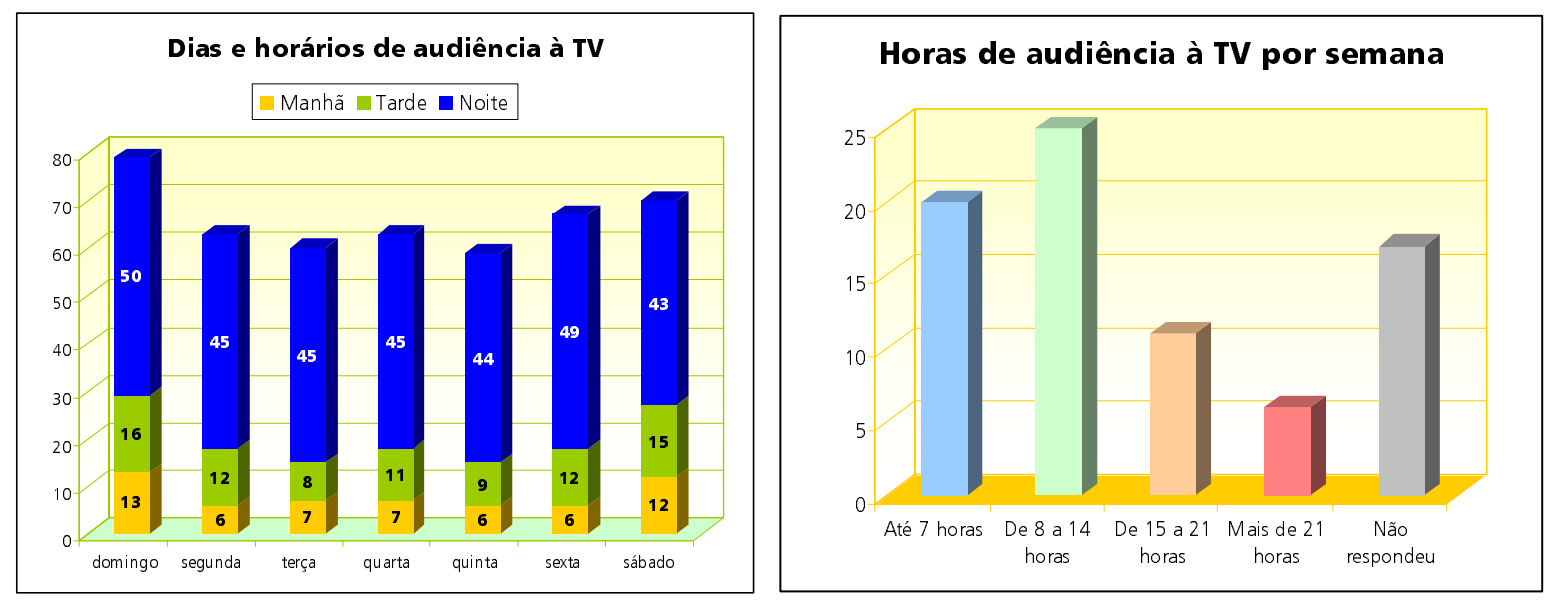
Sobre a audiência da TV aos domingos, uma professora comentou:

- Que triste, né? sinal que não teve nada melhor pra fazer.

Sobre o número de horas em frente à TV, umas acharam pouco; outras se espantaram ao constatar que dedicam várias horas à atividade:

- Você trabalha o dia inteiro. Cê chega em casa, cê não vai pra televisão. Vai fazer comida. Aí cê lava a louça.

- Quando eu respondi o questionário, eu percebi como eu vejo televisão. Eu acho que eu vejo demais. Acho muito. Que eu achava que eu não via nada.

A maioria assiste à TV aberta. Em 2007, porém, houve um aumento do acesso à TV por assinatura.

- Promoção da NET! - esclarece uma professora.

Muitas falam ao mesmo tempo, concordando ou não. Uma colega esclarece que a questão não é o poder aquisitivo, mas a opção por um tipo de programação:

- Eu alugo DVD, né, e vejo o que eu quero. Acho que a programação não compensa o que eles cobram.

[...] Um professor discorda dessa idéia:

- Tem uma diferença entre a TV aberta e a TV paga. Na TV paga você escolhe o que você quer, tem um leque de opçães e não é só informação, é formação também. O que eu aprendi, por exemplo, com o canal, aliás, sou professor de história, o History Channel, eu jamais aprenderia num livro. Então, quer dizer, pra mim não é só informação. Também formação. Tem esse detalhe. Se aprende muito com a televisão também. Assim como o aluno. Só que, claro, o critério deles é outro.

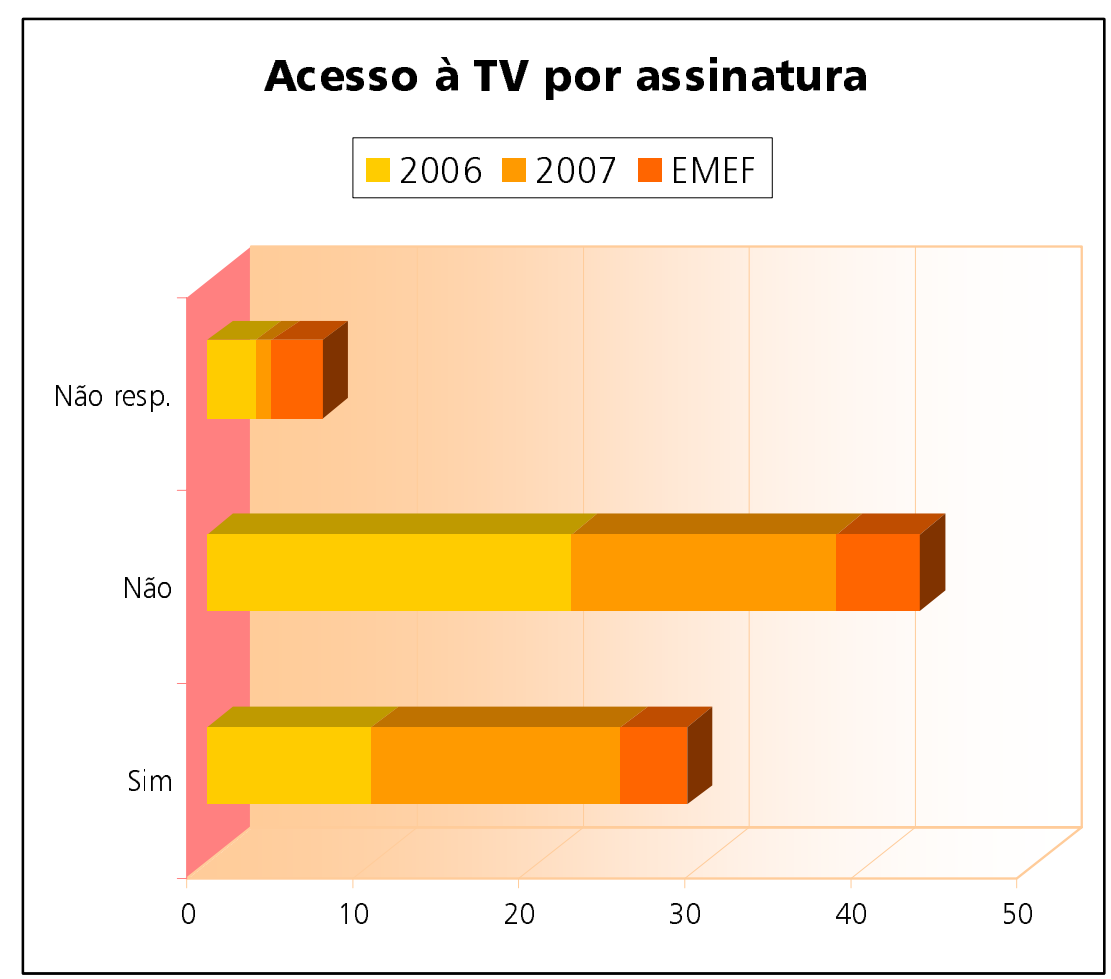

Os canais de TV mais vistos são, ainda, os da TV aberta, prevalecendo a Rede Globo e a TV Cultura. 


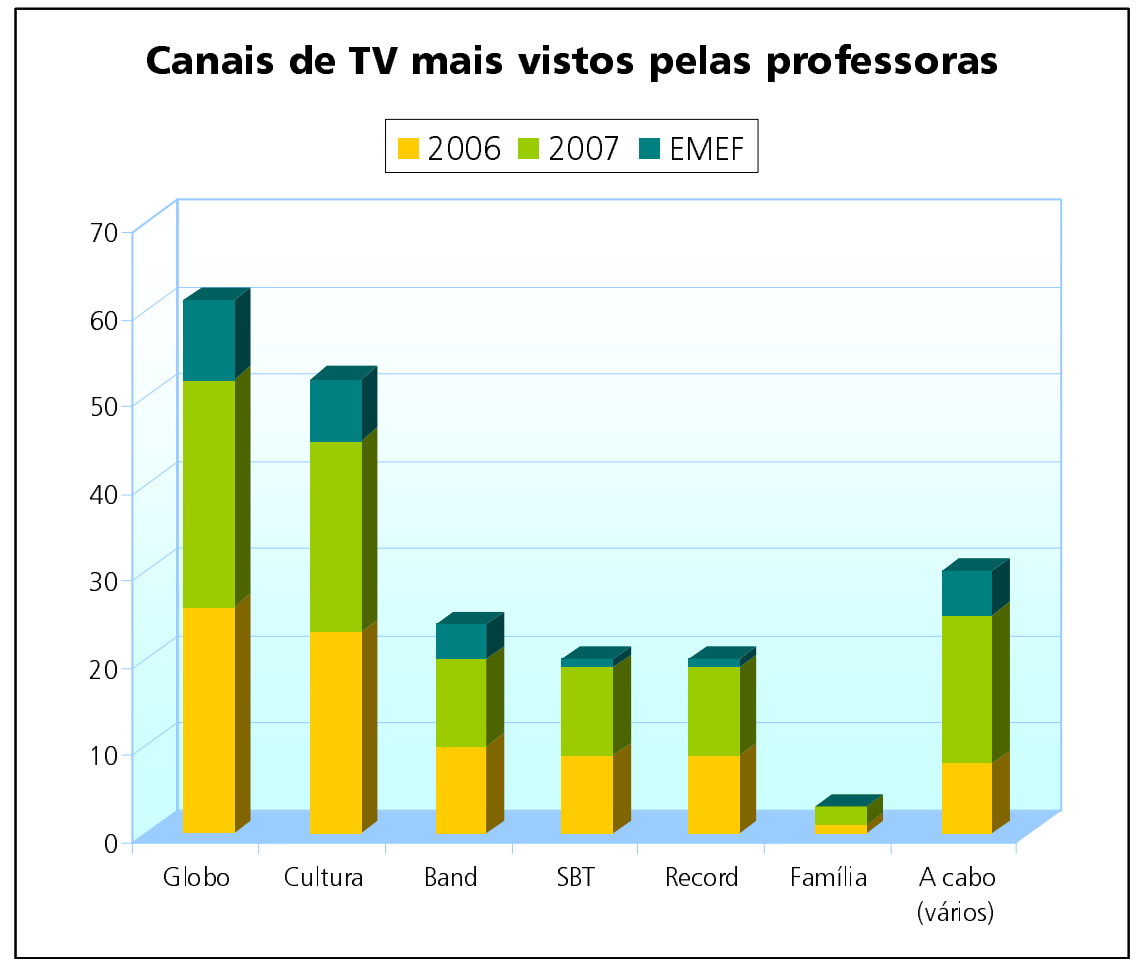

Os programas preferidos são, segundo as professoras, os informativos, que incluem os telejornais (os mais citados), documentários, entrevistas e debates. Em segundo lugar vêm os programas de ficção: filmes, em seguida as novelas, seriados e minisséries.

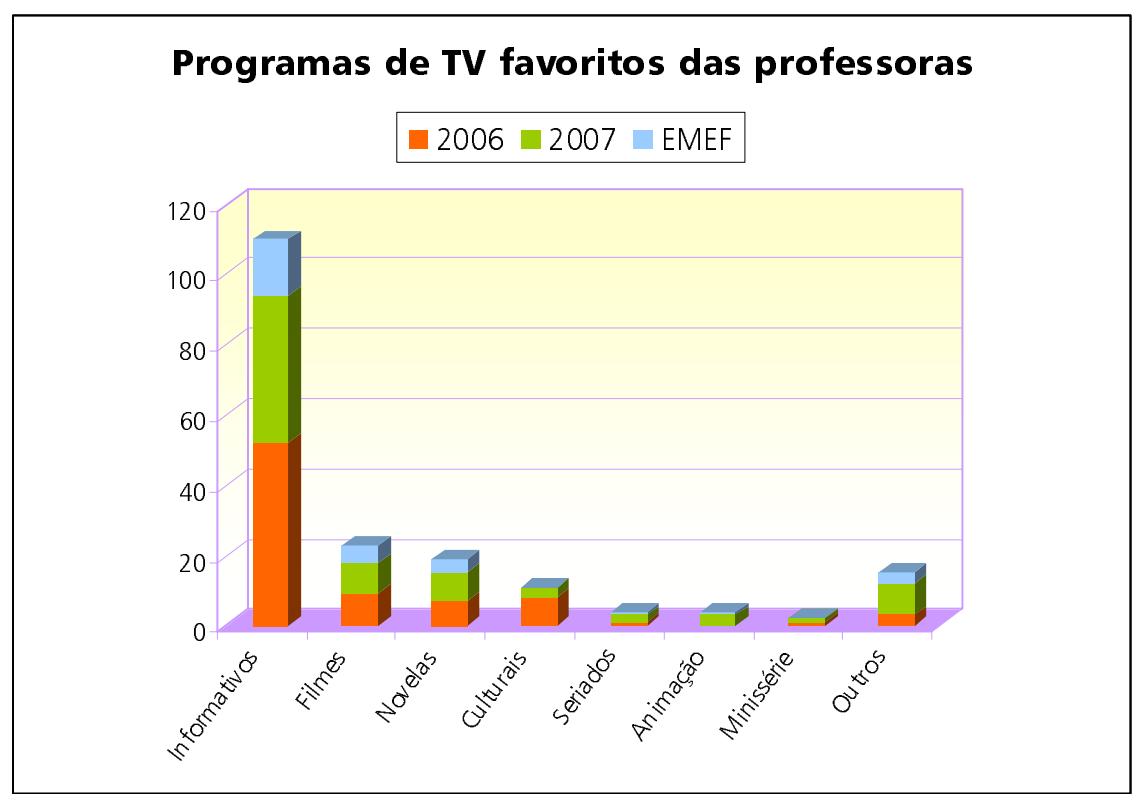

Indagadas sobre a preferência por programas informativos em lugar da ficção, as professoras afirmaram que o uso da TV está ligado à necessidade de informação, mais do que lazer. Afirmam que o tempo para 
se distraírem com filmes e novelas é escasso, pois ao chegarem do trabalho precisam cuidar da casa e dos filhos. Apesar disso, a TV ainda é o principal meio de comunicação e veículo de bens culturais ao qual as professoras têm acesso.

\section{b) A audiência do rádio}

Grande parte das professoras possui mais de um aparelho de rádio, mas, apesar disso, não o ouvem regularmente ou o fazem, em média, uma hora por dia. Os equipamentos se localizam nos diversos locais da casa e também nos automóveis. O horário mais freqüente de audiência é pela manhã, durante a realização de tarefas domésticas ou no caminho para o trabalho. Somente aos sábados há um ligeiro aumento da audiência. Há uma preferência por programas musicais, reforçada pela indicação das estações preferidas. A mais mencionada é especializada em música popular brasileira.
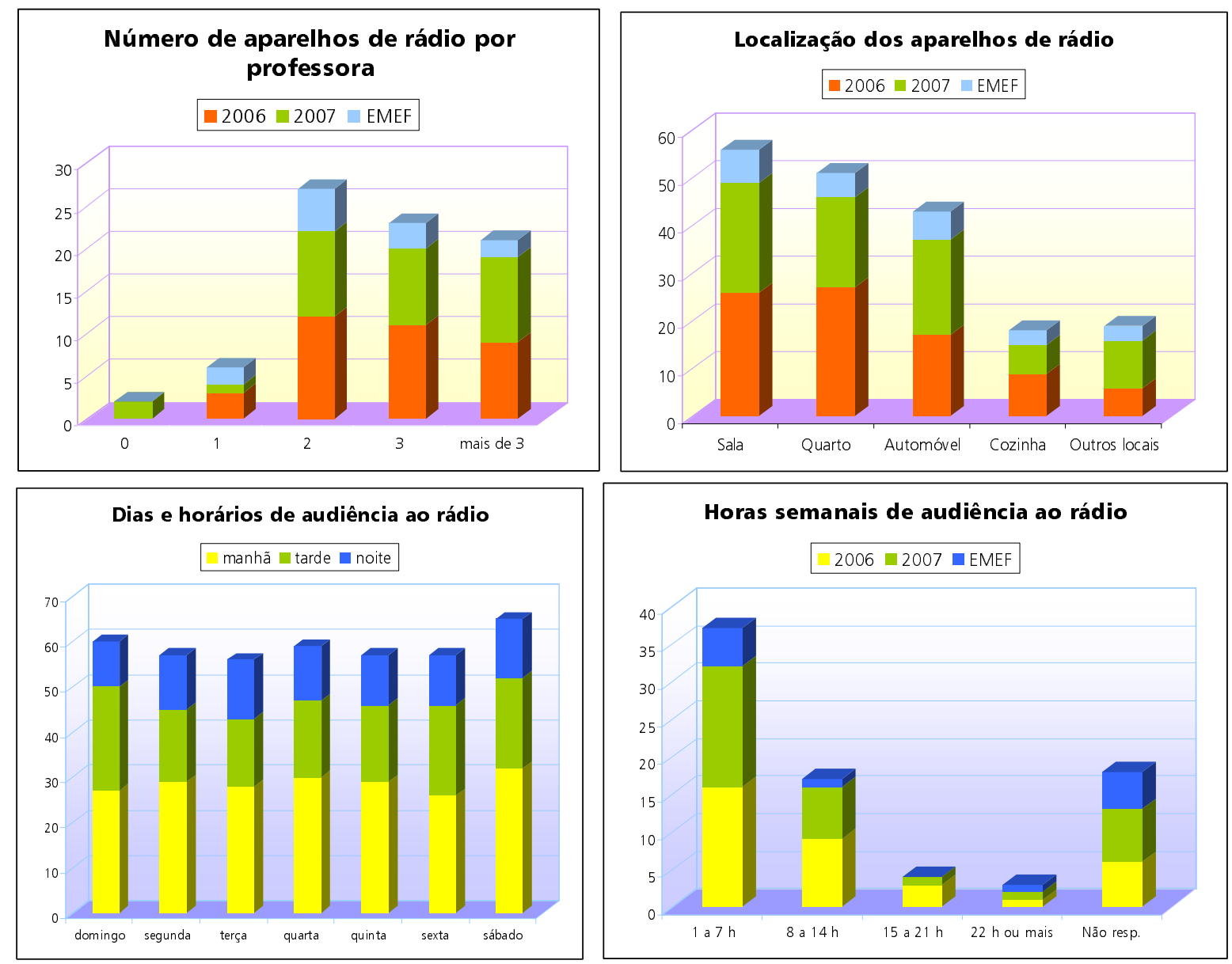

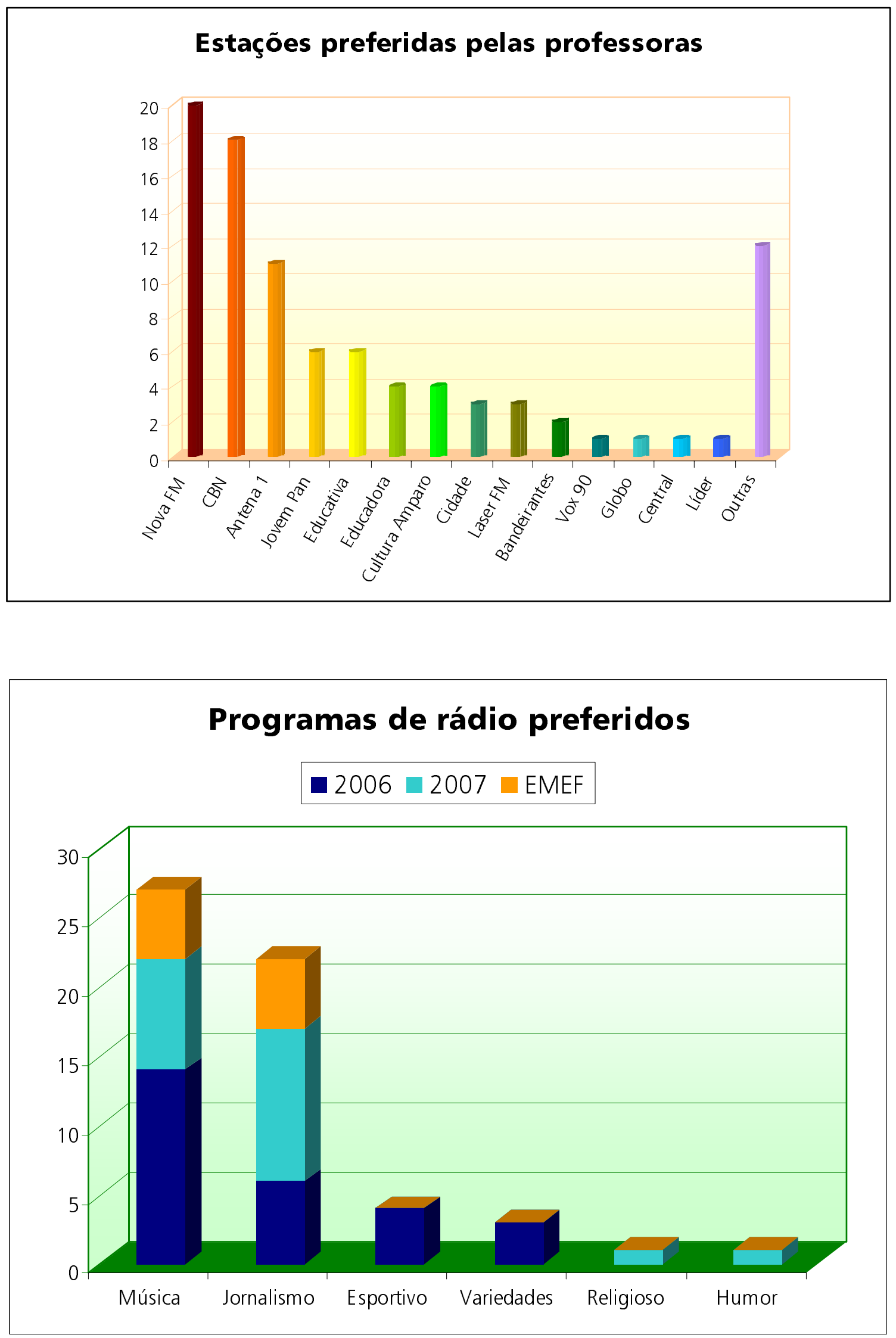


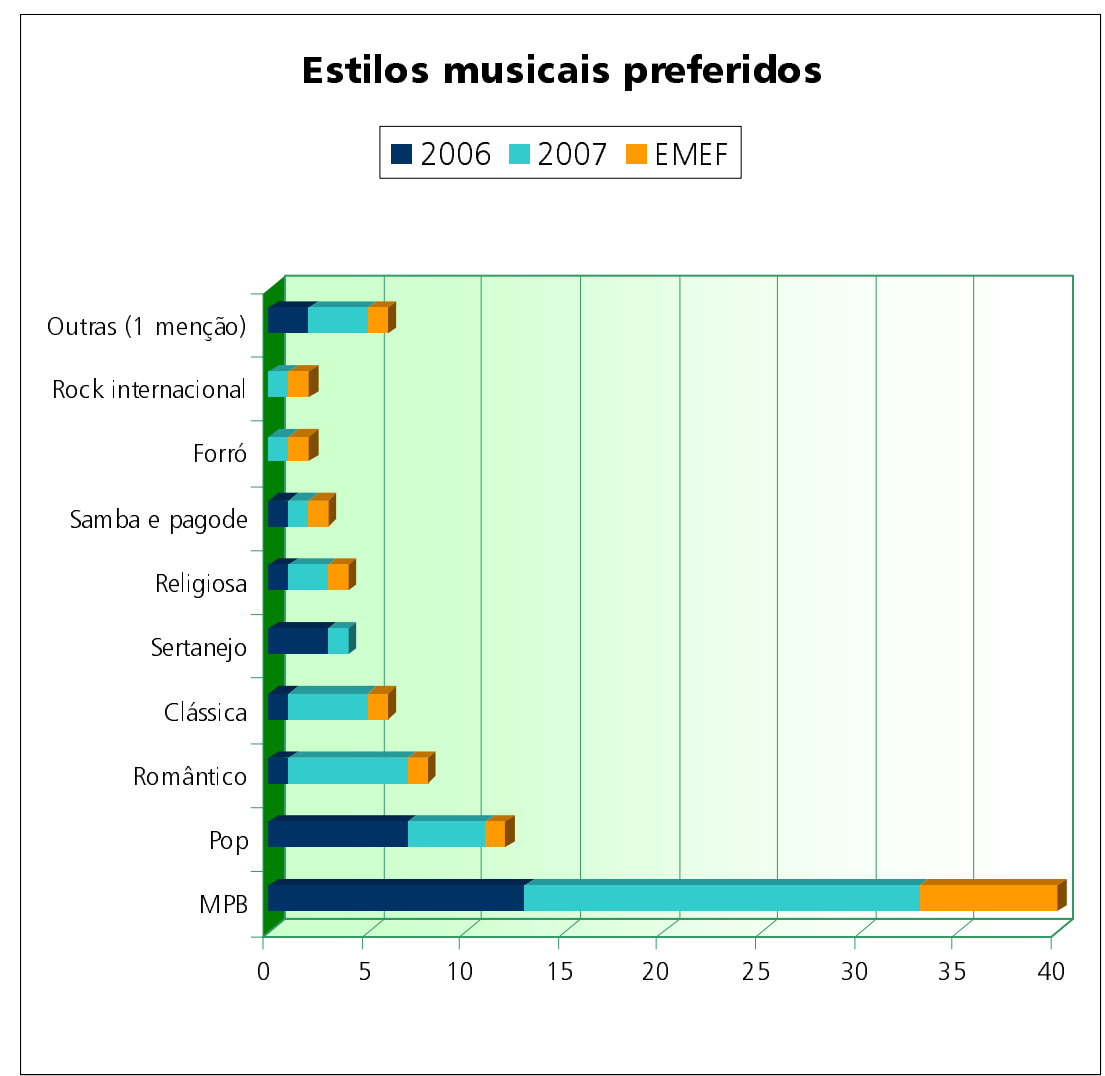

Os dados permitem afirmar que, no grupo estudado, a audiência do rádio é baixa, sobretudo se os índices forem comparados aos da recepção televisiva. Ainda, é possível concluir que o interesse das entrevistadas volta-se prioritariamente para a programação musical, deixando o jornalismo em segundo plano. Considerando o fato de que, face à TV, o rádio é um veículo caracterizado pela agilidade na cobertura jornalística e pela maior proximidade com os temas locais, infere-se um reduzido acesso a informações de interesse comunitário e a abordagens de caráter mais popular. Esse noticiário será buscado pelas professoras por meio dos telejornais regionais e dos diários impressos locais, pautados pela visão típica dos grandes meios de comunicação.

\section{c) O uso do videocassete e do DVD}

Em 2006, quando a pesquisa foi iniciada, o videocassete ainda era um equipamento presente nos lares e comumente utilizado para gravação de programas de TV e reprodução de fitas. Justificava-se, portanto, 
incluí-lo, naquele momento, na enquete apresentada às professoras. Dois anos depois, esse recurso estaria praticamente extinto, tendo sido rapidamente substituído pelos DVD-players.

Constatamos que o videocassete era acionado, predominantemente, para assistir a filmes alugados e, quase nunca, para gravar programas de TV (expediente que poderia ser destinado ao trabalho em sala de aula). Da mesma forma, raramente o equipamento era utilizado para que as educadoras assistissem a produções filmadas por elas próprias.
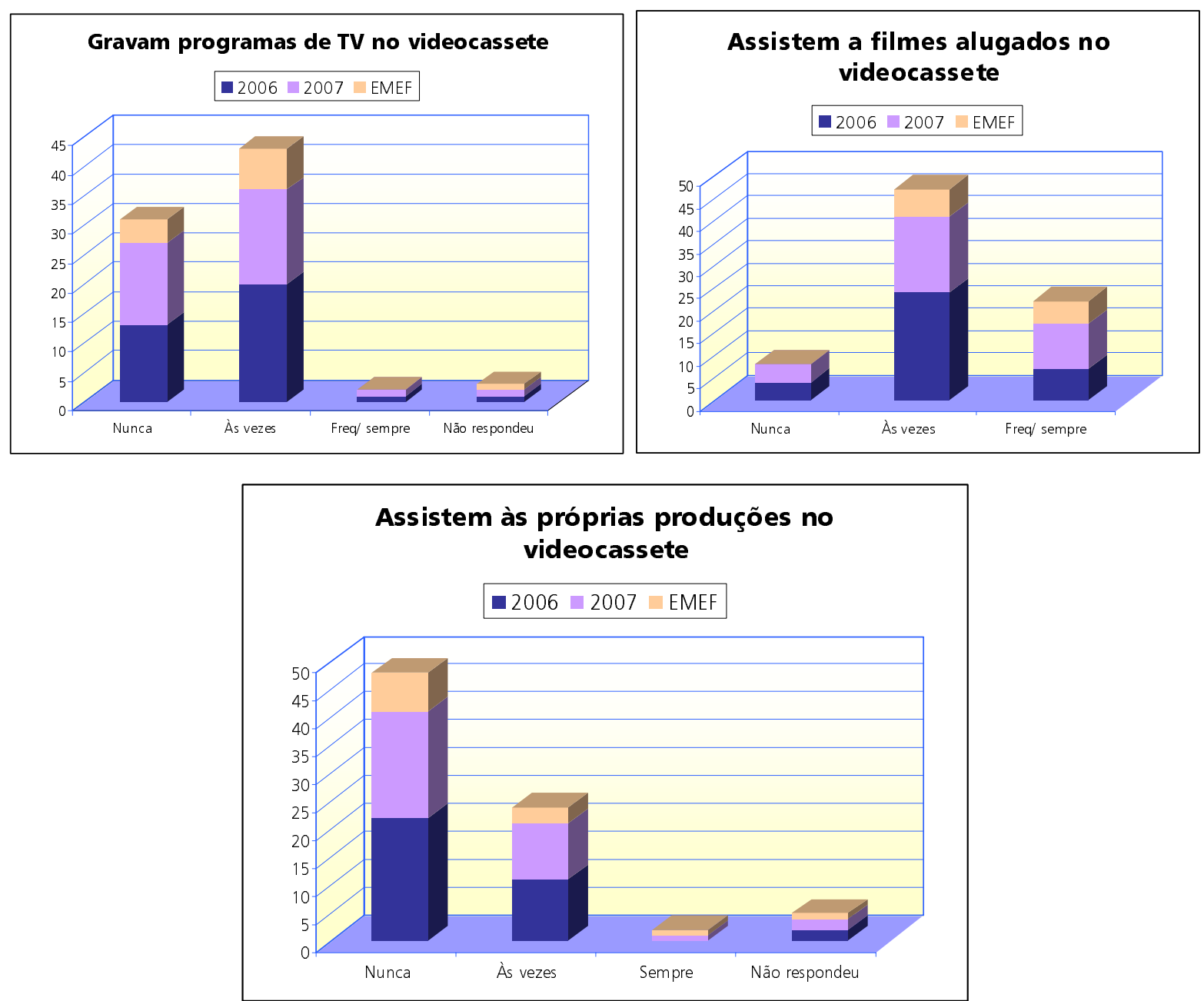

O DVD logo ganhou espaço entre as educadoras. Em 2007, a quase totalidade delas já possuía o aparelho, e seu uso era bem mais freqüente que o do videocassete. A funcionalidade de gravação, existente nesse aparelho, porém, não está disponível nos DVD-players mais vendidos, fazendo com que as professoras não disponham dessa opção para gravar a programação televisiva e exibi-la em sala de aula, com fins de estudo e análise. O DVD é, portanto, utilizado apenas para o lazer. 

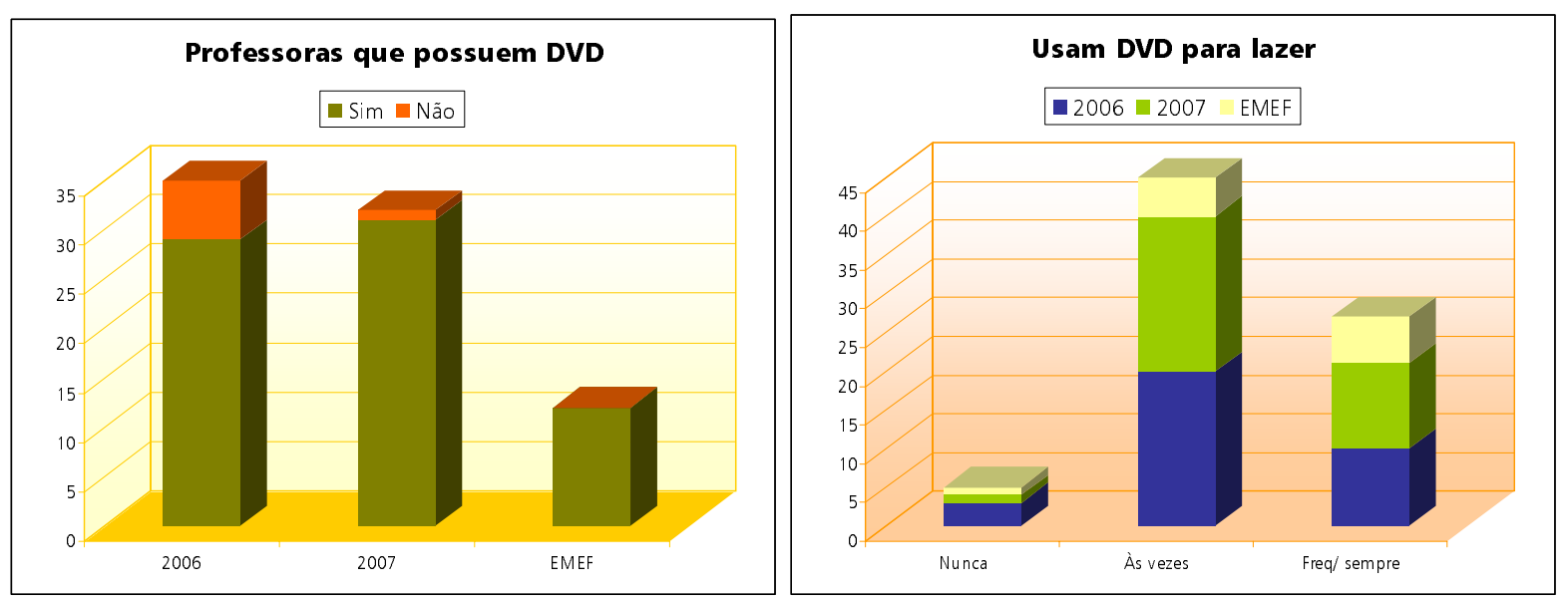

Os dados apresentados podem fornecer uma explicação concreta para o fato de o material televisivo (propagandas, telejornais, peças de ficção, documentários) ser pouco utilizado como recurso pedagógico em sala de aula, conforme vimos no item 1.2 deste capítulo.

\section{d) Freqüência ao cinema e ao teatro}

As professoras vão ao cinema menos de uma vez por mês. Isso pode ser explicado pelo elevado preço dos ingressos e pela comodidade oferecida pelo DVD. Algumas delas foram mais longe na sua justificativa, apontando o escasso tempo de que dispõem para o lazer em geral. Assistem a filmes estrangeiros mais freqüentemente que aos nacionais e creditam essa realidade ao fato de que as películas brasileiras têm espaço limitado no circuito comercial, ficando restritas a poucas salas, num período de exibição curto. A preferência geral é pelos filmes de ficção. Uma pequena parcela de educadoras seleciona animações, para assistirem sozinhas ou com filhos. Não foram citados documentários.

- O hábito de ir ao cinema: vocês revelaram que era pouco freqüente. A maioria vai até uma vez por mês. Uma hipótese que a gente traçou foi que possivelmente o uso do DVD é uma forma de substituição ao cinema.

As professoras concordam.

- E eu não sei, mas eu acho que o cinema também é uma diversão meio cara, né?

$-\mathrm{Uh}$ !

- Quê isso!

- De quarta feira não.

- Mas cê tem condição de ir quarta-feira? 
- Olha, [...] lazer não tenho, não. Cinema, isso eu tava falando com a Luciane, de vez em quando, quando tem alguma coisa que eu gosto, por exemplo, eu poderia ver mais, sinto falta, mas não tenho mesmo muito, não. O último filme que eu vi foi Dois Filhos de Francisco.

- Nossa! - disseram as colegas, pois o filme tinha passado no cinema há mais de um ano.

- Os filmes mais vistos são os estrangeiros. Apenas uma pequena parcela de desenhos animados. Vocês vão com os filhos ou porque gostam também?

- Com os filhos.

- Eu gosto.

- O grande problema do filme estrangeiro é que geralmente eles passam em todos os cinemas. E os filmes nacionais bons ficam restritos a algumas salas de cinema. Então passa Mulheres de areia. Passa no Shopping Jaraguá e não passa em todos os outros shoppings que têm vários cinemas. Então tem uma coisa contrária aí também.

- Reflete também uma questão de mercado, né?

- É. Então, às vezes, o acesso mais fácil que você tem é ao Galleria e não ao Jaraguá. Vai dificultando, né? Se você não comprar com antecedência, você não consegue lugar.

- Mas isso é um problema mundial, porque não é só o Brasil que reduziu a quantidade de cinéfilos, né, que vão a cinema. No mundo inteiro, caiu mesmo. As salas de exibição, etc. E o monopólio do mercado americano, eles dominam. Aqui no Brasil, o cinema brasileiro tá recuperando. [...] E só passa filme que eu não tenho o menor interesse por aquilo. Esse cinema comercial não me interessa.
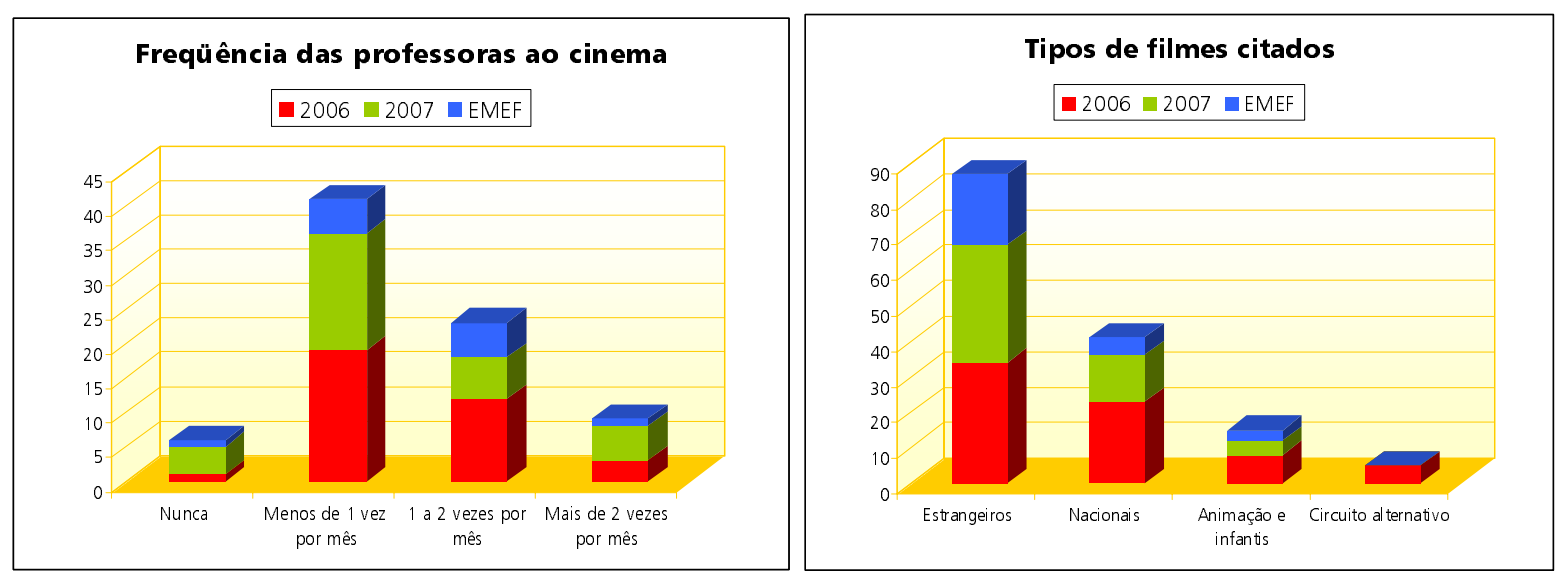

As professoras freqüentam esporadicamente o teatro (75\%), sendo que $20 \%$ nunca assistem a peças.

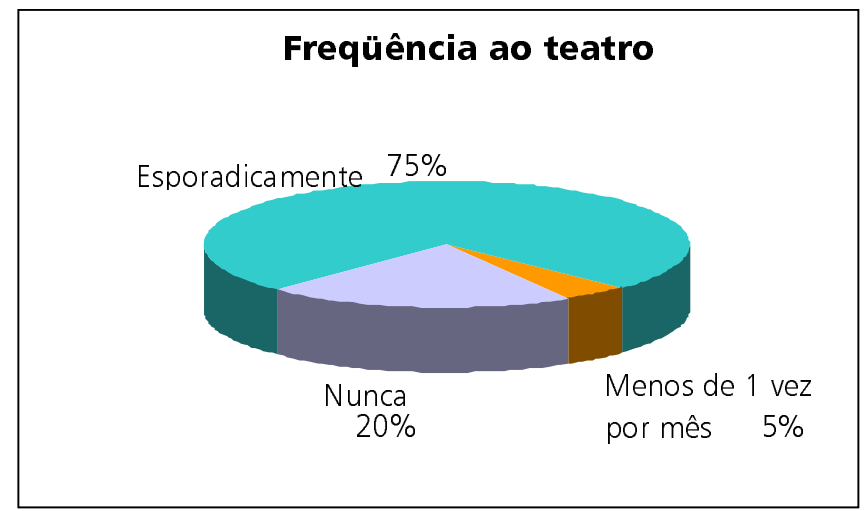




\section{e) Leitura}

Quarenta e cinco por cento das professoras lêem entre um e três livros por ano, com finalidade de lazer. Cerca de 20\% lêem mais de seis livros por ano, enquanto 2\% não possuem esse hábito.

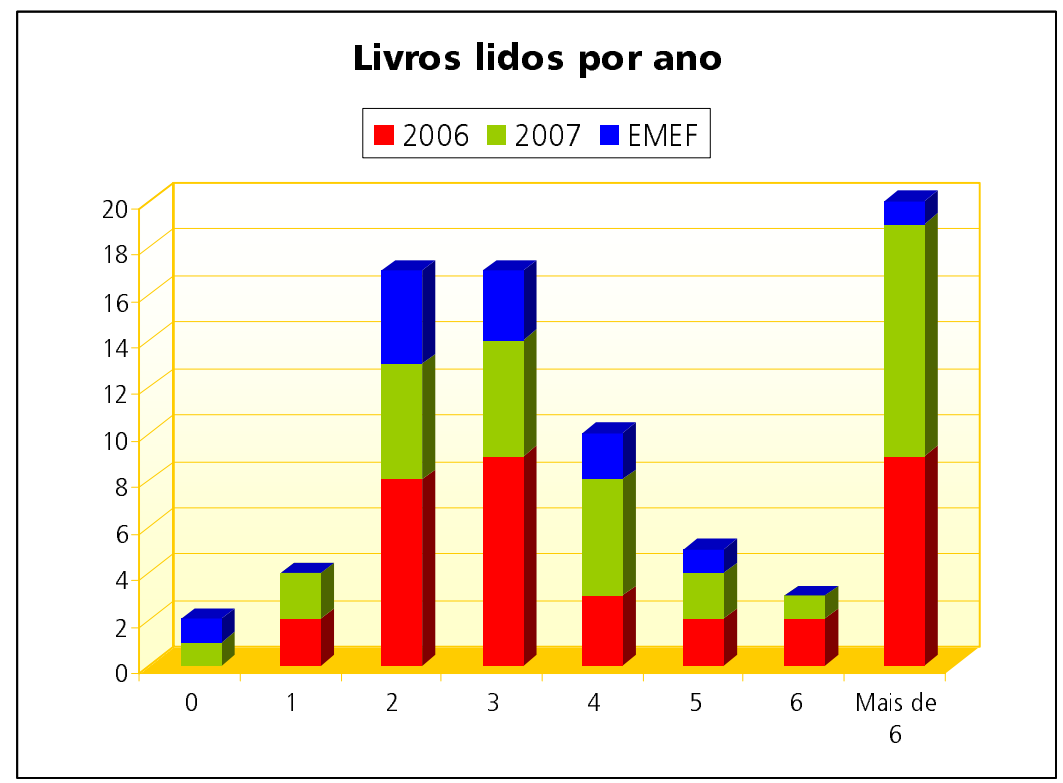

Trata-se de uma freqüência baixa para um público plenamente alfabetizado, residente na região sudeste do país, que tem acesso a livrarias e bibliotecas e trabalha em Educação (média de 4 livros pro ano). Para se ter um parâmetro comparativo, tomemos os dados obtidos na pesquisa Retratos da leitura no Brasil, realizada conjuntamente pela Câmara Brasileira do Livro (CBL), Sindicato Nacional dos Editores de Livros (Snel) e Associação Brasileira dos Editores de Livros (Abrelivros), em 2000 e 2007. A investigação, que pode ser considerada a mais completa já feita no Brasil sobre leitura, fora de uma perspectiva estritamente escolar, abrangeu leitores com idade igual ou acima de 14 anos e o mínimo de três anos de escolaridade. A média de leitura do brasileiro é de 1,3 livros (não escolares) por ano - incluindo-se aí todas as classes sociais, níveis de escolaridade e regiões geográficas. Esse índice, de acordo com relatório dos Ministérios da Educação e Cultura divulgado no Plano Nacional do Livro e Leitura, PNLL, é

...muito baixo, se comparado ao de países como a França $(7,0)$, os Estados Unidos (5,1), a Inglaterra $(4,9)$ ou a Colômbia $(2,4)$. E [...] se revela ainda mais crítico quando a pesquisa demonstra que a pene- 
tração do livro no país e o acesso a esse objeto cultural são ainda bastante restritos, concentrando-se o mercado comprador de livros nas mãos de $20 \%$ da população alfabetizada com 14 anos ou mais, na Região Sudeste, nas grandes cidades e metrópoles, nos estratos de renda mais elevada (classe A) e com instrução superior.

[...] E, paradoxalmente, deve ser frisado que esse cenário desolador se insere no contexto de um país que é o oitavo produtor de livros do mundo, com um poderoso e atualizado mercado editorial, que conta com mais de 2.000 editoras e movimenta mais de 12.000 títulos e 300 milhões de exemplares publicados anualmente. ${ }^{168}$

Jornais e revistas são lidos por um grupo mais numeroso ( $96 \%$ são leitoras de jornais e $94 \%$ de revistas). Entretanto, essa prática não é regular. Apenas 22\% lêem diariamente o jornal, enquanto $24 \%$ o fazem somente nos fins de semana e $18 \%$ esporadicamente.
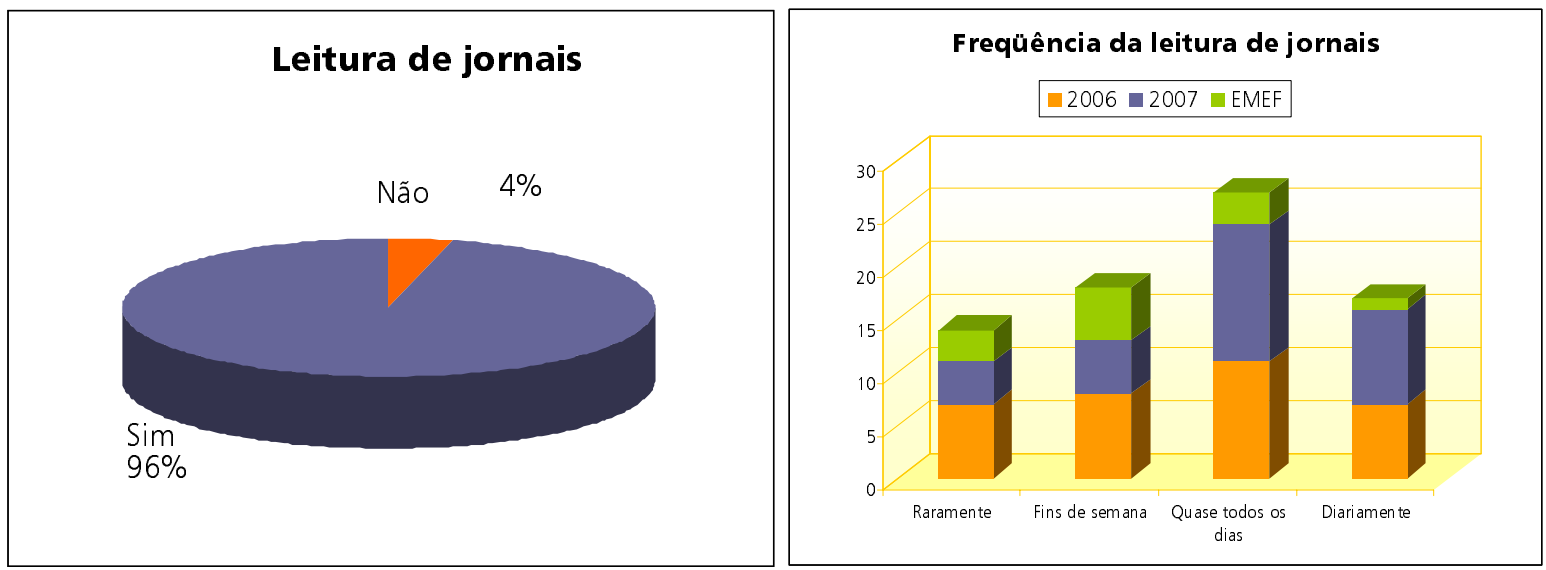

A elevada penetração do jornal no grupo de professoras (96\%) combina com dados do Instituto Ipsos Marplan, publicados pela Associação Nacional de Jornais (ANJ), segundo os quais as faixas etárias onde o veículo tem maior alcance dentro do grupo de leitura variam entre 25 e 54 anos. ${ }^{169}$ A freqüência de leitura irregular também parece coincidir com os dados da pesquisa Retratos da Leitura no Brasil, realizada em 2007. De acordo com seu relatório, já citado, apenas 20\% dos leitores dedicam-se ao jornal diariamente, contra $22 \%$ uma vez por semana e $7 \%$ apenas uma vez por mês. Ainda, pela mesma fonte, a leitu-

\footnotetext{
${ }^{168}$ MINISTÉRIO da Cultura e Ministério da Educação. Plano Nacional do Livro e Leitura. Brasília, s/d. Disponível em <http://www.pnll.gov.br>. Acessado em 13/01/2009. A pesquisa Retratos da Leitura no Brasil de 2000 apontava uma média de 1,8 livros lidos por habitante/ano, mas por terem sido utilizadas metodologias diferentes, os números de 2000 e 2007 não podem ser comparados. O relatório da última pesquisa, publicado em 2008, encontra-se em <http://www.prolivro.org.br/ipl/publier4.0/dados/anexos/48.pdf>, consultado em 27/01/ 2009.

${ }^{169} \mathrm{Cf}$. ANJ. Associação Nacional de Jornais. Idade dos leitores. Estrutura de leitura dos jornais diários. Disponível em <http://www.anj.org.br/a-industria-jornalistica/jornais-no-brasi//idade-dos-leitores>, acessado em 27/01/ 2009.
} 
ra de jornais é menos freqüente que a de revistas (27\% lê semanalmente) e maior que a de livros (14\% lê uma vez por mês). O tempo dedicado à leitura de jornais (1h21min por semana), entretanto, é menor que o dedicado à leitura de textos na Internet, livros (recomendados pela escola ou não), textos de trabalho ou estudo e livros digitais, e só passa à frente das revistas (1h16min/semana) e dos quadrinhos (1h9min/semana). São números modestos, comparados aos de outros países. No site da ANJ, o Brasil está em centésimo primeiro lugar no ranking da leitura de jornais no mundo, numa lista de 187 países, elaborada pela Associação Mundial de Jornais, WAN (o índice avalia a circulação média entre a população adulta, em cópias por mil habitantes). À nossa frente, encontram-se países sul-americanos como Venezuela, Argentina, Guiana Francesa, Guiana e El Salvador. ${ }^{170}$

O jornal mais citado pelas professoras é o local, Correio Popular, seguido pela Folha de S. Paulo. Aquele título é distribuído gratuitamente em diversas escolas, mas as docentes o preferem ler em casa. Suas sessões favoritas são: cultura, noticiário político e local.

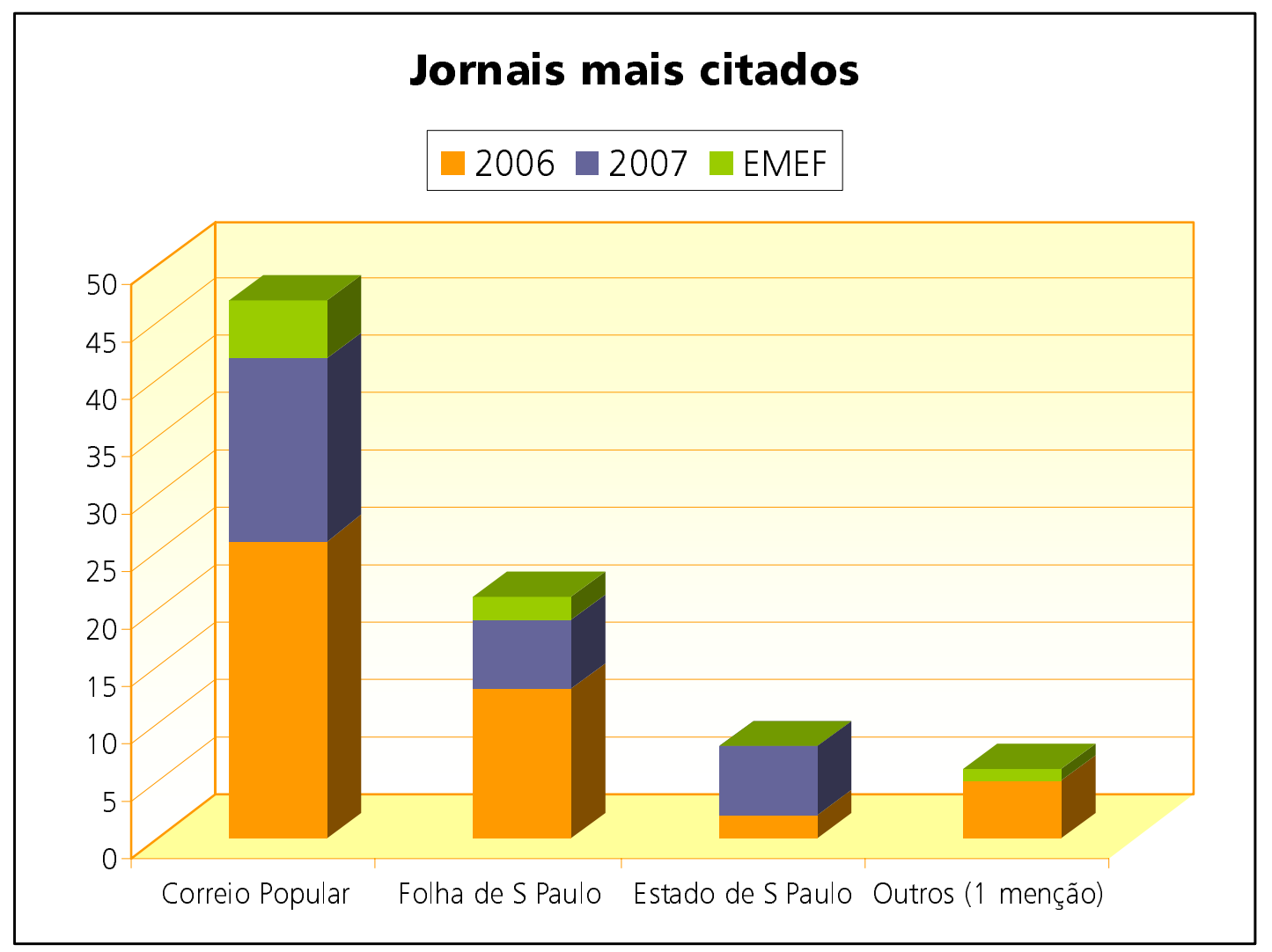

\footnotetext{
${ }^{170}$ ANJ. Associação Nacional de Jornais. Leitura de jornais no mundo. Disponível em <http://www.anj.org.br/ aindustria-jornalistica/leitura-de-jornais-no-mundo>, acessado em 27/01/2009.
} 


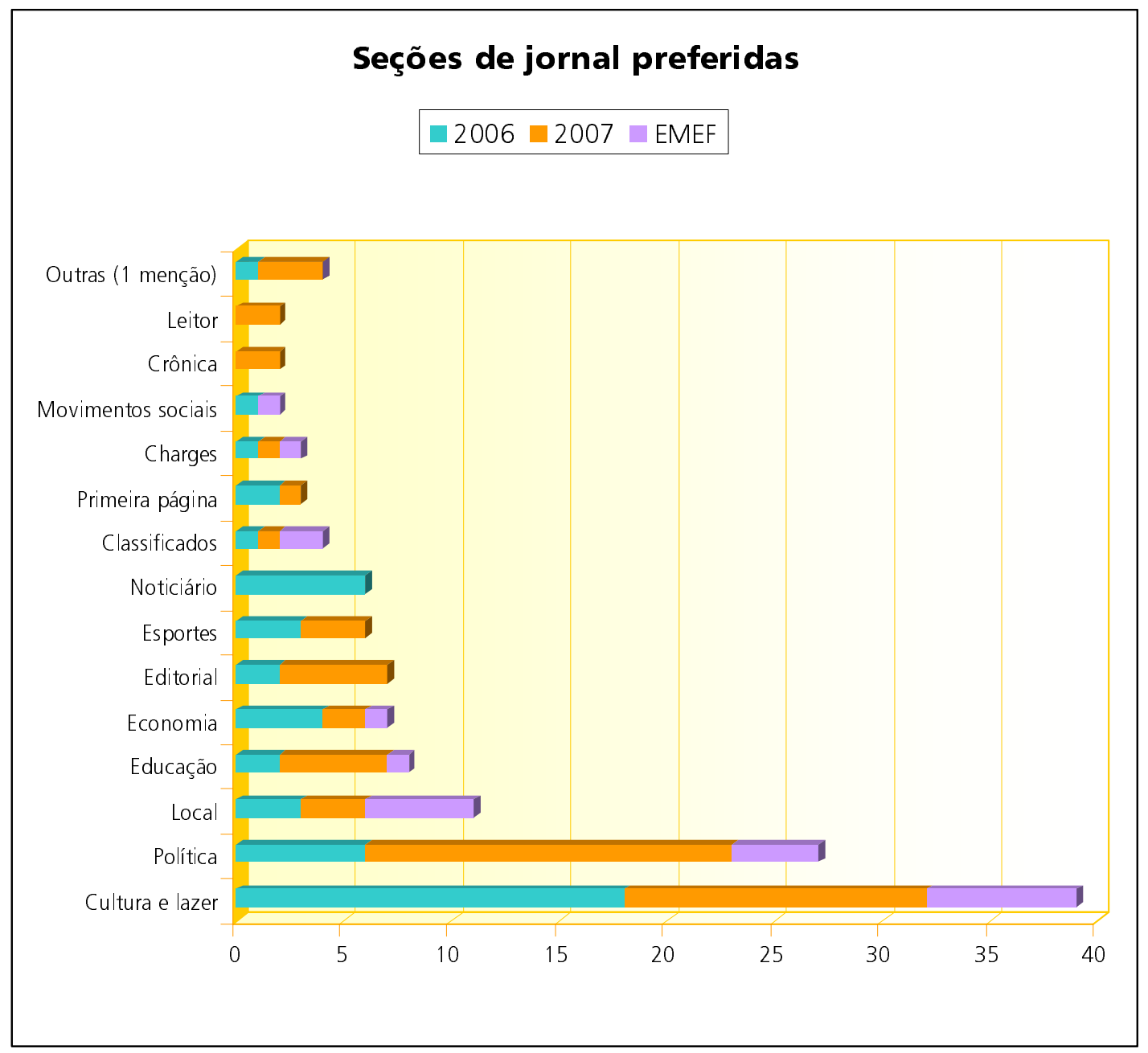

Apesar de afirmarem que lêem o Correio Popular em casa (subentende-se, portanto, que o adquirem ou são assinantes), as professoras costumam criticá-lo. Aqui e ali surgem opiniões ambíguas: umas afirmam que não serve para outra coisa senão "fazer pintura no chão"; outras o utilizam com os alunos. Interessante notar que, também neste caso, as educadoras acreditam que precisam mostrar aos estudantes "coisas diferentes das que eles gostam”.

- Os jornais e revistas mais lidos citados por vocês são aqueles que existem na escola. Então eu queria perguntar: vocês lêem aqui na escola ou vocês compram?

$[\ldots]$

- Eu leio a revista em casa e é a revista Veja. Como a Veja é toda semana, às vezes não dá tempo nem de eu acabar de ler uma, chegou a outra. Então... porque eu não tenho nenhum tempão pra ler.

- Então pelo que eu entendi a maioria lê em casa, não aqui.

- Em casa.

- Em casa.

- $O$ certo seria ler aqui...

- E vocês aí, meninas? 
- Em casa.

- Dificilmente eu consigo ler aqui.

- Porque aqui só tem esse porcaria de Correio Popular.

- E esse jornal que chega aqui na escola, cês usam de alguma maneira ou não conseguem?

- Faz pintura no chão, porque esse jornal Correio Popular é des... deixar as crianças mais incultas.

- Mais é os guardas. Os guardas tão lendo...

- Depende da época.

- Eu acho que depende da série. Esse ano, como eu tô com a turma de seis anos, eu usei bastante.

- Eu uso sempre o implemento infantil [sic] leio pra eles, tô sempre pegando. Eu uso a parte... como as crianças gostam muito de futebol, sempre que fala alguma coisa de futebol, eu leio alguma coisa de futebol pra eles e, assim, de acordo com a turma mesmo, que eles gostam. Às vezes também eu pego uma noticiazinha assim que tá todo mundo falando, falando, falando, [...] aí depois, no final, ninguém dá resposta. Aí eu pego a resposta: "Lembra aquele caso que passou [...] nos jornais? Aí, ó, o quê que deu!" E quando eles tão maiorzinhos.

- Eu trabalho o jornal [...], notícia, [...] de pegar alguns alunos, lerem [...], né, [...] fatos, [...] pra ver se eu consigo fazer com que eles tenham mais acesso ao jornal, outras partes, né, não só naquelas que eles gostam.

- Eu só leio esse [Correio Popular] porque o meu marido compra.

- Leitura é mais esporádica.

- É maior nos fins de semana. As seções mais lidas são as de cultura...

- É.

- O ano passado, a gente tinha o jornal na escola. Eu ficava constrangida de abrir o jornal. Eu sou professora de educação infantil. Então, as crianças iam pro parque, eu ia pegar o jornal. [...] Ficava constrangida, porque se acontecesse alguma coisa, eu tava lendo o jornal, eu não tava olhando as crianças. Olha... né? Mas assim:[...] as crianças aprendiam com a gente.

A fala da professora causa um tumulto na classe. Quando as colegas se acalmam, ela completa:

- Tinha um aluno especial que vinha, gostava do jornal, mas cê ficava constrangida de fazer uma coisa que parece que não... gente, na escola, lendo jornal?

Quanto às revistas, as mais citadas são os semanários de notícias, como Veja, Época e Isto É, seguidas das que se dedicam ao segmento educacional, como Nova Escola, Pátio e Recreio.

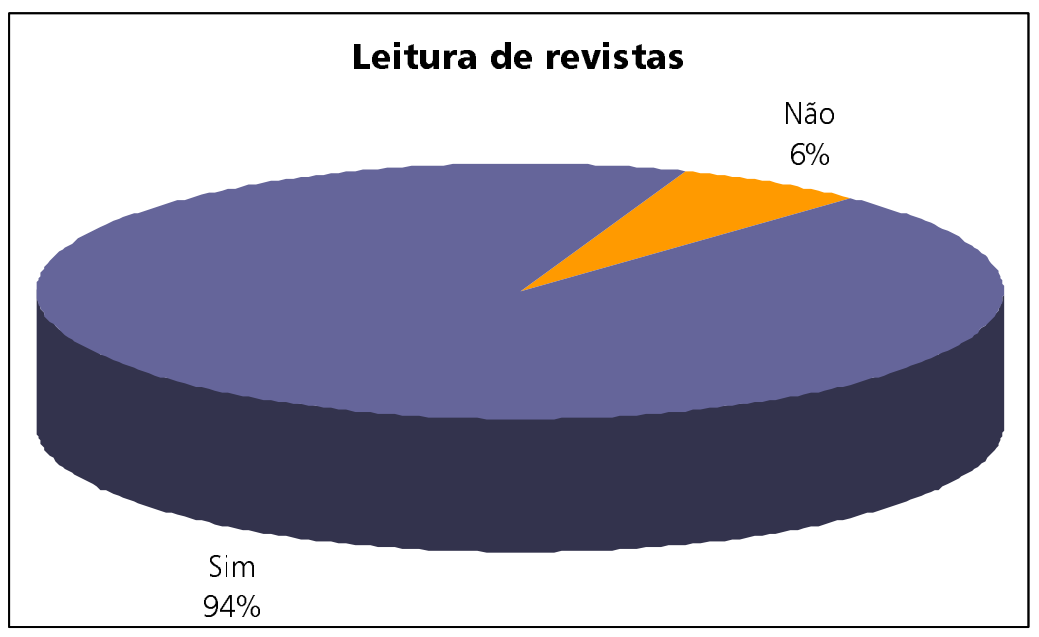




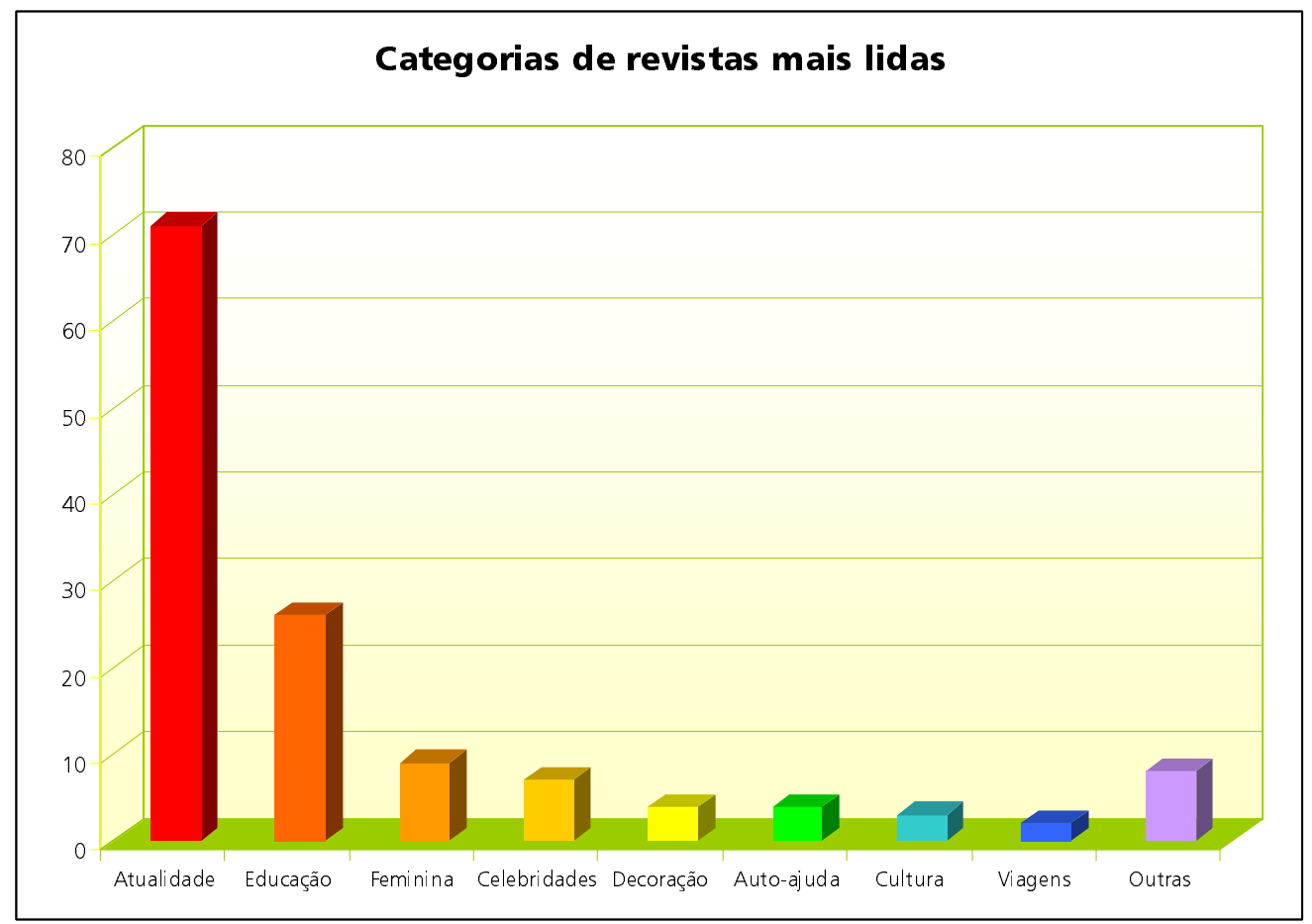

A freqüência de leitura das revistas é mais regular que a dos jornais, considerando-se que as mais citadas são os semanários:

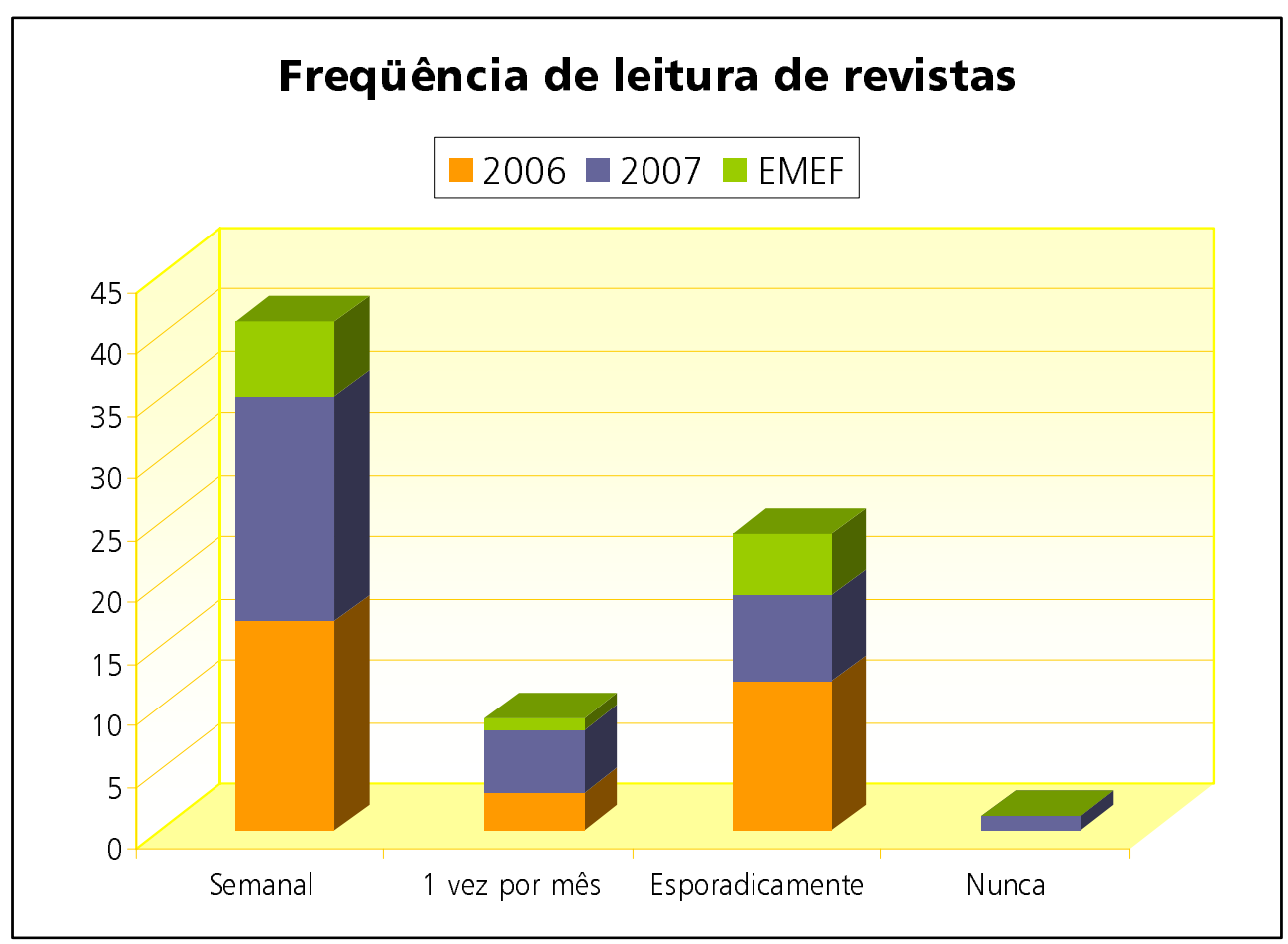




\section{f) Informática}

A quase totalidade das professoras entrevistadas afirmou ter acesso ao computador. Usam, preferencialmente, em casa ou na escola. São equipamentos compartilhados com outros usuários e, portanto, o tempo disponível para a educadora usufruí-los é limitado. Na maioria dos casos, utilizam menos de uma hora por dia, o que demonstra que grande parte de seu trabalho não emprega o recurso da informática.
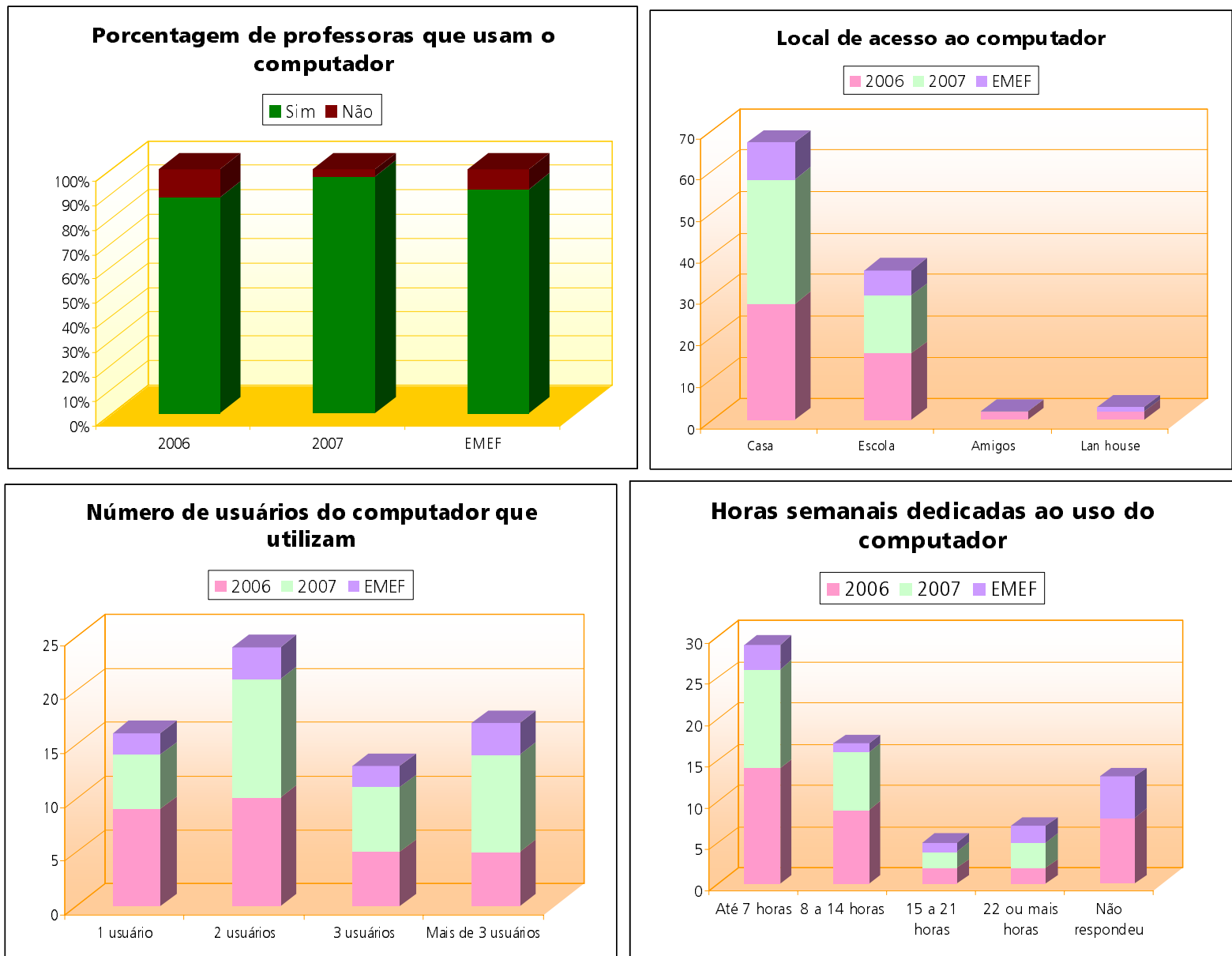

Horas semanais dedicadas ao uso do computador

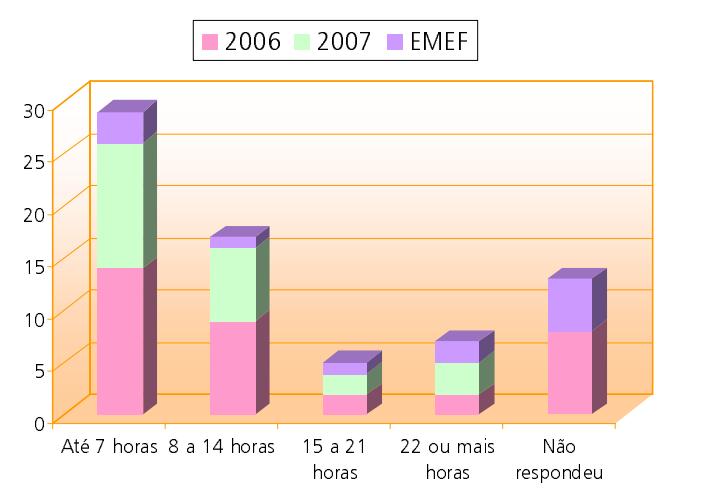

Os depoimentos confirmam essa observação:

- Esse pessoal que não respondeu é porque não usa com freqüência, usa esporadicamente? Eu fiquei sem saber. [...] É porque não é todos os dias?

- Não, não, quando necessita. Quando vou fazer uma pesquisa, como cê falou. Ou pesquisa, ou preparar uma aula, [...] uma coisa, vai lá, digita, faz. 
Na escola, o acesso das educadoras ao computador é limitado. Na maioria dos casos, há poucos equipamentos disponíveis, gerando uma disputa pelo agendamento, que não contenta a ninguém. Em outras situações, como na educação infantil, a equipe da escola pode julgar desnecessário o uso do PC, exigindo das professoras mobilizar-se para o convencimento do grupo e a legitimação do trabalho pedagógico com a tecnologia.

- Eu acho interessante a gente discutir o acesso que o professor tem na escola [ao computador]

- Não tem. Não tem.

- Pois é.

- Não: tem, mas é pouco - um professor discorda e dá ensejo para que todas falem ao mesmo tempo.

- Mas quem tem acesso? Quem tem acesso?

- Todos os professores. Aí é uma briga pra ver quem fica. [...] Tem que agendar.

- Então, mas isso que a gente tá falando: tem dois computadores na escola.

- Ah, porque todo professor quer usar e os alunos querem usar no mesmo dia. Só isso. Então, aí, a briga pra ver quem...

[...]

- Eu ia falar, justamente, que, hoje em dia, o computador nem é o problema. O computador dentro da escola nem é o problema.

- É um problema, porque é o caso [...] do programa [...] Linux.

$[\ldots]$

- Gente, todas as escolas, inclusive as escolas infantis que eu conheço, tem sempre alguém que levou: "ó, meu marido não quer mais esse computador". Então, assim, tem sempre um computador, pra tentar. Não é mais isso. Que antigamente a gente tinha o problema de pôr o computador na escola. Hoje em dia até arruma-se. [...] A prefeitura dá um jeito, alguém empresta, alguém dá de presente. O problema ainda tá sendo as pessoas aceitarem.

- A resistência.

- Eu tinha um computador o ano passado na minha sala. Eu entrei esse ano, a primeira coisa que me disseram: eu não quero computador dentro da sala. [...] Até hoje não me disseram porquê. Mas eu tive que tirar o computador da sala. [...] Por quê? Porque ameaça, não sei, as pessoas, sei lá. É uma coisa do contexto. [...] Então a pessoa que disse "você não pode" é a pessoa portadora de uma ansiedade [...] do grupo. [...] Aí eu vou ter que me virar, eu vou ter que aprender, e como é que vai ser? E, hoje em dia, eu acho assim, até esse curso é muito legal porque as pessoas também começaram a perceber, ou eu me viro, ou eu faço alguma coisa, ou eu corro atrás, ou então eu vou fazer nada.

- Ou vai ficar pra trás.

- Então, eu acho assim: devagar, as coisas vão se disseminando, né? As coisas vão acontecendo. Eu acho que a gente não pode mais ter essa ingenuidade de dizer: "ah, eu não faço mais porque... não, tudo bem". - É interessante, é um movimento. Primeiro se constata, né, ah, por quê? Não tem motivo, é uma resistência. Então não é só chorar: ah, não deixam, não querem, eu sou sozinho, eu tô contra a corrente, nunca vai dar certo [...]. Mas, [...] devagarinho, as coisas estão mudando. Não é no tempo que a gente quer? Pode não ser, mas é um movimento que tá acontecendo, até mundial, né? Uma hora vai ser impossível, mas a gente faz a nossa parte. 
Os números relativos aos dias e horários em que as professoras mais utilizam o computador confirmam essa exclusão digital no espaço escolar. É aos fins de semana e à noite - ou, ainda, nos horários contrários às aulas - que podem acessá-lo.

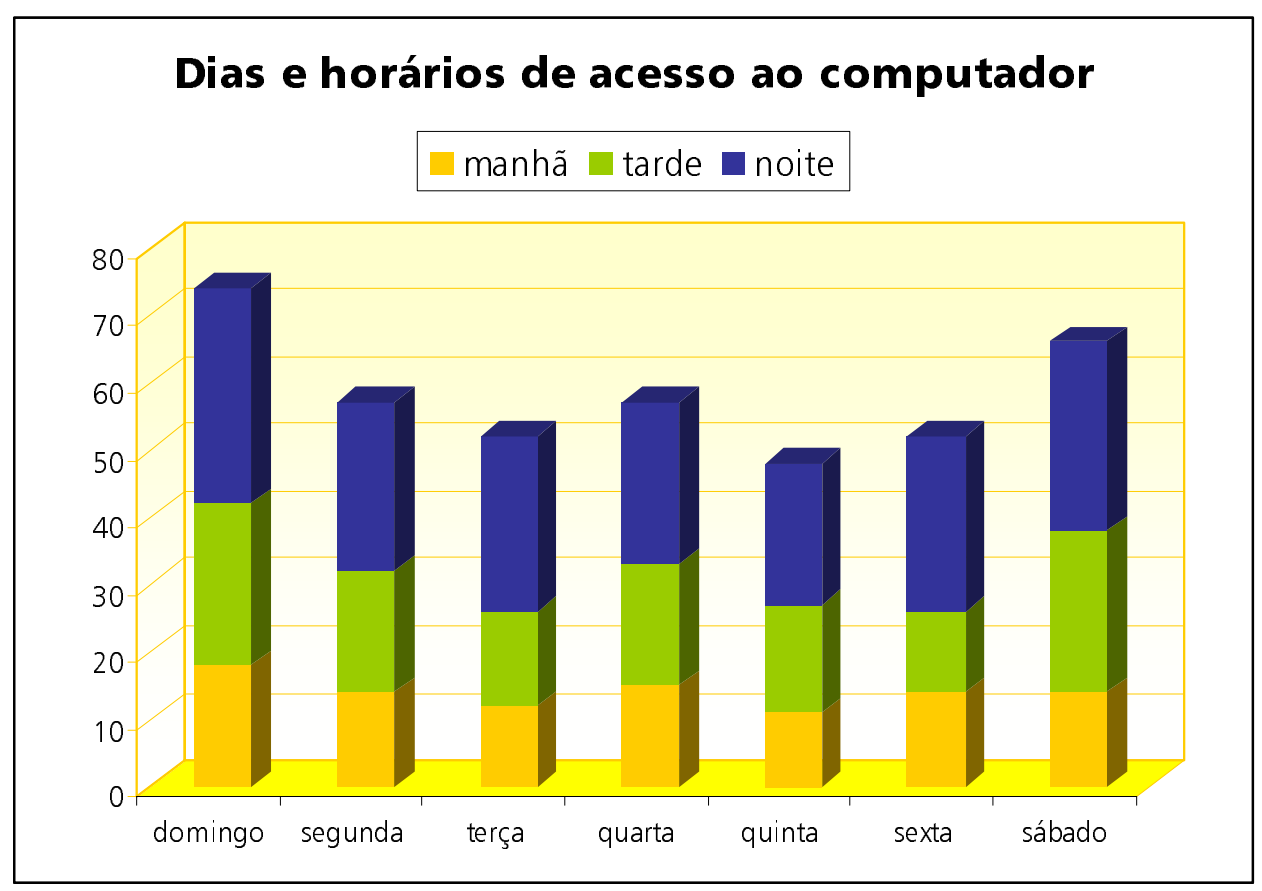

Apenas 52\% das professoras afirmaram ter feito algum curso de informática. Os mais citados são os básicos (Windows e Linux) e os destinados à utilização de processadores de texto. Estes, ao lado dos navegadores de Internet, são os software mais conhecidos e empregados:

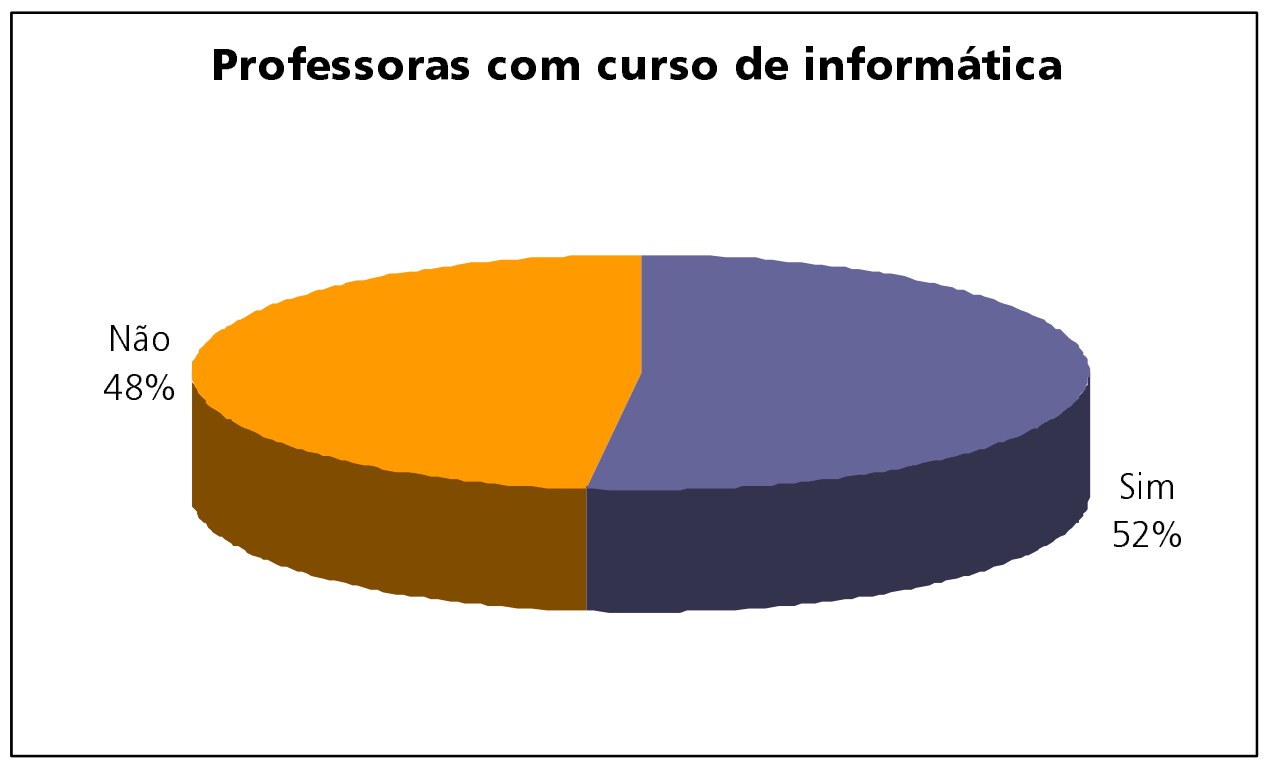



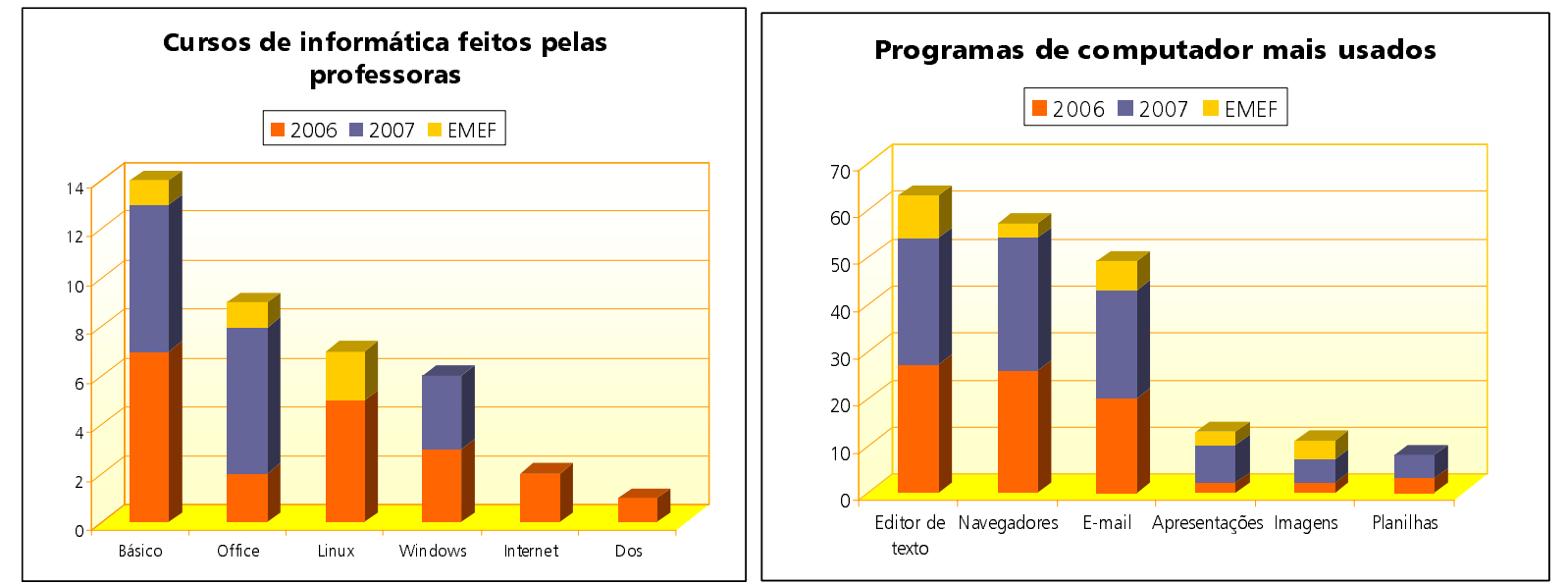

A Internet é familiar a 92\% das docentes, sendo que 43\% utilizavam o acesso banda larga, contra 49\% discado. A rede auxilia as professoras nas pesquisas, correio eletrônico e leitura on-line de jornais, revistas e livros.
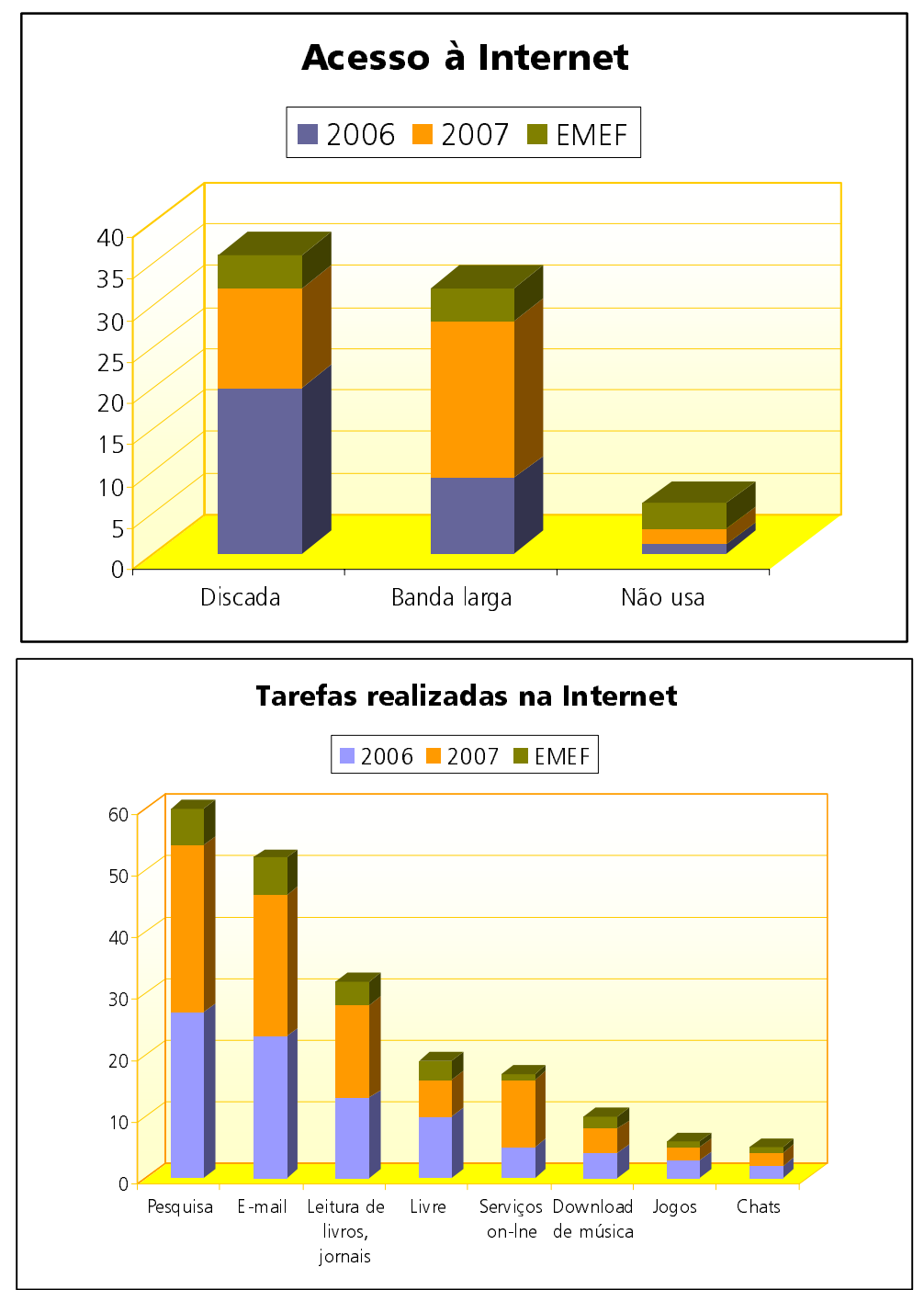
Os websites mais visitados, de acordo com a pesquisa, são os de busca, os portais provedores de acesso e e-mail gratuito e os educacionais.

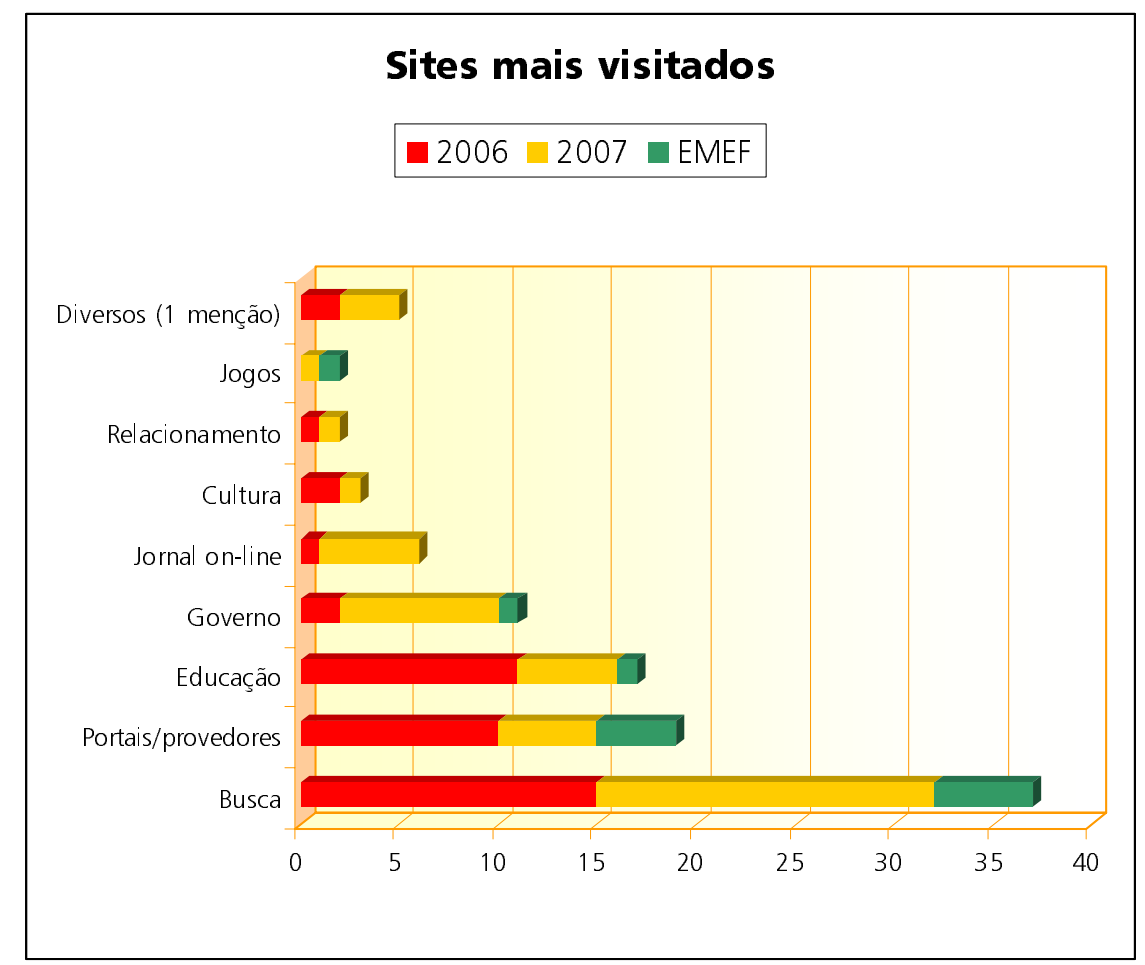

Ainda, o questionário indagou às professoras sobre seu conhecimento acerca dos jogos eletrônicos. Dos $32 \%$ que afirmaram conhecer, a maioria citou jogos comuns de computador, alguns jogos de simulação mais complexos, videogames antigos e atuais e apenas uma menção a um jogo educacional. Explica-se a desinformação geral a respeito do tema: são os seus filhos, alunos e amigos que se divertem com esses programas; apenas seis educadoras declararam jogá-los.

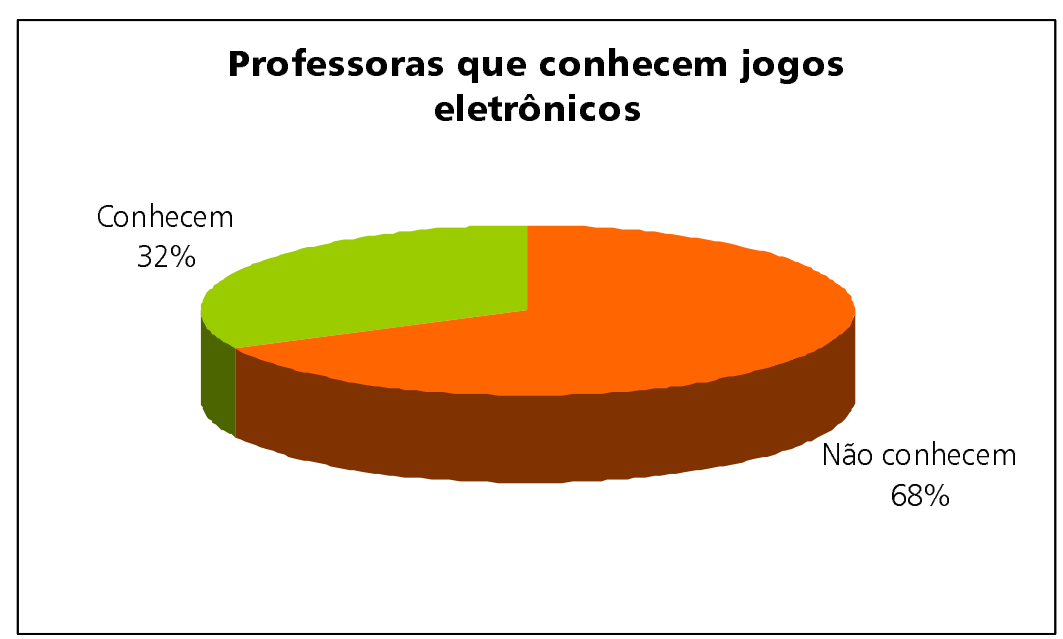


g) Produção de imagens em fotografia e vídeo

A produção de imagens para fins privados é tão restrita quanto o seu uso pedagógico. A maioria das professoras possui câmera fotográfica (em 2007, o número de equipamentos digitais já superava os analógicos, predominantes no ano anterior). Entretanto, as situações em que elas produzem suas imagens se restringem, na maior parte dos casos, a três por ano - o mesmo volume que constatamos nas escolas. Minhas observações mais recentes e informais apontam para o fato de que a popularização das máquinas digitais tem contribuído para alterar esse quadro, graças à eliminação dos gastos com filmes, revelação e ampliação. Os comentários das professoras reforçam essa idéia:

- Agora com o digital, um álbum, você pode ter 500 fotos...

- E é legal também que você pode escolher aquela foto que não ficou boa... no sistema anterior a gente tinha uma perda.

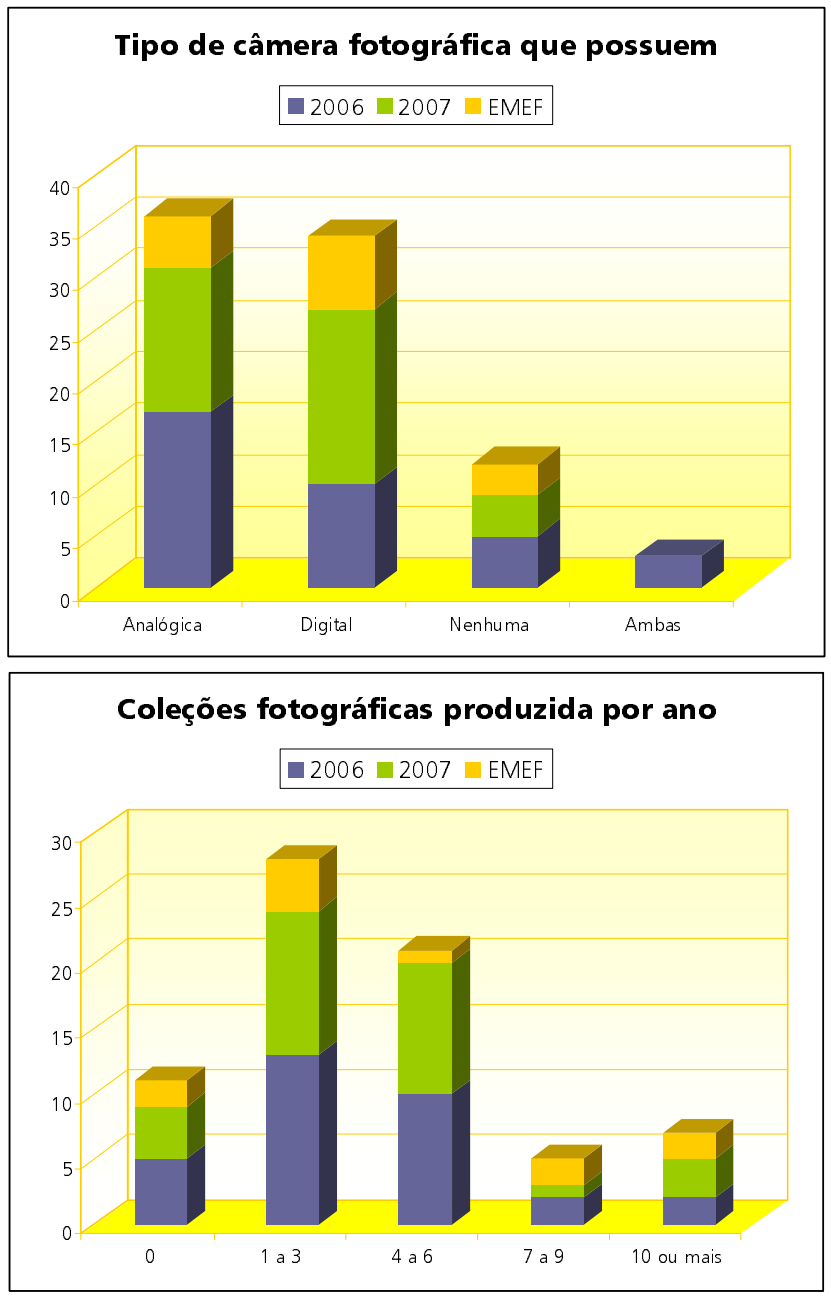


Setenta por cento das professoras não têm câmera filmadora, enquanto $18 \%$ possuem e operam satisfatoriamente e $12 \%$ dispõem do equipamento, mas não sabem como utilizá-lo.

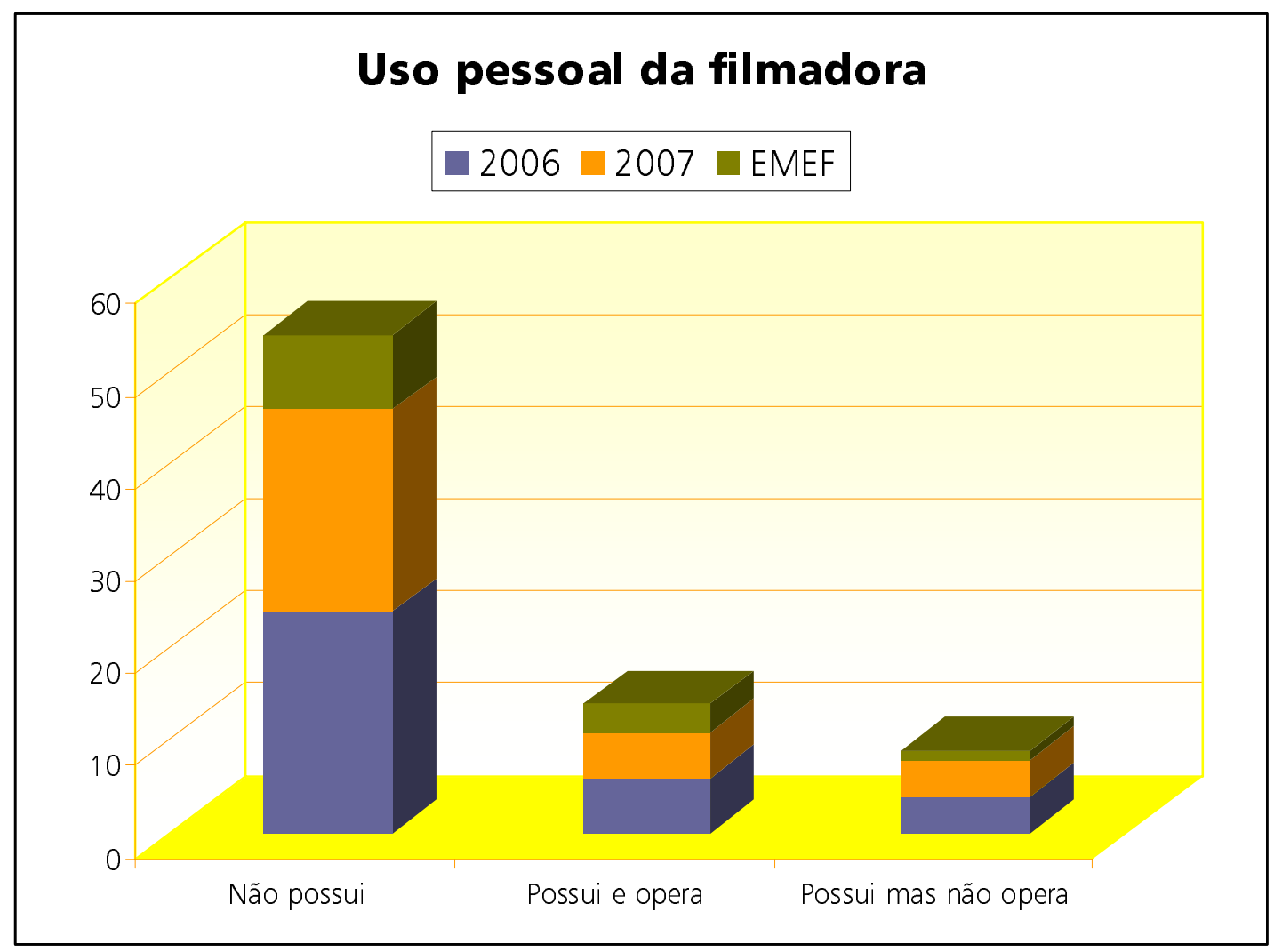

A esta altura do trabalho, já posso retomar os dois primeiros objetivos traçados para esta pesquisa e analisar a forma como os meios e tecnologias da comunicação e as linguagens mediáticas se fazem presentes no cotidiano dos docentes, quer no quesito quantitativo do acesso, quer no aspecto qualitativo, do uso desses elementos. É possível, ainda, avaliar de que maneira as suas proficiências comunicativas e matrizes culturais afetam e são afetadas pelo processo de formação continuada.

Os dados da pesquisa quantitativa, confrontados com as informações geradas nos grupos de discussão, revelaram que as professoras possuem diferentes canais de entrada para os meios e tecnologias da co- 
municação e informação, sendo por intermédio deles que desenvolvem suas proficiências comunicativas: a) a sua vivência social e privada; b) a formação inicial ou continuada e c) o trabalho. Em comum, esses três âmbitos caracterizam-se, de modo geral, pela limitada disponibilidade de bens culturais, começando pela leitura de livros, jornais e revistas, passando pela freqüência ao cinema e ao teatro e alcançando o campo da informática. Entretanto, essas restrições não dizem respeito apenas à oferta desses bens, mas, sobretudo, à natureza do uso que deles fazem. Vejamos:

a) O acesso aos bens culturais pela vivência social e privada abrange as experiências que as docentes podem ter em casa ou em pontos de apoio, como associações, grupos, clubes e outros. Aqui, as oportunidades de fruição cultural dependem da distribuição do tempo livre da professora (isto é, fora da escola). De acordo com seus depoimentos, vimos que esse tempo tem sido cada vez mais escasso. Seja porque, diante de uma remuneração pouco compensadora na rede pública, os educadores são levados a adotar uma rotina de trabalho mais pesada, em mais de uma escola, seja porque as mulheres, predominantes na profissão, sobretudo na primeira fase do ciclo fundamental, já na faixa acima dos 40 anos, ainda têm assumido a maior parte das funções domésticas, conciliando os papéis de profissional, mãe e dona-de-casa. Outros fatores também interferem na organização das horas livres, como a origem social, os hábitos familiares e as inserções sociais e políticas.

Constatamos, portanto, que a sua capacidade de investir tempo e recursos em atividades de fruição cultural e lazer é, de modo geral, bastante reduzida. O mesmo vale para o aprendizado da informática e do trato com equipamentos audiovisuais. Basta retomarmos os números apresentados e veremos que a TV aberta é o bem cultural com maior abrangência no grupo pesquisado. A audiência do rádio é apenas ocasional. Cinema e teatro são opções raras; a leitura de jornais e revistas, irregular e o uso de livros, embora acima da média para os padrões brasileiros, deixa muito a desejar, se considerarmos a ocupação dos respondentes. O computador da casa, compartilhado com outros usuários, está disponível por menos de uma hora por dia, para a maioria dos entrevistados. A Internet discada, por meio da qual acessam prioritariamente a rede, por si só, já limita os tipos de conteúdo e aplicativos executáveis. 
Mais grave do que isso, quando examinamos os veículos de comunicação mais consumidos, notamos que são os hegemônicos (TV Globo, revistas Veja e Isto É, Correio Popular e Folha de S.Paulo, filmes norte-americanos, sites de provedores e busca). Não seria de se esperar, para um grupo de educadoras, maior diversidade de fontes de informação e entretenimento? Ora, essa restrição quantitativa no acesso aos diferentes meios (em volume e variedade) leva a um empobrecimento de seus repertórios, ao desconhecimento de toda uma produção cultural que não passa pelos meios de massa. Nem é preciso mencionar, ainda, o problema da unicidade dos pontos de vista ideológicos. As educadoras, via de regra, mostraramse alheias à existência de uma rede paralela de produção e circulação de bens culturais alternativos ao mercado, podendo ser mais bem definidas como consumidoras que como produtoras independentes.

Contudo, o acesso a amplos e diversificados acervos culturais é uma condição para a compreensão das múltiplas possibilidades de experimentação e uso de uma linguagem, seja ela musical/ sonora, imagética, verbal ou complexa. Isso é o que permite o aguçamento da sensibilidade e da criticidade, o desenvolvimento das proficiências comunicativas e, por conseguinte, a capacidade de expressão e produção cultural. Pode estar aí uma chave para entendermos a grande dificuldade que enfrentam as professoras para a incorporação crítica e dialógica dos meios às práticas cotidianas e de trabalho.

Seja pela origem social ou pela distribuição etária do grupo, nota-se também que alguns bens culturais têm sido introduzidos apenas recentemente no seu cotidiano. Isso significa que nem sempre os hábitos culturais mais antigos dão lugar aos mais recentes (por exemplo, não notamos a substituição da TV pela Internet, comum nas gerações mais jovens, ou o uso intensivo de câmeras digitais). Outra conseqüência é que a incorporação desses novos elementos às práticas cotidianas requer motivação e tempo para adaptação e aprendizado de novos usos. Essa tarefa é trabalhosa e pode ser frustrante para os que tentam empreendê-la no isolamento, fazendo com que tais recursos sejam aproveitados em situações pontuais, estritamente necessárias, mais pragmáticas e objetivas, e menos lúdicas e assistemáticas. Daí que as finalidades de informação, pesquisa e trabalho sejam as mais citadas quando se trata dos meios de comunicação, sobretudo, da Internet. Sublinhe-se que essas aplicações são fundadas na linguagem verbal. 
Esse perfil de uso dos meios de comunicação e tecnologias pelas docentes, quando comparado ao dos alunos, poderá levar a uma importante diferença em relação ao papel dos mesmos na vida dos dois grupos. Embora o questionário não tenha sido aplicado aos estudantes, o convívio com os adolescentes vem demonstrando que os meios estão muito mais integrados ao seu cotidiano, com formas de uso menos restritivas, predominantemente relacionadas ao entretenimento e à sociabilidade, apoiadas em formas narrativas e na linguagem visual (freqüentemente, vista com desconfiança por educadores, que priorizam a palavra escrita). Para crianças e adolescentes, ao contrário de boa parte dos adultos, aprendizado, diversão e experimentação livre podem conjugar-se perfeitamente.

Transposta para as salas de aula, essas diferenças culturais são, comumente, convertidas em preconceitos e exclusões. A ideologia profissional compartilhada pelos educadores faz com que valorizem o desenvolvimento crítico e sensível dos estudantes. Entretanto, por vezes, esse objetivo é interpretado como o dever de julgar e substituir os hábitos e gostos dos alunos, tomados como inferiores, inadequados ou acríticos. De um lado, os professores se privam da oportunidade de se aproximarem dos jovens, conhecê-los e experimentar novas formas de manifestação cultural. De outro lado, o espaço escolar fecha-se para a criação, iniciativa e expressão própria dos aprendizes, apenas toleradas ante a impossibilidade do controle total, mas raramente compreendidas. O fato paradoxal é que constatamos que o próprio educador tem limitadíssimas oportunidades de desenvolvimento crítico e sensível de sua subjetividade.

Uma tarefa importante para a Pedagogia da Imagem é, portanto, discutir as hierarquias culturais, esclarecendo que não se trata de estabelecer uma concorrência entre diferentes formas de linguagem, mas que o intercâmbio entre elas favorece a expressão dos estudantes como um todo e, portanto, a formação das subjetividades e a construção de conhecimentos. A atitude de descentramento cultural ou ideológico, requisito para uma prática educativa inclusiva, é estimulada na medida em que os educadores percebem as próprias limitações, quando confrontados com outras visões de mundo, fontes de informação e produtos culturais até então desconhecidos. Colocando-se em xeque o discurso monocórdio da mídia hegemônica, com sua versão fatalista da história e suas posições dogmáticas sobre a realidade, os educadores desvendam os olhos para inúmeras imagens ocultadas e abrem os ouvidos para as múltiplas vozes silenciadas. 
À Pedagogia da Imagem cabe, pois, auxiliar a comunidade escolar a constituir e compartilhar acervos em diversos suportes e fomentar o desenvolvimento do capital cultural de educadores e educandos, estimulando a sua autonomia para, cooperativamente, acessar, produzir e organizar conteúdos adequados para seus contextos locais e perfis socioculturais. Transformar simples consumidores de (limitados) produtos culturais em realizadores independentes, integrados em rede, significa liberá-los da tutela dos especialistas e da mídia, pelo exercício do direito de dizer a sua palavra e de projetar a própria imagem. Tal desafio precisa ser encarado com persistência, numa visão de longo prazo, pois significa promover novas formas de comunicação e de experiência política e cultural, e não apenas uma atualização tecnológica.

Temos notado, finalmente, que a participação em nosso curso vem servindo de estímulo a muitas professoras para a aquisição de equipamentos como computadores e câmeras e para sua experimentação livre (não necessariamente atrelada ao trabalho docente). Isso é importante porque é através da presença constante e integrada dos meios no cotidiano que se pode desenvolver a fluência em suas linguagens.

b) O acesso aos meios e tecnologias na formação inicial ou continuada, conforme se verifica nos levantamentos que realizei, tem sido, até agora, insuficiente para promover a sua adoção pelas professoras. A formação universitária, em grande parcela dos casos, deu-se antes da disseminação da maior parte dos meios que hoje invadem nosso cotidiano. Cabe, aqui, questionar se, nos dias atuais, essa situação já se reverteu. A formação continuada, por sua vez, não tem sido vinculada a uma firme vontade política ou a uma iniciativa concreta destinada a promover a incorporação do audiovisual ou dos meios de comunicação ao processo educativo, mostrando-se assistemática, dirigida apenas pela ação individual das professoras.

c) A oferta dos bens culturais aos docentes no ambiente de trabalho ainda prioriza os meios tradicionais - livro, jornais, revistas e, no máximo, DVDs. Não é por acaso que eles apareceram em primeiro lugar na pesquisa dos recursos didáticos mais empregados. Além de estarem mais disponíveis, correspondem àqueles em cujo uso as professoras são mais proficientes. Isso significa que, para as educadoras, assim como para os educandos, a escola pode constituir um importante ponto de acesso aos bens culturais, à informação e às inovações tecnológicas, assim como de desenvolvimento das habilidades de uso. 
Contudo, a despeito dessa constatação, no tempo-espaço da escola, o campo cultural não tem sua importância devidamente reconhecida. Centrada na estrutura disciplinar, a rotina docente valoriza desproporcionalmente o material impresso, a palavra escrita, o giz e a lousa. Recursos como as salas de informática e de vídeo, bibliotecas, auditórios, anfiteatros e outros afins - quando existentes e em perfeita ordem - são insuficientes para todas as turmas. Além disso, o tempo do professor é destinado, em sua maior parte, para o desempenho da aula convencional. Mesmo as horas reservadas para projetos têm sido dedicadas ao reforço em conteúdos de Português e Matemática. Normalmente, não há como se voltar, durante a jornada, à preparação de audiovisuais, à formação e ao cuidado com acervos, à pesquisa e elaboração de novos materiais, nem há equipamentos suficientes para isso à sua disposição. Ora, aprender a trabalhar com câmeras e programas de edição de fotos e vídeos, catalogar e publicar imagens, entre outras atividades, são tarefas que demandam muita dedicação. Aqueles que o fazem, em geral, vêm abrindo mão de seus momentos de descanso.

Como esperar que os recursos audiovisuais e as novas tecnologias sejam incorporados ao dia-a-dia das escolas, uma vez que a sua presença no ambiente de trabalho das educadoras é tão limitada? Se estivermos de acordo que tais elementos precisam ser considerados num processo educativo inclusivo e cidadão, temos que reconhecer a urgência de uma política pública abrangente para:

- promover a formação em serviço voltada para essa temática;

- valorizar o magistério, a fim de superar a sua exclusão digital e cultural;

- operar uma redistribuição da jornada de trabalho docente, abrindo espaço para a pesquisa, formação de acervos e desenvolvimento de atividades culturais;

- criar a infra-estrutura adequada na unidade escolar.

A rede pública de ensino necessita direcionar esforços palpáveis para esse fim, em vez de confiar que os educadores o façam por conta própria - é o que tem ocorrido, aqui e ali, voluntariamente, sem a devida organicidade. Não é o suficiente: as condições para a incorporação crítica e dialógica das linguagens e meios de comunicação precisam ser dadas no ambiente de trabalho. Sem isso, a formação em serviço pode resultar inócua. 


\subsection{Histórias de vida: trajetórias singulares desenhando projetos autorais}

Ao longo deste capítulo, tenho investigado os aspectos relacionados aos sujeitos participantes do processo de educação continuada que mediam a recepção da proposta da Pedagogia da Imagem. Explorei, até aqui, aqueles que são socialmente partilhados pelas docentes: suas expectativas de aprendizado (que dizem muito sobre como vêem a tecnologia, a si mesmas e à sua profissão), suas experiências concretas de uso dos meios em sala de aula, sua formação profissional e seus hábitos socioculturais. A partir de agora, porém, tratarei de um fator que distingue o modo como cada professora conjuga tais elementos num projeto pedagógico peculiar: a singularidade de suas trajetórias de vida.

Quatro professoras foram convidadas a dividir comigo suas memórias, retornando à infância e aos tempos de estudante, buscando a experiência com diferentes meios de comunicação e informação ao longo da vida, a decisão de ser professora, os desafios profissionais, a entrada na Pedagogia da Imagem e o projeto em desenvolvimento. Generosas, Walquíria, Analice, Marli e Gracinha acolheram meu pedido e depositaram-me confiança, permitindo que, deste momento em diante, possa recontar suas admiráveis biografias.

\section{Walquíria: "Ser professora é tudo. Vir, entrar de cabeça e fazer acontecer."}

O leitor apressado que, pela leitura do título, tentar adivinhar a personalidade da professora Walquíria pode, equivocadamente, concluir que se trata de uma pessoa agitada, expansiva, até mesmo impositiva. Nada mais distante da realidade. Walquíria é doce, acolhedora e uma excelente ouvinte. Não obstante, ela "vem, entra de cabeça e faz acontecer". Pouco a pouco, sem passar por cima de ninguém, conquistando amizades e respeito, ela tira força da convicção de suas escolhas, do compromisso ético em cada uma de suas ações. 


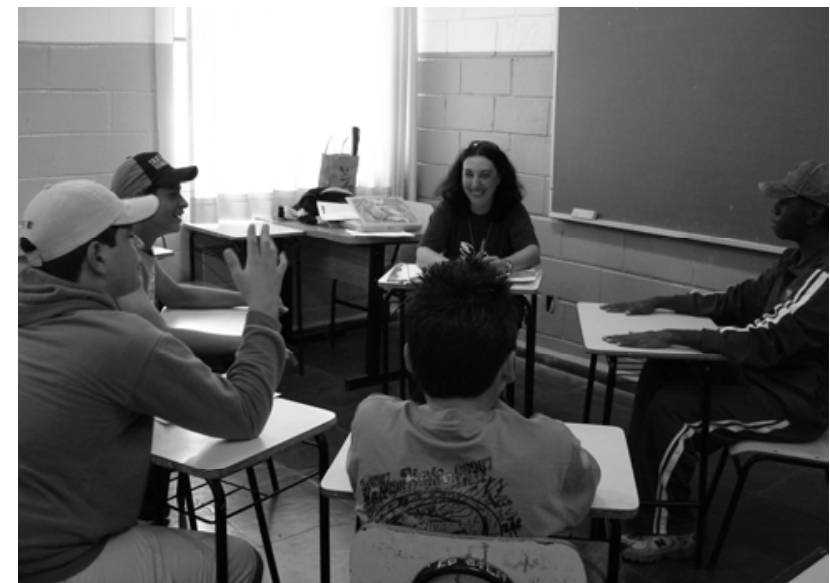

Walquíria entre alunos do projeto
Nascida em Campinas, Walquíria viveu a infância no bairro Chapadão. Tinha pais atenciosos e um irmão mais velho, companheiro. A rua tranqüila, praticamente sem trânsito, era o cenário preferido das brincadeiras com os vizinhos: bicicleta, pega-pega, esconde-esconde. Em casa, as bonecas tinham seus cuidados. Nas férias, à tardezinha, gostava dos desenhos animados que passavam na TV. Quando o pai chegava do trabalho, a família se reunia para assistir ao jornal e às novelas. Entrando na adolescência, os irmãos descobriram o cinema: todo fim-de-semana freqüentavam uma sala na Avenida Aquidabã, há tempos demolida. A sessão dupla, sempre em promoção, trazia comédias, filmes de aventura e super-heróis, que eram a diversão da molecada.

No estudo, os primeiros passos foram difíceis. Não havendo pré-escola, Walquíria foi direto para uma classe de alfabetização. A-E-I-O-U, BA-BE-BI-BO-BU... Isso lá fazia sentido? A professora "grandona" riscava todo o caderno, forçando a mão pequenina a ponto de quebrar-lhe o lápis. O pai tentava ajudar, repassando as lições em casa. Mas a menina, traumatizada, passava mal quando tinha que ir à escola. A mãe, inconformada, tentou dialogar com a professora. Em vão: os problemas só acabaram quando o pai conseguiu transferi-la para outra turma. Daí por diante, a estudante deslanchou.

Walquíria também fazia balé, desde os quatro anos e meio de idade. Começou por causa de uma preocupação da mãe: “disse que eu era muito tímida, né? Eu mudei um pouco, mas não muito." Quando chegavam estranhos em casa, corria para se esconder. Na escola, ambiente rígido, apresentar trabalhos era um terror. Ficava quieta num canto, não gostava muito de perguntar. Nos palcos, porém, ela se transformava. Mergulhava no ritmo e se destacava. A ponto de um dia, já professora de dança, desejar tornarse dona de uma academia.

Entrou para a faculdade, ainda tecendo esse sonho. Era o início da década de 80. A turma de Educação Física, na Pontifícia Universidade Católica, era a única aberta no período intermediário. O isolamento 
do curso não favorecia o contato com outras turmas, nem a participação nos movimentos estudantis. $O$ que despertou o engajamento de Walquíria foi a experiência com a pré-escola, durante o estágio e a pesquisa para elaboração de sua monografia de conclusão de curso. "São coisas que eu não tive. É aquele envolvimento com a criança, descobrir um monte de coisas que você pode fazer por ela com as atividades, o quanto a Educação Física é importante para o seu desenvolvimento.” O antigo sonho acabou ficando para trás: "eu me apaixonei pelo trabalho com os pequenininhos. Acabei vindo dar aula e esqueci a idéia de academia." O elemento que deflagrou a transformação - o exercício prático - para a professora, parece indefinível: "Na verdade eu acho que eu gostei, eu senti essa coisa de dar aula. Aquilo me entusiasmou, me deixou, sabe..." O sentido, como o olhar, fica suspenso no silêncio.

Formada, Walquíria começou a dar aulas no Estado, quando a Educação Física foi instituída no ciclo básico. Mais tarde, efetivou-se na Prefeitura, com a intenção de ensinar as crianças de primeira a quarta série. "Hoje, a minha decisão é trabalhar com a quinta série, que eu adoro." A opção pelos mais novos, a princípio, refletia certo receio por não dominar completamente os diferentes esportes. Com o tempo e a experiência adquirida, percebeu que, para ensinar os fundamentos, não precisaria ser uma excelente jogadora em todas as modalidades: "senão, não tem quem dê aula".

Outros aprendizados vieram com o tempo. Os esforços de Walquíria não se limitam ao ensino do esporte. Ela tenta estimular nos alunos a auto-expressão, a superação das inseguranças, a coragem para se expor e vencer o medo de errar: "A minha preocupação maior são esses alunos que são fechados. Todo mundo tem direito de jogar. Não sabe jogar? Mas ninguém sabe, tá todo mundo aprendendo. Todo mundo vai jogar. Tem que ir pra quadra. Então eles acabam pegando gosto. Eu converso muito com eles." Ela usa, ainda, algumas estratégias para evitar a discriminação e o isolamento dos estudantes menos hábeis no esporte. Infelizmente, essa atitude não é regra na escola: "quem é tímido às vezes se fecha até mais, devido às broncas que leva, situações que acontecem. Por não ter muito que se expor, acaba ficando quieto e ninguém percebe. De uma maneira geral, a escola não o estimula. Fala-se muito que a escola deve preparar o aluno pra vida. Aí nós não estamos preparando pra vida." 
A relação da professora com os estudantes sempre foi de proximidade: "eles têm liberdade de chegar, vêm muito conversar, abraçar." O que não anula o respeito necessário: "eu quero dar aula, entendeu? Então eu sou aquela que dá aquecimento, que ensina vôlei, handebol, basquete... mesmo que eles só queiram futebol. Então eu converso muito, eu brinco quando tem que brincar, fico brava quando tem que ficar brava. Quando a coisa é séria, eles percebem.”

Para comunicar-se melhor com as crianças, Walquíria passou a observar seus hábitos e informar-se sobre seus gostos. "Eu assisto TV, mas muito pouco. Não tenho muita paciência, porque eu gosto de ler. Às vezes, eu escuto comentário dos alunos sobre alguma coisa, então eu acabo assistindo pra saber do que se trata e pra não ficar por fora. Depois que eu fiz a Pedagogia da Imagem, eu vi que a Cultura tem alguns programas sobre filmagem, sobre cinema, então eu comecei a assistir também." Ela, ainda, costuma ir ao cinema e coleciona filmes em DVD, muitos deles, desenhos animados: "Tem gente que fala: nossa! Mas eu gosto. Eu me encanto com desenho." Mais um ponto em comum com os estudantes das quintas séries.

A entrada na Pedagogia da Imagem ocorreu porque Walquíria desejava aprender algo que não estivesse diretamente relacionado com sua área. "A gente tem que cumprir o TDPR. Mas, na Educação Física, mesmo que você queira dar um reforço, o aluno que precisa não vem." Ela tentara, sem sucesso, oferecer aulas de dança. Os cursos de formação continuada feitos anteriormente também não a haviam agradado: "Você trabalha há tanto tempo, eu leio muito, eu procuro muito. Então o pessoal vem falando como se você não fizesse nada, como se você não soubesse nada. E não é assim. O pessoal começa a jogar, parece que você não sabe fazer. Então eu mesma desencantei. De um tempo pra cá eu tenho feito coisas diferentes." Walquíria interessou-se pela proposta da leitura crítica de filmes e matriculou-se em nosso curso. "Eu fui, nem imaginava que fosse aplicar na escola. Não pensei nisso. Eu fui pensando em mim mesma, em ser mais crítica, alguma coisa assim." O ambiente familiar também interferiu na sua escolha. "Em casa sempre teve muita tecnologia, o meu marido gosta. Sempre teve filmadora, máquina fotográfica e eu não usava. Eu mal sabia ligar, e ele perguntava para quê a gente tinha comprado." Hoje a situação se inverteu: "eu estou filmando mais, toda vez que eu vou sair, que eu vou fazer alguma coisa, eu já lembro de levar a máquina fotográfica, a filmadora, de carregar a bateria. E muitas vezes ele fala: deixa que a 
Walquíria filme, que ela filma melhor." Ela ri e confessa: “Eu gosto, eu gosto.” A professora, que em 2006 mal sabia operar uma câmera, dois anos depois está explorando esses recursos e editando filmes no computador, num processo de permanente aprendizado. "Comecei a brincar, a fuçar, a mexer, a ter curiosidade." O que a conduziu até aqui foi a concepção e implementação de um projeto educativo, a sua interpretação particular da Pedagogia da Imagem.

Ao longo do curso, Walquíria teve experiências que correspondiam às suas expectativas, e outras inesperadas. "Com o decorrer das discussões, eu fui mexendo, fui descobrindo a filmadora, fui me interessando e, mais para o final eu comecei a ver que ia ter uma utilidade, que eu ia conseguir aplicar na escola. Eu tive a idéia de fazer o projeto pra 2007, me entusiasmei e vi que realmente consegui chegar." Na Pedagogia da Imagem, havíamos pedido que as professoras elaborassem um projeto prático para aplicar na escola, com a participação dos alunos. A princípio, Walquíria ficou imaginando como iria conciliar esse requisito com as aulas de Educação Física. Em agosto, porém, surgiu na EMEF a proposta de uma semana do folclore. Walquíria quis fazer o registro das atividades, mostrar as brincadeiras e danças. "Eu principiei a filmar e chamei uns alunos meus. Expliquei para eles como a filmadora funcionava e começamos a conversar. Fui envolvendo os estudantes e eles passaram a gravar também.” Ao final da semana, reuniram-se para selecionar as melhores cenas e editar um vídeo, apresentado no encerramento do evento. "Montamos uma sala e os pais entravam para assistir às pinceladas do que tinha acontecido naquela semana." Todos sentiram que a experiência havia sido positiva e Walquíria percebeu que era possível desenvolver uma atividade com os adolescentes. "Eu podia fazer isso, juntar uma turma, trabalhar como se trabalhou na Pedagogia da Imagem, assistir filmes, conversar, fazer roda de discussão... Eu fui juntando algumas coisas que havia visto no curso, na visita à Casa Tainã." Com sua sensibilidade, foi percebendo o interesse dos alunos e compondo experiências singulares.

No ano seguinte, o plano foi posto em prática. Convidou diferentes alunos de quinta a oitava série e os agrupou em duas turmas, de acordo com a idade. Alguns outros tomaram conhecimento do projeto e pediram para entrar, juntando-se ao grupo ao longo do tempo. Seu objetivo principal não era simplesmente ensinar o manejo dos equipamentos. "Eu até falei muito pra eles: o objetivo nosso não é ensinar vocês a tirar foto e filmar. Isso eu venho em dois, três dias, dou a máquina, vocês aprendem, acabou. En- 
tão não é isso. Também vai fazer parte, mas não é só isso." A ambição de Walquíria estava mais adiante: "Uma coisa que eu questiono muito na educação é se a gente ensina. A gente tenta passar uma série de coisas, mas a gente não ensina as pessoas a se olharem, a se conhecerem. Entendeu? Eu pensei que a Pedagogia da Imagem pudesse ser esse momento: de repente, a gente sentar em roda e se conhecer."

É juntamente com os adolescentes que Walquíria vai elaborando o planejamento e trazendo informações e suporte necessário ao desenvolvimento do grupo. "Eu nem sabia se eu ia querer trabalhar mesmo aquela parte toda da teoria da filmagem. Eu estava preocupada porque achava que não sabia o suficiente. Então eu estou caminhando mais ou menos assim: de acordo com o que vai acontecendo, eu vou encaixando. Agora eles precisam saber fazer o roteiro, então eu vou ensinar a fazer o roteiro. Chegou a um ponto onde eles precisam disso, então eu vou mostrar. Uma coisa leva a outra. Logo de cara, foi dar a filmadora na mão deles. Eles gostaram muito, sentiram-se o máximo."

A metodologia foi sendo composta de modo a se adaptar às condições da EMEF. "É uma coisa nova, a gente faz com material que não é só meu, é da escola. Eles se preocupam muito, se vai sumir, se vão roubar... Você fica com aquela responsabilidade." Aos poucos, a confiança da equipe gestora foi sendo conquistada, e os estudantes participantes do projeto adquiriram respeito, com passe livre para acessar os equipamentos e realizar os registros. A infra-estrutura é, de fato, a principal dificuldade encontrada até o momento: "você fala que vai usar o computador, a sala do laboratório está desmontada, não pode usar. Você fala que vai fazer um filme, a filmadora está sem fita, ou não carregou a bateria. Você quer exibir um filme e tem que agendar a sala com vários dias de antecedência. Também não dá pra ficar usando muito, porque tem outras pessoas que precisam usar, não posso monopolizar no meu horário. Mas eu estou conseguindo fazer a coisa acontecer, porque eu estou correndo por fora, usando o que é meu." E Walquíria constata, sem pesar: "se fosse esperar a escola, as coisas não teriam caminhado. Teriam parado."

Ela também teve receio, ao se ver num terreno desconhecido: "O medo era assim: se eu chegar para dar uma aula e acontecer alguma coisa, que aquela aula não saia, que não aconteça... Na Educação Física eu tiro de letra. Mas a preocupação era marcar uma hora e meia, chegar lá, acabar o que você tinha que fazer e não acabar o tempo. E aí?" Hoje ela ri: "Depois eu fui vendo que é a mesma coisa. Você tem a experi- 
ência, você entra e tudo bem. Às vezes o tempo é pouco, porque os meninos se empolgam com as coisas, vão falando e tudo vai acontecendo..." Quando é hora de encerrar as atividades, eles perguntam: "já acabou?"

Inicialmente, as tarefas se voltavam para o registro em vídeo do cotidiano escolar. "Tudo o que acontece na escola a gente filma." Os professores comumente solicitam que atividades especiais, como estudos do meio e passeios, sejam gravadas. "Um professor organizou uma ida ao Hopi Hari e lá os alunos tiveram uma lição de Física. Ele pediu para filmar porque ele queria usar a fita editada para dar aula aos alunos que não foram.” A professora de informática também requisitou uma filmagem sobre o projeto Alunos Monitores, para exibição num encontro municipal. Alguns, porém, não têm tido a mesma compreensão: "Eu escuto falar assim: pra que filmar tanta coisa? Vai fazer o quê com esse monte de filme?" Contrariando esse ceticismo, os alunos foram-se envolvendo cada vez mais no cotidiano da escola, sentindo-se importantes e responsáveis pelas gravações que ajudam a escrever a história da EMEF. Walquíria nota o seu interesse e iniciativa: "eles se propõem a fazer e correm atrás de tudo." Participando das decisões relativas a cada projeto, eles aprendem a argumentar e se tornam ativos: "eles estão trocando idéias, falando o que pensam, colocando o que querem ou não querem, dando sugestões. E eles vibram.”

Com o tempo, os adolescentes foram acrescentando objetivos próprios. Um garoto revelou o sonho de se tornar jornalista. Os demais se mostraram curiosos. Walquíria contactou um repórter do Correio Popular e organizou uma palestra. Com a ajuda do MIS, visitaram o estúdio de gravação e edição de vídeo de uma faculdade de Comunicação Social. Os estudantes puderam conheceram detalhes da profissão e tiraram muitas dúvidas. Propuseram-se a criar um jornal para a escola e Walquíria aceitou o desafio. Elaboraram uma pauta que abrangia fatos não apenas escolares, como também de interesse do bairro. Realizaram pesquisas, entrevistas, saídas fotográficas. Criaram charges e tirinhas divertidas. Fizemos a editoração juntos, no Museu da Imagem e do Som. A impressão de 1700 exemplares foi conseguida por meio de um vereador da região. A primeira edição foi complementada com um blog na Internet. Seguiram-se duas outras, sendo publicadas regularmente, a cada seis meses. 
Um momento marcante para esses repórteres mirins foi a presença do prefeito, Hélio de Oliveira Santos, na escola, a pretexto da inauguração do sistema de câmeras de vigilância. O grupo fez o registro da solenidade e, ao fim, conseguiu uma entrevista com o Dr. Hélio. Perguntas de grande interesse dos estudantes, como a cobertura da quadra de esportes, acabaram irritando o entrevistado, mas não arrefeceram o entusiasmo dos jovens comunicadores. Em 2008, além da publicação de duas edições do jornal e dos registros em vídeo de atividades escolares, os alunos do Projeto Pedagogia da Imagem produziram um documentário sobre a história da EMEF e uma animação sobre o meio ambiente - iniciativas que partiram deles próprios.

O entusiasmo dos estudantes é inquestionável: "outro dia, estavam me perguntando se no ano que vem o projeto vai continuar." Walquíria destaca seu aprendizado: "Tenho notado que alguns alunos, que eram muito quietinhos, nunca falavam, estão se expressando mais e melhor. É uma coisa que para eles vai ser boa." As sessões de cinema, seguidas de debates, têm contribuído para desenvolver sua capacidade de argumentação, de uma maneira plural: "eles estão conseguindo respeitar um ao outro, saber que cada pessoa pensa de um jeito." Mesmo com as diferenças de idade, tornaram-se amigos e solidários: "A integração é tranqüila. Os mais velhos vêm ajudar, os outros aceitam. Não tem problema nenhum.” O saldo também é positivo no quesito criticidade: "eles estão começando a perceber as coisas. Você vê um aluno entrevistar um vereador do bairro onde ele mora e começar a questionar. Sabe, eles mesmos já conversam sobre isso."

A própria Walquíria tornou-se uma aprendiz: "é o que eu falo: não é só pra eles que está sendo bom. Fora a tecnologia, que eu estou aprendendo a usar mesmo, até a edição de filmes, que eu nunca tinha feito antes e acho que estou fazendo bem, a maior lição é de estar mais próxima deles. A gente fica mais amiga, fica conhecendo mais a vida e os problemas dos alunos. Eu sinto uma amizade, uma coisa muito forte. $\mathrm{O}$ que está valendo mais é esse elo." A satisfação de reencontrar sentidos para o trabalho, por meio do projeto, lhe dá ânimo para enfrentar os obstáculos no ambiente escolar: "é algo que dá energia. Tem tanta coisa que acontece... Às vezes eu saio daqui e falo: ah, não quero mais saber. Mas eu não consigo, estou sempre envolvida, fazendo as coisas. É prazeroso, você sai leve, flutuando. Eu vou dirigindo para casa e parece que o carro vai sozinho. Eu vou lembrando, eu vou rindo, literalmente flutuando. Aí, nessas horas, 
você fala: ainda vale a pena, ainda tenho que investir. A educação tem que ter caminhos para a gente insistir. Precisa trabalhar muito, pra mudar muita coisa."

$\mathrm{Na}$ EMEF, a seriedade e visibilidade do projeto the vão conferindo legitimidade. No início do ano letivo, Walquíria elabora um planejamento e apresenta à equipe gestora, juntamente com uma edição especial de tudo o que foi feito no período anterior. De tempos em tempos, faz o relatório das atividades em andamento. "Eles estão vendo que é uma coisa que está acontecendo. Os alunos vivem aí, toda hora, filmando. Eles estão começando a incorporar, a ver que é uma coisa diferente, que está caminhando e está tendo um retorno.” A boa reputação do projeto, até agora, rendeu um acesso mais fácil dos alunos aos equipamentos, com o notável esforço dos gestores para viabilizar as atividades propostas por Walquíria ou pela equipe do MIS.

Nas reuniões pedagógicas, a orientadora demonstra seu apoio, expondo para o corpo docente os produtos desse projeto, incentivando a participação de outros educadores e a integração da Pedagogia da Imagem com as diferentes disciplinas. "Todos os professores estão a par, mas eu acho que eles ainda não conseguiram visualizar uma forma de fazer essa integração. Eu gostaria que fosse uma ferramenta para eles, como um computador, como o giz. Eu queria isso, que eles entrassem com propostas pro jornal, com textos das matérias deles, trabalhando na rede: o professor entraria no laboratório e estudaria um assunto com os alunos, entendeu? Mas eu ainda não estou conseguindo esse retorno."

No espaço coletivo, porém, aspectos políticos têm que ser considerados e, muitas vezes, criam barreiras para a visibilidade e o reconhecimento de projetos. Durante a greve de 2007, Walquíria quis utilizar os vídeos elaborados para demonstrar que as horas de TDPR eram, de fato, úteis e necessárias para o desenvolvimento de projetos com a participação de alunos. Ouviu um conselho desanimador: "Cuidado no que você vai entrar, porque você tem o que mostrar; a maioria não tem.”

A expectativa de Walquíria, contudo, é que, com a consolidação do projeto na EMEF, a conquista de infra-estrutura e recursos necessários para seu andamento se torne mais fácil. "No início do ano eu fiz um projeto com tudo o que precisaria. Algumas coisas eu vou conquistar, outras não. Eu acredito que eles 
vão montar o que precisa, quando tiver verba. Com o tempo, sim. Às vezes, também, a culpa é minha, porque eu não sou muito de reclamar, nem ficar esperando. Eu sou de resolver, e correr atrás, e fazer."

A divulgação do projeto junto aos pais e à comunidade também tem sido limitada. "Foi comunicado no início do ano, quando foi feita uma reunião de pais. A diretora e a orientadora pedagógica informaram que o projeto estava começando e explicaram o que era." Esse relativo distanciamento expressa o tipo de relacionamento entre a escola e seu entorno: "Eu não sinto a comunidade integrada. Uma mãe de aluno tem me ajudado, ela conseguiu o contato de um jornalista para vir aqui falar com os meninos e no dia da palestra ela estava presente. Algumas pessoas me perguntaram: o que essa mãe está fazendo aqui? Ora, por que a mãe não pode estar aqui assistindo? Por que ela não pode acompanhar? A escola ainda tem aquela coisa de só se dirigir aos pais quando vai falar sobre algum problema dos filhos. O contrário também acontece." Algumas atividades abertas à comunidade, aos poucos, foram se extinguindo. "Antigamente, ainda existiam festas grandes, como a festa junina. O pessoal vinha e participava. Hoje em dia, nem isso tem. A escola não se aproxima, não deixa." Apesar disso, a EMEF é bem conceituada na região. "Vem gente de muito longe porque quer estudar nessa escola."

Antes de encerrar a conversa com Walquíria, pedi que ela definisse o que é ser professora. Diante da pergunta, ela suspira e sorri. “Ai... falar que é tudo... Mas é. É ser amigo, é estar próximo, ajudar a crescer, desenvolver. Não sei se eu falo ensinar, porque não sei o quanto a gente ensina alguma coisa. Mas é compartilhar o que você tem com eles, pra eles aprenderem a viver, a progredir, a crescer mesmo. Eu acho que é isso: um caminho aberto." A força dessa convicção a define como profissional: "Se eu estou ganhando para isso, eu tenho que fazer a coisa direito. Senão, é uma corrupção. Quando eu me envolvo com alguma coisa que me agrada, eu dou o sangue, eu visto a camisa, eu faço. Pela escola eu também sou assim. O que precisa a gente vai fazendo. Se você não acredita mais, você morre, porque no meio da Educação, você se deixa abater mesmo. Eu ainda tento. Acho que é o meu jeito de ser. De vir, entrar de cabeça e fazer a coisa acontecer. De um jeito ou de outro, fazer acontecer.” 


\section{Analice: "Uma coisa eu sei: eu sou uma professora."}

Definir Analice? Melhor recontar sua história. Como ela mesma afirma, tudo é processo. "Como julgar uma pessoa? É como um rio: quem pode dizer que conhece um rio? Ele começa numa nascente, mas pra onde é que ele vai? Não dá pra você dizer que conhece um rio. Assim como não dá pra falar que conhece uma pessoa, que a pessoa é isso, a pessoa é aquilo... Muitas coisas que eu fiz na vida me vêm à memória e eu é que tenho que julgar o que foi bom e o que não foi. Tem momentos que você tem tanta segurança naquilo que faz, que não precisa da aprovação de ninguém. Quando tem que esperar a opinião do outro, você tem duas escolhas: ou você não faz, ou você faz e... espera o resultado.”

Três filhos, quarenta anos de idade, dezoito de carreira na Prefeitura, Analice não é de esperar, é de fazer. Nascida em Campinas, pra onde ela vai? "Não sei... Se é que a gente tem escolha. Mas a gente tem que aprender e curtir o que a gente está vivendo agora." A história de Analice explica, de certa forma, seu modo de pensar. Ela começa a entrevista com uma forte declaração: "Eu faço questão de dizer: eu não queria ser uma professora. Mas acabei virando uma." Diz isso emocionada, sem pesar ou arrependimento. Convicta e

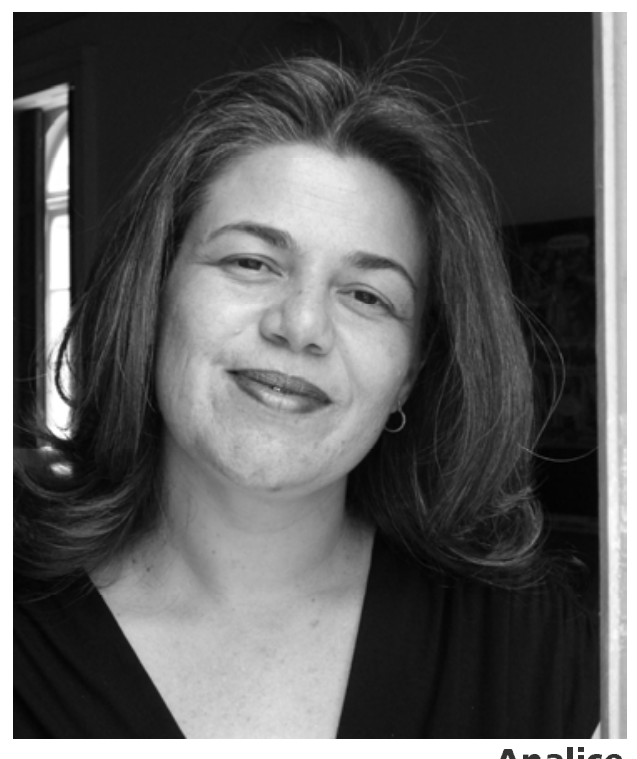
confortável: “Eu sou uma professora.” E também para isso não há definição.

Sua infância, compartilhada com mais três irmãos, foi um tempo de liberdade e experimentações. Primeiro, na colônia da Rhodia, onde o pai trabalhava. Lá, tinha um pouco de tudo: pré-escola, assistência médica, contato com plantas e animais, passeios organizados e sessões de cinema. Mais tarde, mudaramse para o bairro São Quirino (local onde hoje trabalha, na EMEI Recanto da Alegria). "O bairro da minha infância era assim: a gente brincava muito na rua, ficava até de noite. Na garagem de casa, fazia bailinho, chamava a criançada da rua. Era muito tranqüilo. A gente ia sozinha pra escola, voltava sozinha pra casa. Estudava lá mesmo, numa escola estadual. Fiquei nela da primeira à sétima série. Eu gostava de lá, 
era a queridinha da professora. A Tânia [parceira da EMEI] foi minha colega. A gente se encontrava para ir à escola, dividia o lanche na hora do recreio. Na adolescência, participamos de um grupo de jovens da igreja. Fizemos juntas a catequese, primeira comunhão, aquela coisa toda.” Iam também às matinês de cinema, no bairro Taquaral, onde se divertiam com os filmes do Mazzaropi e Guerra nas Estrelas. "Nosso point era ali: tinha a sorveteria, os passeios na lagoa... Íamos sozinhas, sem precisar de pai e mãe. A gente conhecia muito bem aquela comunidade. Até que meu pai precisou se mudar para Conchal."

Assim que completou a oitava série, em Conchal, Analice quis retornar a Campinas: "Eu tinha uma verdadeira paixão por informática, sonhava trabalhar nessa área. Então eu prestei o Cotuca (Colégio Técnico de Campinas), para fazer Processamento de Dados. Só que eu não passei e fiquei muito chateada." Tendo que retornar para junto dos pais, numa cidade pequena, viu-se diante de duas opções: "era magistério ou contabilidade. Embora não quisesse ser professora, eu fiz o magistério. Tinha uns professores interessantes e eu acabei gostando bastante." Terminado o curso, a família retornou a Campinas e ela foi estudar Pedagogia. "Fiz um ano de PUC e, durante esse tempo, eu fui estagiária da Prefeitura, numa EMEI em Barão Geraldo. Lá, uma pessoa me falou: por que você não tenta a Unicamp? E me apoiou muito, me ajudou bastante. Então eu fui fazer a Unicamp, na primeira turma de Educação Especial. Tinha um curso que era oferecido pela professora Afira, Informática Educativa. Eu falei: tá vendo? Eu vou fazer esse curso e vou criar softwares educativos! Na realidade, o curso era para desmistificar o uso da tecnologia na escola, não era nada do que eu estava pensando. Muito pelo contrário: era colocar a ferramenta na mão da criança para que ela criasse, através da tecnologia. Era mais um jeito de trabalhar. A gente usava uns computadorezinhos MSX. Eu fazia muitas experiências com meu irmão caçula, que era criança ainda. Então ele aprendeu a mexer com isso desde pequeno. Hoje em dia, ele me ajuda a editar os vídeos, tem uma certa desenvoltura. Eu tenho só curiosidade.”

Nos tempos da faculdade, Analice tinha um grande amigo estudante de Computação. "Ele foi convidado a dar aula no Colégio Objetivo. Era moda ter informática no colégio e ele veio me pedir ajuda nessa área pedagógica. Depois, ele foi fazer estágio em outro lugar e me indicou para a sua vaga. Eu dei aula uns seis meses para adolescentes. Fiquei super-amiga da molecada, foi muito legal.” Próximo ao final da graduação, ela teve a oportunidade de fazer iniciação científica em Educação e Informática. "Como eu 
sempre gostei dessas coisas, foi muito interessante. A gente trabalhava no colégio estadual, onde a professora montou um laboratório. O projeto se chamava Educom. Eu acompanhei as crianças no uso da informática. Fiz trabalhos e participei de alguns congressos.”

Formada, Analice prestou o concurso para a rede municipal, foi aprovada e se efetivou. "Naquele tempo, ainda não havia uma política de inclusão da criança com necessidades especiais. Já se pensava na sua atenção, mas isso era feito por instituições especializadas, e a Prefeitura dava todo o apoio." Analice foi cedida para uma instituição dedicada a portadores da síndrome de Down. Depois de um certo tempo, ela se afastou para fazer o mestrado - novamente, unindo tecnologia e educação. "Enquanto fazia a pós, eu fui trabalhar na IBM. Foram uns dois anos e meio na área de informática, dando assessoria para escolas particulares que estavam se informatizando. Naquela época, o Estado também estava colocando computadores na rede de ensino. Eu acabei fazendo o que eu sempre quis." Com o título de Mestre nas mãos, Analice retornou ao seu posto na Prefeitura. "Aí a política de inclusão já era outra. As opções eram: assumir uma sala regular ou ser professora itinerante, com crianças especiais. Fiquei trabalhando com as crianças especiais.”

Àquela altura, Analice estava apta a utilizar diferentes recursos tecnológicos e fez muitas experimentações. "A gente não tinha computador na escola. Eu comecei a inventar uns videoclipes com as crianças. Como elas eram especiais, a escola tinha aquela resistência a fazer apresentações, um teatro para os pais... Falavam que ia dar tudo errado. Então, eu sugeri fazer uns clipes, que podiam ser editados. Foi muito legal essa experiência. Produzimos as crianças, eles se maquiaram, a gente filmou. Causou grande impacto nos pais. Eles assistiam ao videoclipe e não reconheciam os filhos, não acreditavam que eles fossem capazes de fazer tudo aquilo. Isso me encantou muito.”

Após cerca de oito anos como professora itinerante de educação especial, Analice escolheu uma escola e assumiu a própria turma. "Eu não gostava dessa história de ser itinerante. Eu queria ter a minha sala de aula, não queria ficar palpitando na vida dos outros. De repente, por conta de política, por conta de uma série de coisas, eu me vi na educação infantil." Para ela, era um verdadeiro desafio. "As pessoas pensam que educação infantil qualquer um faz, é uma coisa simples. Muito pelo contrário. A gente tem que ter 
muito mais atenção, porque nessa idade, quando eles são muito novinhos, tudo que você fala eles guardam. Absolutamente tudo." Para adaptar-se à nova realidade, Analice voltou aos estudos, participando de diversos cursos e congressos. Também passou por algumas escolas: EMEI Maria do Carmo Abreu Sodré, EMEI da Unicamp e CEMEI São João Batista, na Rua Moscou. Seu desejo era conseguir a remoção para o Recanto da Alegria. "Eu estava trabalhando num projeto de educação ambiental e lá a gente discutia a questão do entorno da escola. Uma das professoras participantes contava muito do Recanto da Alegria e de como os problemas da comunidade eram tratados lá. Aquilo foi me encantando, porque o entorno do Recanto tinha a ver com a minha história de vida, é o bairro em que eu cresci. Então eu fiquei curiosa e, quando tive a oportunidade de me remover, eu fui para o Recanto. Estou lá há quatro anos." Nesse tempo, já plenamente integrada à escola, agarrou mais uma oportunidade que lhe surgiu: uma breve viagem de estudos a Reggio Emilia, na Itália, onde teve contato com um modo estimulante de se fazer a educação infantil. Um aspecto chamou sua atenção: o registro que permite comunicar e tecer a memória do percurso educativo.

Analice confessa-se encantada com a educação infantil, mas não tem como explicar o que sente: "Com as crianças, o que é legal é que a gente aprende muito com elas. Quando você tem a oportunidade de ouvir uma criança, de ficar tranqüila, de simplificar, o resultado que você tem... e às vezes você não tem como mostrar esse resultado pras pessoas, porque foi no relacionamento. É como tentar dizer: como é que eu me apaixono por alguém? Com crianças tem coisas que... acontecem! Coisas lindas. Às vezes você vê um desenho de uma criança e ela vem te contar. Então você olha para o desenho: um rabisco. E ela te conta a história do desenho. Ah, já aconteceu de eu chorar ali."

Com sua sensibilidade e experiência, Analice passou a dedicar-se ao Projeto Memória, já existente na EMEI, juntamente com a amiga Tânia. Seu primeiro objetivo era introduzir o computador na sala de aula, para facilitar o trabalho de registro dos acontecimentos cotidianos. Ela acreditava que isso traria mais proximidade com mães e pais de alunos: "Como mãe, eu entendo que a família se preocupe, que tenha insegurança em deixar uma criança na escola, sem saber o que vai acontecer. E as mães são muito cuidadosas, elas têm carinho, querem saber. Sempre que a gente faz alguma coisa, elas participam. Todo dia, se elas puderem ficar conversando, elas ficam. É que a gente não tem tanto tempo assim. Então eu queria 
fazer um resumo diário, chamado Minha vida é assim na escola. A minha vontade era escrever ou gravar e, no fim do ano, fazer um livrinho ou vídeo, contando tudo que aconteceu, aquelas coisas que não são ditas."

Não foi fácil convencer os demais profissionais da necessidade do equipamento na sala de aula. "Computador para crianças tão pequenas?” - diziam. Também foi preciso quebrar preconceitos, já que muitos ali achavam que, num bairro tão carente, a informática não faria parte da vida das famílias atendidas. Havia, ainda, quem acreditasse que o computador era uma distração a perturbar o ofício de cuidar dos pequeninos - muitas vezes, confundido com o seu domínio: "O controle facilita o seu trabalho. Se chegar alguém ali e te perguntar o que está acontecendo, você sabe. Ai de você se não souber!” Mas a obsessão com o controle acaba se transformando numa forma de violência, uma tentativa de domesticação e imposição de uma ordem que mata a espontaneidade e a alegria das crianças (e também das professoras): "Como você vai prever a criatividade, a espontaneidade? Criança tem que ter liberdade. Mesmo no trabalho da gente. Às vezes você quer propor alguma coisa, já te cobram: como é que vai ficar? A gente tem até um certo pudor de dizer: não sei. Porque você tem que saber, é uma profissional! Então, são pequenas violências que você sofre e até que você pratica. Eu procuro trabalhar essas questões tendo mais consciência, mais tranqüilidade, para simplificar, deixar fluir. Porque se você quiser botar tudo numa caixinha, fazer todo mundo ir pra um mesmo lado... aí vira uma violência mesmo." Havia, ainda, quem confundisse a seriedade e o profissionalismo, requisitos para o trabalho com as crianças, com sisudez. Para estes, ao professor não cabe ousar, mas citar e aplicar fórmulas consagradas pelos especialistas, e a máxima antropofágica de que "a alegria é a prova dos nove" não passa de uma balela: "Às vezes você é cobrado de uma justificativa. Porque é bom para os alunos é uma resposta muito rasa. Você tem que ter lido alguém, tem que ter uma opinião. Hoje em dia eu aprendi a me divertir no trabalho. Criança quer se divertir. Adulto também. Mas, às vezes, o adulto não tem esse direito. Tem que ser sempre sério. Na graduação, eu me diverti bastante, eu realizei muitas coisas que, hoje em dia, eu lembro e me pergunto: eu fiz tudo isso? Na época, fui muito influenciada pelos professores, tive muito embate com os colegas. Agora, na maturidade, eu reencontrei muitos deles e hoje eles me entendem. Tudo a seu tempo.” 
Novata na EMEI, cheia de energia e entusiasmo, Analice não teve sua vontade de mudança vista com bons olhos por todas as colegas - a princípio, inseguras quanto a experimentar métodos desconhecidos, com resultados imprevisíveis. Ela precisou justificar o que lhe parecia óbvio, depois de tantos anos estudando e praticando a integração entre educação e tecnologia. A tarefa de criar um consenso no ambiente escolar foi exaustiva. O ritmo lento das mudanças não lhe agradava. Preferia seguir abrindo caminhos: "Quando você não tem que ficar explicando o trabalho que está fazendo, você faz muito mais. Porque ter que justificar é um segundo trabalho. E o professor, acho que tem um pouco isso: tem momentos em que você precisa se dar ao trabalho de explicar. Hoje eu tenho mais tranqüilidade. A gente vai ficando centrada e, de repente, lembra de um monte de coisas que fazia quando julgavam que a gente não era tão centrada assim. Você vai se refreando, vai endurecendo... Chega um momento em que tudo recomeça e você volta a fazer aquilo em que você acredita. Você tenta, ué! As pessoas em volta dizem que não vai dar certo, mas você vai fazer aquilo em que acredita. E chega lá na frente, você vê que estava certa. Então, hoje eu faço o que eu acredito e vejo o resultado. Não vou mudar o mundo com isso. Mas eu vou mudar o meu mundo, aquele sobre o qual eu tenho alcance, o que dá pra fazer. Quero fazer sentido para as crianças com as quais eu convivo, pros pais com quem eu convivo. Se eu conseguir isso, não precisa mais. Não tenho pretensão de mudar a educação do Brasil, a educação de Campinas. Não! Mas a educação que eu estou fazendo, o meu trabalho."

E foi com essa intenção que Analice procurou a Pedagogia da Imagem. Precisava de um apoio, um respaldo para as ações que desejava implementar. Matriculou-se no curso e trouxe consigo duas colegas de trabalho - Tânia e Eliete. Era uma forma de criar um grupo afinado no meio da escola e acelerar as transformações. Já nos primeiros encontros, solicitou-nos que visitássemos a EMEI e conversássemos com a equipe gestora. Acabamos mediando uma dinâmica com exibição e debate de filme, durante uma reunião de TDC, com a presença de todos os profissionais da escola. O resultado foi surpreendente. Estabelecemos um ótimo relacionamento com a direção, abrindo caminho para que a equipe do Projeto Memória conquistasse os equipamentos desejados (computador e câmera digital) e implementasse seus diversos projetos. Analice e Tânia passaram a fazer os registros do cotidiano, editando-os em forma de um jornal diário, afixado na porta da sala de aula, à vista dos pais e das crianças. Com a máquina fotográfica, produziram centenas de imagens que, ao final do ano, segundo um roteiro criado por elas, foram e- 
ditadas em dois belos vídeos, "Passagens" e "Minha vida é assim na escola" (constantes do DVD que acompanha este trabalho). Além de exibidos aos pais, os DVDs foram distribuídos aos alunos. E as conquistas não pararam por aí. As resistências à presença do equipamento na escola foram arrefecendo. As colegas, antes receosas, passaram a disputar o acesso ao computador e descobriram inúmeros usos pedagógicos.

Em 2008, o Projeto Memória deu um salto significativo. Em parceria com o MIS, Analice e Tânia organizaram um planejamento cujo objetivo era aproximar a EMEI e seu entorno, tornando a escola um centro de referência não apenas da memória dos seus processos educativos, mas da vida da comunidade. Numa primeira etapa, as profissionais da EMEI foram habilitadas a trabalhar com suas câmeras fotográficas digitais. A intenção era melhorar a qualidade dos registros produzidos na escola. Numa segunda fase, a comunidade foi convidada a participar de uma oficina de fotografia digital. No rápido curso, adolescentes, jovens e adultos, moradores da região, tiveram a oportunidade de explorar os recursos de seus equipamentos e conhecer as noções básicas do processo e da linguagem fotográfica. Em contrapartida, os participantes definiram os locais que consideravam mais significativos da vida da comunidade, traçando o roteiro dos passeios fotográficos. O grupo produziu centenas de fotos, das quais selecionamos 700 para doação ao acervo do Museu da Imagem e do Som. Trinta fotos foram escolhidas para serem ampliadas e compor uma exposição, inaugurada na EMEI e com data marcada para ocupar o museu. O resultado mais significativo não foi o aprendizado técnico (que empolgou bastante os novos fotógrafos amadores), mas a transformação de seu olhar sobre a própria realidade. Revendo as fotografias ampliadas, eles não cansavam de admirar as ruas de terra e as casas simples, diante das quais passam todos os dias, críticos ou indiferentes. Pareciam surpreendidos em poder reconhecer, também ali, a beleza.

O percurso até aqui não foi fácil, mas Analice certamente não desistirá dos desafios que ainda estão por vir. "Uma coisa eu sempre soube: problemas a gente tem. Mas uma coisa eu também sei: eu sou uma professora. Se você está ali para resolver os problemas, você vai resolver. Não adianta achar que vai ser tudo legal." As lágrimas percorrem o seu rosto e calam, por um instante, a sua voz. 
Quando ela se acalma, peço-lhe para definir a sua profissão. "Ah, eu não sei... até essa imagem do rio é engraçada. E também estou lembrando de uma frase que um professor do magistério dizia: não apresse o rio, ele corre sozinho. Eu sempre fui muito ansiosa e ele me falava: você é tão ingênua! Eu ficava irritada: não queria ser ingênua; queria ser esperta. Hoje, eu sei que conservar a pureza em certos momentos é muito importante. E tudo que foi acontecendo na minha vida foi assim. Eu não escolhi os meus filhos, não escolhi meus amigos. Eles chegaram e eu os acolhi. O magistério também não fui eu que escolhi. Mas aconteceu. E foi bom. Não quero perder nenhuma oportunidade de ser feliz. É isso: eu estou aqui e estou inteira."

Marli: "Hoje a gente tem tudo pra fazer o que a gente quer. E vale a pena."

Diante da câmera que grava seu depoimento, a professora Marli revela sua personalidade delicada e discreta. Aguarda cada pergunta, atenta e sorridente. Responde a todas elas com sua voz calma e grave, sem expandir-se em excessos. Paciente, como artesão preciso, vai talhando a própria história com o buril das suas lembranças.

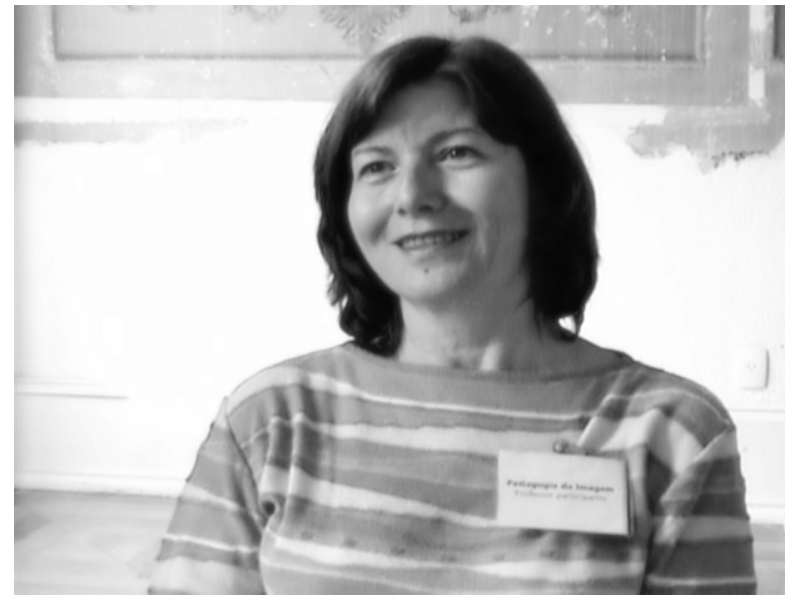

Marli, durante entrevista no MIS
Marli nasceu em Fortaleza de Minas, cidadezinha encravada aos pés da serra que lhe empresta o nome, antigo distrito de Jacuí, emancipado em 1962 e que, ainda hoje, não conta 4 mil habitantes. Algumas décadas atrás, seus horizontes eram ainda mais curtos para aqueles que sonhassem com um destino diferente do trabalho nas lavouras de milho ou nas lavras niquelíferas. Jovens como menores sacrifícios. 
E foi isso que fizeram. "Estudamos em escolas públicas, porque lá, na época, só tinha escolas públicas. Eu era boa aluna, sempre fui a primeira da classe. Meu pai fazia questão que todos os filhos fossem. Incentivava muito e sentia muito orgulho também." O tipo de educação oferecido não era nada estimulante, mas era a única opção. "Eu estudei na época do regime militar. Era o livro didático, e o professor passava as lições ali. A gente respondia e ele corrigia. Era bem assim: a gente prestava a atenção, fazia as provas e só. Tinha que adotar aquele comportamento e se adaptar, porque nem conhecia outras alternativas. Quem não quisesse aquilo, que ficasse fora da escola." A relação com os mestres era de autoritarismo: "A professora era autoridade máxima. Aluno não podia abrir a boca. Não tinha diálogo. E tinha medo.”

Terminado o ensino fundamental, Marli cursou o Magistério: "Não existia outro curso lá. Só esse. Ou eu fazia o Normal, ou não fazia nada. Então eu fiz e, depois, eu optei por Letras, porque eu adoro literatura. A faculdade eu fiz em Passos. Na época era particular. Hoje é a Estadual de Minas. Eu me formei em 1974." Ser professora não era, na época, uma escolha, mas uma circunstância: "Nunca pensei em ser professora. Mas era o que a gente tinha. Ou a gente ia ser professora, ou ia casar e cuidar de marido e filho. Lá em Minas não havia outra perspectiva, era aquilo ali mesmo. A gente não tinha nem o que pensar, não tinha nem dilema.”

Naquele cenário fechado, o cinema era janela para o mundo. Teatro não tinha. O cinema era um só: Cine Brasil. Mas, ao contrário do que o nome sugeria, as produções exibidas vinham de Hollywood. "A cidade era pequena, mas passava bons filmes, assim que eles eram lançados. Lembro de ter assistido Ben Hur, Os dez mandamentos, Cidadão Kane... Filme nacional só me lembro de O pagador de promessas." A diversão converteu-se em paixão, cultivada por muitos anos: "Eu ia às matinês. Depois de dezoito anos é que comecei a freqüentar a sessão da noite, com a minha irmã mais velha. A gente se produzia... Mas até chegar aí era aquela preocupação: às vezes eu queria ver um filme e não tinha dezoito anos ainda... A gente dava um jeitinho e eu conseguia entrar. Muito filme inapropriado pra minha idade eu acabei assistindo... e gostando!"

O hábito de ir ao cinema continuou quando a família se mudou, em peso, para Campinas. "Aí o mundo se abriu. As opções eram muitas, e eu continuei indo ao cinema e assistindo a tudo que chegava. Eu fre- 
qüentava esses cinemas aqui do Centro, o Regente, que era muito bom, o Cine Brasília... Tinha o Ouro Verde, o Jequitibá, o Windsor... Passavam filmes maravilhosos. Eu me lembro d'O beijo da mulher aranha, do Babenco, que eu adoro, Um estranho no ninho, Comboio... Do cinema brasileiro não via muita coisa, porque era durante o regime militar e não tinha muita produção."

As oportunidades abertas em Campinas não se restringiam ao campo cultural, mas diziam respeito, principalmente, ao trabalho. Marli, então com 23 anos e um diploma de Letras, e os irmãos, encaminhados em suas profissões, buscavam uma chance de aplicar seus anos de estudo. "Em Minas, a situação estava insustentável. As possibilidades de trabalho eram muito pequenas. No meu caso, não havia muitas escolas, e as existentes tinham um pessoal muito antigo, com todo aquele passado... não sobrava muito para os novatos. Além disso, lá eu sentia que eles valorizavam o professor de mais idade. Como eu estava começando, ficavam me testando muito, me colocando contra a parede. Eu me via naquela situação e me perguntava: ah, sala de aula é isso? Não quero isso pra minha vida! Eu achei que não fosse a profissão ideal para mim. Mas, quando chegamos aqui, em meados dos anos 70, foi muito bom. Todos nós da família tivemos oportunidade de conseguir bons trabalhos." Marli, decepcionada com a experiência nas salas de aula, a princípio, não quis ser professora. Conseguiu um emprego de secretária: "Comecei, fiquei uns três meses. Até que um colega meu da faculdade, que já estava dando aulas numa escola particular em Campinas, me telefonou, falando: olha, lá onde eu trabalho tem umas aulas... Você está a fim? Ah, eu fui na hora! Deixei a empresa onde eu trabalhava e fui dar aula na hora. Não tive dúvida. Não! Eu estudei tanto, tinha tanto conhecimento. Era o que eu sabia fazer. E na empresa eu não estava aplicando nada do que eu tinha estudado. Pensei: quem sabe eu me ajeito numa sala de aula? E fui, e mergulhei assim... de cabeça: é aqui que eu vou ficar! E comecei a gostar, a partir daî."

Já no primeiro ano em Campinas, Marli conseguiu vaga em três diferentes escolas particulares. Esse mergulho, no qual finalmente abraçou a profissão, fez com que suas experiências em sala de aula fossem percebidas de modo diferente e se tornassem melhores: "Eu senti uma grande mudança. Fui muito bem aceita pelos alunos, colegas, direção. Comecei dando as minhas aulas e eles, muito interessados, anotando, perguntando - para saber, não para me testar. Aí comecei a gostar. Acho que foi mais pelo lado humano de Campinas... Conhecer esses alunos, conviver com os colegas e diretores que me aceitaram de 
braços abertos, me deram oportunidade, acreditaram em mim. Foi muito bom esse começo aqui. Eu adquiri muita experiência e, pra minha vida profissional, foi o que me deu um embasamento, para eu continuar trabalhando até hoje. E desde então eu passei a gostar muito do que eu faço.”

As dificuldades enfrentadas em Campinas vieram pelas circunstâncias históricas. "Eu comecei a dar aula ainda durante a ditadura militar, quando o regime estava assim, bem forte mesmo. Então era preciso tomar cuidado. Não era qualquer texto que eu podia levar para os alunos. Desde aquele tempo eu já trabalhava música com eles, e não podia tocar qualquer música. Mas era o que a sociedade na época queria que os professores fizessem, não é? Os pais iam reclamar. Eu recordo que eu levei um texto do Padre Vieira para uma sala de colegial, numa escola particular. Um aluno foi falar na direção que eu tinha levado aquele texto. A direção me chamou e eu tive que me justificar, falando que o texto era importante, que eu tinha que trabalhar, que era um texto que caía em vestibular. Naquela época, não havia esses cursinhos disseminados, como tem hoje. A escola particular se pautava muito pelo vestibular. Então foi a partir daí que eu argumentei com a direção. O diretor foi até a classe, conversou com a turma. Por coincidência, aquele texto acabou caindo no vestibular daquele ano. Então, eu fiquei mais tranqüila quanto a isso. A escola passou a não vigiar tanto o que eu estava fazendo. Mas, trabalhar naquela época era uma coisa muito delicada. Mais tarde, com a abertura política, foi toda uma aprendizagem. Dos anos 80 para cá tudo já era possível. Nessa época, eu tinha me efetivado no Estado. Com a abertura, um novo horizonte se abriu na profissão, muita coisa foi redefinida. A gente já podia trabalhar qualquer texto, qualquer filme, o diálogo se tornou mais aberto com os alunos. Ficou muito mais fácil. Então eu acho que a escola hoje dá muitas possibilidades para o professor trabalhar, é muito melhor do que na época em que eu comecei."

Se, no início da carreira, Marli sentia que preparar os estudantes para o vestibular era o que se esperava dela, hoje ela tem outra visão e demonstra empolgação quando fala de sua tarefa. "Eu trabalho com adolescentes e adultos. A relação com os pais é mais distante, eles é que já são os pais, entende? Então eu os oriento. A minha profissão hoje é totalmente diferente de quando eu comecei." E, abrindo um largo sorriso, esclarece: "Educar é transformá-los em cidadãos. Porque eles são tão marginalizados, eles são tão esquecidos pela sociedade, em geral, que eles não têm perspectiva nenhuma. Então eu acho que se eu conseguir resgatar um pouquinho dessa perspectiva de futuro deles, de cidadania, está bom.” Para cum- 
prir essa missão, ela lança mão de diferentes recursos. "Eu toco música, passo filmes, trabalho com jornal, reportagens. Matérias jornalísticas são principalmente da região onde eles moram (eu não deixo passar uma sem levar para eles). Eu leio com eles tudo que sai sobre a região do Campo Grande, lá do Parque Valença, que é onde eu trabalho. E eles ficam informados, se sentem importantes lendo a notícia sobre a região deles. Leio, discuto, peço que eles escrevam dando a sua opinião. Isso tem sido muito bom. Eu procuro mais o debate com eles na sala de aula, a produção de textos. Todo ano eu faço um livro com as melhores produções deles. Na minha aula não tem muita coisa que copiar, não. É mais leitura, debate e produção. E tem os filmes, os curtas e longas-metragens que eu tenho passado, para interpretação.”

Marli confessa que a idéia de exibir vídeos nas aulas tem relação com sua paixão pelo cinema. Mas, atualmente, os filmes que exibe são produções nacionais: "Eu descobri o cinema brasileiro há pouco tempo. Eu não era muito de assistir filmes nacionais. Até uns trinta anos atrás, eu não sabia praticamente nada sobre o nosso cinema. Eu até me lembro que, quando eu estava no segundo ano do curso Normal, o professor de Português recomendou que a gente assistisse O pagador de promessas. Eu fui e detestei, acho que eu já estava contaminada pelo cinema americano. Muita cor, ação... Então eu detestei. Mas, de uns vinte anos pra cá, eu venho me dedicando mais ao cinema brasileiro e descobrindo o que ele tem de bom, através de muita leitura. Eu acesso muito o site da Cinemateca Brasileira, Programadora Brasil, Ministérios da Educação e Cultura. Também busco em jornais, revistas e na Internet. Hoje, O pagador de promessas é um filme que eu adoro. Até passei para uma classe de adolescentes, há cinco anos atrás. Eles assistiram até o fim, fizemos debate, eles fizeram um trabalho. Foi muito bom." Ela ainda conta que, como professora de português, procura trabalhar com os alunos os elementos da narrativa cinematográfica. "Eu peço para eles prestarem atenção aos personagens principais, o espaço onde acontece a ação, o narrador, a ação e o tempo. No tempo, eu peço para eles observarem a época da história. Se não tem uma indicação, uma data, que eles observem objetos, trânsito, carros, moda, tudo isso que é uma indicação de época. E a duração da história. E eles observam corretamente." Além do aprendizado relacionado à disciplina, Marli tem consciência sobre a importância do acesso ao bem cultural audiovisual: "Eu percebo que, assim como eu não tive, eles não têm acesso à maioria dos filmes brasileiros. E, quando eles têm, eles gostam. Tanto que, quando termina a sessão, eles vêm falar comigo, pedindo para emprestar 
ou fazer uma cópia para eles. Ou seja: eles não têm é a oportunidade de conhecer o cinema brasileiro, de saberem mais. Então esse é um filão que eu encontrei, e que tem dado muito certo.”

Os alunos a que Marli se refere são os adolescentes, jovens e adultos das sétimas e oitavas séries e da EJA, período noturno, da EMEF Padre Leão Vallerie, onde leciona desde o ano 2000. "Eu escolhi ir para essa escola. Já havia trabalhado lá em 1998, como contratada da Prefeitura, e tinha gostado muito. Então a minha primeira opção, quando me efetivei, foi trabalhar lá." São 25 aulas semanais, distribuídas em cinco classes diferentes, de segunda a sexta-feira, das 19 às 23 horas. O largo sorriso que abre demonstra a sua satisfação com a escolha. "É uma escola que a comunidade respeita. Tem uma imagem positiva no entorno. Os alunos vêm dos bairros próximos ali: Campo Grande, Floresta, Itajaí, Maracanã, Valença I, Valença II...” Não é pouco. A Leão Vallerie é uma das maiores unidades da rede municipal e, no entanto, fica comprimida em um espaço físico insuficiente para a demanda da região. "A estrutura é pequena. Nós funcionamos em quatro turnos, são 14 salas de aula. Então, é muito apertado mesmo. Às vezes a gente quer trabalhar e não tem o espaço ali pra você sentar, atender um aluno, atender um pai. Não tem. E é uma correria também. A escola não tem tempo pra fazer uma faxina mais adequada, porque é um entra e sai constante. É difícil. É muito difícil. A nossa biblioteca, por exemplo, está há três anos, abrigada em um local de difícil acesso. A sala de vídeo foi instalada onde era a biblioteca, porque tem os materiais mais caros, e a biblioteca foi empurrada lá para cima. É uma sala independente da escola, isolada. O ambiente lá dentro não é legal, deixa muito a desejar, porque as estantes ficam muito próximas, não tem espaço para a circulação. Nossos alunos não têm como ficar indo lá. Às vezes, não tem professor lá no horário pra atender e nada funciona. Estamos lutando para trazê-la novamente cá pra baixo, mas está difícil. O espaço é pequeno.”

Foi por insistência de um dos colegas da Leão Vallerie que Marli inscreveu-se na Pedagogia da Imagem. "Eu vim por indicação do Rubens. Ele ajuntou um grupo lá e falou: vamos fazer o curso. Eu já estava inscrita no projeto Correio Escola e falei: olha, não dá para fazer dois cursos e se dedicar. Mas ele pressionou: nós vamos sim, vamos, todo mundo, fazer. E eu vim. Hoje eu acho que foi bom ter feito com o grupo da escola. Foi fundamental. Não sei se sozinha eu teria condições. Na verdade, acho que todos os 
professores teriam que fazer, não só esse grupo, mas todos. Aí ficaria mais fácil a gente produzir uma coisa e fazer a integração interdisciplinar."

Durante o curso, Marli desenvolveu o projeto prático junto com a professora Akiko, de ciências. Elas reuniram uma turma de alunos da oitava série e fizeram a proposta de produção de um vídeo sobre o meio ambiente ou o entorno da escola. "No nosso primeiro encontro, nós fizemos um círculo e ficamos trocando idéias. Os alunos falaram, nós também. Foi bem democrático. A gente trocou muita idéia com eles, como eles pensavam em fazer esse filme. Eles foram falando, a gente foi discutindo com eles. E, do segundo dia em diante, a gente já começou a gravar. Eles ficaram entusiasmados com a idéia da gente filmar a [avenida] John Boyd Dunlop, do começo até o fim, depois a escola e o bosquinho ao lado. Eles acharam que ficaria bom. Aí nos fizemos assim.”

O resultado foi o vídeo Caminhos do Valença (vide DVD anexo) - um pequeno inventário de elementos representativos da vida e da história das populações da região noroeste de Campinas, que integram o seu "patrimônio cultural" não-oficial e, muitas vezes, ignorado ou esquecido. "Filmamos praticamente toda a John Boyd Dunlop, não ficou nada de fora. Tudo que tem de importante na avenida tá registrado. E fomos muito pelo que os alunos sugeriram. Tudo partiu deles. E foi bom, porque eu conheci um pouco mais. Eu não conhecia a John Boyd. A gente pega o carro e vai pra escola, ali, preocupada com o trânsito, e não presta atenção em mais nada. Essa avenida leva lá pro Parque Valença, e foi esse o nosso ponto de partida: como chegar ao Parque Valença. Uma coisa que nos influenciou muito foi o vídeo Ilha das Flores, que nós assistimos aqui no curso e levamos para os alunos.” À medida que o grupo ia fazendo as filmagens, seguindo as indicações dos estudantes, desenvolvia-se um processo de pesquisa a respeito a história de Campinas e sua expansão rumo à periferia. "Foi trabalhoso, mas foi bom."

O saldo positivo não se limita ao produto final - que foi um dos vídeos mais interessantes produzidos em 2007, durante o curso, mas alcança também o amadurecimento e o relacionamento do grupo. "Ah, muda bastante. Os alunos vêem a escola como um lugar mais democrático. Eles percebem que também podem agir ali dentro, criar, e não só ficar na condição de receptor de informações. Eles já vêem o espaço ali como um espaço de criação deles. E isso é muito bom. Eu percebo que eles estão mais responsáveis, 
eles mudaram a forma de tratar as pessoas - um com o outro e com a professora. Eles estão mais educados, mais sensíveis ao que acontece em volta. Eu acho que nós conseguimos despertar tudo isso neles. A criatividade, que eles trazem, e que não tinha aflorado. E também o trabalho em grupo, que foi importantíssimo. Tanto que a classe toda quer entrar no projeto." A exibição do vídeo na escola, ansiosamente aguardada por todos - participantes do projeto ou não -, integrando a cerimônia de formatura dos alunos da oitava série, revelou outros benefícios, como o sentimento de ser capaz de realizações, a autoconfiança e o reconhecimento coletivo.

Para as professoras também houve aprendizados significativos: "Eu não sabia nem como manusear a câmera e, agora, eu já domino, pelo menos isso eu sei fazer. E eu pretendo continuar produzindo vídeos, que eu acho que pros alunos foi muito bom. Eles amadureceram muito durante todo esse processo aí, que faz poucos meses que estamos trabalhando... Eles aprenderam muito, e acho que eu aprendi muito mais. Então, quero continuar fazendo. Eu acho que como projeto coletivo fica melhor. A gente teria que ter horários comuns entre os professores que se envolvem no projeto, para trabalharmos juntos. Agora, eu acho que também dá para fazer individualmente, em sala de aula. Eu tenho planos de fazer assim com meus alunos. Quero, por exemplo, filmar com eles um conto de Machado de Assis." E, de fato, em 2008, Marli pôs em prática suas idéias. Adquiriu uma câmera filmadora digital e um computador com configuração adequada para fazer a edição de vídeos e... mãos à obra! Transformou as aulas de reforço de Língua Portuguesa em momentos para estudo e adaptação de peças literárias ao vídeo. Estudantes com dificuldades de leitura não apenas liam poemas e contos, mas os memorizavam e interpretavam em frente à câmera. Usando figurinos trazidos pelos alunos e tendo como cenário o Bosque Ferdinando Tilli, vizinho à escola, o grupo produziu imagens verdadeiramente poéticas. Foi a maneira que Marli encontrou de conjugar a disciplina que ministra com a proposta da Pedagogia da Imagem. Para ela, a produção de vídeos é mais um recurso à sua disposição e uma maneira de envolver os alunos na experiência literária. Além disso, em parceria com outra colega de trabalho, a professora Ana Luíza, Marli também iniciou a produção de vídeos sobre bens culturais que compõem o patrimônio histórico de Campinas.

À época em que todo esse trabalho foi iniciado, as condições da escola não eram as ideais para o desenvolvimento da Pedagogia da Imagem. "A dificuldade maior é que nós não tínhamos o computador com 
tudo instalado para fazer edição. A nossa filmadora ainda era aquela antiga, não era uma filmadora digital." A participação de um grupo numeroso na Pedagogia da Imagem, com uma produção respeitável e com um compromisso de continuidade das ações, fez com que essa situação se alterasse. A direção da escola teve a compreensão e abertura suficientes para acreditar no projeto e investir na infra-estrutura necessária. As orientadoras pedagógicas, por sua vez, apostaram na formação do corpo docente, cedendo-nos importantes horas dos TDCs para oficinas da Pedagogia da Imagem. Os professores também fizeram sua parte, com uma forte mobilização para conquistar os equipamentos. Uma vez apresentada a proposta ao conselho escolar, o investimento foi prontamente aprovado. Assim, a EMEF Padre Leão Vallerie tornou-se, em meados de 2008, a primeira unidade a estar plenamente equipada para produção e edição de vídeos e com um número significativo de docentes preparados para fazer uso adequado desses recursos. O que não significa que nosso trabalho acabe por aqui: esse é apenas o prelúdio para a consolidação da Pedagogia da Imagem na escola.

Ao final da conversa com Marli, peço que deixe uma mensagem sobre o seu trabalho. E, na contramão dos desiludidos, ela revela a rara consciência e alegria dos que se encontraram e se realizam na profissão. "Uma mensagem? Eu adoro dar aula. E aconselho a todos que terminaram o curso de Letras, particularmente: que encarem, que vistam a camisa e vão para a sala de aula, que vale a pena. Hoje é muito bom. É melhor do que trinta, quarenta anos atrás. É muito melhor! Hoje a gente tem computador, tem Internet e, sobretudo, tem liberdade de expressão. Tem tudo pra fazer o que a gente quer. E vale a pena.”

\section{Gracinha: "Todo mundo acha que eu sou diferente. Realmente eu sou: eu gosto muito de gente."}

Maria das Graças, Graça, Gracinha. Que ninguém se engane com as aparências: essa mulher, de figura delicada e pequenina é, na realidade, uma gigante. O sorriso constante no rosto, a gargalhada fácil e o oThar atento são marcas de quem já enfrentou muitas batalhas - e venceu todas elas com persistência e sabedoria. 
A primeira delas, a infância, no interior do Piauí. Gracinha é natural de Santa Maria, um lugarejo pertencente a Capitão de Campos, município rural do centro-norte do Estado. Ali, não era incomum que as famílias tivessem de enterrar seus “anjinhos”. Gracinha não lembra mais quantos de seus irmãos pequenos faleceram. Conta apenas os sobreviventes: "A família era pequena. Somos quatro irmãos. Eu sou a mais velha. Depois vêm a

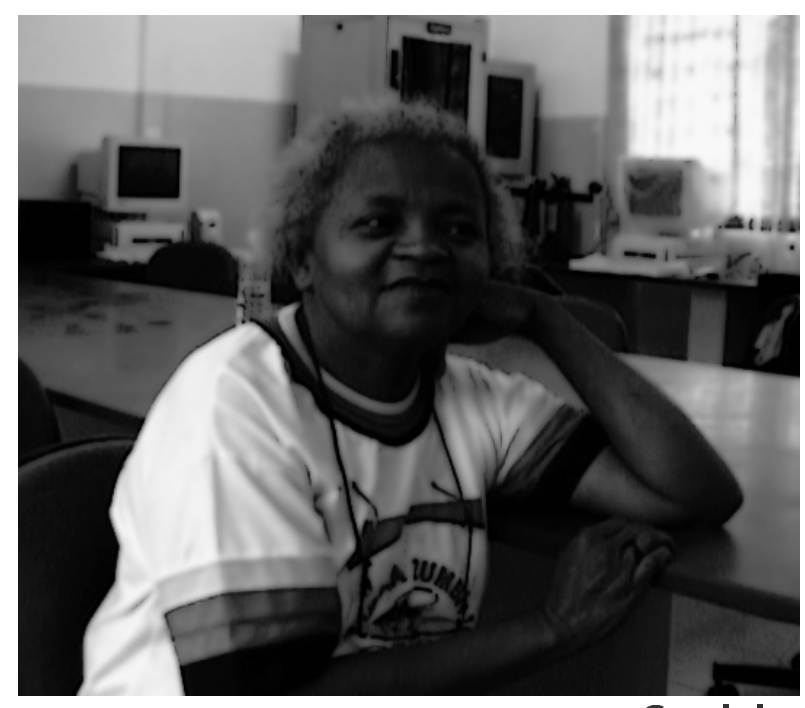

Gracinha Rita, o Luís e a Luísa, que eu chamo de Pretinha." Ainda menina, ajudava os pais trabalhando na roça. "Eu lembro que eu colhia arroz. A minha mãe ficava em casa, fazendo a comida. A gente também ia buscar lenha, com aqueles feixes na cabeça. Chuva tinha em janeiro, fevereiro e março. Por volta de maio já parava. Quando era época de seca, faltava água e tinha que ir buscar. Também aprendi com minha mãe a fazer chapéu e corda, pra vender e ajudar em casa. Lá tem um tipo de palmeira, o tucum. Ela dá uma palha e dessa palha a gente tira uma pelezinha, que se chama embira. Então a gente corta a palha, puxa e tira a embira. Tinha um espinho que, nossa! O dedo da gente ficava cheio de espinho." Não parecem lembranças tristes. Sorrindo, Gracinha esclarece: "Gosto de fazer corda. Se for preciso fazer corda, ensinar a fazer, eu também ensino.”

Mas, a vida não era só trabalho. Havia tempo também para as diversões de criança. "Brincava... brincava de casinha com uma turma. Brincava de boneca. Fazia boneca de milho e boneca de pano - aprendi com minhas coleguinhas mesmo. Na época de São João tinha aquela festa! A gente fazia juramento ao lado da fogueira. Chamava uma amiguinha pra ser a madrinha ou a comadre de fogueira. Ah, isso é muito interessante! Acho muito legal. Uma coisa que me encuca é que eu chegava a passar nas brasas sem me queimar. Isso me impressiona muito. Fico me perguntando se era a fé. Porque passar descalço naquele fogo... Todo mundo passava.” 
$\mathrm{Na}$ escola não havia moleza. "Lembro como fosse hoje. O que mais me marcou foi o sábado, que tinha... como que chamava? Era tipo uma prova oral. E assim: a tabuada tinha que saber de cor. E, quando não soubesse, palmatória! Sou da época da palmatória. E, como era na roça, eu lembro do caminho que eu fazia... uma trilha. O professor se chamava Luís - já faleceu. Era um professor só, várias turmas na mesma sala." Quem a influenciou na escolha da profissão, contudo, foi um tio, também educador: "Foi uma escolha. Eu tinha um tio que era professor. Era Francisco que ele se chamava. Ele era professor e eu falei: eu vou ser professora também. Eu gostava - e gosto - de ensinar. Por isso que eu escolhi a profissão de professora: porque eu gosto mesmo de ensinar as pessoas a fazerem as coisas. Não só a ler e escrever, como outras coisas. Tudo que eu sei fazer eu gosto de ensinar."

Além das rudezas da vida na roça, Gracinha teve, ainda, que derrotar os preconceitos. "O Piauí é muito sofrido, mas é muito bom. Eu gosto. Se não fosse aquele sofrimento da vida de lá... Mas também tem muito preconceito. Mais do que aqui, em São Paulo. Eu acho que aqui é mais fácil da gente lidar. Por exemplo: não lembro de aqui alguém me dizer: ah, sua neguinha! E lá tem disso. Pelo menos na minha época de jovem, quando eu morei lá, eu passei por isso.”

Adolescente, Gracinha deixou Santa Maria, em busca de seus sonhos. Queria trabalhar, formar-se. Não queria mais a lida na roça. "Eu saí de casa, eu tinha quinze anos. Saí pra trabalhar de doméstica. Fui pra Campo Maior. Acho que foi em 1966 que eu fui pra lá, na casa de uma família. Trabalhei dez anos com eles. E continuei o estudo lá na cidade, eu lembro que eu entrei na segunda série. Aí fiz a segunda, terceira e quarta série." Para continuar sua formação, ela precisou recorrer à Justiça. "Eu queria estudar, mas já estava com 21 anos, já estava velha, né? Não podia mais. Tinha que juntar uma certa quantidade de pessoas, fazer uma lista, levar pro advogado entrar com mandado de segurança, mover uma ação. E eu encabecei isso." Naqueles tempos sombrios, as mobilizações eram vistas como coisa de desocupados, e Gracinha foi censurada: “Nossa, a turma falava: ah, lá vem você com esse pessoal, não faz nada...” Ela ri: "Eu, desde sempre, lutando. Eu lembro que é uma marca. Começou lá. Mas eu não podia ficar sem estudar. Tinha que estudar." 
Em meados dos anos 70, os patrões de Gracinha mudaram-se para Cruzeiro, interior de São Paulo. "Eu pedi: mãe, me deixa ir junto... e vim." Gracinha tinha terminado a oitava série e ingressara no curso de Magistério. A família dos patrões, porém, não ficaria muito tempo naquela cidade, logo voltando para o Piauí. Gracinha preferiu continuar por aqui e foi trabalhar para o irmão da antiga patroa, que vivia em Campinas. "Eu estudava na escola estadual. Fazia o Magistério de manhã e trabalhava à tarde. Morava no emprego." Quando se formou, em 1978, o patrão não permitiu que ela trabalhasse como professora. "Assim que eu formei, eu fiz a inscrição na Delegacia de Ensino, para pegar uma classe. Meu patrão não queria. Falou assim: ah, se você quiser, vai ser mestre-cuca! Você vai ganhar muito mais que uma professora. Eu falei: não, eu quero ser professora! Eu não quero mais ficar aqui. Aí, em março de 79 eu já tinha escolhido uma classe de substituição e saí de lá.”

Já lecionando, Gracinha foi morar na casa de uma senhora, no bairro Taquaral. "Aí eu comecei a freqüentar a Igreja da Vila Costa e Silva. Conheci um pessoal legal. Você já ouviu falar das Comunidades Eclesiais de Base? É aquele pessoal lá: me envolveu e eu estou até hoje. Ixe! Eu gosto muito da igreja, mas nessa linha de ação, que faça o povo pensar, que faça o povo lutar, que não fique parada..." - e Gracinha faz um gesto, juntando as palmas das mãos. "Tem que ter ação política." A atuação nos movimentos da comunidade mudou a visão de mundo de Gracinha, despertando a consciência que já trazia consigo, mas estava adormecida. "A minha participação começou ali. Aliás, nem começou, porque eu acho que tem um pouco do dom da pessoa. Mas eu lembro que antes eu era cega, né? Então é ruim você não enxergar as coisas, nada! Tudo o que o governo fizesse era bom. Nossa! No passado, tinha que votar até no candidato do governo, meus patrões falavam. Mas daí em diante, mudei. Foi a partir da minha participação lá na comunidade Costa e Silva que eu fui ver: nossa, quanta injustiça! Antes eu não enxergava nada." Nesse período, as mobilizações que mais the marcaram foram as greves.

Era o ano de 1980 e Gracinha inscreveu-se para trabalhar na rede municipal, como professora substituta. Foi designada para a EMEF Edson Luís Lima Souto, recém-inaugurada no bairro San Martin. Acabou conhecendo ali o homem com quem se casaria dois anos depois. "O irmão dele estudava na minha sala. Ele, que era mais velho, foi ver a lista de material escolar. Quando foi 82 nos casamos, e vim morar aqui. Tive três filhos e tô aqui até agora." Gracinha passou por várias escolas antes de se efetivar na Prefeitura. 
O concurso público, realizado em1984, só seria homologado quatro anos depois. De 1988 a 1990, trabalhou na escola do bairro São Marcos, na mesma região. Finalmente, em 1991, removeu-se para a EMEF Edson Souto, de onde não saiu mais.

Esse não foi o fim das batalhas. "No início eu tive problema com os pais. Naquela época era o projeto de alfabetizar sem cartilha. E aí, nossa senhora! Coitada da diretora! Ela me apoiava muito, mas parece que os pais chegaram até a fazer abaixo-assinado para me tirar. Eu alfabetizava as crianças, ensinava. Mas o negócio que eles queriam era ter a cartilha ali na mão.” Nas relações de trabalho com as colegas, sua estratégia é evitar os conflitos, sem cair no isolamento. "As pessoas captam com muita facilidade o lado negativo e trazem pra escola. A fofoca corre solta. Não acho que o que a gente ouve tem que contar pra todo mundo saber. Não deve esconder... mas o pessoal conta de um jeito, conta de outro, quando você vê já estourou. As relações ficam muito difíceis. Eu tento não me isolar, mas também não me envolver. Acaba que o trabalho fica menos produtivo.”

Ao longo de sua vida profissional, Gracinha jamais deixou de lado seu engajamento político. Participa de um grupo de mulheres da periferia, é filiada ao Partido dos Trabalhadores, é membro da Pastoral do Negro, da Arquidiocese de Campinas, e é a presidente da Associação de Moradores do bairro San Martin - onde vive e trabalha. Muito ativa na comunidade, já foi catequista, atuou nos mutirões para a construção de uma creche e mobilizações para conquista de infra-estrutura de água, esgoto e pavimentação do bairro. Ela lamenta que os movimentos tenham arrefecido. "As pessoas não têm interesse. Não sei o porquê. Quando não tinha asfalto e água, as pessoas eram mais presentes. Depois... parece que eles não sentem a necessidade. Precisa de um posto de saúde, precisa de um lugar para as crianças, um núcleo, uma praça. Mas ah, pra quê praça? Essas coisas não! Deixaram na mão da associação. Não interessa nada. Você chama, ninguém aparece. Na escola é a mesma coisa. Por exemplo, o conselho: as pessoas têm dificuldade de participar. Você tem que ficar pegando aquele que você conhece, aquele outro: vamos, fulano, vamos! Não percebem a importância de estarem junto com a escola. Eu até gostaria de saber por quê.” E ela balança a cabeça, inconformada: "Muito difícil." 
Seu posicionamento libertário não fica de fora das salas de aula. "Eu sempre tento trabalhar incluindo essas coisas, né? Defendendo a mulher, defendendo o negro, fazendo com que as pessoas tomem consciência, aprendam o respeito. Por exemplo, o machismo. Na aula precisa ter isso: o quê que nós temos de diferente? É coisa pouca. Então por que é que o menino não pode ajudar, por que é que a mãe não ensina o seu filho, desde pequeno, a ajudar em casa? Por que só a menina tem que fazer? Isso eu já vou encaminhando, conversando com os alunos. A questão da justiça social, eu acho fundamental. A questão do MST: é uma luta justa, precisa haver reforma agrária. Também converso com eles."

Com as colegas, porém, parece não haver muita abertura para essas discussões. "Aqui na escola o que eu percebo é muito individualismo. Não tem o trabalhar no coletivo. E vejo também julgarem muito os alunos, só para o lado negativo. Na prática, eu acredito que seja um preconceito porque são da periferia. Até a questão da agressividade. Não que o professor seja agressivo, mas a maneira de lidar com as situações... deixa muito a desejar." Seu rosto demonstra perplexidade e, por um momento, ela se cala. "Essa distância toda parece que assusta as crianças, até as torna mais violentas. O olhar: olhar para a pessoa. Não é porque eu sou professora que já olho brigando. Não: você tem que ter um momento diferente com a criança, se aproximar. Mas sem exagerar, sem meleira. Tudo tem o momento certo. É ter esse respeito." Pergunto como ela aprendeu todas essas coisas. "É mais com a vida. E acho que tem muito a ver também com a minha participação na comunidade. De aprender a respeitar o outro, de valorizar, de se preocupar com o outro. Não é com o eu. Eu, eu, é tudo eu. Não! E o nós? Isso é muito importante. Acho que ajuda muito. Mas alguns nem percebem. É interessante. Todo mundo acha que eu sou diferente. Realmente eu sou, mas assim: eu gosto muito de gente."

Gracinha sente vontade de compartilhar suas vivências com as colegas, mas nem sempre encontra brechas. "Eu fico tão triste quando eu vejo as pessoas não aproveitarem os momentos... O ano passado eu propus, esse ano também: gente, antes de iniciar a aula, vamos fazer um relaxamento? Cinco minutos. Não sai. Eu fico entristecida, que eu tenho uma sabedoria pra passar para os outros... Sempre me perguntam: ai, por que você é alegre? Por que você é assim?" Ela ergue os ombros, estendendo as mãos. "É uma escolha, não é?" 
Os meios de comunicação são outro alvo da atenção de Gracinha. Confessa que já foi noveleira, há muito tempo. "Mas, atualmente, eu estou muito cri-cri. Eu só leio Caros amigos, Brasil de Fato. E da Nova Escola, vejo as reportagens que me interessam e pronto. TV eu só vejo a Cultura. As outras - e ela balança a cabeça - fico irritada. Ah, eu fico tão nervosa!" Com relação aos alunos, ela tenta encaminhá-los: "A minha fala é no sentido de que as pessoas tomem consciência da nossa igualdade, das injustiças que passam na televisão e na vida real. Eu trabalho nessa linha. Gravar programas eu não faço. Isso seria interessante, para fazer uma análise daquilo que passa na televisão, que é o que eles assistem. Mas eu não fiz ainda. Filme eu só passo quando é algo que eu vou trabalhar na sala de aula. Não passo se for só para eu descansar, não! Semana passada eu exibi um sobre o prefeito Toninho e a cidade de Campinas.”

Foi por sua dificuldade em lidar com as tecnologias que Gracinha procurou a Pedagogia da Imagem. "Esse é o segundo ano que participo do curso. Pelo menos mexer com a câmera eu acredito que eu aprendi. E também a questão dos textos, que têm uma visão crítica, eu gostei muito.” O primeiro projeto de Gracinha na Pedagogia da Imagem foi uma pesquisa sobre as plantas medicinais presentes nas casas dos alunos. Ela queria resgatar os saberes das famílias sobre as ervas e suas propriedades terapêuticas. A escolha do tema não foi aleatória. "Eu gosto muito desse negócio de plantas. Ervas medicinais é comigo mesmo, desde a infância. Eu lembro que a tal da babosa, a minha mãe fazia um melado pra curar gripe: era um lambedor de babosa. Ai, meu Deus do céu! Até hoje, na minha casa, eu tenho muitas ervas. Desde bálsamo, até cana-do-brejo, arruda, alfavaca, hortelã, guaco, amora. Amora é um remedião, sabia? E o pessoal da vizinhança vai lá buscar." Gracinha pediu que os estudantes fizessem uma pesquisa em família, elaborando um levantamento das ervas conhecidas e suas utilidades. As apresentações de cada um foram gravadas, compondo um vídeo. No seu roteiro, ela também incluiu filmagens e entrevistas nas casas de alguns deles. Em 2007, ela desenvolveu o projeto com as colegas Cida e Luciane. A temática escoIhida foi a mobilização da comunidade para a construção do posto de saúde do bairro. O grupo realizou fotos e entrevistas com membros da associação de moradores e do conselho de saúde do bairro, além de autoridades da prefeitura.

A intenção de Gracinha é que os alunos se apropriem do recurso audiovisual: "Olha, eu gostaria de aprender realmente a lidar com a câmera para ensinar as crianças. Eu vejo, por exemplo, meninos que não 
se interessam em ficar na sala de aula. Mas as imagens que eles fazem: filmam direitinho. Eu acho que tem que tentar quebrar essa resistência de não dar o instrumento na mão do aluno. Eu tinha resistência a isso. Ai, medo de quebrar! Que nada! Eles já fazem direitinho. Ficou tão bonita a filmagem que o aluno fez! Talvez seja esse um ponto dele: mexer com a câmera. Você vê o documentário Xingu, a terra ameaçada, aquele pessoal lá tá fazendo vídeo. E por que nós não fazemos, gente? Ah, não deve fazer? Deve sim! As pessoas têm capacidade. Nem todas aprendem do mesmo jeito, mas aprendem um pouco. Eu não sabia mexer com a câmera, e já sei um pouquinho.”

Gracinha ainda está aprendendo, mesmo faltando pouco tempo para sua aposentadoria. Pergunto o que pretende fazer quando essa fase chegar. Engana-se quem pensa que vai descansar, depois de tanta luta: "Olha, se eu pudesse, trabalhar com aquelas crianças que têm muita dificuldade de aprendizado. Porque eu acho que no individual elas aprendem. Com trinta, com vinte crianças na sala, nossa! Difícil! Pretendo também continuar com o grupo de mulheres, fazer algum tipo de atividade no Sesc e mexer com as minhas plantinhas."

\subsection{O elemento subjetivo na formação continuada: poderes e limites do agente e parâmetros para ação}

Em que medida cabe aos docentes em formação continuada a responsabilidade por implementar transformações na sua prática educativa, no sentido de promover uma Pedagogia da Imagem ou a Educomunicação? Como já temos assinalado inúmeras vezes, esse encargo não é exclusivamente seu. Mas, que poderes e limites possuem, diante das condições que lhes são dadas? A narrativa das histórias de vida das professoras trouxe importantes lições nesse sentido. Existem pontos significativos que Walquíria, Analice, Marli e Gracinha compartilham, e cada uma ressalta aspectos singulares que compõem a experiência de sua profissionalização. 
Todas elas são experientes, realizadas na profissão e demonstram genuína alegria no exercício de seu trabalho. No relato das quatro, notamos que o significado de ser professora (diferente para cada uma) não se define pelo cumprimento burocrático de um programa pedagógico, nem pela formação e ensino de uma disciplina. Ao contrário: esse sentido está numa práxis (ação-reflexão) desenvolvida ao longo da vivência em salas de aula, durante toda a vida profissional. Tal práxis é singular porque configura-se a partir de um processo de internalização e amadurecimento dos conceitos aprendidos e experiências adquiridas - não vem de fora para dentro ou de cima para baixo. É um processo de conquista de (ou de constante luta por) autonomia, no qual as determinações e expectativas de terceiros vão sendo cada vez mais filtradas pelos anseios, saberes e convicções dessas professoras.

Analice, por exemplo, relata que deixava de fazer muitas coisas em virtude das opiniões alheias, até o momento em que se percebeu tolhida e decidiu agir conforme sua consciência. Claro que o ambiente e o grupo ainda oferecem limites e a obrigam a justificar-se permanentemente, mas agora ela aposta na autoconfiança, fortalecida nos cursos que freqüentou e no convívio com outros especialistas. O relato de Marli também é representativo: demonstra que, no início da carreira, sentia-se testada por alunos e colegas, vigiada pelos superiores e pautada pelas expectativas dos pais em relação ao vestibular. Agora, já experiente, enxerga-se livre para expressar-se, selecionar e compor os materiais que julga necessários para suas aulas. Sua segurança vem dos anos de prática e também de sua inquietude, da atitude de quem está permanentemente pesquisando e estudando, jamais acomodada na repetição de fórmulas. Por sua vez, Gracinha demonstra que, mesmo sendo "diferente" das demais, uma voz dissonante no ambiente de trabalho, conserva a lucidez e, no seu agir, faz prevalecer sua sabedoria. A origem da sua força está nas suas múltiplas vinculações aos movimentos sociais e comunitários. E, finalmente, Walquíria nos ensina que é possível superar a falta de condições de trabalho e de apoio do grupo, quando se tem sensibilidade para reconhecer as necessidades dos estudantes, para muito além dos conteúdos disciplinares, e se assume o compromisso de atendê-las. Essa capacidade de compreender o outro vem do autoconhecimento, da consciência das próprias limitações e do esforço permanente de superá-las (no caso, sua alegada timidez é o que, paradoxalmente, a torna mais capaz de se relacionar com os alunos, por sua atitude de escuta, abertura e acolhimento, pelo desejo de aproximar-se, fazê-los se desenvolverem e se expressarem 
mais e melhor). Menos que certezas inabaláveis, ela possui flexibilidade para ler os cenários e propor respostas aos problemas que se apresentam. Assim, transforma sua suposta fraqueza em força.

As diferentes histórias narradas mostram que a subjetividade dessas mulheres desenvolveu-se e consolidou-se a partir de suas inserções socioculturais - cursos e grupos de formação, pesquisa constante, participação em movimentos sociais e nas relações interpessoais. Superando o isolamento na profissão, conquistam a capacidade de olhar o próprio fazer de modo vigilante, crítico, descentrado. Essa atitude é o crivo pelo qual examinam as determinações exteriores ao seu fazer, re-humanizando o seu trabalho. Suas experiências de vida, invariavelmente, emergem em suas dinâmicas profissionais e compõem aspectos fundamentais e singulares de seus projetos pedagógicos. É isso que faz delas grandes profissionais.

Estariam elas, então, acima das circunstâncias externas, das políticas educacionais ou do poder coercitivo do grupo? Certamente que não. Seus depoimentos também são inequívocos a respeito das muitas propostas que não conseguem implementar, das contas que têm de prestar à comunidade escolar, da necessidade permanente de negociar melhores condições de trabalho e das dificuldades e frustrações que vivenciam. Ocorre, porém, que elas não se vêem (nem são) passivas, meros instrumentos educativos. E o que lhes confere esse poder é a assunção do compromisso com a profissão, o fato de aceitar e optar, conscientemente, pela docência. Mesmo que ser professora não fosse o sonho de algumas delas. Esse envolvimento com a profissão é, sobretudo, um posicionamento ético: não cumpri-lo é uma forma de omissão.

Alguém se forma professor quando recebe o diploma da academia. Mas somente se torna professor quando, ativamente, compromete-se eticamente com o ensino. Por que seria diferente com a Educomunicação ou a Pedagogia da Imagem? Se tais concepções carregam, em seu ventre, a inspiração libertária e humanizadora da educação freireana, a pedagogia do oprimido, a pedagogia da autonomia, então a formação continuada que propomos não se realiza na distribuição anual de certificados, na instrumentalização dos quadros escolares para uso de recursos mais "modernos". Ela requer um engajamento ativo do educador e da educadora que acreditam na necessidade e na importância desses projetos. Onde houver esse engajamento, haverá disposição para driblar as barreiras oferecidas pela estrutura ou pelo 
coletivo. Sem esse envolvimento, porém, apoio institucional e disponibilidade de infra-estrutura serão sempre insuficientes.

Os programas de formação, portanto, devem fazer mais que divulgar princípios e métodos. É preciso estimular a diversificação das inserções socioculturais dos docentes, incentivando sua participação nas questões comunitárias e coletivas e a ampliação de seu universo cultural. Ainda, necessitam requerer o posicionamento ativo do professor, fazendo-lhe um convite para assumir sua responsabilidade ética em relação aos estudantes e solicitando sua abertura para explorar e inserir elementos significativos de sua trajetória de vida na elaboração de um projeto pedagógico. A atuação dos orientadores é no sentido de auxiliar na tessitura do método, de forma que os educadores possam dispor de critérios de análise e validação da própria prática.

Anteriormente, examinamos a limitada experiência das professoras em formação com relação aos meios de comunicação e tecnologias da informação. Mas, nas entrevistas em profundidade, vemos que esse não é um fator impeditivo ao desenvolvimento de projetos em Pedagogia da Imagem, mas superável. Para tanto, é preciso que os educadores compreendam que não devem buscar, aqui, apenas uma nova forma de trabalho que se enquadre em uma rotina desumanizada, burocrática, anti-dialógica. Cabe-nos, enquanto formadores, negociar com eles os significados dos princípios fundamentais de nossa proposta: a dialogicidade, a criticidade, a participação ativa dos estudantes, o envolvimento nas questões comunitárias e o desenvolvimento de suas proficiências comunicativas. Co-autores, co-constutores do sentido da Pedagogia da Imagem, os docentes ampliam o seu alcance e empenham-se firmemente na crítica dos projetos, na manutenção de sua coerência e adicionam, uma a uma, múltiplas contribuições à proposta inicial. Ela se torna, assim, um modelo dinâmico, orgânico, hibridizável, adaptável, enxame de infinitas possibilidades de atualização, sem, contudo, perder o núcleo de sua identidade, seu "DNA" libertário e humanizador. Eis, então, o que é a formação continuada: uma permanente negociação e produção de sentidos em torno de princípios educativos enunciados, visando à elaboração e avaliação das metodologias aplicadas. 
Embora subjetivamente tecidos, singulares e autorais, os projetos em Pedagogia da Imagem precisam assegurar a sua comunicabilidade. Requerem, pois, o registro, o intercâmbio de experiências e o compartilhamento de parâmetros ou critérios mínimos de validação. O acompanhamento dos projetos desenvolvidos nas escolas (formação clínica ou coaching) mostra-se fundamental nesse processo. Seu objetivo não é conseguir que os professores cumpram aquilo que os formadores esperam, mas que, numa dinâmica partilhada com outros profissionais, sejam capazes de pensar sobre sua prática, analisar os resultados obtidos e defender os saberes construídos, fortalecendo sua autonomia, num movimento de contínua aprendizagem-ação-reflexão. Nesse percurso, caminham das abordagens mais instrumentais da tecnologia em direção às práticas dialógicas e emancipadoras.

Tomando como base os projetos descritos nas entrevistas individuais, cujo desenvolvimento e implementação acompanhei in loco, e considerando ainda o núcleo das proposições da Pedagogia da Imagem, posso ensaiar a definição de critérios avaliativos para as práticas dos docentes em formação. Seriam eles relativos aos processos pedagógicos e aos produtos da ação.

Os critérios concernentes aos processos avaliam o nível de dialogicidade implicado na prática educativa, tanto nas relações entre os participantes do projeto como entre eles e seu ambiente ou entorno. São:

a) a gestão participativa - que compreende o grau de inclusão dos diversos participantes nas decisões relevantes da produção e o "coeficiente comunicativo" das ações educativas. A gestão participativa adequada requer o diálogo constante entre professores e alunos e a atitude de relativismo cultural;

b) o protagonismo ou envolvimento dos participantes nas questões comunitárias, sociais ou relativas ao entorno da escola. ${ }^{171}$ Aqui, não me refiro apenas ao protagonismo juvenil, mas também dos educadores, muitas vezes alheios ao que acontece fora das salas de aula.

\footnotetext{
${ }^{171}$ Em sua tese de doutorado, que nos serve de inspiração, Genésio Zeferino da Silva Filho, orientado por Ismar de Oliveira Soares, propõe-se a identificar a metodologia típica dos projetos educomunicativos. A análise das práticas de oito instituições que utilizam a educomunicação como forma de intervenção social revelou que seu modus operandi fundamenta-se no tripé: protagonismo juvenil, gestão participativa e ação por projetos. Cf. SILVA FILHO, G. Z. da. Educomunicação e sua metodologia: um estudo a partir de práticas de ONGs no Brasil. São Paulo, 2004. 238 p. Tese (Doutorado) - Escola de Comunicações e Artes, Universidade de São Paulo.
} 
Os parâmetros referentes aos produtos da ação analisam o incremento da criticidade dos agentes, englobando os seguintes aspectos:

a) proficiências comunicativas - a ampliação e apropriação de repertórios culturais e o domínio da linguagem audiovisual, promovendo a educação sensível e estética dos participantes;

b) ética polifônica - a abertura do grupo para acolher a maior diversidade de fontes de informação e visões de mundo.

O processo avaliativo não deve ser conduzido de fora, mas conjuntamente pelos participantes do projeto e seus orientadores. Também é desejável que assuma um caráter qualitativo e que seus resultados sejam um ponto de partida para a reorientação de futuras ações.

\section{Ecossistema educativo-comunicativo}

O ecossistema comunicativo-educativo compreende o ambiente escolar do ponto de vista dos processos comunicativos que ali acontecem, englobando os tempos-espaços das ações educativas, os recursos e meios disponíveis para sua realização, as relações entre os sujeitos envolvidos e as regras de atuação nesse campo. A Pedagogia da Imagem, assumindo-se como proposta educomunicativa, preocupa-se com o "coeficiente comunicativo" desse ecossistema, isto é, com o nível de participação dos agentes envolvidos e sua capacidade de estabelecer um diálogo democrático. Essa é uma questão não apenas quantitativa, mas qualitativa: tanto quanto a existência de uma infra-estrutura adequada à implementação dos projetos audiovisuais, importa a natureza das relações tecidas entre os sujeitos. Portanto, identificar os elementos que ajudam a configurar esse ecossistema é importante para compreendermos os limites colocados à formação continuada pela estrutura escolar - não para nos conformarmos a eles, mas para projetar seu enfrentamento.

Com relação à disponibilidade de recursos materiais, diversos depoimentos de professoras, transcritos no capítulo anterior, fornecem um painel das dificuldades e inadequações que temos enfrentado. Sendo 
desnecessário repeti-los, transcrevo apenas o parecer de um membro do Conselho Municipal de Educação, constante da ata de reunião realizada em 24/04/2008, publicada no Diário Oficial. Ele resume bem a situação:

Encerrada a discussão, a suplente de Conselheiro Rosely Poleto [...] disse que muitas vezes falta espaço físico nas escolas para atender esses alunos [em Carga Horária Pedagógica, atividade prevista para ser realizada no horário contrário ao das aulas] e solicitou a flexibilização da obrigatoriedade no período contrário, sugerindo também a CHP em horários livres. [...] Para ela, os alunos da Rede Municipal não estão lendo o tanto quanto deveriam, uma vez que as bibliotecas encontram-se fechadas na maioria das escolas. Já os laboratórios de informática, segundo afirmou, estão sem um programa integrado com o NTE [Núcleo Técnico Educacional] e necessitando de reforma e atualização dos softwares. [grifo meu ] ${ }^{172}$

A falta de espaços físicos nas EMEFs, perceptível nas visitas que realizamos para acompanhamento de projetos, tem sido peremptoriamente negada pela SME. Na mesma ata, registra-se que a conselheira técnica da Ana Cláudia contra-argumentou:

Quanto ao apontamento de que não haveria espaços nas EMEFs para o cumprimento da CHP [...], lembrou, primeiro, que não se trata de uma nova hora de trabalho; o que é inédito é a regulamentação que disciplina o seu cumprimento, pois que ela já era cumprida pelos educadores sob a denominação de TDPR e, como se sabe, os espaços físicos das EMEFs não se alteraram. [grifo meu $]^{173}$

No seu pronunciamento, a própria conselheira admite que os espaços físicos não se alteraram, querendo dizer, com isso, que as escolas não diminuíram de tamanho. Contudo, ela deixou de ponderar que, nem sempre, o número de alunos se mantém o mesmo, tendendo a aumentar em certos casos. Além disso, sua argumentação assume que os espaços existentes anteriormente eram satisfatórios. Ora, só se poderia considerá-los suficientes quando se tem em mente a atividade convencional, dentro das salas de aula (no caso das escolas que funcionam em quatro turnos ininterruptos, nem isso vale). Quando se pensa em realizar projetos extraclasse, transversais, em audiovisual ou de outra natureza, a defasagem é inegável.

Subjacente a essa discussão, reside uma primeira linha de tensão entre educadores e administradores da SME: a concepção sobre o espaço-tempo escolar e a forma de organizá-lo. Não é um problema mera-

\footnotetext{
${ }^{172}$ CONSELHO Municipal de Educação. Ata da quarta reunião ordinária do plenário. Diário Oficial do Município de Campinas. Campinas, 5 de junho de 2008, p. 3-4.

${ }_{173}$ CONSELHO Municipal de Educação. Ata da quarta reunião ordinária do plenário, p. 3-4.
} 
mente logístico: ele traz no seu bojo a disputa pelo tipo de educação que se deva praticar. De um lado, um sistema afeito à educação bancária, linha de montagem da inculcação de conteúdos, depositária de informações nas mentes jovens, alinhadas nas fileiras de carteiras das salas de aula, por sua vez, seriadas em corredores insípidos e, estes, em blocos, e assim por diante... Do outro lado, agentes abertos a incorporar a dinâmica cultural como o próprio contexto do processo educativo, carentes de espaços de encontro, leitura, estudo, convívio, arte, experimentação. Tais sujeitos, dentre os quais se podem incluir os gestores de algumas UEs, atuam de maneira isolada. Atendo-se às margens de sua autonomia, buscam prover a escola dos recursos cuja importância ou urgência não tem sido reconhecida oficialmente pela SME. No caso dos docentes, muitos têm tomado a iniciativa de adquirir e manter aquilo que seria considerado equipamento de trabalho e, portanto, deveria ser-lhe fornecido. Claramente, trata-se de uma atitude de resistência.

Essa constatação é apenas um indício do que percebi ao longo desta pesquisa: a escola é um campo conflituoso e contraditório, no qual se entrecruzam e se chocam inúmeros vetores de força: o sistema municipal, a equipe gestora escolar, a comunidade e os próprios educadores. Um episódio, em especial, tornou-se emblemático dessa realidade, condensando seus embates e incongruências: a greve de 2007. O acontecimento irrompeu ainda no início do ano, logo após a realização das discussões sobre o perfil sociocultural das educadoras. No curso, em vez de paralisar as atividades, aproveitamos o momento para debatê-lo intensamente com as nossas interlocutoras. Temperamos as conversas com a exibição do filme Pequeno grão de areia, ${ }^{174}$ sobre a mobilização dos professores rurais da região de Oaxaca, no México. Um dos principais pontos abordados no filme, e que exploramos intencionalmente, é a relação dos educadores com as suas comunidades. ${ }^{175}$

Embora a greve só tenha eclodido em maio de 2007, às vésperas do dissídio dos funcionários públicos municipais, a tensão pairava no ar desde antes, quando o novo Plano de Cargos, Carreiras e Vencimentos (PCCV) começou a ser elaborado pelo executivo, em meio a muitas polêmicas e de modo pouco transparente, sem uma participação ativa do funcionalismo ou sequer uma divulgação adequada. Em

\footnotetext{
${ }^{174}$ PEQUENO GRÃO DE AREIA. Granito de arena. Direção: Jill Freidberg. México: Corrugated Films, 2005. 1h.

${ }^{175}$ A partir deste ponto, as citações das falas das professoras são retiradas das discussões em grupo realizadas nos dias 22 e 29 de maio de 2007 (no MIS) e 04 e 18 de junho de 2007 (na EMEF Edson Luís Lima Souto), gravadas em vídeo e posteriormente transcritas.
} 
maio, a proposta do governo estava a ponto de ser votada pela Câmara Municipal, havendo grande probabilidade de ser aprovada, mas ainda conservava muitos pontos obscuros para os principais interessados. A expectativa geral era de que o novo plano traria muitas perdas, especialmente para a educação e a saúde.

A coincidência da votação com o período de dissídio colaborou para aumentar a confusão em torno dos motivos da mobilização e para desorganizar os trabalhadores. A questão de fundo não deveria ser - e não era - uma discussão puramente salarial. Tratava-se de um problema de longo prazo, que envolvia a formação continuada, o incentivo à titulação, as formas de progressão na carreira, a relação do professorado com os especialistas, os processos avaliativos (amplitude, garantia de isenção e proteção contra abuso de poder pelo superior imediato) e, com conseqüências instantâneas, a distribuição da jornada de trabalho. Mediante a atuação fraca do sindicato, muitos profissionais não compreenderam todo o alcance do PCCV. A professora Walquíria, que participou das manifestações, relatou a situação em sua escola: "Você vê que no nosso plano de cargos a gente ia ser prejudicado. Mas você não conseguia mobilizar o pessoal pra lutar, entendeu? Diziam assim: ah, eu não sei por que eu tô lutando, não sei pra que vai ter greve. As desculpas são as mais variadas." A desinformação favoreceu o governo, que se baseava na argumentação de que não haveria perdas salariais e que, em alguns casos, ocorreriam melhoras. Os mais informados, porém, conservavam a lucidez e vislumbravam o que estaria por trás das propostas:

Estamos vivendo um momento de greve, pela prefeitura, onde essa greve tem um fundo de [ir contra a] privatização da educação, que [...] foi o ponto principal da nossa discussão. E essa privatização da educação, que até então tá mascarada, e no entanto tá presente [...] na nossa realidade? Que qualidade iremos oferecer às crianças? Que ensino? É uma questão a se pensar.

[É] um plano de cargos extremamente perverso. Eu sou orientadora pedagógica. Muitos acham que o orientador pedagógico é um especialista e não está em greve porque teve um aumento significativo no salário. Os especialistas não têm ilusão desse aumento. Não estou em greve por causa desse aumento, porque eu sei que o plano é perverso, eu sei que um plano que atrela tudo a se houver verba ou não, que depois de quinze anos congela a carreira, que de três em três anos fica a mercê do superior imediato para ter uma progressão na carreira... É ou não é um plano perverso? Eu não concordo com ele.

Após ver o filme Pequeno grão de areia na EMEF Edson Souto, uma professora comentou:

- Olha, eu vi realmente o que acontece conosco, principalmente, que eu fui professora do Estado muitos anos e eu percebi que essa jogada política é a mesma. A escola estadual ela está sumindo do mapa realmente porque eles estão querendo privatizar tudo, né, principalmente o ensino médio, com as empre- 
sas. Então eu percebi assim: realmente é o mesmo caminho, é a mesma luta, os sindicatos perdendo a força, a gente acuando por medo, porque precisa sobreviver. Fiquei até deprimida, sabe, vendo a situação idêntica à que está se passando aqui. Parece que acompanha, os países do quintal dos Estados Unidos... Se bem que eu acho que nós somos uma classe de pessoas que nós não desanimamos. Vamos sempre à luta, né? Pode ser que eu não vá corpo a corpo, mas eu estou sempre procurando conscientizar os alunos, a postura nossa, entendeu?

A cobertura da greve, feita pela mídia local, não fugiu ao padrão dos grandes meios, de classificar manifestações legítimas como "confusão" e "tumulto", sem aprofundar as motivações da luta. A reação da sociedade, diante do movimento, pode ser exemplificada pela fala de uma educadora:

Sexta-feira de manhã, eu estava dentro do ônibus, quando o pessoal [grevista] acabou de fechar a Anchieta. O pessoal estava lá e eu estava atravessando. E não fiquei surpresa, como orientadora pedagógica, com a minha própria prática quando eu vi o que o [pessoal do] ônibus falou e o que os [motoristas dos] carros falaram. Xingaram: vagabundos, cês não têm o que fazer, cês tão atrapalhando a vida da gente, vocês têm emprego, tem gente que não tem salário, não tem o que comer, tá à busca do emprego, cês tão atrapalhando aí, que a gente não vai chegar na hora. Então é uma comunidade que está contra nós porque a escola está contra a comunidade.

A falta de apoio da sociedade à greve das professoras foi discutida e compreendida pelo grupo como resultado do distanciamento entre a escola e a comunidade.

- Ah, eu fiquei chocada [com o filme exibido]. Porque eu participei de muita coisa, [...] eu fiquei chocada, mas também fiquei emocionada pela participação da comunidade. É muito bonito, aqueles pais, gente! E é muito triste ver as pessoas destruindo as escolas assim.

- Coisa que nós não temos... [participação da comunidade.]

- É.

- Mas talvez tá faltando a gente puxar a população junto, né, pra alguma briga. Que ninguém fala nada.

- Eu fiz uma greve onde a gente... em 89, né? Foi aquela greve que durou três meses, mais ou menos: 82 dias letivos. Eu fui atrás da comunidade, [...] a gente saiu pondo carta nas casas.

- Ah, então, a gente tava falando que quando acontece uma greve aqui, a comunidade só pensa que a gente tá errado de fazer greve, porque a gente ganha bem, não sei quê lá, não tinha que tá fazendo. Mas [...] a gente tinha que mostrar pra eles o contrário, né, que não é bem assim, que as crianças também tão perdendo com isso. Talvezé por isso que aqui eles não tão com a gente nunca, né?

- Os pais hoje, vocês acham que eles tão conscientizados das dificuldades que a escola passa?

- Eu acho que não. Não, e nem em relação à criança. Tanto que eles nem brigam por nada, né? Nem em relação à qualidade do ensino, nada. 
Esse afastamento é, em parte, atribuído pelas professoras às famílias dos alunos, que, segundo suas falas, não estariam interessados em se envolver nas questões pedagógicas e disciplinares, ou não teriam condições de participar delas devido à sua desorganização ou despreparo:

E eu percebo que a família precisa receber mais subsídios no lidar com as crianças, porque hoje é muito difícil [...] trabalhar com as crianças, com os filhos, né, a situação que a gente vivencia hoje é muito diferente de tempos atrás. Então a autoridade paterna, ela muitas vezes [...] tá muito reduzida, às vezes ela deixa de existir e então eu acredito que as famílias precisam ser fortalecidas nessa missão que elas têm né, de educar os filhos. E eu comecei um trabalho nesse sentido e [...] a gente conseguiu formar um grupo, que [...] poderia ser muito maior [...], mas [não é...] por conta de vários fatores de que os pais trabalham, compatibilidade de horários, [...]. Eu acho que deveria ter uma aproximação. Um movimento voltado pra isso.

- E a comunidade, os pais?

- Ih...

- Não é participativo.

- Os pais não participam. Aqui a gente tem a participação do mínimo, com vontade, $10 \%$ de cada classe de pais ou uma média de $30 \%$ da escola no total.

- Houve um conselho de escola que nós precisamos resolver problemas disciplinares. Foram convocado os pais, eles tavam sabendo da pauta. Chegou um pai, ele falou: eu vou decidir esse problema de aluno? Com licença, então me retiro. Era um problema que hoje o filho dele não tava sendo prejudicado por causa desse grupo de alunos, mas futuramente poderia acontecer a mesma coisa. Então eu percebo que os pais são imediatistas, eles querem só ver o lado deles, lava a mão como todos[...]. Eu falei, então, o que faltou? Explicar pra ele quê que é um conselho de escola. O que é ser participante de um conselho de escola. Qual que é a função dele. Primeiro tem de arrebanhá-los a laço. Então ele veio, mas eu fiquei decepcionadíssima. Foi a hora que nós começamos a reunião ele falou: não, eu não vou dar o meu parecer porque eu não vim aqui pra isso. Ele achou que ele ia só assinar lá o que foi gasto, sabe? Então eu acho que nós precisamos fazer um trabalho pra envolver esses pais da comunidade. Então, como eu falo: o que nós, nós tamos esperando também? Que ele não vem sozinho, gente!

Entretanto, esses discursos acabam desmascarados pelas próprias colegas, que questionam os papéis delegados pela escola às famílias.

Eu percebo assim, que essa relação com a comunidade, por exemplo, de onde eu trabalho, essa relação ela deveria existir porque seria positiva pra ambos os lados, pra escola e pra família, pra comunidade. Mas eu vejo a escola muito desvinculada. Como se fosse uma ilha. Eu vejo assim, por exemplo, a família sendo chamada na escola apenas para cada final de bimestre, pra dizer as notas, se o filho tá se comportando bem ou não.

- A escola não aceita a comunidade como parceria, como transformação, como gente, gente explorada como ela própria. A escola não aceita. A escola não aceita aluno em conselho de escola, porque acha que o aluno vem pra atrapalhar, a escola chama a mãe que já trabalha, explora a mãe quando chama a mãe, 
eu faço isso como orientadora, eu faço isso, eu chamo a mãe, e tenho consciência que eu estou sobrecarregando [...] essa mãe que tem uma carga de trabalho o dia inteirinho, e é obrigada lá, pra ser cúmplice [...] da nossa irresponsabilidade de educar, de formar. Porque a responsabilidade de educação formal não é da família. É da escola. Sinto muito. Chamar a mãe pra responsabilizá-la porque o filho está indo mal na escola [...] é uma covardia nossa, porque a responsabilidade é nossa, não é da mãe e do pai. A mãe e o pai educam. Educam, mas ensinar, sinto muito, a educação formal... ou então eu não sei qual é o papel da escola. Ou eu tô equivocada, se não for esse o papel da escola pública. E então a mãe é chamada e a gente explora mais ainda a mãe. Porque com a carga de trabalho dela, eu ainda chamo pra falar: seu fitho não faz dever, o seu filho brinca, o seu filho faz isso. Eu acho isso muito ingrato.

- Mas você vai falar pra quem, se você não for falar pra mãe?

- Pra nós mesmos que somos escolas. Quais as nossas propostas pedagógicas para ensinar alunos que não sabem ler e escrever? Essa responsabilidade é nossa, não é da família. A da família é educar, sim. Mas não educação formal. Ela tem que ajudar.

- Mas cê tá falando só do conteúdo, a gente tá falando de forma....

- Eu não estou falando de conteúdo! Não estou falando de conteúdo, eu estou falando de comunidade, tá, parceira de escola, enquanto sujeitos! Enquanto sujeitos. Enquanto formadores de sujeitos, enquanto parceiros de comunidade que se unem para um projeto transformador. É isso que eu estou falando. Então a maneira como nós fazemos, nós estamos na verdade é explorando mais ainda o pai e uma mãe que já são superexplorados aí fora. Não sei se a minha reflexão tá correta ou não, nem sei se todo mundo concorda comigo.

- Claro que não.

$[\ldots]$

- Eu tenho a impressão de [que] quando eu falei de chamar a mãe e pai algumas pessoas aqui acharam que eu sou contra chamar a família. Mas não é isso. Eu sou contra a maneira como nós chamamos a família. Se for de uma maneira pra resgatar a identidade das famílias na escola, pra ver a face da comunidade e pra escola mostrar a sua face à comunidade eu não sou, lógico, louca de trabalhar com educação e ser contra isso. Eu tenho a impressão de que quando eu falei isso eu choquei algumas pessoas dizendo que eu sou contra a família na escola. Não é isso. Eu sou contra como nós chamamos a família atualmente pra fazer parte da escola - na verdade, pra não fazer parte da escola.

- [...] Então, aí, por isso que eu entendo, né, o chamar os pais. Por quê que há uma evasão na reunião de pais? Porque chega lá na reunião só fala assim: olha, seu filho é isso, isso e isso. Não fala assim uma coisa boa, né. [...] Às vezes, quando o aluno de destaca, aí fala, na frente de todos os outros: olha o seu filho, nossa, é maravilhoso, o melhor aluno que eu tenho. Aí eu, meu filho que é péssimo, acabo ficando cada vez menor. Uma hora vai ter que chegar no meu filho, vai falar dele e eu vou ficando desse tamaninho, né? Então [...] a gente tem que repensar mesmo [...] como tá trazendo essa comunidade na escola.

Nota-se que a expectativa da escola é que os pais participem dentro de certos limites rígidos, apoiando as decisões das educadoras. Quando as questionam, tornam-se incômodos e são vistos como invasores de um espaço que não é seu, ao qual somente iniciados (educadores formados) têm direito. As professoras freqüentemente se sentem ofendidas com a interferência da família, como se o seu profissionalismo fosse posto em xeque.

Eu acho que o professor é que é muito cobrado pelos pais. Porque os pais, além de falar com o professor eles vão direto pra direção. Sabendo que a direção não está em sala de aula. Quem tá em sala de aula é o 
professor. O professor conhece melhor o aluno, ele sabe que é uma dificuldade do aluno, sabe aquele que tá acompanhando, eu acho que não tem isso de ele levar na direção, e comentar, falar que o professor não sabe dar aula, que o professor não sabe fazer isso. Eu acho que eles cobram demais. Eles têm barrado um pouco isso.

E aí qualquer pessoa se sente no direito de dizer que os professores estão mal formados e não sabem dar aula. Todo mundo se sente no direito de falar isso. Todos.

Uma das falas exemplifica até mesmo como o recurso audiovisual, introduzido como elemento mediador da relação com a comunidade, pode ser mal empregado do ponto de vista da Pedagogia da Imagem. Vestindo numa roupagem pretensamente democrática, ele acaba tendo como efeito reduzir a participação ativa da família no processo pedagógico. O problema é que esse uso, fundado no paradigma informacional da divulgação, requisita apenas a adesão da comunidade ao modelo de educação praticado. $\mathrm{O}$ relato a seguir evidencia a necessidade de uma discussão profunda do uso do audiovisual na escola, pois, mesmo com boa-vontade e bem intencionado, o educador menos atento pode ser pego em armadilhas autoritárias.

$\mathrm{O}$ ano passado a gente fez isso: a gente pegou as crianças de seis anos, com muita dificuldade em relação ao trabalho [e fez] uso de imagens, de filmes. Quando a gente faz um documento, documenta o dia-adia da sala de aula e traz os pais pra vivenciar, pra ver o registro que é feito, é uma forma da gente conscientizar. Mostrar o que é feito, com o que é feito, como que é feito, né. Então, assim, a gente vai mostrando, sem cair naquela armadilha do tipo abrir demais o espaço ou abrir pra participação, de repente, que eles comecem a interferir no trabalho de uma forma não-produtiva, mas assim eles tando junto no dia-a-dia do filho e dialogando com a gente na sala de aula. Eaí a gente tem uma proximidade maior desses pais, até no relacionamento mesmo. Eu sinto nessa turma que eu tô dando aula esse ano, é o segundo ano que eu tô com a turma, assim, é uma proximidade muito maior que eu não tive em outras turmas. Porque eles têm uma clareza maior do trabalho que foi feito dentro da sala. Por essa questão, de toda reunião a gente tá levando esse registro.

A discussão caminha para o aprofundamento dessas tensões entre escola e comunidade e atinge o cerne da questão: o sentido do modelo educativo que educadores e comunidade devem negociar. As professoras destacam a necessidade de se posicionarem eticamente diante do problema. Entretanto, percebem que as mudanças não dependem exclusivamente da vontade individual, mas da unidade entre a categoria (e desta com a comunidade) em torno de uma proposta - algo que, até o momento, tem sido difícil alcançar. 
Eu queria pegar o gancho [e discutir a idéia de que] a escola também pode ser ascensão social, [de que o aluno...] pode ascender socialmente através da escola. Eu acho que [esse é ] um grande problema nosso atualmente. [...] O nosso discurso escolar é o discurso da ascensão social, por isso que nós perdemos o aluno de sala de aula, que tem o projeto de vida de ser preso sim, porque isso pra ele traz poder, faz status, tá, e pra eles é muito importante status. Que [...] enquanto nós estivermos com esse discurso de que a escola dá trabalho, a escola te dá futuro, que vai ser no dia de amanhã, chama o pai, chama a mãe, nós estamos decretando a falência de qualquer discurso libertador, porque nós estamos distantes do que o filme coloca, [...] eu lembro que o Eduardo Galiano fala, né, a gente é como um trem, que a gente pensa que está lutando pra formar uma sociedade transformadora, quando na verdade a gente vai chegar lá sem os vagões e sem a locomotiva, a gente vai estar na verdade anulando nós mesmos e anulando todos que fazem parte da escola, aluno e tudo mais, que a gente tá se anulando, na verdade. É um discurso anulador. E não um discurso transformador. E isso me faz ainda pensar mais na maneira como a gente se relaciona [...] com a comunidade.

Eu acho que [...] a gente tem respaldo, pelo menos eu digo aqui, no nosso meio de trabalho. A gente tem respaldo do plano, né, que a gente trabalha [...]. Um tempo muito grande a gente pensa sobre ele. Mas a cobrança eu acho que é mais [...] dos pais mesmo. [...] Essa questão do mercado de trabalho, especificamente, são eles que levantam, que colocam isso pra gente, muito. [...] A gente pensa, sim, no mercado de trabalho, mas não é o objetivo. Não é o ponto final. A gente pensa na educação dessas crianças na forma como eles vão construir o conhecimento.

- Eu tava justamente refletindo assim: [...] existe uma tensão de forças [...]. Então a gente fala em política internacional, a gente fala em sistema econômico, a gente fala no capitalismo, a gente sempre tá se colocando como os oprimidos. Só que eu vejo as coisas em cadeia, então o FMI vai pressionar o governo, o governo vai pressionar o secretário, o secretário vai pressionar o diretor, o diretor vai pressionar a gente, então assim, essa relação de opressão ela tá sendo reproduzida dentro da sala de aula. Porque o quê que eu tô ensinando na sala de aula? Que língua eu estou falando na sala de aula? Eu tô dentro dessa cultura de opressão. Então na relação com aluno, [...] toda vez que existir um eu e um você não tem mais paridade, né, eu acho que a paridade tá num conjunto. Toda vez que a gente fala a família, a gente tá falando de uma instituição burguesa e é como se a gente tivesse olhando de fora a escola, e na verdade a gente tá dentro disso e tá reproduzindo isso. Eu chego pros meus alunos com propostas que eu acho interessantes, eu tento trocar com eles, mas na verdade eu só tô trocando de posição, tem horas que eu oprimo, tem horas que eu sou oprimida. Porque eles também têm as demandas próprias. É muito complicado quebrar esse elo que existe de exploração. Achei muito interessante isso [que a outra professora colocou] da gente tá explorando os pais.

- Eu acho que não tem nada interessante não. Eu acho que família é família, escola é escola e cada um fazendo o seu papel a gente consegue uma harmonia.

- Eu tô há quatro anos como Orientadora Pedagógica [...] é uma escola de ensino fundamental e eu acho [que...] a gente não dá conta de quebrar não, viu! Eu acho que [...] é preciso entender, se colocar diante, como é que eu me coloco diante disso? [...] Eu acho que essa é a reflexão que a gente tem tentado fazer nesses quatro anos enquanto grupo, não é uma questão que sou eu... eu proponho mais pelo meu papel, né, de orientadora pedagógica. É uma questão que eu tenho trazido bastante, mas o grupo também traz. E é uma discussão que a gente tem feito: qual é a educação que a gente acredita? Vamos clarear isso pra gente? E eu acho que pra todo educador é necessário ter clareza disso. Individualmente, coletivos, enquanto grupos de escola, qual é a educação que eu acredito? Qual é, quais são os principais objetivos da educação que eu acredito? Como é que ela se materializa na prática minha, cotidiana, na sala de aula, na sala da OP, na relação com o aluno, na relação com a professora que eu coordeno, né? Então assim, 
eu acho que analisar essa nossa prática e tentar fazer essa relação com esses princípios maiores, com esses objetivos maiores, eu acho que [...] é fundamental pra [...] gente entender e como é que a gente se coloca diante disso. Então [...], a questão do fracasso que a colega traz e [...] as famílias são... é isso mesmo. Se eu for contar as histórias que eu tenho pra contar pra vocês, que vocês também têm pra contar, tem cada história! Bom: são essas! São essas as famílias que nós acolhemos nas nossas escolas! Nós não os iremos mudar. Agora: como é que nós vamos trabalhar com eles? Eu acho que tem que ser essa a questão que a gente tem que se colocar. [...] Tem que ter essa [...] clareza de qual é a educação que eu acredito, e como é que é que a minha prática cotidiana, todos os dias, como é que eu me coloco diante da comunidade, das famílias, das professoras, dos meus colegas de trabalho, dos movimentos sociais que acontecem, de uma greve no serviço municipal, como é que eu me relaciono com isso e quê que isso tem a ver com esses princípios que nós discutimos. Eu acho que é isso mesmo. É essa a reflexão que precisa fazer. [...] Agora, quebrar [essa cadeia de opressão mencionada pela professora], eu acho que não quebra não.

De fato, as educadores não têm conseguido quebrar a relação de opressão sequer entre elas próprias. Um conflito bastante freqüente é entre as professoras e a equipe gestora, especialmente quando as assimetrias de poder se manifestam como censura ou recusa ao diálogo. Em certos casos, qualquer reivindicação das docentes é encarada pela direção ou orientação pedagógica como ameaça, boicote, oposição, resistência - gerando represálias sobre elas. Mesmo as famílias têm medo de se posicionar nessas situações.

- Fui registrar o protesto das carteiras, quase que... Fui advertida oralmente, só não me fez assinar porque eu levei testemunha. Registrei as crianças com as cadeiras balançando e fui ameaçada. Então [...] você pode bater de frente com a direção. Qualquer coisa que prejudicar... Porque [o problema é da...] criança [faz um sinal com a mão: tanto faz - a direção] não tá nem aí, problema é dela...

$[\ldots]$

- Agora eu não sei, os pais não perceberam isso ainda, porque quando a gente vai mostrar, como no caso dela, as forças, diretor e as forças maiores vêm e os pais [se...] inibem, não ficam do nosso lado.

- Eu saí um dia com as crianças pela escola, duas semanas depois que a gente tava na escola nova, que nós professores registramos a mudança. Depois, com as crianças, registrei a escola nova, depois saí com eles registrando a depredação. Mas pergunta se eu vou poder mostrar a depredação. Os bancos quebrados, tudo riscado, as torneiras quebradas... Pergunta se vai poder mostrar em algum momento.

Uma estratégia empregada pelas docentes para evitar retaliações às suas justas demandas é torná-las difusas, de modo que o grupo todo se comprometa a expor-se diante dos superiores:

- Pra falar a verdade, eu que sou nova na escola, o único momento de união desse grupo que cê tá falando, o único que eu vi nesses quase dois anos que eu tô aqui, foi o dia que a gente foi reclamar várias coisas no TDC e cada um ficou responsável por fazer um tipo de reclamação ou de denúncia ou de pedido, 
porque sempre são os bocudos que falam mais. Foi a única vez que eu vi assim que todo mundo se organizou e cada um falou uma coisa pra não ficar um só marcado. Eu não sinto sinceramente essa união. Após o desabafo da professora, sala entrou em pesado silêncio.

Contudo, o significado da democracia e da participação perverte-se num ambiente marcado pelo abuso de poder.

- Existe a política dos amigos do rei. Se você é amigo do rei, tem os amigos aqui dentro da escola, cê pode tudo. Você faz o seu horário, você vai e passeia, se você tiver que fazer seu trabalho cê faz, se você não fizer também não tem problema, cê pode fazer projeto, desde que seja amigo do rei. E isso, assim, é uma coisa: é fato. Ocorre.

[...]

- Quer dizer, quando eles dizem: o professor tem que acolher o aluno, mas dentro da sala de aula. Se for pra dialogar, se for problematizar, então acabou.

$[. .$.

- Democracia só da gente para com o aluno.

- E mal entendido isso também né?

- Mal entendido porque a gente tem que aceitar tudo. A democracia na realidade é assim: uma abertura permissiva, cê tem que ser tão permissiva que cê acaba sendo desrespeitada.

A coletividade se desagrega e os indivíduos, isolados e enfraquecidos, desistem da luta:

- Vocês vislumbram alguma possibilidade de mudar esse cenário?

- Eu como tenho muito tempo de magistério, eu já vi mudanças boas. Mesmo porque eu mudei muito.

- Mas adianta mudar só a pessoa?

- Olha, eu não acreditava nisso. Mas vivendo, que essa escola é uma grande ilusão. Quando cê tá fora dela, nossa, ouve-se assim flores e cores dessa escola. Agora estando aqui dentro no dia-a-dia, de flor não tem nada, de cor não tem nada. E uma pessoa consegue agregar um grupo com ela, que tem a força de desagregar todo um grupo maior. Então, tendo o poder na mão, conseguindo agregados, aliados, consegue. Eu não acreditava nisso. Eu acreditava que o todo era mais forte que o um. Mas aqui eu passei a desacreditar.

$[\ldots]$

- A pessoa pode mudar e tudo muda? Não muda não, eu acho. Porque se a gente quisesse a gente pode mudar agora também. Mas é todas que não querem. A impressão que dá. Eu senti que a gente tava querendo fazer alguma coisa no começo do ano, mas depois cada um vai cuidar da sua vida, ninguém faz nada.

- Mas por quê? Porque não tem esse apoio pra gente mudar, pra gente fazer coisas interessantes, não tem. Não tem. Esse negócio da brincadeira dos amigos do rei é isso. Se parte de alguém que faz parte de um determinado grupo, a coisa flui. Se não é...

[...]

- Mas sabe quê que é? É o conformismo. Ah, é assim mesmo, ah, nenhum lugar é perfeito, ah, não pode ficar arrumando briga... Aí você vai, eu não fotografei que eu parei com as fotografias dos desleixos. Mas você vai, no refeitório, quanto tempo faz que a gente pediu banco pro refeitório? Você vai em junho, na 
biblioteca, e tem gente recebendo para trabalhar na biblioteca, cê chega lá na biblioteca, cê não pode usar uma biblioteca enorme, linda, maravilhosa. Foi pedido pra usar. Foi pedido pra tirar os entulhos. Depois que a gente pediu, ainda ficou um mês os entulhos aqui, coisa quebrada, tudo jogado, daí mais foco de dengue. Então, assim: ou desanima, ou você briga, ou você cruza os braços, fecha a sua porta e não faz nada.

Divididas, sem apoio da comunidade, as professoras foram derrotadas na greve, que terminou melancolicamente. O Plano de Cargos foi aprovado em sessão tumultuada na Câmara dos Vereadores. Os manifestantes que protestavam em frente à sede foram violentamente reprimidos pela Guarda Municipal, com o auxílio de cães policiais e spray de pimenta, numa cena indigna de um regime democrático.

Os reflexos na distribuição da jornada e na política da formação continuada seriam sentidos logo no início do ano letivo de 2008. Vejamos as principais alterações. Até 2007, a educação em serviço era regulada pelas seguintes diretrizes:

Artigo $1^{\circ}$ - As Unidades Educacionais, em seus espaços/tempos de reflexão coletiva, deverão promover, implementar e avaliar, permanentemente, a formação continuada e os projetos desenvolvidos com os alunos, como parte integrante do Currículo.

Artigo 2 - O horário de realização do Trabalho Docente de Participação em Projetos (TDPR) da jornada dos professores deve ser planejado levando-se em consideração a organização escolar e os espaços físicos existentes, privilegiando o trabalho pedagógico com o aluno ou a participação em programas de formação continuada, que podem se dar na escola ou em outros espaços organizados pela SME, de forma a atingir as metas do Projeto Pedagógico da Unidade Educacional.

Artigo $3^{\circ}$ - As horas de TDPR investidas em atividades com alunos deverão estar comprometidas com a promoção do acesso e permanência do aluno na escola, articuladas às metas para diminuição dos índices de repetência dos alunos do Ensino Fundamental, e com o atendimento das crianças do período integral ou em atividades planejadas para o enriquecimento curricular das crianças, no caso da Educação Infantil.

Artigo $4^{\circ}$ - As horas de TDPR realizadas em Grupos de Trabalho ou cursos deverão estar voltadas para: I - estudo e orientação do Currículo da Rede Municipal de Ensino;

II - avançadas formas de ensino-aprendizagem e avaliação escolar;

III - estudos sobre a organização dos ciclos de formação;

IV - temáticas dos programas: MIPID (Memória e Identidade: Promoção da Igualdade na Diversidade; Orientação Sexual; Educação Ambiental; LIMAE (Linguagens: Mídia, Arte e Educação); NTE (Informática); Cidadania: Exercício da Política e Democrática, incluídas como temas transversais da matriz curricular.

Artigo $5^{\circ}$ - O professor poderá também realizar sua formação continuada participando de atividades e experiências enriquecedoras na área de ensino e aprendizagem, desenvolvidas por outros profissionais da SME, em sua própria escola ou em outra. 
Artigo $6^{\circ}$ - Os professores que utilizarem as horas de TDPR para formação continuada estão comprometidos em socializar os conhecimentos adquiridos por meio de relatórios, que serão discutidos em reuniões de Trabalho Docente Coletivo (TDC) ou em outros momentos de reunião pedagógica. ${ }^{176}$

Ressaltemos os seguintes aspectos: o TDPR englobava tanto a formação continuada quanto o desenvolvimento de projetos com alunos. Muitos cursos oferecidos pelo Ceforma conjugavam esses dois aspectos do dispositivo, fazendo com que os professores em formação desenvolvessem propostas práticas nas escolas. Os programas de formação, supondo-se que mantêm uma vinculação com as propostas educativas da SME, possuíam um escopo amplo, abrangendo diversos temas transversais, dentre os quais o trabalho com as linguagens e as tecnologias.

Alegando que a hora pedagógica denominada TDPR "não cumpria adequadamente o papel para o qual fora aprovada”, a SME a extinguiu e, em seu lugar, promoveu dois novos tempos pedagógicos, a HP ou Hora Pedagógica, e a CHP, Carga Horária Pedagógica. ${ }^{177}$ Ocorre, porém, que os novos dispositivos não englobaram totalmente as funções da antiga TDPR. A CHP destina-se exclusivamente ao trabalho de "reforço" nas disciplinas de Português e Matemática no horário contrário ao das aulas.

A segunda motivação para a regulamentação da CHP deveu-se ao fato de a Secretaria Municipal de Educação entender que as alterações regimentais que introduziram os ciclos na Rede Municipal demandavam um esforço coletivo no sentido de otimizar os tempos pedagógicos remunerados para propiciar aos alunos todas as possibilidades de efetiva aprendizagem. Sendo assim, e para aqueles casos em que a aprendizagem não se desse no âmbito do TDA, Trabalho Docente com Aluno, estava posto, com a CHP, mais um tempo remunerado para a execução do Projeto Pedagógico de cada Unidade Escolar.

Já as HPs destinam-se à formação continuada e ao desenvolvimento de projetos com alunos. Contudo - aí está a armadilha - as HPs não fazem parte da jornada docente, sendo consideradas horas extras. Para serem realizadas, dependem de aprovação prévia, que só é dada de acordo com um saldo limitado de horas distribuído entre as diferentes regionais (NAEDs). Além disso, o leque de opções de formação continuada oferecido sofreu sensível redução, desaparecendo as diversas temáticas transversais:

176 CAMPINAS. Secretaria Municipal de Educação. Resolução SME/FUMEC No 2/2006. Dispõe sobre a jornada docente, jornada especial, formação continuada e programas e projetos da Secretaria Municipal de Educação.

Diário Oficial do Município. Campinas, 10 de fevereiro de 2006, p. 3-4.

177 CONSELHO Municipal de Educação. Ata da quarta reunião ordinária do plenário, p. 3-4. 
Art. $8^{\circ}$ A Secretaria Municipal de Educação (SME) colocará à disposição do DEPE [Departamento Pedagógico] um saldo quantitativo de HPs para a realização de projetos com alunos e/ ou de formação continuada.

$\$ 11^{\circ}$. Caberá ao DEPE a distribuição e/ ou redistribuição das HPs entre os NAEDs;

$\$ 2^{\circ}$. Caberá ao Representante Regional da SME o controle e a distribuição do respectivo saldo de HPs entre as Unidades Educacionais pertencentes ao NAED no qual atua.

[...]

Art. 11 As propostas de Projetos de Formação Continuada, desenvolvidos sob a forma de GTs, nas unidades Educacionais ou nos NAEDs, deverão:

$[\ldots]$

IV - estar voltadas para as seguintes temáticas:

a) Diretrizes Curriculares da SME/DEPE;

b) Avaliação Institucional;

c) Organização dos ciclos e/ou agrupamentos. [grifo meu] ${ }^{178}$

Compreendemos imediatamente o que essas diretrizes representavam para a Pedagogia da Imagem: uma situação semiclandestina, que nos exigira novas estratégias de sobrevivência. A solução que encontramos - realizar a formação diretamente nas escolas, em horários coletivos ou alternativos -, não obstante algumas perdas, permitiu-nos difundir ainda mais o trabalho e consolidar núcleos ativos em torno de projetos nas escolas.

\subsection{O entorno das escolas, na lente das professoras}

Durante o período de greve, as discussões que realizamos no curso Pedagogia da Imagem nos revelaram o distanciamento das professoras em relação à comunidade escolar. Dispostos a estimulá-las a adotar uma postura mais aberta, propusemos que o estudo da fotografia fosse realizado por meio de um passeio fotográfico pelos bairros. Cada educadora deveria identificar os locais mais significativos para a comunidade e registrá-los, aplicando as técnicas de enquadramento, luz e sombra, contraste, angulação de câmera, entre outras, que abordamos em classe.

${ }^{178}$ CAMPINAS. Secretaria Municipal de Educação. Resolução SME No 02/08. Dispõe sobre a regulamentação das Horas-Projeto na Rede Municipal de Ensino de Campinas. Diário Oficial. Campinas, 14 de fevereiro de 2008, p. 3-4. 
É significativo constatar que algumas educadoras abraçaram a proposta e chegaram a entrevistar alunos para conhecer os locais mais importantes para eles, incluindo-os no passeio, enquanto outras limitaramse a fazer suposições, restringiram-se ao registro de prédios públicos, ou sequer saíram da própria escola. Solicitamos que apresentassem as fotos produzidas, descrevendo as cenas e suas intenções, enquanto comentávamos os aspectos técnicos da imagem.

Não obtive a permissão dos autores para reproduzir aqui suas fotografias, ${ }^{179}$ razão pela qual irei descrever apenas suas falas. ${ }^{180}$ Seu interesse para esta pesquisa reside no fato de revelarem a compreensão que as professoras possuem a respeito das comunidades em que se inserem e o modo como procuram relacionar-se com ela. De modo geral, percebe-se que as docentes conhecem pouco dos bairros onde trabalham. Normalmente não são moradoras do local, chegam de carro ou de ônibus e, assim que terminam as aulas, vão embora, sem envolver-se com o entorno. É o que confirmam os depoimentos:

...Não pertencemos à comunidade. A gente não mora no bairro, então a nossa vida se restringe à escola $\mathrm{e}$ ao entorno, assim, bem próximo. Eu não conheço muito do bairro. Sabe, a gente passa de oito a dez horas dentro da escola e não dá pra conhecer o bairro de uma maneira geral.

Essa é uma casa abandonada da rua, que eu, particularmente, como venho de carro, nem tinha reparado nela. Então andando a pé pela rua que eu observei.

Eu tirei algumas fotos. Aqui é a frente né da escola. [...] Aqui é uma padaria. Eu não sabia onde era essa padaria, mas eu sabia pelos funcionários que é um lugar onde eles freqüentam.

Esse desconhecimento dos bairros gera, muitas vezes, medo e preconceito no educador:

...É um local [...] que oferece certos riscos por falta de policiamento, falta de um gerenciamento um pouco mais [...] eficaz. Então a gente sabe que as periferias estão mais [...] na mão dos marginais e a gente corre risco de tá passeando por aí. Eu inclusive, quando fui tirar essas fotos eu presenciei o pessoal fazendo uso de drogas ali por perto e fiquei com medo de, de repente, fotografar e eles viessem em cima de mim. Então deixei, fiquei só no foco geral mesmo.

Aqui eu pus uma foto que é um contraste. Porque o São Bernardo às vezes as pessoas acham que ele é muito bom. Só que tem muitos defeitos, então nós temos uma população muito carente e mesmo no lado

\footnotetext{
179 As professoras argumentaram, legitimamente, que muitas de suas fotos retratam outras pessoas, que por sua vez, não haviam sido consultadas a respeito do uso de sua imagem.

180 Nesta parte, os depoimentos foram extraídos do grupo de discussão realizado em 19 de junho de 2007, no MIS. Como sempre, mantive o sigilo sobre os nomes das professoras.
} 
de baixo, né, no Baixo São Bernardo, também tem essas diferenças sociais, econômicas. Então tem uma casa assim mais organizada enquanto que a outra tá quase caindo do lado.

Muitos se impressionaram com os contrastes sociais existentes numa mesma comunidade e, principalmente, a contradição de reconhecerem potentes símbolos de consumo numa região habitada, majoritariamente, por moradores de baixa renda:

- É um bairro de periferia, mas ele é todo asfaltado, ele tem as necessidades básicas, o lixeiro passa constantemente.

- Não é uma favela?

- Não é. É um bairro assim simples, mas que tem uma infra-estrutura boa.

- Muitos moram em casa própria.

- Essa daí nós fizemos pra mostrar que o bairro, apesar de ser um bairro simples, a gente percebe por cima que é cheio de parabólicas.

- Carros novos, parabólicas, aparelhos de última geração, a convivência dos dois opostos, né?

Achei bem interessante o tamanho de placa do McDonalds pro tipo de bairro que eu trabalho.

Alguns, ao contrário, demonstram transitar tranqüilamente pelo bairro e falam de seus pontos principais com familiaridade, sem preconceitos:

Do lado direito tem uma pracinha muito mal-cuidada, acho que vai aparecer depois [...]. Ela fica na lateral da escola, um ponto de ônibus. Aí passa ônibus pro centro, pro terminal de Barão Geraldo e pra aquele terminal Anchieta. Lá atrás, no fundo, tem um mercadinho que fica aberto até umas oito, então se a gente inventa de fazer um lanche diferente que a gente quer ratear, comprar um refrigerante, até dá tempo da gente comprar nele. Essa praça eu já tive uma proposta com os alunos da gente trabalhar nela, mas não foi pra frente não, porque é à noite, o pessoal chega cansado, teria que trabalhar durante o dia na praça pra plantar flores e tal, então eles não se animam. [...] Há uns três anos atrás tinha um senhor que cuidava também, que fica do lado desse mercadinho aí. Mas agora eu não tenho mais notícias não. Aqui à esquerda é a frente da escola e essa rua, indo reto, vai dar na passarela. [...] Aqui é a vista, [...] tem uma barraquinha ali que vende quentão a um real, na esquina, e pra esquerda fica aquela árvore bem bonita, que foi uma das primeiras [fotos] que eu tirei.

Eu queria trazer pra vocês esse clima. Aí é o churrasquinho que fica na esquina, churrasquinho de gato. Não dá nada, viu, gente? Pode comer que, ó, o meu estômago é fraco mas eu sobrevivo. É gostoso. Fica bem na frente da passarela. Aí a gente tá a umas duas quadras de distância da escola

Houve quem atentasse para o fato de que o ambiente não envolve apenas as construções e paisagens, mas também o elemento humano - aquele que ocupa, organiza e transforma esse espaço. Assim, incluíram alunos, ex-alunos e a dinâmica do bairro em seus relatos: 
-A primeira coisa que nós pensamos [em fotografar] foi o terminal porque na nossa escola [...] sempre vêm alunos de todos os lugares da redondeza. [...] E como nós encontramos as ex-alunas, elas queriam tirar fotografia. [...] Então elas fazem parte da nossa escola, mas já saíram. [...] Nós pensamos no caminho dos alunos que vão pra cidade e pros bairros. [...] Nós pensamos em termos assim: nós recebemos alunos de toda a redondeza. [...] A vida deles tá muito relacionada com tudo, acidente, quem morreu, [...] então é comum escutar morte, tem muito problema por causa das motos, eles usam muito moto, então a gente sempre tem algum acidente e todos os alunos passam a contar as histórias [sobre a avenida...]. Nós tiramos acho que duas fotos, tá. Essa aqui eu achei interessante, nós távamos tirando a foto e faz quinze dias que elas tavam reclamando comigo que não estavam conseguindo emprego, de empregada doméstica. Ela falou: [...] até pra empregada doméstica tá difícil. [...] Eu achei interessante, tirar a foto. Daí quando eu cheguei, vi que era minha aluna no EJA [vendendo frutas no sinal]. Ela falou: dona [...], pelo menos eu tô fazendo isso. Eu falei, eu vou tirar umas fotos [...] e depois eu vou revelar e vou dar pra ela. Então tem várias, ela tá desempregada, ela quer trabalhar como empregada doméstica, e ela falou que tá difícil conseguir. Então ela tá nessa economia informal. Aqui é um novo bairro da nossa região [...]. Então a maioria que vem desse bairro é de gente que comprou um terreno e tá construindo a casa. Então quê que acontece? A maioria tá voltando a estudar [...]. Nós temos vários alunos que vão a pé, eles não pegam ônibus, eles vão a pé até a nossa escola, então eles contam muita história da [avenida]. [...] Aqui é a parte onde passa ônibus, então é uma parte que os alunos sempre tiram sarro, brincam com a gente: como passa ônibus, é asfaltado, só a parte da passagem do ônibus que tá asfaltado, o restante não. [...] Aqui é um campinho que os meninos brincam muito, por isso que eu tirei, principalmente da tarde. [...] Aqui já é o Bosque [...] que fica [...] num espaço grande, só que a gente, por exemplo, lá tem muito problema de violência então é muito bonito, quadras, o pessoal faz educação física aqui, de manhã, os alunos de quinta a oitava fazem educação física aqui. Aí também é o bosque, a parte onde as crianças menores vêm brincar. Só que não tem muita segurança não. Aqui nós pegamos uma criança que tava brincando, aqui é uma parte que nós achamos bonita do bosque e essa árvore toda florida. Aqui é onde [...] os nossos alunos passam muito pra ir pra escola, mas as senhoras, os senhores, o pessoal faz muita caminhada aqui. Aqui é a parte onde tem a mina, quando cê tá explicando sobre a água, os alunos sempre se referem a esse local, por isso que nós tiramos. Aqui é onde eles fazem o trajeto, tem muita vezes pra cortar o caminho, eles fazem o trajeto pra ir pra casa ou pra ir para escola. E aqui nós pegamos um pouco a escola de fora. [...] Nós fomos tirar foto, [um aluno] se ofereceu pra acompanhar, ele não quis que nós fossemos sozinhas, o aluno, dois alunos da oitava série eles tavam vindo pra escola, daí eles falaram, não nós vamos acompanhar a senhora e as outras professoras porque não é tão seguro ficar com uma máquina... então eu fui com dois alunos. Ainda eu falei com os alunos, que eles tiveram outras sugestões. [...] Eles gostam muito, por exemplo, de uma praça que o Dr. Hélio [inaugurou]. [...] E eles adoram porque lá tem música, [...] é um lugar de passeio que eles fazem à noite, sexta, sábado, domingo, que eles ficam até a madrugada, então antes tinha música mas hoje não, hoje eles ficam mais brincando, namorando, é uma praça nova que foi inaugurada o ano passado. [...] Então as minhas ex-alunas que tinham nenê já elas tão reclamando, ah, não agüento mais, vou mudar. Mas parece que agora melhorou, tem venda de salgadinho, sorvete, milk shake, isso daí eles gostam [...] Daí eles falaram pra mim que tem uma parte lá do Valença que parece que nem é mais Campinas mesmo, de tão abandonada que tá. Então nós fizemos assim.

Aqui é uma sorveteria e pastelaria, atende ali aos alunos da escola, aliás é uma briga constante nossa, a criançada toda comprando bala, pirulito, chiclete ali, já na frente da escola. Aqui à direita o muro da escola, e essa é a avenida por onde a gente sai, é uma rua por onde eles entram e saem pra escola. 
Eu virei pro outro lado, aí tava passando esse aluno aqui assim e falou: filma nós aí. Eu fui tirar a foto dele, então. E ele fazendo pose, dando a mostra da máquina dele, eles se sentem o máximo assim andando de bicicleta pra cima e pra baixo no bairro.

Para os professores que se permitiram extrapolar as fronteiras da escola, a experiência revelou um outro olhar para o bairro, que não vê apenas violência e carência, mas enxerga ali também a beleza:

A gente sabe que dentro da realidade do aluno [...] sempre fala da questão da violência, mas se a gente tiver um olhar [...] mais apurado, a gente pode perceber certas cenas bucólicas mesmo, assim de um campo, de uma paz assim infinita, dentro do próprio ambiente escolar, se a gente buscar na realidade dele.

Aqui a escola fica numa esquina, então é um cruzamento eu tô na esquina da escola e o céu tava muito lindo, bom eu pego um horário assim que realmente é uma poesia, é um pôr-do-sol e as várias cores que tem. E tinha árvore, é bem bonito.

Eles puderam verificar, ainda, como é importante realizar esse exercício com os alunos, resgatando e valorizando sua identidade:

Aqui é um enquadramento de detalhe, é uma primavera bem assim na entrada do bosque. Também [...] mostra o enfoque mais pontual da região e o enfrentamento que a gente tem dentro do ambiente urbano. Mas você pode extrair imagens bem interessantes, imagens bonitas mesmo, do próprio ambiente escolar e das proximidades. Então, sempre que eu posso, eu levo [os alunos...] pra fazer visitas nessa região, pra buscar dentro do cotidiano deles o que eles vêm todo dia, mas com olhares diferentes, né. Então trabalhar esse olhar dele, trabalhar essa idéia que ele tem a respeito do meio, pra poder valorizar o aluno. Porque, infelizmente, quando a gente conversa com eles, ah, você mora no bairro tal, tipo assim, isso é pejorativo pra eles, é como se ele tivesse recebendo um xingamento. Mas se a gente mostra o outro lado pra ele, puxa, como pode ser bonito o lugar que você mora, né? Você valoriza o indivíduo, você valoriza o local, e finalmente você acaba melhorando a condição pessoal dele, por ele se sentir melhor dentro de um espaço como esse, né?

Eu percebo muito isso com os alunos que são ditos pichadores, quando eles fazem as marcas deles, as marcas tribais, praticamente, deles, no ambiente, o que na verdade eles tão querendo fazer é participar da imagem do local. Mesmo [...] que o local fique feio, mas a marca dele está exposta lá. Então, quando eles fixam a marca deles, seja num filme, seja numa foto ou uma pichação, ele se sente presente no ambiente, ele se sente um indivíduo. O fazer parte é se contextualizar no ambiente pra dizer que é importante. Eu senti isso: num indivíduo que a sociedade sempre acaba tratando como algo problemático, na verdade é um indivíduo anônimo, mas ele agora é um personagem que faz parte de um grupo de imagens que a gente pode até tratar na questão da beleza, né? Buscar no sorriso de uma criança a beleza plena, assim, tão bonita quanto as outras... 
Ao incluir os estudantes na dinâmica fotográfica, um professor pôde perceber como eles se sentem em relação ao espaço escolar e a maneira como elaboram a própria imagem e a projetam nesse cenário:

- Aqui eu procurei focar a questão do... eles falaram assim: a gente tá aqui no presídio. Eles tavam dentro da escola. Então o que eles sentem, né, quando eles tão dentro da escola é como se eles tivessem prisioneiros, né? Então, assim, a grade escolar como se fossem as barras de uma cela e eles se sentem lá dentro como se fossem os malvados. Então é uma imagem [...] que dentro do cotidiano deles é uma realidade. Eles dentro da escola como se estivessem dentro de uma prisão. E quando a gente leva eles pra dar uma volta pela escola eles se sentem livres, se sentem libertos, é um momento assim que eles estão presentes ali como os prisioneiros, né? E nessa hora eu extraí deles assim aquela coisa que eles gostam de mostrar: ah, eu sou um indivíduo significativo. Eu sou um indivíduo perigoso, olha como eu sou mau. É aquela coisa de se expressar a partir basicamente da violência mas dentro do contexto da realidade deles, é assim que eles vêm as pessoas que são mais perigosas, tipo o traficante: é mais perigoso que ele, então merece mais respeito do que eles. Então, às vezes, eles demandam um grau de importância na sociedade como uma questão de violência. Então a gente externaliza isso. Daí aqueles olhares lá dentro.

Uma colega observa:

- Mas [...] eu achei interessante a postura do segundo da direita pra esquerda, ele se posicionou, ele se adequou para olhar no meio do quadradinho ali [a tela de proteção da escola].

- E acabou enquadrando o olhar. O interessante pra eles é que o [...] o primeiro, de blusa preta, tá com livro na mão. É o que [...] mostra que ele pode tá numa atitude de mudança. Mesmo simpatizando como o pseudomarginal, [...] mas com o livro na mão. Ele é um livro de poesia, [...] que depois ele mostrou.

Os passeios fotográficos realizados foram o ponto de partida para aproximar as educadoras do entorno escolar. Não temos a ilusão de que tenham transformado radicalmente a visão de todas elas e, a partir daí, uma nova relação tenha se estabelecido com a comunidade. Seria uma visão ingênua e simplista. $\mathrm{O}$ que se pode afirmar, contudo, é que as diversas vivências propostas na Pedagogia da Imagem são um convite à abertura, uma oportunidade de observar a escola, a comunidade e a si mesmas com um olhar mais atento e sensível, capaz de perceber as contradições entre a realidade que pulsa fora das salas e aula e o mundo fechado dos estereótipos, das idéias inquestionadas a respeito de si e do outro, dos procedimentos burocráticos.

$\mathrm{Na}$ etapa seguinte, trabalhamos a linguagem do vídeo. Embora cada sujeito tivesse a liberdade de escolher a temática e a forma de abordagem, insistimos em sugerir que o assunto fosse pesquisado junto à comunidade e que o roteiro e a produção fossem desenvolvidos com a ativa participação dos estudantes. Os projetos que surgiram foram acompanhados de perto, por meio de visitas às escolas. Nessas ocasiões, pude realizar ensaios fotográficos que me auxiliaram a compreender melhor as relações escola x 
comunidade e a configuração do ambiente de trabalho das professoras. $\mathrm{O}$ resultado de minhas percepções é apresentado a seguir.

2.2 Escola, do entorno ao interno: duas visões contrastantes

Usando lentes variadas, um fotógrafo pode criar um efeito de proximidade ou distância em relação a um objeto. Pode também enquadrar uma paisagem ampla ou apenas um detalhe, dar nitidez aos contornos ou suavizar os traços. Assim também a minha aproximação às escolas revelou diferentes perspectivas sobre essas instituições.

EMEF Corrêa de Mello

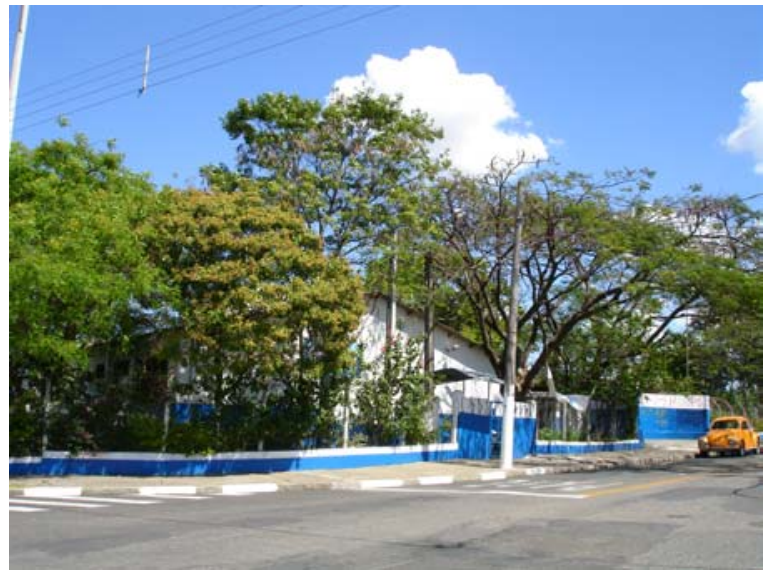

Vista da entrada principal

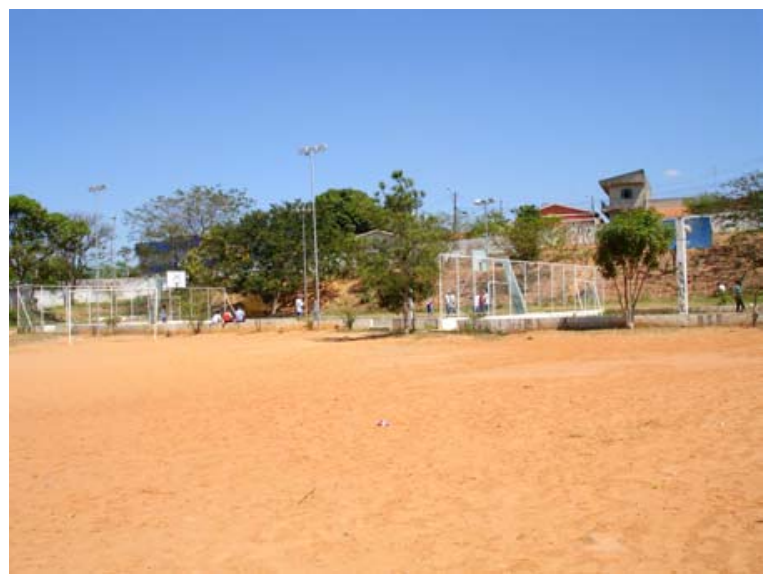

Quadras esportivas

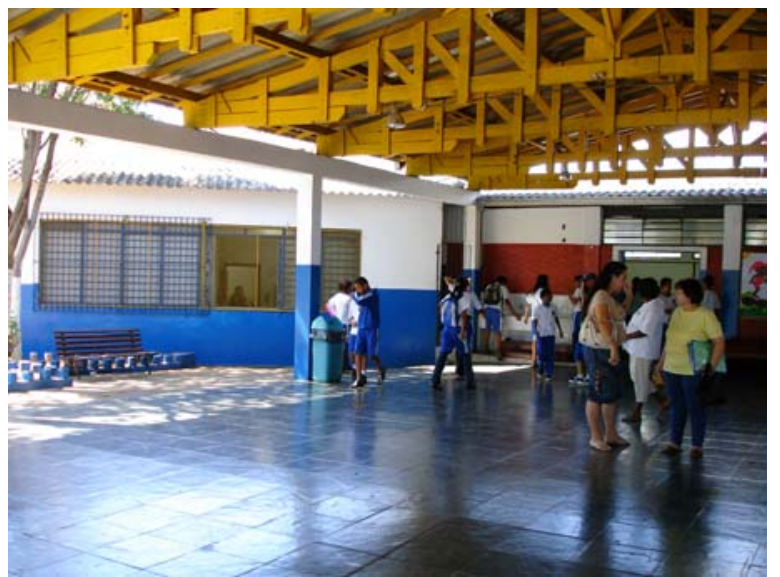

Pátio por onde entram os alunos

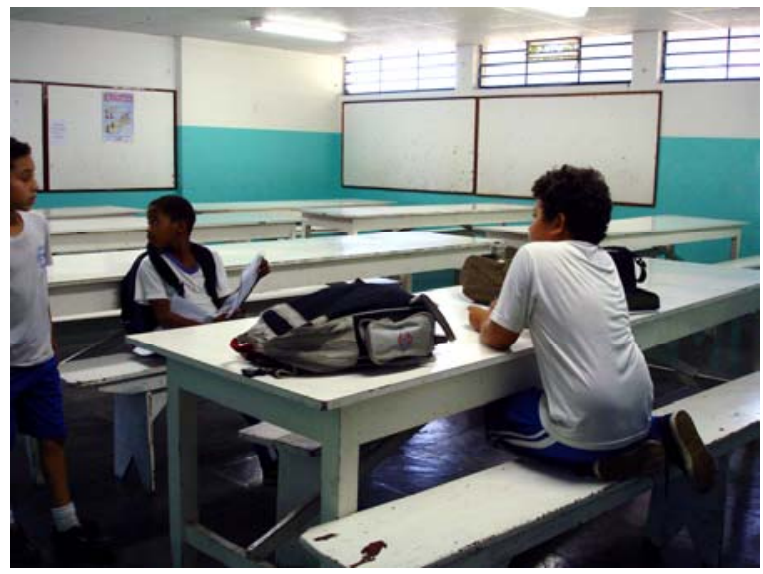

Refeitório 
Vistas de fora, a partir do Centro da cidade, é impossível não notá-las como um equipamento público encravado num bairro de periferia. Chego até elas por longas avenidas, que me conduzem a uma outra Campinas. Como se diz por aqui, há duas cidades em uma: a do centro e a que está além da Rodovia Anhangüera. É a essa outra urbe que me dirijo.

\section{EMEF Padre Leão Vallerie}

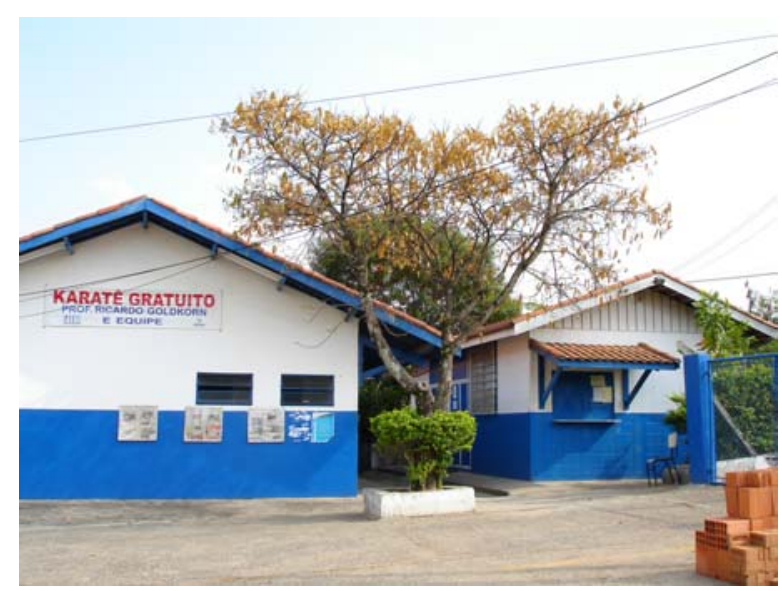

Vista da entrada principal

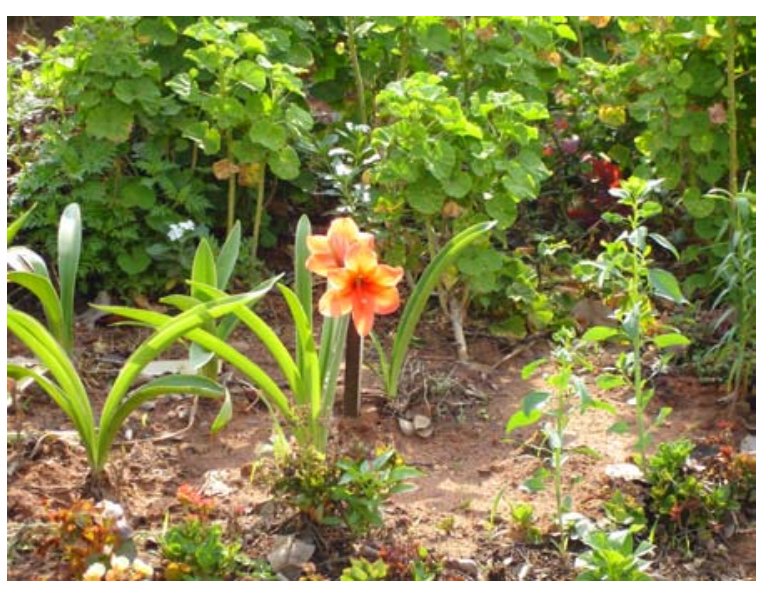

Pequeno jardim

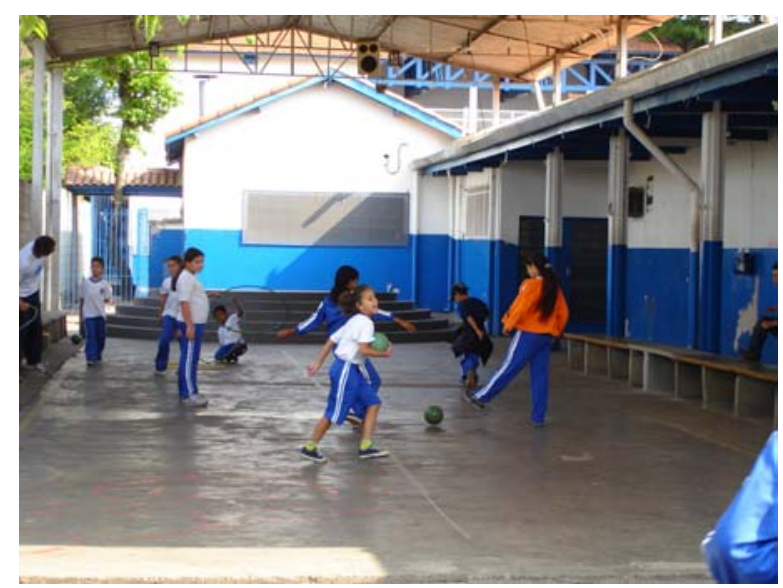

Pátio de recreação

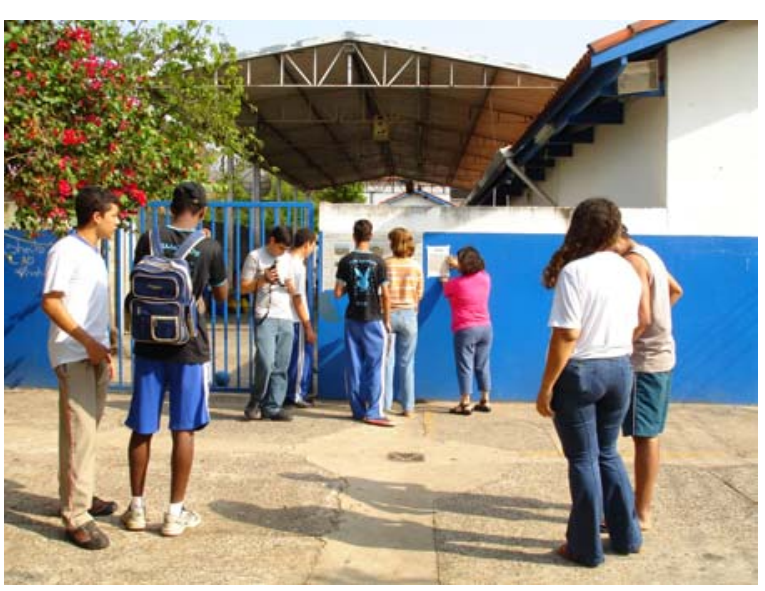

Alunos do Projeto Pedagogia da Imagem

Os caminhos vão me preparando para encontrá-la com um olhar estrangeiro. A ocupação do espaço é menos densa. Os prédios cedem lugar às casas. Primeiro, os sobradinhos. Mais adiante, as habitações térreas, algumas sem reboco, por fim, os barracos, muitas vezes, aglomerados ao longo dos rios. E muitos terrenos vazios. $\mathrm{O}$ trânsito pesado vai ficando para trás. As avenidas movimentadas deságuam em ruas tranqüilas, onde as motos e bicicletas quebram a monotonia. Posso ver as vicinais, ainda em terra batida, produzindo poeira ou barro, conforme a estação do ano. O comércio e os serviços também mudam de figura. As grandes empresas, com seus letreiros luminosos, coloridos e padronizados, agora estão distan- 
tes. Pontuando o trajeto, irrompem a fábrica de cerâmica, o hipermercado, a universidade, o prontosocorro. Até mesmo uma antiga fazenda, ainda produtiva, resiste ao passar do tempo. Quem domina a paisagem, no entanto, são as pequenas lojas de carros usados, oficinas mecânicas e depósitos de materiais de construção, nas vias de maior circulação. Nas vizinhanças das casas, a padaria, o açougue, o mercado, os bazares e o salão de beleza revelam os hábitos dos moradores. Instaladas em pequenos galpões, sob os mais variados nomes, proliferam igrejas, templos e assembléias. Sem dúvida, são bairrosdormitórios, sem muitas opções de trabalho para os próprios habitantes. Os grandes terminais de ônibus denunciam: esse é um lugar de passagens, mais que de encontros. Talvez porque aqui não existam muitas praças. Ou, talvez, porque essas regiões cresceram rápido demais nas últimas décadas, recebendo migrantes das mais variadas origens, e que ainda precisam redefinir a própria identidade.

\section{EMEF Edson Luís Lima Souto}

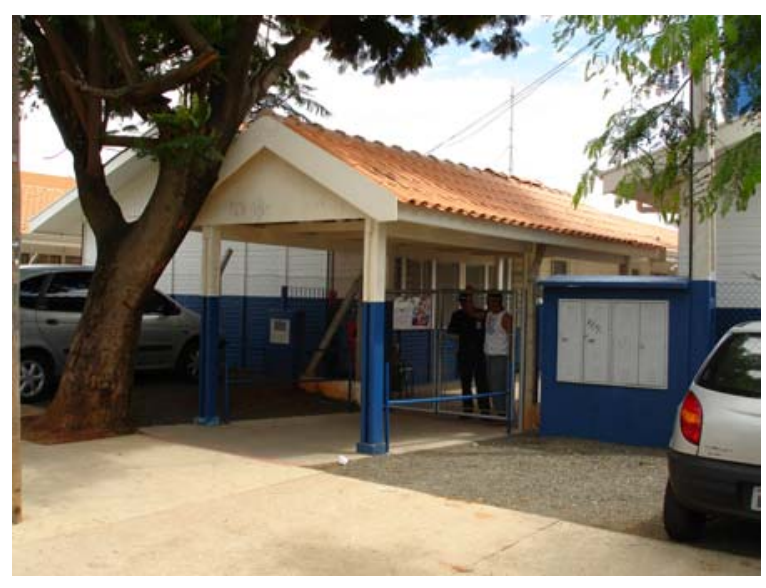

Vista da entrada principal

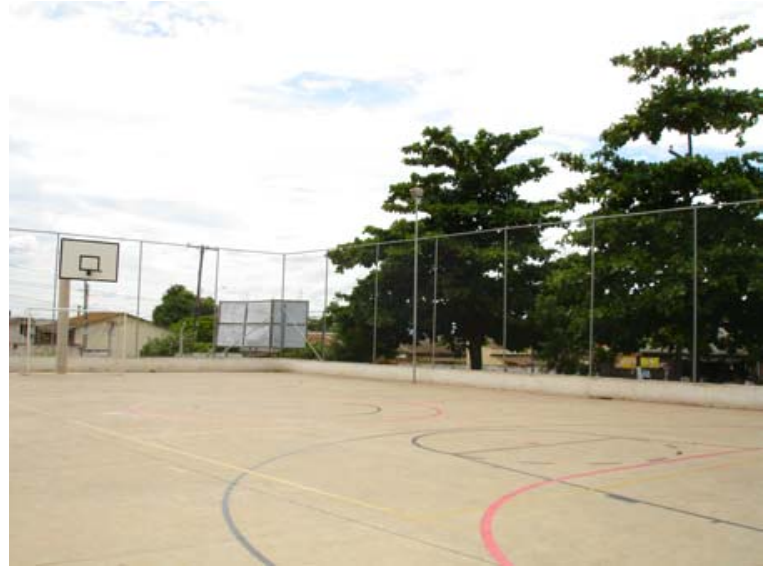

Quadra esportiva

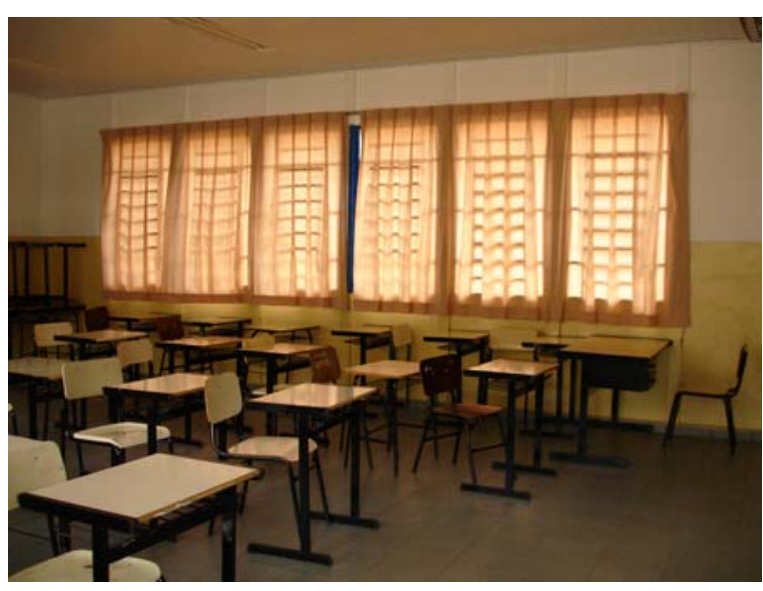

Sala de aula

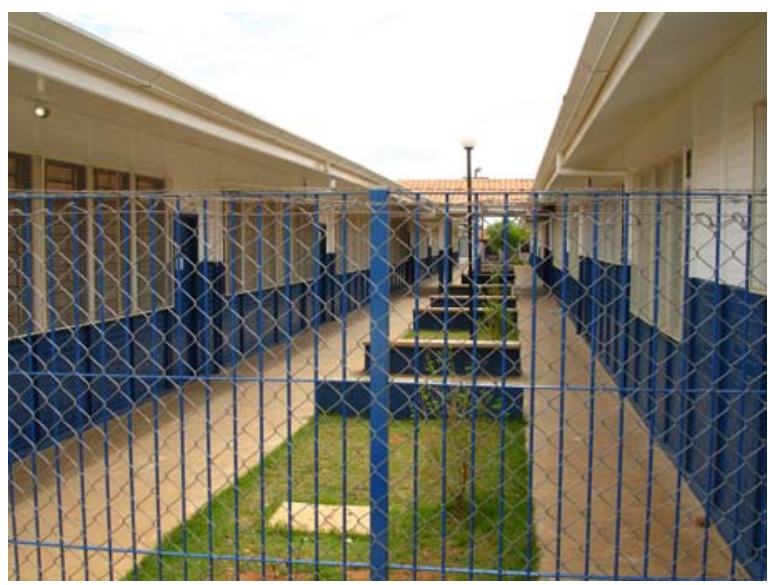

Corredor de salas de aula 
O processo de urbanização acelerada, pelo qual essa outra Campinas foi sendo erguida, pode ser lido nas grades das janelas, nos muros altos e ruas desertas, assim como no aparente caos da paisagem. Aqui, afirmar sua existência, projetar a própria imagem e fazer-se reconhecido é tarefa superlativa. Não por acaso a estética dominante é o grafite. Nas fachadas das lojas, escolas infantis e até mesmo igrejas, a arte feita com spray não apenas informa, mas, principalmente, ilustra a função de cada imóvel. Curiosamente, os grafites costumam ser respeitados. As pichações feitas por gangs predominam nos muros mal-cuidados, fachadas-padrão de empresas maiores e, para desespero das educadoras, as escolas.

\section{EMEI Recanto da Alegria}

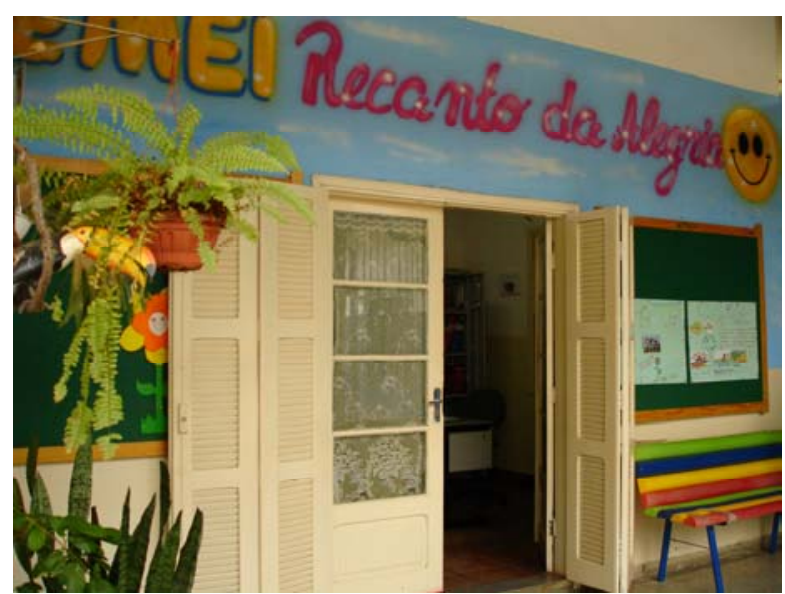

Vista da entrada principal

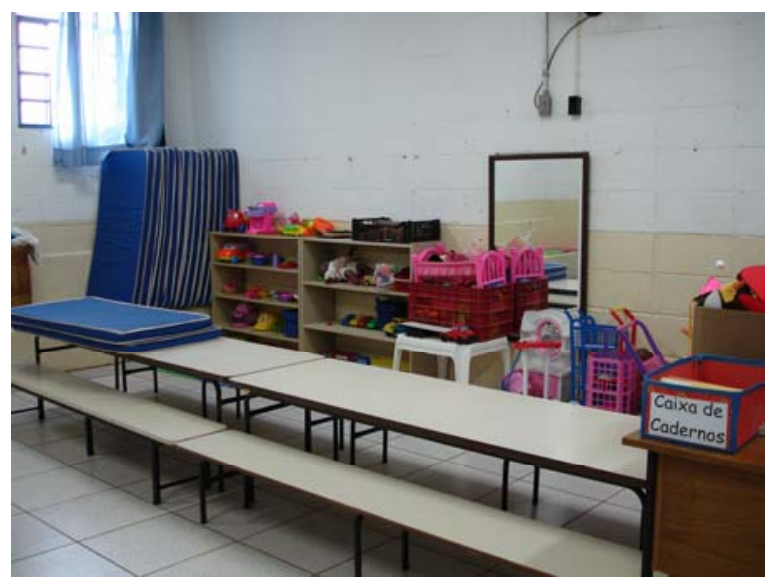

Sala de aula

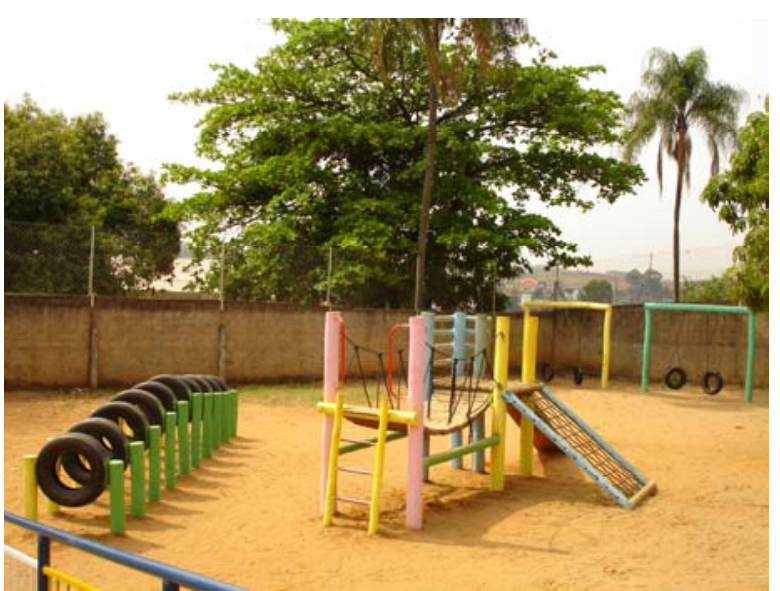

Parque de brincadeiras das crianças

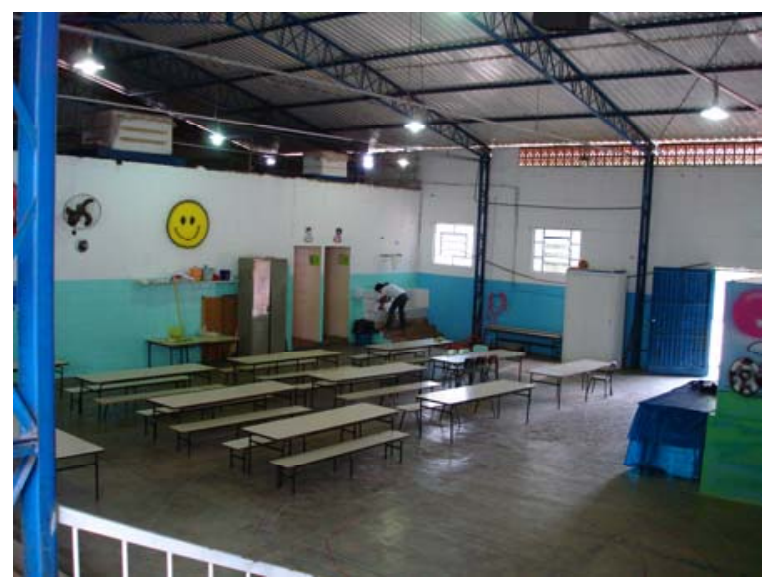

Refeitório

É fácil entender como elas se tornam um alvo. No cenário colorido e variado da periferia, a escola é um corpo estranho, pintado de azul e branco, padrão municipal. É como um espelho que não emite reflexo: a comunidade do entorno (e, desse ponto de vista, ela fica mesmo de fora) não vê sua imagem projetada 
naquele espaço. A fachada asséptica anuncia o que a escola é: um aparelho do Estado, instrumento de poder sobre a comunidade, para a comunidade, mas não da comunidade. Instituição que ainda vem para trazer a cultura e o saber àqueles que supostamente não os possuem. Cercada de muros e grades, vigiada por guardas e monitorada por câmeras, destinadas a proteger aquilo que é patrimônio público num único sentido: a sua estrutura física.

Mas, eis que transponho os portões e surge uma outra visão, que também a escola é. Vista por dentro, aquele corpo estranho se humaniza, preenchido pelos sorrisos das crianças e adolescentes. O que era entorno está interno e irremediavelmente o contagia. Tímidos jardins brotam entre os carros estacionados, lembrando que a vida pode resistir nos lugares menos prováveis. Na quadra, chão seco de terra fina e argilosa, sob o sol escaldante do meio-dia, as turmas fazem a aula de educação física. Pelos corredores, há sempre conversas e gritos. As paredes estão forradas de desenhos, poesias, cartazes. Ponto de encontro: o refeitório. No pequeno pátio, os alunos brincam no recreio. Em dias especiais, a escola se espreme ali para acompanhar apresentações musicais e outras solenidades. Daqui, de dentro e de perto, a arquitetura perde importância e a escola se transforma nas pessoas e suas relações. Enfocada com essa lente, ela revela seu verdadeiro patrimônio - aquele que ainda não está construído, pronto e acabado, mas que por isso mesmo pode ser lapidado: o elemento humano, em todo seu potencial.

No DVD em anexo, estão incluídas as demais fotografias feitas nas escolas.

\subsection{O elemento estrutural na formação: criando ecossistemas participativos}

Os limites colocados à Pedagogia da Imagem como proposta de formação continuada pelo elemento estrutural são muitos. Eles se originam, principalmente, da política educacional do município e das concepções que the servem de base. Podemos enumerá-los como a inadequação dos espaços físicos e obsolescência dos equipamentos, a forma de regulação dos tempos-espaços de trabalho docente, a restrição da formação em serviço e dos projetos com estudantes a uma perspectiva disciplinar e a acentuada as- 
simetria nas relações entre professores e especialistas, resultando num ambiente de trabalho que favorece a censura e punição das atitudes participativas, de cunho reivindicatório. Essa cadeia opressiva isola os educadores entre si e, ao mesmo tempo, os afasta da comunidade. Entretanto, a configuração do ecossistema educativo-comunicativo depende não apenas dos recursos disponíveis, mas da disposição de seus agentes. Assim, a Pedagogia da Imagem coloca-se como uma ação contra-hegemônica, que assume o compromisso de estimular os sujeitos a criar estratégias de enfrentamento dessas barreiras.

$\mathrm{Na}$ análise que aqui realizei, a aproximação escola-comunidade mostrou ser um ponto prioritário. Muito se fala dessa relação, mas até o momento ela parece mal compreendida e subestimada. Pensa-se e pratica-se essa aproximação, freqüentemente, como o envolvimento de pais e mães nas questões nãoresolvidas pelos educadores, nos dilemas enfrentados nas salas de aula: problemas de violência, disciplina e aprendizado. Outras vezes, a abordagem resvala para uma atitude etnocêntrica, que pretende levar, mostrar, proporcionar cultura e conhecimento a quem "não tem" e transforma as famílias em meros expectadores. É nessa condição que, normalmente, a comunidade entra na escola: com papéis definidos, script limitado. Assim, ela permanece apenas no entorno da escola, à margem das decisões que realmente importam, como cliente das soluções dos especialistas, alheia à definição e construção da educação de seus filhos, sem reconhecer-se culturalmente naquele espaço.

É necessário e possível ir além. Trazer a comunidade para escola como protagonista é também dirigir-se à comunidade e resgatar sua história, suas origens, seus valores e sua cultura. Essa população, ainda novata no território de Campinas, enfrenta e sofre as conseqüências danosas de um processo de urbanização acelerada e migração intensiva, ocorrido na segunda metade do século XX: o esfacelamento de suas identidades socioculturais e a falta de referências em seu novo lugar, aliados à violência simbólica da discriminação e da imposição de seu silêncio e invisibilidade na esfera pública. Tudo isso que invade o espaço escolar com os jovens, em forma de apatia, falta de perspectiva de futuro, conflitos e drogas. Não tem que ser sempre assim. Articular os sujeitos para promover seu reconhecimento pode ser uma resposta mais efetiva a esses problemas sociais que a repressão - até agora, uma estratégia mal-sucedida. 
Nossa proposta é, pois, que os agentes dispostos à mudança busquem transformar a escola num espaço aberto à discussão e reinvenção de identidades. Torná-la palco e cenário do intercâmbio entre diferentes manifestações da cultura popular, vindas da comunidade e não para ela. Resgatar as memórias e valores dessas populações (sem idealizar e romantizar o passado, numa perspectiva nostálgica que nega o presente e prega um retorno impossível ao que já ficou para trás), ao mesmo tempo em que se promove a apropriação das novas tecnologias e suas linguagens. Num diálogo com o devir, afirmar-se-ia a possibilidade de tecer outras identidades - dinâmicas, híbridas, plurais, éticas, emancipadoras. A produção de vídeos, blogs, jornais, animações e quaisquer produtos audiovisuais que tematizem a vida da comunidade é um exemplo de ação a ser promovida e que temos estimulado.

Parceiros nessa empreitada, os educadores também se formam e transformam nesse processo, aprendem com a comunidade, redefinem seu papel e sua identidade profissional.

\section{A dimensão coletiva da formação: o professor reflexivo e a busca de uma nova identidade profissional ${ }^{181}$}

Ao longo do curso Pedagogia da Imagem, promovemos muitas dinâmicas com exibição de filmes e discussão de textos, que visam a problematizar, junto às educadoras, o modo como vêem a sua profissão. A intenção é estimulá-las a enxergar sua prática cotidiana como o resultado de decisões tomadas conscientemente, a partir da atitude vigilante e crítica em relação às suas concepções, crenças e valores. Trata-se de promover a práxis reflexiva, que não somente envolve o posicionamento individual dos sujeitos em formação, mas alimenta uma dinâmica coletiva de negociação de sentidos em torno da sua identidade profissional.

\footnotetext{
181 Os dados referidos nesta seção foram coletados nos grupos de discussão realizados em 7 e 27 de novembro de 2006, 27 de novembro e 4 de dezembro de 2007 (no MIS) e 10 de dezembro de 2007 (na EMEF Edson Luís Lima Souto) e dos formulários de avaliação anual de 2006 e 2007, expedidos pelo Ceforma.
} 
Nas sessões que realizamos, sobressaiu a idéia de que, diante dos desafios colocados pela sociedade contemporânea, o educador necessita rever o seu papel:

Nós colocamos que a escola não terá condições de acompanhar o ritmo dos alunos, se continuarmos no mesmo ritmo que temos. A solução é recriar. Agora, como recriá-la... é que é o x da questão. Preparar para o mercado de trabalho, a gente viu o seguinte: [é] a função da escola? Nós trabalhamos, acho que todos, com o ensino fundamental, né? Então a pergunta que nós fizemos é a seguinte: a nossa função é preparar para o mercado de trabalho? [... Qual seria a função da escola, até legalmente? É preparar para o mercado de trabalho ou é discurso nosso? Se é preparar para o mercado de trabalho, o que a gente acha que é isso? [...] O quê que é bom pro aluno? Aquilo que nós achamos que é bom pro aluno ou aquilo que leva em consideração o aluno, vivências, experiências, trocas?

O problema proposto pela educadora remete ao compromisso ético com as novas gerações. A idéia de prepará-las para o amanhã, a partir do que hoje entendemos ser o melhor, envolve riscos e equívocos. Subentende uma concepção teleológica da realidade, pois traz no seu bojo uma noção de como o futuro deve ser, aonde todos devemos chegar. Entretanto, ela é como uma profecia que não se realiza, pois nossa visão histórica e nossa consciência ideológica são condicionadas e limitadas pelo presente. Isso significa que, necessariamente, tal preparação não conduzirá os jovens ao ponto onde julgávamos que deveriam estar. Essa educação falharia duplamente: por formar uma geração que se perceberia inadaptada ao seu tempo e por subtrair-lhe a confiança e o sentido de serem construtores da própria realidade. Preocupada com o futuro, ela deixa de lado o que realmente importa: as vivências, experiências e trocas no presente, que, afinal, é o único tempo histórico em que podemos agir.

O que deflagra esse questionamento das educadoras é sua constatação da falência do nosso modelo de sociedade. Um modo de vida marcado pela desumanização, pelo consumismo, pelas violências de todos os tipos, pela negação da vida. Uma realidade sobre a qual a educação também possui uma parcela de responsabilidade. Afinal, para que estamos educando?

- A sociedade hoje em dia [...] vai sempre valorizar aqueles que têm as coisas e não aqueles que são alguma coisa. Então é, vamos dizer assim, a sociedade do ter e não a sociedade do ser. E isso faz com que a gente tenha então um enfrentamento: quanto menos você tem, menos você é valorizado e chega no ponto de que isso gera violência. Então a maior, a veia principal da violência é na verdade a diferença social, essa má distribuição de renda, essa péssima distribuição de renda que a gente tem como exemplo no nosso país, é o que vai gerar a maior parte das violências. [...] 
- Violência não é só com traficantes. Violência é muito mais que apontar uma arma. Violento é quem tira o direito de vida do outro. Violento é quem tira a dignidade do outro. Pelo menos eu vejo dessa maneira o que é violência. Violência é quem tolhe a minha palavra. Quem tolhe o meu pensamento. Quem tira minha qualidade de vida. Quem me tira o direito do emprego. Isso é violência. Quem restringe o acesso à educação e ao saber. [...] Não é uma sociedade que gera a violência, que gera o desemprego, que gera a exclusão, que gera o lucro? Quem precisa de princípios morais? [...] A quem serve o desenvolvimento tecnológico e econômico? Quem tem acesso a bens? É a mídia que impõe o consumismo ou somos nós que somos educados e educamos para o consumismo? De quem é a culpa? É da mídia? Pra quê nós educamos? Como nós vamos ser educados? [...] E nós fazemos o quê? E nós estamos educando pra quê? Talvez esteja aí, oprimidos e opressores, quem são os verdadeiros culpados. Quem tá traindo os seus pares aqui? Sei nem se é traição, uma palavra muito forte, né? Mas quem é que está fazendo o jogo da mídia? É a própria mídia ou talvez nós como educadores? [...] A pergunta do nosso grupo é essa. É: pra quê que nós estamos educando? A nossa pergunta não é culpar a mídia, é o que nós estamos fazendo com isso que a mídia faz, com o que a sociedade faz.

- Nós estamos sendo coniventes, né?

Outro elemento relevante que motiva a redefinição da profissão docente são as novas demandas que as crianças e adolescentes trazem para a sala de aula. Uma geração que lida com desenvoltura com tecnologias e linguagens que não fizeram parte da infância nem da formação profissional das educadoras. Uma geração ativa, que tem acesso a um volume de informações capaz de por em xeque o conhecimento enciclopédico do qual os professores se julgavam os portadores e transmissores. Desafios que os impelem à condição de permanente instabilidade e à necessidade de se dedicarem à formação em serviço:

- As crianças são hoje são outras crianças. Eu, por exemplo, ficava quieta na minha sala, eu não dava um palpite. Hoje tudo é dividido, a gente trabalha em grupo, as crianças dão opinião, põe na lousa várias opiniões, eles têm direito a escolher, bom, a gente tem tentado trabalhar assim, né? Desde que eu cheguei nessa escola e na outra que eu trabalhava, era assim.

- Nossos alunos nasceram, né, na era digital, diferente de nós, que na época de faculdade a gente não tinha acesso, imagina que teria aula de tecnologia. Imagina! Quando nós estávamos nos formando professoras, eu já nem digo na nossa infância. Digo enquanto formação. Agora as nossas crianças elas já nascem, né, tem mães, mesmo aqui, das classes menos favorecidas, que já têm foto da criança da ecografia 4D. Agora não é mais nem três [dimensões]. E tira foto da criança e põe no porta-retrato, da criança com três meses [de gestação], com quatro meses, com oito meses, com nove meses. Então a criança antes de nascer ela já tá nessa era digital. Então cabe a nós, aí sim, que o professor, essa coisa, é uma profissão que eu tenho um amigo, [...] ele falava: quando o professor morre, na hora de fechar o caixão tem que falar, espera, espera, espera, eu vou virar mais uma página pra eu ir lendo. Então a gente tem que morrer lendo, estudando, se aperfeiçoando. E essa questão da tecnologia, mesmo que ah, eu não gosto, ai, eu não me dou, a gente tem, sim, que ir atrás, nem que for devagarzinho, passo a passo. Eu acho lindo assim, a Graça, a Sônia, que já estão sempre falando em aposentadoria, mas tão sempre atrás, procurando superar, não é nem limite, é uma formação que elas e nós não tivemos. A gente tem que tá sempre atrás. Sempre atrás. Porque as nossas crianças $[. .$.$] nasceram nessa era, nesse mundo, e a gente precisa es-$ tar, né... plugado mesmo. 
Percebe-se, ainda, uma polêmica em torno da credibilidade da educação pública. A sociedade, de maneira geral, tem demonstrado pouca confiança nos educadores e critica a qualidade da formação proporcionada às novas gerações. Trata-se de um debate complexo, que envolve interesses de múltiplos segmentos, e não deveria ser reduzido à comparação entre os sistemas público e privado e à elaboração de rankings ou estatísticas de aprovação. De qualquer maneira, uma vez estabelecido, ele obriga os educadores a se pronunciarem, oferecendo sua resposta às demandas sociais. Esse movimento de discussão da identidade e das ideologias profissionais não é, contudo, uma exigência inédita para os educadores e tem suas raízes históricas na sucessão de políticas educacionais. A professora Luciane, da EMEF Edson Souto, procurou contextualizar dois momentos recentes, onde os seus parâmetros de atuação foram jogados por terra, forçando a redefinição de seu papel desde os fundamentos. Para ela, o questionamento atual não é tão radical e encontra os professores mais seguros a respeito de sua capacidade de enfrentá-lo e legitimar suas decisões junto aos pares e à comunidade escolar. Essa maior desenvoltura está relacionada à formação continuada de cunho reflexivo. A partir de sua profissionalização, o professor deixa de ser refém de modismos impostos por especialistas e integra seus saberes e sua experiência à tarefa de crítica e transformação da própria prática.

- Pra nós, nos últimos 25 anos, mais ou menos, tem dois divisores de água aí que poderiam explicar um pouquinho essa cobrança dos pais [... sobre o professor]. Um divisor de água começa na década de $80 \mathrm{e}$ o outro na década de 90 . E os dois tão ligados à questão política da educação. Da década de 80 , foi a febre, quem deu aula naquela época, a febre do construtivismo. O que até então era tudo ali, né, tinha que ser a cartilha $\mathrm{O}$ caminho suave, a letra de mão, é isso, é aquilo, é aquilo, de repente o professor não sabe mais nada, joga tudo na lata do lixo o que vocês, como vocês aprenderam, a formação de vocês, e como vocês ensinam, tá tudo errado. Joga tudo fora. Porque agora o certo é fazer da forma - que eles não admitem falar método, né - a forma construtivista. Então é a criança descobrindo, é a criança aprendendo através do erro, só que como sempre, principalmente no Brasil, a formação do professor foi muito rasa pra essa mudança. Só o que o professor sabia, tá tudo errado. E agora, o que fazer? Ah, o que fazer? Você vai estudar. Só que: e pra o professor ter essa formação? Daí foi tudo: deixa o aluno pra não traumatizar o aluno. Deixa o aluno errar, o aluno vai aprender por ele mesmo. E traz caixinha de sabão em pó, e traz revista, e traz selo, e traz não sei o quê, e a classe lotada, aquela poluição visual. E o professor que se recusasse era antiquado, era tradicional, era resistente. Então, aí foi um primeiro ponto dessa mudança aí da nossa cobrança, da nossa exigência anterior, era uma coisa antiquada. Isso foi a década de 80 inteirinha aqui no Brasil. Quando chegou a década de 90, o quê que aconteceu? A bendita progressão continuada. Que apesar de ser no estado uma marca forte, refletiu muito aqui pra gente porque a gente até hoje recebe muitos alunos, [...] não sendo preconceituosa, mas porque eu dei aula no estado muito tempo, mas é aquela coisa da não repetência. Então juntava o construtivismo, que foi a primeira febre, com a febre da progressão que não existe mais repetência, o professor, o aluno e os pais ficaram sem norte, a gente ficou totalmente assim, perdido mesmo. Não pode falar que tá errado, o aluno não repete, o aluno não tem 
aquela obrigação da escola, do estudar, do fazer, não que a repetência e a prova prove alguma coisa, eu sou contra prova, em qualquer série, mas assim, o aluno não tinha mais aquela forma que o Luís Carlos Freitas até coloca, foi tirado um dos únicos mecanismos que o professor tinha pra estar fazendo com que o aluno desse o melhor de si. A partir da progressão continuada, se aprendeu, se não aprendeu, no final do ano vai passar mesmo. Então, essas duas políticas educacionais aí refletiram muito no dia-a-dia do professor, do aluno e do pai e nós ficamos sem esse norte. Agora, depois que viu que não é nem tanto ao céu nem tanto ao inferno, nem construtivismo nem tradicional, nem progressão continuada nem repetência em exagero, a gente tá começando, eu acho agora nos últimos 5,6 anos, a gente tá começando assim, se sentir novamente mais seguro, se sentir mais firme, se quer trabalhar hoje, com ba-be-bi-bo-bu, a gente pode tomar por exemplo o Paulo Freire e falar: por que não? A nossa língua, a língua portuguesa, eu fiz o curso da Elvira em 2002, quando a Corinta trouxe a Elvira, maravilhosa, que trabalhou com a alfabetização com a gente, ela coloca, nossa língua é uma língua silábica. Por que ter vergonha de falar que trabalha com a sílaba? Só que a gente não precisa trabalhar, como Paulo Freire critica, o Ivo viu a uva. Daí o a-e-i-o-u, va-ve-vi-vo-vu, só. A gente pode trabalhar o ba-be-bi-bo-bu mas a partir do quê? Que o Paulo Freire chama das palavras geradoras, que tenham, quando eu cheguei que cês tavam falando do contexto da criança e da realidade, que tenha a ver com a realidade da criança, com o contexto que a gente vive ou com um tema que tá estudando na aula, a partir do tema. Agora a gente vai estudar por exemplo, o projeto lá, amigos do mar. A gente vai trabalhar muito com água. Por quê que a gente não pode trabalhar o ga-go-gu, ge, gi, gua, guo, gue, gui? A gente pode trabalhar sílaba sim, só que dentro de um contexto. E não a sílaba solta, a letra solta. Dentro de um contexto. Então o Paulo Freire coloca isso, né, que todo texto tem um contexto. Então água pode ser um texto dentro do contexto que a gente tá estudando. Então se a gente levar em consideração isso o pai pode vir cobrar letra cursiva, o pai pode vir cobrar um monte de texto porque a gente vai ter argumento, a gente vai ter embasamento, fundamentação pra falar, pai, olha, eu tô trabalhando isso, isso, isso, isso, se você quiser acompanhar a gente pode marcar um horário, a gente tem argumento. Diferente na década de 80 e 90 que a gente ficou assim meio sem chão. Tiraram nosso chão. Então acho que essas duas coisas pode explicar um pouquinho ainda essa cobrança e insegurança de muitos pais, não só de alguns. De muitos pais, que eles ficam naquele medo, ah meu filho vai passar de ano sem aprender ler escrever, meu filho não tem caderno suficiente, lição suficiente mas é por conta dessa insegurança dos últimos 20 anos. E daí cabe à gente ter essa segurança pra colocar pros pais. Um profissionalismo que a gente sabe o que tá fazendo, se ele quiser participar e se inteirar, vem pra conversar com a gente. Mas a gente não tá deixando nem tudo solto, né, pro aluno fazer o que quiser, só que a criança tem o seu tempo.

- Então, nessa sua passagem sobre como o método, as políticas públicas vão interferir no processo pedagógico, nós vamos ver ali o filme sobre o movimento dos professores no México. Não sei se vocês conhecem e tem uma coisa que você não citou, mas eu acho que tá por trás da progressão continuada, que é a universalização da educação a partir da Constituição de 1988. A obrigação do estado de assumir, de abrigar todo o universo das crianças em idade escolar. Quer dizer, a resposta hipócrita do estado foi: bom, a gente pega mas quê que a gente faz com eles? Oh, passa! Passa, passa!

- É que isso calha com a discussão enorme da questão do acesso e a queda da qualidade. Hoje qualidade é uma palavra muito batida, carne de vaca, né, como se diz no português popular. Então aí é uma discussão bem grande da questão do acesso, da permanência e como esse aluno sai. Então hoje nós estamos um pouquinho melhores no ranking da escolarização. Só que qual é a qualidade real dessa escolarização? Daí é uma discussão bem profunda, ardente assim.

O resgate das idéias de Paulo Freire é um movimento essencial nessa discussão, uma referência na busca de novos sentidos para a profissão docente: 
Quanto ao Paulo Freire, nós vimos que nós nunca precisamos tanto de Paulo Freire! Nós nunca precisamos tanto de valorizar aluno, as vivências, valorizar os educadores, as trocas, os diálogos, e nunca foi tão essencial, não só olhar pro outro, né, às vezes a gente olha pro outro e nem... passa, né? O reconhecer o outro. Que a gente reconhece aquilo que a gente conhece. Se a gente não conhece, a gente não reconhece. Se a gente não reconhece, a gente não tem condições de trabalhar em parceria, em crescimento juntos, eu reconheço a realidade do outro, o outro reconhece a minha realidade. Então nós achamos que realmente o Paulo Freire, atualmente, ele é essencial.

Assumir a parcela de responsabilidade sobre o presente e encarar o desafio de buscar uma concepção transformadora do próprio fazer exige que se abandone o comportamento ingênuo e que cada decisão seja tomada atentamente, segundo o crivo ético. Para as educadoras, já não é possível se manterem iludidas ao próprio respeito e fechar os olhos para o mundo ao redor. Em vez de culpar a sociedade ou as políticas educacionais, e simplesmente abdicarem da luta, é preciso que cada um desempenhe seu papel de sujeito histórico.

Não há nada mais triste do que uma pessoa iludida a seu próprio respeito. E às vezes a gente entra nessa de achar que não, mas tá fazendo tudo igual a todo mundo. A gente tem que se colocar, a gente se identifica. [...] A gente se identificou com o momento que a gente tá vivendo, o momento da greve. [...] Eu acho que a gente só pode falar do lugar que a gente está. $\mathrm{E}$ acho que o movimento que a gente tem que fazer é de quebrar essa ilusão e tomar consciência, como você diz, né, que lugar que eu ocupo? A gente fica falando da sociedade, mas e eu? Então [é preciso] a gente se colocar, que afinal de contas a gente fica pensando essa coisa do papel do professor. Qual que é o nosso papel? Que script a gente vai ter? Já vem um roteiro pronto pra ser professor ou a gente que escreve o roteiro, como é que é que a coisa se dá? Então eu fico pensando se eu tô vivendo um momento triste da minha vida, que é estar iludida a meu próprio respeito, como professora, como pessoa, como mãe, então eu levanto essa questão.

Para algumas pessoas, essa tomada de consciência se manifesta como desilusão. Tendo aceitado sua responsabilidade e se proposto à mudança, deixaram-se prender na armadilha de acreditar que bastaria a transformação individual. Ao deparar com os limites estruturais, desarticuladas de um grupo, viram-se sobrecarregadas, esgotando suas forças. Com isso, perderam a visão do todo e sobreveio o sentimento de que as cobranças são injustas.

Quando eu li aquele texto a primeira vez [Pedagogia do Oprimido], eu achei maravilhoso. Agora eu já acho que tão judiando demais da gente. Porque eu já tô com trinta anos [de profissão], já fiz tanta coisa assim, pra tentar mudar e pra resolver que eu acho que aquilo lá me deprime. $\mathrm{Na}$ minha opinião. [ri]. Eu fico deprimida quando eu leio... Ah, eu acho que, bom, na minha prática, eu mudei um pouco. 
Assumir uma posição nesse debate, portanto, não deve ser um ato individualista, mas coletivo, articulado em rede. $\mathrm{O}$ devir se tece e tira sua força da delicada trama que une os agentes em torno de um projeto histórico.

Eu lembrei de um poema do João Cabral de Melo Neto, que é dos galos, né, que aqui diz o seguinte: ninguém consegue mudar nada sozinho. No poema do João Cabral, é um único galo que canta, um único galo que canta. À medida que ele canta, o outro vem e pega e canta, o outro vem e pega, o outro vem e pega e cada um canta e a madrugada é toda o cantar de galos. E se faz a luz, se tece a madrugada com os fios do cantar dos galos. Pra mim é o mais belo poema sobre a importância de uma única idéia que gera o coletivo, a mudança, que gera a transformação, que no poema do João Cabral a luz se faz com um pegando o cantar do outro. Então a gente não muda nada sozinho, não. Mas quando a gente lança e o outro pega, e o outro pega, e o outro pega, a gente tece a madrugada. A gente tece o advir. Então como diz Paulo Freire, é tecer o advir, tecer seres humanos, tecer seres que olham um para o outro sem pensar em lucro, sem pensar em levar vantagem, mas em construir o outro como ser humano. É isso.

Que papel cabe à formação continuada nesse processo? Não é o de fornecer ou impor a definição dessas identidades, mas de criar um ecossistema aberto para essas formulações. Sua primeira tarefa é aproximar e articular os educadores - algo apenas aparentemente banal, uma vez que envolve a disposição para o trabalho coletivo, a solidariedade com o outro e a valorização da participação ativa no ambiente escolar. Tais características as professoras têm reconhecido na experiência da Pedagogia da Imagem:

Eu acho que houve uma interação nossa, eu acho que a gente conversava até mais, a gente ficava muito distante uma das outras, na minha opinião isso até nos aproximou, tá, da gente ter que conversar, de um ajudar o outro, foi uma coisa muito legal, [...] Então a gente capturar tudo isso que a gente tem na escola e que a gente não dava valor, tava ali e a gente não acessava tudo isso. Então eu acho que foi um resgate muito bom, e eu acho que de tudo, com falhas, erros, e acertos, o aprendizado de todas nós foi excelente.

Eu esqueci de falar mas foi uma coisa que aconteceu, no nosso grupo, [é] a questão da gente tá assim não sei, a questão não é de estar [...] usando [os recursos]. Talvez eu trabalhando aqui na escola, ah, vamos pegar... Ah, mas isso é realmente um momento que a gente se encontrava, trocava idéias e foi muito bom esse momento da integração.

À medida que essa integração acontece, os sujeitos e suas ações conquistam visibilidade no ecossistema escolar e os conhecimentos produzidos na formação são socializados, favorecendo o desenvolvimento e a legitimação de projetos interdisciplinares e ampliando o poder de barganha dos sujeitos na melhoria da infra-estrutura da escola. Os depoimentos das professoras no processo de avaliação da Pedagogia da Imagem, conduzido pelo Ceforma, ilustram esse processo: 
Os professores, orientadores e diretores, bem como alunos, passaram a desenvolver um novo olhar sobre a produção midiática como forma de expressão.

Foi adquirido novo equipamento para viabilizar o acesso e desenvolvimento de uma metodologia de registro do cotidiano escolar, que trouxe grande visibilidade do processo pedagógico que envolve alunos e professores.

Foram realizados, ou melhor, estão sendo realizados projetos junto aos alunos.

O grupo discutiu alguns pontos sugeridos pelos integrantes do curso, além de ter sido fundamental para a compra de um computador com o qual se pretende trabalhar com as crianças, servir como ilha de edição...

Durante a elaboração do trabalho de fotos, os alunos foram envolvidos, os professores e funcionários.

Houve muita discussão, no uso do computador gerou polêmica, dúvidas e impulsionou desafios e abriu horizontes.

Finalmente o tema mídia e educação foi assimilado por todos a ponto de toda a escola mobilizar-se no sentido de produzir registros para uma documentação pedagógica que amplie a memória da escola.

O material utilizado no curso foi socializado na escola, de acordo com as necessidades dos prof. Por exemplo: tem um grupo produzindo um vídeo sobre Darwin e a teoria da evolução. As discussões sobre roteiro que tivemos no curso eu passei para o grupo.

O curso está dando encaminhamento a um projeto que desenvolvo com minha turma.

Além disso, a socialização favorece a reflexividade docente, e os registros audiovisuais tornam-se instrumentos de observação e avaliação da prática pedagógica.

Projeto Meio Ambiente, projeto Mutirão Leão Legal e Ciência na Escola passaram a ser registrados como fonte de material pedagógico e encarados como instrumentos de pesquisa.

No Projeto Meio Ambiente utilizamos recursos aprendidos no GT (filmagem, fotos artísticas, enfoque profissional).

As discussões, principalmente em relação ao projeto memória da escola e os usos do computador, foram muito produtivas.

A avaliação do PP [passou a] ser feita com imagens do cotidiano da escola e não somente com palavras.

Projeto Memória, houve encontro dos especialistas do Projeto Imagem em nossa escola [...], que fez com que todos os outros professores começassem a ter interesse em documentar suas atividades e incrementar suas atividades pedagógicas com o uso do computador. Conseguimos a compra de um computador novo e com recursos. 
Esses percursos reflexivos necessitam ser mapeados e registrados, para que o grupo possa perceber o seu crescimento e construir sua memória profissional, sem a qual a identidade não pode ser definida. A sistematização das experiências e conhecimentos produzidos constitui, portanto, uma segunda tarefa da formação continuada. As falas das professoras, proferidas na sessão de encerramento da Pedagogia da Imagem, em 2006, demonstram as várias possibilidades de uso dos registros: instrumento de planejamento e reflexão sobre a prática, visibilidade do trabalho cotidiano e dos sujeitos da educação, avaliação das interações com as crianças, memória individual e coletiva, estímulo ao protagonismo de alunos e professores.

Acho que a gente consegue ter uma reflexão maior sobre a prática em sala de aula, né, uma melhor visão do todo, do grupo, e maior clareza para o planejamento...

Maior adesão do grupo, há um interesse muito grande por parte das crianças, (...) maior participação, possibilita a auto-análise, permite aos participantes se verem como atores do processo.

Como o recurso audiovisual pode ajudar você no processo de sistematização? Enriquece a troca de experiências, possibilita a criação de novas idéias, ampliando a aquisição e a transmissão de significados.

No dia-a-dia, o trabalho quase que fica invisível. [...] Aquele registro pessoal que fica no meu caderno eu converso com a OP. Ele serve pra isso. Dependendo, pode servir até pra uma conversa com mãe de aluno. [...] Mas muitas vezes infelizmente também morre ali com a gente. $\mathrm{Ou}$, dependendo, ele pode servir também, dependendo da qualidade do registro, serve: bom, no ano que vem, o que não vai acontecer? Então a gente já... o que não deu certo, o que foi frustrante demais, a gente já deixa registrado também, assim, pode funcionar e pode não. Então eu acho que o registro sempre faz com que a gente cresça um pouco mais, né, pensar a questão da sala de aula, né. O duro é a gente ter o hábito de registrar também, né, eu tenho 25 anos de magistério agora que eu consigo fazer um pouquinho de registro. Eu sempre, a gente é mais jovem, pensa que guarda tudo de memória. Então algumas coisas boas, muito boas que já aconteceram, se eu não vejo alguma coisa que eu registrei, eu nem lembro mais que eu realizei aquilo. Parece que foi outra pessoa.

Acho que a gente não tem o hábito de valorizar o registro enquanto documento da escola, enquanto memória. Realmente importante. Infelizmente [não valorizamos esse aspecto].

Eu tô com 32 alunos na sala, se tiver alguma coisa importante ou um comentário importante do aluno, eu não posso anotar na hora. E depois eu não vou lembrar do jeito que é. Cê entendeu, então quer dizer, é importante [realizar um registro].

O registro e a visibilidade do projeto em audiovisual abrem caminho para sua legitimação junto à comunidade escolar. Um primeiro sinal de consolidação da Pedagogia da Imagem é o estreitamento do 
relacionamento com as famílias e o incremento de sua participação, percebidos pelas educadoras como um saldo positivo de seu investimento na formação:

Eu acho que aumenta até a freqüência dos pais, na assembléia de pais. Porque aquelas reuniões que normalmente são só comentadas, ou só, verbalizadas, ou mesmo pra comentar o pedagógico ou pra falar sobre o trabalho, eles acham cansativo, eles começam a olhar no relógio, sabe? Então eu acho que quando você apresenta algo que seja mesmo visual, chama muito mais a atenção e a freqüência acaba ficando maior mesmo. Porque aí entendem...

E você acaba introduzindo algumas palavras pra comunidade, às vezes você fala, estudo do meio, cê fala passeio, ah, passeio! Passeio é passeio. Passeio não é igual a estudo do meio. Mas se você vai apresentar fotos, ou um vídeo, vai mostrando as fotos e fala estudo do meio, vai criando a noção. Estudo do meio e passeio. E aí eles quando você falar estudo do meio eles já têm noção, né?

Eu também queria falar em relação com a comunidade. Eu sempre trabalho numa comunidade onde tem uma baixa auto-estima né, e quando e a escola e a comunidade se vê, ela tem uma coisa assim, como uma atenção. Você vê a filmagem do seu filho lá, brincando, fazendo aquele filme, você vê o resultado da produção final fotografado, você joga no data-show, aumenta a auto-estima dela, você acaba criando o vínculo com o bairro, levando isso à comunidade escolar. É: a escola é boa, então, por conseguinte, né, a comunidade também faz parte dessa escola, então eu acho importante o registro audiovisual pra autoestima do aluno, da comunidade, de uma forma muito positiva.

Ela se vê nisso. Então a comunidade, os alunos, se vêem bonitos, aí cria esse vínculo, essa integração da escola com os pais, do ponto de vista, não somente, que às vezes eles acham só que a gente passa tanto pro aluno, como obrigatório, que ele tem que ir, e a beleza, né, eu entendo a escola, quando o aluno vê a escola aberta, ele se vê nela também e ele vê a escola como uma coisa agradável, uma coisa positiva.

Eu acho que, se tem um registro, o que você consegue fazer pra mostrar, acaba por enriquecer o que você tá dizendo. [...] A gente pode demonstrar, em vez só de falar, a gente tem escrito, gravado, fotografado.

Eu acho que com a apresentação de um trabalho, que foi um projeto, que foi desenvolvido, que foi registrado, que foi... exibido e apresentado, né, pra comunidade, eu acho que tem um apoio muito grande principalmente no conselho de escola, onde a gente pede, né, olha nós vamos precisar disso daqui, memória de computador, peça, não sei, programa. Aí cê fala, vai ter custo x pra melhorar a memória dos computadores, porque vai fazer isso, aquilo foi feito assim [...]. Eu acredito assim, que em todas as reuniões com a comunidade, o apelo visual é essencial. Tudo que você mostra visualmente você consegue muito mais. Junto com a comunidade, na conversa, às vezes a gente não consegue. Porque a gente usa termos, que, pedagógicos, por exemplo, que não é comum a eles, tal, ou fica muito baseado em blablablá-blablablá, e é assim que eles entendem, e eu acho muito importante com a comunidade.

O aspecto mais palpável da legitimação coletiva das ações em Pedagogia da Imagem é a sua aprovação pelo conselho escolar e a inclusão no Projeto Político-Pedagógico (PP) da unidade. É a partir daí que 
nossa proposta poderá inserir-se no sistema escolar como uma política pública efetivamente implementada.

- A gente tava comentando que é muito novo esse processo de uso do audiovisual no dia-a-dia da escola. Mais em momentos especiais da escola. Então falta colocar isso mesmo, no PP da escola, nos projetos... particular, um a um, a gente tenta fazer com que desenvolvam alguns projetos, até tentam inserir o audiovisual. É aí que entra essa fase do convencimento, eu acho que falta, né, [...] pra inserir no PP. Então eu acho que tem que conhecer primeiro o equipamento, ter um convencimento, que vale a pena, que né, pra colocar no PP.

- O próprio convencimento vai ser se esse trabalho de conclusão ficar legal, pros próprios colegas, é um incentivo importante pra que haja novas adesões.

Ficar constando no projeto pedagógico da escola é uma revolução.

Sim, oficializar a Pedagogia da Imagem, concebida como uma ação contra-hegemônica, construída "de baixo para cima”, de maneira difusa e descentralizada, participativa e plural, é uma revolução. Façamo-la! 

IV À GUISA DE CONCLUSÃO: REVENDO O PERCURSO 

Quem educará os educadores?

Eles próprios, sujeitos que são do seu processo formativo.

A comunidade, parceira na configuração da escola como ecossistema aberto ao diálogo entre identidades socioculturais e à apropriação crítica das tecnologias.

Seus pares, interlocutores que constroem coletivamente os sentidos dessa profissão.

$\mathrm{Na}$ jornada desta pesquisa, percorri inúmeros territórios para investigar o alcance e as fronteiras da formação continuada para a incorporação crítica e dialógica dos meios de comunicação e suas linguagens às práticas educativas.

Durante a preparação para a caminhada, recorri aos mapas e guias existentes, buscando alinhavar, num mesmo quadro teórico, abordagens dos campos da Comunicação e da Educação capazes de pôr em destaque o papel do sujeito na produção social (simultaneamente transformação e reprodução), sem ignorar as determinações estruturais que constrangem sua ação. Municiada pela Teoria da Estruturação de Giddens, pelas Mediações Culturais de Martín-Barbero, pela pedagogia libertária de Paulo Freire e pelo conceito de Reflexividade de Schön, planejei meu percurso como uma abordagem educomunicativa da formação continuada. Em outros termos, pretendi analisar uma ação educativa como um processo comunicativo, investigando as mediações envolvidas na recepção da mensagem da Pedagogia da Imagem e na produção de novos sentidos pelas educadoras. Metodologicamente, foi preciso recorrer a um arsenal híbrido, que incluiu técnicas de coleta de dados qualitativas e quantitativas, extensivas e intensivas.

O primeiro terreno explorado foi o meu próprio lugar de fala. Procurei definir a Pedagogia da Imagem a partir de suas origens, fundamentos teóricos e formulações metodológicas, situando o contexto estrutural que the serviu de solo e as estratégias que utilizamos para legitimá-la e consolidá-la. Tendo afinado os instrumentos de navegação, em campo familiar, parti rumo às grandes metas da viagem. 
A dimensão subjetiva envolvida na formação continuada me conduziu à compreensão do perfil sociocultural das educadoras, revelando sua pouca familiaridade com os meios e tecnologias da comunicação. A análise da sua produção, porém, demonstrou ser este um limite superável quando a proposta formativa obtém o comprometimento ativo do educador na sua recriação - algo que só é possível quando a formação em serviço é configurada como um processo de negociação de sentidos, aberto a incorporar as contribuições e hibridizações propostas pelos sujeitos em interlocução.

A análise do âmbito estrutural da formação em serviço desvendou um contexto escolar pouco afeito à participação e ao protagonismo de educadores e educandos e, portanto, pouco favorável à implementação de projetos educomunicativos. Entretanto, também permitiu concluir que a falta de infra-estrutura e equipamentos adequados não é o maior limite à Pedagogia da Imagem. O aspecto mais relevante são as relações entre os sujeitos e as configurações políticas do ecossistema educativo. Assim, integrar a comunidade à escola revelou-se a estratégia mais efetiva para consolidar nossa proposta e deslocar as barreiras geradas pelo sistema escolar. Integração que significa abertura aos seus saberes, à sua diversidade cultural, às suas memórias e às suas identidades, e produção compartilhada de sentidos para se estar no mundo e educar os filhos.

Finalmente, o exame da esfera coletiva detectou que os educadores têm enfrentado um momento crítico, de revisão de suas ideologias profissionais e de redefinição da identidade docente. A formação continuada, sem querer assumir a responsabilidade de ditar os sentidos buscados pelos educadores, pode fornecer-lhes uma valiosa contribuição, ao gerar um ambiente horizontal e participativo para seus encontros e trocas. Incentivando a profissionalização pela práxis reflexiva, a Pedagogia da Imagem deve favorecer a conquista da autonomia pelo educador, não como indivíduo isolado, mas como rede articulada, fortalecendo-o na sistematização, defesa e legitimação de seus projetos educomunicativos. 
V REFERÊNCIAS BIBLIOGRÁFICAS 

ADORNO, Theodor. A indústria cultural. In: COHN, Gabriel. Comunicação e indústria cultural. São Paulo: Companhia Editora Nacional e Editora da USP, 1971.p. 293-295.

.Educação e emancipação. 4. ed. Rio de Janeiro: Paz e Terra, 2006.

ALMEIDA, José Joelson Pimentel de. Formação contínua de professores: um contexto e situações de uso de tecnologias de comunicação e informação. 2006. 192p. Dissertação (Mestrado). Faculdade de Educação da Universidade de São Paulo, São Paulo, 2006.

ALVES, Patrícia Horta. Educom.rádio: uma política pública em educomunicação. 2007, 229p. il. Tese (Doutorado). Escola de Comunicações e Artes da Universidade de São Paulo, São Paulo, 2007.

ANDRADE, Oswald. Manifesto Antropofágico. In: Revista Antropofágica. São Paulo, n. 1, ano 1, maio de 1928.

Associação Nacional de Jornais. Idade dos leitores. Estrutura de leitura dos jornais diários. Disponível em <http://www.anj.org.br/a-industria-jornalistica/jornais-no-brasil/idade-dos-leitores>, acesso em 27/01/2009.

Leitura de jornais no mundo. Disponível em <http://www.anj.org.br/a-industriajornalistica/leitura-de-jornais-no-mundo>, acesso em 27/01/2009.

AZEVEDO, Maria Verônica Rezende de. Telejornalismo e educação para a cidadania. São Paulo: Beca Produções Culturais, 2004.

Telejornalismo e educação para a cidadania: uma experiência de educomunicação. 2003, 257p. Tese (Doutorado). Escola de Comunicações e Artes da Universidade de São Paulo, São Paulo, 2003.

BAKHTIN, Mikhail. Marxismo e filosofia da linguagem. 11. ed. São Paulo: Hucitec, 2004.

Problemas da poética de Dostoievski. São Paulo: Forense-Universitária, 1963.

BATISTA, Simone Rodrigues. Televisão e formação inicial de professores:a importância da mediação docente. 1998. 160 p. Dissertação (Mestrado). Faculdade de Educação da Universidade de São Paulo, São Paulo, 1998.

BELLONI, Maria Luiza. Educação para a mídia: missão urgente da escola. In: Comunicação e Sociedade. Revista de Estudos de Comunicação. v. 10, no 17, ago 1991. 
BENJAMIN, W. O narrador. Considerações sobre a obra de Nikolai Leskov. In: Magia e técnica, arte e política; ensaios sobre literatura e história da cultura. 7. ed. São Paulo: Brasiliense, 1994.

BERGMANN, Helenice Maria Barcellos. Escola e inclusão digital: desafios na formação de redes de saberes e fazeres. 2006. 362p. Tese (Doutorado). Faculdade de Educação da Universidade de São Paulo, São Paulo, 2006.

BORELLI, Sílvia H. Simões; PRIOLLI, Gabriel (coord). A deusa ferida. Por que a TV Globo não é mais campeã absoluta de audiência. São Paulo: Summus, 2000.

BOURDIEU, Pierre. Ofício de sociólogo: metodologia da pesquisa na sociologia. 5. ed. Petrópolis: Vozes, 2004.

BRAGA, José Luiz e CALAZANS, Maria Regina Zamith. Comunicação e educação: questões delicadas na interface. São Paulo: Hacker, 2001.

BRANDÃO, Helena H. Nagamine. Introdução à análise do discurso. 4. ed. Campinas: Ed. Unicamp, 1995.

BRASIL. MINISTÉRIO da Cultura e Ministério da Educação. Plano Nacional do Livro e Leitura. Brasília, s/d. Disponível em <http://www.pnll.gov.br>. Acessado em 13/01/2009.

BRASIL. Ministério da Educação. Lei no 10.172/2001. 9 jan. 2001. Aprova o Plano Nacional de Educação e dá outras providências. Diário Oficial da União. Brasília, 10 jan. 2001.

CALDAS AULETE, Francisco J.; VALENTE, Antonio Lopes dos Santos. Dicionário contemporâneo da língua portuguesa Caldas Aulete. Edição brasileira original: Hamílcar de Garcia, 2007. Atual.

CALVINO, Ítalo. Seis propostas para o próximo milênio. 2. ed. São Paulo: Companhia das Letras, 1990.

CAMARGO, Dulce Maria Pompêo de. Conhecimento escolar: o mito da fronteira entre a ciência e a cultura. IN; VEIGA, I. e CASTANHO, M.E. (orgs.) Pedagogia universitária: a aula em foco. Campinas: Papirus, 2000.

CAMPINAS. Conselho Municipal de Educação. Ata da quarta reunião ordinária do plenário. Diário Oficial do Município de Campinas. Campinas, 5 de junho de 2008, p. 3-4.

CAMPINAS. Lei no 12.985. 28 jun 2007. Dispõe sobre o Plano de Cargos, Carreiras e Vencimentos dos Servidores do Município de Campinas e dá outras Providências. Diário Oficial do Município, Campinas, 29 jun 2007. Suplemento. 
. Lei no 14.460. 30 set. 2003. Reorganiza a estrutura administrativa, as atribuições dos departamentos, coordenadorias e setores da Secretaria Municipal de Educação e dá outras providências. Diário Oficial do Município, Campinas, 1 out. 2003.p. 8.

CAMPINAS. Secretaria Municipal de Educação. Comunicado SME/FUMEC No 01/2007. Diário Oficial do Município. Campinas, 29 mar. 2007.p. 3-9.

. Comunicado SME No 42/2008. Diário Oficial do Município. Campinas, 15 abr. 2008. p. $4-7$

. Educação abre inscrições para cursos de formação continuada. Disponível em <www.campinas.sp.gov.br/smenet/ noticias/noticia_2004_02_26b.htm.> Acessado em 13 set 2005.

. Resolução no 15/2007. Dispõe sobre o trabalho docente de participação em CHP. Diário Oficial do Município, Campinas, 24 nov 2007.p. 7.

. Resolução SME/FUMEC No 2/2006. Dispõe sobre a jornada docente, jornada especial, formação continuada e programas e projetos da Secretaria Municipal de Educação. Diário Oficial do Município. Campinas, 10 de fevereiro de 2006, p. 3-4.

. Resolução SME No 02/08. Dispõe sobre a regulamentação das Horas-Projeto na Rede Municipal de Ensino de Campinas. Diário Oficial do Município. Campinas, 14 de fevereiro de 2008, p. 3-4.

CASTELLS, Manuel. Internet e sociedade em rede. In: MORAES, Dênis de. (org) Por uma outra comunicação: mídia, mundialização cultural e poder. Rio de Janeiro: Record, 2003. p. 255-287.

CASTRO, M. C. P. S. e VAZ, P. B. F. Folhas do tempo; imprensa e cotidiano em Belo Horizonte. 18951926. Belo Horizonte: UFMG; Associação Mineira de Imprensa; Prefeitura de Belo Horizonte, 1997.

CBL; SNEL; Abrelivros. Retratos da Leitura no Brasil. 2008. <http://www.prolivro.org.br/ipl/publier4.0/dados/anexos/48.pdf >. Acesso em 27/01/2009.

CERVANTES BARBA, Cecília. El grupo de discusión: de la mercadotecnia al estudio de la cultura y la comunicación. VI Congresso ALAIC. Bolívia, 2002.

CITELLI, Adilson. (coord.) Aprender e ensinar com textos não escolares. 5. ed. São Paulo: Cortez, 2002. (Coleção aprender e ensinar com textos; v. 3) 
Comunicação e educação: perspectivas. In: LOPES, M. I. V; MELO, J. M.; MOREIRA, S. V.; BRAGANÇA, A. (orgs) Pensamento comunicacional brasileiro. Intercom, São Paulo, 2004, p. 77-93.

. (coord.) Outras linguagens na escola. 4. ed. São Paulo: Cortez, 2004. (Coleção aprender e ensinar com textos; v. 6)

Palavras, meios de comunicação e educação. São Paulo: Cortez, 2006.

CRUZ, Maria Teresa. A estética da recepção e a crítica da razão impura. Revista de Comunicação e Linguagens. Lisboa: Centro de Estudos de Comunicação e Linguagens. Junho. 1986, n. 3, p. 57-67.

Diretório dos grupos de pesquisa no Brasil, CNPq. Disponível em <http:// dgp.cnpq.br>.

EZPELETA, Justa; ROCKWELL, Elsie. Pesquisa participante. São Paulo: Cortez, Autores Associados, 1986.

FELTES, Heloísa Pedroso de Moraes. (org.) Produção de sentido; estudos transdisciplinares. São Paulo: Annablume; Porto Alegre: Nova Prova; Caxias do Sul: Educs, 2003.

FERIN, Isabel. Comunicação e culturas do quotidiano. Lisboa: Quimera, 2002.

FOUCAULT, Michel. A ordem do discurso. 11. ed. São Paulo: Edições Loyola, 1996.

FREIRE, Paulo. Pedagogia do Oprimido. 17. ed. Rio de Janeiro: Paz e Terra, 1987.

FUNARI, Cláudia Vicenza. A prática da mediação em processos educomunicacionais: o caso do projeto Educom.rádio. 2007, 2v. Dissertação (Mestrado). Escola de Comunicações e Artes da Universidade de São Paulo, São Paulo, 2007.

GADOTTI, Moacir. Pensamento pedagógico brasileiro. 8. ed. rev. ampl. São Paulo: Ática, 2006.

GARCIA, E. G. Comunicação e educação: campos e relações interdisciplinares. Disponível em <http://www.eca.usp.br/nucleos/nce/perfil_edson.html>. Acesso em 20 jul 2006.

GARCÍA CANCLINI, Néstor. As culturas populares no capitalismo. São Paulo: Brasiliense, 1983.

Culturas híbridas; estratégias para entrar e sair da modernidade. 4. ed. São Paulo: Edusp, 2003. 
GERALDI, C. M. G.; FIORENTINI, D.; PEREIRA, E. M. A. (orgs.) Cartografias do trabalho docente: professor(a)-pesquisador(a). Campinas: Mercado de Letras: Associação de Leitura do Brasil, 1998. (Coleção Leituras no Brasil).

GIDDENS, Anthony. A constituição da Sociedade. São Paulo: Martins Fontes, 2003.

HALL, Stuart. A identidade cultural na pós-modernidade. 3. ed. Rio de Janeiro: DP\&A Editora, 1999.

A relevância de Gramsci para o estudo de raça e etnicidade. In: Da diáspora: identidades e mediações culturais. Belo Horizonte: Editora UFMG; Brasília: Representação da Unesco no Brasil, 2003, p. 294-334.

HUERGO, Jorge A. Comunicación/Educación: itinerarios transversales. In: VALDERRAMA, Carlos. Comunicación \& Educación. Bogotá: Universidad Central, 2000.p. 3-25.

INNERARITY, Daniel. A transformação da política. Lisboa: Teorema, 2005.

KAPLÚN, Mário. Processos educativos e canais de comunicação. In: Revista Comunicação e Educação. São Paulo: CCA/ ECA/ USP, no 14, jan-abr. 1999.p. 68-75.

KHEL, Maria Rita. Imaginar e pensar. In: NOVAES, Adauto. (org) Rede imaginária: televisão e democracia. 2. ed. São Paulo: Companhia das Letras: Secretaria Municipal de Cultura, 1999.

LAGO, C.; ALVES, P. H. Educom.rádio: uma política pública que pensa a mudança da prática pedagógica. Disponível em <http://www.usp.br/nce/aeducomunicacao/saibamais/ textos>. Acessado em 10 out 2005 .

LEÃO, Maria Izabel de Araújo. O papel da Internet nos projetos educomunicacionais do NCE/USP. 2008, 186p. il. Dissertação (Mestrado). Escola de Comunicações e Artes da Universidade de São Paulo, São Paulo, 2008.

LÉVY, Pierre. O que é o virtual? São Paulo: Ed. 34, 1997.

LIMA, Maria Emília Caixeta de Castro. Sentidos do trabalho: a educação continuada de professores. Belo Horizonte: Autêntica, 2005.

LOPES, Maria Immacolata Vassallo de. Estratégias metodológicas da pesquisa de recepção. In: Intercom. Revista Brasileira de Comunicação. São Paulo, v. XVI, nº 2, jul-dez 1993. p. 78-86.

. Pesquisa e gestor: proposta de um modelo metodológico para a pesquisa de intervenção. In: BACCEGA, Maria Aparecida (org). Gestão de processos comunicacionais. São Paulo: Atlas, 2002. 
Pesquisa em comunicação. 8. ed. São Paulo: Loyola, 2005.

Por um paradigma transdisciplinar para o campo da Comunicação. In: DOWBOR, Ladislau et al. (orgs). Desafios da comunicação. Petrópolis: Vozes, 2001.p. 112-116.

Sobre o estatuto disciplinar do campo da comunicação. In: Epistemologia da comunicação. São Paulo: Loyola, 2003.

Uma metodologia para a pesquisa das mediações. Coletânea Mídias e recepção. Porto Alegre: Unisinos, Compós, 2000.

MACIEL, Lizete S.; SHIGUNOV NETO, A. Formação de professores: passado, presente e futuro. São Paulo: Cortez, 2004.

MARTÍN-BARBERO, Jesús. Dos meios às mediações: comunicação, cultura e hegemonia. 2. ed. Rio de Janeiro: Editora UFRJ, 2003, p. 305-310.

Ensanchando territorios en Comunicación/Educación. In: VALDERRAMA, Carlos. Comunicación \& Educación. Bogotá: Universidad Central, 2000.

Globalização comunicacional e transformação cultural. In: MORAES, Dênis de. Por uma outra comunicação: mídia, mundialização cultural e poder. Rio de Janeiro: Record, 2003. p. 57-86.

Heredando el futuro. Pensar la educación desde la comunicación. In: Revista Nómadas. Bogotá: Fundación Universidad Central. nº 5, set. 1996.

Retos a la investigación de comunicación en América Latina. In: FERNANDEZ, F. et al. Comunicación y teoría social. México: UNAM, 1984.

MARX, Karl e ENGELS, Friedrich. A ideologia alemã e outros escritos. (Primeira parte). Rio de Janeiro: Zahar Editores, 1965.

MATTELART, Armand; MATTELART, Michèle. História das teorias da comunicação. 7. ed. São Paulo: Edições Loyola, 2004.

MEDINA, Cremilda de Araújo. A arte de tecer o presente: narrativa e cotidiano. São Paulo: Summus, 2003.

Entrevista: o diálogo possível. 4. ed. São Paulo: Ática, 2004.

Símbolos e narrativas: rodízio 97 na cobertura jornalística. São Paulo: Secretaria do Meio Ambiente, 1998.p. 20. 
MÍDIA e educação: perspectivas para a qualidade da informação. Brasília: MEC, 2000.

MORAES, Dênis de. Por uma outra comunicação. Rio de Janeiro: Record, 2003.

MORAGAS SPA, Miguel de. Ubicación epistemológica e ideológica de la comunicación de masas. In: FERNANDEZ, F. et al. Comunicación y teoría social. México: UNAM, 1984.

MORAN, J. M. O vídeo na sala de aula. Revista Comunicação \& Educação. São Paulo: ECA: Ed. Moderna, n. 2, jan-abr. de 1995. p. 27 a 35.

MORIN, Edgar. A cabeça bem-feita. Repensar a reforma. Reformar o pensamento. Rio de Janeiro: Bertrand Brasil, 2000.

Educação e complexidade: os sete saberes e outros ensaios. 3. ed. São Paulo: Cortez, 2005.

Os sete saberes necessários à educação do futuro. São Paulo: Cortez; Brasília: Unesco, 2002.

NIED. Disponível em <www.nied.unicamp.br>.

NÓVOA, António. (coord.) Os professores e a sua formação. 2. ed. Lisboa: Publicações Dom Quixote, 1995. (Nova Enciclopédia, 39).

OLIVEIRA, T. A. Uso da TV e do vídeo no espaço escolar: uma experiência de educomunicação. 2003, 225p. Dissertação (Mestrado). Escola de Comunicações e Artes da Universidade de São Paulo, São Paulo, 2003.

OROFINO, Maria Isabel. Mídias e mediação escolar. São Paulo: Cortez; Instituto Paulo Freire, 2005.

OROZCO GÓMEZ, G. (coord.) Lo viejo y lo nuevo: investigar la comunicación en el siglo XXI. Madrid: Ediciones de La Torre, 2000.

Professores e meios de comunicação: desafios, estereótipos. In: Revista Comunicação e Educação. São Paulo: CCA/ECA/USP; Editora Moderna, nº 10, set.-dez. 1997.

PENTEADO, Heloísa Dupas. Comunicação escolar: uma metodologia de ensino. São Paulo: Salesiana, 2002. (org) Pedagogia da comunicação: teorias e práticas. 2. ed. São Paulo: Cortez, 2001. 
PEQUENO GRÃO DE AREIA. Granito de arena. Direção: Jill Irene Freidberg. México: Corrugated Films, 2005. 1h.

PERRENOUD, Philippe. Práticas pedagógicas, profissão docente e formação: perspectivas sociológicas. Lisboa: Publicações Dom Quixote, 1993.

PORÃO. Direção: Fernando Mozart. Rio de Janeiro: Expressão Filmes, 2003. 15 min.

PROUST, Marcel. A prisioneira. 13. ed. Trad. Manuel Bandeira e Lourdes de Sousa de Alencar. São Paulo: Globo, 2002.

REZENDE E FUSARI, Maria Felisminda de. Meios de comunicação na formação de professores: televisão e vídeo em questão. 1990.218p. Tese (Doutorado). Instituto de Psicologia da Universidade de São Paulo, São Paulo, 2008.

RICOEUR, Paul. Interpretação e ideologias. Rio de Janeiro: Francisco Alves, 1983.

SANTOS, Boaventura de Sousa. Para um novo senso comum - A ciência, o direito e a política na transição paradigmática. 6. ed. São Paulo: Cortez, 2007. (v. 1. Crítica da razão indolente: contra o desperdício da experiência).

SAYÃO, Rosely; AQUINO, Júlio Groppa. Em defesa da escola. Campinas: Papirus, 2004. (Papirus Debates)

SIERRA, Francisco. El legado de Gramsci. In: Introducción a la teoría de la comunicación educativa. Madrid: Sevilla Editorial, 2000.p. 145-173.

SILVA FILHO, Genésio Zeferino da. Educomunicação e sua metodologia: um estudo a partir de práticas de ONGs no Brasil. São Paulo, 2004. 238 p. Tese (Doutorado) - Escola de Comunicações e Artes, Universidade de São Paulo.

SIQUEIRA, J. BH 100 anos; uma lição da História. Belo Horizonte: Prefeitura de Belo Horizonte, 1997.

SOARES, Ismar de Oliveira. Comunicação/Educação - emergência de um novo campo e o perfil de seus profissionais. Disponível em <www.eca.usp.br/nucleos/nce/perfil_ismar.html>. Acessado em 7 maio 2006.

EaD como prática educomunicativa: emoção e racionalidade operativa. Disponível em <http://www.usp.br/nce/aeducomunicacao/saibamais/textos>. Acessado em 10 out 2005. 
. Manifesto de la Educación para la Comunicación en los países en vías de desarrollo. La Coruña, Espanha, 1995.

Metodologias da Educação para a Comunicação e Gestão Comunicativa no Brasil e na América Latina. In: BACCEGA, Maria Aparecida (org). Gestão de processos comunicacionais. São Paulo: Atlas, 2002.

Sociedade de informação ou da comunicação? São Paulo: Cidade Nova, 1997.

Teoría y practica de la comunicación: incidencia sobre los proyectos de educación para los medios en América Latina. In: CENECA. Santiago, 1992, p. 273-289.

SOARES, Maria Salete Prado. Processos comunicacionais em espaços educativos: estudos de caso sobre linguagens não escolares ativando ecossistemas comunicativos no projeto retratos do Butantã, realizado na escola Estadual Virgília de Carvalho Pinto. 2004, 182p. Dissertação (Mestrado). Escola de Comunicações e Artes da Universidade de São Paulo, São Paulo, 2004.

TARDIF, Maurice. Saberes docentes e formação profissional. 6. ed. Petrópolis: Vozes.

TAVARES, Neide Rodriguez Barea. Formação continuada de professores em informática educacional. 2001. 174p. Dissertação (Mestrado). Faculdade de Educação da Universidade de São Paulo, São Paulo, 2001.

TEZZA, Cristóvão. A polifonia como uma categoria ética. X Congresso Internacional sobre Mikhail Bakhtin, Gdansk, Polônia, jul. 2001.

THIOLLENT, Michel. Crítica metodológica, investigação social e enquete operária. São Paulo: Polis, 1980.

TRINDADE, Helgio. Tentativa de reconstituição empírica de um movimento político radical. In; NUNES, E. (org.) A aventura sociológica. Rio de Janeiro: Zahar, 1978.

TRIVIÑOS, A. N. S. Introdução à pesquisa em ciências sociais: a pesquisa qualitativa em educação. São Paulo: Atlas, 1987.

VATTIMO, Gianni. A sociedade transparente. Lisboa: Relógio d'água, 1992.

VEIGA, Ilma Passos Alencastro; FONSECA, Marília (orgs). As dimensões do projeto políticopedagógico: novos desafios para a escola. 3. ed. Campinas: Papirus, 2004.

VIANA, Claudemir Edson. O processo educomunicacional: a mídia na escola. 2000, 237 p. Dissertação (Mestrado). Escola de Comunicações e Artes da Universidade de São Paulo, São Paulo, 2000. 
WALLERSTEIN, Immanuel et al. (orgs) Para abrir as ciências sociais. Lisboa: Europa-América, 1996.

WERSIG, G. Information science: the study of postmodern knowledge usage. Information Processing \& Management, v. 29, n. 2, 1993.

WILLIAMS, Raymond. Cultura. 2. ed. Rio de Janeiro: Paz e Terra, 2000. 




\section{A.1 Cursos e Grupos de Trabalho (GTS) de FormaçÃo Continuada - 2006}

1. A Lei 10.639/03: reflexão sobre o currículo (5 turmas)

2. Arte e educação ( 2 turmas)

3. Crianças de 6 anos no ensino fundamental (3 turmas)

4. Educação alimentar ( 1 turma)

5. Curso para cozinheiras ( 1 turma)

6. Curso para monitoras (10 turmas)

7. Educação, corpo e movimento (2 turmas)

8. Francês (1 turma)

9. GF articulador de convivência democrática (1 turma)

10. GF Bibliotecas (2 turmas)

11. GT Educação alimentar e currículo (1 turma)

12. GT Fanfarra (1 turma)

13. GT Memória e Identidade: Promoção da Igualdade na Diversidade (1 turma)

14. GT Orientação sexual ( 5 turmas)

15. Imprensa - jornal na escola (3 turmas)

16. Infância, brincadeiras, fantasias ( 2 turmas)

17. Jogos, brincadeiras e atividades lúdicas (1 turma)

18. Leitura e efetivação da aprendizagem ( 2 turmas)

19. Letra e vida (2 turmas)

20. Música e movimento: uma combinação mágica (1 turma)

21. Novos horizontes de EJA (1 turma)

22. Pedagogia da imagem (1 turma)

23. Pró-dança ( 1 turma)

24. Teoria e prática na produção de programa de rádio ( 1 turma)

25. Violão I ( 2 turmas) e Violão II (2 turmas)

Fonte: Coordenadoria Setorial de Formação da Secretaria Municipal de Educação. 


\section{A. 2 CuRSOS E GTS DE FORMAÇÃO CONTINUADA - 2007}

\section{I - Programa Educação básica}

1. O aluno com deficiência física e apropriação do conhecimento: discutindo possibilidades tecnológicas para o sucesso escolar (30 vagas)

2. O ensino de Português como segunda língua para surdos (25 vagas)

3. Educação Infantil: A vida entrando na sala de aula (35 vagas)

4. Os anos iniciais do Ensino Fundamental: exercício da cidadania (35 vagas)

5. Ensino Fundamental: adolescência cidadã ( 2 turmas de 35 vagas cada)

6. Educação de Jovens e Adultos (35 vagas)

7. A construção do trabalho coletivo: cuidar de si para interagir e orientar novas práticas pedagógicas (30 vagas)

8. Qualidade de vida aos profissionais não docentes das Escolas Municipais de Campinas (30 vagas)

9. Das primeiras formas de contagem à utilização do ábaco (35 vagas)

10. Curso básico de informática educativa ( 2 turmas com 18 vagas cada)

11. Laboratório de informática, novo espaço para o professor ( 2 turmas com 18 vagas cada)

12. Formação de coordenadores de projetos em informática. Módulo I: alunos monitores (2 turmas com 18 vagas cada)

13. Podcast: dando voz aos alunos da rede (18 vagas)

14. História em quadrinhos - uma proposta envolvente (18 vagas)

15. Leitura e releitura de imagens (18 vagas)

16. Estudos avançados de educação infantil: o "currículo em construção" em movimento I (5 turmas com 30 vagas cada)

17. Estudos avançados de educação infantil: o "currículo em construção" em movimento II (30 vagas)

18. O projeto pedagógico e a formação de professores: escrita, encontros e diálogos da/na escola (2 turmas com 40 vagas)

19. Aprender a perguntar, pesquisar e descobrir: o desenvolvimento de projetos com crianças do ciclo de alfabetização (30 vagas)

20. Memória de professores (30 vagas)

21. Letra e vida (35 vagas)

22. Alfabetização e cultura letrada (35 vagas)

23. O ensino fundamental de nove anos e o ciclo de alfabetização: teorias e práticas ( 5 turmas com um total de 300 vagas)

24. Um novo olhar para os registros: produção de conhecimentos (30 vagas)

25. Classes voltadas a alunos em defasagem idade/série ( 35 vagas)

26. Ensino/aprendizagem da matemática: alternativas para a diversidade da sala de aula (2 turmas com 35 vagas cada) 


\section{Programa Linguagem e educação}

27. Entrou por um fio... saiu por um laço... quem quiser que dê um abraço (40 vagas)

28. Pedagogia da Imagem (40 vagas)

29. Francês básico I (15 vagas)

30. Francês básico II (duas turmas com 15 vagas cada)

31. Francês básico III (duas turmas com 15 vagas cada)

32. Italiano básico I (20 vagas)

33. Italiano intermediário (20 vagas)

34. Libras - módulo I (20 vagas)

35. Libras - módulo II (20 vagas)

36. Libras - módulo I (20 vagas)

37. Libras - módulo II (20 vagas)

38. GT Formação pedagógica para o ensino de Francês na SME

39. GT Imprensa na escola - iniciante (40 vagas)

40. GT Imprensa na escola - continuidade (40 vagas)

41. GT Rádio e TV (4 turmas com 15 vagas cada)

42. GT A leitura na escola: práticas existentes e práticas possíveis (35 vagas)

\section{Programa Arte e movimento}

43. Dança educação (30 vagas)

44. O circo educando ( 2 turmas de 20 vagas)

45. Vivências de atividades circenses na escola (35 vagas)

46. Musicalizando Campinas: naipe de cordas - violino ou viola (duas turmas de 8 vagas)

47. Musicalizando Campinas: naipe de sopro - flauta doce (soprano) (5 turmas com 12 vagas)

48. Musicalizando Campinas: Branda rítmica infantil 1 ( 2 turmas de 40 vagas)

49. Musicalizando Campinas: Banda rítmica infantil 2 (30 vagas)

50. Musicalizando Campinas: Regência coral (6 turmas de 30 vagas)

51. Musicalizando Campinas: Ritmo - fanfarra nas escolas

52. Musicalizando Campinas: Naipe de percussão (5 vagas)

53. Musicalizando Campinas: Naipe de metal: trompete, trombone, tuba etc ( 5 vagas)

54. Musicalizando Campinas: Corpo coreográfico e baliza (5 vagas)

55. Ensinando com o jogo de xadrez ( 2 turmas de 20 vagas)

56. Oficina de teatro para professores ( 2 turmas de 20 vagas)

57. História da arte - abrangência: desenho e pintura, relações intersemióticas com a literatura (30 vagas)

58. Educação física: construção de políticas públicas no currículo escolar - Jogos Escolares Municipais e regulamentos ( 2 turmas de 40 vagas)

59. GT Arte - construção de políticas públicas no currículo escolar (30 vagas) 


\section{Programa Transversalidade}

60. Educação por natureza ( 2 turmas de 20 vagas)

61. Educação ambiental (2 turmas de 20 vagas)

62. Educação alimentar e currículo (35 vagas)

63. Brinquedista ( 2 turmas de 25 vagas)

64. Bio-educação (20 vagas)

65. Trabalhando conceitos de Educação Ambiental através de maquetes e jogos 1 (20 vagas)

66. Trabalhando conceitos de Educação Ambiental através de maquetes e jogos 2 (20 vagas)

67. Ações Educativas em Museus (60 vagas)

68. Convivendo com o universo das infâncias (20 vagas)

69. Convivendo com o universo da adolescência (20 vagas)

70. A amizade como ato educativo na visão da filosofia (30 vagas)

71. GT Educação e Sexualidade (3 turmas de 20 vagas)

V. Programa MIPID - Memória e Identidade: promoção da igualdade na diversidade

72. A Lei 10.639/03 - Compromissos e mudanças na educação (10 turmas de 35 vagas)

73. GT A Lei 10.639/03: discutindo relações étnico-raciais nas práticas pedagógicas ( 2 turmas de 20 vagas)

74. GT A Lei 10.639/03 - Capoeira na escola, estudo das africanidades, diversidade étnico-racial e currículo ( 2 turmas de 25 vagas)

75. GT A Lei 10.639/03 - Reflexões teóricas e práticas sobre o currículo no cotidiano escolar (2 turmas de 25 vagas)

76. GT Valores e referenciais afro-brasileiros na Educação Infantil ( 2 turmas de 20 vagas)

Fonte: CAMPINAS. Secretaria Municipal de Educação. Comunicado SME/FUMEC No 01/2007. Diário Oficial do Município. Campinas, 29 mar. 2007. p.3-9. 


\section{A. 3 CURSOS E GFS DE FORMAÇÃO CONTINUADA - 2008}

EIXO A Programação dos Grupos de Formação pela Área do Conhecimento (200 vagas no total)

1. Anos Finais do Ensino Fundamental ( $3^{\circ}$ e $4^{\circ}$ ciclos)

1.1. História

1.2. Língua Portuguesa

1.3. Matemática

1.4. Geografia

1.5. Ciências

1.6. Língua Estrangeira: Inglês

1.7. Arte

1.8. Educação Física

(B) Programação da Formação por Temática (465 vagas no total)

1. Curso: A Lei 10.639/03: Compromissos e Mudanças na Educação

2. Grupo de Formação por temática: A Cor da Cultura

3. Curso: EJA II: Uma Proposta Interdisciplinar

4. Curso: Consolidando as "Diretrizes Curriculares para o trabalho pedagógico com leitura e escrita na Educação Infantil"

5. Grupo de Formação por Temática: Grêmio Estudantil

(C) Programação dos Grupos de Formação com Metodologia de Projetos (689 vagas no total)

1. Grupo de Formação: Formação Pedagógica para o Ensino do Francês

2. Curso: Francês I

3. Curso: Francês II

4. Curso: Francês III

5. Curso: Italiano I

6. Curso: Italiano II

7. Curso: Avaliação Institucional na Educação Básica

8. Curso: Desmistificando o uso do Computador

9. Curso: Trazendo o Espaço Virtual para a Sala de Aula: Blogs, Fotologs, Wikis e Podcasts

10. Curso: Atuação com a pessoa com Deficiência Visual: abordagem Teórica e Prática 
11. Curso: Diretrizes Curriculares para o trabalho pedagógico com leitura e escrita na Educação Infantil: teorias e práticas

12. Curso: Ensinando com o Jogo de Xadrez - Lei Municipal 8.829/96

13. Curso: Musicalizando Campinas: Naipe de Sopro - Flauta Doce (soprano)

14. Curso: Musicalizando Campinas: Banda Rítmica

15. Curso: Musicalizando Campinas: Ritmo - Fanfarra nas Escolas

16. Curso: Letra e Vida

17. Curso: Educação para Mobilidade / EMDEC

Fonte: CAMPINAS. Secretaria Municipal de Educação. Comunicado SME No 42/2008. Diário Oficial do Município. Campinas, 15 abr. 2008. p. 4-7. 


\section{Anexo B - Programas do curso Pedagogia da IMAgem - 2006 e 2007}

\section{B. 1 Programa 2006}

\begin{tabular}{|c|c|c|}
\hline Data & Tema & Referências \\
\hline 07/03 & $\begin{array}{l}\text { Apresentação do museu. Apresentação dos participantes. } \\
\text { Levantamento de expectativas. Apresentação do curso, } \\
\text { metodologias e dinâmicas. }\end{array}$ & $\begin{array}{l}\text { Performance poética Cora Coralina. } \\
\text { Apresentação do website. }\end{array}$ \\
\hline $14 / 03$ & $\begin{array}{l}\text { Levantamento da infra-estrutura da escola para trabalhos } \\
\text { com audiovisual. Filmamos a participação dos professo- } \\
\text { res. }\end{array}$ & $\begin{array}{l}\text { Projeção do curta-metragem A alma do negó- } \\
\text { cio. Dir: J. R Torero. Discussão }\end{array}$ \\
\hline $21 / 03$ & $\begin{array}{l}\text { Reapresentação do curso e programa para novos partici- } \\
\text { pantes. } \\
\text { Dinâmica sobre o uso dos meios de comunicação (ques- } \\
\text { tionário e discussão). } \\
\text { Discussão sobre a adaptação do instrumento de pesquisa } \\
\text { com os alunos e com a escola. }\end{array}$ & \\
\hline $28 / 03$ & $\begin{array}{l}\text { Oficina de análise da estrutura narrativa e da construção } \\
\text { da linguagem visual em material cinematográfico. Exercí- } \\
\text { cio de ação pedagógica a partir da projeção de um filme } \\
\text { em sala de aula. Leitura crítica de filmes. O filme narrati- } \\
\text { vo clássico americano e a relação com o folhetim e for- } \\
\text { mas de cultura popular. } \\
\text { Detectou-se a necessidade de aprofundar os conceitos de } \\
\text { linguagem com os professores. } \\
\text { Debate sobre o resultado do diagnóstico dos professores } \\
\text { (uso dos meios - gráficos em power point). Apresentação } \\
\text { dos gráficos e comentário dos resultados. }\end{array}$ & $\begin{array}{l}\text { Filme: O conde de Monte-Cristo. } \\
\text { Texto-base: Jesús Martín-Barbero, Dos meios às } \\
\text { mediações (parte 2). } \\
\text { Multimídia - gráficos. }\end{array}$ \\
\hline 04/04 & $\begin{array}{l}\text { Oficina de análise da estrutura de filmes direcionados aos } \\
\text { jovens, baseados em games. Novas características emer- } \\
\text { gem. Projeção e debate sobre filme. }\end{array}$ & $\begin{array}{l}\text { Filme: Lara Croft Tomb Raider. } \\
\text { Entrega de textos-referência. }\end{array}$ \\
\hline $11 / 04$ & Discussão em grupos sobre a natureza da linguagem. & Textos-referência sobre linguagem. \\
\hline $18 / 04$ & $\begin{array}{l}\text { Formação de grupos de trabalho para adaptação dos } \\
\text { questionários de diagnóstico dos alunos. Discussão de } \\
\text { leitura sobre pesquisas do uso dos meios de comunica- } \\
\text { ção na escola. }\end{array}$ & Texto-base: Adilson Citelli. \\
\hline $25 / 04$ & $\begin{array}{l}\text { Discussão sobre a Educação Bancária e a Educação Pro- } \\
\text { blematizadora. } \\
\text { Exibição e debate de filme. }\end{array}$ & $\begin{array}{l}\text { Leitura: Paulo Freire, Pedagogia do Oprimido. } \\
\text { Filme: The Wall. }\end{array}$ \\
\hline 02/05 & $\begin{array}{l}\text { Problematização dos conceitos que fundamentam a prá- } \\
\text { tica do professor, a partir do exame de trechos transcri- } \\
\text { tos das gravações das sessões de } 14 \text { e } 21 \text { de março. } \\
\text { Revisão do programa de curso a partir das discussões e } \\
\text { das necessidades apresentadas pelos professores. }\end{array}$ & Power Point "Ouvindo nossa voz" \\
\hline
\end{tabular}




\begin{tabular}{|c|c|c|}
\hline 09/05 & $\begin{array}{l}\text { Início da discussão sobre o livro didático. } \\
\text { Discussão sobre a prática pedagógica com o livro didáti- } \\
\text { co. }\end{array}$ & $\begin{array}{l}\text { Texto-base: Rui Vieira de Castro e Maria de } \\
\text { Lourdes Dionísio. } \\
\text { Filme: A Sociedade dos poetas mortos. }\end{array}$ \\
\hline $16 / 05$ & Discussão sobre a violência, o papel da mídia e a escola. & $\begin{array}{l}\text { Estudo do caso da ação do PCC em São Paulo. } \\
\text { Matérias jornalísticas publicadas. }\end{array}$ \\
\hline $23 / 05$ & Discussão sobre a violência, o papel da mídia e a escola. & Filme: O porão \\
\hline $30 / 05$ & Discussão sobre os questionários feitos com os alunos. & $\begin{array}{l}\text { Texto-base: Rui Vieira de Castro e Maria de } \\
\text { Lourdes Dionísio. }\end{array}$ \\
\hline 06/06 & $\begin{array}{l}\text { Discussão do texto sobre o livro didático. } \\
\text { Tratamento dos dados dos questionários com os alunos. } \\
\text { Formação dos grupos para trabalho prático de desenvol- } \\
\text { vimento de projeto para aplicação em sala de aula. }\end{array}$ & \\
\hline $20 / 06$ & $\begin{array}{l}\text { Tabulação dos questionários. } \\
\text { Leitura de texto sobre desenvolvimento de projeto de mí- } \\
\text { dia-educação na sala de aula } \\
\text { Trabalho em grupo para definição dos trabalhos práticos. }\end{array}$ & $\begin{array}{l}\text { Leitura: Maria Isabel Orofino (capítulo 3) Mídias } \\
\text { e mediação escolar. }\end{array}$ \\
\hline $27 / 06$ & $\begin{array}{l}\text { Oficina de filmagem - utilizando a câmera filmadora de } \\
\text { vídeo. }\end{array}$ & \\
\hline 04/07 & Avaliação do semestre & Questionários de avaliação do Ceforma \\
\hline $01 / 08$ & $\begin{array}{l}\text { Possibilidades e andamento dos projetos pedagógicos de } \\
\text { cada professor. Sessão de discussão e acompanhamento. }\end{array}$ & Filmagens produzidas pelos professores. \\
\hline 08/08 & $\begin{array}{l}\text { A linguagem do vídeo. Discussão sobre a gramática au- } \\
\text { diovisual. }\end{array}$ & $\begin{array}{l}\text { Texto: Introdução à mídia eletrônica: vídeo. } \\
\text { Glossário de termos técnicos (Maria Isabel Oro- } \\
\text { fino). Depoimento de roteiristas sobre criação } \\
\text { de roteiro. Vídeo: Mera coincidência. } \\
\text { Filmagens produzidas pelos professores. }\end{array}$ \\
\hline $15 / 08$ & $\begin{array}{l}\text { O roteiro do vídeo. Exercícios práticos. Criação de roteiros } \\
\text { curtos pelos professores. }\end{array}$ & $\begin{array}{l}\text { Texto: Mídias e mediação escolar (Maria Isabel } \\
\text { Orofino). } \\
\text { Roteiros de curtas-metragens. } \\
\text { Vídeo: Ilha das Flores. }\end{array}$ \\
\hline $22 / 08$ & $\begin{array}{l}\text { Roteiro de vídeo. Filmagem dos roteiros criados pelos } \\
\text { professores. }\end{array}$ & $\begin{array}{l}\text { Vídeo documentário. } \\
\text { Filmagens produzidas pelos professores. }\end{array}$ \\
\hline 29/08 & $\begin{array}{l}\text { Roteiro: acompanhamento do trabalho desenvolvido pe- } \\
\text { los professores. }\end{array}$ & $\begin{array}{l}\text { Texto: O vídeo na sala de aula. } \\
\text { Filmagens produzidas pelos professores. }\end{array}$ \\
\hline 05/09 & Entrevista. & $\begin{array}{l}\text { Texto "Entrevista". } \\
\text { Debate sobre entrevistas gravadas na TV (dife- } \\
\text { rentes tipos de entrevistas). }\end{array}$ \\
\hline $12 / 09$ & $\begin{array}{l}\text { Como montar uma pequena ilha de edição na escola. } \\
\text { Leitura crítica da TV: a propaganda eleitoral. }\end{array}$ & $\begin{array}{l}\text { Palestra com especialistas em informática. } \\
\text { Programa eleitoral gratuito. } \\
\text { Texto: A transformação da política (Innerarity) }\end{array}$ \\
\hline
\end{tabular}




\begin{tabular}{|c|c|c|}
\hline $19 / 09$ & Leitura crítica da TV: a propaganda eleitoral. & $\begin{array}{l}\text { Vídeo: Poder e mídia: O Marketing político - } \\
\text { Eleições nos EUA. }\end{array}$ \\
\hline $26 / 09$ & $\begin{array}{l}\text { Acompanhamento dos projetos produzidos pelos profes- } \\
\text { sores em sala de aula. }\end{array}$ & $\begin{array}{l}\text { Questionário de acompanhamento de projetos. } \\
\text { Filmagens efetuadas pelos professores. }\end{array}$ \\
\hline $03 / 10$ & $\begin{array}{l}\text { Temas transversais e a mídia: Diversidade étnica na escola } \\
\text { e na mídia. }\end{array}$ & Palestra com Carlindo Fausto Antônio. \\
\hline $10 / 10$ & Discussão sobre a diversidade étnica na escola & Filme: A negação do Brasil \\
\hline $17 / 10$ & $\begin{array}{l}\text { Discussão sobre as dificuldades dos professores com rela- } \\
\text { ção aos roteiros. Exercício de produção de roteiros para } \\
\text { campanha educativa. }\end{array}$ & Comerciais gravados da TV. \\
\hline $24 / 10$ & Cultura popular viva e dinâmica & Visita à Casa de Cultura Tainã \\
\hline $31 / 10$ & $\begin{array}{l}\text { O funcionamento de um estúdio de TV e das ilhas de e- } \\
\text { dição de áudio e vídeo. }\end{array}$ & $\begin{array}{l}\text { Visita aos estúdios e ilhas de edição do IPEP - } \\
\text { Instituto Paulista de Ensino e Pesquisa. }\end{array}$ \\
\hline $07 / 11$ & Sistematização de conhecimentos & Trabalho em grupos (seminário) \\
\hline $14 / 11$ & Culturas jovens: o movimento hip hop em Campinas & Palestra: Adriano Bueno \\
\hline $21 / 11$ & O funcionamento de uma ilha de edição de vídeo & $\begin{array}{l}\text { Palestra e demonstração na ilha de edição do } \\
\text { MIS - Manuel Bento }\end{array}$ \\
\hline $28 / 11$ & $\begin{array}{l}\text { Avaliação geral do curso, apresentação dos trabalhos dos } \\
\text { participantes e confraternização da turma }\end{array}$ & \\
\hline
\end{tabular}

Fonte: Equipe Pedagogia da Imagem - MIS 


\section{B. 2 Programa 2007}

\begin{tabular}{|c|c|c|}
\hline Data & Tema & Referência \\
\hline $17 / 04$ & $\begin{array}{l}\text { Apresentação dos participantes. Levantamento de expec- } \\
\text { tativas. Apresentação do curso, metodologias e dinâmi- } \\
\text { cas. Discussão do programa. Performance teatral. }\end{array}$ & \\
\hline $24 / 04$ & $\begin{array}{l}\text { Discussão sobre o uso do vídeo na sala de aula (texto). } \\
\text { Aplicação de questionário de diagnóstico sobre os usos } \\
\text { dos meios de comunicação pelo professor. } \\
\text { Oficina: uso de equipamentos de projeção }\end{array}$ & $\begin{array}{l}\text { Texto José Manoel Moran. O vídeo na sala de } \\
\text { aula. }\end{array}$ \\
\hline 08/05 & $\begin{array}{l}\text { Uso do vídeo em sala de aula. Discussão de texto. } \\
\text { Elaboração de instrumento para diagnóstico do uso dos } \\
\text { meios pelos alunos. }\end{array}$ & Texto: artigo de Adilson Citelli. \\
\hline $15 / 05$ & $\begin{array}{l}\text { Apresentação e discussão dos resultados da pesquisa so- } \\
\text { bre o uso dos meios de comunicação pelos professores. }\end{array}$ & \\
\hline $22 / 05$ & $\begin{array}{l}\text { Seminário: o discurso e a estrutura escolar. Educação } \\
\text { bancária x educação dialógica. Exibição e debate de fil- } \\
\text { me. }\end{array}$ & $\begin{array}{l}\text { Rosely Sayão. Sobre rankings escolares } \\
\text { Paulo Freire. Pedagogia do oprimido } \\
\text { Vídeo: Pequeno Grão de Areia }\end{array}$ \\
\hline 29/05 & $\begin{array}{l}\text { Discussão sobre provocações - a estrutura escolar e o } \\
\text { papel do professor. Dinâmica em grupos. }\end{array}$ & Vídeo: The Wall \\
\hline 05/06 & $\begin{array}{l}\text { Uso do vídeo em sala de aula. } \\
\text { Elementos da linguagem audiovisual: planos, enquadra- } \\
\text { mentos, movimentos. } \\
\text { Introdução à linguagem fotográfica (Batata). } \\
\text { Conversa com a fotógrafa Patrícia Rodolpho e visita à ex- } \\
\text { posição. }\end{array}$ & $\begin{array}{l}\text { Vídeo: A alma do negócio } \\
\text { Pranchas - planos, enquadramentos, ângulos e } \\
\text { pontos de vista. } \\
\text { Exposição fotográfica: Na rua }\end{array}$ \\
\hline $12 / 06$ & $\begin{array}{l}\text { Programação especial Semana do Meio Ambiente. Proje- } \\
\text { to Anhumas - vídeo e meio ambiente. }\end{array}$ & $\begin{array}{l}\text { Palestra com Roseli Torres e vídeo: } 3 \text { x 4: Retra- } \\
\text { tos da vida à margem de um rio. Visita à expo- } \\
\text { sição. }\end{array}$ \\
\hline $19 / 06$ & $\begin{array}{l}\text { Fotografias produzidas pelos professores sobre o bairro. } \\
\text { Comentários sobre fotografias. } \\
\text { Dicas sobre estética e luz na fotografia. }\end{array}$ & \\
\hline $26 / 06$ & $\begin{array}{l}\text { Orientação para uso da câmera fotográfica. } \\
\text { Saída fotográfica na Rua } 13 \text { de Maio. }\end{array}$ & \\
\hline 03/07 & $\begin{array}{l}\text { Avaliação do curso } \\
\text { Seminário: Leitura crítica da TV }\end{array}$ & $\begin{array}{l}\text { Dossiê: Carta Capital } \\
\text { Vídeo: A revolução não será televisionada }\end{array}$ \\
\hline $31 / 07$ & $\begin{array}{l}\text { Retomada dos resultados da avaliação. } \\
\text { Tirando dúvidas sobre o programa, revendo o curso. } \\
\text { Questionários, tabulação de dados, projetos individuais e }\end{array}$ & $\begin{array}{l}\text { Indicação de livro: como usar a televisão em } \\
\text { sala de aula. } \\
\text { Vídeo: Mera coincidência. }\end{array}$ \\
\hline
\end{tabular}




\begin{tabular}{|c|c|c|}
\hline & $\begin{array}{l}\text { em grupos. } \\
\text { Como trabalhar a TV em sala de aula. }\end{array}$ & \\
\hline 07/08 & Oficina de filmagem. O uso da filmadora. & \\
\hline $14 / 08$ & $\begin{array}{l}\text { Visita a estúdio de filmagem e de rádio profissional no } \\
\text { Instituto Paulista de Ensino e Pesquisa. }\end{array}$ & \\
\hline $21 / 08$ & $\begin{array}{l}\text { Questionário de acompanhamento de projetos nas esco- } \\
\text { las. Sistematização de conhecimentos sobre a filmagem e } \\
\text { a fotografia. }\end{array}$ & \\
\hline $28 / 08$ & $\begin{array}{l}\text { Introdução ao roteiro. Técnicas de roteirização. Compa- } \\
\text { ração entre filme e roteiro. Oficina de criatividade em ro- } \\
\text { teiros. }\end{array}$ & Vídeo: Ilha das Flores. \\
\hline 04/09 & $\begin{array}{l}\text { Oficina de produção e edição de vídeo. Criação de rotei- } \\
\text { ros, filmagem e edição no Windows Movie Maker. Intro- } \\
\text { dução à roteirização de trilha sonora. }\end{array}$ & Produção de vídeo: Transformação. \\
\hline $11 / 09$ & $\begin{array}{l}\text { Montagem de ilha de edição na escola: recursos técnicos } \\
\text { necessários. Palestra técnica com convidado. }\end{array}$ & \\
\hline $18 / 09$ & $\begin{array}{l}\text { Acompanhamento de projetos nas escolas. Atividades } \\
\text { práticas de roteirização, filmagem e edição. Sistematiza- } \\
\text { ção de conhecimentos sobre roteirização, produção, fil- } \\
\text { magem e edição. }\end{array}$ & \\
\hline $25 / 09$ & Oficina: Leitura crítica da TV e temas transversais & Filme: A negação do Brasil \\
\hline $02 / 10$ & $\begin{array}{l}\text { Acompanhamento de projetos nas escolas. } \\
\text { Palestra com convidado: rádios comunitárias. }\end{array}$ & \\
\hline $09 / 10$ & Oficinas culturais: a cultura popular. & Visita à Casa de Cultura Tainã \\
\hline $16 / 10$ & Oficinas culturais: a cultura jovem: hip hop & Palestra com convidado - Movimento Hip Hop \\
\hline $23 / 10$ & Oficinas culturais: grafite x pichação & Filme: Ela dança, eu danço \\
\hline $30 / 10$ & Oficinas culturais: diversidade étnica e respeito. & Palestra: Fausto - Programa MIPID \\
\hline $06 / 11$ & Oficinas interdisciplinares: violência e cidadania & Filme: O porão, debate \\
\hline $13 / 11$ & Oficina de sistematização de conhecimentos. & \\
\hline $27 / 11$ & Mostra de trabalhos dos participantes parte I. & \\
\hline $04 / 12$ & $\begin{array}{l}\text { Mostra de trabalhos dos participantes parte II. } \\
\text { Avaliação do curso e confraternização }\end{array}$ & \\
\hline
\end{tabular}

Fonte: Equipe Pedagogia da Imagem - MIS 